\title{
3. MIDDLE VALLEY: BENT HILL AREA (SITE 1035) ${ }^{1}$
}

\author{
Shipboard Scientific Party²
}

\section{HOLE 856H}

Position: $48^{\circ} 26.020^{\prime} \mathrm{N}, 128^{\circ} 40.859^{\prime} \mathrm{W}$

Date occupied: 24 August 1996

Date departed: 1 September 1996

Time on hole: 8 days, $12 \mathrm{hr}, 30 \mathrm{~min}$

Bottom felt (drill pipe measurement from rig floor, m): 2434.5

Distance between rig floor and sea level (m): 11.3

Water depth (drill pipe measurement from sea level, m): 2423.2

Total depth (from rig floor, $\mathbf{m}$ ): 2934.5

Penetration (m): 500

Number of cores (including cores with no recovery): 49

Total length of cored section (m): 406.2

Total core recovered (m): 49.11

Core recovery (\%): 12.1

Oldest sediment cored:

Depth (mbsf): Section 169-856H-62R-1, Piece 14B ( 471.1 mbsf)

Nature: mudstone and siltstone

Hard rock:

Depth (mbsf): 496.59

Nature: diabase and basalt

Comments: Reentered and deepened Hole 856 drilled during Leg 139. The top of Core $19 \mathrm{R}$ is $93.8 \mathrm{mbsf}$. Core $18 \mathrm{~W}$ is a wash core.

\section{HOLE 1035A}

Position: $48^{\circ} 26.0204^{\prime} \mathrm{N}, 128^{\circ} 40.9219^{\prime} \mathrm{W}$

Date occupied: 7 September 1996

Date departed: 9 September 1996

Time on hole: 1 day, $18 \mathrm{hr}, 45 \mathrm{~min}$

Bottom felt (drill pipe measurement from rig floor, m): 2456.4

Distance between rig floor and sea level (m): 11.5

Water depth (drill pipe measurement from sea level, m): 2444.9

Total depth (from rig floor, m): 2627.2

Number of cores (including cores having no recovery): 19

Total core recovered (m): 119.46

Core recovery (\%): 69.9
Oldest sediment cored: Depth (mbsf): 170.8

Nature: claystone

\section{HOLE 1035B}

Position: $48^{\circ} 25.9923^{\prime} \mathrm{N}, 128^{\circ} 40.8553^{\prime} \mathrm{W}$

Date occupied: 11 September 1996

Date departed: 11 September 1996

Time on hole: $8 \mathrm{hr}$

Bottom felt (drill pipe measurement from rig floor, $\mathbf{m}$ ): 2459.0

Distance between rig floor and sea level (m): 11.5

Water depth (drill pipe measurement from sea level, m): 2447.5

Comments: Core barrel was bent when it hit the seafloor. One centimeter of material was scraped from the core barrel.

\section{HOLE 1035C}

Position: $48^{\circ} 25.9917^{\prime} \mathrm{N}, 128^{\circ} 40.8615^{\prime} \mathrm{W}$

Date occupied: 11 September 1996

Date departed: 12 September 1996

Time on hole: $22 \mathrm{hr}$

Bottom felt (drill pipe measurement from rig floor, m): 2459.0

Distance between rig floor and sea level (m): 11.5

Water depth (drill pipe measurement from sea level, m): 2447.5

Total depth (from rig floor, m): 2503.0

Number of cores (including cores having no recovery): 5

Total core recovered (m): 2.09

Core recovery $(\%): 4.8$

Oldest sediment cored:

Depth (mbsf): 44.0

Nature: massive sulfide

\section{HOLE 1035D}

Position: $48^{\circ} 26.0208^{\prime} \mathrm{N}, 128^{\circ} 40.7985^{\prime} \mathrm{W}$

Date occupied: 12 September 1996

Date departed: 15 September 1996

Time on hole: 2 days $5 \mathrm{hr}$

Bottom felt (drill pipe measurement from rig floor, $\mathbf{m}$ ): 2459.8

Distance between rig floor and sea level $(\mathbf{m}): 11.5$

Water depth (drill pipe measurement from sea level, m): 2448.3
${ }^{1}$ Fouquet, Y., Zierenberg, R.A., Miller, D.J., et al., 1998. Proc. ODP, Init. Repts., 169: College Station, TX (Ocean Drilling Program).

${ }^{2}$ Shipboard Scientific Party is given in the list preceding the Table of Contents.

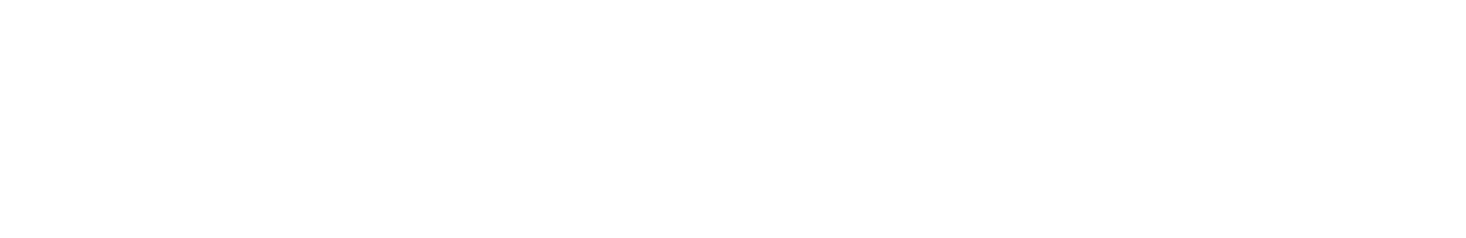


Total depth (from rig floor, m): 2638.3

Number of cores (including cores having no recovery): 24

Total core recovered (m): 51.37

Core recovery (\%): 29.0

Oldest sediment cored:

Depth (mbsf): 178.5

Nature: mudstone with disseminated sulfide and anhydrite

Comments: Drilled from 57.7 to $59.3 \mathrm{mbsf}(1.6 \mathrm{~m})$.

\section{HOLE 1035E}

\section{Position: $48^{\circ} 25.9657^{\prime} \mathrm{N}, 128^{\circ} 40.8555^{\prime} \mathrm{W}$}

Date occupied: 15 September 1996

Date departed: 15 September 1996

Time on hole: $12 \mathrm{hr}$

Bottom felt (drill pipe measurement from rig floor, $\mathbf{m}$ ): 2465.0

Distance between rig floor and sea level (m): 11.9

Water depth (drill pipe measurement from sea level, m): 2453.1

Total depth (from rig floor, m): 2510.5

Number of cores (including cores having no recovery): 5

Total core recovered (m): 47.72

Core recovery (\%): 104.9

Oldest sediment cored:

Depth (mbsf): 45.5

Nature: mud with disseminated anhydrite

\section{HOLE 1035F}

Position: $48^{\circ} 25.9873^{\prime} \mathrm{N}, 128^{\circ} 40.8607^{\prime} \mathrm{W}$

Date occupied: 17 September 1996

Date departed: 19 September 1996

Time on hole: 2 days

Bottom felt (drill pipe measurement from rig floor, $\mathbf{m}$ ): 2459.0

Distance between rig floor and sea level (m): 11.6

Water depth (drill pipe measurement from sea level, m): 2447.4

Total depth (from rig floor, $\mathbf{m}$ ): 2683.8

Number of cores (including cores having no recovery): 23

Total core recovered $(\mathrm{m}): 22.55$

Core recovery $(\%): 10.0$

Oldest sediment cored:

Depth (mbsf): 224.8

Nature: sandstone

\section{HOLE 1035G}

Position: $48^{\circ} 26.0242^{\prime} \mathrm{N}, 128^{\circ} 40.9140^{\prime} \mathrm{W}$

Date occupied: 19 September 1996

Date departed: 20 September 1996

Time on hole: 1 day, $2 \mathrm{hr}, 15 \mathrm{~min}$

Bottom felt (drill pipe measurement from rig floor, m): 2456.6

Distance between rig floor and sea level (m): 11.6
Water depth (drill pipe measurement from sea level, $\mathbf{m}$ ): 2445.0

Total depth (from rig floor, m): 2665.1

Number of cores (including cores having no recovery): 13

Total core recovered $(\mathbf{m}): 16.63$

Core recovery $(\%): 15.6$

Oldest sediment cored:

Depth (mbsf): 208.5

Nature: sandstone

Comments: Drilled from 0.0 to 44.4 and from 83.3 to $140.9 \mathrm{mbsf}$ (after Core $5 \mathrm{R})$ - total of $102.0 \mathrm{~m}$. One wash core $(4.47 \mathrm{~m})$ was recovered from the washed interval 83.3-140.9 mbsf.

\section{HOLE 1035H}

Position: $48^{\circ} 25.8321^{\prime} \mathrm{N}, 128^{\circ} 40.9108^{\prime} \mathrm{W}$

Date occupied: 20 September 1996

Date departed: 23 September 1996

Time on hole: 2 days, $17 \mathrm{hr}, 15 \mathrm{~min}$

Bottom felt (drill pipe measurement from rig floor, $\mathbf{m}$ ): 2455.0

Distance between rig floor and sea level (m): 11.7

Water depth (drill pipe measurement from sea level, $\mathbf{m}$ ): 2443.3

Total depth (from rig floor, m): 2702.9

Number of cores (including cores having no recovery): 27

Total core recovered $(\mathbf{m}): 33.25$

Core recovery $(\%): 13.4$

Oldest sediment cored:

Depth (mbsf): 247.9

Nature: sandstone, claystone, and siltstone

Principal results: The lithostratigraphic characterization of the Bent Hill Massive Sulfide (BHMS) deposit, which was initiated during Leg 139 and continued during Leg 169, is one of the most remarkable achievements of the Ocean Drilling Program (ODP). Eight new holes (Holes 1035A through 1035H) were drilled in the vicinity of BHMS to assess the thickness and lateral extent of the massive sulfide and to determine the nature of the hydrothermal feeder zone in sediments and basalt underlying the deposit. Hole $856 \mathrm{H}$, which had been drilled during Leg 139 to a depth of $93.8 \mathrm{~m}$ before abandonment because of unstable hole conditions, also was deepened to 500.0 meters below seafloor (mbsf).

The BHMS deposit is the result of a complex interaction between hemipelagic and turbiditic sedimentation, igneous activity, and hydrothermal circulation. The deposit includes iron- and zinc-rich massive and semi-massive sulfides; a well-developed feeder zone characterized by sulfide impregnations and crosscutting copper-rich veins; and a deep copperrich zone that may be an important conduit for lateral fluid flow. Hydrothermal alteration provides a record of past and present fluid flow and is controlled by small variations in lithology and large-scale variations in sedimentary facies. The Ore Drilling Program (ODP) Mound, referred to in the Ocean Drilling Program Leg 169 Scientific Prospectus (an informal publication through ODP) as the Sunnyside-Up Deposit, is $350 \mathrm{~m}$ south of the BHMS and is significantly enriched in $\mathrm{Zn}$ compared to the BHMS. It is not clear if it is correlative with the BHMS or a product of a spatially and temporally separate hydrothermal system. However, pore-water compositions suggest that both mounds are presently underlain by similar hydrothermal fluids. Drilling at Site 1035 created two new hydrothermal vents, Holes $1035 \mathrm{~F}$ and $1035 \mathrm{H}$, from which hydrothermal fluids were vigorously expelling when we left this location. Seven lithologic units have been recognized as follows:

Unit I: hemipelagic sediment (Holocene and upper Pleistocene) 
Unit II: interbedded turbidites and hemipelagic sediments (Pleistocene) Unit III: clastic sulfides

Unit V: massive and semi-massive sulfides

Unit VI: sulfide feeder zone and mineralized sediments

Unit VII: basaltic sills intruded into sediments

Unit VIII: basaltic flows

Hole $856 \mathrm{H}$ can be considered as a reference section where all major lithologies were drilled; this includes $93.8 \mathrm{~m}$ of massive sulfide drilled during Leg 139. During Leg 169, pyrrhotite/pyrite massive sulfide was drilled from the lower part of the mound between 93.8 and 103.6 mbsf. The underlying feeder zone (lithologic Unit VI) is divided into three subunits. Subunit VIA is sulfide-veined siltstone and mudstone (103.6-152.9 mbsf) where major sulfides are isocubanite, chalcopyrite, and pyrrhotite occurring in vertical veins. Subunit VIB (152.9-201 mbsf) consists of sediments with only minor disseminated sulfides and veins. Subunit VIC (201-210.6 mbsf) is a sulfide-banded sandstone highly enriched in copper relative to the overlying mineralization and is informally called the Deep Copper Zone (DCZ). The next unit, Unit II (210.6-431.7 mbsf), is nonmineralized to slightly mineralized turbidites. The contact with the overlying DCZ is extremely sharp. There is evidence for a fault from drilling rates and the Formation MicroScanner (FMS). Based on hydrothermal alteration and color, three units are identified in these turbidites. Subunit IIA is relatively unaltered sediment occurring at the upper part (210.6-249.0 mbsf) and the lower part (307.7-431.7 mbsf) of the unit and consists of gray fine sandstone. Between these two intervals is the characteristic greenish gray siltstone and mudstone containing abundant chlorite of Subunit IID (249.0-307.7 mbsf). The next unit, Unit VII (431.7-471.3 mbsf), is a basaltic sill-sediment complex where igneous rocks are variably altered and crosscut by veins containing quartz, chalcopyrite, pyrrhotite, sphalerite, calcite, and epidote. The underlying basaltic flows (Unit VIII, 471.1-500 mbsf) are similar in mineralogy and alteration to the sill unit.

Holes $1035 \mathrm{~A}$ though $1035 \mathrm{G}$ were drilled east to west $(1035 \mathrm{~A}, 1035 \mathrm{D}$, and 1035G) and north to south (Holes 1035B, 1035C, 1035F, and 1035E) as transects. The general lithostratigraphy recognized in these cores is interbedded clastic sulfides of Unit III (likely shed from the mound), which in some cores are interlayered with hemipelagic and turbiditic sediment of Unit I. In the more distal holes (relative to the mound), these strata are underlain by Unit II hemipelagic and turbiditic sediments. Holes $1035 \mathrm{~F}$ and $1035 \mathrm{C}$ (closest to the mound in the transect to the south) contained massive to semi-massive sulfides underneath the clastic debris. Massive to semi-massive sulfides (Unit V) were also recovered from the more distal holes (Holes 1035A, 1035D, and 1035G), although these units were thinner and recovered from a greater depth than in cores taken closer to the mound. A distinct asymmetry has been recognized in the distribution of feeder zone mineralization below the massive sulfides. In the east-west transect, the massive sulfides are underlain by hemipelagic and turbiditic sediments, and all the holes terminated in sediment with weak sulfide veining and impregnation. The north-south transect is characterized by more intense mineralization of sediments below the massive sulfide and more intense development of a sulfide feeder zone. This zone is particularly enriched in copper with some samples containing more than $16 \mathrm{wt} \%$ copper.

Hole $1035 \mathrm{H}$ was drilled on a relatively flat bench $\sim 8 \mathrm{~m}$ from the top of the southern peak of the ODP massive sulfide mound. The only previously known active venting in the Bent Hill area is located $50 \mathrm{~m}$ away at the north end of this mound and consists of a single anhydrite chimney issuing fluid at $264^{\circ} \mathrm{C}$. Hole $1035 \mathrm{H}$ intersected $248 \mathrm{~m}$ of a relatively complex sequence comprising three massive sulfide zones interbedded with feeder zones and weakly mineralized sediments, suggesting multiple episodes of mineralization. Zinc content is significantly higher than in the core of the BHMS, and several analyzed samples contained more than $40 \% \mathrm{Zn}$. The underlying copper-rich mineralization is also generally higher grade than observed under BHMS.

With few exceptions, all hydrothermal veins recovered are extensional and typically a few millimeters wide. Structural measurements indicate the stockwork was formed by multiple increments of hydraulic fracturing caused by periodic changes in pore pressure and mineral infilling. Subvertical veins dominate, but subhorizontal veins are not uncommon. There is no structural evidence in the recovered core of major faulting.

Most constituents of the pore fluids display only minor changes with depth. Increasing $\mathrm{Ca}, \mathrm{Sr}$, and sulfate is explained by retrograde dissolution of anhydrite caused by decreasing temperature. A slight chloride maximum at $\sim 25 \mathrm{mbsf}$ is interpreted as a remnant of the higher chloride content of seawater during the last glaciation. In Hole $1035 \mathrm{~A}, \mathrm{Cl}$ concentration shows a gradual increase with depth and a steep decrease below $150 \mathrm{mbsf}$. This decrease is explained by an increasing contribution of a lower salinity hydrothermal fluid that appears to be characteristic of the Bent Hill area. This fluid is distinct from the higher salinity fluid associated with the nearby Dead Dog Vent Field (DDVF). It is possible that there is lateral advection of the Bent Hill hydrothermal fluid below the depth of an extensive silicified layer interpreted as an impermeable barrier. Pore fluid sampled below this horizon shows strong similarities with the hydrothermal fluid venting from the north end of ODP Mound. Penetration of this suspected cap rock in Hole 1035F may have been responsible for initiation of hydrothermal venting from this hole (see video on CD-ROM, this volume)

Headspace measurements indicate that hydrocarbon gas is moving advectively through the subsurface and had reentered Hole $856 \mathrm{H}$ prior to our deepening this hole. Extractable bitumen shows accelerated maturation because of high heat flow, but low concentrations indicate in situ alteration without migration.

Natural gamma and magnetic susceptibility records for the upper $40 \mathrm{~m}$ of core from Holes 1035A, 1035D, and 1035E can be correlated to provide constraints on the original sedimentary record. Significant features of the deeper Multisensor Track (MST) records include high magnetic susceptibility associated with the DCZ in many of the holes and a high natural gamma count in this zone in Hole $1035 \mathrm{H}$. Index properties measurements show low porosity in sediments located below the DCZ in the cores from Holes $1035 \mathrm{G}, 1035 \mathrm{H}$, and $856 \mathrm{H}$.

Rock magnetic parameters, particularly in Hole $856 \mathrm{H}$, reflect the varying lithologic units by abrupt changes in magnetic mineralogy. These data show a transitional shift down section from high concentrations of hematite to low concentrations of magnetite associated with an increase in paramagnetic minerals such as pyrrhotite and pyrite.

In general, foraminifer preservation at Site 1035 is poor. Foraminiferbearing sediments are found only in the upper $25 \mathrm{~m}$ or shallower at Holes $1035 \mathrm{~A}$ through 1035E. The Holocene/Pleistocene boundary was found in three holes at Site 1035, but no other biostratigraphic horizons were found during shipboard study. The dextral coiling event of Neogloboquadrina pachyderma during the penultimate interglacial period at $\sim 125 \mathrm{ka}$ occurs at $\sim 20 \mathrm{mbsf}$ in Hole 856A at the top of Bent Hill; however, it was not observed at Site 1035 at that depth below seafloor, where fossil preservation is moderate to poor and occurrence is sporadic, perhaps because of alteration.

Two successful logging runs were completed in Hole $856 \mathrm{H}$. The Triple Combination and FMS combination tools were used to define five logging stratigraphic units, based on differing response to electrical resistivity, density, sonic velocity, and gamma ray attenuation. FMS images of the stockwork sulfide veining underlying the massive sulfide demonstrate the intensity of mineralization in this interval, but do not indicate strong preferred orientation of the veins. Below the stockwork (220-270 mbsf), the images suggest that the hole could have intersected a large fault dipping to the west at $\sim 50^{\circ}$. FMS images at the bottom of the hole suggest the presence of basaltic pillows.

\section{INTRODUCTION Geological Setting}

The BHMS deposit is located in the eastern part of Middle Valley $3 \mathrm{~km}$ west of the eastern rift-bounding normal (Fig. 1). Extrapolation of the spreading rate suggests that the deposit is located over oceanic crust that dates to $\sim 320 \mathrm{ka}$ (Davis and Villinger, 1992). Bent Hill is 


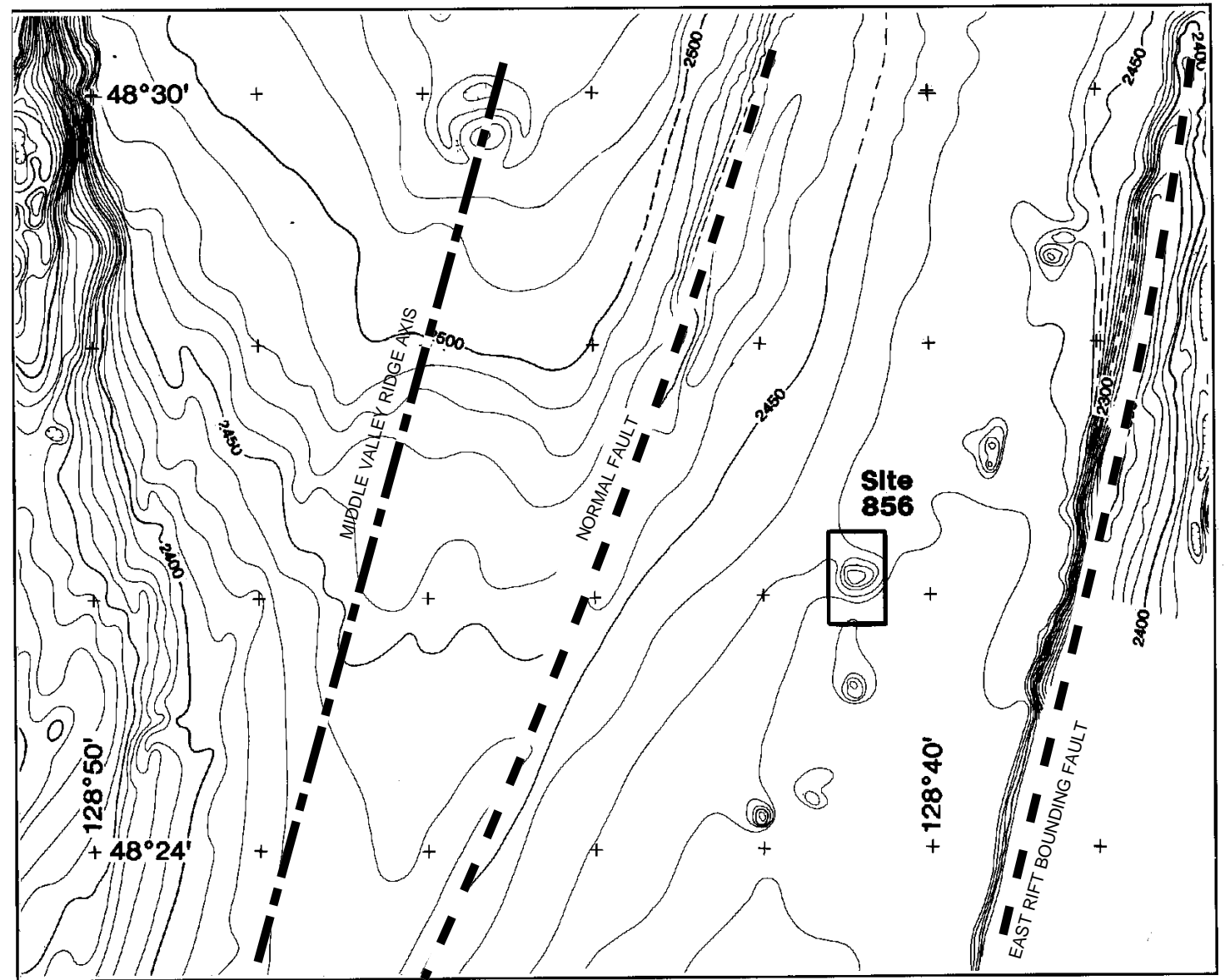

Figure 1. Seabeam bathymetry of Middle Valley (Shipboard Scientific Party, 1992b). The location of Bent Hill is outlined (see details on Fig. 2).

one of a series of hills developed along the eastern side of the rift valley (Fig. 1). Bent Hill is $\sim 400 \mathrm{~m}$ in diameter and rises $50 \mathrm{~m}$ above the smooth turbiditic sediment that fills Middle Valley. The steep scarp that forms the western flank of Bent Hill exposes semilithified turbiditic sediment and may be fault-controlled (Fig. 2; Goodfellow and Franklin, 1993; Davis, Mottl, Fisher, et al., 1992).

The rapid rate of the infilling of Middle Valley by turbidite sedimentation requires that Bent Hill was uplifted relatively recently. A bright seismic reflector underlying the hill at a depth of $120 \mathrm{~ms}$ twoway traveltime (TWT) was confirmed by drilling during Leg 139 to be the result of basaltic sills (Rohr and Schmidt, 1994). The uplift of Bent Hill may be because of the intrusion of a sill or laccolithic plug, as has been proposed for similar features observed at Guaymas Basin (Lonsdale and Becker, 1985) and Escanaba Trough (Morton et al., 1987; Zierenberg et al., 1994b). Depth to acoustic basement in the surrounding region is considerably greater, typically $400-500 \mathrm{~m}$ (Fig. 3; Rohr and Schmidt, 1994), and is interpreted to represent the uppermost igneous unit in the sill-sediment complex that marks the transition to oceanic crust in this sedimented rift environment (Davis, Mottl, Fisher, et al., 1992).

A ridge of massive sulfide that rises $35 \mathrm{~m}$ above the surrounding turbidite fill of the valley is located $\sim 100 \mathrm{~m}$ south of the southern edge of Bent Hill and is referred to here as the BHMS deposit. The massive sulfide mound is extensively weathered to iron oxyhydroxides and partially buried by sediment. Massive sulfide extends a minimum distance of $60 \mathrm{~m}$ north-south and $90 \mathrm{~m}$ east-west. The precise size of the deposit is not known, but a large-amplitude, short wavelength magnetic anomaly over the sulfide mound has been modeled to predict that the deposit is $300 \mathrm{~m}$ in diameter and that mineralization extends $120 \mathrm{mbsf}$ (sphere model) to $180 \mathrm{mbsf}$ (pipe model; Tivey, 1994).

A second mound of massive sulfide occurs $\sim 300 \mathrm{~m}$ further south and is referred to here as the Ore Drilling Program (ODP) Mound. This deposit may be located above the southern extension of the fault that was postulated to bound the west side of Bent Hill, but the fault has not been imaged seismically. The morphology, degree of oxidation, and sediment cover indicate that this deposit is younger than the BHMS deposit. A single $264^{\circ} \mathrm{C}$ hydrothermal vent is present on the north flank of this deposit. Contoured heat-flow values for the Bent Hill area show high values centered around this active vent.

Hydrothermal fluids responsible for the formation of the BHMS may have been heated either locally by the intrusion of basalt beneath Bent Hill, or the fluid could be derived from a more regional, hightemperature reservoir developed by convective circulation in the upper igneous crust developed beneath the relatively impermeable sediment fill (Davis and Fisher, 1994). The negative magnetic anomaly of the crust at Middle Valley has been interpreted as resulting from extensive hydrothermal alteration beneath the hydrologic sediment seal (Currie and Davis, 1994). Mass- and heat-balance calculations indicate that a volume of $<1 \mathrm{~km}^{3}$ of hot rock or magma would be sufficient to supply the heat and mass of sulfur for a 1-million-ton deposit (Davis and Fisher, 1994).

\section{Biostratigraphy}

Biostratigraphic zonation of late Quaternary sequences (Brunhes Chron, $0-0.78 \mathrm{Ma}$ ) is poorly known in the subarctic North Pacific Ocean and areas of the eastern Pacific Ocean influenced by the Cali- 


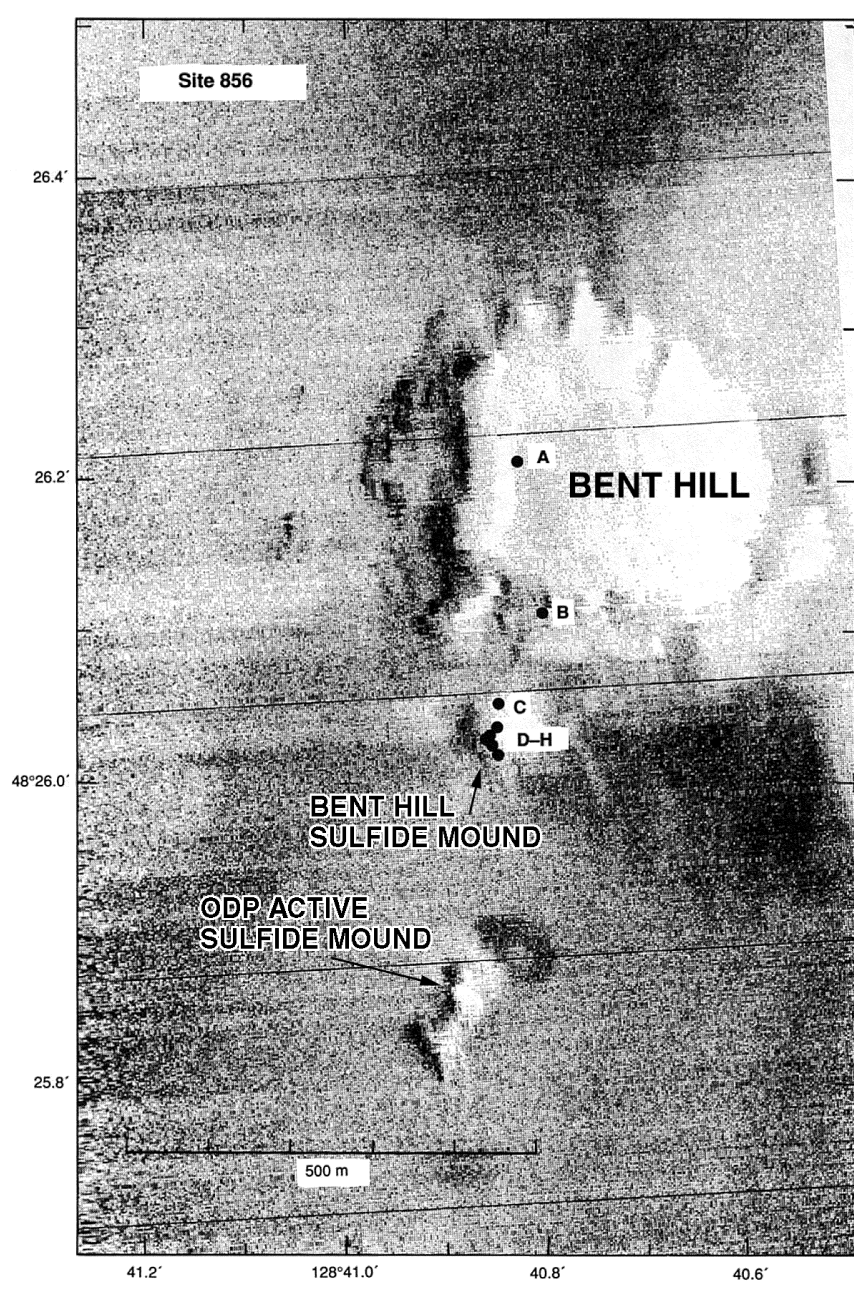

Figure 2. SeaMARC I side-scan acoustic image of Bent Hill (Shipboard Scientific Party, 1992b) showing the location of holes drilled on Leg 139, Site 856.

fornia Current. Little well-preserved material older than the latest Pleistocene has been recovered by conventional coring; because the calcium carbonate compensation depth is shallow in the northeast $\mathrm{Pa}$ cific Ocean (4400 $\mathrm{m}$ during glacial periods and $2600 \mathrm{~m}$ during interglacial periods; Karlin et al., 1992), the seafloor has few bathymetric highs beneath transitional and subarctic waters, and sedimentation rates are fast in shallow areas, often greater than $\sim 20 \mathrm{~cm} / \mathrm{k} . \mathrm{y}$. because of dilation with terrigenous sediment derived from the continental margin. At present, interglacial assemblage zones are reported only from the climatic optima of the Holocene and oxygen isotope Stage 5e along the California continental margin (Brunner, 1994; Kennett and Venz, 1995; Brunner and Ledbetter, 1989, and references therein), and none are yet reported from older Brunhes interglacial periods, though data from slow sedimentation rate cores suggest that such assemblages occur (Moffett, 1995).

The high-latitude zonation is fraught with other difficulties. The zonation at Middle Valley is limited to planktonic foraminifers, principally because other microfossils, such as diatoms, radiolarians, and calcareous nannofossils, are poorly preserved in the hydrothermal setting. The zonation relies on assemblage zones rather than evolutionary first and last appearances, because there have been no such events among the planktonic foraminifers of the subarctic during the late Quaternary.

Interglacial periods in the late Quaternary are flagged by a transitional assemblage of planktonic foraminifers (Bradshaw, 1959) dom- inated by dextrally coiled Neogloboquadrina pachyderma with abundant Turborotalita quinqueloba and traces of warm-water species, such as Globorotaloides hexagonus, which appear at the closest approach of the polar front during climatic optima (Moffett, 1995). The present Holocene interglacial is tentatively called CD1 (Coiling Direction Zone 1) and succeeding older interglacial assemblages will be designated $\mathrm{CD} 3, \mathrm{CD} 5, \ldots, \mathrm{CD}(n)$. Intervening glacial assemblages dominated by sinistral N. pachyderma will be designated CD2, CD4, ..., $\mathrm{CD}(n+1)$ following the convention of Lagoe and Thompson (1988). The nominal Pleistocene boundary of the western boundary current of the northeast Pacific Ocean is based on the shallowest sinistral to dextral coiling change in N. pachyderma (Bandy, 1960). The age of this event at the eastern end of the polar front is somewhat uncertain, because the event transgresses time between $\sim 15$ and 8 k.y. from Santa Barbara to some point south of Middle Valley.

The interglacial events at Middle Valley are quite short in time and space, typically involving $<1$ to $4 \mathrm{~m}$ of sediment in depth, so they can easily be missed when sampling intervals are as course as one per section or one per core. More detailed shore-based work may prove fruitful where shipboard work has failed to discover pre-Holocene interglacial assemblage zones.

\section{Principal Results Obtained During Leg 139}

During Leg 139, two holes (Holes 856A and 856B) were drilled at the top of Bent Hill, and six holes (Holes $856 \mathrm{C}$ through $856 \mathrm{H}$ ) were drilled on the BHMS (Figs. 3, 4). Both of the holes drilled on Bent Hill ended in the top of an olivine-rich basaltic sill encountered at 112 mbsf and 121 mbsf at Holes 856A and 856B, respectively. Hydrothermally altered sediments were recovered in both holes, and temperature and intensity of alteration increased in the direction of the massive sulfide mound (Goodfellow and Peter, 1994; Fig. 4). Holes $856 \mathrm{G}$ and $856 \mathrm{H}$ penetrated 65.1 and $93.4 \mathrm{~m}$ of massive sulfide, respectively, establishing that the BHMS deposit was a significant accumulation of sulfide. The surface of the mound consists of angular blocks of oxidized sulfide rubble near the summit and interbedded hemipelagic sediments and clastic sulfides on the flanks. Important questions that remained unanswered after Leg 139 were the vertical extent of the sulfide mineralization and the nature of mineralization and alteration in the rocks underlying the sulfide deposit. Drilling during Leg 139 established that the base of the deposit was, at minimum, $60 \mathrm{~m}$ below the present turbidite fill of the Middle Valley. All mineralogical, textural, and geochemical studies on the recovered core suggest that the majority of the deposit was formed near or above the seafloor and not by sediment replacement. Downhole geochemical and electrical resistivity logging supports this interpretation. The FMS confirmed the presence of numerous filled and open fractures in the massive sulfide. The lack of interbedded sediment argues for rapid growth of sulfide relative to turbidite deposition. Stratigraphic relationships and other evidence suggest that the massive sulfide mound began to form in the Pleistocene, whereas Bent Hill was uplifted in the Holocene (Mottl et al., 1994).

Mineralogical composition, textures of the primary sulfides, and fluid inclusion homogenization temperatures (Goodfellow and Peter, 1994; Peter et al., 1994) suggest that the BHMS deposit formed by venting of $350^{\circ}$ to $400^{\circ} \mathrm{C}$ fluid at or near the seafloor and are consistent with the derivation of metals from basaltic source rocks. Low concentrations of $\mathrm{As}, \mathrm{Sb}, \mathrm{Pb}, \mathrm{Sr}$, and $\mathrm{He}$ isotopic compositions of the BHMS suggest that the hydrothermal fluid that formed the BHMS deposit did not derive significant amounts of metals from sedimentary source rocks (Shipboard Scientific Party, 1992b; Ames et al., 1993; Goodfellow and Franklin, 1993; Duckworth et al., 1994; Goodfellow and Peter, 1994; Krasnov et al., 1994; Stuart et al., 1994a) and seem to preclude reaction of the fluid with sediments at high temperature (Shipboard Scientific Party, 1992b). The fluids that formed the BHMS deposit were clearly distinct from those that are presently venting in Middle Valley, which are interpreted to be derived from a regional hydrother- 


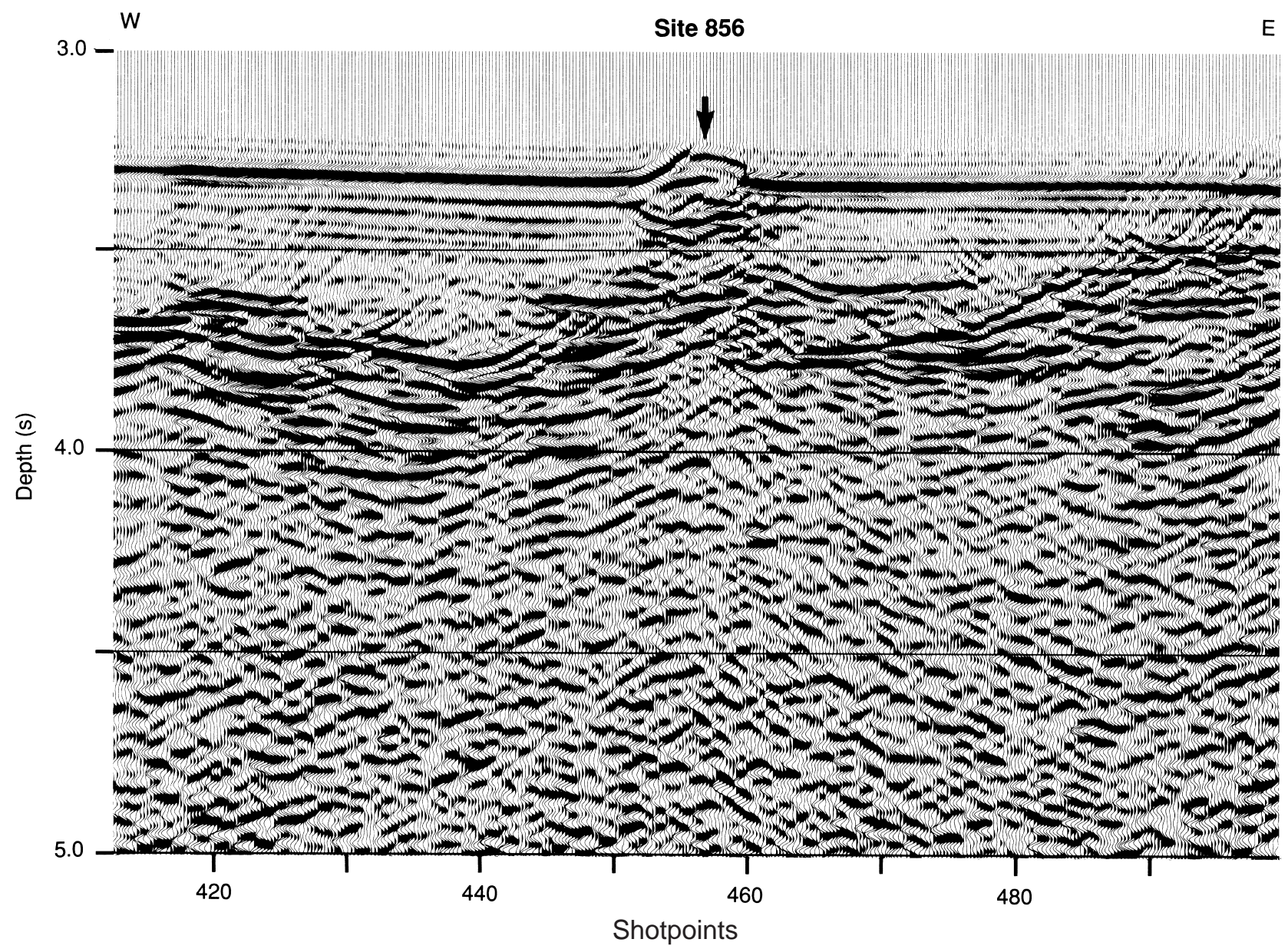

Figure 3. Detailed seismic reflection Profile 89-14 crossing Site 856 (Shipboard Scientific Party, 1992b).

mal reservoir developed in and below the sediment-sill complex that forms the uppermost part of the oceanic crust at this sediment-covered spreading center. However, both systems have a relatively heavy sulfur isotopic composition of sulfide minerals (6\%o; Zierenberg, 1994; Duckworth et al., 1994), indicating a mixed source of sulfur, including basalt and reduced seawater sulfate. A late stage hydrothermal episode overprints the primary pyrrhotite-wurtzite-isocubanite with a pyritemagnetite assemblage. Fluid inclusions in secondary quartz and carbonate are consistent with formation from a fluid with a temperature similar to fluids currently venting from the regional reservoir. Goodfellow and Peter (1994) and Duckworth et al. (1994) suggest that fluids from the primary high temperature (basaltic) reaction zone mixed with fluid from hydrothermal basement (sediment-sill complex) to produce fluid that formed the BHMS deposit (Fig. 5).

\section{Objectives}

Several scientific questions concerning the formation of the sulfide deposits were unanswered after the completion of Leg 139 and were major objectives for Leg 169. This included the study of the vertical and lateral extent and compositional variability of sulfide mineralization and wall rock alteration. To document the timing and growth history of the sulfide mound, drilling was undertaken on the flanks of the BHMS deposit, where the sedimentary record of hydrothermal activity was likely to be preserved. Drilling of the alteration zones beneath the deposit was completed to constrain the sources of metals in the deposit and geochemical reactions that control mineral- ization. Detailed objectives include the determination of the following:

1. Mechanism of the formation of the BHMS deposit;

2. Size and geometry of the mound;

3. Vertical extent of massive sulfide;

4. Type, zonation, and extent of hydrothermal alteration in the stockwork zone under the sulfide mound;

5. Extent, composition, and zonation of alteration lateral to the deposit;

6. Lateral and vertical mineralogical, textural, and compositional zonation of the hydrothermal precipitates;

7. Mechanisms that focus hydrothermal flow including formation of cap rocks, intrusion of sills, and faulting;

8. Sources of metals and geochemical reactions that control mineralization;

9. Constraints on fluid temperatures and compositions;

10. Timing and duration of hydrothermal activity by clastic deposition of sulfides shed from the mound in the sediment record;

11. Mechanism of mound growth and maturation and the relative importance of subsurface precipitation and recrystallization vs. growth at the surface via chimney formation;

12. Tectonic controls of fossil fluid flows;

13. Controls on igneous activity and the importance of sill emplacement;

14. Permeability and structural controls on hydrothermal circulation; 


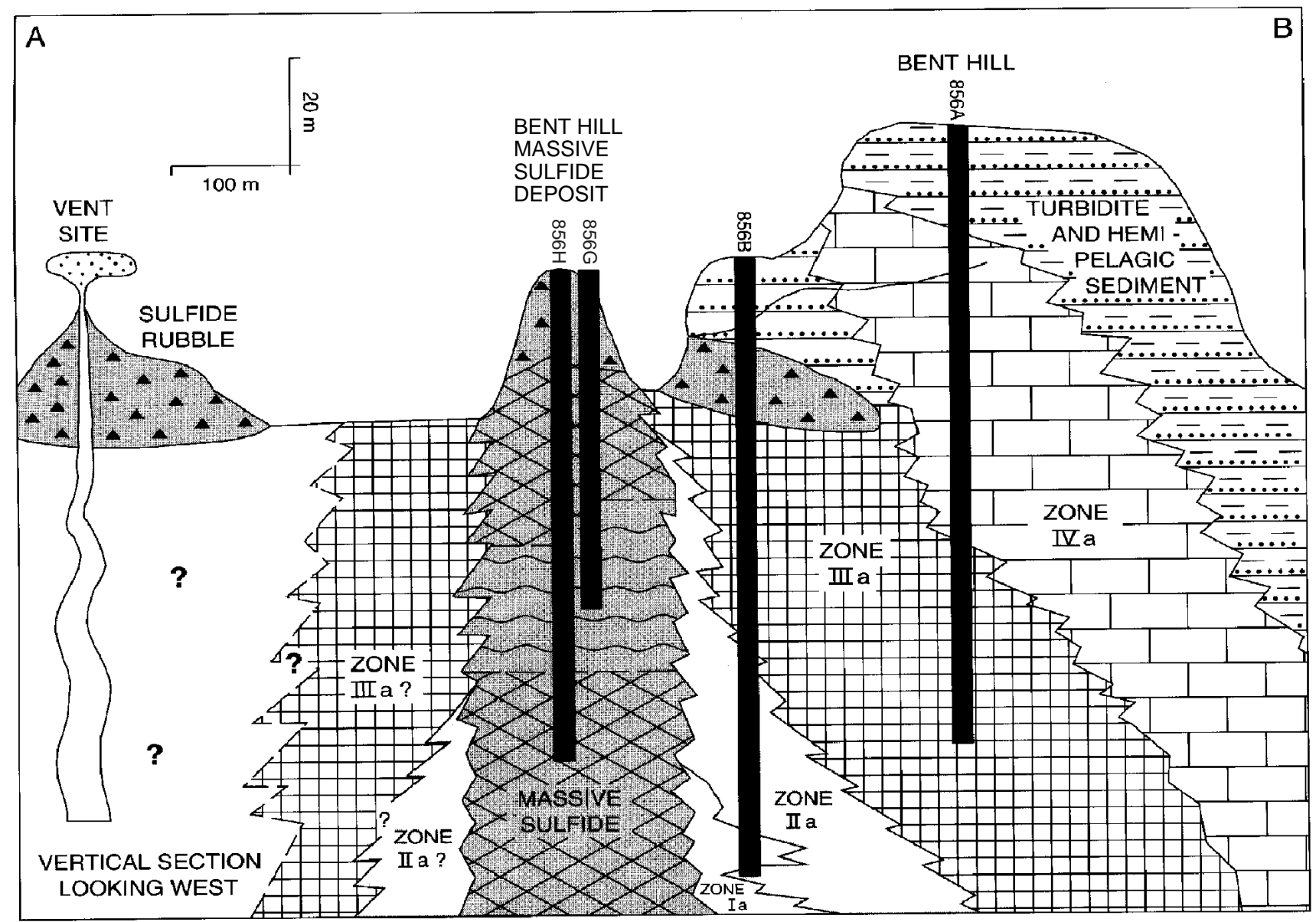

Figure 4. South-north cross section (A-B) of the Bent Hill and BHMS deposit showing the major stratigraphic units, brecciated and fracture-indurated sediment, and the distribution of the major hydrothermal alteration assemblages relative to Bent Hill and the adjacent massive sulfide deposit. Mineralogy of alteration zone is as follows: Zone Ia (quartz-chlorite-muscovite-rutile-pyrrhotite-chalcopyrite), Zone IIa (albite-chlorite-muscovite-pyrite), Zone IIIa (anhydriteillite-pyrite), and Zone IVa (calcite-illite-pyrite; Goodfellow and Peter, 1994). See plan view and position of holes on Figure 2.

15. Source and deposition rate of sediments;

16. Diagenetic reactions in a high heat-flow regime;

17. Organic matter alteration and generation of hydrothermal petroleum; and

18. Role of bacteria in oxidation of organic matter and oxidation of sulfides.

\section{OPERATIONS SUMMARY}

Operations around the BHMS deposit consisted of deepening Hole $856 \mathrm{H}$ and drilling eight new holes to systematically characterize massive sulfide mineralization in this area. For more details on operational parameters (drill-string configurations, time expended on operations, and drilling conditions, etc.) the reader is referred to the Operations Data Appendix on CD-ROM in the back pocket of this volume.

\section{Hole 856H}

This hole had been drilled during Leg 139 to a depth of $93.8 \mathrm{~m}$ before it was abandoned because of unstable hole conditions. Our plan was to attempt to deepen this hole through the massive sulfide deposit sampled during Leg 139 and into the underlying alteration zone. We surmised that circulation of oxygenated seawater into the borehole during the last $5 \mathrm{yr}$ may have altered the pyrrhotite/pyrite massive sulfide assemblage to iron oxide/oxyhydroxide, effectively stabilizing the borehole wall. After reentry with a rotary core barrel (RCB) bottom-hole assembly (our only option as this hole was initiated with the same configuration), we successfully recovered 47 cores sampling the interval from 93.8 to 500.0 mbsf (Cores 169-856H-19R through $65 \mathrm{R}$ ). Overall recovery was just over $12 \%$ (see Table 1 ), probably caused by fragments of the core jamming in the core catcher. However, we experienced significantly higher recovery rates (34\% in nine cores) when the core barrel was retrieved prior to full penetration of a joint of drill pipe. Coring operations ended on $28 \mathrm{Au}-$ gust, when the scientific objectives had been achieved and the time allocated for this operation had expired.

Logging operations began with a temperature run to evaluate which tools would be operable in what was expected to be a particularly hostile (high-temperature) environment. A ledge prevented the Bureau de Recherches Géologiques et Minières (BRGM) high-temperature wireline probe from logging to the bottom of the hole, so hole cleaning operations were initiated. Although we had dropped the first bit on the seafloor to allow future deepening of Hole $856 \mathrm{H}$, the hole-cleaning operation ended with dropping the bit in the bottom of the hole to avoid pulling the drill string out of an unstable hole. Three logging runs were made. The Triple Combo (natural gamma, density, porosity, and resistivity), was deployed first, followed by the FMS/ sonic string, and finally, after circulating to cool the hole, a second run of the FMS/sonic string was made. Internal temperature monitors on these tools, however, indicated that it would be imprudent to con- 


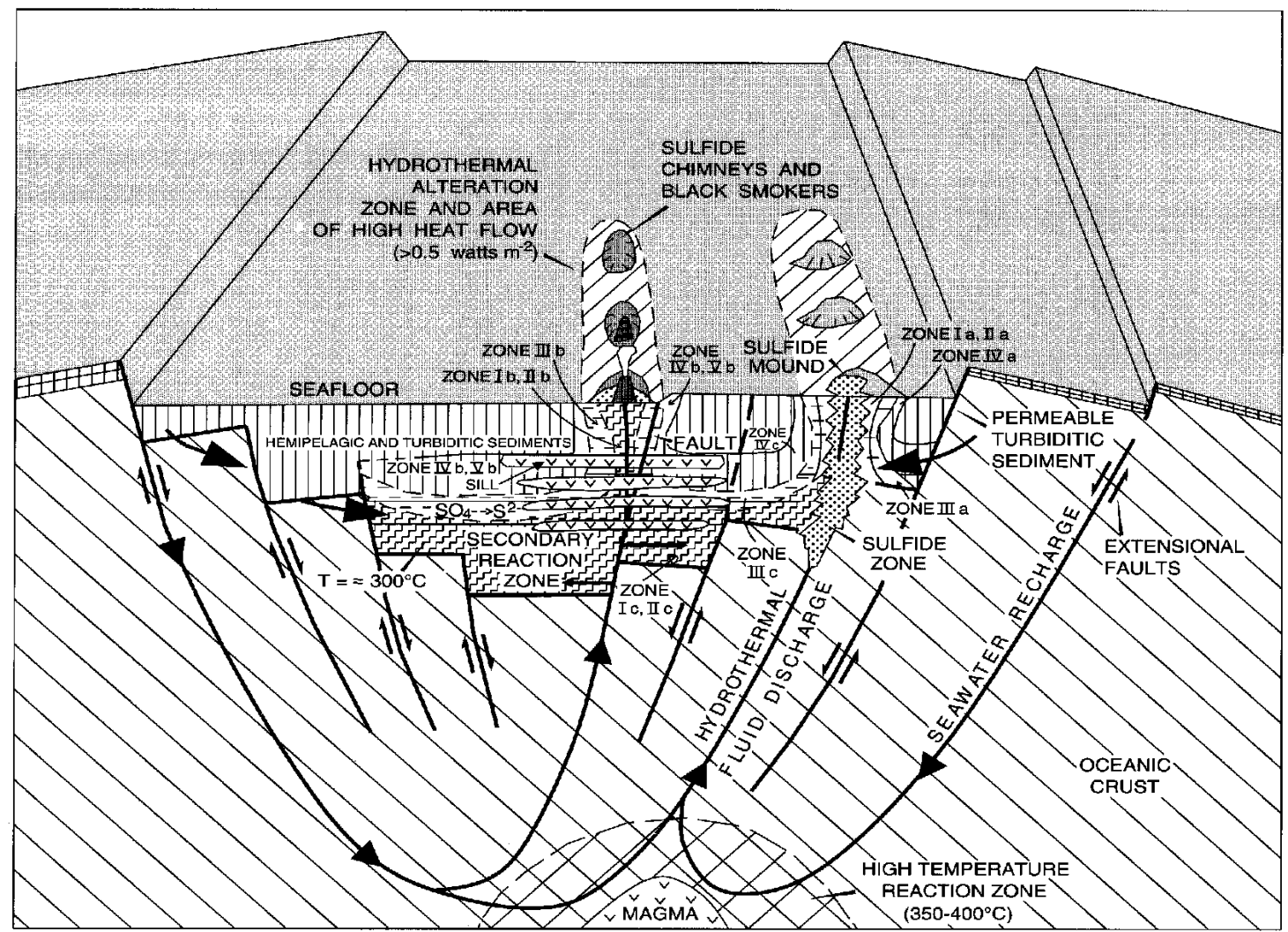

Figure 5. Schematic block diagram of the Middle Valley hydrothermal system showing the inactive BHMS deposit and related alteration zone (Site 856) at the eastern side of the valley; and the active Dead Dog hydrothermal field and associated alteration and reaction zones. Also shown is an inferred high-temperature reaction zone associated with magma body at depth (Goodfellow and Peter, 1994).

tinue logging operations with the more temperature sensitive geochemical tool, so logging operations were terminated.

During one of the pipe trips made for cleaning Hole $856 \mathrm{H}$, the ship was moved in dynamic positioning (DP) mode to the DDVF to launch two Pop-Up Pore Pressure Instruments (PUPPIs). These instruments are programmable memory tools with pressure-sensing probes that penetrate $3 \mathrm{~m}$ into the seafloor sediment. The devices record differential pore pressure between two ports on the embedded probes. Installation and recovery of the PUPPIs were operations similar to the deployment and recovery of site transponder beacons. They were deployed by dropping them over the side of the JOIDES Resolution. After release on the differential Global Positioning System (dGPS) coordinates, the PUPPIs were acoustically tracked to the bottom. Upon completion of operations at the Dead Dog area, a coded acoustic signal initiated severing of the data loggers from the probes, and the data loggers floated to the sea surface and were recovered by the ship before leaving the Dead Dog area. This release operation was undertaken during a pipe trip to maximize efficient use of ship time.

\section{Hole 1035A}

This hole is located $77 \mathrm{~m}$ west of Hole $856 \mathrm{H}$ and $\sim 40 \mathrm{~m}$ west of the positive topographic expression of the BHMS deposit $\left(48^{\circ} 26.020^{\prime} \mathrm{N}, 128^{\circ} 40.922^{\prime} \mathrm{W} ; 2445 \mathrm{~m}\right.$ water depth). Advanced piston corer (APC) Cores $169-1035 \mathrm{~A}-1 \mathrm{H}$ through $6 \mathrm{H}(0.0-55.0 \mathrm{mbsf})$ and extended core barrel (XCB) Cores 169-1035A-7X through 11X (55.0-99.4 mbsf) were taken with $\sim 85 \%$ recovery (Table 1). Temperatures were measured with the Adara tool after Cores $169-1035 \mathrm{~A}-3 \mathrm{H}$ (26.5 mbsf) and $169-1035 \mathrm{~A}-6 \mathrm{H}$ (55 mbsf), and a water sampler temperature probe (WSTP) measurement was taken after Core 169$1035 \mathrm{~A}-4 \mathrm{H}$ (36.0 mbsf).

\section{Hole 1035B}

This hole was initiated $50 \mathrm{~m}$ south of Hole $856 \mathrm{H}\left(48^{\circ} 25.992^{\prime} \mathrm{N}\right.$, $128^{\circ} 40.862^{\prime} \mathrm{W} ; 2448 \mathrm{~m}$ water depth). APC Core 169-1035B-1H was a partial stroke, and the core barrel could not be retrieved. The Vibration-Isolated Television (VIT) camera was run to check on the status of the core barrel. The barrel was obviously bent, so the drill pipe was pulled. Once the core barrel was on deck, a small mud scraping was taken for paleontological reference, and the sample was curated as Core $169-1035 \mathrm{~B}-1 \mathrm{H}$, although there was no apparent penetration.

\section{Hole 1035C}

Hole $1035 \mathrm{C}$ was initiated with the XCB system at the same location as Hole $1035 \mathrm{~B}\left(48^{\circ} 25.992^{\prime} \mathrm{N}, 128^{\circ} 40.862^{\prime} \mathrm{W} ; 2448 \mathrm{~m}\right.$ water depth) because of the hard massive sulfides that were probably the cause of the APC refusal during the first stroke of Hole 1035B. XCB Cores $169-1035 \mathrm{C}-1 \mathrm{X}$ through $5 \mathrm{X}$ were taken from 0.0 to $44.0 \mathrm{mbsf}$ with $5 \%$ recovery (Table 1). After Core 169-1035C-5X, $7 \mathrm{~m}$ of fill was observed in the bottom of the hole, and torque increased despite circulation of a mud sweep. The pipe was pulled because the hole was unstable and caving in. The bit cleared the seafloor at $2050 \mathrm{hr}$ on 12 September, ending Hole 1035C.

\section{Hole 1035D}

The drill pipe was offset to the eastern side of the BHMS deposit at $48^{\circ} 26.021^{\prime} \mathrm{N}, 128^{\circ} 40.799^{\prime} \mathrm{W} ; 2448 \mathrm{~m}$ water depth, $75 \mathrm{~m}$ east of Hole $856 \mathrm{H}$. APC Cores $169-1035 \mathrm{D}-1 \mathrm{H}$ through $5 \mathrm{H}$ were taken from 0.0 to 40.6 mbsf with $110 \%$ recovery. Core $169-1035 \mathrm{D}-5 \mathrm{H}$ was a partial stroke, and coring changed to the XCB system. XCB Cores 1691035D-6X through 7X were taken from 40.6 to 57.7 mbsf with $3 \%$ 
Table 1. Coring summary, Bent Hill sites.

\begin{tabular}{|c|c|c|c|c|c|c|c|c|c|c|c|c|}
\hline Core & $\begin{array}{c}\text { Date } \\
(1996)\end{array}$ & $\begin{array}{l}\text { Time } \\
\text { (UTC) }\end{array}$ & $\begin{array}{l}\text { Depth } \\
\text { (mbsf) }\end{array}$ & $\begin{array}{l}\text { Length } \\
\text { cored } \\
(\mathrm{m})\end{array}$ & $\begin{array}{l}\text { Length } \\
\text { recovered } \\
(\mathrm{m})\end{array}$ & $\begin{array}{c}\text { Recovery } \\
(\%)\end{array}$ & Core & $\begin{array}{c}\text { Date } \\
(1996)\end{array}$ & $\begin{array}{l}\text { Time } \\
\text { (UTC) }\end{array}$ & $\begin{array}{l}\text { Depth } \\
\text { (mbsf) }\end{array}$ & $\begin{array}{l}\text { Length } \\
\text { cored } \\
(\mathrm{m})\end{array}$ & $\begin{array}{l}\text { Length } \\
\text { recovered } \\
(\mathrm{m})\end{array}$ \\
\hline $169-856 \mathrm{H}-$ & & & & & & & $2 \mathrm{H}$ & 13 Sept. & 0855 & $5.1-14.6$ & 9.5 & 10.04 \\
\hline $18 \mathrm{~W}$ & 25 Aug. & 0030 & $0.0-93.8$ & 93.8 & 0.11 & (wash core) & $3 \mathrm{H}$ & 13 Sept. & 1000 & $14.6-24.1$ & 9.5 & 9.85 \\
\hline $19 \mathrm{R}$ & 25 Aug. & 0300 & $93.8-103.6$ & 9.8 & 0.45 & 4.6 & $4 \mathrm{H}$ & 13 Sept. & 1245 & $24.1-33.6$ & 9.5 & 10.02 \\
\hline $20 \mathrm{R}$ & 25 Aug. & 0455 & $103.6-113.4$ & 9.8 & 0.80 & 8.2 & $5 \mathrm{H}$ & 13 Sept. & 1325 & $33.6-40.6$ & 7.0 & 9.06 \\
\hline $21 \mathrm{R}$ & 25 Aug. & 0710 & $113.4-117.1$ & 3.7 & 1.91 & 51.6 & $6 \mathrm{X}$ & 13 Sept. & 1630 & $40.6-48.1$ & 7.5 & 0.25 \\
\hline $22 \mathrm{R}$ & 25 Aug. & 1025 & $117.1-124.1$ & 7.0 & 2.39 & 34.1 & $7 \mathrm{X}$ & 13 Sept. & 1845 & $48.1-57.7$ & 9.6 & 0.25 \\
\hline $23 \mathrm{R}$ & 25 Aug. & 1300 & $124.1-133.7$ & 9.6 & 1.85 & 19.3 & & & & Drilled 57.7-5 & $.3 \mathrm{mbsf} *$ & \\
\hline $24 \mathrm{R}$ & 25 Aug. & 1445 & $133.7-143.3$ & 9.6 & 2.34 & 24.4 & $8 \mathrm{~N}$ & 13 Sept. & 2200 & $59.3-60.8$ & 1.5 & 0.09 \\
\hline $25 \mathrm{R}$ & 25 Aug. & 1615 & $143.3-152.9$ & 9.6 & 3.04 & 31.6 & $9 \mathrm{X}$ & 14 Sept. & 0025 & $60.8-66.5$ & 5.7 & 0.83 \\
\hline $26 \mathrm{R}$ & 25 Aug. & 1745 & $152.9-162.5$ & 9.6 & 1.29 & 13.4 & $10 \mathrm{X}$ & 14 Sept. & 0325 & $66.5-72.4$ & 5.9 & 0.68 \\
\hline $27 \mathrm{R}$ & 25 Aug. & 1900 & $162.5-172.1$ & 9.6 & 1.12 & 11.6 & $11 \mathrm{X}$ & 14 Sept. & 0545 & $72.4-77.4$ & 5.0 & 0.56 \\
\hline $28 \mathrm{R}$ & 25 Aug. & 2020 & $172.1-181.7$ & 9.6 & 0.86 & 9.0 & $12 \mathrm{X}$ & 14 Sept. & 0725 & $77.4-87.0$ & 9.6 & 0.30 \\
\hline $29 \mathrm{R}$ & 25 Aug. & 2200 & $181.7-191.4$ & 9.7 & 0.69 & 7.1 & $13 \mathrm{X}$ & 14 Sept. & 0855 & $87.0-96.6$ & 9.6 & 0.00 \\
\hline $30 \mathrm{R}$ & 26 Aug. & 0050 & $191.4-201.0$ & 9.6 & 0.70 & 7.3 & $14 \mathrm{X}$ & 14 Sept. & 1030 & $96.6-106.2$ & 9.6 & 0.00 \\
\hline $31 \mathrm{R}$ & 26 Aug. & 0410 & $201.0-210.6$ & 9.6 & 2.05 & 21.3 & $\begin{array}{l}15 \mathrm{X} \\
15 \mathrm{x}\end{array}$ & 14 Sept. & 1255 & $106.2-115.8$ & $\begin{array}{l}9.0 \\
9.6\end{array}$ & 0.22 \\
\hline $32 \mathrm{R}$ & 26 Aug. & 0605 & $210.6-220.2$ & 9.6 & 0.83 & 8.6 & $16 \mathrm{X}$ & 14 Sept. & 1445 & $115.8-120.4$ & 4.6 & 0.20 \\
\hline $33 \mathrm{R}$ & 26 Aug. & 0735 & $220.2-229.8$ & 9.6 & 0.56 & 5.8 & $17 \mathrm{X}$ & 14 Sept. & 1625 & $120.4-125.4$ & 5.0 & 0.59 \\
\hline $34 \mathrm{R}$ & 26 Aug. & 0910 & $229.8-239.4$ & 9.6 & 0.16 & 1.7 & $18 \mathrm{X}$ & 14 Sept. & 1845 & $125.4-135.0$ & 9.6 & 0.20 \\
\hline $35 \mathrm{R}$ & 26 Aug. & 1045 & $239.4-249.0$ & 9.6 & 1.43 & 14.9 & $19 \mathrm{X}$ & 14 Sept. & 2030 & $135.0-144.7$ & 9.7 & 0.07 \\
\hline $36 \mathrm{R}$ & 26 Aug. & 1245 & $249.0-258.7$ & 9.7 & 0.14 & 1.4 & $20 \mathrm{X}$ & 14 Sept. & 2215 & $144.7-154.3$ & 9.6 & 1.10 \\
\hline $37 \mathrm{R}$ & 26 Aug. & 1415 & $258.7-268.3$ & 9.6 & 0.27 & 2.8 & $21 \mathrm{X}$ & 15 Sept. & 0000 & $154.3-163.9$ & $\begin{array}{l}9.0 \\
9.6\end{array}$ & 0.66 \\
\hline $38 \mathrm{R}$ & 26 Aug. & 1600 & $268.3-278.0$ & 9.7 & 0.21 & 2.2 & $22 \mathrm{X}$ & 15 Sept. & 0255 & $163.9-168.5$ & 4.6 & 0.00 \\
\hline $39 \mathrm{R}$ & 26 Aug. & 1730 & $278.0-287.6$ & 9.6 & 0.65 & 6.8 & $23 \mathrm{X}$ & 15 Sept. & 0535 & $168.5-173.5$ & 5.0 & 0.12 \\
\hline $40 \mathrm{R}$ & 26 Aug. & 1915 & $287.6-297.3$ & 9.7 & 0.41 & 4.2 & $24 \mathrm{X}$ & 15 Sept. & 0740 & $173.5-178.5$ & 5.0 & 0.40 \\
\hline $41 \mathrm{R}$ & 26 Aug. & 2040 & 297.3-306.9 & 9.6 & 0.70 & 7.3 & Coring to & & & & & 50.52 \\
\hline $42 \mathrm{R}$ & 26 Aug. & 2210 & $306.9-316.5$ & 9.6 & 0.88 & 9.2 & $\begin{array}{l}\text { Coring to } \\
\text { Drilled to }\end{array}$ & & & & $\begin{array}{r}176.9 \\
16\end{array}$ & 50.52 \\
\hline $43 \mathrm{R}$ & 26 Aug. & 2340 & $316.5-326.2$ & $\begin{array}{l}9.7 \\
96\end{array}$ & $\begin{array}{l}1.27 \\
0.83\end{array}$ & $\begin{array}{r}13.1 \\
8.6\end{array}$ & $\begin{array}{l}\text { Drilled to } \\
\text { Combine }\end{array}$ & $\begin{array}{l}\text { al: } \\
\text { total: }\end{array}$ & & & $\begin{array}{r}1.6 \\
178.5\end{array}$ & \\
\hline $\begin{array}{l}44 R \\
45 R\end{array}$ & $\begin{array}{l}27 \text { Aug. } \\
27 \text { Aug. }\end{array}$ & $\begin{array}{l}0115 \\
0255\end{array}$ & $\begin{array}{l}326.2-335.8 \\
335.8-345.5\end{array}$ & $\begin{array}{l}9.6 \\
9.7\end{array}$ & $\begin{array}{l}0.83 \\
0.46\end{array}$ & $\begin{array}{l}8.6 \\
4.7\end{array}$ & $169-1035$ & total. & & & & \\
\hline $46 \mathrm{R}$ & 27 Aug. & 0425 & $345.5-355.1$ & 9.6 & 0.44 & 4.6 & $1 \mathrm{H}$ & 15 Sept. & 1040 & $0.0-7.5$ & 7.5 & 7.45 \\
\hline $47 \mathrm{R}$ & 27 Aug. & 0625 & $355.1-364.6$ & 9.5 & 1.57 & 16.5 & $2 \mathrm{H}$ & 15 Sept. & 1120 & $7.5-17.0$ & 9.5 & 10.08 \\
\hline $48 \mathrm{R}$ & 27 Aug. & 0755 & $364.6-374.2$ & 9.6 & 0.54 & 5.6 & $3 \mathrm{H}$ & 15 Sept. & 1230 & $17.0-26.5$ & 9.5 & 9.90 \\
\hline $49 \mathrm{R}$ & 27 Aug. & 0930 & $374.2-383.8$ & 9.6 & 0.67 & 7.0 & $4 \mathrm{H}$ & 15 Sept. & 1300 & $26.5-36.0$ & 9.5 & 10.04 \\
\hline $50 \mathrm{R}$ & 27 Aug. & 1115 & $383.8-393.4$ & 9.6 & 1.24 & 12.9 & $\begin{array}{l}4 \mathrm{H} \\
5 \mathrm{H}\end{array}$ & 15 Sept. & $\begin{array}{l}1300 \\
2100\end{array}$ & $\begin{array}{l}20.5-30.0 \\
36.0-45.5\end{array}$ & 9.5 & $\begin{array}{l}10.04 \\
10.19\end{array}$ \\
\hline $51 \mathrm{R}$ & 27 Aug. & 1310 & $393.4-403.0$ & 9.6 & 0.68 & 7.1 & & & & & 455 & 47.66 \\
\hline $52 \mathrm{R}$ & 27 Aug. & 1525 & $403.0-412.6$ & 9.6 & 1.35 & 14.0 & Coring to & & & & & \\
\hline $53 \mathrm{R}$ & 27 Aug. & 1845 & $412.6-422.2$ & 9.6 & 0.39 & 4.1 & $169-1035$ & & & & & \\
\hline $54 \mathrm{R}$ & 27 Aug. & 2100 & $422.2-431.7$ & 9.5 & 0.76 & 8.0 & $1 \mathrm{R}$ & 17 Sept. & 2250 & $0.0-14.5$ & 14.5 & 0.20 \\
\hline $55 \mathrm{R}$ & 27 Aug. & 2350 & $431.7-434.3$ & 2.6 & 1.02 & 39.2 & $2 \mathrm{R}$ & 17 Sept. & 2345 & $14.5-22.5$ & 8.0 & 0.12 \\
\hline $56 \mathrm{R}$ & 28 Aug. & 0130 & $434.3-441.3$ & 7.0 & 0.80 & 11.4 & $3 R$ & 18 Sept. & 0100 & $22.5-32.1$ & 9.6 & 0.13 \\
\hline $57 \mathrm{R}$ & 28 Aug. & 0355 & $441.3-451.0$ & 9.7 & 0.58 & 6.0 & $4 \mathrm{R}$ & 18 Sept. & 0320 & $32.1-41.7$ & 9.6 & 0.86 \\
\hline $58 \mathrm{R}$ & 28 Aug. & 0655 & $451.0-460.7$ & 9.7 & 0.47 & 4.8 & $5 R$ & 18 Sept. & 0550 & $41.7-51.4$ & 9.7 & 2.05 \\
\hline $59 \mathrm{R}$ & 28 Aug. & 0815 & $460.7-465.7$ & 5.0 & 1.03 & 20.6 & $\begin{array}{l}3 \mathrm{R} \\
6 \mathrm{R}\end{array}$ & $\begin{array}{l}18 \text { Sept. } \\
18 \text { Sept. }\end{array}$ & 0815 & $\begin{array}{l}41.1-51.4 \\
51.4-61.0\end{array}$ & 9.6 & 1.06 \\
\hline $60 \mathrm{R}$ & 28 Aug. & 1030 & $465.7-468.2$ & 2.5 & 1.42 & 56.8 & $\begin{array}{l}0 \mathrm{~K} \\
7 \mathrm{R}\end{array}$ & 18 Sept. & 1030 & $\begin{array}{l}51.4-01.00 \\
61.0-70.6\end{array}$ & $\begin{array}{l}9.0 \\
9.6\end{array}$ & 0.34 \\
\hline $61 \mathrm{R}$ & 28 Aug. & 1230 & $468.2-470.3$ & 2.1 & 1.32 & 62.8 & $8 \mathrm{R}$ & $\begin{array}{l}18 \text { Sept. } \\
18 \text { Sept. }\end{array}$ & 1205 & $70.6-80.2$ & 9.6 & 0.88 \\
\hline $62 \mathrm{R}$ & 28 Aug. & 1520 & $470.3-479.9$ & 9.6 & 0.81 & 8.4 & $\begin{array}{l}8 \mathrm{R} \\
9 \mathrm{R}\end{array}$ & 18 Sept. & 1355 & $80.2-89.9$ & 9.7 & 0.28 \\
\hline $63 \mathrm{R}$ & 28 Aug. & 1900 & $479.9-489.5$ & 9.6 & 1.87 & 19.5 & $10 \mathrm{R}$ & 18 Sept. & 1530 & $89.9-99.7$ & 98 & 206 \\
\hline $64 \mathrm{R}$ & 28 Aug. & 2235 & $489.5-494.2$ & 4.7 & 2.05 & 43.6 & $11 \mathrm{R}$ & 18 Sept. & 1800 & $99.7-109.3$ & 9.6 & $\begin{array}{l}.00 \\
1.79\end{array}$ \\
\hline $65 \mathrm{R}$ & 29 Aug. & 0325 & $494.2-500.0$ & 5.8 & 1.81 & 31.2 & $12 \mathrm{R}$ & $\begin{array}{l}18 \text { Sept. } \\
18 \text { Sept. }\end{array}$ & $\begin{array}{l}1800 \\
1925\end{array}$ & $\begin{array}{r}99.1-109.3 \\
109.3-119.0\end{array}$ & $\begin{array}{l}9.0 \\
9.7\end{array}$ & 2.44 \\
\hline Coring total: & & & & 406.2 & 49.11 & 12.1 & $13 \mathrm{R}$ & 18 Sept. & 2110 & $119.0-128.6$ & 9.6 & 3.23 \\
\hline Washin & & & & 93.8 & 0.11 & & $14 \mathrm{R}$ & 18 Sept. & 2245 & $128.6-138.2$ & 9.6 & 1.44 \\
\hline Combined to & totals: & & & 500.0 & 49.22 & & $15 \mathrm{R}$ & 19 Sept. & 0015 & $138.2-147.9$ & 9.7 & 0.83 \\
\hline & & & & & & & $16 \mathrm{R}$ & 19 Sept. & 0120 & $147.9-157.5$ & 9.6 & 0.93 \\
\hline 169-1035A- & & & & & & & $17 \mathrm{R}$ & 19 Sept. & 0320 & $157.5-167.1$ & $\begin{array}{l}.0 \\
9.6\end{array}$ & $\begin{array}{l}0.93 \\
0.76\end{array}$ \\
\hline $1 \mathrm{H}$ & 4 Sept. & 1315 & $0.0-7.5$ & 7.5 & 7.45 & 99.3 & $18 \mathrm{R}$ & 19 Sept. & 0420 & $167.1-176.8$ & $\begin{array}{l}9.0 \\
9.7\end{array}$ & 0.31 \\
\hline $2 \mathrm{H}$ & 4 Sept. & 1400 & $7.5-17.0$ & 9.5 & 9.94 & 104.0 & $19 \mathrm{R}$ & 19 Sept. & 0545 & $176.8-186.4$ & 9.6 & 0.94 \\
\hline $3 \mathrm{H}$ & 4 Sept. & 1500 & $17.0-26.5$ & 9.5 & 9.97 & 105.0 & $20 \mathrm{R}$ & 19 Sept. & 0705 & $186.4-196.0$ & 9.6 & 0.58 \\
\hline $4 \mathrm{H}$ & 4 Sept. & 1545 & $26.5-36.0$ & 9.5 & 9.99 & 105.0 & $21 \mathrm{R}$ & 19 Sept. & 0825 & $196.0-205.6$ & 9.6 & 0.22 \\
\hline $5 \mathrm{H}$ & 4 Sept. & 1830 & $36.0-45.5$ & 9.5 & 9.97 & 105.0 & $22 \mathrm{R}$ & 19 Sept. & 1025 & $205.6-215.2$ & 9.6 & 0.76 \\
\hline $6 \mathrm{H}$ & 4 Sept. & 2015 & $45.5-55.0$ & 9.5 & 7.70 & 81.0 & $23 \mathrm{R}$ & 19 Sept. & $\begin{array}{l}1029 \\
1150\end{array}$ & $215.2-224.8$ & 9.6 & 0.34 \\
\hline $\begin{array}{l}7 \mathrm{X} \\
8 \mathrm{X}\end{array}$ & 4 Sept. & 2300 & $\begin{array}{l}55.0-61.0 \\
61.0-70.6\end{array}$ & 6.0 & 2.07 & 34.5 & Coring to & & & & 224.8 & 22.55 \\
\hline $\begin{array}{l}8 \mathrm{X} \\
9 \mathrm{X}\end{array}$ & $\begin{array}{l}4 \text { Sept. } \\
9 \text { Sept. }\end{array}$ & $\begin{array}{l}0045 \\
0155\end{array}$ & $\begin{array}{l}61.0-70.6 \\
70.6-80.2\end{array}$ & $\begin{array}{l}9.6 \\
9.6\end{array}$ & $\begin{array}{l}4.31 \\
9.06\end{array}$ & $\begin{array}{l}44.9 \\
94.4\end{array}$ & $\begin{array}{l}\text { Coring to } \\
169-1035\end{array}$ & & & & 224.8 & 2.53 \\
\hline $\begin{array}{l}9 \mathrm{X} \\
10 \mathrm{X}\end{array}$ & 9 Sept. & 0315 & $\begin{array}{l}10.0-80.2 \\
80.2-89.8\end{array}$ & $\begin{array}{l}.0 \\
9.6\end{array}$ & $\begin{array}{l}.000 \\
5.26\end{array}$ & $\begin{array}{l}94.4 \\
54.8\end{array}$ & $\begin{array}{c}169-1035 \\
1 \mathrm{~W}\end{array}$ & - 19 Sent & 2130 & $00-444$ & & 000 \\
\hline $11 \mathrm{X}$ & 9 Sept. & 0430 & $89.8-99.4$ & 9.6 & 1.01 & 10.5 & $\begin{array}{l}1 \mathrm{~W} \\
2 \mathrm{R}\end{array}$ & $19 \mathrm{~S}$ & 2300 & $\begin{array}{l}0.0-44.4 \\
44.4-54.4\end{array}$ & $\begin{array}{l}4.4 \\
10.0\end{array}$ & $\begin{array}{l}0.00 \\
0.46\end{array}$ \\
\hline $12 \mathrm{X}$ & 9 Sept. & 0545 & $99.4-109.0$ & 9.6 & 6.49 & 67.6 & $3 R$ & 20 Sept. & 0040 & $\begin{array}{l}44.4-54.4 \\
54-64.0\end{array}$ & 9.6 & $\begin{array}{l}0.40 \\
0.58\end{array}$ \\
\hline $13 \mathrm{X}$ & 9 Sept. & 0715 & $109.0-118.6$ & 9.6 & 6.98 & 72.7 & $\begin{array}{l}3 \mathrm{R} \\
4 \mathrm{R}\end{array}$ & $\begin{array}{l}20 \text { Sept. } \\
20 \text { Sept. }\end{array}$ & 0145 & $\begin{array}{l}54.4-64.0 \\
64.0-73.6\end{array}$ & $\begin{array}{l}9.6 \\
9.6\end{array}$ & $\begin{array}{l}0.58 \\
0.16\end{array}$ \\
\hline $14 \mathrm{X}$ & 9 Sept. & 0840 & $118.6-128.2$ & 9.6 & 9.82 & 102.0 & ${ }_{5 \mathrm{R}}^{4 \mathrm{R}}$ & 20 Sept. & 0305 & $73.6-83.3$ & 9.7 & 3.08 \\
\hline $15 \mathrm{X}$ & 9 Sept. & 1035 & $128.2-137.8$ & 9.6 & 8.77 & 91.3 & $\begin{array}{l}5 \mathrm{R} \\
6 \mathrm{~W}\end{array}$ & 20 Sept. & 0645 & $83.3-140.9$ & 57.6 & 4.47 \\
\hline $16 \mathrm{X}$ & 9 Sept. & 1220 & $137.8-147.4$ & 9.6 & 6.96 & 72.5 & $7 \mathrm{R}$ & 20 Sept. & 0800 & $140.9-150.5$ & $\begin{array}{r}37.0 \\
9.6\end{array}$ & $\begin{array}{l}.47 \\
5.23\end{array}$ \\
\hline $17 \mathrm{X}$ & 9 Sept. & 1405 & $147.4-157.1$ & 9.7 & 0.34 & 3.5 & $8 \mathrm{R}$ & 20 Sept. & 0910 & $150.5-160.1$ & 9.6 & 2.68 \\
\hline $18 \mathrm{X}$ & 9 Sept. & 1545 & $157.1-166.7$ & 9.6 & 0.23 & 2.4 & $\begin{array}{l}8 \mathrm{~K} \\
9 \mathrm{R}\end{array}$ & 20 Sept. & 1040 & 160. & $\begin{array}{l}9.0 \\
9.7\end{array}$ & $\begin{array}{l}.08 \\
1.44\end{array}$ \\
\hline $19 \mathrm{X}$ & 9 Sept. & 1750 & $166.7-170.8$ & 4.1 & 3.14 & 76.6 & $\begin{array}{l}9 \mathrm{~K} \\
10 \mathrm{R}\end{array}$ & 20 Sept. & 1235 & $169.8-179.5$ & 9.7 & 1.13 \\
\hline Coring totals & & & & 170.8 & 119.46 & 69.9 & $11 \mathrm{R}$ & 20 Sept. & 1415 & $179.5-189.2$ & 9.7 & 1.01 \\
\hline & & & & & & & $12 \mathrm{R}$ & 20 Sept. & 1540 & $189.2-198.9$ & 9.7 & 0.48 \\
\hline 169-1035B- & & & & & & 1000 & $13 \mathrm{R}$ & 20 Sept. & 1700 & $198.9-208.5$ & 9.6 & 0.38 \\
\hline $1 \mathrm{M}$ & 11 Sept. & 1100 & $0.0-0.0$ & 0.0 & 0.01 & 100.0 & Coring & & & & 106.5 & 16.63 \\
\hline Coring total: & & & & 0.0 & 0.01 & 100.0 & Washin & & & & 102.0 & 4.47 \\
\hline $169-1035 \mathrm{C}-$ & & & & & & & Combine & totals: & & & 208.5 & 21.10 \\
\hline $1 \mathrm{X}$ & 12 Sept. & 2040 & $0.0-12.0$ & 12.0 & 1.47 & 12.3 & $169-10$ & & & & & \\
\hline $2 \mathrm{X}$ & 12 Sept. & 2200 & $12.0-20.1$ & 8.1 & 0.00 & 0.0 & 10 & $21 \mathrm{~s}$ & 05 & 0. & 8.8 & 2.17 \\
\hline $3 \mathrm{X}$ & 12 Sept. & 2310 & $20.1-29.7$ & 9.6 & 0.06 & 0. & $2 \mathrm{R}$ & 21 Sept. & 07 & & $\begin{array}{l}8.0 \\
8.0\end{array}$ & 2.02 \\
\hline $4 \mathrm{X}$ & 13 Sept. & 0050 & $29.7-39.3$ & 9.6 & 0.20 & 2.1 & $3 R$ & 21 Sept. & 0850 & $16.8-26.4$ & 9.6 & 0.40 \\
\hline $5 \mathrm{X}$ & 13 Sept. & 0345 & $39.3-44.0$ & 4.7 & 0.36 & 7.7 & $4 \mathrm{R}$ & 21 Sept. & 1025 & $26.4-36.0$ & 9.6 & $\begin{array}{l}.40 \\
1.50\end{array}$ \\
\hline Coring totals & & & & 44.0 & 2.09 & 4.8 & $5 \mathrm{R}$ & 21 Sept. & 1140 & $36.0-45.6$ & 9.6 & 1.15 \\
\hline $169-1035 \mathrm{D}-$ & & & & & & & $6 \mathrm{R}$ & 21 Sept. & 1300 & $45.6-55.2$ & 9.6 & 2.07 \\
\hline $1 \mathrm{H}$ & 13 Sept. & 0815 & $0.0-5.1$ & 5.1 & 5.03 & 98.6 & $7 \mathrm{R}$ & 21 Sept. & 1415 & $55.2-64.9$ & 9.7 & 0.88 \\
\hline
\end{tabular}


Table 1 (continued).

\begin{tabular}{|c|c|c|c|c|c|c|}
\hline Core & $\begin{array}{c}\text { Date } \\
(1996)\end{array}$ & $\begin{array}{l}\text { Time } \\
\text { (UTC) }\end{array}$ & $\begin{array}{l}\text { Depth } \\
\text { (mbsf) }\end{array}$ & $\begin{array}{l}\text { Length } \\
\text { cored } \\
(\mathrm{m})\end{array}$ & $\begin{array}{l}\text { Length } \\
\text { recovered } \\
\text { (m) }\end{array}$ & $\begin{array}{c}\text { Recovery } \\
(\%)\end{array}$ \\
\hline $8 \mathrm{R}$ & 21 Sept. & 1610 & $64.9-74.6$ & 9.7 & 0.80 & 8.3 \\
\hline $9 \mathrm{R}$ & 21 Sept. & 1720 & $74.6-84.2$ & 9.6 & 1.20 & 12.5 \\
\hline $10 \mathrm{R}$ & 21 Sept. & 1805 & $84.2-94.0$ & 9.8 & 0.50 & 5.1 \\
\hline $11 \mathrm{R}$ & 21 Sept. & 1915 & $94.0-103.7$ & 9.7 & 0.69 & 7.1 \\
\hline $12 \mathrm{R}$ & 21 Sept. & 2030 & $103.7-113.4$ & 9.7 & 0.51 & 5.3 \\
\hline $13 \mathrm{R}$ & 21 Sept. & 2140 & $113.4-123.0$ & 9.6 & 0.40 & 4.2 \\
\hline $14 \mathrm{R}$ & 21 Sept. & 2300 & $123.0-127.6$ & 4.6 & 0.33 & 7.2 \\
\hline $15 \mathrm{R}$ & 22 Sept. & 0025 & $127.6-132.6$ & 5.0 & 0.23 & 4.6 \\
\hline $16 \mathrm{R}$ & 22 Sept. & 0225 & $132.6-142.3$ & 9.7 & 2.90 & 29.9 \\
\hline $17 \mathrm{R}$ & 22 Sept. & 0850 & $142.3-151.9$ & 9.6 & 3.79 & 39.5 \\
\hline $18 \mathrm{R}$ & 22 Sept. & 1035 & $151.9-161.5$ & 9.6 & 0.14 & 1.5 \\
\hline $19 \mathrm{R}$ & 22 Sept. & 1155 & $161.5-171.1$ & 9.6 & 1.00 & 10.4 \\
\hline $20 \mathrm{R}$ & 22 Sept. & 1315 & $171.1-180.7$ & 9.6 & 1.27 & 13.2 \\
\hline $21 \mathrm{R}$ & 22 Sept. & 1440 & $180.7-190.3$ & 9.6 & 0.85 & 8.9 \\
\hline $22 \mathrm{R}$ & 22 Sept. & 1545 & $190.3-199.9$ & 9.6 & 1.03 & 10.7 \\
\hline $23 R$ & 22 Sept. & 1700 & $199.9-209.5$ & 9.6 & 1.39 & 14.5 \\
\hline $24 \mathrm{R}$ & 22 Sept. & 1800 & $209.5-219.1$ & 9.6 & 1.30 & 13.5 \\
\hline $25 \mathrm{R}$ & 22 Sept. & 1900 & $219.1-228.7$ & 9.6 & 1.22 & 12.7 \\
\hline $26 \mathrm{R}$ & 22 Sept. & 2020 & $228.7-238.3$ & 9.6 & 1.60 & 16.6 \\
\hline $27 \mathrm{R}$ & 22 Sept. & 2200 & $238.3-247.9$ & 9.6 & 1.91 & 19.9 \\
\hline \multicolumn{4}{|c|}{ Coring totals: } & 247.9 & 33.25 & 13.4 \\
\hline
\end{tabular}

Note: An expanded version of this coring summary table that includes lengths and depths of sections, location of whole-round samples, and comments on sampling disturbance is included on CD-ROM in the back pocket of this volume.

recovery. One Motor-Driven Core Barrel core was attempted, 1691035D-8N (59.3-60.8 mbsf), with only $1.5 \mathrm{~m}$ of penetration and without significantly improved recovery $(7 \%)$. XCB coring was resumed from Core 169-1035D-6X through 24X (60.8-178.4 mbsf). Average recovery for the entire cored interval was $28 \%$ (Table 1). Operations at Hole 1035D were terminated when the objective of the hard layer determined to be at $\sim 170 \mathrm{mbsf}$ in Hole 1035A was reached. Temperature measurements were made after Core 169-1035D-3H (24.1 mbsf) with the Adara tool and WSTP probe.

\section{Hole 1035E}

The ship was moved in DP mode to the next location at Hole $1035 \mathrm{E}, \sim 50 \mathrm{~m}$ south of Holes $1035 \mathrm{~B}$ and $1035 \mathrm{C}\left(48^{\circ} 25.966^{\prime} \mathrm{N}\right.$, $128^{\circ} 40.856^{\prime} \mathrm{W} ; 2454 \mathrm{~m}$ water depth). APC Cores $169-1035 \mathrm{E}-1 \mathrm{H}$ through $5 \mathrm{H}$ were taken from 0 to $45.5 \mathrm{~m}$ (2510.5 meters below rig floor [mbrf]) with $104.8 \%$ recovery (Table 1 ). The coring wireline parted at 12,000 lb overpull when attempting to retrieve after Core $169-1035 \mathrm{E}-5 \mathrm{H}$, and the bottom-hole assembly was pulled. Temperature measurements were made with the Adara probe after Cores 1691035E-3H (26.5 mbsf) and 5H (45.5 mbsf).

\section{Hole 1035F}

DP mode was used to return to Hole $1035 \mathrm{~B}$, and the ship was offset $10 \mathrm{~m}$ south to initiate Hole $1035 \mathrm{~F}\left(48^{\circ} 25.987^{\prime} \mathrm{N}, 128^{\circ} 40.861^{\prime} \mathrm{W}\right.$; $2448 \mathrm{~m}$ water depth). RCB Cores 169-1035F-1R through 23R were taken from 0 to $224.8 \mathrm{~m}$ (2683.8 mbrf) with $10.0 \%$ recovery (Table 1). In anticipation that we might have time at the end of Middle Valley operations to log this hole, and recognizing that Hole $1035 \mathrm{~F}$ had the potential to be a legacy site, a free-fall funnel (FFF) was deployed to facilitate reentry. During the ensuing VIT inspection (run to ensure the FFF had seated properly), the FFF was not visible because of high turbidity in the water column. The water column did not clear more than $45 \mathrm{~min}$ after the removal of the drill pipe from the hole, and operations were terminated.

\section{Hole 1035G}

The final operation adjacent to the BHMS deposit was the attempted recovery of material from the west side of the mound (near Hole 1035A) at a depth inaccessible to the APC/XCB assembly be- cause of the presence of an intensely silicified horizon encountered at the base of Hole 1035A. Hole 1035A was located with dGPS coordinates. The drill string was moved $10 \mathrm{~m}$ closer to the mound, and Hole $1035 \mathrm{G}\left(48^{\circ} 26.024^{\prime} \mathrm{N}, 128^{\circ} 40.914^{\prime} \mathrm{W}\right.$; $2445 \mathrm{~m}$ water depth) was drilled without coring the surface sediment, and Core 169-1035GIW (0.0-44.0 mbsf) was recorded as a wash core with no recovery. Just above the depth where we estimated the top of the massive sulfide to be located, Cores 169-1035G-2R through 5R (44.0-83.3 mbsf) were subsequently retrieved with $10 \%$ recovery through the massive sulfide and into the underlying stringer zone. Drilling without coring was again utilized to a target depth of $140 \mathrm{mbsf}$ (recovering another wash barrel, Core 169-1035G-6W, 83.3-140.9 mbsf) before rotary coring operations continued. Cores 169-1035G-7R through 13R (140.9-208.5 mbsf, 16\% recovery) were sampled (Table 1), and upon reaching the target depth in excess of $200 \mathrm{mbsf}$, the hole was terminated. Because we suspected that Hole 1035F south of the BHMS deposit might now be actively venting, as indicated by excessive turbidity, we lowered the VIT camera to the seafloor to see if Hole $1035 \mathrm{G}$ might also be discharging fluid. There was, however, no visible evidence of active venting at this site, so we pulled the drillstring out of the hole and headed for our next target.

\section{Hole 1035H}

Operations in Middle Valley concluded with a reconnaissance hole to explore the nature of the massive sulfide deposit $~ 300 \mathrm{~m}$ south of the BHMS deposit. This location was home to the only observed active hydrothermal vent in the Bent Hill area exuding $264^{\circ} \mathrm{C}$ hydrothermal fluid. During the DP transit to Hole $1035 \mathrm{H}$, we passed over Hole $1035 \mathrm{~F}$ and noted that we could see active venting through the throat of the FFF, making Hole 1035F the second known active vent in the Bent Hill area. After a 6-hr camera survey of the mound south of the BHMS deposit, Hole $1035 \mathrm{H}\left(48^{\circ} 25.832^{\prime} \mathrm{N}, 128^{\circ} 40.911^{\prime} \mathrm{W}\right.$; $2443 \mathrm{~m}$ water depth) was initiated on a reasonably flat bench, adjacent to an inactive toppled chimney at least $2 \mathrm{~m}$ long. Cores 169$1035 \mathrm{H}-1 \mathrm{R}$ through $27 \mathrm{R}$ (0.0-247.9 mbsf, $13 \%$ recovery) were sampled (Table 1). The butyrate liner of Core 169-1035H-11R (99.7 mbsf) melted, encasing the core; previous core liners showed evidence of heat stress. We suspected that if temperatures were high enough to melt the core liners, this hole might be exuding fluid as well. Given operational uncertainties, we decided to attempt a water sample with the Los Alamos tool at a depth of $70 \mathrm{mbsf}$, where we had seen evidence of high borehole temperatures. The timer released prematurely, however, and no sample was collected. During the water sample attempt, we sent the VIT camera down the drill string and saw that indeed Hole $1035 \mathrm{H}$ was actively venting. High-temperature core liners were used for the last several cores, and some of these showed evidence of heat stress (in some cases extreme) as well. We tried again to collect a water sample once coring operations ended, but failed to get a sample when the seals in the Los Alamos tool failed. A VIT inspection of the pipe withdrawal operation showed that Hole $1035 \mathrm{H}$ was still vigorously venting fluid as we left Middle Valley.

\section{LITHOSTRATIGRAPHIC SUMMARY AND SEDIMENTOLOGY}

\section{Lithostratigraphic Summary}

The lithostratigraphic characterization of the BHMS deposit, initiated during Leg 139 and continued during Leg 169, is one of the most remarkable achievements in the 28-yr history of ODP and its predecessor, the Deep Sea Drilling Project (DSDP). Although seafloor metalliferous sulfide deposits have been known since the mid-1960s when the Red Sea brine deposits were discovered (Miller et al., 1966; Bischoff, 1969), and many active "black smoker" vents are now known from the world's mid-ocean and back-arc spreading ridges, none are as well-developed analogs to ancient sediment-hosted volcanic-associated mas- 


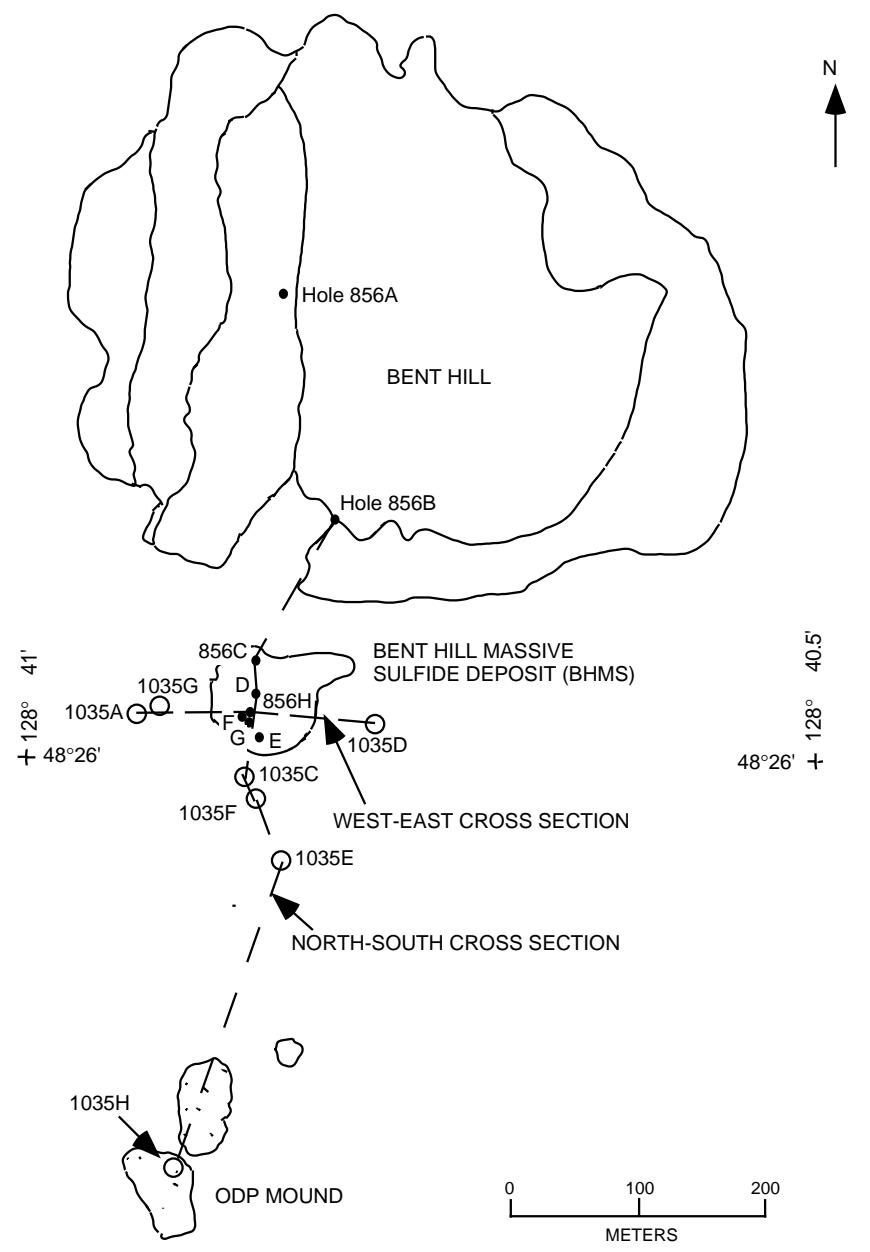

Figure 6. Location of holes drilled during Legs 169 and 139, Bent Hill and ODP Mound, Middle Valley, northern Juan de Fuca Ridge.

sive sulfides as the BHMS. Lithostratigraphic studies of the BHMS indicate a complex history of hemipelagic and turbiditic sedimentation, hydrothermal fluid flow, sulfide deposition at the seafloor and within underlying feeder zones, and igneous activity. The interplay of these processes has produced a large, heterogeneous mineral deposit that includes facies of iron-rich and zinc-rich massive and semi-massive sulfide, a well-developed feeder zone characterized by crosscutting sulfide veins, and a deep copper-rich zone that may represent an important conduit for fluid flow. Hydrothermal alteration provides a record of past and present fluid flow and is variably developed on both a small scale, controlled by detailed variations in host lithology, and at a large scale, controlled by structural, stratigraphic, and sedimentary facies variations.

The BHMS deposit is located $100 \mathrm{~m}$ south of Bent Hill. Seven lithologic units were recovered from the eight holes drilled at sites in the vicinity of the BHMS during Leg 139 (Davis, Mottl, Fisher, et al., 1992; table 3, p. 173). The BHMS was revisited during Leg 169 for the chief purposes of assessing the thickness and the lateral extent of mineralization and determining the nature of the hydrothermal feeder zone underlying the deposit.

The BHMS deposit was penetrated during Leg 169 in Holes 856H, 1035A, 1035C, 1035D, 1035F, and 1035G. An additional hole $(1035 \mathrm{H})$ was sited on the ODP Mound $350 \mathrm{~m}$ to the south (Fig. 6) and also penetrated a considerable thickness of massive and nonmassive sulfides. The deposit drilled beneath ODP Mound is significantly more zinc rich and is underlain by a thicker zone of copper mineralization than the BHMS. This deposit has a significantly different distribution of sulfide and sedimentary facies.
Table 2. Lithologic units and subunits, Middle Valley.

\begin{tabular}{|c|c|c|}
\hline $\begin{array}{l}\text { Lithologic } \\
\text { unit }\end{array}$ & Subunit & $\begin{array}{l}\text { Description } \\
\quad \text { (age) }\end{array}$ \\
\hline \multirow[t]{4}{*}{ I } & & Hemipelagic sediments (Holocene and late Pleistocene) \\
\hline & IA & Unaltered silty clay \\
\hline & IB & Carbonate concretions and cement \\
\hline & IC & Anhydrite concretions and authigenic crystals \\
\hline \multirow[t]{5}{*}{ II } & & $\begin{array}{l}\text { Interbedded turbidites and hemipelagic sediments } \\
\text { (Pleistocene) }\end{array}$ \\
\hline & IIA & $\begin{array}{l}\text { Unaltered interbedded hemipelagic and turbiditic sand and silt; } \\
\text { sedimentary breccia }\end{array}$ \\
\hline & IIB & Carbonate concretions and cement \\
\hline & IIC & Anhydrite concretions and authigenic crystals \\
\hline & IID & Silicate alteration \\
\hline III & & Clastic sulfides \\
\hline IV & & Clastic sulfate chimney residue \\
\hline \multirow[t]{5}{*}{$\mathrm{V}$} & & Massive and semi-massive sulfides (50\% sulfide) \\
\hline & VA & Fine-grained Po-Sp-Is-Cp (Type 1) \\
\hline & VB & Fine-grained Py-Po-Mt-Sp-Is-Cp (Types 2, 3, 4) \\
\hline & $\mathrm{VC}$ & Sp-Po-Py-Mt \\
\hline & VD & Colloform and vuggy pyrite (Type 5) \\
\hline \multirow[t]{4}{*}{ VI } & & Sulfide feeder zone and mineralized sediments \\
\hline & VIA & Sulfide-veined sediment ( $10 \%-50 \%$ sulfide $)$ \\
\hline & VIB & Sediment with sulfide veins and/or impregnations $(2 \%-10 \%)$ \\
\hline & VIC & Sulfide banded/impregnated sediment (10\%-50\% sulfide) \\
\hline VII & & Basaltic sills \\
\hline VIII & & Basaltic flows \\
\hline
\end{tabular}

Notes: Po = pyrrhotite, $\mathrm{Sp}=$ sphalerite, $\mathrm{Is}=$ isocubanite, $\mathrm{Cp}=$ chalcopyrite, $\mathrm{Py}=$ pyrite, and $\mathrm{Mt}=$ magnetite. Types 1 through 5 refer to the types of massive sulfide defined in the Leg 139 Initial Reports volume (Davis, Mottl, Fisher, et al., 1992).

The eight lithologic units recognized during Leg 169 are described in the following paragraphs and in Table 2. A summary of unit assignments for each hole is presented in Table 3. Generalized stratigraphic summaries for each hole (Figs. 7-14) have been prepared using shipboard visual core descriptions, augmented by selected shipboard petrographic and X-ray diffraction (XRD) studies and by biostratigraphic and sedimentologic studies. Each summary indicates depth in meters below seafloor and a graphic indication of percent recovery in each core. Lithologic units, based on recovered core, are apportioned over the drilled interval to create these generalized, continuous sections.

\section{Hole 856H}

Hole $856 \mathrm{H}$, drilled near the summit of the BHMS deposit, penetrated $93.8 \mathrm{~m}$ of massive sulfide during Leg 139 and was deepened by $406.2 \mathrm{~m}$ during Leg 169 to a total depth of $500.0 \mathrm{~m}$. This hole (Fig. 7) consists of unconsolidated clastic sulfides (Unit III, 0-4.0 mbsf), massive sulfides (Unit V, 13.5-94.4 mbsf), a sulfide feeder zone (Unit VI, 103.6-203.3 mbsf) consisting of sulfide veins and impregnations, interbedded and variably altered hemipelagic and turbiditic sediments (Unit II, 210.6-431.7 mbsf), a basaltic sill-sediment complex (Unit VII, 431.7-471.3 mbsf), and basaltic flows (Unit VIII, 471.3-500 mbsf). The clastic and massive sulfides are texturally, mineralogically, and compositionally heterogeneous (see also Davis, Mottl, Fisher, et al., 1992). A distinctive sulfide-banded sandstone (Subunit VIC, 201-203.3 mbsf) containing high contents of $\mathrm{Cu}-\mathrm{Fe}$ sulfides at the base of the sulfide feeder zone forms part of a stratiform horizon characterized by silicification and sulfide mineralization. The copper-rich portions of this horizon intersected in this hole and in Holes $1035 \mathrm{~F}$ and $1035 \mathrm{H}$ are informally referred to as the DCZ (see "Deep Copper Zone" subsection, "Sulfide Mineralization: Massive Sulfide" section, this chapter).

\section{Hole 1035A}

Hole 1035A (Fig. 8) was drilled to a depth of $170.8 \mathrm{mbsf}$ and is the most westerly hole, located $\sim 77 \mathrm{~m}$ west of the presumed center of 
Table 3. Summary of lithologic unit designations for drill holes in the vicinity of the Bent Hill Massive Sulfide deposit, Middle Valley.

\begin{tabular}{|c|c|c|c|c|c|}
\hline $\begin{array}{l}\text { Lithologic } \\
\text { unit }\end{array}$ & $\begin{array}{l}\text { Description } \\
\quad \text { (age) }\end{array}$ & Hole $856 \mathrm{H}$ & Hole $1035 \mathrm{~A}$ & Hole $1035 \mathrm{C}$ & Hole $1035 \mathrm{D}$ \\
\hline I & $\begin{array}{l}\text { Hemipelagic sediments (Holocene and late } \\
\text { Pleistocene) }\end{array}$ & & & & \\
\hline II & $\begin{array}{l}\text { Interbedded turbidites and hemipelagic sediments } \\
\text { (Pleistocene) }\end{array}$ & 32R-1 through $54 \mathrm{R}-1$ & $\begin{array}{l}2 \mathrm{H}-2 \text { through } 7 \mathrm{X}-1 \\
7 \mathrm{X}-1 \text { through } 7 \mathrm{X}-\mathrm{CC} \\
8 \mathrm{X}-1 \text { through } 19 \mathrm{X}-2\end{array}$ & & $\begin{array}{l}2 \mathrm{H}-2 \text { through } 5 \mathrm{H}-2 \\
5 \mathrm{H}-3 \text { through } 5 \mathrm{H}-\mathrm{CC} \\
17 \mathrm{X}-1 \\
19 \mathrm{X}-1 \text { through } 21 \mathrm{X}-\mathrm{CC}\end{array}$ \\
\hline III & Clastic sulfides & 139-856H-1R-1 through 1R-CC & $1 \mathrm{H}-1$ through $2 \mathrm{H}-1$ & $1 \mathrm{X}-1$ through $1 \mathrm{X}-\mathrm{CC}$ & $\begin{array}{l}1 \mathrm{H}-1 \text { through } 2 \mathrm{H}-2 \\
5 \mathrm{H}-2 \text { through } 5 \mathrm{H}-3\end{array}$ \\
\hline IV & Clastic sulfate chimney residue & & & & \\
\hline $\mathrm{V}$ & Massive and semi-massive sulfides [ $>50 \%$ sulfide] & $\begin{array}{l}139-856 \mathrm{H}-2 \mathrm{R}-1 \text { through } 17 \mathrm{R} \\
169-856 \mathrm{H}-19 \mathrm{R}-1\end{array}$ & $7 \mathrm{X}-1$ and $7 \mathrm{X}-\mathrm{CC}$ & $3 \mathrm{X}-\mathrm{CC}$ through $5 \mathrm{X}-1$ & $\begin{array}{l}6 \mathrm{X}-\mathrm{CC} \text { through } 10 \mathrm{X}-1 \\
10 \mathrm{X}-1 \text { through } 12 \mathrm{X}-1\end{array}$ \\
\hline VI & Sulfide feeder zone and mineralized sediments & 20R-1 through 31R-2 & $19 \mathrm{X}-2$ & & $\begin{array}{l}10 \mathrm{X}-1 \\
15 \mathrm{X}-1 \text { through } 18 \mathrm{X}-\mathrm{CC} \\
23 \mathrm{X}-1 \text { through } 24 \mathrm{X}-\mathrm{CC}\end{array}$ \\
\hline VII & Basaltic flows & 55R through 59R & & & \\
\hline VIII & Basaltic flows & $62 \mathrm{R}$ through $65 \mathrm{R}$ & & & \\
\hline
\end{tabular}

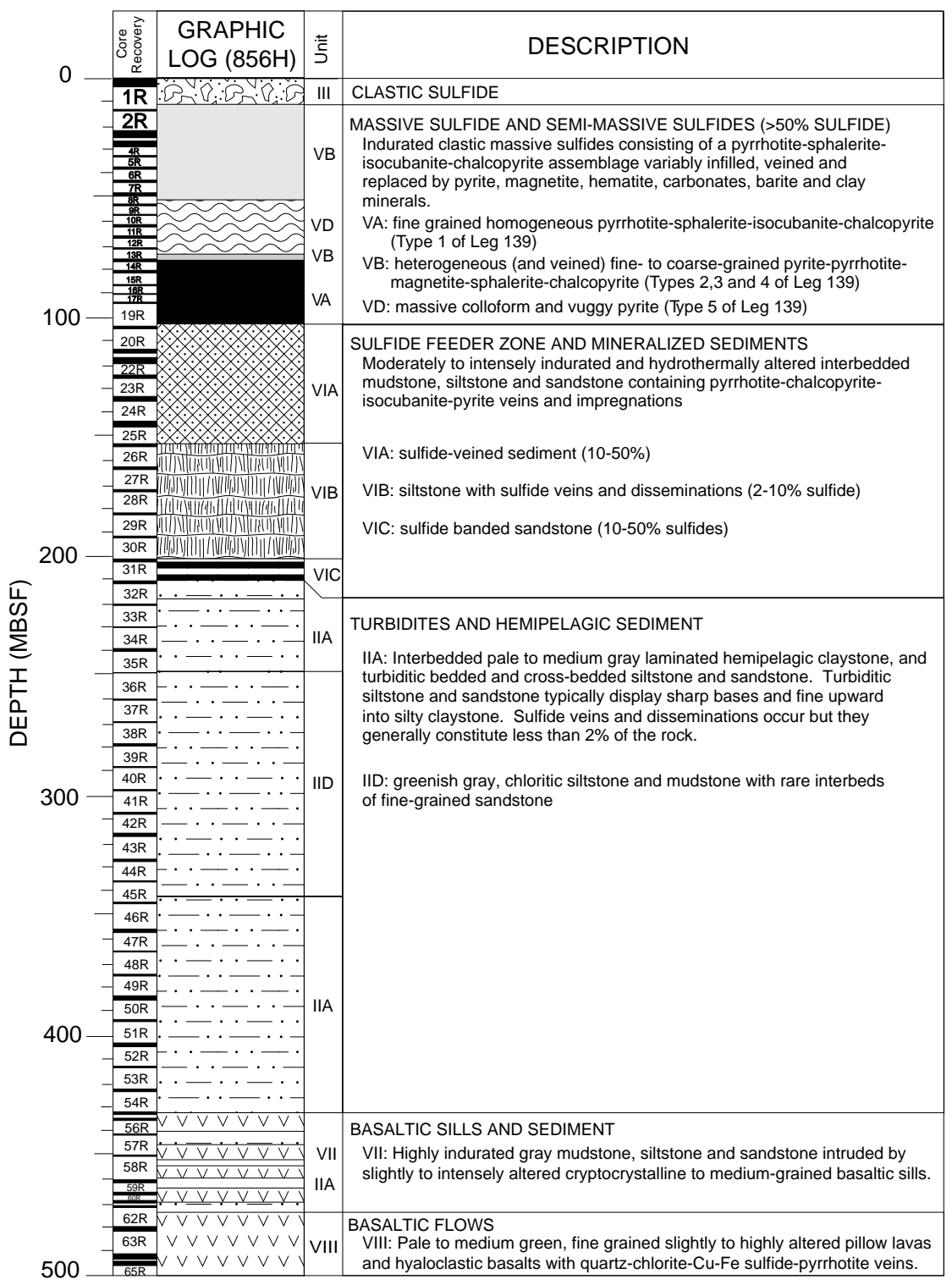

UNIT I HEMIPELAGIC SEDIMENTS (HOLOCENE AND LATE PLEISTOCENE)

Interbedded hemipelagic silty clay and minor turbiditic silt and sand

UNIT II TURBIDITES AND HEMIPELAGIC SEDIMENTS (PLEISTOCENE)

-.- Interbedded turbiditic sand (sandstone) and silt (siltstone), and hemipelagic silty clay (claystone)

S. Slumped and brecciated hemipelagic and turbiditic sediment

UNIT III CLASTIC SULFIDES

Sulfide breccia, sand and mud interbedded with hemipelagic and turbiditicsilt and sand; also includes sulfide rubble from the top of the also includes sulfide rubble frive sulfides (Unit V)
massive

UNIT V MASSIVE AND SEMI-MASSIVE SULFIDES $(>50 \%$ SULFIDE)

VA Fine-grained pyrrhotite-sphalerite-isocubanitechalcopyrite (Type 1, Leg 139)

VB Fine-grained pyrite-pyrrhotite-magnetitesphalerite-isocubanite-chalcopyrite (Types 2, 3, and 4, Leg 139)

VC Sphalerite-pyrrhotite-pyrite-magnetite

2 VD Colloform and vuggy pyrite (Type 5, Leg 139)

UNIT VI SULFIDE FEEDER ZONE AND MINERALIZED SEDIMENTS

VIA Sulfide-veined sediment (10-50\% sulfide)

VIB Sediment with sulfide veins and/or impregnations $(2-10 \%$ sulfide)

VIC Sulfide banded/impregnated sediment (10-50\% sulfide)

UNIT VII BASALTIC SILLS

Basaltic sills intercalated with altered hemipelagic and turbiditic sediment

UNIT VIII BASALTIC FLOWS

Figure 7. Left. Stratigraphic section for Hole $856 \mathrm{H}$, Bent Hill, showing the distribution of mineralized and nonmineralized subunits, Legs 139 and 169 . Right. Legend for Figures 7 through 16. 
Table 3 (continued).

\begin{tabular}{|c|c|c|c|c|c|}
\hline $\begin{array}{l}\text { Lithologic } \\
\text { unit }\end{array}$ & $\begin{array}{l}\text { Description } \\
\text { (age) }\end{array}$ & Hole $1035 \mathrm{E}$ & Hole $1035 \mathrm{~F}$ & Hole $1035 \mathrm{G}$ & Hole $1035 \mathrm{H}$ \\
\hline I & Hemipelagic sediments (Holocene and late Pleistocene) & $1 \mathrm{H}-1$ through $1 \mathrm{H}-3$ & & & \\
\hline II & $\begin{array}{l}\text { Interbedded turbidites and hemipelagic sediments } \\
\text { (Pleistocene) }\end{array}$ & $2 \mathrm{H}-3$ through $5 \mathrm{H}-\mathrm{CC}$ & 19R-1 through 23R-1 & 5R-1 through 9R-1 & $\begin{array}{l}\text { 6R-2 through 8R-1 } \\
12 \mathrm{R}-1 \\
25 \mathrm{R}-1 \text { through } 27 \mathrm{R}-2\end{array}$ \\
\hline III & Clastic sulfides & $1 \mathrm{H}-3$ through $2 \mathrm{H}-2$ & 1R-1 & & 1R-1 through 1R-CC \\
\hline IV & Clastic sulfate chimney residue & & & & \\
\hline $\mathrm{V}$ & Massive and semi-massive sulfides [ $>50 \%$ sulfide] & & 1R-1 through 9R-1 & $2 \mathrm{R}-1$ through $4 \mathrm{R}-1$ & $\begin{array}{l}\text { 2R-1 through } 4 \mathrm{R}-1 \\
9 \mathrm{R}-1 \\
\text { 14R-1 through 19R-1 }\end{array}$ \\
\hline VI & Sulfide feeder zone and mineralized sediments & & 10R-1 through $18 \mathrm{R}-1$ & 10R-1 through 13R-1 & $\begin{array}{l}\text { 4R-1 through } 6 \mathrm{R}-2 \\
\text { 9R-1 through } 11 \mathrm{R}-1 \\
\text { 13R-1 through } 14 \mathrm{R}-1 \\
\text { 19R-1 } \\
\text { 20R-1 through } 24 \mathrm{R}-2\end{array}$ \\
\hline VII & Basaltic flows & & & & \\
\hline VIII & Basaltic flows & & & & \\
\hline
\end{tabular}

the BHMS deposit at the location of Hole $856 \mathrm{H}$. Hole $1035 \mathrm{~A}$ penetrated interbedded clastic sulfides (Unit III; 0-8.9 mbsf), interbedded hemipelagic and turbiditic sediments with intervals of carbonate and anhydrite concretions and authigenic crystals (Unit II, 8.9-52.6 and 62.5-168.9 mbsf), a thin interval of massive vuggy pyrite (Unit V, 55.0-56.9 mbsf), and a silicified, sulfide-veined and impregnated silty mudstone (Unit VI, 168.9-169.8 mbsf) at the bottom of the hole. This silicified interval is interpreted to be laterally equivalent to the top of the DCZ underlying the Hole $856 \mathrm{H}$ sulfide feeder zone. Below $170.8 \mathrm{mbsf}$, the silicified sediment was too hard to drill with the extended core barrel.

\section{Hole 1035C}

Hole 1035C (Fig. 9) is a short hole that was drilled to a depth of $39.8 \mathrm{~m}, 53 \mathrm{~m}$ south of Hole $856 \mathrm{H}$, near the southern edge of the BHMS deposit. This hole intersected clastic sulfides (Unit III, 0-1.47 mbsf), interbedded hydrothermally altered silty clay (Unit I), and massive pyrrhotitic and vuggy pyritic sulfides (Unit V, 20.1-39.8 mbsf). The clastic sulfides are composed of angular clasts of vuggy pyrite, pyrrhotite-sphalerite and iron oxide-rich fragments, and sulfidic muds. The massive sulfides consist predominantly of pyrrhotitic massive sulfide, with lesser pyrite and minor magnetite.

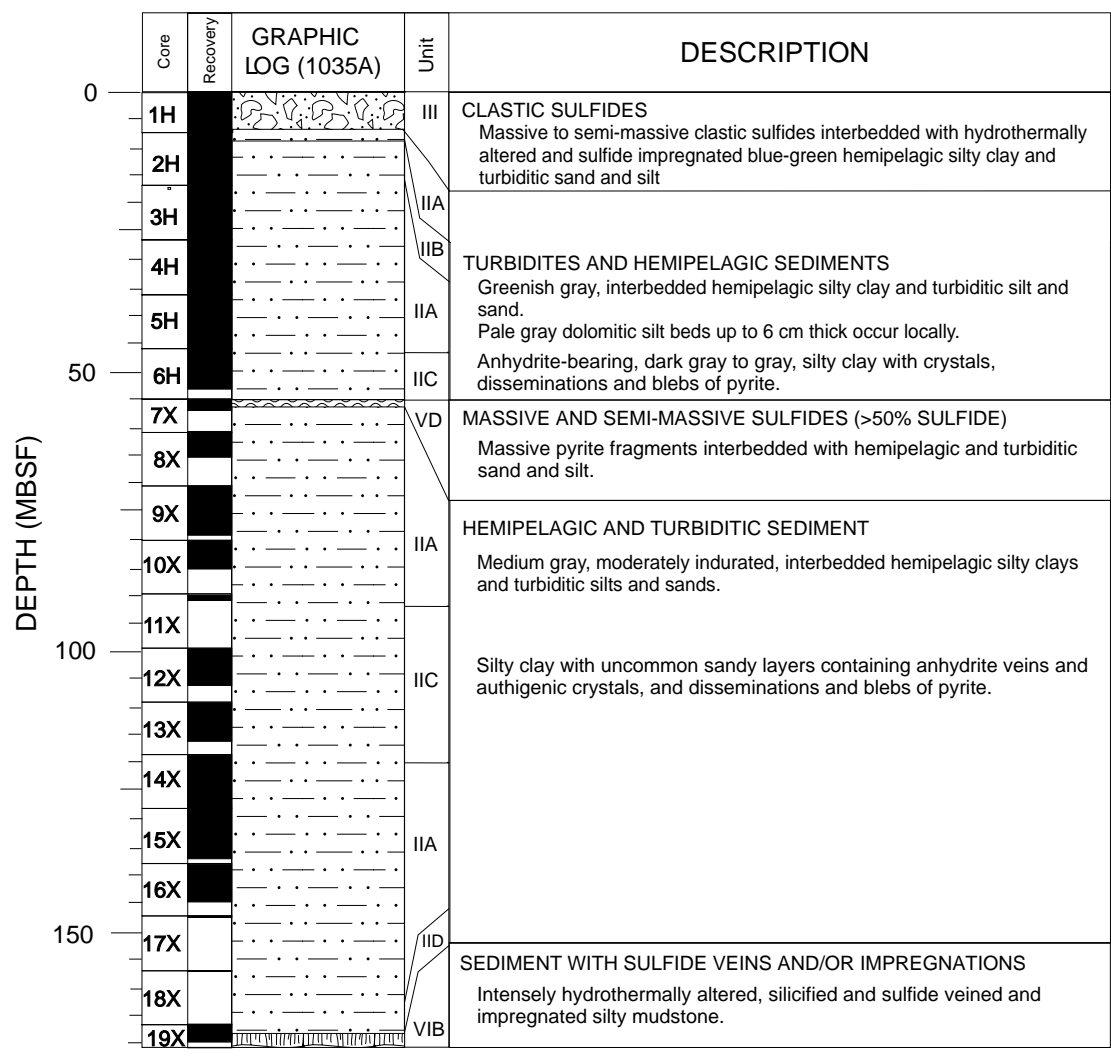

Figure 8. Stratigraphic section for Hole 1035A showing the distribution of mineralized and nonmineralized subunits, Leg 169 (see Fig. 7 for legend). 
Figure 9. Stratigraphic section for Hole $1035 \mathrm{C}$ showing the distribution of mineralized and nonmineralized subunits, Leg 169 (see Fig. 7 for legend).
Figure 10. Stratigraphic section for Hole 1035D showing the distribution of mineralized and nonmineralized subunits, Leg 169 (see Fig. 7 for legend).

Figure 11. Stratigraphic section for Hole 1035E showing the distribution of mineralized and nonmineralized subunits, Leg 169 (see Fig. 7 for legend).
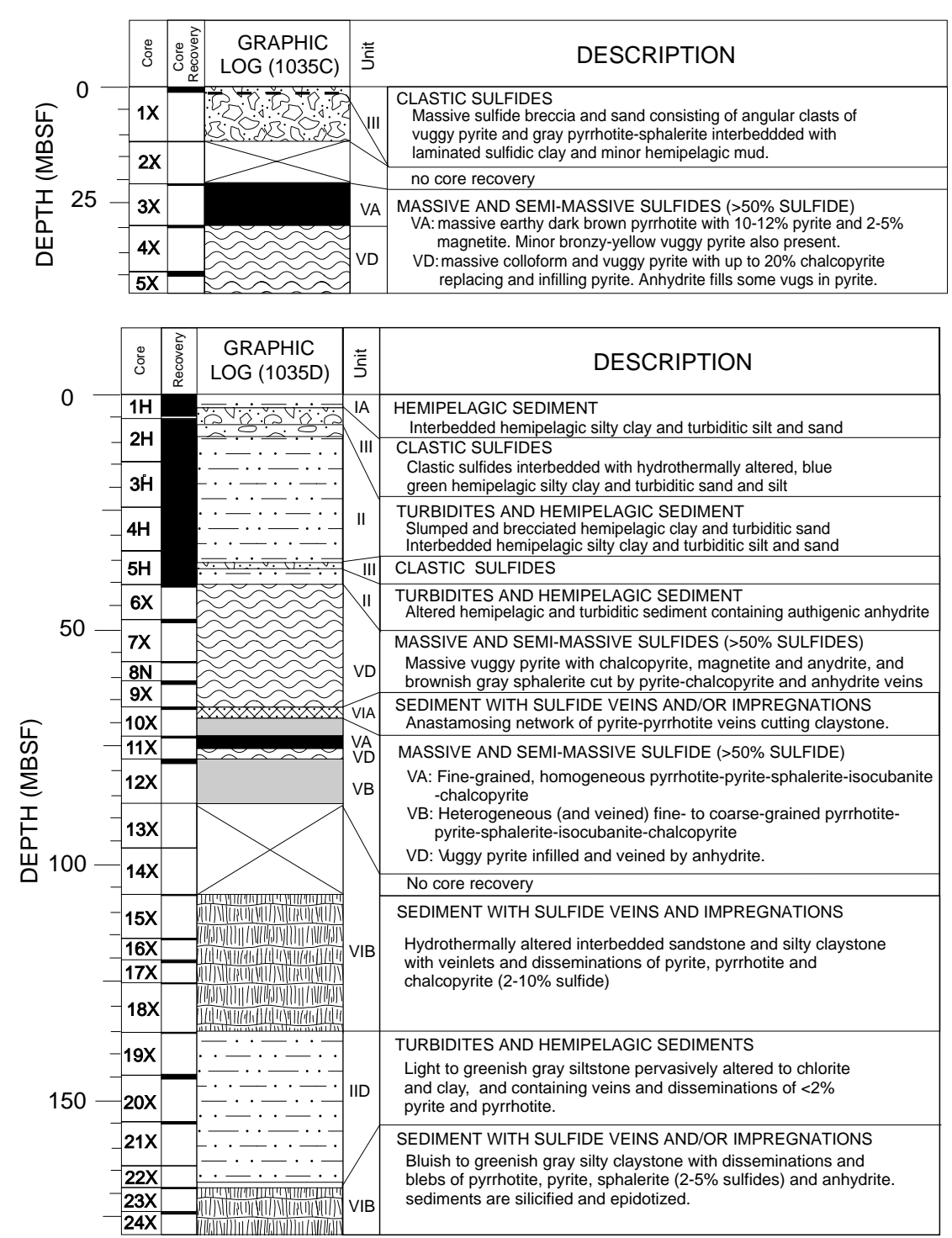

\section{Hole 1035D}

Hole $1035 \mathrm{D}$ was drilled $75 \mathrm{~m}$ east of Hole $856 \mathrm{H}$ to test the eastward extent of sulfide mineralization and to understand fluid flow as reflected by hydrothermal alteration patterns. Hole 1035D (Fig. 10) penetrated $173.9 \mathrm{~m}$ of sediments and rocks consisting of unaltered hemipelagic silty clay with minor turbiditic silt and sand (Unit I, 0$2.7 \mathrm{mbsf}$ ), clastic sulfides (Unit III, 2.7-7.1 mbsf), interbedded and weakly altered hemipelagic and turbiditic sediments (Unit II, 7.1$40.6 \mathrm{mbsf}$ ), a second interval of clastic sulfides (35.6-36.8 mbsf), massive and semi-massive sulfides (Unit V, 40.6-61.8 mbsf and
72.4-77.8 mbsf), a sulfide feeder zone (Unit VI, 66.5-66.7, 106.2125.6, and 168.5-173.9 mbsf), and weakly mineralized hemipelagic and turbiditic sediment (Unit II, 135-155.3 mbsf).

In interval $169-1035 \mathrm{D}-2 \mathrm{H}-2,80 \mathrm{~cm}$, to $2 \mathrm{H}-3,150 \mathrm{~cm}(7.4-9.6$ mbsf), a 2.2-m-thick slumped interval of sedimentary breccia is interbedded with hemipelagic clay and turbiditic sand. Sections 169$1035 \mathrm{D}-3 \mathrm{H}-5$ through $5 \mathrm{H}-7$ (20.6-24.4 mbsf) and 169-1035D-4H-3 through $4 \mathrm{H}-7$ (27.10-33.81 mbsf) are characterized by disseminations and nodules of anhydrite and pyrite. Calcite nodules and two thin dolomicrite beds occur only in Sections 169-1035D-3H-3 through 3H-4 (17.6-20.6 mbsf). The clastic sulfides consist of sul- 


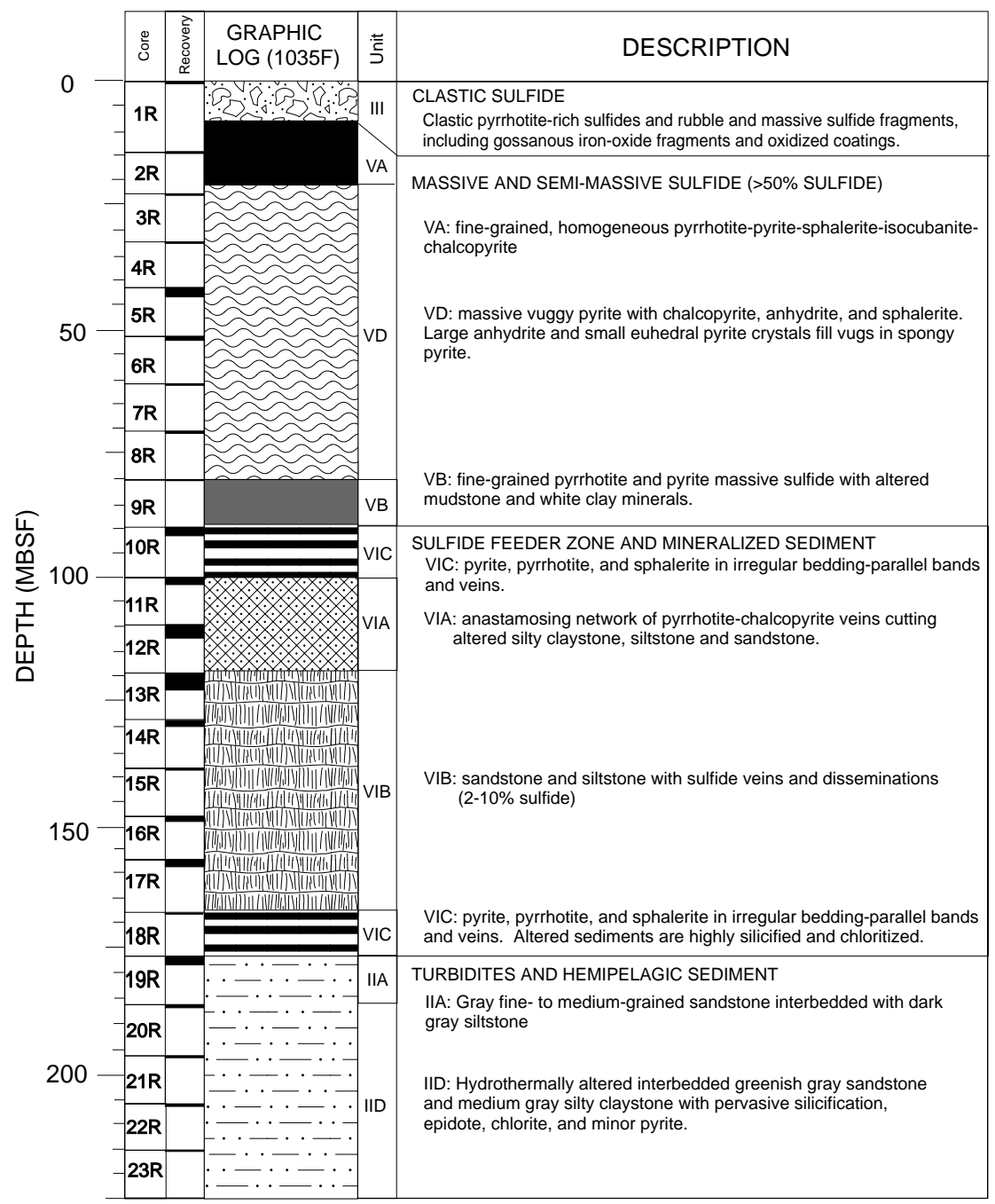

Figure 12. Stratigraphic section for Hole 1035F showing the distribution of mineralized and nonmineralized subunits, Leg 169 (see Fig. 7 for legend). fide mud, sand, and clasts up to $3 \mathrm{~cm}$ diameter, comprising pyrite, pyrrhotite, and minor sphalerite and chalcopyrite. The massive sulfides are characterized by vuggy massive pyrite containing veins, patches, and disseminations of chalcopyrite, sphalerite, magnetite, and anhydrite. The sulfide feeder zone in this hole consists mostly of sulfide-veined mudstone with an anastomosing network of pyritepyrrhotite veins. Below $173.9 \mathrm{~m}$, drilling with XCB was stopped by the intense silicification noted in Hole 1035A (correlated to the DCZ) and the hole was ended.

\section{Hole 1035E}

Hole $1035 \mathrm{E}$ was drilled $100 \mathrm{~m}$ south of Hole $856 \mathrm{H}$, but was terminated after only $46.19 \mathrm{~m}$ because of a stuck core barrel and a parted wire line. This hole (Fig. 11) consists of a thin interval of unaltered hemipelagic sediment with minor turbidites (Unit I, 0-3.4 mbsf) that is underlain by clastic sulfides (Unit III, 3.4-10.1 mbsf) and variously altered interbedded hemipelagic silty clay and turbiditic sediments, and sedimentary mud-clast breccias (Unit II, 10.5-46.19 mbsf). The sedimentary breccia consists of angular mud and sand clasts up to 4 $\mathrm{cm}$ in diameter and is underlain by a $2.4-\mathrm{m}$-thick interval of silty clay that is interpreted to be a thick slump deposit.

The clastic sulfides beds are typically 2 to $10 \mathrm{~cm}$ thick, but a few are up to $20 \mathrm{~cm}$ thick. The percentage of sulfides varies from $5 \%$ to $60 \%$. In general, the clastic sulfides have a grain size from fine to coarse sand, but the uppermost clastic sulfide bed contains clasts up to $1 \mathrm{~cm}$ diameter, which are similar to the coarse-grained clastic sulfide interval recovered in Hole 1035D.

\section{Hole $1035 F$}

Hole $1035 \mathrm{~F}$ was drilled $1 \mathrm{~m}$ east and $8 \mathrm{~m}$ south of Hole $1035 \mathrm{C}$ near the margin of the BHMS deposit, $60 \mathrm{~m}$ south of Hole $856 \mathrm{H}$ (Fig. 6). The hole (Fig. 12) intersected clastic pyrrhotite-rich sulfide rubble and gossanous iron oxide fragments (Unit III, 0.0-0.2 mbsf), massive sulfide (Unit V, 0.2-80.7 mbsf), sulfide feeder mineralization (Unit VI, 89.9-167.6 mbsf), and hydrothermally altered interbedded hemipelagic and turbiditic sedimentary rocks (Unit II, 176.8-224.8 mbsf).

The massive sulfides are composed of pyrrhotite with lesser pyrite and minor magnetite, pyrite-pyrrhotite-magnetite-sphalerite-isocubanite-chalcopyrite, and colloform and vuggy pyrite with interstitial chalcopyrite, sphalerite, and anhydrite. The feeder zone sulfides comprise an anastomosing network of pyrrhotite-chalcopyrite veins crosscutting altered mudstone. The sulfide-banded siltstone and sandstone (Subunit VIC) at the base of the sulfide feeder zone consists of pyrite and sphalerite in irregular bedding-parallel bands and veins. The sediments are highly silicified and chloritized in places. This interval is included as part of the DCZ and is interpreted to be correlative with similarly mineralized rocks near the base of the feeder zone in Hole $856 \mathrm{H}$. 
Figure 13. Stratigraphic section for Hole 1035G showing the distribution of nonmineralized subunits, Leg 169 (see Fig. 7 for legend).

\section{Hole $1035 G$}

Hole $1035 \mathrm{G}$ is located $\sim 10 \mathrm{~m}$ east of Hole $1035 \mathrm{~A}$ and was drilled to a depth of $208.5 \mathrm{mbsf}$ using the RCB to enable penetration of the silicified zone encountered at the base of Hole 1035A and to intercept the possible continuation of the DCZ. The upper section, from 0 to 44.4 mbsf, was therefore drilled without coring. The section where massive sulfide was expected was cored to examine thickness and compositional changes in this unit relative to Hole 1035A.

Hole 1035G (Fig. 13) consists of interbedded hemipelagic and turbiditic sediment (Unit II) that overlies massive vuggy pyrite (Unit $\mathrm{V}, 44.4-64.3 \mathrm{mbsf}$ ), which is cut by pyrite veins and partly filled by clear anhydrite, carbonate, and barite. Unit V is underlain by weakly mineralized hemipelagic claystone and turbiditic sandstone and siltstone (Unit II, 73.6-170.6 mbsf), sulfide impregnated siltstone and sediment (Subunit VIC, 170.6-170.9 mbsf), and a sulfide feeder zone (Subunit VIB, 170.9-199.6 mbsf) that extends to the bottom of the hole.

The sulfide-impregnated siltstone and sedimentary breccia are mineralized with mainly pyrite with very minor pyrrhotite. The sulfide feeder zone is composed of hydrothermally altered turbiditic sandstone with impregnations and veins of sphalerite, pyrrhotite, and pyrite. Small clusters of anhydrite and/or zeolite occur near the base of this unit.

\section{Hole $1035 \mathrm{H}$}

Hole $1035 \mathrm{H}$ was drilled $350 \mathrm{~m}$ south of Hole $856 \mathrm{H}$ near the southernmost peak of the ODP Mound and penetrated to a depth of 238.30 mbsf. Three major massive sulfide zones (Unit V) were encountered

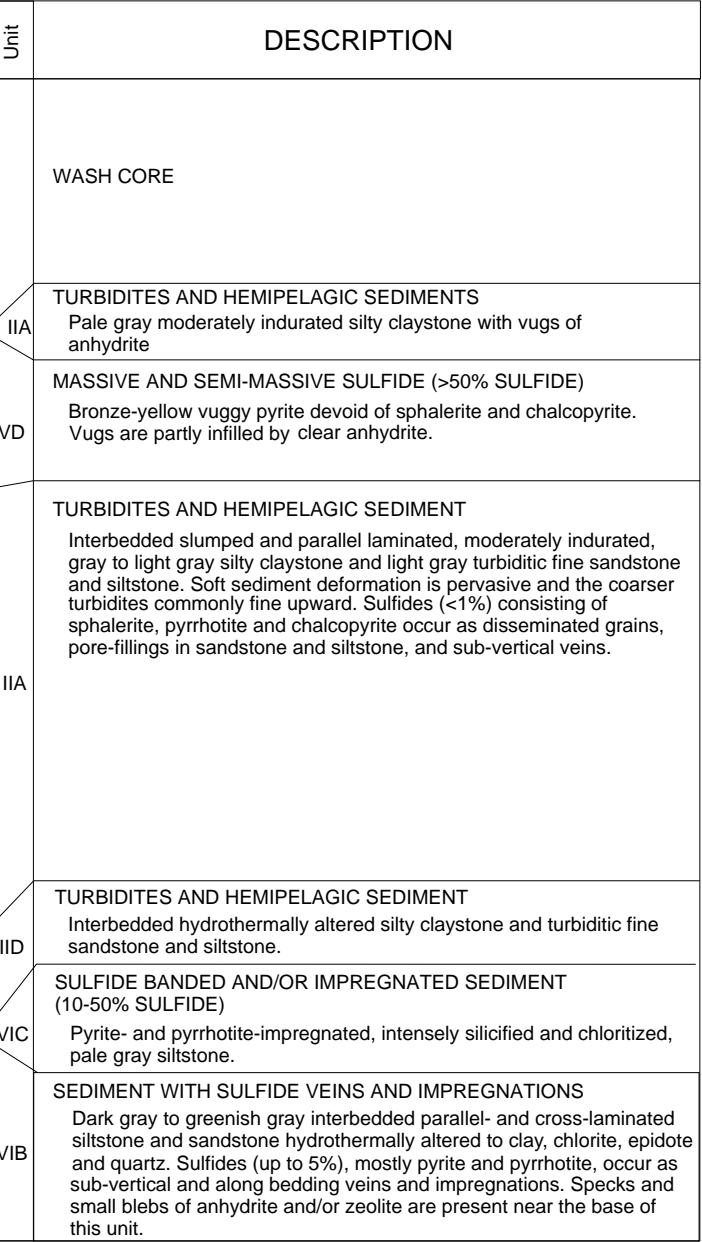

(Fig. 14), each underlain by variably sulfide impregnated and veined (Unit VI), hydrothermally altered hemipelagic and turbiditic sedimentary rocks. The uppermost part of this hole comprises intensely clay-altered silty claystone with some clasts of vuggy pyrite and sphalerite (Unit III, $0-2.2 \mathrm{mbsf}$ ). This unit grades into an $18-\mathrm{m}$-thick unit of clast-supported massive sulfide breccia (Unit V, 8.8-26.6 mbsf) composed of pyrite, marcasite, and black iron-rich sphalerite, with minor chalcopyrite, isocubanite, and pyrrhotite. The clastic sulfides are underlain by a sulfide feeder zone (Unit VI, 26.6-47.4 mbsf) and weakly mineralized hemipelagic and turbiditic sediment (Unit II, 47.4-74.6 and 103.7-113.4 mbsf). A thin massive sulfide unit occurs within Section 169-1035H-9R-1 and is underlain by a sulfide feeder zone (Unit VI, 75.1-94.0 and 113.4-123.4 mbsf) that overlies a thick massive sulfide interval (Unit V, 123.4-162.0 mbsf). This massive sulfide unit is underlain by a sulfide feeder zone, which includes semi-massive sulfides (Unit VI, 162.0-211.2 mbsf), which in turn, is underlain by interbedded turbiditic and hemipelagic sediment (Unit II) to the base of the hole.

Massive sulfide in Hole $1035 \mathrm{H}$ is relatively enriched in zinc compared to massive sulfide from the BHMS deposit. Furthermore, the DCZ underlying massive sulfide in Hole $1035 \mathrm{H}$ is thicker and has a higher copper content than similar mineralization at Bent Hill. Unit $\mathrm{V}$ in Hole $1035 \mathrm{H}$ is dominated by black iron-rich sphalerite, pyrrhotite, and/or pyrite. Sphalerite typically constitutes between $40 \%$ and $60 \%$, but may be up to $70 \%$ of the sulfide. Magnetite is generally associated with pyrite. Isocubanite occurs in minor amounts, as the dominant copper sulfide, whereas chalcopyrite is less abundant. Pyrite in massive sulfide units between 134.5 and $136.0 \mathrm{mbsf}$, and, 145.2 and $146.7 \mathrm{mbsf}$ is very coarse grained, with grain size up to 1.5 $\mathrm{cm}$, giving the rock a distinctive neoblastic texture. The occurrence 


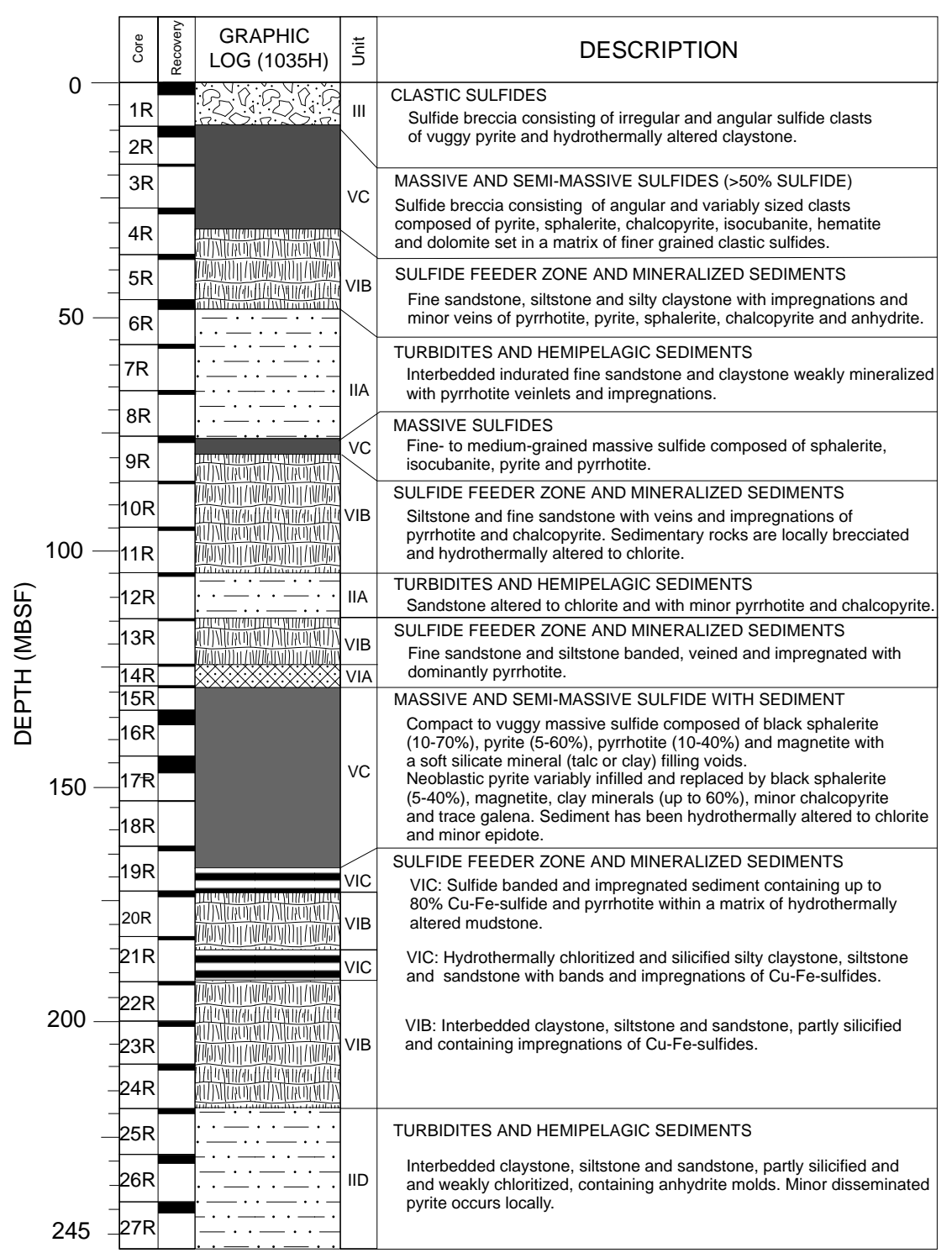

Figure 14. Stratigraphic section for Hole $1035 \mathrm{H}$ showing the distribution of mineralized and nonmineralized subunits, Leg 169 (see Fig. 7 for legend). of highly altered, recrystallized sedimentary rock with pervasive fine-grained actinolite and epidote alteration in interval $169-1035 \mathrm{H}-$ $16 \mathrm{R}-3,17 \mathrm{~cm}$, to $17 \mathrm{R}-3,15 \mathrm{~cm},(136-145 \mathrm{mbs})$ suggests that this zone experienced unusual hydrothermal fluid flow and thermal affects (see "Igneous Petrology and Geochemistry" section, this chapter).

The semi-massive sulfide occurs as mainly subhorizontal veins or laminae and very rich impregnations of $\mathrm{Cu}-\mathrm{Fe}$ sulfide in siltstone and silty claystone. The $\mathrm{Cu}-\mathrm{Fe}$ sulfide has a yellow color, between chalcopyrite and pyrite, and looks very similar to the banded $\mathrm{Cu}-\mathrm{Fe}$ sulfide that was found in Hole $856 \mathrm{H}$ within the DCZ under the BHMS deposit. Similar to the DCZ at Bent Hill, the sulfide in the DCZ at Hole $1035 \mathrm{H}$ is monomineralic and has partly replaced both planar laminae and cross-bedding in the original sediment. The sediment is chloritized and silicified.

Sulfide-veined and impregnated sediment generally underlies the semi-massive to massive sulfide zones. Beneath the sphalerite-pyrrhotite rich massive sulfides, the veins and impregnations consist mainly of these two minerals, but marcasite is also present, as well as minor pyrite and chalcopyrite. Zones that are only weakly impregnated by sulfide contain mostly pyrrhotite. Veins associated with and underlying the $\mathrm{Cu}$ $\mathrm{Fe}$ mineralization consist mainly of the same $\mathrm{Cu}-\mathrm{Fe}$ mineral.

\section{Cross Sections}

The stratigraphic and lateral distribution of clastic and massive sulfides, the Sulfide Feeder Zone (SFZ), and nonmineralized sedimentary and igneous units are shown in east-west (Fig. 15) and northsouth (Fig. 16) sections. These cross sections give an overview of the stratigraphy and possible correlations between units in the different holes.

\section{Sedimentology of Bent Hill}

\section{Lithologic Units I and II}

Sediments recovered in the Bent Hill area are characterized by Holocene and Pleistocene hemipelagic and turbiditic deposits. These sediments can be subdivided into two major lithologic units (Units I and II). This same unit division was used for the rocks recovered during Leg 139 (Davis, Mottl, Fisher, et al., 1992) and for Site 1036 (this volume). Unit I consists of fine-grained hemipelagic sediment of Holocene and late Pleistocene age. Unit II is characterized by alternating hemipelagic and turbiditic sediments of Pleistocene age and is subdivided into four subunits based on sediment texture and hydrothermal alteration assemblages (Table 4). Subunit IIA is an unaltered gray, interbedded hemipelagic silty clay and turbiditic sand and silt. A dis- 
Figure 15. East-west cross section of the BHMS showing the stratigraphic and lateral distribution of the massive sulfides, the underlying sulfide feeder zone, host turbiditic and hemipelagic sedimentary rocks, and basaltic sills and flows (see Fig. 7 for legend).

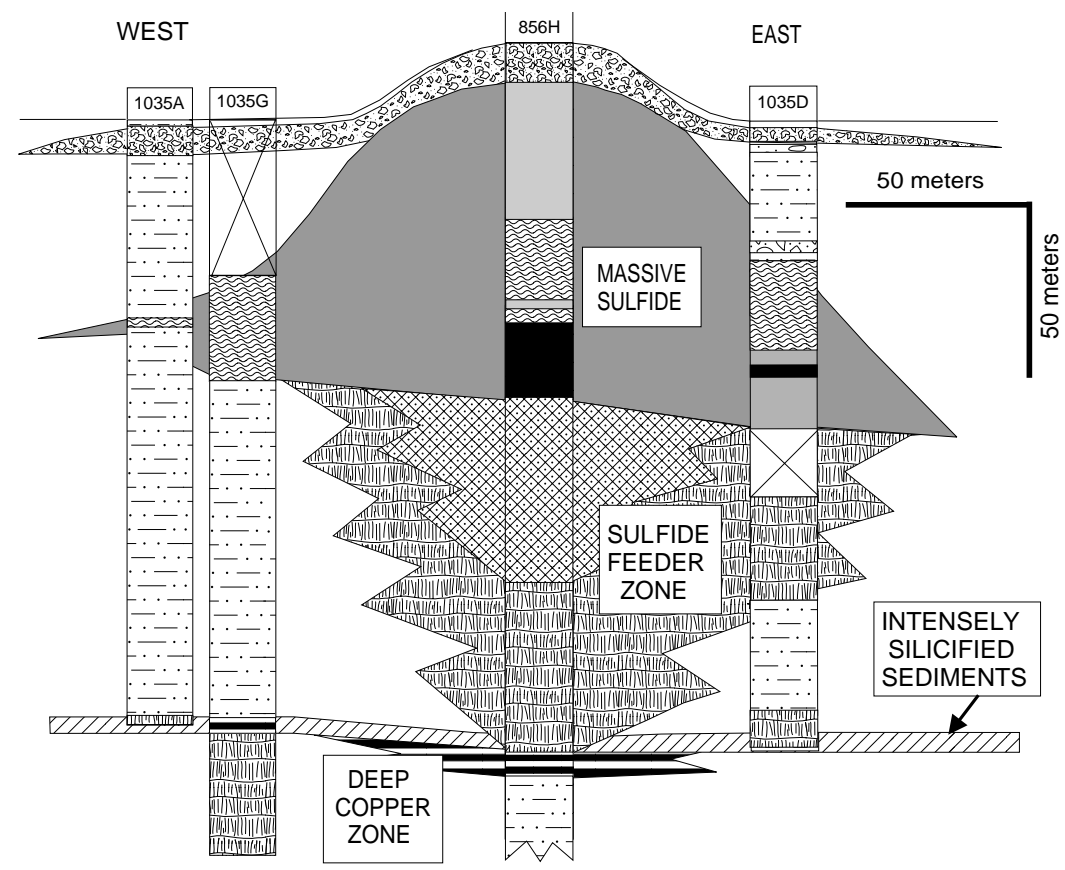

tinctive sedimentary breccia that occurs in several holes was included in this subunit. Subunit IIB is recognized as an alteration facies superimposed on Unit II and is distinguished by the presence of carbonate concretions and cement. Subunit IIC is distinguished by the presence of abundant anhydrite concretions and authigenic crystals. A fourth subunit, Subunit IID, is characterized by chlorite alteration and silicification.

\section{Subunit IA (Unaltered Silty Clay, Holocene to Late Pleistocene)}

Unit I is $\sim 25 \mathrm{~m}$ in total thickness in most parts of Middle Valley. Less than $10 \%$ of this unit is silt or sand. Because of the presence of clastic sulfide beds (see "Sulfide Mineralization: Clastic Sulfides" section, this chapter) and a slumped zone near the top of some of the holes at Site 1035, it is difficult to recognize Unit I at this site. Any unaltered silty clay that overlies the shallow clastic sulfide is assigned to Subunit IA. Subunit IA is found only in the upper 2 to $4 \mathrm{~m}$ of Holes 1035D and 1035E.

\section{Subunit IIA (Unaltered Interbedded Hemipelagic and Turbiditic Sand and Silt and Sedimentary Breccia, Late Pleistocene)}

Unit IIA comprises interbedded turbidites and hemipelagic sediment. These rocks consist of unaltered interbedded gray to greenish gray silty clay, silt, and fine-grained sand that exhibit varying, but minor amounts of sulfide mineralization $(<2 \%)$. In the upper 7 to $17 \mathrm{~m}$ of Holes 1035A, 1035D, and 1035E, this unit is interbedded with a 3to 4-m-thick slump and mud clast breccia.

\section{Subunit IIB (Interbedded Hemipelagic and Turbiditic Sand and Silt} with Carbonate Concretions, Late Pleistocene)

Subunit IIB is characterized by carbonate minerals (e.g., calcite and dolomite) that occur as concretions, crystals, and thin layers (see "Sulfide Mineralization: Hydrothermal Alteration" section, this chapter). Two dolomitic sediment layers are present in intervals 1691035A-3H-4, 10-14 cm, and 5H-3, 99-103 cm (Fig. 17). Dolomite was identified in a smear slide (on CD-ROM in the back pocket of this volume) and by XRD analysis (Table 5) in Sample 169-1035A$5 \mathrm{H}-5,102 \mathrm{~cm}$. These sediments consist of 2- to 4-mm-sized dolomite rhombs that appear to be slightly corroded. They are not interlocked or cemented and are interpreted to be an authigenic hydrothermal component developed in the sediment, similar to beds studied in Holes 858B and 858D (Baker et al., 1994). An 8-cm-thick nodule of dolomicrite is present in interval 169-1035D-3H-3, 130-138 cm.

Subunit IIC (Interbedded Hemipelagic and Turbiditic Sand and Silt with Anhydrite Concretions and Authigenic Crystals, Late Pleistocene)

Subunit IIC is characterized by moderately altered, dark gray to gray clay to silty clay that contains authigenic anhydrite, (see "Sulfide Mineralization: Hydrothermal Alteration" section, this chapter). Anhydrite occurs randomly distributed throughout this interval as colorless, translucent nodules and irregular anhydrite veins and fine euhedral crystals in intervals 169-1035A-5H-7, 18-35 cm (Fig. 18), and $5 \mathrm{H}-\mathrm{CC}, 0-14 \mathrm{~cm}$. Anhydrite was identified in a smear slide (on CD-ROM in the back pocket of this volume) in Sample 169-1035A5H-7, $102 \mathrm{~cm}$, and by XRD analysis in Sample 169-1035A-5H-7, 66 $\mathrm{cm}$ (Table 5). Anhydrite also occurs as coarsely crystalline concretions commonly exhibiting a radial habit in intervals 169-1035A$12 \mathrm{X}-2,64-66 \mathrm{~cm}$, and $12 \mathrm{X}-3,117-125 \mathrm{~cm}$. These concretions range in color from white to colorless with white cores (Fig. 19). Molds that mimic anhydrite morphology and indicate dissolution are present locally. Such dissolution is consistent with the high sulfate content of pore waters in the same intervals (see "Inorganic Geochemistry" section, this chapter).

Subunit IID (Interbedded Hemipelagic and Turbiditic Sand and Silt with Silicate Alteration, Late Pleistocene)

Chlorite alteration and silicification occurs in sedimentary rocks in the deeper parts of Holes 856H, 1035A, 1035D, 1035F, 1035G, and $1035 \mathrm{H}$ (see "Sulfide Mineralization: Hydrothermal Alteration" section, this chapter). Chlorite alteration imparts a distinct green color to the sedimentary rocks. Petrographic observations show that chlorite is more abundant in silty-clayey laminae, whereas quartz is more abundant in fine-grained sand laminae. The fine-grained dull matrix with scattered chlorite crystals probably consists mainly of chlorite derived from the alteration of detrital feldspar grains and matrix. Thin-section observations (on CD-ROM in the back pocket of this volume) and XRD analysis (Table 5) from interval $169-856 \mathrm{H}$ $39 \mathrm{R}, 66-74 \mathrm{~cm}$, indicate that the green color is the result of an in- 


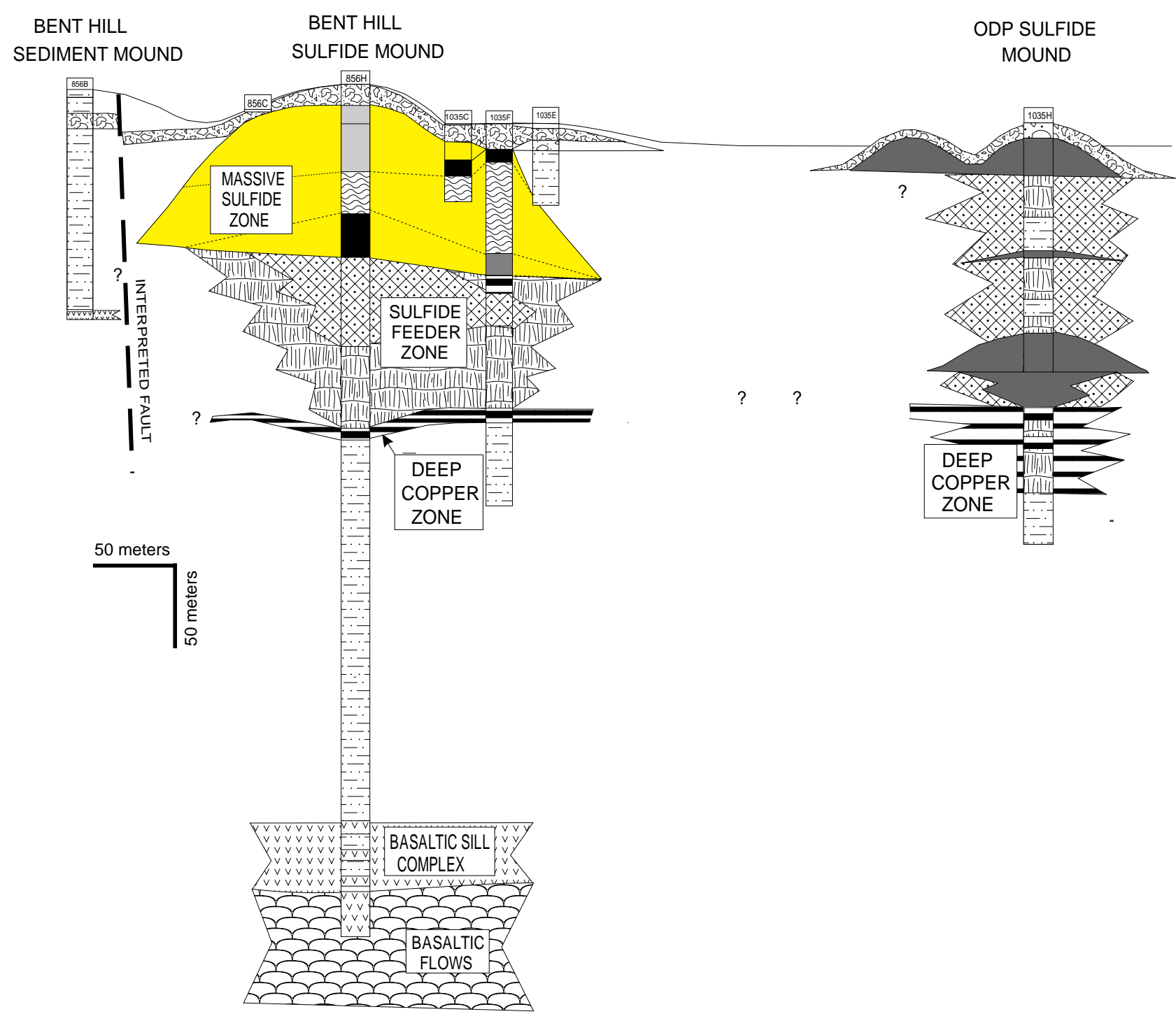

Figure 16. North-south cross section of the BHMS deposit and ODP Mound, the underlying sulfide feeder zones, the DCZ, host turbiditic and hemipelagic sedimentary rocks, and underlying basaltic sills and flows (see Fig. 7 for legend).

crease in authigenic chlorite. Silicification in some hemipelagic and turbiditic sediments occurs commonly as pale gray silica and quartz lining fractures.

\section{Lithofacies of the Sediments}

The primary objective of Leg 169 was to investigate the hydrothermal mineral deposits forming at a seafloor spreading center covered by sediments. Sedimentary facies provide one control on these processes and are the focus of this section, which provides lithofacies descriptions of the hemipelagic and turbiditic succession hosting the sulfide deposits.

Sediments recovered in the Bent Hill area, although locally hydrothermally altered, still preserve many of their primary sedimentary structures. Unfortunately, sediments from several deeper cores suffered from drilling disturbance that resulted in drill-induced brecciation and the formation of "rock biscuits" (Fig. 20). In these cases, detailed bed-by-bed observation was not possible, but the lithology and structures of the rock pieces from these cores are still recognizable. The recovery is also incomplete (the average recovery ranging from $100 \%$ in Hole $1035 \mathrm{E}$ to $10 \%$ in Hole $1035 \mathrm{~F}$ ). It is possible that the recovered core is not representative of some of the cored intervals. However, with these limitations in mind, there is enough information to outline the sedimentary succession and processes that have controlled sedimentation in the Bent Hill area.

The sedimentary column is mostly made up of hemipelagic and terrigenous turbiditic beds, but it also contains intrabasinal, autochthonous, and locally resedimented sulfide sands and breccia. In distinct intervals, the host rock is transformed by post-depositional hydrothermal processes resulting in impregnation and replacement of sediments by sulfides and alteration minerals. The lithologic units distinguished in the eight holes drilled at this site are therefore complex (Tables 2, 4).

\section{Lithofacies Types}

The Middle Valley depositional system was likely supplied by turbidite currents that originated by the slope failure on the western Canada shelf north of the Columbia River delta and not from a single delta point source. The sedimentation in Middle Valley area is influenced by topographic variations in a triple-junction area that control the sedimentation at various scales. Formation of transform walls or 
Table 4. Sedimentary lithologic units, Bent Hill sites.

\begin{tabular}{|c|c|c|c|c|c|}
\hline $\begin{array}{l}\text { Lithologic } \\
\text { unit/subunit }\end{array}$ & $\begin{array}{l}\text { Description } \\
\quad \text { (age) }\end{array}$ & Hole $856 \mathrm{H}$ & Hole $1035 \mathrm{~A}$ & Hole 1035D & Hole $1035 \mathrm{E}$ \\
\hline I & $\begin{array}{l}\text { Hemipelagic sediments with minor } \\
\text { turbidites (Holocene to late } \\
\text { Pleistocene) }\end{array}$ & & & & \\
\hline IA & Unaltered silty clay & & & $\begin{array}{l}1 \mathrm{H}-1,0 \mathrm{~cm}, \text { to } 1 \mathrm{H}-2,119 \mathrm{~cm} \\
\quad(0.00-2.69 \mathrm{mbsf})\end{array}$ & $\begin{array}{l}1 \mathrm{H}-1,0 \mathrm{~cm}, \text { to } 1 \mathrm{H}-3,37 \mathrm{~cm} \\
(0.00-3.4 \mathrm{mbsf})\end{array}$ \\
\hline II & $\begin{array}{l}\text { Interbedded hemipelagic and turbiditic } \\
\text { sediment (Pleistocene) }\end{array}$ & & & & \\
\hline IIA & $\begin{array}{l}\text { Interbedded silty clay and turbiditic } \\
\text { silt and sand }\end{array}$ & $\begin{array}{l}32 \mathrm{R}-1,0 \mathrm{~cm}, \text { to } 35 \mathrm{R}-2,96 \mathrm{~cm} \\
(210.60-249.00 \mathrm{mbsf}) \\
46 \mathrm{R}-1,0 \mathrm{~cm} \text {, to } 54 \mathrm{R}-1,50 \mathrm{~cm} \\
(307.65-431.70 \mathrm{mbsf})\end{array}$ & $\begin{array}{c}2 \mathrm{H}-2,0 \mathrm{~cm} \text {, to } 3 \mathrm{H}-\mathrm{CC}, 37 \mathrm{~cm} \\
(8.90-26.5 \mathrm{mbsf}) \\
4 \mathrm{H}-7,0 \mathrm{~cm} \text {, to } 5 \mathrm{H}-6,150 \mathrm{~cm} \\
(35.50-44.92 \mathrm{mbsf}) \\
8 \mathrm{X}-2,0 \mathrm{~cm} \text {, to } 11 \mathrm{X}-\mathrm{CC}, 36 \\
\mathrm{~cm}(62.50-99.40 \mathrm{mbsf}) \\
15 \mathrm{X}-6,0 \mathrm{~cm}, \text { to } 19 \mathrm{X}-2,74 \\
\mathrm{~cm}(135.70-168.94 \mathrm{mbsf})\end{array}$ & $\begin{array}{l}2 \mathrm{H}-2,52 \mathrm{~cm} \text {, to } 3 \mathrm{H}-2,150 \mathrm{~cm} \\
(7.12-17.60 \mathrm{mbsf}) \\
3 \mathrm{H}-\mathrm{CC}, 0 \mathrm{~cm} \text {, to } 4 \mathrm{H}-2,150 \\
\mathrm{~cm}(24.35-27.10 \mathrm{mbsf}) \\
4 \mathrm{H}-\mathrm{CC}, 0 \mathrm{~cm}, \text { to } 5 \mathrm{H}-2,67 \mathrm{~cm} \\
(33.81-35.60 \mathrm{mbsf})\end{array}$ & $\begin{array}{r}2 \mathrm{H}-3,0 \mathrm{~cm}, \text { to } 4 \mathrm{H}-2,150 \\
\mathrm{~cm}(10.50-29.50 \mathrm{mbsf}) \\
5 \mathrm{H}-1,0 \mathrm{~cm}, \text { to } 5 \mathrm{H}-5,140 \\
\mathrm{~cm}(36.00-42.24 \mathrm{mbsf})\end{array}$ \\
\hline IIB & $\begin{array}{l}\text { Interbedded hemipelagic and turbiditic } \\
\text { sediment with carbonate } \\
\text { concretions/cement }\end{array}$ & & $\begin{array}{l}4 \mathrm{H}-1,0 \mathrm{~cm}, \text { to } 4 \mathrm{H}-6,150 \mathrm{~cm} \\
\quad(26.50-35.50 \mathrm{mbsf})\end{array}$ & $\begin{array}{l}3 \mathrm{H}-3,0 \mathrm{~cm}, \text { to } 3 \mathrm{H}-4,140 \mathrm{~cm} \\
\quad(17.60-20.60 \mathrm{mbsf})\end{array}$ & $\begin{array}{l}4 \mathrm{H}-3,0 \mathrm{~cm}, \text { to } 4 \mathrm{H}-\mathrm{CC}, 10 \\
\mathrm{~cm}(29.50-36.00 \mathrm{mbsf})\end{array}$ \\
\hline IIC & $\begin{array}{l}\text { Interbedded hemipelagic and turbiditic } \\
\text { sediment with anhydrite } \\
\text { concretions/crystals }\end{array}$ & & $\begin{array}{l}5 \mathrm{H}-7,0 \mathrm{~cm}, \text { to } 6 \mathrm{H}-5,110 \mathrm{~cm} \\
\quad(44.92-52.60 \mathrm{mbsf}) \\
12 \mathrm{X}-1,0 \mathrm{~cm}, \text { to } 15 \mathrm{X}-5,150 \\
\mathrm{~cm}(99.40-135.70 \mathrm{mbsf})\end{array}$ & $\begin{array}{l}3 \mathrm{H}-5,0 \mathrm{~cm} \text {, to } 3 \mathrm{H}-7,75 \mathrm{~cm} \\
\quad(20.60-24.35 \mathrm{mbsf}) \\
\\
4 \mathrm{H}-3,0 \mathrm{~cm}, \text { to } 4 \mathrm{H}-7,71 \mathrm{~cm} \\
(27.10-33.81 \mathrm{mbsf}) \\
5 \mathrm{H}-3,15 \mathrm{~cm}, \text { to } 5 \mathrm{H}-\mathrm{CC}, 20 \\
\mathrm{~cm}(36.75-40.60 \mathrm{mbsf})\end{array}$ & $\begin{array}{c}5 \mathrm{H}-6,0 \mathrm{~cm} \text {, to } 5 \mathrm{H}-\mathrm{CC}, 60 \\
\mathrm{~cm}(42.24-46.19 \mathrm{mbsf})\end{array}$ \\
\hline IID & $\begin{array}{l}\text { Interbedded hemipelagic and turbiditic } \\
\text { sediment with silicate alteration }\end{array}$ & $\begin{array}{l}36 \mathrm{R}-1,0 \mathrm{~cm} \text {, to } 45 \mathrm{R}-1,75 \mathrm{~cm} \\
(249.00-307.65 \mathrm{mbsf})\end{array}$ & $\begin{array}{l}19 \mathrm{CC}, 0-38 \mathrm{~cm} \\
(169.46-170.80 \mathrm{mbsf})\end{array}$ & $\begin{array}{c}19 \mathrm{X}-\mathrm{CC}, 0 \mathrm{~cm}, \text { to } 21 \mathrm{X}-1,96 \\
\mathrm{~cm}(135.0-155.26 \mathrm{mbsf})\end{array}$ & \\
\hline
\end{tabular}

Table 4 (continued).

\begin{tabular}{|c|c|c|c|c|}
\hline $\begin{array}{l}\text { Lithologic } \\
\text { unit/subunit }\end{array}$ & $\begin{array}{l}\text { Description } \\
\quad \text { (age) }\end{array}$ & Hole $1035 \mathrm{~F}$ & Hole $1035 \mathrm{G}$ & Hole $1035 \mathrm{H}$ \\
\hline I & $\begin{array}{l}\text { Hemipelagic sediments with minor } \\
\text { turbidites (Holocene to late } \\
\text { Pleistocene) }\end{array}$ & & & \\
\hline IA & Unaltered silty clay & & & \\
\hline II & $\begin{array}{l}\text { Interbedded hemipelagic and } \\
\text { turbiditic sediment (Pleistocene) }\end{array}$ & & & \\
\hline IIA & $\begin{array}{l}\text { Interbedded silty clay and turbiditic } \\
\text { silt and sand }\end{array}$ & $\begin{array}{l}19 \mathrm{R}-1,0-129 \mathrm{~cm} \\
(176.80-178.1 \mathrm{mbsf})\end{array}$ & $\begin{array}{l}5 \mathrm{R}-1,0 \mathrm{~cm} \text {, to } 7 \mathrm{R}-\mathrm{CC}, 42 \mathrm{~cm}(73.60- \\
150.5 \mathrm{mbsf})\end{array}$ & $\begin{array}{l}6 \mathrm{R}-2,38 \mathrm{~cm} \text {, to } 8 \mathrm{R}-1,87 \mathrm{~cm}(47.4- \\
74.60 \mathrm{mbsf}) \\
12 \mathrm{R}-1,0 \mathrm{~cm} \text {, to } 12 \mathrm{R}-1,85 \mathrm{~cm}(103.70- \\
113.40 \mathrm{mbsf})\end{array}$ \\
\hline IIB & $\begin{array}{l}\text { Interbedded hemipelagic and } \\
\text { turbiditic sediment with carbonate } \\
\text { concretions/cement }\end{array}$ & & & \\
\hline IIC & $\begin{array}{l}\text { Interbedded hemipelagic and } \\
\text { turbiditic sediment with anhydrite } \\
\text { concretions/crystals }\end{array}$ & & & \\
\hline IID & $\begin{array}{l}\text { Interbedded hemipelagic and } \\
\text { turbiditic sediment with silicate } \\
\text { alteration }\end{array}$ & $\begin{array}{l}20 \mathrm{R}-1,0 \mathrm{~cm}, \text { to } 23 \mathrm{R}-1,58 \\
\mathrm{~cm}(186.4-224.80 \mathrm{mbsf})\end{array}$ & $\begin{array}{l}8 \mathrm{R}-1,30 \mathrm{~cm} \text {, to } 10 \mathrm{R}-1,8 \mathrm{~cm} \\
\quad(150.80-170.60 \mathrm{mbsf})\end{array}$ & $\begin{array}{l}25 \mathrm{R}-1,0 \mathrm{~cm} \text {, to } 27 \mathrm{R}-2,90 \mathrm{~cm}(219.1- \\
240.3 \mathrm{mbsf})\end{array}$ \\
\hline
\end{tabular}

rift fault escarpments can prevent turbidite currents from reaching the spreading center, thus lowering the sedimentation rate for substantial lengths of time. Smaller scale morphological variations caused by lava flows, the growth of hydrothermal mounds, or the uplift of sediment hills similar to Bent Hill may also influence the deposition of turbiditic currents resulting in a lack of lateral continuity. The sedimentary succession in each hole at Site 1035 therefore has been analyzed to identify broad vertical and lateral changes of the mud/sand ratio. On this base, the succession has been divided into two lithofacies (Fig. 21), hemipelagic mudstone and siltstone (Lithofacies A) and turbiditic siltstone and sandstone (Lithofacies B).

\section{Lithofacies A: Mudstone and Siltstone}

Lithofacies A consists of an upper interval lying above the sulfide-banded/impregnated sediment (DCZ, 200 mbsf; see "Sulfide Mineralization: Sulfide Feeder Zone," section, this chapter) and two lower intervals below the DCZ in Hole $856 \mathrm{H}$.

Lithofacies A above the DCZ consists of Holocene to late Pleistocene hemipelagic silty clay, interbedded thin parallel-laminated silt/clay, and some fine-sand turbidites. The Holocene/Pleistocene boundary lies within the first section of Holes 1035A, 1035D, and $1035 \mathrm{E}$ (see "Biostratigraphy" section, this chapter). All investigated samples of the uppermost core of Holes $1035 \mathrm{~F}, 1035 \mathrm{H}$, and $856 \mathrm{H}$ 


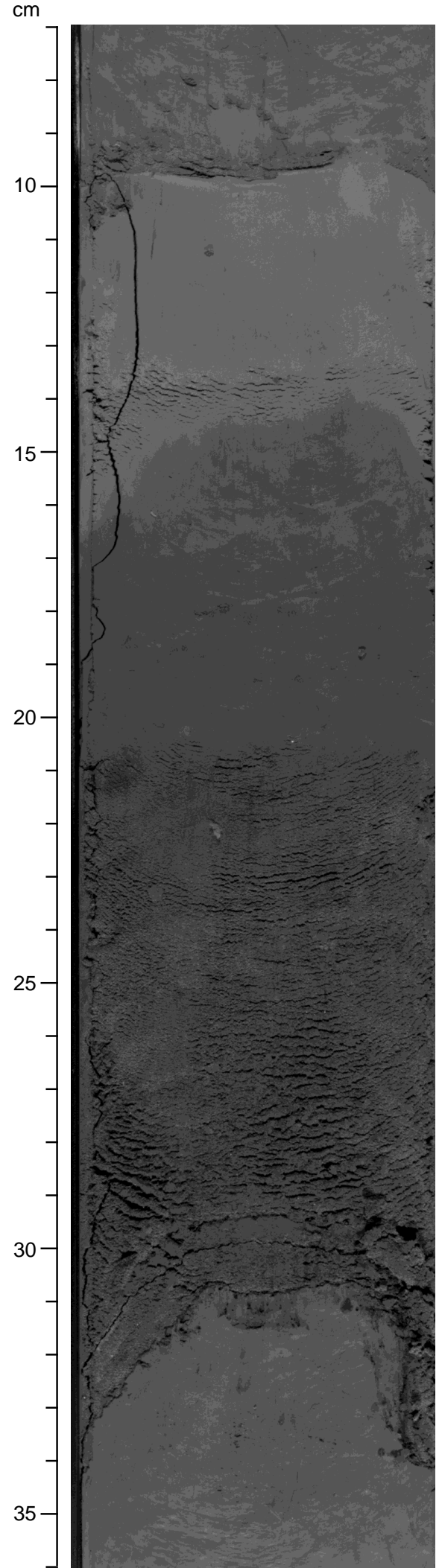

Figure 17. Light gray dolomicrite interval $(10-14 \mathrm{~cm})$ between two turbidite beds, probably a selective diagenetic replacement of a hemipelagic bed (interval 169-1035A-3H-4, 7-36 cm).
(Davis, Mottl, Fisher, et al. 1992) are barren of planktonic foraminifers. In general, Hole 1035A contains the best "background" record of Lithofacies A above the DCZ. It is only weakly affected by the hydrothermal activity that altered and sulfide impregnated the sediments in Holes 856H, 1035D and 1035F.

The hemipelagic sediments of Lithofacies A consist of silty clay to clayey silt. Smear-slide analysis indicates that they are composed of abundant clay minerals and common to rare quartz and feldspar. Sections $169-1035 \mathrm{~A}-2 \mathrm{H}-3$ through $4 \mathrm{H}-1$ are characterized by several very fine sand and silt laminations. The sediments of interval 169$1035 \mathrm{E}-1 \mathrm{H}-1,0 \mathrm{~cm}$, to $1 \mathrm{H}-3,100 \mathrm{~cm}(0-4.0 \mathrm{mbs})$, and interval 169 $1035 \mathrm{E}-2 \mathrm{H}-3,0 \mathrm{~cm}$, to $5 \mathrm{H}-\mathrm{CC}(10.5-46.2 \mathrm{mbsf})$ contain $\sim 65$ silty laminae. The fine sand and silt laminae contain abundant quartz and feldspar with minor mica, dolomite, and chlorite. Commonly, these interbedded laminae are characterized by a sharp base. Locally, they fine upward to hemipelagic silty clay indicating turbiditic deposits.

Thick intervals of the drilled succession in Cores 169-1035A-5H through 9X consist of homogeneous gray, bioturbated silty clay, virtually devoid of carbonate. This lithology commonly constitutes the top interval of graded beds and has been classified as being of hemipelagic origin. In interval $169-1035 \mathrm{~A}-8 \mathrm{X}-1,8-25 \mathrm{~cm}$, a turbiditic interval consists of an incomplete Bouma sequence, whereas Section 169-1035A-10X-1 contains silty turbidites with a Ta-Tc sequence. Parallel, wavy, or cross-stratified millimeter-scale laminae of silt and clay are present among graded beds in some cores. These may be the product of distal turbidites or of reworking by bottom currents.

Two pale green laminations that could represent altered ash layers are present in Section 169-1035D-1H-2. The sand-sized chlorite may be devitrified glass shards. However, no definitive shard texture is preserved (see the smear-slides on CD-ROM in the back pocket of this volume). These possible ash layers may be correlative with pale green laminations in Core 857A-1H-1 of Leg 139 (Davis, Mottl, Fisher, et al., 1992).

In interval $169-1035 \mathrm{E}-2 \mathrm{H}-3,3-58 \mathrm{~cm}$, a $0.57-\mathrm{m}$-thick interval of a greenish gray (5GY 5/1), non-indurated mud clast breccia with angular mud clasts up to $4 \mathrm{~cm}$ in diameter is present. Clasts are composed of silty clay, fine sand turbidites, and sulfides. This interval is underlain by a $2.4-\mathrm{m}$-thick interval $(169-1035 \mathrm{E}-2 \mathrm{H}-3,60 \mathrm{~cm}$ - to $2 \mathrm{H}-$ $4,150 \mathrm{~cm})$ of silty clay that is interpreted, on the basis of disrupted beds and high angle bedding, to be a slump deposit. The whole sequence is similar to the 2.9 -m-thick slumped sedimentary breccia in interval $169-1035 \mathrm{D}-2 \mathrm{H}-2,80 \mathrm{~cm}$, to $2 \mathrm{H}-4,70 \mathrm{~cm}$ (Fig. 22), and the $3.8-\mathrm{m}$-thick slumped interval $169-1035 \mathrm{~A}-2 \mathrm{H}-5,60 \mathrm{~cm}$, to $2 \mathrm{H}-7,40$ $\mathrm{cm}$.

Lithofacies A below the DCZ is present only in Hole $856 \mathrm{H}$. The first interval (169-856H-33R-1, $0 \mathrm{~cm}$, to 40R-1, $65.5 \mathrm{~cm}$ ) occurs just beneath the DCZ and is characterized by interbedded turbidites and hemipelagic sediments. The rocks in Sections 169-856H-33R-1 through 35R-1 consist of slightly hydrothermally altered, finely laminated, and bioturbated gray mudstone. Sections 169-856H-34R-1 through 40R-1 are characterized by extensively hydrothermally altered, interbedded greenish gray mudstone and siltstone with interbeds of fine-grained sandstone. Limited recovery $(\sim 7.3 \%)$ makes reconstruction of individual sedimentary sequences difficult, but examination of recovered intervals reveals the presence of sedimentary structures and textures similar to those found in other sedimentary cores in this area, specifically, those recovered at Sites 856 and 857 of Leg 139 (Davis, Mottl, Fisher, et al., 1992). Figure 23 shows typical planar cross-laminations. Quartz, although affected by extensive overgrowths of chlorite, is the only primary coarse-grained detrital mineral preserved. Smectite and chlorite are present in the groundmass in thin sections viewable on CD-ROM in the back pocket of this volume.

The lowermost interval of Lithofacies A (interval 169-856H-48R$1,0 \mathrm{~cm}$, to $62 \mathrm{R}-1,85 \mathrm{~cm}$ ) extends from 364.6 to 479.9 mbsf. Interval $169-856 \mathrm{H}-48 \mathrm{R}-1,0 \mathrm{~cm}$, to $54 \mathrm{R}-1,50 \mathrm{~cm}$, consists of finely laminated gray mudstone and gray/light gray siltstone. Massive planar-laminated 
Table 5. X-ray diffraction identifications of minerals, Bent Hill sites.

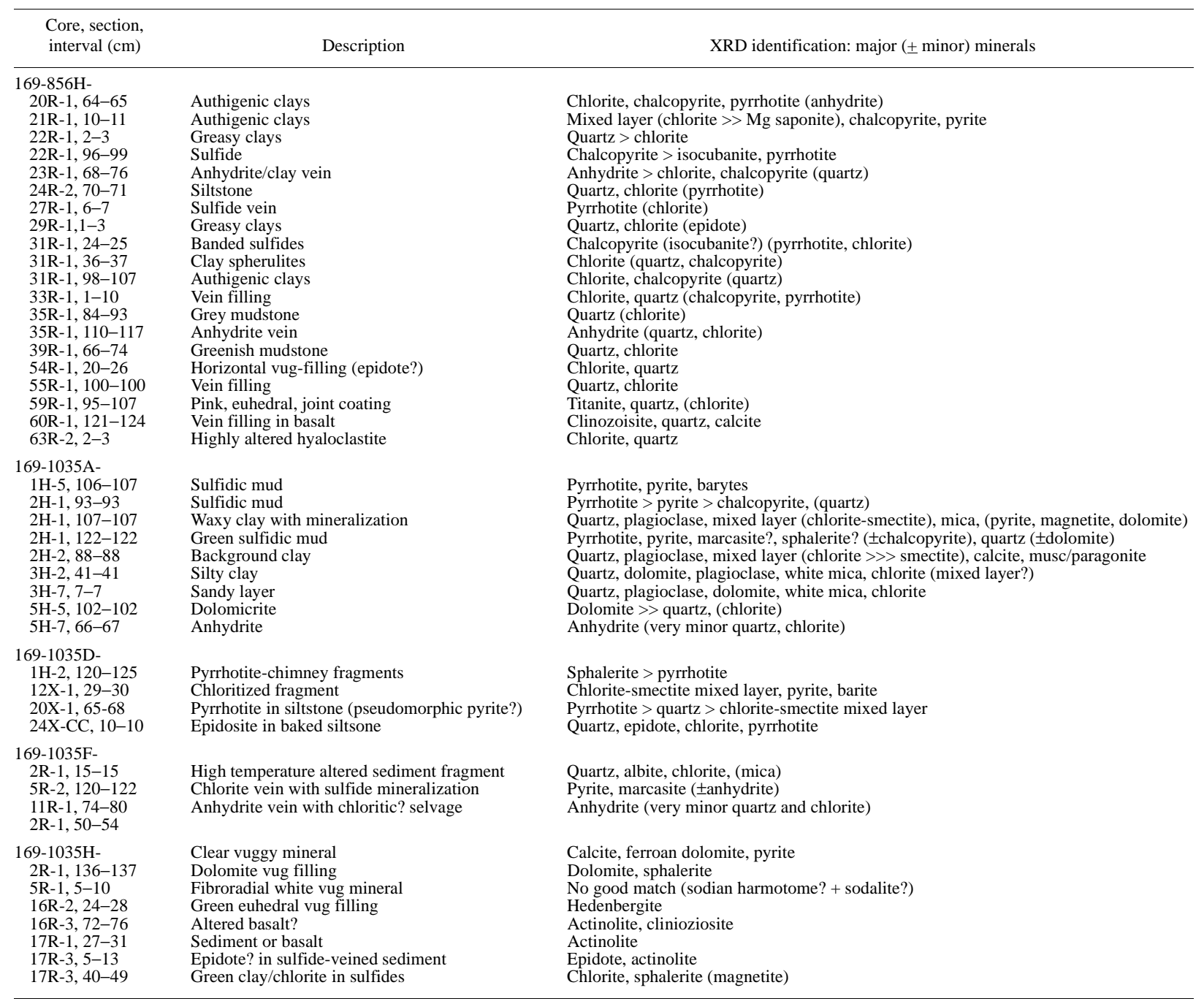

and cross-laminated mudstone and siltstone with local convoluted bedding are present in this interval (Fig. 24). In Sections 169-856H-55R-1 through 62R-1, five sills intrude intervals, up to $9 \mathrm{~m}$, of greenish gray mud and interbedded mudstone and siltstone (see also Table 2, Unit VII). Primary sedimentary structures preserved in the sediments include parallel laminations, cross-laminations, and graded beds with scoured basal contacts. Bioturbation is common throughout Lithofacies A. A zone of Chondrites burrows is present in Sample 169-1035A$10 \mathrm{X}-4(30-34 \mathrm{~cm})$.

\section{Lithofacies B: Siltstone and Sandstone}

Lithofacies B consists of an upper interval in all of the holes and a deeper interval that is only present in Hole $856 \mathrm{H}$. It is characterized by an alternation of siltstone and sandstone. Beds consisting predominantly of gray and light-gray, fine sand fining upward to silty clay with minor silt and medium sand are interpreted to be turbidites (Fig. 25 ). Bed thicknesses range from a few centimeters to $20 \mathrm{~cm}$, and rarely up to $50 \mathrm{~cm}$. Erosional basal contacts are common. Bouma sequences observed are $\mathrm{Ta} / \mathrm{ce}, \mathrm{Ta} / \mathrm{e}$, and Tce. Te intervals are commonly bioturbated, and the transition to hemipelagic beds is not well preserved. Beds are locally affected by soft sediment deformation in the form of convolute ripple laminations and folded laminae (Figs. 26, 27). Some cross-laminations are present. Interval 169-1035A-19X-1 (30-33 cm and $96-111 \mathrm{~cm}$ ) is characterized by two silty sand turbid- ites with a Ta/c Bouma sequence. The turbidites contain angular to subangulars and grains. They consist of quartz, feldspar (plagioclase), and fragments of fine-grained volcanic rocks (felsic, microlithic texture). Clinopyroxene, hornblende, and epidote have been identified among the accessory minerals.

The lowermost interval of Lithofacies B in interval $169-856 \mathrm{H}-$ $41 \mathrm{R}-1,0 \mathrm{~cm}$, to $47 \mathrm{R}-1,150 \mathrm{~cm}$, is characterized by greenish gray laminae of clayey siltstone and interbeds of fine-grained sandstone. The sandstone interbeds become thicker and more common downcore, and the sediments are well indurated and slightly hydrothermally altered. Parallel and wavy laminations occur throughout this interval. Cross-laminations and bioturbation are common. Contorted bedding is present locally, indicating soft-sediment deformation. Finingupward sequences with scoured bases indicate that the sandstones and siltstones were probably deposited by turbidity currents. Interbedded horizons of mudstones may be hemipelagic deposits.

Sediments of Hole $1035 \mathrm{H}$ (interval $169-1035 \mathrm{H}-4 \mathrm{R}-1,18 \mathrm{~cm}$, to $8 \mathrm{R}-1,87 \mathrm{~cm}$ ) consist of a thick interval of Lithofacies B that is characterized by dark gray to gray (N4-N6), interbedded siltstone and fine sandstone with impregnations of pyrrhotite and minor chalcopyrite and sphalerite. Sedimentary structures include planar laminations, fining upward, cross-laminations, and climbing ripples (Fig. 28). In Sections 169-1035H-6R and 11R, some bioturbation (Zoophycus, Chondrites, and Rhizocorallium?) occurs (Fig. 29). 
$\mathrm{cm}$

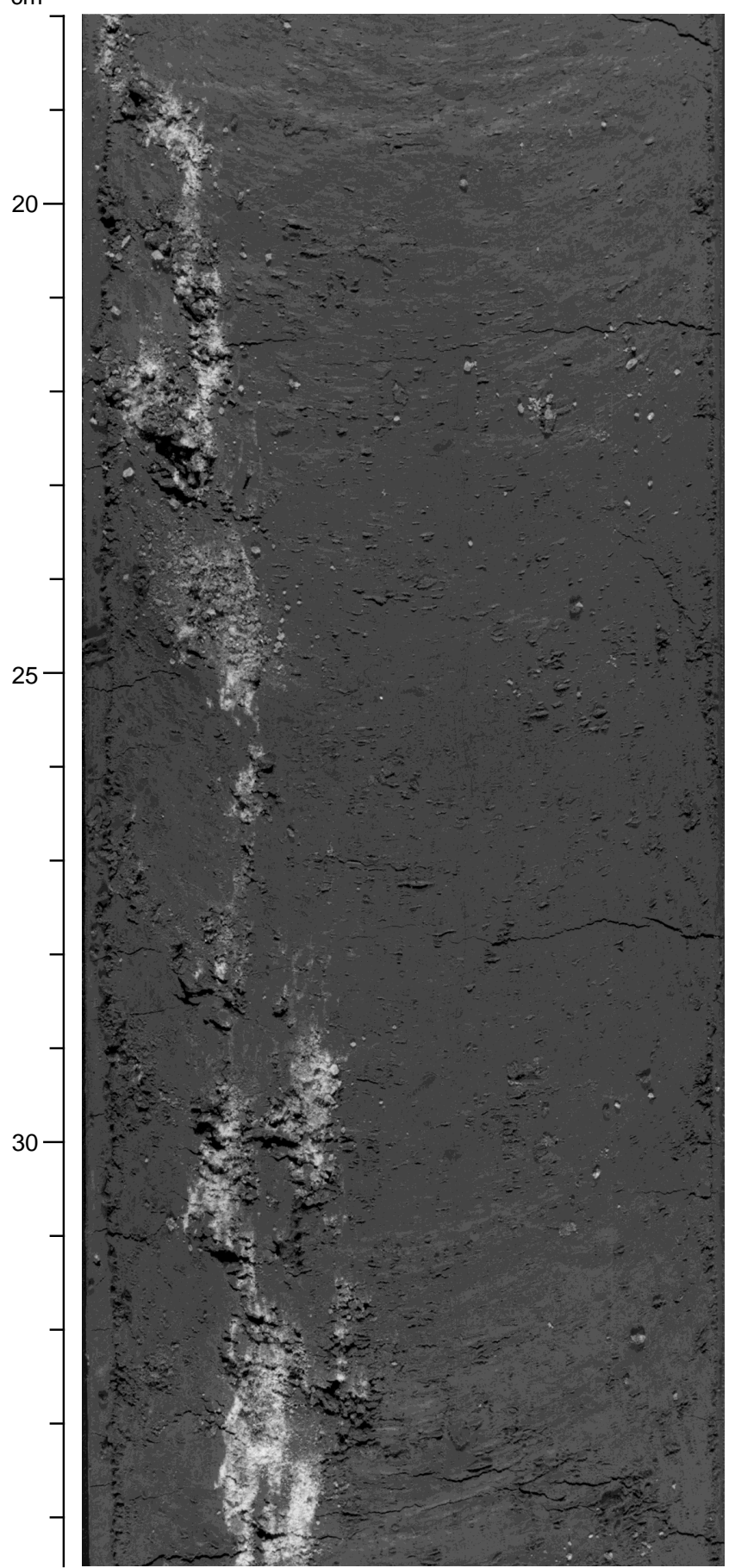

Figure 18. Subunit IIC. Silty clay with subvertical anhydrite nodules (interval 169-1035A $5 \mathrm{H}-7,18-34.5 \mathrm{~cm})$.

\section{Discussion}

Visual core descriptions and barrel sheet syntheses show that lateral facies variations occur on a scale of tens of meters or less. Turbidite beds are generally thin $(<10 \mathrm{~cm})$ or very thin and are not laterally continuous. For example, comparison of the grain-size logs between stratigraphic intervals 10-30 mbsf of Holes 1035A and 1035D, which are located $150 \mathrm{~m}$ apart on the western and eastern side of the BHMS deposit (see Section 3, this volume), indicate differences in

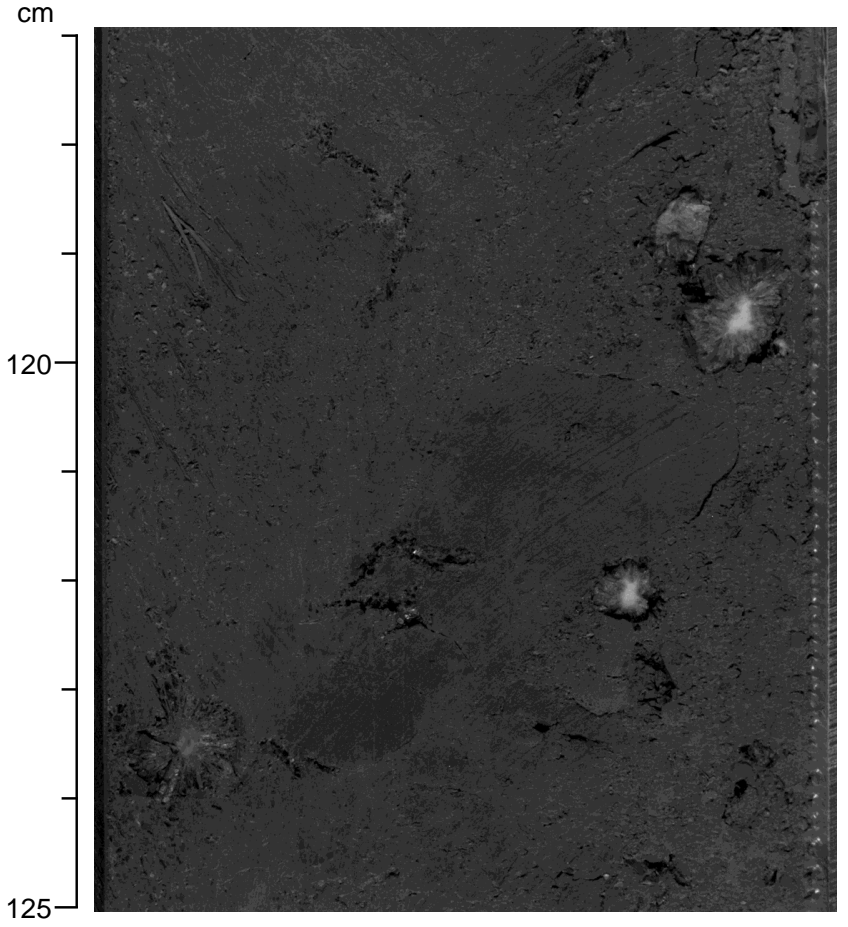

Figure 19. Subunit IIC. Gray mud containing anhydrite concretions with white massive cores and radiating colorless crystals in the outer portions, Subunit IIC (interval 169-1035A-12X-3, 117-125 cm).

the number and thickness of sand and silt beds, with Hole 1035A containing more sandy intervals than Hole 1035D.

The scoured bases of most of the turbidite beds indicate that turbidite currents, although small, were erosive. Current ripple sets a few centimeters thick and thin clay/silt laminae are the most common structures. Starved ripples are commonly present, and climbing ripples were observed in the sediments of Hole $1035 \mathrm{H}$. Muddy intervals are generally bioturbated. These structures are generally modified by soft-sediment deformation processes. Sag structures, such as balls and pillows, flames, and loads are common, indicating the water saturation of sediment. Dragging effects are also common, as shown by convoluted and imbricated laminae. Slumped intervals, $<1 \mathrm{~m}$ thick, suggest the existence of local variations of bathymetry. Sedimentary structures are more common in the sandier intervals.

A lithofacies correlation diagram (Fig. 21) was made, using the DCZ, a horizontally sulfide-banded and silicified unit that has a sulfide fabric that mimics primary sedimentary structures (see "Sulfide Mineralization: Sulfide Feeder Zone" section, this chapter). This unit is thought be the product of sulfide infiltration and replacement along a bedding in coarse-grained, graded, and cross-laminated turbidite sandstones, and thus, represents a "key layer" that has been used to correlate between layers. This key layer is contained within a thick sandstone/siltstone body (up to $100 \mathrm{~m}$ ) and underlies fine-grained sediments of Lithofacies A that reach a maximum thickness of $\sim 100$ $\mathrm{m}$ in Hole 1035A. Massive and subordinate clastic sulfide deposits make up most of the upper part of the succession in the neighboring holes, thus preventing an accurate estimate of the mudstone/siltstone thickness.

\section{BIOSTRATIGRAPHY}

In general, foraminifer preservation at Site 1035 is poor (Table 6 , back-pocket foldout, this volume). Foraminifer-bearing sediments 


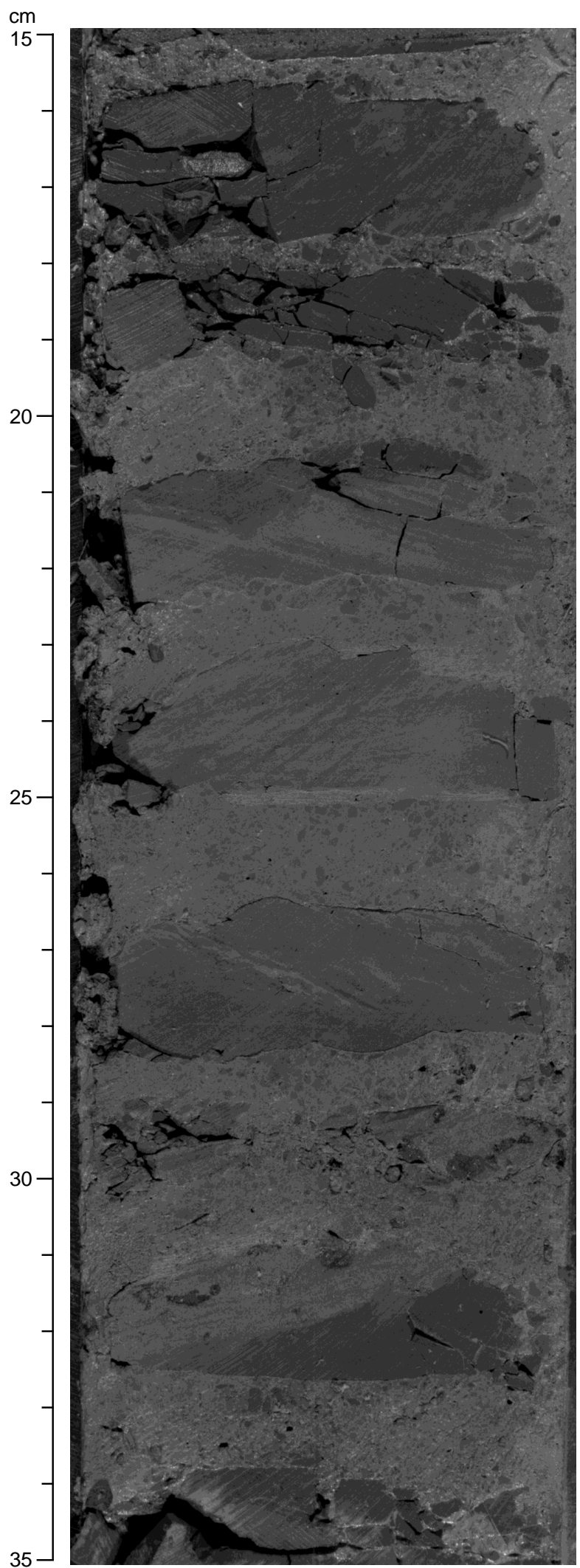

Figure 20. Drilling breccia of sandstone and siltstone with parallel lamination and soft sediment deformation structures. The piece at $30-33 \mathrm{~cm}$ consists of a sandstone bed with a Ta/c Bouma sequence (interval 169-1035A$19 \mathrm{X}-1,15-35 \mathrm{~cm})$ are found only in the upper $25 \mathrm{~m}$ or shallower at Holes 1035A through 1036E (Fig. 30). The mudline sediment contains an assemblage of agglutinated foraminifers in a thin layer of reddish brown oxidized sediment with radiolarians, diatoms, sponge spicules, and rare planktonic foraminifers (also reported by Brunner, 1994; Jonasson et al., 1995; and Quinterno, 1994). Beneath this, an assemblage of carbonate foraminifers is found in a sequence of olive-gray hemipelagites interlayered with distal turbidites. Planktonic foraminifers at Hole $1035 \mathrm{~A}$ are abundant to common from 0.02 to $18 \mathrm{mbsf}$, few in abundance to $20.9 \mathrm{mbsf}$, sporadic to $36.10 \mathrm{mbsf}$, and absent from the remainder of the hole. Hole 1035B, which is only $\sim 1 \mathrm{~cm}$ deep, and $1035 \mathrm{C}$, which consists of massive sulfides, do not include preserved foraminifers. Hole $1035 \mathrm{D}$ has calcite foraminifers to $16.46 \mathrm{mbsf}$ (stratigraphic uncertainty $+7.88 \mathrm{~m}$ deeper, where stratigraphic uncertainty is the interval between samples), with three intervals of abundant foraminifers interspersed with barren or near barren intervals from 7.23 to 9.98 mbsf (stratigraphic uncertainty -2.22 and +2.33 , respectively) and from 13.88 to $14.84 \mathrm{mbsf}$ (stratigraphic uncertainty $-1.08+0.29$, respectively). The depth at which foraminifers disappear at all three fossiliferous holes coincides with the shallowest occurrence of weakly indurated sediments and hydrothermal influence.

Based on benthic foraminifer assemblages as well as the mineral content of the sand fraction, turbidites clearly come from two different source areas. Turbidites with silicate mineral grains generally contain many benthic foraminifers displaced from a neritic environment (e.g., Sample 169-1035E-1H-3, 0-2 cm), whereas turbidites with sulfide clastic material, including pyrrhotite, are dominated by a bathyal assemblage of benthic foraminifers (e.g., Sample 169$1035 \mathrm{E}-1 \mathrm{H}-4,0-2 \mathrm{~cm}$ ). Some turbidites with a local source contain agglutinated foraminifers typical of the surficial sediments in proximity to hydrothermal vents in Middle Valley (Jonasson et al., 1995; e.g., Sample 169-1035E-3H-CC, 23-25 cm).

The Holocene/Pleistocene boundary was found in three holes at the site, but no other biostratigraphic horizons were found during shipboard study. The nominal Holocene/Pleistocene boundary of the North Pacific eastern boundary current lies between 0.34 and 0.86 mbsf in Hole 1035A, 0.02 and 0.50 mbsf in Hole 1035D, and between 0.69 and $1.5 \mathrm{mbsf}$ in Hole 1035E. This result is consistent with other reports of the boundary at Middle Valley (Fig. 31). A 3-cm-diameter clast of oxidized mud in a disturbed interval was found at the top of Core 169-1035E-2H. The planktonic foraminifer assemblage sampled from the clast (Sample 169-1035E-2H-1, 6-8 cm) contains dextral N. pachyderma and siliceous microfossils suggesting a Holocene age. The disturbed interval may have caved to the bottom of the hole after the first hydraulic core was taken. The dextral coiling event of $N$. pachyderma during the penultimate interglacial period at $\sim 125 \mathrm{ka}$ occurs at $\sim 20$ mbsf in Hole 856A at the top of Bent Hill, however, it was not observed at Site 1035 at that depth below seafloor, where fossil preservation is moderate to poor and occurrence is sporadic, perhaps caused by alteration.

\section{SULFIDE MINERALIZATION: CLASTIC SULFIDES}

\section{Clastic Sulfides (Unit III)}

Hole $1035 \mathrm{~A}$ was spudded $77 \mathrm{~m}$ west of Hole $856 \mathrm{H}$. The uppermost $8.9 \mathrm{~m}$ of Hole $1035 \mathrm{~A}$ (interval $169-1035 \mathrm{~A}-1 \mathrm{H}-0,1 \mathrm{~cm}$, to $2 \mathrm{H}-$ $1,140 \mathrm{~cm}, 0.00-8.90 \mathrm{mbsf}$; Table 7) recovered a sequence of unconsolidated, black, fine-grained, sulfide-rich intervals interbedded with gray silty turbidites and green hemipelagic mud (Fig. 32). This unit is designated as Unit III, clastic sulfides, and was also recovered in Hole 1035D, located $75 \mathrm{~m}$ east of Hole 856H (interval 169-1035D$1 \mathrm{H}-2,119 \mathrm{~cm}$, to $2 \mathrm{H}-2,52 \mathrm{~cm} ; 2.69-7.12 \mathrm{mbsf}$ ) and Hole $1035 \mathrm{E}$ (interval $169-1035 \mathrm{E}-1 \mathrm{H}-3,37 \mathrm{~cm}$, to $2 \mathrm{H}-2,112 \mathrm{~cm}$; 3.37-10.12 mbsf), located $\sim 100 \mathrm{~m}$ south of Hole $856 \mathrm{H}$. Further downcore in Hole $1035 \mathrm{D}$, there is a second, older interval of clastic sulfide sedimenta- 


\section{LITHOFACIES OF BENT HILL}

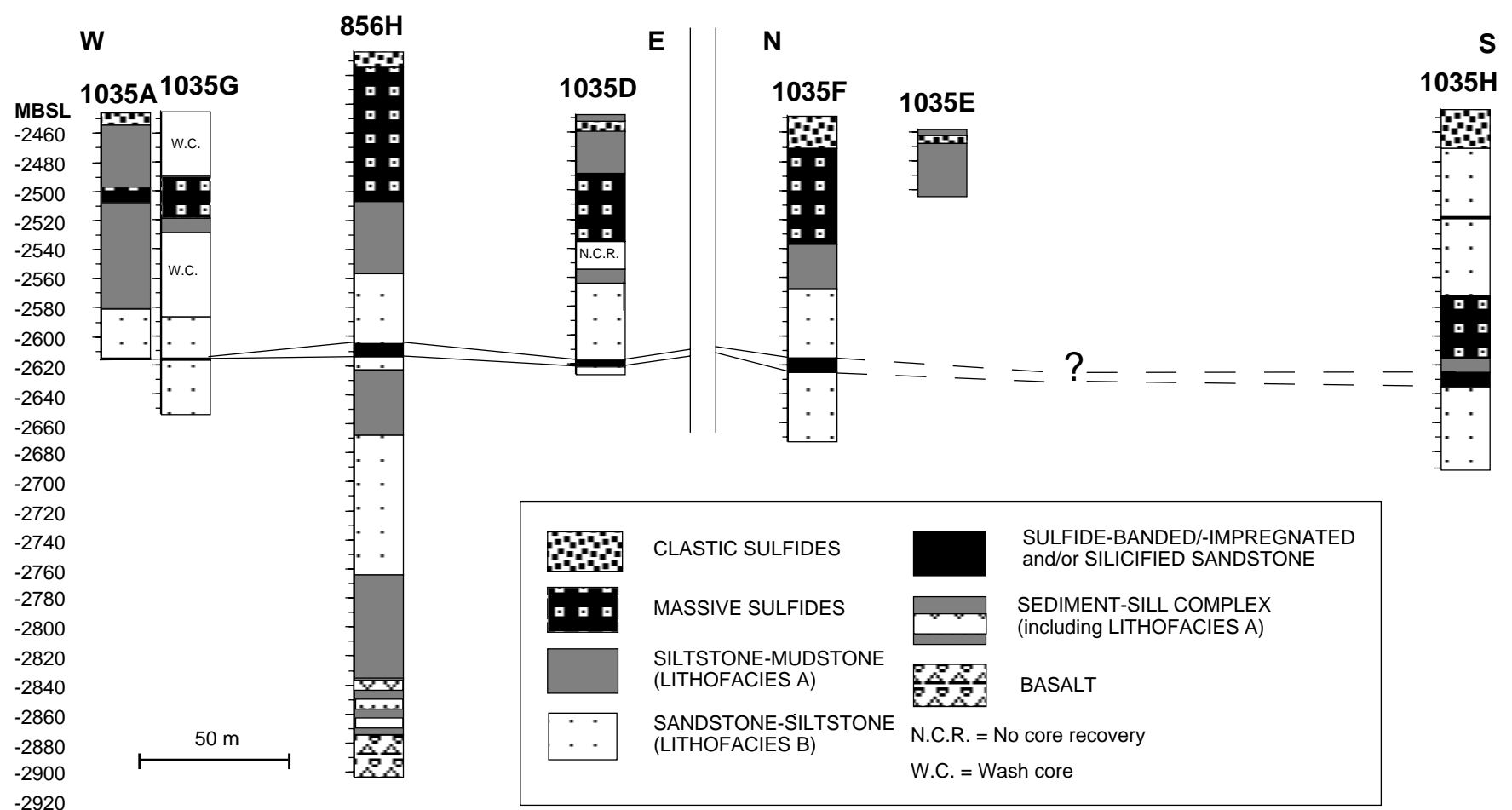

Figure 21. Distribution of Lithofacies A and B in Holes 856H, 1035A, and 1035D through 1035H.

tion (interval 169-1035D-5H-2, $67 \mathrm{~cm}$, to $5 \mathrm{H}-3,15 \mathrm{~cm} ; 35.60-36.75$ mbsf). Similar clastic sulfide sediments also were recovered in shallow cores from the flanks of the sulfide mound (Goodfellow and Franklin, 1993) and from Hole 856B near the southern margin of Bent Hill during Leg 139 (Davis, Mottl, Fisher, et al., 1992).

The clastic sulfides are part of a larger sedimentary interval that is important for understanding the tectonic and stratigraphic evolution of the BHMS deposit. The generalized stratigraphy of the clastic sulfide interval is schematically illustrated in Figure 32.

At the top of lithologic Unit II (or the base of Unit I), the nearly flat-lying, interbedded hemipelagic and fine-sand strata are interrupted by a slumped interval that ranges from $\sim 6$ to $9.5 \mathrm{~m}$ in thickness. The thickness of the slumped interval is greatest in Hole 1035A (west of the BHMS), where there are many sand-turbidite beds contained within the slump, and thinnest in Hole 1035E (south of the BHMS), where the slump includes mostly fine-grained, hemipelagic sediments. The top of the slumped interval grades upward into a matrixsupported, mud-clast breccia that is $35-40 \mathrm{~cm}$ thick in Hole 1035D and $55 \mathrm{~cm}$ thick in Hole 1035E (Fig. 33). No mud clasts are evident in Hole 1035A. Sulfide clasts were found in the breccia at Hole 1035E (interval 169-1035E-2H-3, 30-32 cm; 10.80-10.82 mbsf), otherwise the clasts are composed of predominantly hemipelagic clays and minor sand turbidites. The brecciated facies is interpreted to be the product of a debris flow, developed at the culmination of slumping. Immediately overlying the slump and breccia in all three holes are two silt to fine-sand turbidites, separated by a few centimeters of hemipelagic silty clay. These, in turn, are immediately overlain by the first of many clastic sulfide strata.

Intervals that are very rich in clastic sulfides comprise 2 to $3 \mathrm{~m}$ in each of the three holes and contain several decimeter-thick beds of clastic sulfides, separated by somewhat thinner beds of indurated, dark greenish gray (5GY 4/1) claystone (Fig. 34). A typical clastic sulfide bed in this interval has the following characteristics: it contains coarse-sand to granule-sized (up to $2 \mathrm{~cm}$ ), subangular clasts of pyrrhotite and pyrite, comprising $50 \%$ of the grains. Sulfide clasts at the basal contact of some units indent into the underlying sediment because of loading. Nonsulfide clasts $(2-5 \mathrm{~cm}$ diameter) in sulfide units consist of unaltered and altered hemipelagic and turbiditic sediment and blue-green clay that may be composed of $\mathrm{Mg}$-smectite. The clasts are supported in a terrigenous silt or very fine sand. Typical beds have sharp bases, fine upward, and have diffuse upper contacts with the claystone (Fig. 35). Sulfide beds are locally rust colored because of the presence of iron oxyhydroxides. Graded layers and parallel lamination indicate that the sulfides have been resedimented and are not in situ sulfide precipitates or degradations. The clastic sulfides are interpreted as erosional products shed from the mound. The terrigenous nature of the majority of the nonsulfide sediment in the clastic sulfide beds suggests that extra-basinal turbidity currents may play a role in accelerating the mass wasting of sulfide debris.

The clastic-sulfide-rich interval is, in turn, overlain by a sequence of generally finer grained and more thinly bedded clastic sulfides with a lower sulfide component. These strata comprise sulfide grains of clay, silt, or very fine-sand size and are $1-3 \mathrm{~cm}$ thick. The sulfidic strata are separated by $10-50 \mathrm{~cm}$ of hemipelagic silty clay or finesand turbidites. In Holes 1035A and 1035E, these interbeds are contorted and are probably mildly slumped. In Hole 1035A, the zone of sulfide laminae is $\sim 6 \mathrm{~m}$ thick; in Hole $1035 \mathrm{D}$ it is $\sim 2.4 \mathrm{~m}$ thick; and in Hole $1035 \mathrm{E}$ it is $\sim 5.1 \mathrm{~m}$ thick. However, the thicknesses in Holes $1035 \mathrm{D}$ and 1035E should be interpreted with extra caution, because the zone straddles the boundary between the uppermost two cores in both holes. The uppermost clastic stratum occurs respectively at subbottom depths of $6 \mathrm{~cm}, 269 \mathrm{~cm}$, and $338 \mathrm{~cm}$ in Holes 1035A, 1035D, and $1035 \mathrm{E}$, respectively. In all three holes, a surface oxidized layer was retrieved at the top of the uppermost core.

In polished thin section, the sulfide beds comprise predominantly pyrrhotite, pyrite, sphalerite, and $\mathrm{Cu}-\mathrm{Fe}$ sulfides. Sulfide contents range from $10 \%$ to $50 \%$. Rare barite is present in some clastic sulfide beds. The primary mineral assemblage in the most massive parts of 


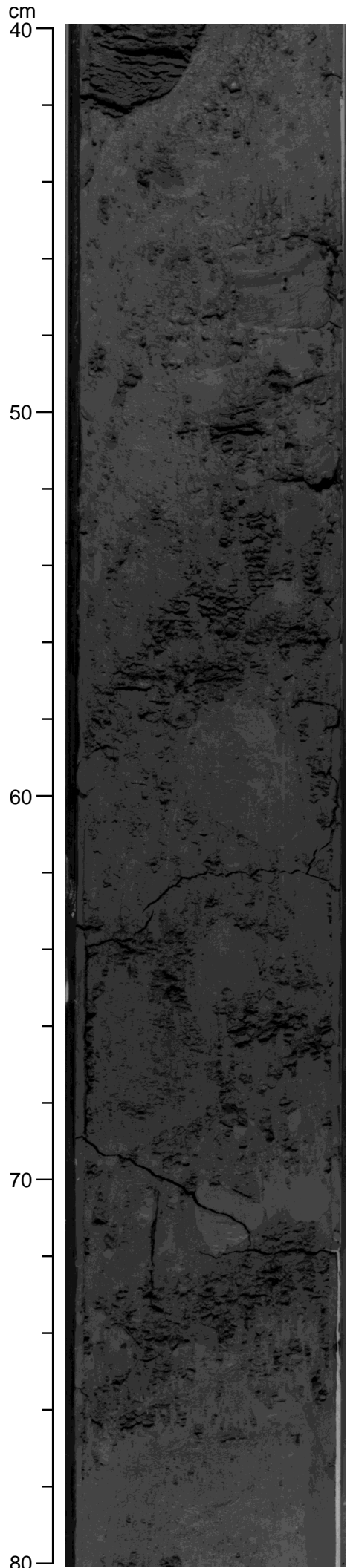

Figure 22. Sedimentary slump with mud clasts in a mud-clast breccia consisting of clasts of silty clay in a matrix of fine-grained sand. The subangular clasts range in size from 0.5 to $5 \mathrm{~cm}$ (interval 169-1035D-2H-3, 40-80 cm).

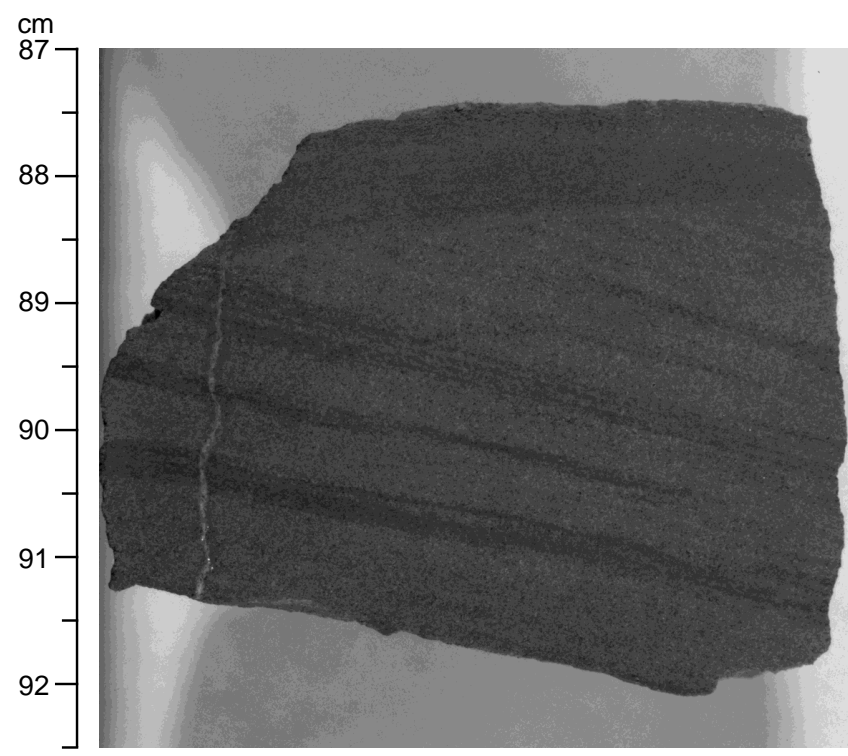

Figure 23. Planar cross-laminations (interval 169-856H-39R-1, 87-92.5 cm).

the clastic sulfides is an open interlocking network of hexagonal pyrrhotite platelets that is partly infilled by black subhedral to euhedral sphalerite with cores and lamellae of $\mathrm{Cu}$-Fe sulfide minerals (Fig. 36). The porosity of this pyrrhotite network is highly variable and ranges up to $20 \%$ by volume. Pyrrhotite plates are variably replaced and overgrown by a lacy network of pyrite and possibly marcasite. Black, high Fe sphalerite typically occurs in the interstices of the pyrrhotite network, commonly at the boundary between intergrown crystals. In other places it rims pyrrhotite plates. The intergrowth of sphalerite and pyrrhotite in many samples suggests that they were co-precipitated. Zinc sulfide within some clasts displays an hexagonal outline. The $\mathrm{Cu}-\mathrm{Fe}$ sulfides are probably isocubanite and display a cross-hatch pattern of chalcopyrite exsolution lamellae. Lamellae of $\mathrm{Cu}-\mathrm{Fe}$ sulfides also occur in sphalerite.

A second type of clastic sulfide is that formed in situ on the top of the sulfide mound. Fragmental sulfides comprising in situ rubble and sulfide breccias were recovered in intervals $169-1035 \mathrm{~F}-1 \mathrm{R}-1,0-16$ $\mathrm{cm}(0-0.16 \mathrm{mbsf}), 169-1035 \mathrm{C}-1 \mathrm{X}-1,0 \mathrm{~cm}$, to $1 \mathrm{X}-\mathrm{CC}, 37 \mathrm{~cm}(0-$ $1.47 \mathrm{mbsf})$, and $169-1035 \mathrm{H}-1 \mathrm{R}-1,0 \mathrm{~cm}$, to $1 \mathrm{R}-\mathrm{CC}, 16 \mathrm{~cm}(0-2.17$ mbsf). These sulfides have not been significantly transported and represent the upper, less consolidated part of the sulfide mounds (see "Sulfide Mineralization: Massive Sulfide" section, this chapter).

The sedimentary sequence described above has important implications for the geological evolution of the BHMS. The massive sulfide section of the BHMS deposit is interpreted to have been formed as a sulfide mound exposed above the seafloor. Although it is apparently being onlapped by sediment, it does not appear to have been buried by sediment and recently exhumed. Clastic sulfides and sulfide rubble appear to overlie the massive sulfide, so it would seem that fine-grained sulfide debris was available for the formation of resedimented clastic sulfides throughout the history of the Bent Hill mound. Despite this, it appears that the well-developed, interbedded turbiditic/hemipelagic sediment and resedimented clastic sulfides are generally restricted to the uppermost part of the sedimentary sequence overlying the sulfide mound. The slumped interval is present on the east, west, and south sides (and possibly to the north at Hole 856B; see Davis, Mottl, Fisher, et al., 1992) of the BHMS deposit, and may signal the uplift and the mass wasting of sedimentary overburden, and, eventually, the mass wasting of the massive sulfides themselves. If the uplift took place as a result of activation or reactivation of faulting at the BHMS deposit, it is logical to link the deposition of the clastic sulfides to uplift and to new or renewed hydro- 


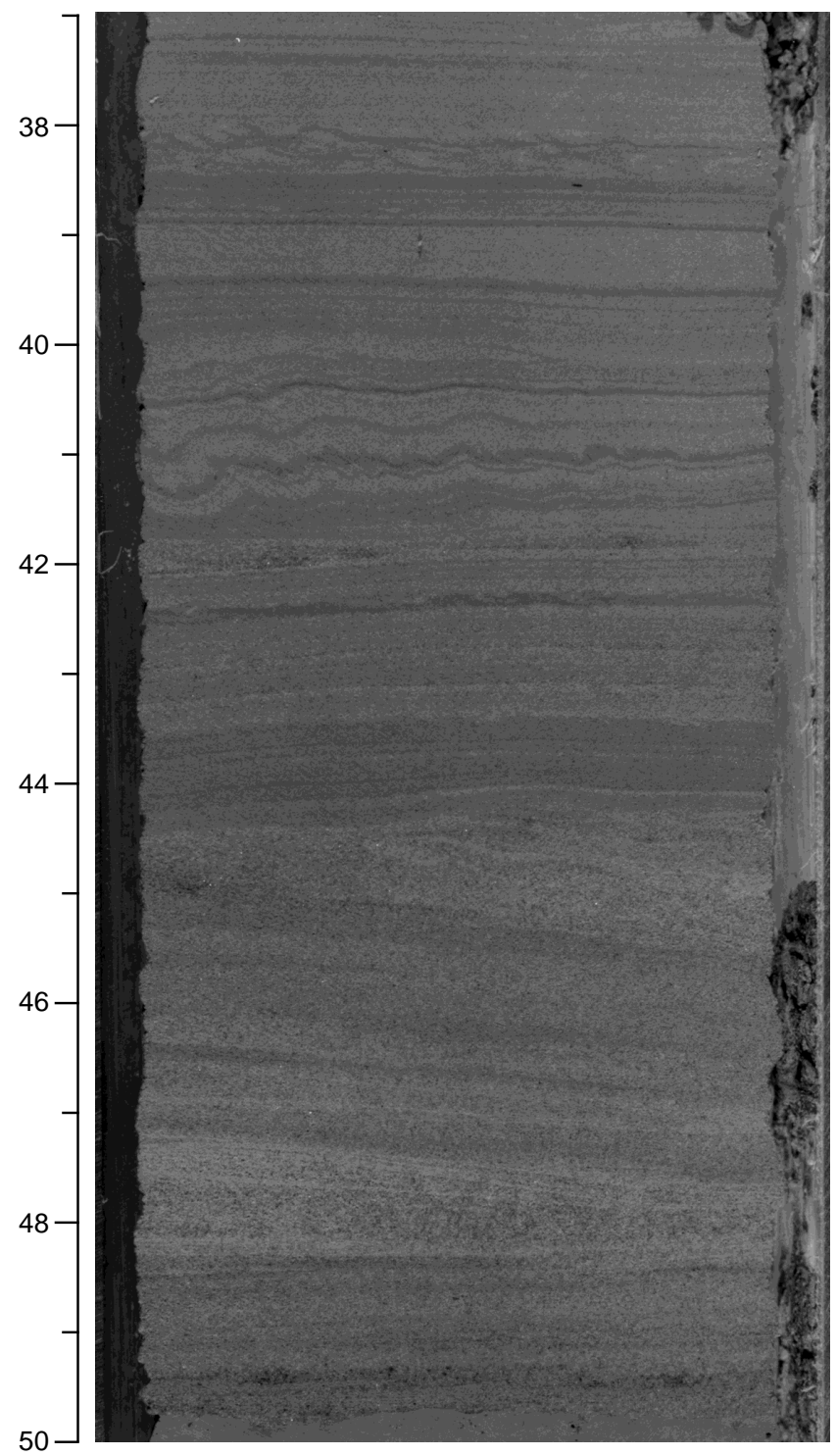

Figure 24. Cross-laminated fine to medium sandstones $(44-48 \mathrm{~cm})$, parallellaminated fine sandstone, siltstone and mudstone with deformation structures. Sag structures $(41 \mathrm{~cm})$ and parallel laminae sheared by current drag (38 cm; interval 169-1035G-7R-3, 37-50 cm).

thermal activity and sulfide precipitation at the BHMS deposit. Renewed tectonic and/or hydrothermal activity could speculatively be related to the intrusion of basaltic sills and uplift of Bent Hill (Mottl et al., 1994).

\section{SULFIDE MINERALIZATION: MASSIVE SULFIDE}

\section{Bent Hill and ODP Massive Sulfide Deposits (Unit V)}

The BHMS deposit is located $100 \mathrm{~m}$ south of Bent Hill, a circular sediment hill $\sim 400 \mathrm{~m}$ in diameter that has recently been uplifted above the level of turbiditic fill in Middle Valley (Davis, Mottl, Fisher et al., 1992). BHMS was revisited during Leg 169 for the chief purposes of assessing the thickness and the lateral extent of mineralization and to determine the nature of the hydrothermal feeder zone underlying the deposit. During Leg 169, eight holes were drilled through the BHMS and nearby ODP Mound (Fig. 6), and four sulfide

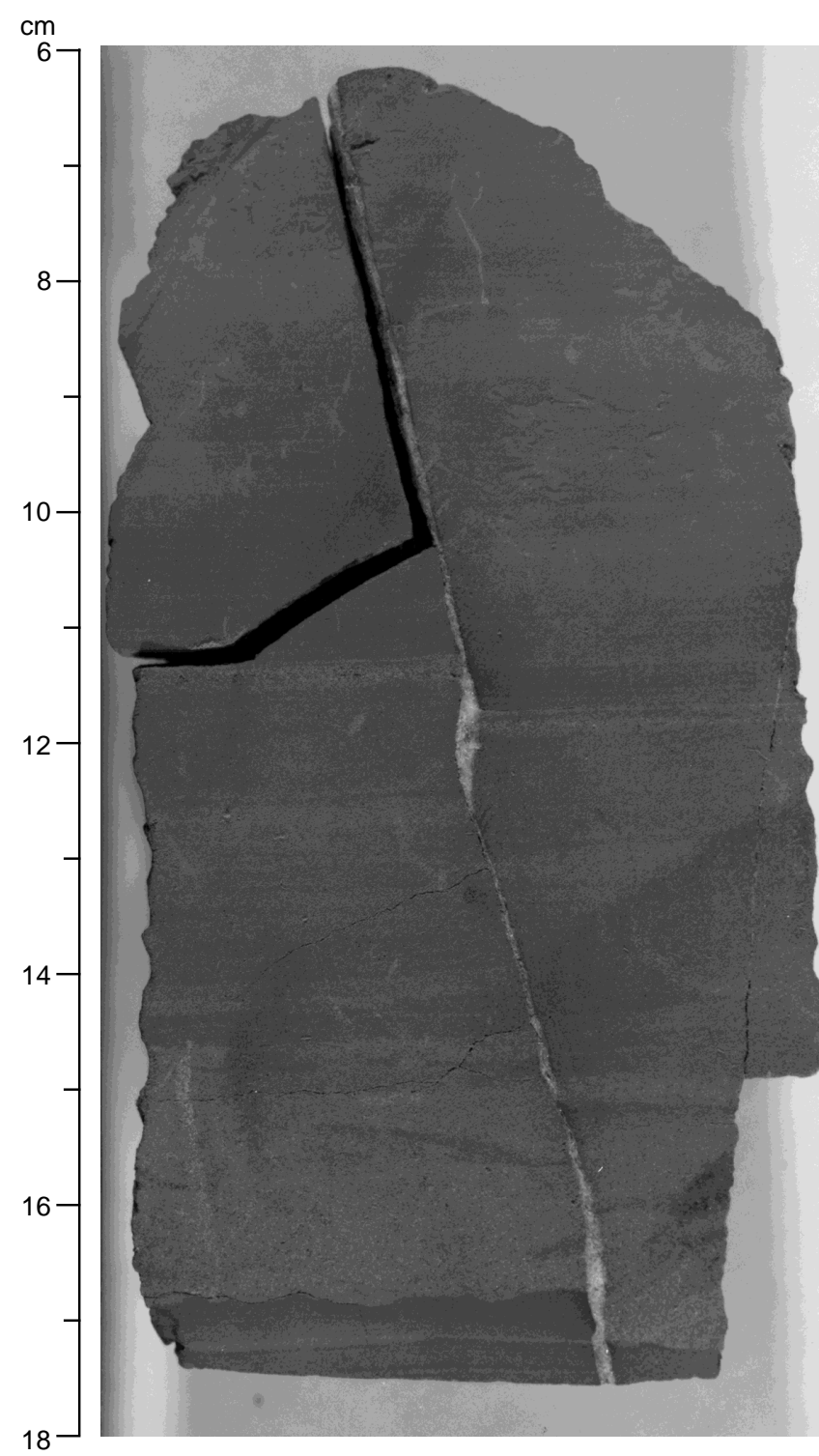

Figure 25. Graded turbidite bed with slightly erosional base $(17 \mathrm{~cm})$. Bioturbated parallel-laminated mudstone interval $(8-10 \mathrm{~cm})$. Anhydrite fills the subvertical fracture that displays normal offset (interval 169-856H-42R-1, 6$18 \mathrm{~cm})$.

facies units were recognized. Some of these were also recovered during Leg 139. Table 8 summarizes these facies types and their main occurrences.

\section{Vertical and Lateral Extent of the BHMS Deposit}

The BHMS deposit was intercepted in Holes 856H, 1035A, 1035G, 1035C, 1035F, and 1035D (Figs. 15, 16). Sulfide mineralization was also encountered during Leg 139 in Holes 856C, 856D, $856 \mathrm{E}, 856 \mathrm{~F}$, and $856 \mathrm{G}$. These holes constrain the minimum extent of sulfide mineralization at the BHMS deposit. Massive sulfide extends at least $40 \mathrm{~m}$ north, $60 \mathrm{~m}$ south, and $75 \mathrm{~m}$ to the west and east of Hole $856 \mathrm{H}$, which is located on a topographic high and was drilled initially during Leg 139, but substantially deepened during Leg 169 . The reentry of Hole $856 \mathrm{H}$ during Leg 169 has constrained the vertical thickness of the massive sulfide deposit at the center of the mound to 94.43 $\mathrm{m}$. The ODP Mound is located $\sim 354 \mathrm{~m}$ south of Hole $856 \mathrm{H}$ and was 


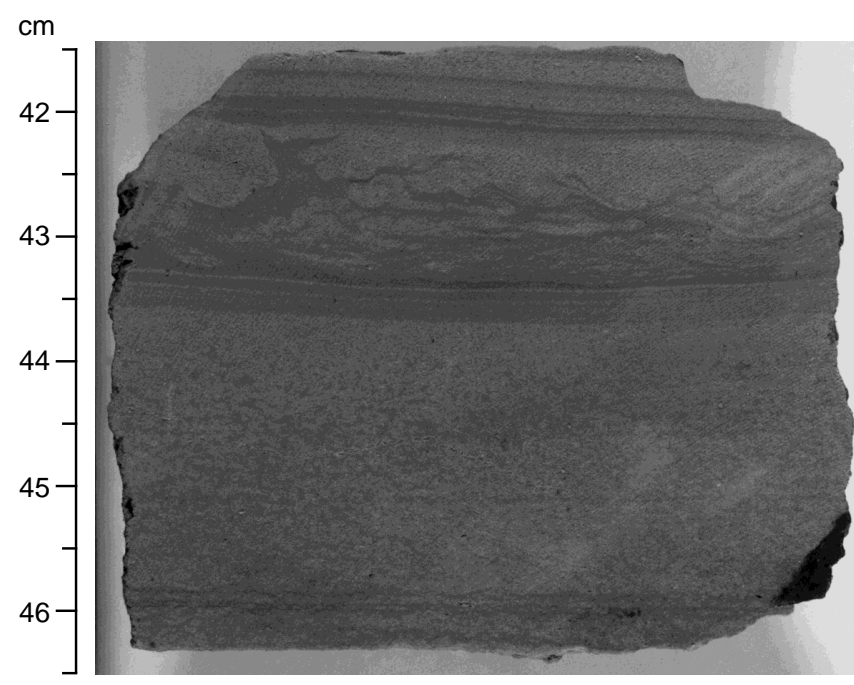

Figure 26. Soft sediment deformation. The 1.5-cm-thick fine-grained sand bed is almost completely disrupted downward to subspherical pockets and strings of sands floating in the underlying clayey material (interval 1691035F-19R-1, 41.5-46.5 cm).

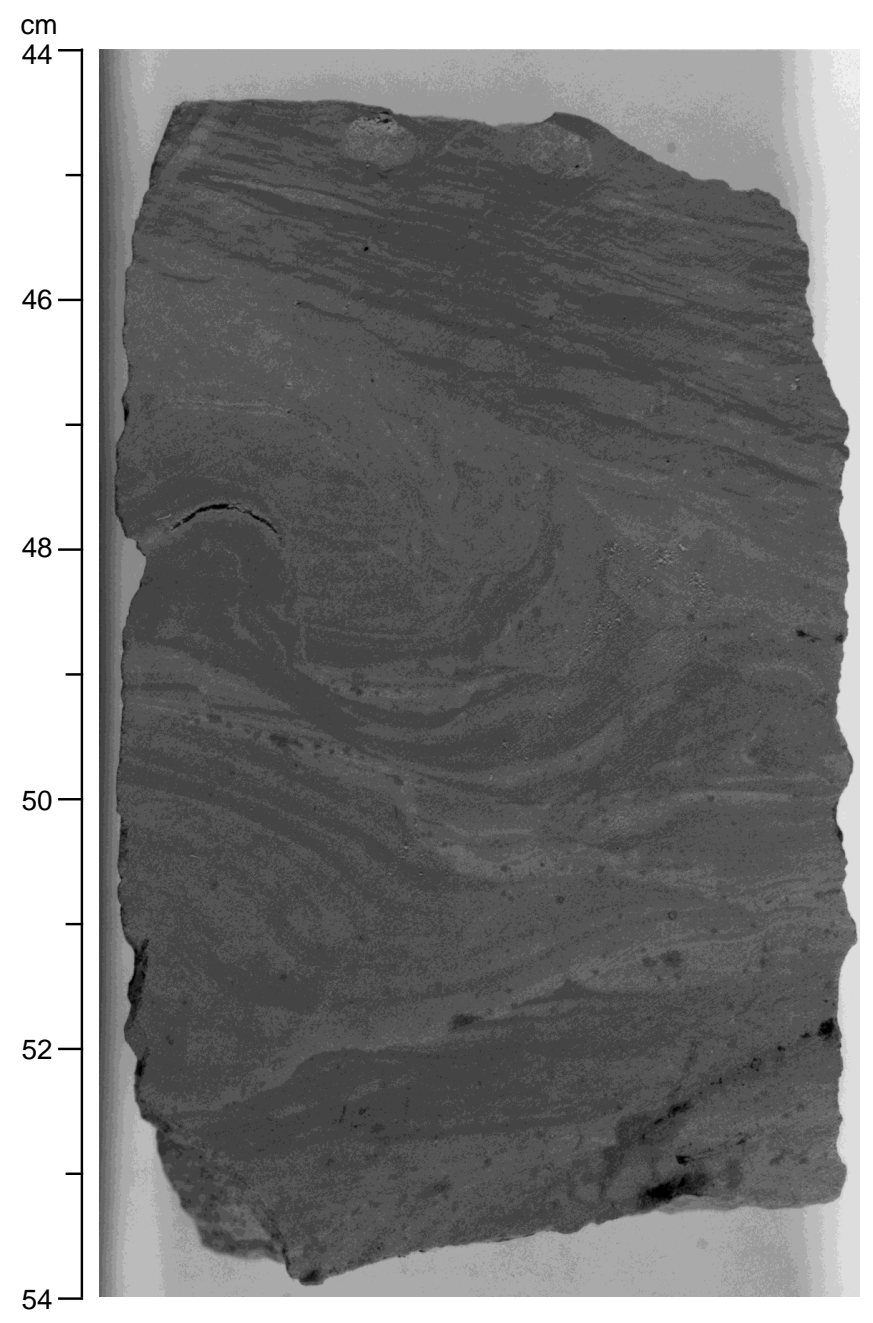

Figure 27. Convolute lamination (45.5-62.5 cm; interval 169-1035H-27R-2, $44-54 \mathrm{~cm})$.

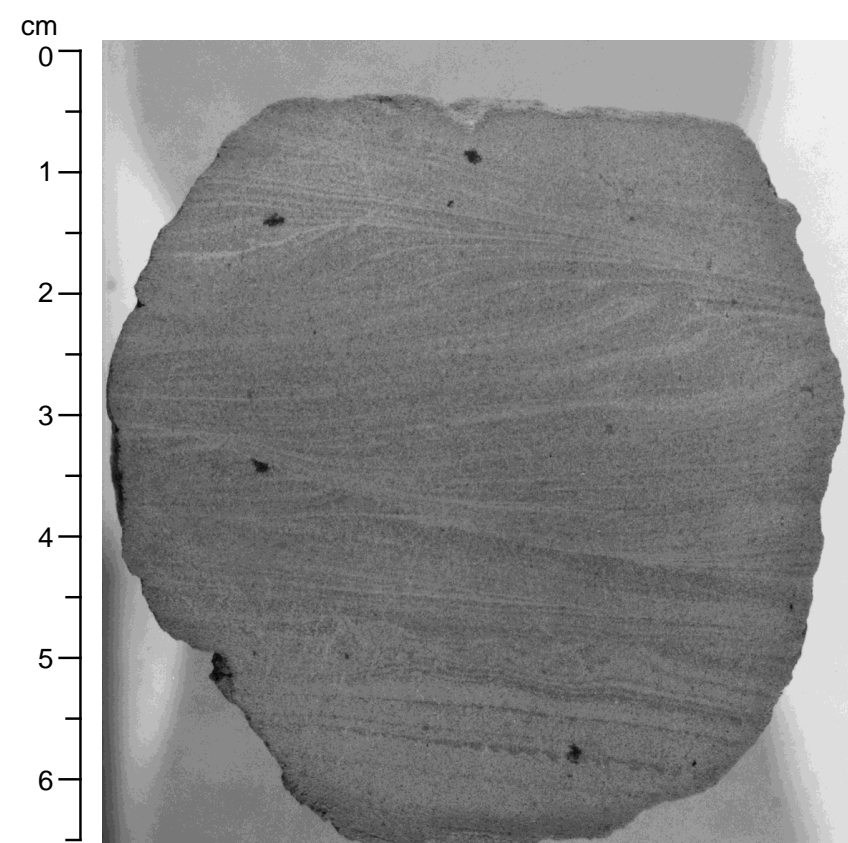

Figure 28. Climbing ripples (interval 169-1035H-7R-1, 0-6.5 cm).

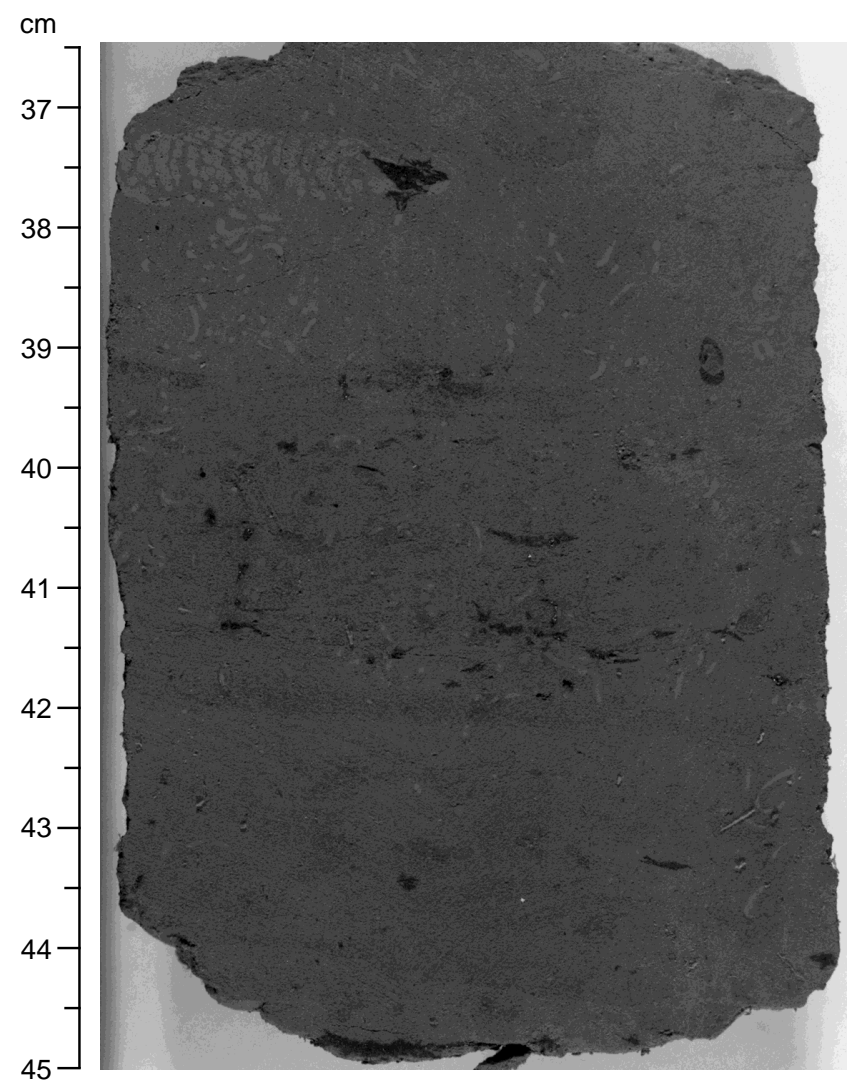

Figure 29. Bioturbation. Chondrites and a horizontal burrow of Rhizocorallium (?) (37-38 cm; interval 169-1035H-6R-1, 36.5-44.9 cm). 


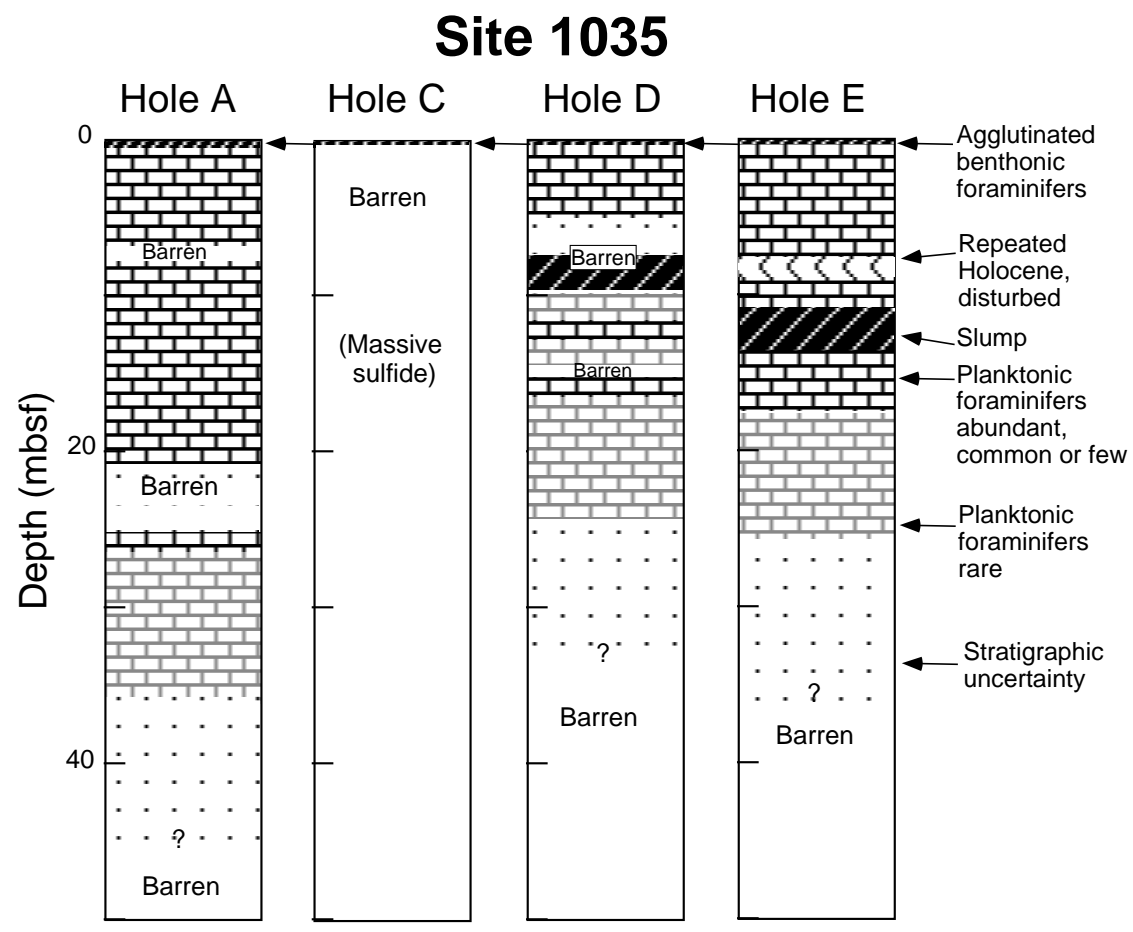

Figure 30. Distribution of planktonic foraminifers at Holes 1035A, 1035C, 1035D, and 1035E.

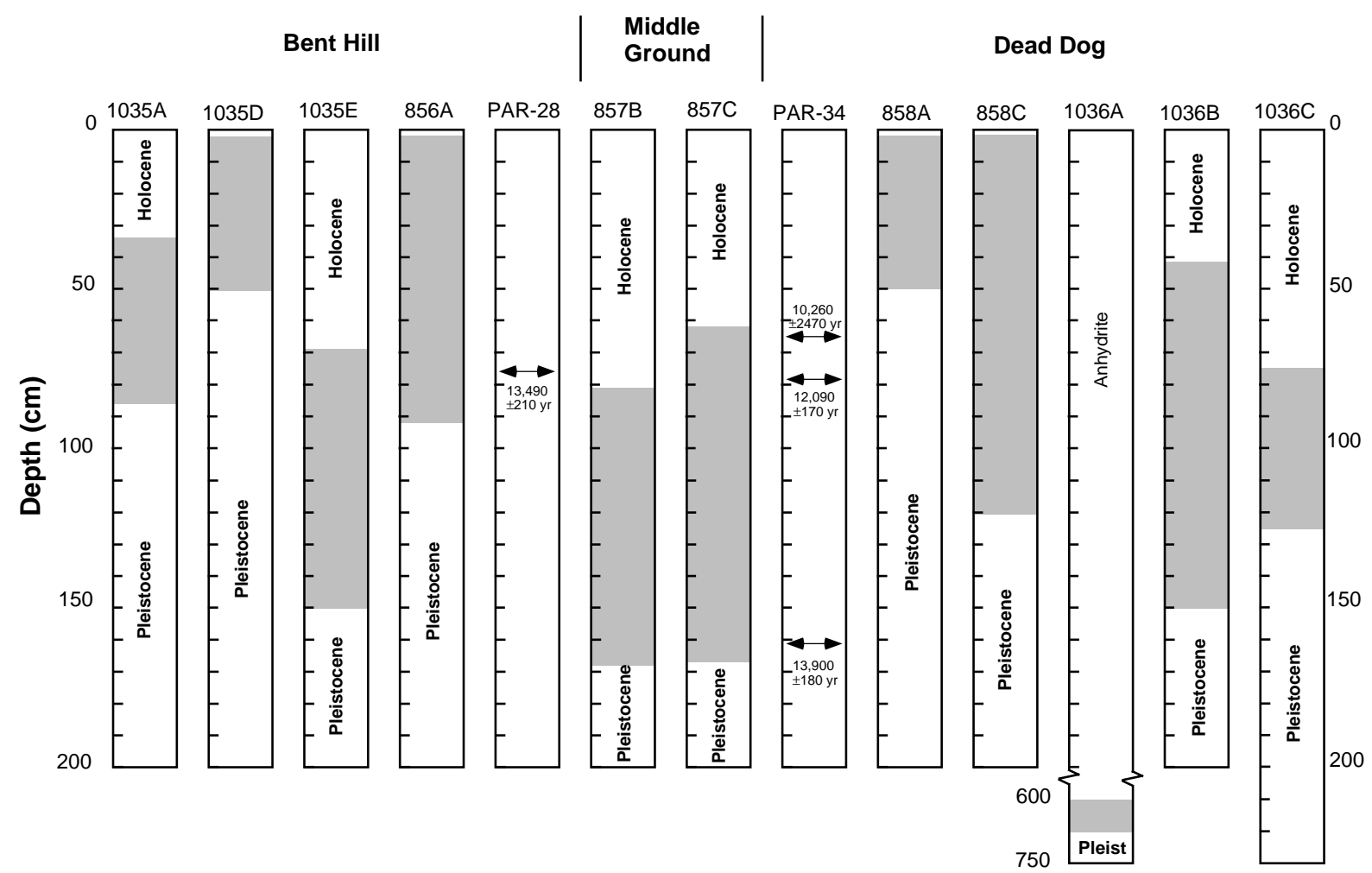

Figure 31. Depth of the Holocene/Pleistocene boundary in Middle Valley. The shaded area delimits the stratigraphic error defined as the interval between the deepest Holocene sample and the shallowest Pleistocene sample examined. The boundary is based on the change in coiling of $N$. pachyderma from sinistral to dextral at the end of the last glacial stage. Sites 856 and 857 data are from Brunner (1994). Data for columns with PAR prefix are from Goodfellow et al. (1993). 
Table 7. Occurrence of clastic sulfide intervals, Bent Hill area, Middle Valley.

\begin{tabular}{|c|c|c|c|c|c|c|c|}
\hline & Hole $856 \mathrm{H}$ & Hole $1035 \mathrm{~A}$ & Hole $1035 \mathrm{C}$ & Hole 1035D & Hole 1035E & Hole $1035 \mathrm{~F}$ & Hole $1035 \mathrm{H}$ \\
\hline \multirow[t]{2}{*}{$\begin{array}{l}\text { Clastic sulfide } \\
\text { occurrence: }\end{array}$} & $\begin{array}{l}\text { 1R-1 through 1R- } \\
\text { CC }(0.0-4.04 \\
\text { mbsf })^{*}\end{array}$ & $\begin{array}{l}\mathrm{H}-1,0 \mathrm{~cm}, \text { to } \\
2 \mathrm{H}-1,140 \mathrm{~cm} \\
(0.0-8.90 \mathrm{mbsf})\end{array}$ & $\begin{array}{l}1 \mathrm{X}-1,0 \mathrm{~cm}, \text { to } \\
1 \mathrm{X}-\mathrm{CC}, 37 \mathrm{~cm} \\
(0.0-1.47 \mathrm{mbsf})\end{array}$ & $\begin{array}{l}1 \mathrm{H}-2,119 \mathrm{~cm}, \text { to } 2 \mathrm{H}- \\
2,52 \mathrm{~cm} \\
(2.69-7.12 \mathrm{mbsf})\end{array}$ & $\begin{array}{l}1 \mathrm{H}-3,37 \mathrm{~cm} \text {, to } 2 \mathrm{H}-2 \text {, } \\
112 \mathrm{~cm} \\
(3.39-10.12 \mathrm{mbsf})\end{array}$ & $\begin{array}{l}1 \mathrm{R}-1,0-16 \mathrm{~cm} \\
\quad(0.0-0.16 \mathrm{mbsf})\end{array}$ & $\begin{array}{l}\text { 1R-1, } 0 \mathrm{~cm} \text {, to } \\
1 \mathrm{R}-\mathrm{CC}, 16 \mathrm{~cm} \\
(0.0-2.17 \mathrm{mbsf})\end{array}$ \\
\hline & & & & $\begin{array}{l}5 \mathrm{H}-2,67 \mathrm{~cm} \text {, to } \\
\quad 5 \mathrm{H}-3,15 \mathrm{~cm} \\
(35.60-36.75 \mathrm{mbsf})\end{array}$ & & & \\
\hline
\end{tabular}

Note: $*$ sampled on Leg 139

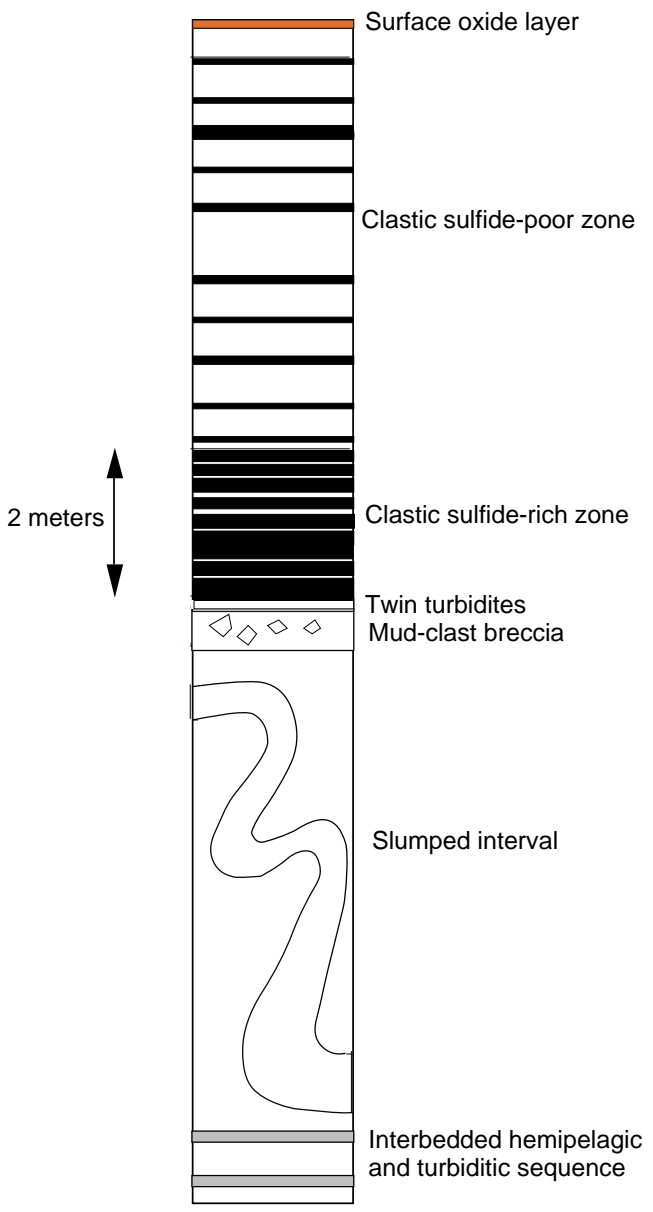

Figure 32. Generalized stratigraphic section of the clastic sulfide unit with associated sediments, as based on observations from Holes 1035A, 1035D, and 1035E. The black layers are the clastic sulfides.

drilled in Hole $1035 \mathrm{H}$. There is no drilling between this hole and the BHMS deposit to the north to test the possible continuity of the massive sulfide mineralization. Three separate massive and semimassive sulfide zones were penetrated in Hole $1035 \mathrm{H}$, the deepest extending to $162 \mathrm{mbsf}$.

The first hole drilled at the BHMS deposit was a reentry of Hole $856 \mathrm{H}$ (Fig. 7). This hole was washed down through the previously cored interval to a depth of 93.8 mbsf. The material drilled during Leg 139 consisted of $4.04 \mathrm{~m}$ of surficial clastic sulfide, a drilled (but not cored) interval of $9.4 \mathrm{~m}$, and $77.0 \mathrm{~m}$ of massive sulfide. Drilling and coring at Hole $856 \mathrm{H}$ during Leg 169 began at $93.8 \mathrm{mbsf}$. During Leg 169, only Unit VA (equivalent to Type 1 of Leg 139; Davis, Mottl, Fisher, et al., 1992) from the base of the massive sulfide deposit was recovered (93.8-94.4 mbsf). The underlying sulfide feeder zone (103.6-203.3 mbsf), which, on the basis of intensity of sulfide veining and texture, is divided into three subunits, is described in detail separately. The sulfide feeder zone is, in turn, underlain (210.6-431.7 mbsf) by nonmineralized or weakly mineralized sandstone, siltstone, a unit of interbedded basaltic sills and sediment (431.7-471.1 mbsf), and pillow basalt (471.1-500.0 mbsf).

Hole $1035 \mathrm{C}$ was sited $52 \mathrm{~m}$ to the south of Hole $856 \mathrm{H}$ at a water depth of $2448 \mathrm{~m}$. Cores 169-1035C-3X through 5X (20.1-39.8 mbsf) recovered massive sulfide (Fig. 9), but the hole was abandoned because of poor drilling conditions.

Hole $1035 \mathrm{D}$ is located $75 \mathrm{~m}$ east of Hole $856 \mathrm{H}$ and recovered lithologies similar to those in Hole 1035A, at the west side of the mound. Clastic sulfide interbedded with sediment was recovered between 2.7 and 7.1 mbsf (interval 169-1035D 1H-2, $119 \mathrm{~cm}$, to $2 \mathrm{H}-2$, $52 \mathrm{~cm}$ ). Massive sulfide, interpreted to be the east flank of the BHMS mound, was recovered from 40.6 to 77.8 mbsf (Fig. 10). Highly altered and partly replaced sediment is present locally in the lower part of the massive sulfide zone (65-77.8 mbsf). The massive sulfide in Hole 1035D is enriched in sphalerite relative to most of the sulfide recovered from Hole $856 \mathrm{H}$.

Hole $1035 \mathrm{E}$ was located $100 \mathrm{~m}$ south of Hole $856 \mathrm{H}$ to test the southern extent of clastic sulfide shed from the BHMS, and to examine the continuity of BHMS with the morphologically younger and active ODP Mound that occurs further south. After coring $36 \mathrm{~m}$ of sediment, the hole had to be abandoned because of a jammed core barrel and problems with the wireline.

Hole $1035 \mathrm{~F}$ was drilled at the base of the BHMS, $60 \mathrm{~m}$ south of Hole $856 \mathrm{H}$. Massive sulfide was recovered between 0.2 and 80.7 mbsf (interval 169-1035F-1R-1, $16 \mathrm{~cm}$, to 9R-1, $53 \mathrm{~cm}$; Fig. 12). This interval includes (1) massive to semi-massive pyrrhotite and pyrite with altered sediment $(0.2-14.7 \mathrm{mbsf})$, (2) vuggy massive pyrite with minor chalcopyrite, anhydrite, and sphalerite (22.5-71.9 mbsf), and (3) massive to semi-massive, fine-grained pyrrhotite and pyrite with altered mudstone and white clay minerals ( 80.2 to $80.7 \mathrm{mbsf}$ ). Sulfide-banded siltstones and sandstones are present between 89.9 and 90.5 mbsf, at the contact between sulfide and sediment (Core 1691035F-10R); these are mineralized with pyrite, pyrrhotite, and sphalerite in irregular bedding-parallel bands and veins. Stringer zone sulfide mineralization was cored between 109.3 and $167.6 \mathrm{mbsf}$ (Cores 169-1035F-11R through 18R).

Hole $1035 \mathrm{G}$ was drilled $68 \mathrm{~m}$ west of Hole $856 \mathrm{H}$ and $9 \mathrm{~m}$ east of Hole 1035A, near the base of the sulfide mound (see Fig. 13). The interval of silty clay between 0 and $44.4 \mathrm{~m}$ recovered in Hole 1035A was not cored. Coring began near the upper contact of the massive sulfide unit recovered in Core 169-1035A-7X. Massive sulfides were recovered between 44.4 and 64.3 mbsf (Cores 169-1035G-1R through $4 \mathrm{R}$ ). The massive sulfide is principally composed of recrystallized vuggy massive pyrite with some anhydrite. At the base of the sulfide, silty claystone was recovered (Core 169-1035G-5R, 73.6$83.3 \mathrm{mbsf}$ ). The hole was washed between 83.3 and 140.9 through silty claystone cored in Hole 1035A. Silty claystones were also recovered in Hole 1035G between 140.9 and 169.8 mbsf (Cores 169$1035 \mathrm{G}-7 \mathrm{R}$ through 9R). Soft sediment deformation is pervasive in these sediments. Sulfide $(<1 \%)$, consisting of sphalerite, pyrrhotite, and chalcopyrite, occurs as disseminated grains, pore filling, and as subvertical veins. Underlying this is an interval of silicified and chloritized siltstone that contains $25 \mathrm{~cm}$ of massive to semi-massive sulfide composed of pyrite and $\mathrm{Cu}-\mathrm{Fe}$ sulfide that impregnate the hydro- 


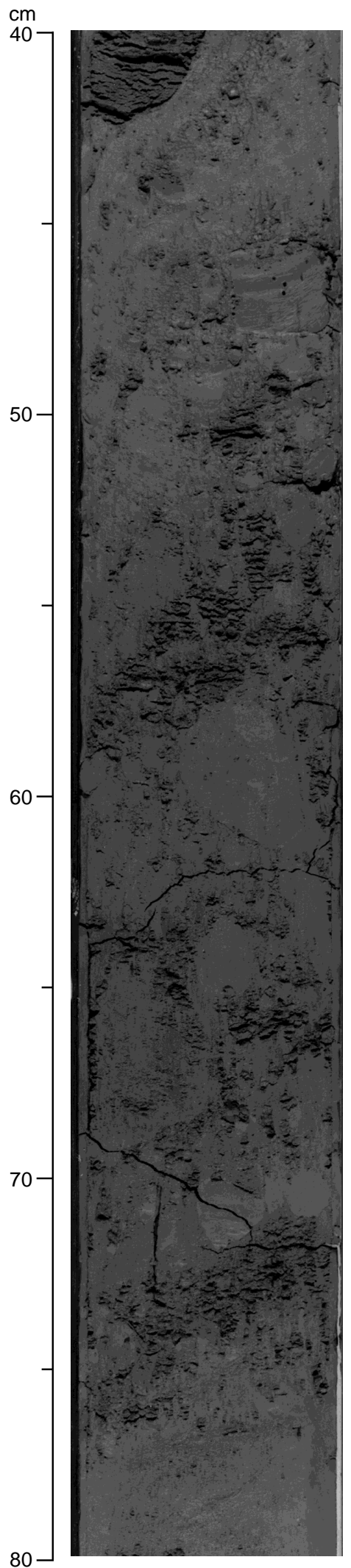

Figure 33. Sedimentary mud-clast breccia consisting of clasts of silty clay in a matrix of fine sand. The subangular clasts range in size from 0.5 to $5 \mathrm{~cm}$ (interval $169-1035 \mathrm{D}-2 \mathrm{H}-3,40-80 \mathrm{~cm}$ ).

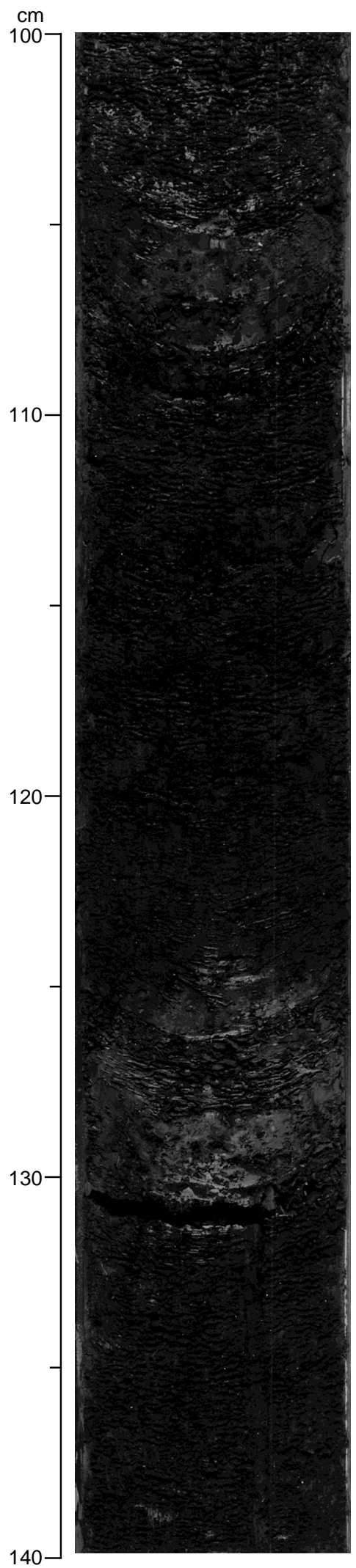

Figure 34. Black, fine-grained, sulfide-rich interval interbedded with greenish gray altered hemipelagic claystone (interval 169-1035D-2H-1, 100-140 $\mathrm{cm})$. 


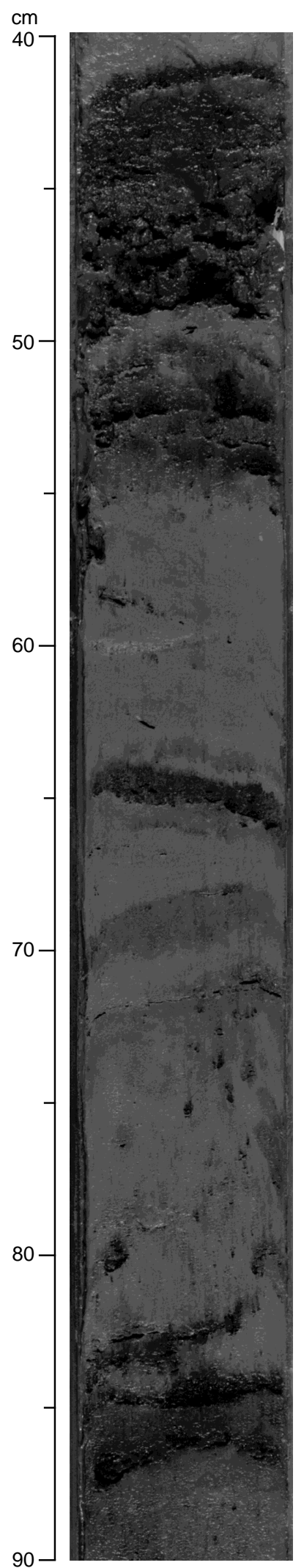

Figure 35 . Interbedded clastic sulfide and silty clays, showing sulfide breccia (at $42-49 \mathrm{~cm}$ ) with sharp basal contact and fining upward. Laminae of sulfide sand at 64-65 cm and 83-87 cm (interval 169-1035D-1H-3, 40-90 cm).

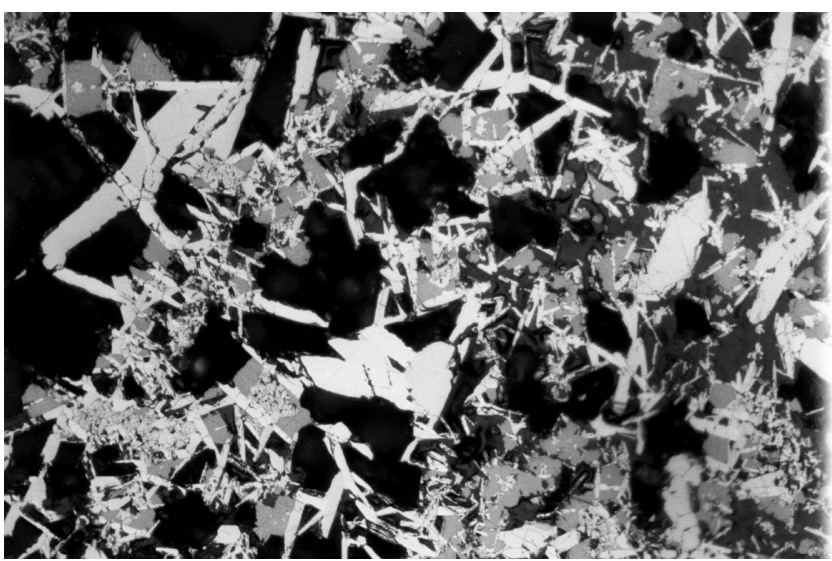

Figure 36. Massive clastic sulfides with a network of hexagonal pyrrhotite platelets, partly infilled by sphalerite (photomicrograph of Sample 169$1035 \mathrm{~A}-1 \mathrm{H}-5,104-105 \mathrm{~cm}$; 20× magnification; field of view $=0.6 \mathrm{~mm}$; reflected light).

thermally altered siltstone (170.6-170.9 mbsf; Core 169-1035G10R). The last sequence in this hole is mineralized siltstone and sandstone (170.9-199.6 mbsf; Cores 169-1035G-10R through 13R) altered to clay, chlorite, epidote, and quartz. Sulfide (up to 5\%), comprised mostly of pyrite and pyrrhotite, occurs as subvertical veins and bedding-parallel veins and impregnations.

Hole $1035 \mathrm{H}$ is situated $\sim 350 \mathrm{~m}$ south of Hole $856 \mathrm{H}$ and cored through the hydrothermally active ODP Mound to a depth of 238.3 mbsf (see Fig. 14). The hole cored massive sulfide in intervals $2 \mathrm{R}-1$, $0 \mathrm{~cm}$, to $4 \mathrm{R}-1,18 \mathrm{~cm}, 8.8-26.6 \mathrm{mbsf}$; $9 \mathrm{R}-1,4-50 \mathrm{~cm}, 74.6-75.1$ mbsf; $14 \mathrm{R}-1,0 \mathrm{~cm}$, to $16 \mathrm{R}-3,90 \mathrm{~cm}, 123.4-135.5 \mathrm{mbsf} ; 17 \mathrm{R}-1,110$ $\mathrm{cm}$, to $17 \mathrm{R}-3,150 \mathrm{~cm}, 143.4-146.8 \mathrm{mbsf}$; and 19R-1, 0-49 cm, 161.5-162.0 mbsf. Massive sulfide intervals are separated by an interval of semi-massive sulfide with sediment in intervals $169-1035 \mathrm{H}-$ $16 \mathrm{R}-3,90 \mathrm{~cm}$, to $17 \mathrm{R}-1,110 \mathrm{~cm}$ (135.5-143.4 mbsf). All the massive sulfide intersections from the ODP Mound contain more sphalerite than the massive sulfides recovered from the BHMS deposit. Other major sulfides are pyrrhotite and pyrite. Magnetite and, in the upper interval, hematite, are locally abundant.

The top part of Hole $1035 \mathrm{H}$ consists of sulfide breccia that formed in situ with little or no sedimentary transport of sulfides. The uppermost core (interval $169-1035 \mathrm{H}-1 \mathrm{R}-1,0 \mathrm{~cm}$, to $1 \mathrm{R}-\mathrm{CC}, 16 \mathrm{~cm}, 0-2.3$ mbsf) comprises intensely clay-altered silty claystone with some clasts of vuggy pyrite and sphalerite. Pyrite in one clast forms a reticulate boxwork that replaces interlocking hexagonal pyrrhotite crystals. The core was so highly disturbed during drilling that the whole 10 -m barrel was more or less homogenized. This zone grades into an 18-m-thick interval of moderately indurated sulfide breccia (interval $169-1035 \mathrm{H}-2 \mathrm{R}-1,0 \mathrm{~cm}$, to $4 \mathrm{R}-1,18 \mathrm{~cm} ; 8.8-26.6 \mathrm{mbsf}$ ), in which millimeter- to several centimeter-sized, irregular and angular sulfide fragments support themselves in a predominantly fine-grained sulfide matrix (Fig. 37). The fragments are mineralogically and texturally heterogeneous. Both the fragments and matrix are commonly composed of pyrite, marcasite, and black, Fe-rich, sphalerite with minor chalcopyrite, isocubanite, and pyrrhotite. Sphalerite- and chalcopyrite-rich clasts are present in places.

Microscopic investigations show that both pyrite and marcasite replace primary hexagonal pyrrhotite. Magnetite and hematite occur in variable amounts. Hematite, where present, imparts a mottled reddish color. The major nonsulfides are milky white dolomite and translucent, whitish to tan, coarsely crystalline ankerite. This unit could be considered transitional to the well-indurated hydrothermally recrystallized massive sulfide typical of the BHMS deposit (similar to Types 3 and 4 pyrite-pyrrhotite-magnetite massive sulfide of Leg 139; Davis, Mottl, Fisher, et al., 1992) and the deeper massive sulfide zones at the ODP Mound. 
Table 8. Occurrence of massive sulfide facies, Bent Hill and ODP mounds.

\begin{tabular}{|c|c|c|c|c|c|c|c|c|}
\hline Description & Unit & Hole $856 \mathrm{H}$ & Hole $1035 \mathrm{~A}$ & Hole $1035 \mathrm{C}$ & Hole $1035 \mathrm{D}$ & Hole $1035 \mathrm{~F}$ & Hole $1035 \mathrm{G}$ & Hole $1035 \mathrm{H}$ \\
\hline $\begin{array}{l}\text { Fine-grained } \\
\text { homogeneous } \\
\text { pyrrhotite }+ \text { pyrite }+ \\
\text { sphalerite }+ \text { isocubanite } \\
\text { + chalcopyrite }\end{array}$ & VA & $\begin{array}{l}14 \mathrm{R}-1,0 \mathrm{~cm} \text {, to } \\
17 \mathrm{R}-1,33 \mathrm{~cm} \\
(75.7-90.43 \\
\text { mbsf) } \\
19 \mathrm{R}-1,0-63 \mathrm{~cm} \\
(93.8-94.43 \\
\text { mbsf) }\end{array}$ & & $\begin{array}{l}3 \mathrm{X}-\mathrm{CC}, 0-6 \mathrm{~cm} \\
(20.10-20.16 \\
\text { mbsf })\end{array}$ & $\begin{array}{l}11 \mathrm{X}-1,0-30 \mathrm{~cm} \\
(72.4-72.7 \\
\text { mbsf })\end{array}$ & $\begin{array}{l}1 \mathrm{R}-1,16 \mathrm{~cm}, \text { to } \\
2 \mathrm{R}-1,17 \mathrm{~cm} \\
(0.16-14.67 \\
\text { mbsf })\end{array}$ & & \\
\hline $\begin{array}{l}\text { Heterogeneous (and } \\
\text { veined) fine- to coarse- } \\
\text { grained pyrite }+ \\
\text { pyrrhotite } \pm \text { magnetite } \pm \\
\text { sphalerite } \pm \text { chalcopyrite }\end{array}$ & VB & $\begin{array}{l}2 \mathrm{R}-1,0-40 \mathrm{~cm} \\
(13.5-13.9 \mathrm{mbsf}) \\
5 \mathrm{R}-1,0 \mathrm{~cm}, \text { to } 8 \mathrm{R}- \\
1,54 \mathrm{~cm}(32.4- \\
48.54 \mathrm{mbsf}) \\
13 \mathrm{R}-1,25-50 \mathrm{~cm}, \\
(71.15-71.4 \\
\text { mbsf })\end{array}$ & & & $\begin{array}{l}12 \mathrm{X}-1,0-42 \mathrm{~cm} \\
(77.4-77.8 \\
\text { mbsf) }\end{array}$ & $\begin{array}{l}9 \mathrm{R}-1,0-53 \mathrm{~cm} \\
\quad(80.2-80.73 \\
\text { mbsf })\end{array}$ & & \\
\hline $\begin{array}{l}\text { Fine- to medium-grained } \\
\text { sphalerite }+ \text { pyrrhotite }+ \\
\text { pyrite }+ \text { magnetite }+ \\
\text { chalcopyrite }+ \\
\text { isocubanite }\end{array}$ & $\mathrm{VC}$ & $\begin{array}{l}3 \mathrm{R}-1,0 \mathrm{~cm} \text {, to } 4 \mathrm{R}- \\
3,20 \mathrm{~cm}(22.1- \\
29.2 \mathrm{mbsf})\end{array}$ & & & & & & $\begin{array}{l}\text { 2R-1, } 0 \mathrm{~cm} \text {, to } 4 \mathrm{R}-1, \\
18 \mathrm{~cm}(8.8-26.6 \\
\text { mbsf }) \\
\text { 9R-1, 4-50 cm } \\
(74.64-75.1 \mathrm{mbsf}) \\
14 \mathrm{R}-1,39 \mathrm{~cm}, \text { to } \\
19 \mathrm{R}-1,49 \mathrm{~cm} \\
(123.4-162.0 \\
\text { mbsf })\end{array}$ \\
\hline $\begin{array}{l}\text { Massive, colloform and } \\
\text { vuggy pyrite: anhydrite } \\
\text { locally fills vugs; locally } \\
\text { sphalerite rich }\end{array}$ & VD & $\begin{array}{l}8 \mathrm{R}-1,54 \mathrm{~cm}, \text { to } \\
13 \mathrm{R}-1,25 \mathrm{~cm} \\
(48.54-71.15 \\
\text { mbsf })\end{array}$ & $\begin{array}{l}7 \mathrm{X}-1,0-15 \mathrm{~cm} \\
(55.0-55.15 \\
\mathrm{mbsf}) \\
7 \mathrm{X}-\mathrm{CC}, 21-40 \\
\mathrm{~cm}(56.71- \\
56.90 \mathrm{mbsf})\end{array}$ & $\begin{array}{l}4 \mathrm{X}-\mathrm{CC}, 0-35 \\
\mathrm{~cm}(29.70- \\
30.05 \mathrm{mbsf}) \\
5 \mathrm{X}-1,0-50 \mathrm{~cm} \\
(39.3-39.8 \\
\text { mbsf })\end{array}$ & $\begin{array}{l}6 \mathrm{X}-\mathrm{CC}, 0 \mathrm{~cm}, \text { to } \\
9 \mathrm{X}-1,95 \mathrm{~cm} \\
(40.6-61.75 \\
\text { mbsf) } \\
11 \mathrm{X}-1,30-63 \mathrm{~cm} \\
(72.70-73.05 \\
\text { mbsf })\end{array}$ & $\begin{array}{l}3 \mathrm{R}-1,0 \mathrm{~cm}, \text { to } \\
8 \mathrm{R}-1,124 \mathrm{~cm} \\
(22.5-71.94 \\
\text { mbsf })\end{array}$ & $\begin{array}{l}2 \mathrm{R}-1,0 \mathrm{~cm}, \text { to } \\
4 \mathrm{R}-1,25 \mathrm{~cm} \\
(44.4-64.25 \\
\text { mbsf })\end{array}$ & \\
\hline
\end{tabular}

Massive to semi-massive $\mathrm{Cu}-\mathrm{Fe}$ sulfide was recovered in two horizons below the Zn-rich massive sulfides, at 162.0-162.5 mbsf (interval 169-1035H-19R-1, 49-108 cm) and 181.0-182.0 mbsf (interval 21R-1, 26-126 cm; see "Sulfide Mineralization: Sulfide Feeder Zone" section, this chapter). Sulfide-impregnated and veined sandstone and siltstone stratigraphically underlie the semi-massive to

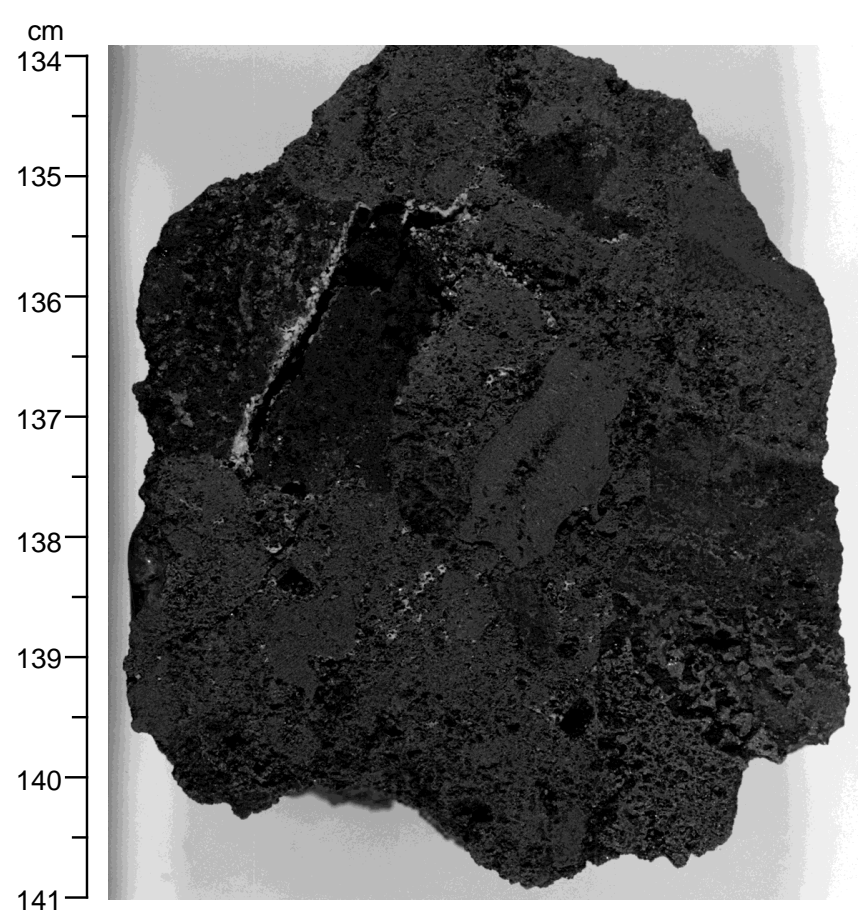

Figure 37. In situ sulfide breccia with angular sulfide clasts (interval 1691035H 2R-1, 134-141 cm). massive sulfide zones, and these subunits grade into non-mineralized sediment. Generally, these subunits are only weakly mineralized, but contain the same sulfide minerals as the massive sulfides overlying them.

The core recovery from the eight holes drilled in the vicinity of the BHMS deposit therefore indicates that the mineralization has a maximum thickness of $>94 \mathrm{~m}$ and a minimum east-west width of $152 \mathrm{~m}$. The north-south dimensions are not well constrained, but exceed 100 $\mathrm{m}$. The possible continuity of mineralization between the BHMS deposit and the ODP Mound has not been tested by drilling between Holes $1035 \mathrm{~F}(60 \mathrm{~m}$ south of $856 \mathrm{H})$ and $1035 \mathrm{H}$.

\section{Sulfide Facies}

The massive sulfide facies recovered from Holes $856 \mathrm{H}$ and 1035A through $1035 \mathrm{H}$ are summarized in Table 8 and are described in more detail below.

\section{Fine-Grained Homogeneous Massive Pyrrhotite (Subunit VA)}

The first core recovered from Hole $856 \mathrm{H}$ during Leg 169 was a wash core (Core $169-856 \mathrm{H}-18 \mathrm{~W}$ ) that consists of three pieces of massive pyrrhotite with pyrite and up to $10 \%$ magnetite. These pieces are probably rubble that collected at the bottom of the hole during Leg 139 drilling or during Leg 169 reentry and are similar to massive pyrrhotite (Leg 139, Type 1) collected from the bottom of the hole during Leg 139. Below this, $0.65 \mathrm{~m}$ of massive sulfide was recovered from the basal part of the massive sulfide zone in Core 169-856H$19 \mathrm{R}$. Most of the sulfide pieces in this core are massive fine-grained pyrrhotite. The massive pyrrhotite is partly replaced and veined by coarser grained pyrite and some areas contain pyrite blebs (Fig. 38). The last piece (interval 169-856H-19R-1, 59-64 cm) is massive finegrained pyrrhotite breccia with interstitial chalcopyrite (Fig. 39). This piece of pyrrhotite breccia consists of subrounded clasts of massive pyrrhotite in a matrix of isocubanite/chalcopyrite with minor pyrite, anhydrite, and amorphous silica. Chalcopyrite and isocubanite 


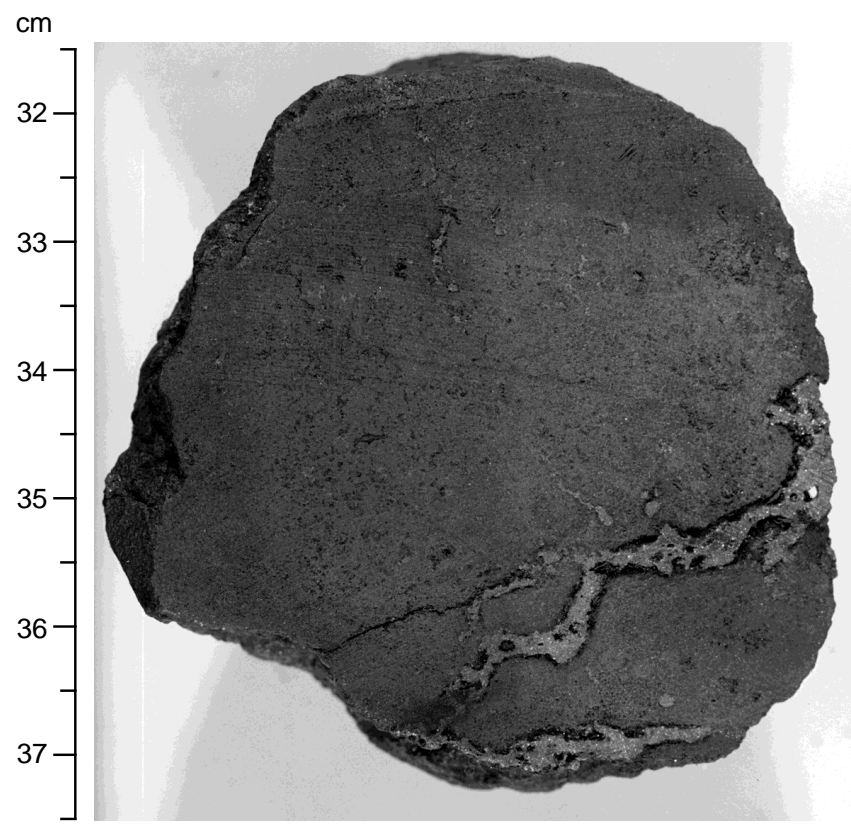

Figure 38. Massive fine-grained pyrrhotite cut by pyrite veins (interval 169856H-19R-1, 31.5-37.5 cm).

form lamellar intergrowths governed by crystallography of the minerals (Fig. 40). The clasts of pyrrhotite are recrystallized into a granoblastic texture with minor interstitial chalcopyrite and pyrite. Pyrrhotite clast margins are commonly replaced by pyrite and marcasite aggregates. The replacement typically follows the cleavage in pyrrhotite. Anhedral, fine-grained magnetite is associated with this pyrite, but does not occur in the unaltered pyrrhotite clasts.

In Holes $1035 \mathrm{C}$ and 1035D (intervals 169-1035C-3X-CC, 0-6 $\mathrm{cm}$; 20.1-20.2 mbsf, and 169-1035D-11X-1, 0-30 cm; 72.4-72.7 mbsf), massive fine-grained pyrrhotite was recovered that consists of $50 \%-90 \%$ pyrrhotite, $10 \%-\% 30 \%$ pyrite, $2 \%-5 \%$ magnetite, and

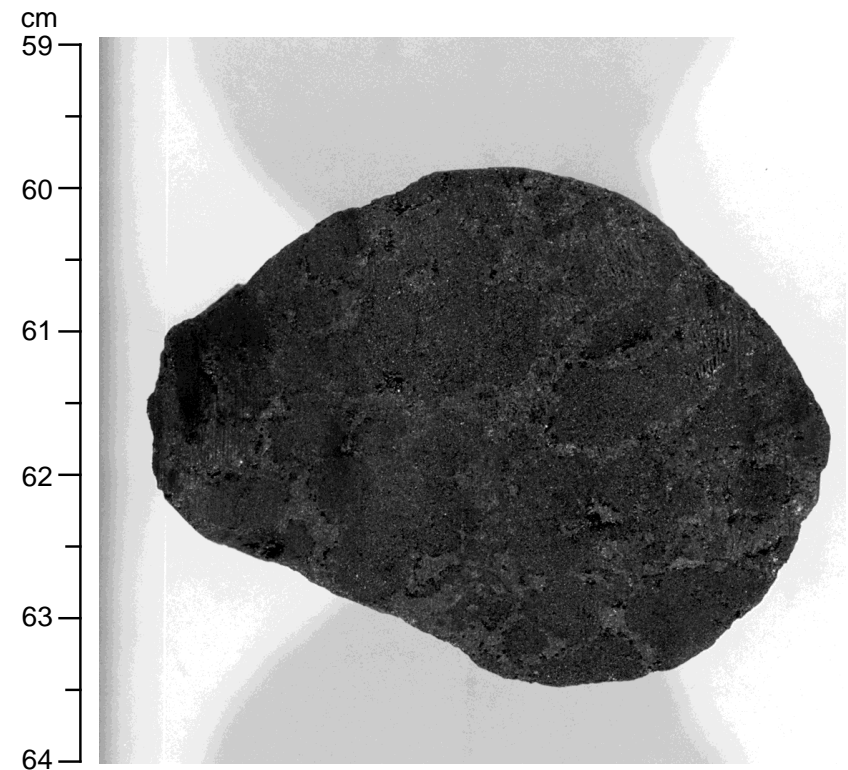

Figure 39. Massive fine-grained pyrrhotite-chalcopyrite breccia. Chalcopyrite (light gray) is interstitial to subrounded clasts of pyrrhotite (dark gray; interval 169-856H-19R-1, 59-64 cm).

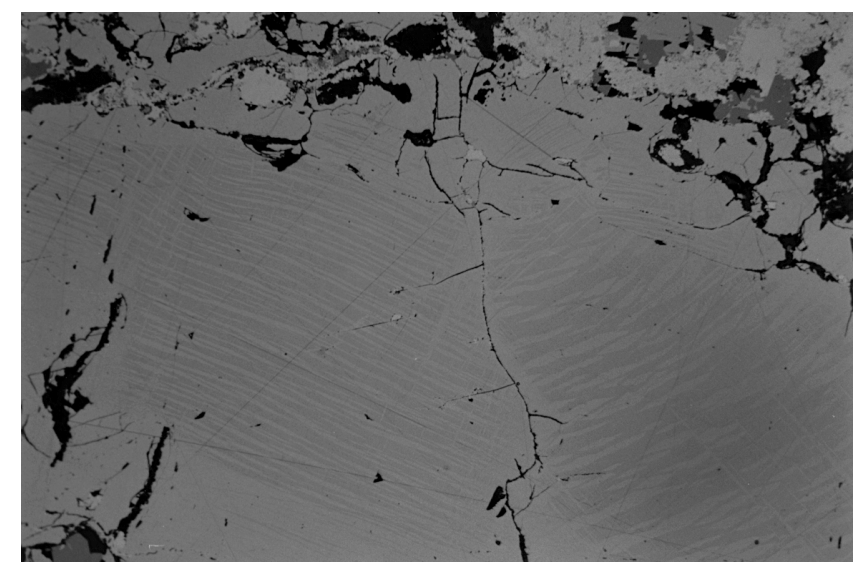

Figure 40. Reflected light photomicrograph showing exsolution of chalcopyrite and isocubanite from intermediate solid solution phase. In the center of the photo, later chalcopyrite has formed along the fracture (width of field $=$ $\sim 0.6 \mathrm{~mm}$; Sample 169-856H-19R-1, 59-64 cm).

trace chalcopyrite. Rubble samples in Section 169-1035C-3X-CC occur with siltstone and mudstone fragments that are partially to completely replaced by pyrrhotite. This sulfide type was also recovered in Hole 1035F (Sections 169-1035F-1R-1 through 2R-1, 0.2-14.7 mbsf). Piece 2 from Section 169-1035F-1R-1, which is not oriented, has a banded internal texture and may be either a piece of chimney or mound crust (Fig. 41).

\section{Heterogenous Pyrrhotite-Pyrite \pm Magnetite, Sphalerite, and Cu-Fe Sulfides (Subunit VB)}

This type of sulfide mineralization is similar to Types 2,3 , and 4 of the Leg 139 sulfide classification scheme; they were originally distinguished by their grain size and more heterogeneous nature compared to the other types (Davis, Mottl, Fisher et al., 1992). However, a common characteristic of these three types is the occurrence of fineto coarse-grained pyrite and pyrrhotite with minor magnetite,

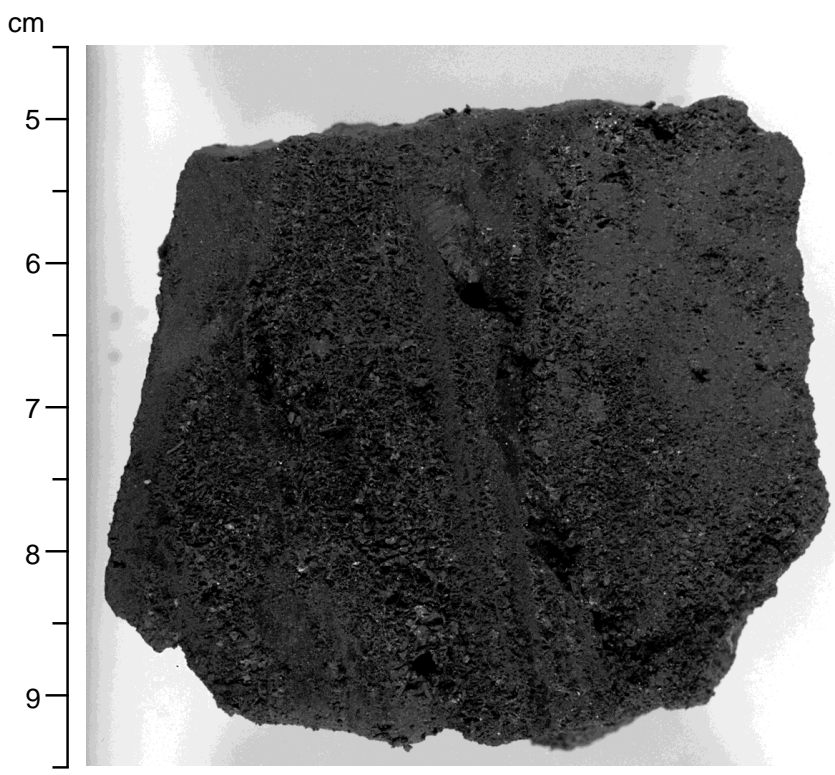

Figure 41. Banded pyrrhotite sample from the upper parts of Hole 1035F, possibly a mound crust or chimney fragment (interval 169-1035F-1R-1, 4.5$9.5 \mathrm{~cm})$. 


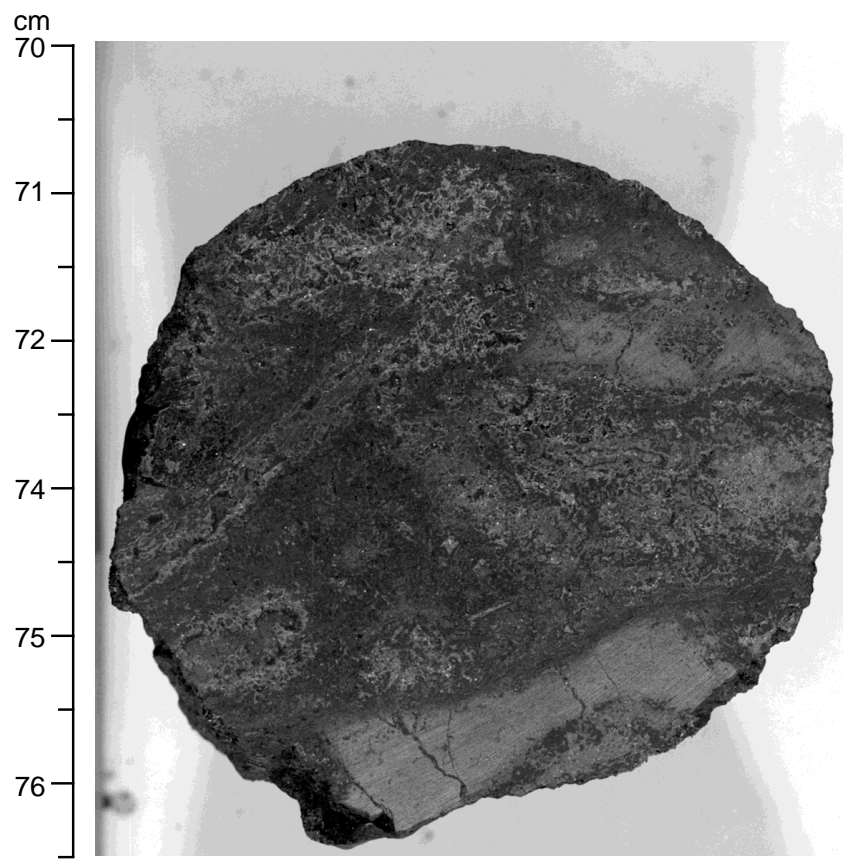

Figure 42. Massive pyrite-pyrrhotite sulfide replacing sediment. Small remnants of sediment (light gray) are still present (interval 169-1035D-10X-1, $70-76.5 \mathrm{~cm})$.

sphalerite, and chalcopyrite. This massive sulfide facies was recovered only from Section 169-1035D-12R-1 and is best described as heterogenous, fine-grained pyrrhotite-pyrite-magnetite with minor $(\sim 1 \%)$ chalcopyrite and anhydrite. However, in intervals $169-1035 \mathrm{D}-$ $10 \mathrm{X}-1,21-93 \mathrm{~cm}$ (66.7-67.4 mbsf), and 1035F-9R-1, 0-53 cm (80.2-80.7 mbsf), sulfide-sediment rocks were recovered that are characterized by subequal amounts of fine-grained pyrite and pyrrhotite that crosscut and impregnate hydrothermally altered mudstone (Fig. 42). The sulfide content generally varies between 50 and 70 vol\%. Altered mudstone clasts rarely exceed $5 \mathrm{~cm}$. Pyrrhotite is locally partly replaced by pyrite, and pyrite also rims altered sediment clasts. Magnetite and chalcopyrite are present within the pyritepyrrhotite intergrowths and also in millimetric veinlets that crosscut both the pyrite-pyrrhotite and altered sediment. Pyrite and magnetite occur in a fine-grained intergrowth, which suggests that they coprecipitated, possibly as a result of the oxidation of primary pyrrhotite. A maximum of $2 \%$ sphalerite occurs in this facies.

\section{Sphalerite-Pyrrhotite-Pyrite-Magnetite (Subunit VC)}

Sphalerite-pyrrhotite-pyrite-magnetite massive to semi-massive sulfide is the most common sulfide facies in the ODP Mound (Hole $1035 \mathrm{H}$ ), whereas the only zinc-rich interval recognized from samples collected from the BHMS deposit during Leg 139 was between 25 and $30 \mathrm{mbsf}$ in Hole $856 \mathrm{H}$, where post-cruise analysis indicated $2 \%-$ $8 \%$ zinc in sulfide Types 4 and 6 of the Leg 139 classification (Davis, Mottl, Fisher, et al., 1992; R. Zierenberg, pers. comm, 1996). This type of mineralization occurs at five different intervals in Hole $1035 \mathrm{H}$, with the main concentrations in the uppermost $26 \mathrm{~m}$ (interval $169-1035 \mathrm{H}-2 \mathrm{R}-1,0 \mathrm{~cm}$, to $4 \mathrm{R}-1,18 \mathrm{~cm} ; 8.8-26.6 \mathrm{mbsf}$ ) and in three intervals between 123 and 162 mbsf (interval 169-1035H-14R-1, 40 $\mathrm{cm}$, to $19 \mathrm{R}-1,0-49 \mathrm{~cm})$. A thin interval $(35 \mathrm{~cm}$ recovered) of the same type is also present at a depth of 74.7-75.1 mbsf (interval 1691035H-9R-1, 4-50 cm).

The massive sulfides between 123 and 162 mbsf (interval 169$1035 \mathrm{H}-14 \mathrm{R}-1,40 \mathrm{~cm}$, to $19 \mathrm{R}-1,0-49 \mathrm{~cm}$ ) are dominated by black,

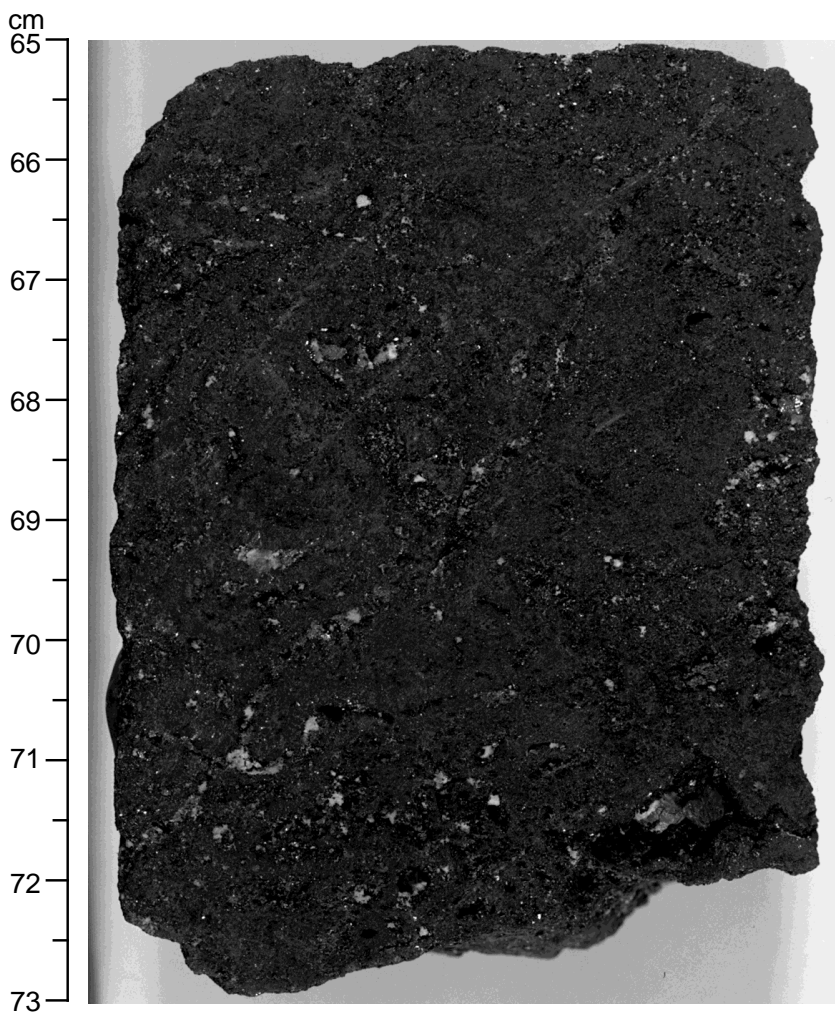

Figure 43. Vuggy, coarse-grained, sphalerite-rich ore (interval 169-1035H$16 \mathrm{R}-1,65-73 \mathrm{~cm})$.

iron-rich sphalerite and pyrrhotite or pyrite (Fig. 43). Galena occurs as rare inclusions in the sphalerite. The sphalerite content is typically between 40 and $60 \mathrm{vol} \%$ and ranges up to 70-80 vol\%. Larger amounts of magnetite are generally associated with pyrite. The predominant $\mathrm{Cu}$-sulfide is a presently unidentified $\mathrm{Cu}$-Fe sulfide (probably of intermediate solid solution [ISS] composition) that occurs in minor amounts with subordinate chalcopyrite. This $\mathrm{Cu}-\mathrm{Fe}$ sulfide has higher reflectance than isocubanite, only slightly lower than pyrite (like chalcopyrite) and is slightly more yellowish in color than pyrite. It appears to be isotropic. Some samples have up to $10 \%$ interstitial white clay minerals (Fig. 44). Pyrrhotite-rich parts of this subunit commonly form an open network texture, with interstitial sphalerite, and voids filled with a white and greenish mineral, probably a mixture of talc, smectite, and/or chlorite. The sulfide + oxide content of this massive sulfide type, based on five polished thin sections, averages $66 \%(50 \%-80 \%)$ total sulfides + oxides, which in turn, comprises $32 \%(8 \%-50 \%)$ sphalerite, $10 \%(0 \%-20 \%)$ pyrrhotite, $8 \%(0 \%-$ $18 \%)$ pyrite, $4 \%(0 \%-13 \%)$ marcasite, $4 \%(0 \%-8 \%) \mathrm{Cu}-\mathrm{Fe}$ sulfide, $3 \%(0 \%-5 \%)$ chalcopyrite, $1 \%(0 \%-5 \%)$ magnetite, and $1 \%(0 \%-$ $4 \%$ ) hematite.

Sphalerite-rich parts of the massive sulfide are either compact, earthy and fine grained, or vuggy and coarse grained (Fig. 45). In some of the vugs, zinc sulfide is present as hexagonal crystals that could be wurtzite or sphalerite pseudomorphs after wurtzite. Texturally, the sphalerite-rich type consists of a fine-grained (0.01-0.05 $\mathrm{mm}$ ) matrix of sphalerite in which pyrrhotite and other sulfides occur. $\mathrm{Cu}-\mathrm{Fe}$ sulfide and locally marcasite occur as fine-grained inclusions in the sphalerite-rich areas. $\mathrm{Cu}-\mathrm{Fe}$ sulfide also forms trails along the crystallographic directions in the sphalerite. Pyrite uncommonly replaces pyrrhotite. Chlorite is the most abundant nonsulfide, typically forming a reticulate boxwork pattern interstitial to the sulfides. The only other nonsulfide recognized is carbonate, probably dolomite, as an aggregate in one of the sections. 
In the intervals of massive to semi-massive sulfide at 134.5-136.4 mbsf (interval 169-1035H-16R-2, $42 \mathrm{~cm}$, to $16 \mathrm{R}-3,90 \mathrm{~cm}$ ) and at 145.2-146.7 mbsf (interval 169-1035H-17R-3, 0-150 cm), there is a higher content of pyrite $(18 \%-33 \%)$ and magnetite $(6 \%-9 \%)$, whereas the content of sphalerite $(9 \%-10 \%)$ and pyrrhotite $(3 \%-4 \%)$ is lower. Characteristic of this zone is the abundance of very coarsegrained neoblastic pyrite (up to $1.5 \mathrm{~cm}$ diameter) that results in a spotted texture (Fig. 46). This coarse-grained pyrite has been fractured locally and infilled by later pyrrhotite (Fig. 47). Pyrrhotite forms up to 1-mm large skeletal and poikiloblastic grains and aggregates, with inclusions of sphalerite, magnetite, and chlorite; this is ev-

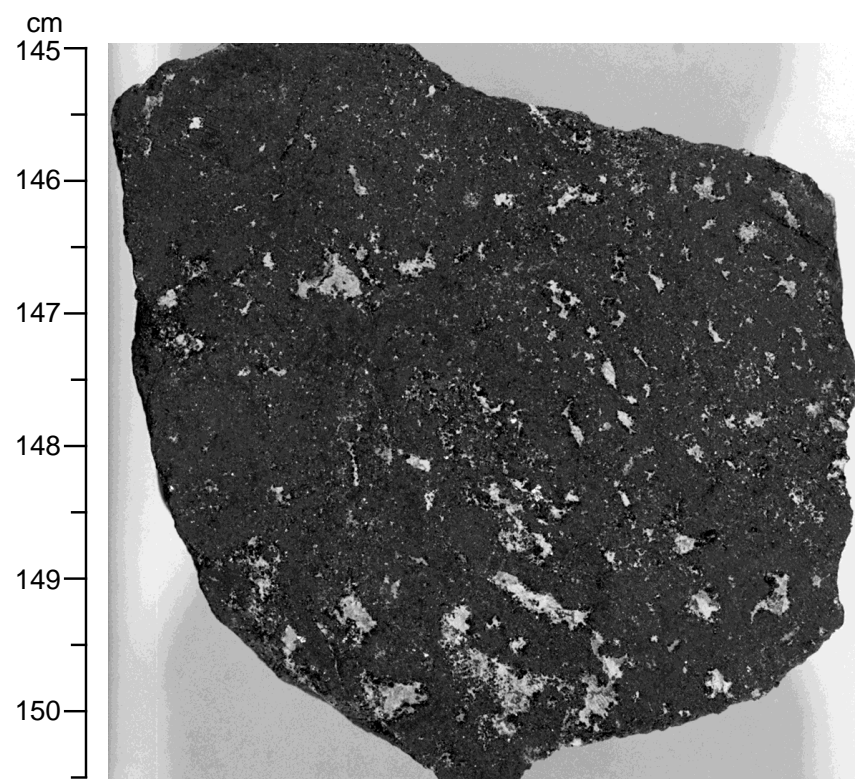

Figure 44. Sphalerite ore with white interstitial clay minerals (interval 169$1035 \mathrm{H}-16 \mathrm{R}-1,145-150.5 \mathrm{~cm})$.

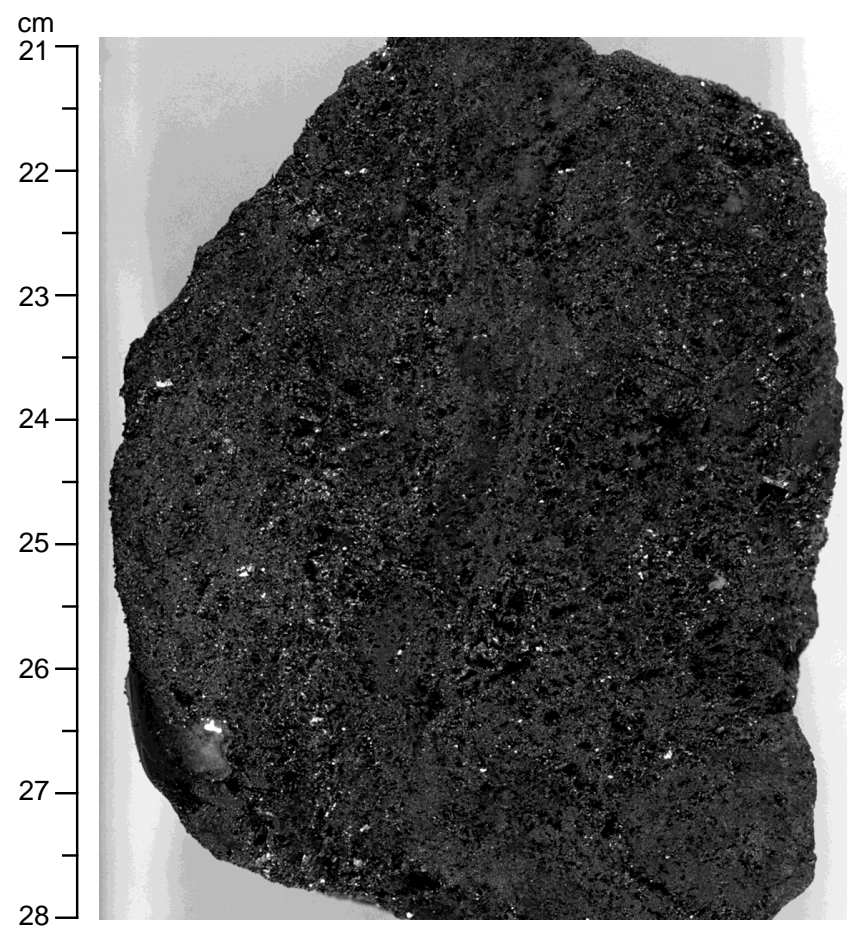

Figure 45. Sphalerite-rich massive sulfide (interval 169-1035H-15R-1, 21$28 \mathrm{~cm})$. idence of fast crystal growth. Similarly, magnetite forms partly euhedral, poikiloblastic, octahedral grains with sulfide inclusions. Magnetite has partially replaced hematite, and earlier formed globular aggregates of hematite laths have been totally and locally replaced by magnetite. Sphalerite occurs as subhedral cubes, commonly with an inclusion-free rim surrounding a $\mathrm{Cu}-\mathrm{Fe}$ sulfide-diseased core. Carbonate (probably dolomite), quartz, and fibrous talc are interstitial to the sulfides.

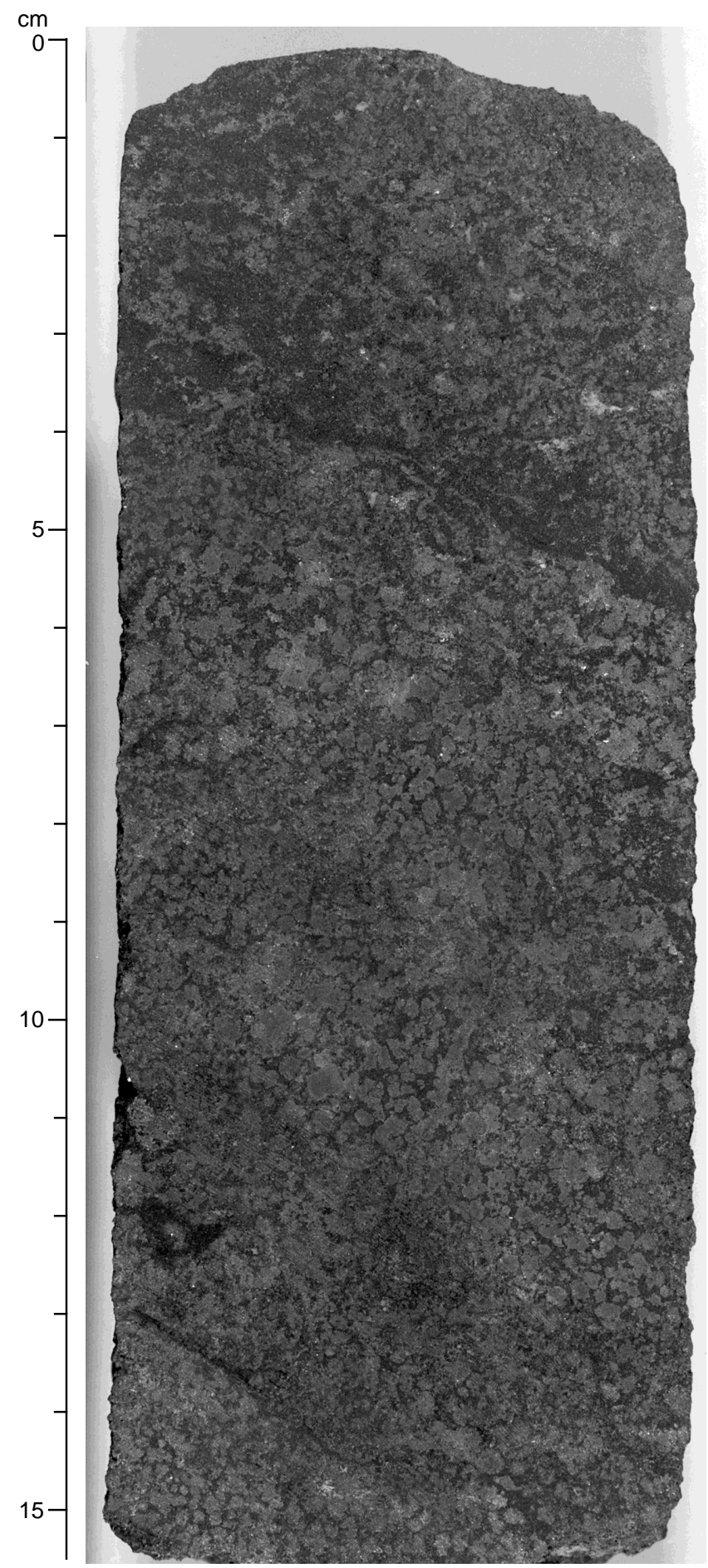

Figure 46. Sphalerite-rich ore with neoblastic pyrite (interval $169-1035 \mathrm{H}-$ $16 \mathrm{R}-3,0-15.5 \mathrm{~cm})$. 


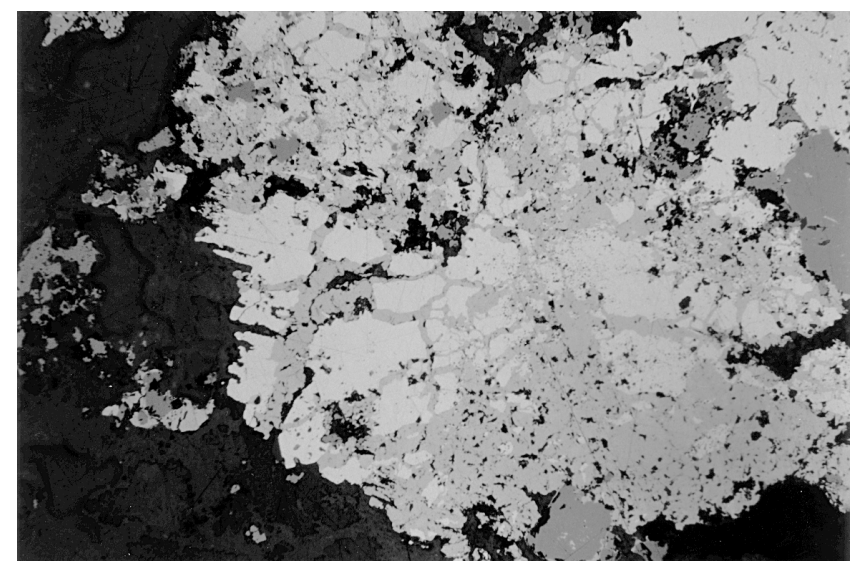

Figure 47. Reflected light photomicrograph showing late pyrrhotite (medium gray) infilling fractures in pyrite (light gray; interval 169-1035H-16R-2, $122-126 \mathrm{~cm}$; width of field $=1.2 \mathrm{~mm}$ )

The factors that resulted in the coarse recrystallization of pyrite and the other sulfides in this interval are not well constrained. The presence of epidote, actinolite, and hedenbergite (confirmed by XRD; Table 5) and the highly recrystallized and indurated nature of the sediments indicates reaction with very large fluxes of hydrothermal fluid and possibly the close proximity of an igneous body not intersected by this hole.

\section{Massive Vuggy and Colloform Pyrite-Marcasite $( \pm$ Sphalerite \pm Chalcopyrite)}

This is the most common sulfide facies recovered from the BHMS deposit during Leg 169. It is characterized by massive pyrite and marcasite that is most commonly vuggy (10\%-50\% vugs) with wavy colloform banding on a submillimeter to centimeter scale (Fig. 48). A mesh network of fine-grained pyrite enclosing an open space results in a reticulate texture. These vugs vary in size and shape, but are commonly irregular and between $0.1 \mathrm{~mm}$ and $2 \mathrm{~cm}$ long. A salient difference between rocks of this facies recovered during Leg 169 compared with those recovered during Leg 139 is the presence of anhydrite and carbonate (probably dolomite) that partly fills the vugs (Fig. 49). Although this sulfide type is common in Holes $856 \mathrm{G}$ and $856 \mathrm{H}$ of Leg 139 , the vugs are commonly filled with white amorphous silica or smectite. However, the nonsulfide minerals noted infilling vugs in samples recovered during Leg 169 is generally clear to gray anhydrite that, in places, occurs as euhedral crystals up to $2 \mathrm{~cm}$ long and coarsegrained carbonate (probably dolomite). Vugs are generally lined with euhedral pyrite crystals. Vertical fluid channel structures are common (Fig. 50), and channel walls are commonly lined with coarsegrained marcasite (Fig. 51). Indeed, some samples of massive and vuggy "pyrite" contain up to $50 \%$ marcasite with secondary pyrite. This facies type is also locally enriched in sphalerite and/or chalcopyrite that was not observed in samples from Leg 139. Brown or black sphalerite is present as colloform bands and veinlets that parallel and rhythmically alternate with the pyrite-marcasite bands lining the vertical channel structures (Fig. 52). Bands of dark material (mostly clay minerals) are also partially intergrown with pyrite. Additionally, black sphalerite locally also occurs interstitial to the pyrite in vugs. Two generations of sphalerite are present; an earlier phase that is coeval with a generation of pyrite that replaces marcasite and which displays extensive chalcopyrite disease (Barton and Bethke, 1987), and later, less Fe-rich sphalerite that occurs in veinlets crosscutting pyrite. Pyrrhotite and isocubanite also occur in these late veinlets. In

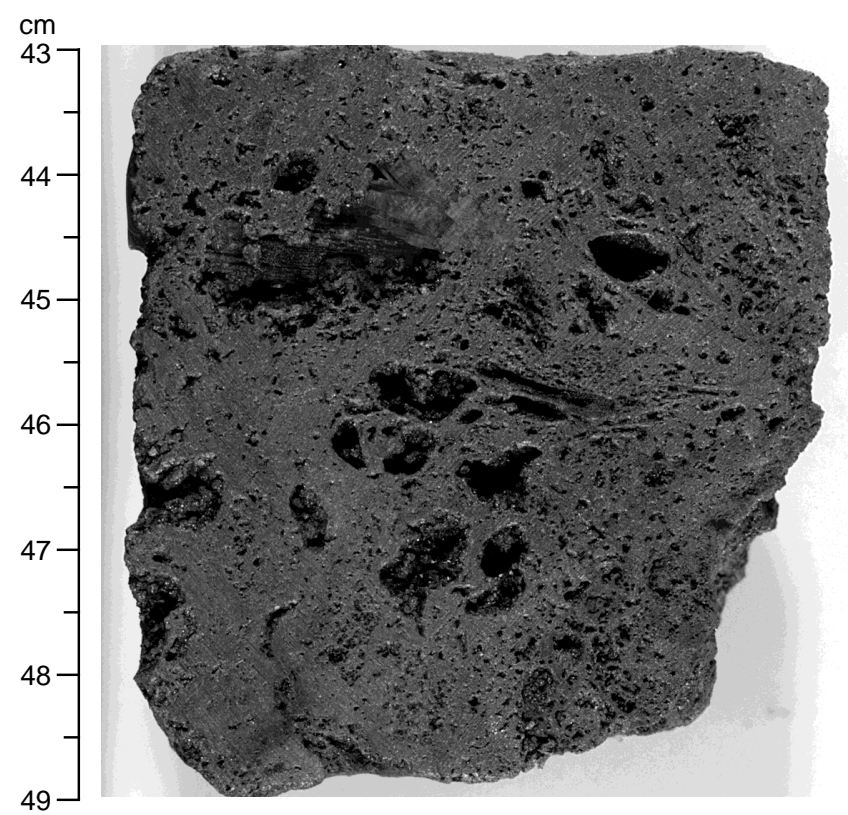

Figure 48. Massive and colloform vuggy pyrite (interval 169-1035C-5X-1, $43-49 \mathrm{~cm}$ ).

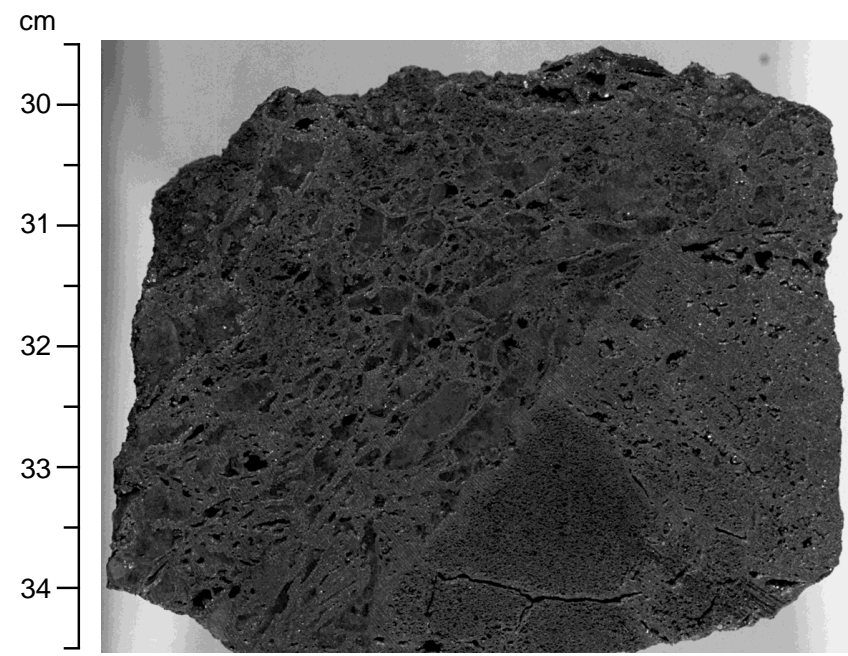

Figure 49. Coarse anhydrite (filling vugs in lower half of photograph) in vuggy pyrite (interval $169-1035 \mathrm{~F}-5 \mathrm{R}-2,29.5-34.5 \mathrm{~cm}$ ).

Hole 1035C (Section 169-1035C 5X-1, 39.3 mbsf), massive vuggy pyrite was recovered that contains up to $20 \%$ chalcopyrite as vug infill and crosscutting veins.

Estimation of mineral abundances in this sulfide facies, based on examining nine polished thin sections, indicates a total sulfide content averaging $80 \%$ and comprising $45 \%(18 \%-76 \%)$ pyrite, $24 \%$ $(0 \%-56 \%)$ marcasite, $5 \%(0 \%-30 \%)$ pyrrhotite, $4 \%(0 \%-16 \%)$ sphalerite, and $2 \%(0 \%-9 \%)$ isocubanite and chalcopyrite.

It is likely that this massive marcasite-pyrite facies is the precursor through which later hydrothermal fluids have flowed and precipitated later iron, copper, and zinc sulfides. In areas of intense paleohydrothermal fluid flow, this facies has been mineralogically modified to produce the distinctly different sulfide types recovered in Holes $856 \mathrm{H}$ and $1035 \mathrm{H}$. 


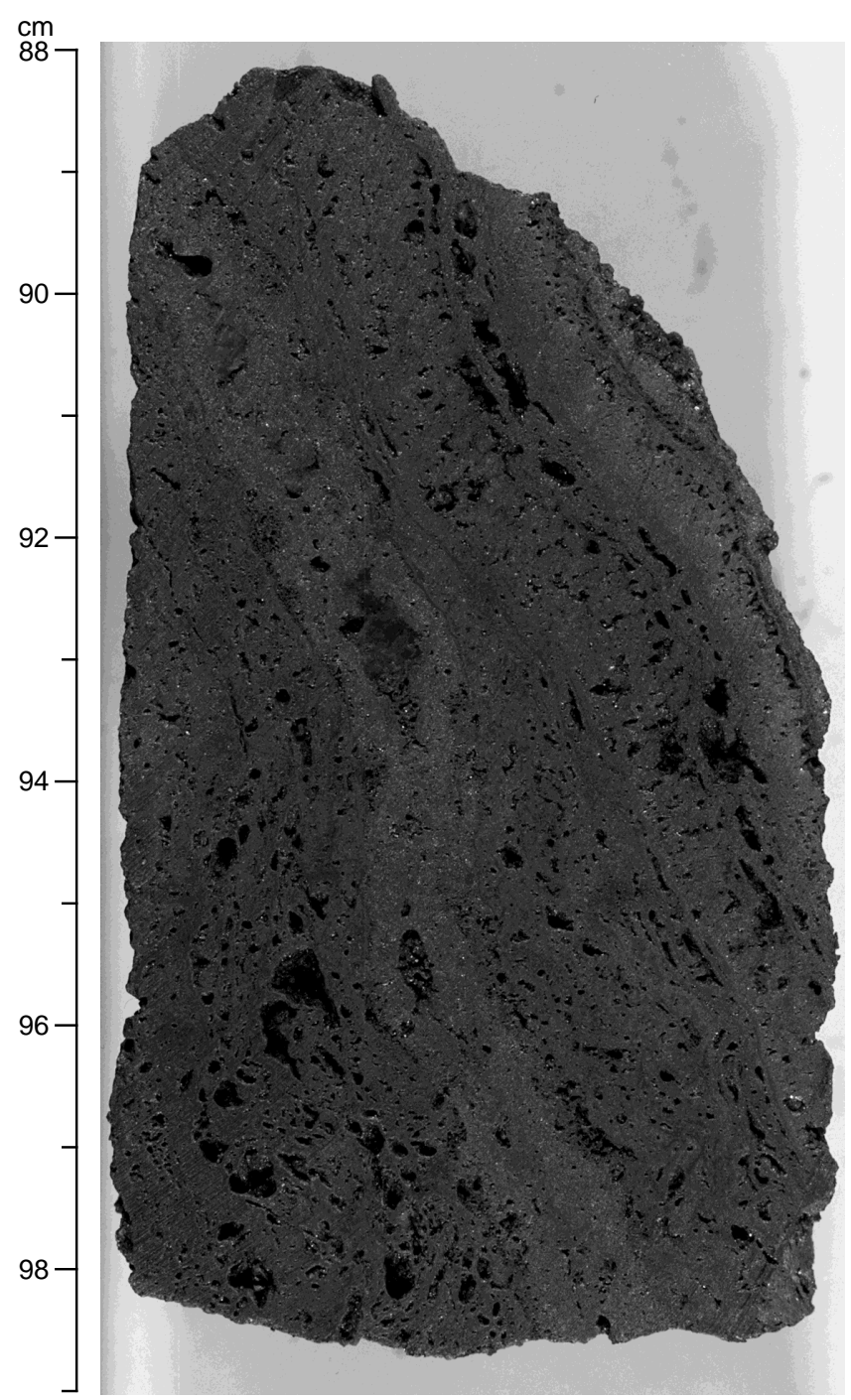

Figure 50. Vertical fluid channel in massive vuggy pyrite (+marcasite). Paleovein with up to $30 \%$ pore space forming a still-permeable pathway. Pores range in size up to $5 \mathrm{~mm}$ wide and $30 \mathrm{~mm}$ long (interval 169-1035F$5 \mathrm{R}-1,88-99 \mathrm{~cm})$.

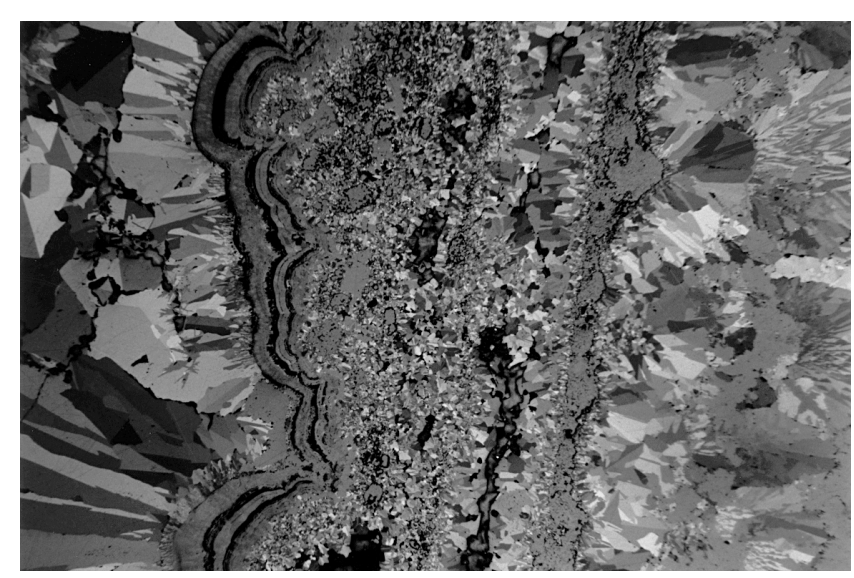

Figure 51. Reflected light photomicrograph showing marcasite-pyrite banding (width of field $=\sim 5 \mathrm{~mm}$; Sample 169-1035H-7R-1, 3-4 cm).

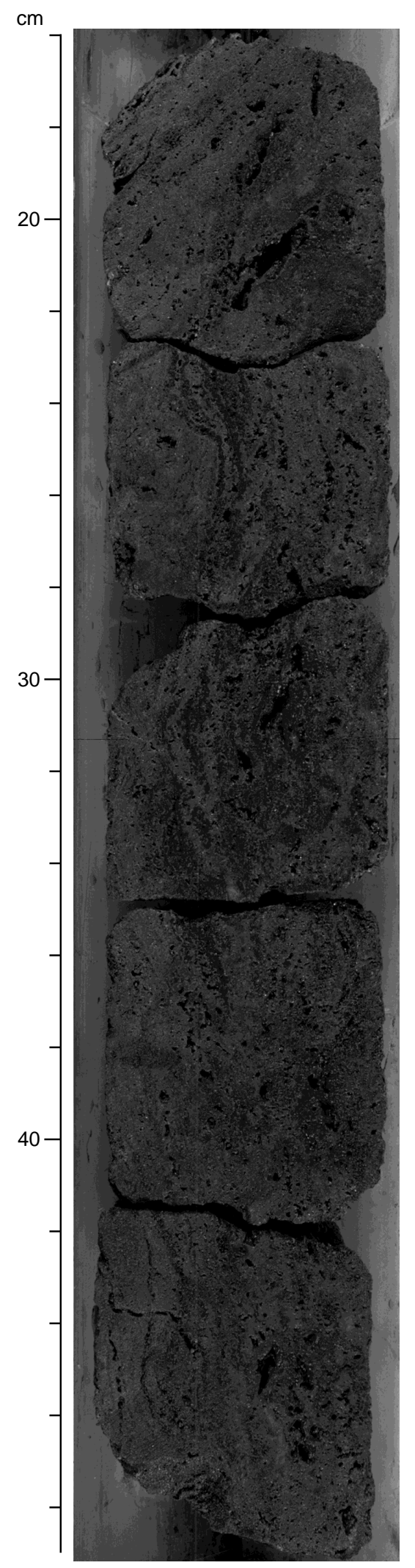

Figure 52. Collomorphic banding of sphalerite in massive vuggy pyrite (interval 169-1035F-4R-1, 18-49.5 cm) 


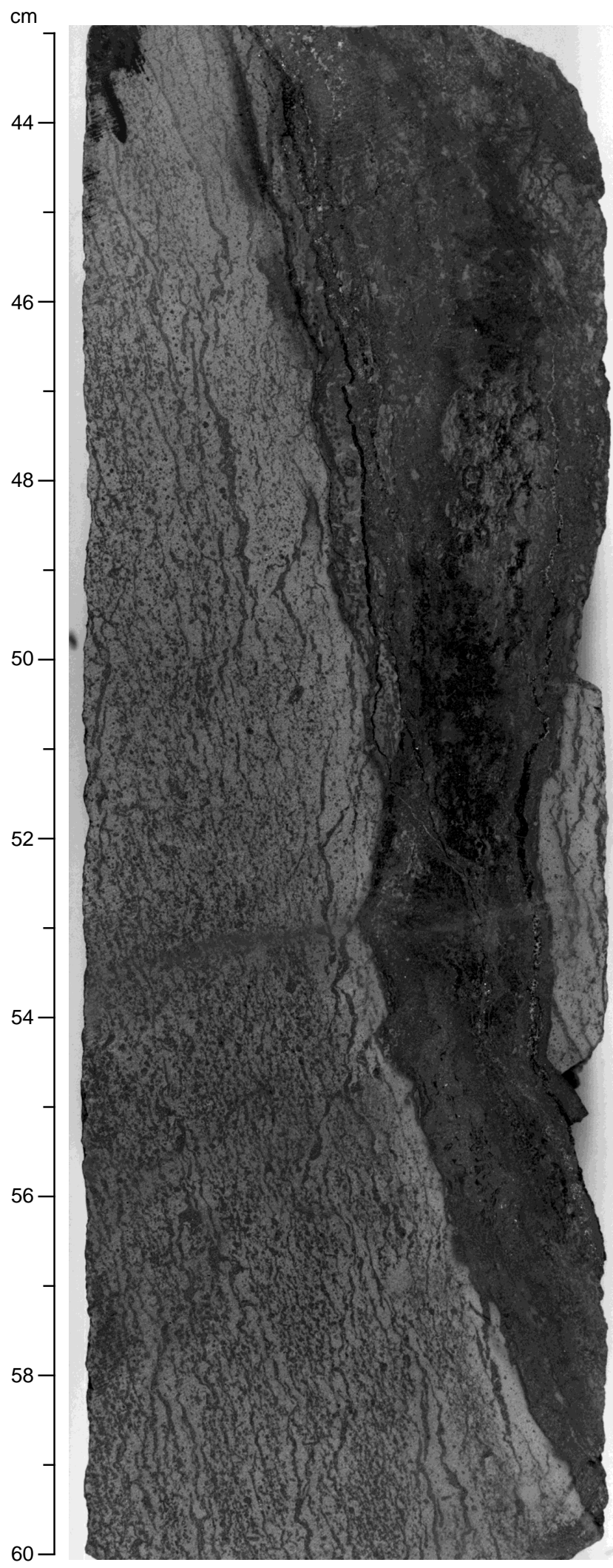

Figure 53. Subunit VIA subvertical, massive medium- to coarse-grained sulfide (pyrrhotite, isocubanite, and chalcopyrite, with variable secondary pyrite and magnetite) veins up to $3 \mathrm{~cm}$ thick (and smaller secondary veins) cutting hydrothermally altered turbiditic siltstone and fine-grained sandstone (interval $169-856 \mathrm{H}-22 \mathrm{R}-2,43-60 \mathrm{~cm})$.

\section{SULFIDE MINERALIZATION: SULFIDE FEEDER ZONE}

\section{Characteristics of the Sulfide Feeder Zone (Unit VI)}

This section provides a summary of the vein geometry, lithology, mineralogy, alteration, and mineral textures of the feeder zone of the Bent Hill and ODP massive sulfide deposits at Middle Valley, as deduced from shipboard core logging, polished thin sections, X-ray diffraction analysis, and logging information. The subunits of the feeder zone (Table 2) are defined on the basis of the abundance of sulfide minerals and vein morphology. Subunit VIA, consisting of sulfideveined sediment (10-50 vol\% sulfide minerals), represents the intensely veined feeder zone that is dominated by crosscutting subvertical veins. Subunit VIB consists of sediment with sulfide veins and/ or impregnations and has similar, but weaker feeder zone mineralization (2-10 vol\% sulfide minerals) and is transitional to disseminated sulfides. Subunit VIC consists of sulfide-banded/impregnated sedimentary rock and is distinct from the other two in that it contains 1050 vol\% sulfide minerals, mostly as subhorizontal sulfide replacements along original bedding.

The SFZ stratigraphically underlies the massive sulfide zones at the Bent Hill and ODP deposits. It consists of veins and impregnations that vary greatly in thickness and orientation, commonly forming "stockworks" or "stringers" and dominated by pyrrhotite and chalcopyrite/isocubanite (Figs. 53-57). The distribution of the feeder zone and its relation to the massive sulfides and other units is represented on schematic sections from west to east (Fig. 15) and from north to south (Fig. 16). All intersections of the Unit VI sulfide feeder zone from the Bent Hill area drilled during Leg 169 are summarized in Table 9.

The SFZ is generally well developed immediately beneath massive sulfides except in the westernmost holes (Holes 1035A and 1035G; Fig. 15). The westernmost feeder zone is only poorly developed in the bottom of Hole 1035A as sparse pyrite, sphalerite, and pyrrhotite disseminations and narrow subvertical veinlets in intensely silicified sedimentary rocks. The feeder zone is well developed in the most easterly hole, Hole 1035D (Figs. 15, 10). Correlations of the

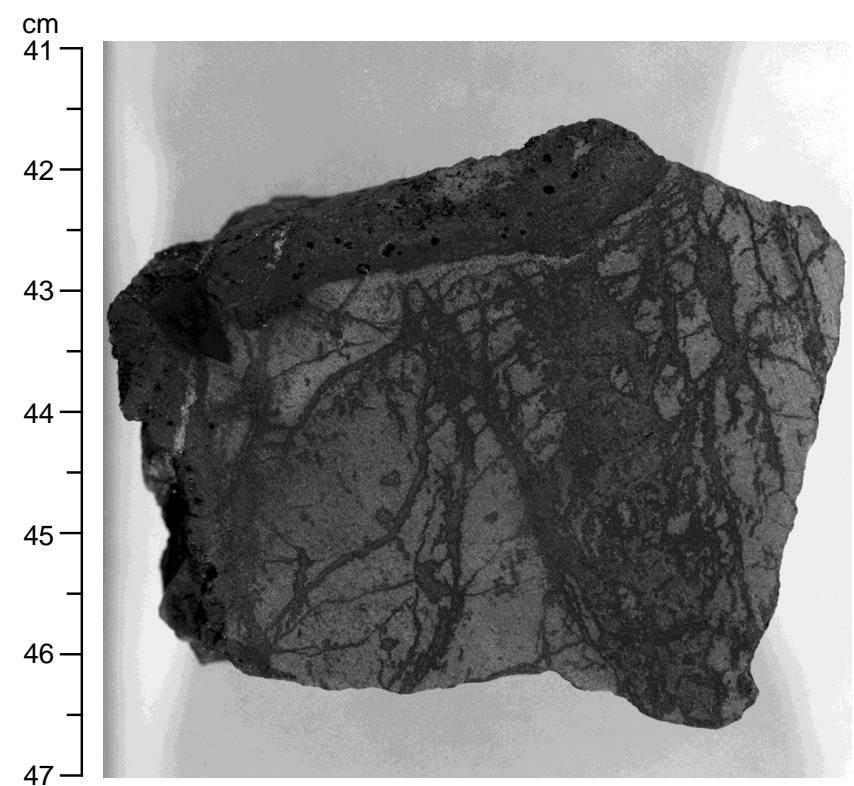

Figure 54. Subunit VIA vertical to subhorizontal, medium- to coarsegrained, massive sulfide veins cutting hydrothermally lithified turbiditic siltstone and sandstone. Sulfides are composed mostly of pyrrhotite, isocubanite, and chalcopyrite that are variably replaced by pyrite and magnetite (interval 169-856H-23R-1, 41-47 cm). 


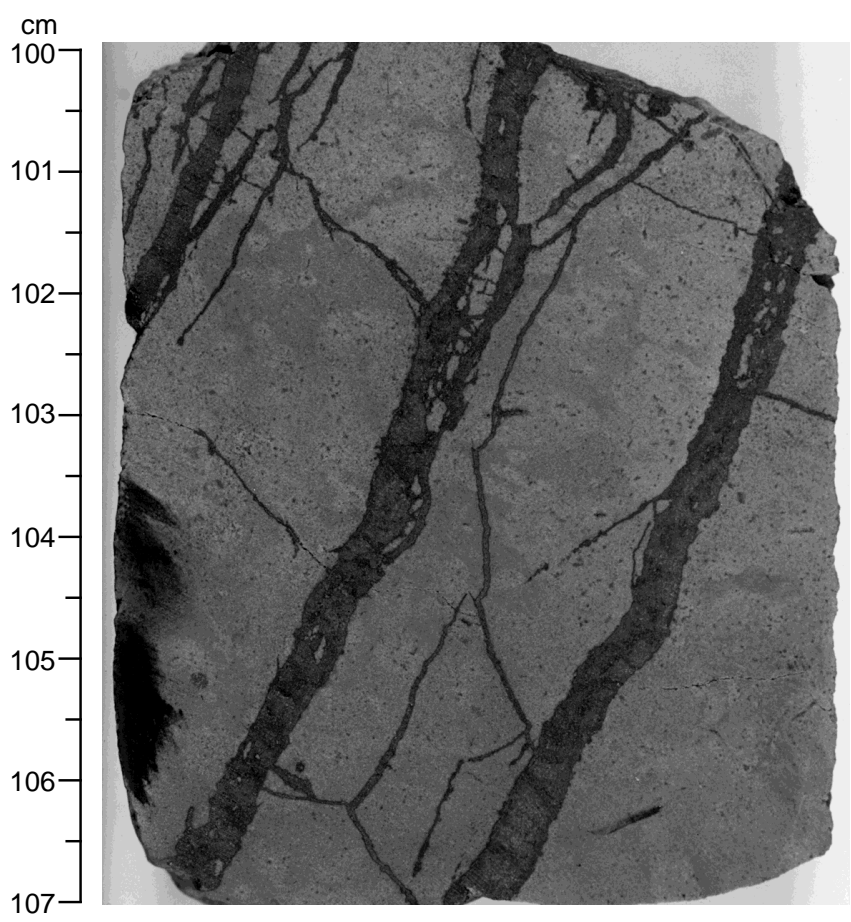

Figure 55. Subunit VIA subvertical, massive pyrrhotite-isocubanitechalcopyrite veins cutting hydrothermally altered sedimentary rocks (interval 169-856H-23R-1, 100-107 cm).

BHMS feeder zone to the south are unclear, because most of the subunits do not correspond directly with the ODP Mound feeder zone subunits to the south. Hole $1035 \mathrm{H}$ is much more complex; it contains three significant intervals of Unit VI feeder zone lithologies (Table 9), each underlying a massive sulfide zone.

At the BHMS deposit, penetrated by Holes $856 \mathrm{H}$ and $1035 \mathrm{~F}$, the base of the feeder zone is marked by silicified and $\mathrm{Cu}-\mathrm{Fe}$ sulfidebanded/impregnated siltstones and sandstones informally known as the DCZ. This zone is similar to the ODP Mound DCZ to the south (Fig. 16) that occurs at the same depth below the seafloor and has a very similar lithology, alteration, and mineralization.

\section{Subunit VIA: Sulfide-Veined Sediment}

\section{Occurrence}

An interval of sulfide-veined siltstone and mudstone (10-50 vol\% sulfides) is best developed in Hole $169-856 \mathrm{H}$, where it immediately underlies the massive sulfides. In Core 169-1035D-10X, pyrite-pyrrhotiteveined mudstone occurs as a narrow interval between overlying colloform, vuggy massive sulfide (Subunit VD), and underlying massive/ semi-massive sulfide (Subunit VB). In Sections 169-1035F-11R-1 through 12R-3, a well-developed anastomosing network of pyrrhotitechalcopyrite veins crosscuts altered mudstone and underlies Subunit VIC (sulfide banded/impregnated sandstone).

\section{Vein Geometry}

Vein abundance, orientation, thickness, and composition vary considerably; although most veins in the intervals of core recovered are vertical or subvertical and anastomosing (Figs. 53-59), whereas others are at low angles to bedding (Fig. 60). Veins range in thickness from $<1 \mathrm{~mm}$ to $8 \mathrm{~cm}$, although most are $\sim 1 \mathrm{~mm}$ wide. Where underlain by Subunit VIB (in Holes 169-856H and 1035F), the intensity of veining in Subunit VIA generally decreases toward the lower contact. Although sulfides in these sections are confined predominantly to

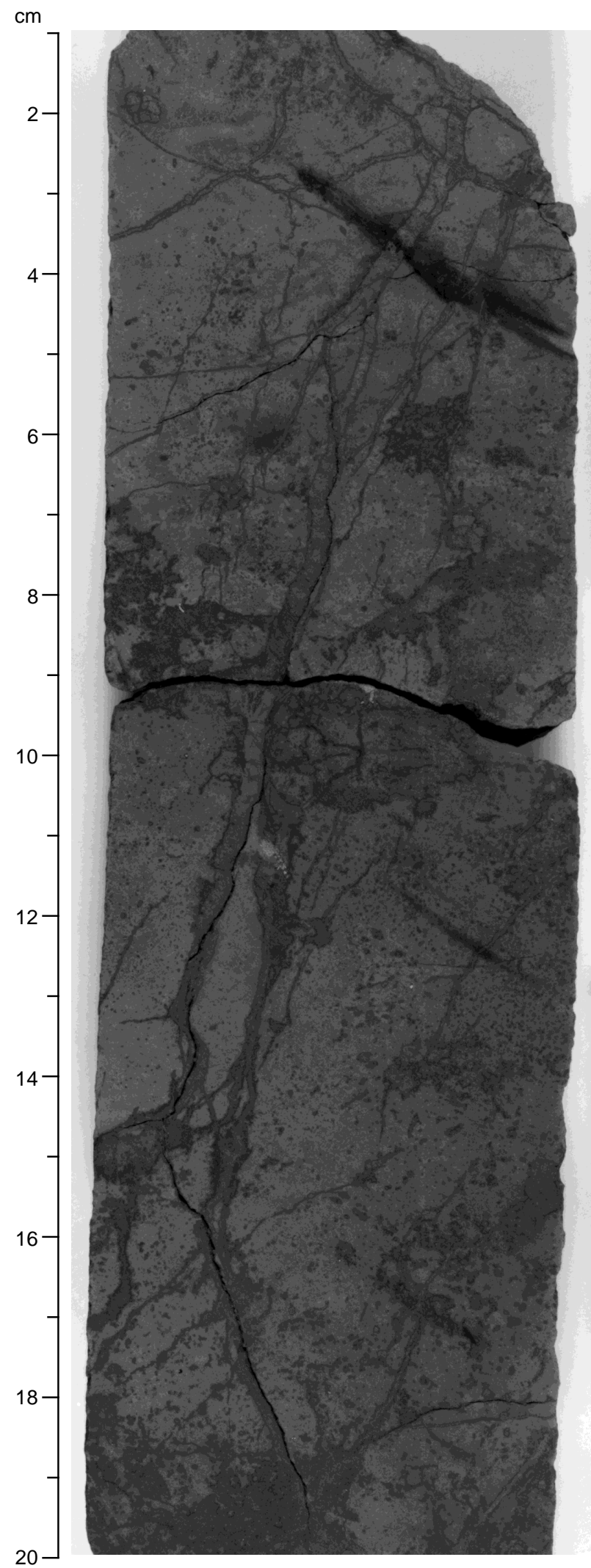

Figure 56. Subunit VIA pyrrhotite-isocubanite-chalcopyrite veins, blebs, and disseminations with variable pyrite in hydrothermally altered siltstone and fine-grained sandstone (interval 169-856H-23R-2, 1-20 cm). 


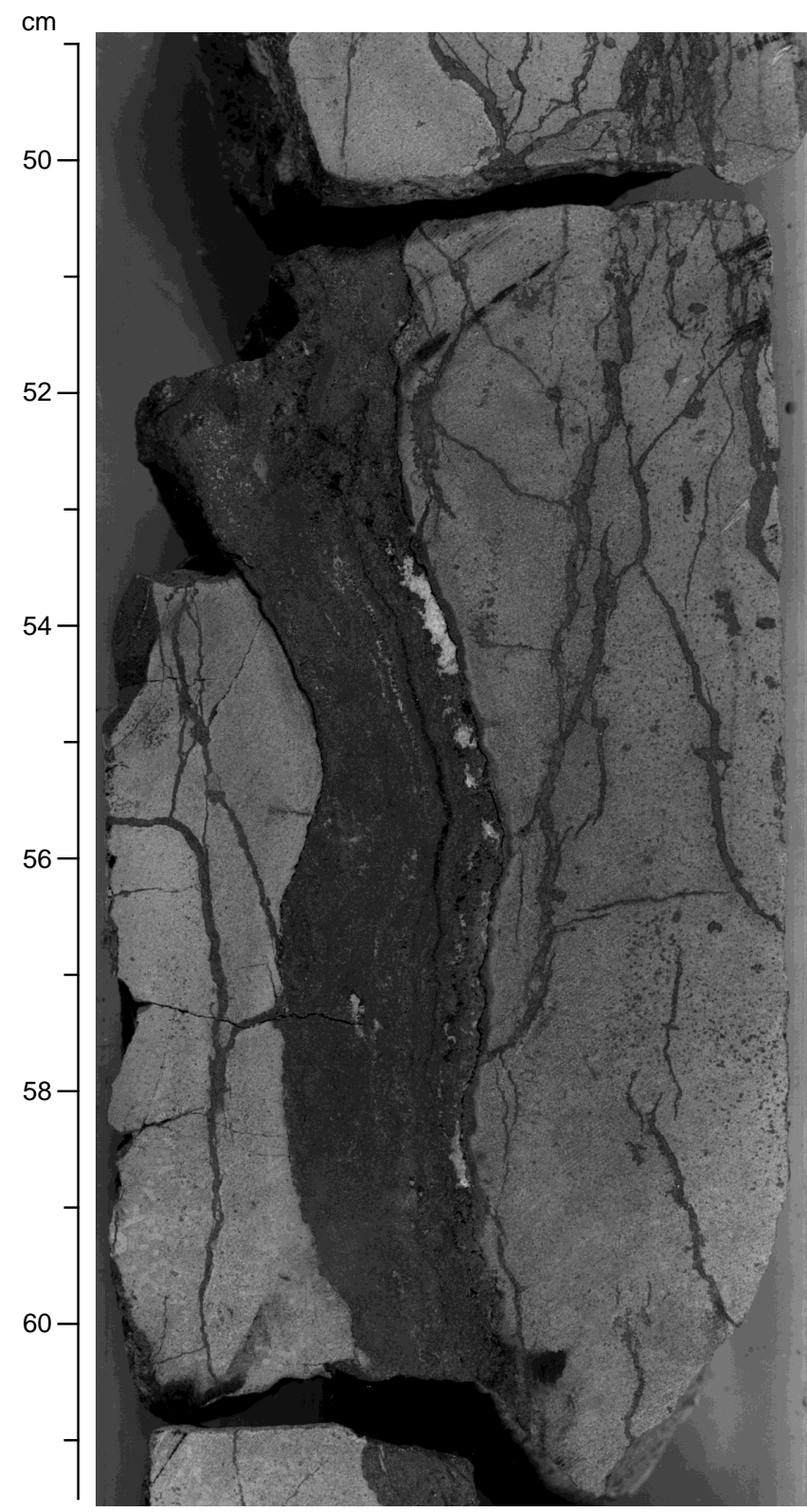

Figure 57. Subunit VIA subvertical single and multiple (ribboned) massive sulfide veins composed of pyrrhotite, isocubanite, chalcopyrite, pyrite, magnetite, and anhydrite cutting hydrothermally altered sedimentary rock (interval $169-856 \mathrm{H}-24 \mathrm{R}-1,49-61.5 \mathrm{~cm})$.

veins, they are also present as fine-grained disseminations and blebs $(0.1-20 \mathrm{~mm})$

\section{Sulfide Mineralogy}

The major sulfides present are isocubanite, chalcopyrite, and pyrrhotite, with minor pyrite and traces of marcasite and galena in a few samples (Table 10). Sphalerite abundance varies widely. Some veins are zoned from a chalcopyrite/isocubanite assemblage in the center to pyrrhotite at the margins (interval 169-856H-20R-1, 32-36 cm; Sections $169-856 \mathrm{H}-23 \mathrm{R}-2$ through 24R-2). Chalcopyrite and isocubanite exhibit crystallographically controlled lamellar intergrowths. The chalcopyrite/isocubanite-pyrrhotite assemblage displays pseudomorphic textures after elongate crystals, possibly earlier-formed pyrrhotite (Fig. 61). In several sections, the chalcopyrite/isocubanite vein assemblage is replaced by pyrrhotite, indicating multiple stages of hydrothermal fluid flow (Fig. 62). Sphalerite sometimes occurs as a minor vein mineral accompanying other $\mathrm{Fe}$ and $\mathrm{Cu}-\mathrm{Fe}$ sulfides ( $\mathrm{Sec}-$ tion 169-1035F-11R-1); it is predominantly black because of high iron content. In places, sphalerite is partly replaced and "diseased" by $\mathrm{Cu}-\mathrm{Fe}$ sulfides (interval 169-1035H-5R-1, 94-96 cm). Sphalerite/ wurtzite is present as separate monominerallic veins, for example, in Section 169-856H-24R-1.

Pyrite, generally present in minor amounts in the feeder zone, commonly occurs as a late-stage mineral (Fig. 63) and as a replacement of pyrrhotite. Other minor sulfide minerals include marcasite, digenite, and bornite.

\section{Nonsulfide Vein Minerals}

Trace to minor magnetite in the veins and host rocks is relatively late and generally associated with pyrite. Hematite, where present, commonly occurs along fractures (Fig. 63) and at grain boundaries in the isocubanite/chalcopyrite assemblage and also replaces magnetite and chalcopyrite. Non-opaque vein minerals include chlorite, quartz, anhydrite, titanite, and rutile. Chlorite occurs in some of the veins as fibrous intergrowths with sulfides (interval 169-1035H-5R-1, 94-96 $\mathrm{cm})$. Quartz selvages occur in the veins as euhedral, mostly singly terminated crystals growing on vein walls and oriented inward in a cockade structure (Fig. 64), indicating open fractures that were hydrothermal conduits. Anhydrite occurs mainly as a late mineral and fills open spaces in some sulfide veins (Fig. 57). Rare rutile and sphene occur as acicular and anhedral crystals, respectively, intergrown with sulfides in the veins (Sections 169-856H-20R-1, 22R-2, and 23R-1).

In many places, late anhydrite veins crosscut the sulfide veins and altered sedimentary rocks (Sections 169-1035F-11R-2 and 12R-1). Because high-temperature hydrothermal fluid contains no sulfate, the presence of anhydrite in late veins, which crosscut the sulfide veins, indicates that sulfate-bearing seawater was either drawn into the subsurface and mixed with the hydrothermal fluid or conductively heated.

\section{Alteration}

Most of the sulfide veins in this subunit have medium to dark green chlorite alteration envelopes (Fig. 58). Vein alteration envelopes vary in thickness and decrease in intensity away from the massive sulfide contact and away from the sulfide vein margin. Narrow $(\sim 1 \mathrm{~mm})$ chlorite alteration envelopes predominate; optical properties suggest it is Fe rich (Section 169-856H-21R-1). In a few places, vein selvages are bleached and composed of fine-grained quartz (Section 169-1035D-10X-1). Most veins have sharp contacts, although several contain $\sim 1$-cm-wide alteration envelopes with disseminated sulfides (Section 169-856H-21R-2). Many of the veins are ribboned (Section 169-856H-22R-1; Fig. 57), and many also display crack-seal textures and hydraulic brecciation (Section 169-1035H17R-1) indicative of episodic fluid overpressuring (see "Structural Geology" section, this chapter).

\section{Subunit VIB: Sediment with Sulfide Veins and/or Impregnations}

\section{Occurrence}

This subunit generally occurs immediately below Subunit VIA and represents weakly developed feeder zone mineralization. It is well represented in Holes $856 \mathrm{H}, 1035 \mathrm{D}, 1035 \mathrm{~F}, 1035 \mathrm{G}$, and $1035 \mathrm{H}$ (Table 9). In Hole 1035G, Subunit VIB occurs directly below sulfidebanded/impregnated sediment, Subunit VIC. In Hole 1035A, Subunit VIB occurs as a thin unit of highly silicified sediments at the bottom of the recovered core.

\section{Vein Geometry}

Sulfides occur as subvertical to subhorizontal thin veins and disseminations, blebs, and impregnations (Fig. 65). In some places, sulfide veins predominate (Sections 169-1035F-13R-2 through 13R- 
Table 9. Summary of Sulfide Feeder Zone (Unit VI) occurrences, Bent Hill and ODP Mound massive sulfide deposits, Middle Valley.

\begin{tabular}{|c|c|c|c|c|c|c|c|}
\hline Description & Subunit & Hole $856 \mathrm{H}$ & Hole $1035 \mathrm{~A}$ & Hole $1035 \mathrm{D}$ & Hole $1035 \mathrm{~F}$ & Hole $1035 \mathrm{G}$ & Hole $1035 \mathrm{H}$ \\
\hline $\begin{array}{l}\text { Sulfide-veined sediment }(10 \%-50 \% \\
\text { by volume sulfide minerals) }\end{array}$ & VIA & $\begin{array}{l}20 \mathrm{R}-1,0 \mathrm{~cm}, \text { to } \\
25 \mathrm{R}-1,100 \mathrm{~cm} \\
(103.6-144.3 \\
\text { mbsf })\end{array}$ & & $\begin{array}{l}10 \mathrm{X}-1,0-21 \mathrm{~cm} \\
\quad(66.5-66.7 \mathrm{mbsf})\end{array}$ & $\begin{array}{l}11 \mathrm{R}-1,0 \mathrm{~cm}, \text { to } \\
12 \mathrm{R}-3,37 \mathrm{~cm} \\
(109.3-112.67 \\
\text { mbsf })\end{array}$ & & $\begin{array}{l}\text { 14R-1, } 0-39 \mathrm{~cm} \\
(123.0-123.4 \\
\text { mbsf })\end{array}$ \\
\hline $\begin{array}{l}\text { Sediment with sulfide veins and/or } \\
\text { impregnations }(2 \%-10 \% \text { by } \\
\text { volume sulfide minerals })\end{array}$ & VIB & $\begin{array}{l}26 \mathrm{R}-1,0 \mathrm{~cm}, \text { to } \\
30 \mathrm{R}-1,91 \mathrm{~cm} \\
(152.9-192.31 \\
\text { mbsf })\end{array}$ & $\begin{array}{l}19 X-2,74-127 \mathrm{~cm} \\
(168.9-169.5 \\
\text { mbsf })\end{array}$ & $\begin{array}{l}15 \mathrm{X}-1,0 \mathrm{~cm}, \text { to } \\
18 \mathrm{X}-\mathrm{CC}, 20 \mathrm{~cm} \\
(106.2-135.0 \\
\text { mbsf) } \\
23 \mathrm{X}-1,0 \mathrm{~cm}, \text { to } \\
24 \mathrm{X}-\mathrm{CC}, 39 \mathrm{~cm} \\
(168.5-178.5 \\
\text { mbsf })\end{array}$ & $\begin{array}{l}13 \mathrm{R}-1,0 \mathrm{~cm}, \text { to } \\
17 \mathrm{R}-1,94 \mathrm{~cm} \\
(119.0-158.44 \\
\text { mbsf })\end{array}$ & $\begin{array}{l}10 \mathrm{R}-1,33 \mathrm{~cm} \text {, to } \\
13 \mathrm{R}-1,67 \mathrm{~cm} \\
(170.9-199.6 \\
\text { mbsf })\end{array}$ & $\begin{array}{l}4 \mathrm{R}-1,18 \mathrm{~cm} \text {, to } \\
6 \mathrm{R}-2,38 \mathrm{~cm} \\
(26.6-47.44 \\
\text { mbsf) } \\
\text { 9R-1, 50 cm, to } \\
11 \mathrm{R}-1,103 \mathrm{~cm} \\
(75.1-94.03 \\
\text { mbsf) } \\
13 \mathrm{R}-1,0-51 \mathrm{~cm} \\
(113.4-113.9 \\
\text { mbsf) } \\
20 \mathrm{R}-1,0 \mathrm{~cm}, \text { to } \\
21 \mathrm{R}-1,26 \mathrm{~cm} \\
(171.1-181.0 \\
\text { mbsf) } \\
22 \mathrm{R}-1,0 \mathrm{~cm}, \text { to } \\
24 \mathrm{R}-2,19 \mathrm{~cm} \\
(190.3-211.2 \\
\text { mbsf) }\end{array}$ \\
\hline \multirow[t]{2}{*}{$\begin{array}{l}\text { Sulfide banded/ impregnated } \\
\text { sediment }(10 \%-50 \% \text { by volume } \\
\text { sulfide minerals })\end{array}$} & VIC & $\begin{array}{l}31 \mathrm{R}-1,0 \mathrm{~cm}, \text { to } \\
31 \mathrm{R}-2,80 \mathrm{~cm} \\
(201.0-203.3 \\
\text { mbsf })\end{array}$ & & & $\begin{array}{l}10 \mathrm{R}-1,0 \mathrm{~cm} \text {, to } \\
10 \mathrm{R}-\mathrm{CC}, 20 \mathrm{~cm} \\
(89.9-90.5 \mathrm{mbsf})\end{array}$ & $\begin{array}{l}10 \mathrm{R}-1,8-33 \mathrm{~cm} \\
\quad(170.6-170.85 \\
\text { mbsf })\end{array}$ & $\begin{array}{l}\text { 19R-1, 49-108 cm } \\
\quad(161.99-162.48 \\
\text { mbsf) }\end{array}$ \\
\hline & & & & & $\begin{array}{l}18 \mathrm{R}-1,0-53 \mathrm{~cm} \\
(167.1-167.6 \\
\text { mbsf })\end{array}$ & & $\begin{array}{l}\text { 21R-1, 26-126 cm } \\
\quad(181.0-182.0 \\
\text { mbsf })\end{array}$ \\
\hline
\end{tabular}

$\mathrm{CC})$, and in others, disseminations and blebs are more common than veins (Sections 169-856H-27R-2 and 28R-2, 169-1035D-16X-CC, and $169-1035 \mathrm{H}-6 \mathrm{R}-1$ through $6 \mathrm{R}-2)$. Sulfide blebs may be interconnected by narrow veinlets (Section 169-1035F-16R-1). Where subhorizontal veins are abundant, they may be evenly spaced and discontinuous, giving the rock a "tiger striped" appearance (Section 1691035F-13R-1; Fig. 65). Some veins have textures characteristic of hydraulic brecciation (Section 169-1035F-14R-1).

\section{Sulfide Mineralogy}

The sulfides are predominantly pyrrhotite, chalcopyrite/isocubanite, and pyrite with minor sphalerite (Table 10). Some intervals are $\mathrm{Cu}$ and $\mathrm{Zn}$ poor and consist mainly of pyrrhotite (Sections $169-856 \mathrm{H}-$ 26R-1 through 29R-1); others are Cu rich and dominated by chalcopyrite and/or isocubanite (Sections 169-856H-30R-1, 169-1035F13R-1 through 13R-CC, and 169-1035H-20R-1 through 24R-1), and others are $\mathrm{Zn}$ rich (Section 169-1035H-4R-1). In zones with weakly developed sulfide impregnation, mineralization consists mainly of pyrrhotite. Disseminations of pyrite cubes with pyrrhotite occur with disseminated anhydrite in Section 169-1035D-24X-CC. Fine-grained pyrrhotite and chalcopyrite pseudomorph of cubic pyrite occur in Sections 169-1035F-16R-1 through 17R-1. In Hole 1035H, beneath the pyrrhotite-sphalerite-rich massive sulfides, the veins and impregnations also consist of mainly sphalerite and pyrrhotite, reflecting the composition of the overlying massive sulfides. This grades downward into weak impregnations of mainly pyrrhotite.

\section{Nonsulfide Vein Minerals and Alteration}

Magnetite is locally abundant as disseminations and overgrowths on sulfides. Hematite fills late fractures and selectively replaces magnetite. Anhydrite is present in this subunit as late, 1- to 2-mm-wide veins that crosscut the sulfide veins and altered sedimentary rocks (Sections 169-1035F-13R-1, 13R-CC, and 15R-1; 169-1035H-4R1).

Most veins have deep green chlorite alteration envelopes or dark gray quartz alteration envelopes (Sections 169-1035F-13R-1 and 22R-1); however, in some areas, such envelopes are conspicuously absent (Sections 169-1035F-13R-2 and 17R-1). Chloritization is generally confined to narrow (1-3 mm wide) envelopes immediately adjacent to vein margins. Epidote is a less common mineral and occurs as clusters of intergrown anhedral crystals (Section 169-1035D-24X$\mathrm{CC})$ in a highly fractured, silicified silty claystone.

\section{Subunit VIC: Sulfide Banded/Impregnated Sandstone}

The sulfide banded/impregnated sandstone occurs in Hole $856 \mathrm{H}$ (Core 169-856H-31R) in Hole $1035 \mathrm{~F}$ at two different levels (Cores 169-1035F-10R and 18R), in Hole 1035G (Core 169-1035G-10R), and in Hole 1035H (Cores 169-1035H-19R and 21R). The upper banded sulfide horizon in Core 169-1035F-10R and the thin subunit in Core 169-1035G-10R are both pyrite-pyrrhotite-sphalerite rich. All other occurrences of Subunit VIC are $\mathrm{Cu}-\mathrm{Fe}$ sulfide rich.

Sulfide minerals occur as replacements of primary sedimentary features in laminar- or cross-bedded sandstones (Fig. 66) or burrowed siltstones (Fig. 67). In general, the subunit has a predominantly horizontal sulfide fabric that mimics primary sedimentary structures. Sulfide minerals include isocubanite with chalcopyrite, pyrrhotite, pyrite, and sphalerite. Both $\mathrm{Cu}$-rich and $\mathrm{Fe}$-rich variants have been recognized. Late anhydrite veins crosscut sulfides in several sections of this subunit (Sections 169-1035F-10R-1 through 10RCC; Fig. 68). Sediments adjacent to sulfide can be altered to clay/ smectite as in Core 169-856H-31R, silicified as in Section 1691035F-18R-1, chloritized as in Core 169-1035F-10R (Fig. 69), or altered to clinoamphibole as in Hole $1035 \mathrm{H}$.

\section{Deep Copper Zone}

\section{Occurrence}

In several intersections, especially in drill holes along the northsouth trend between the BHMS and ODP Mound, Subunit VIC is distinctly $\mathrm{Cu}$ rich and is referred to informally as the Deep Copper Zone or DCZ. The DCZ is well developed in Hole $856 \mathrm{H}$ at the base of the feeder zone (Sections 169-856H-31R-1 and 31R-2; Fig. 66) and in Hole 1035F (Section 169-1035F-18R-1). In Hole 1035H, $350 \mathrm{~m}$ to 
$\mathrm{cm}$

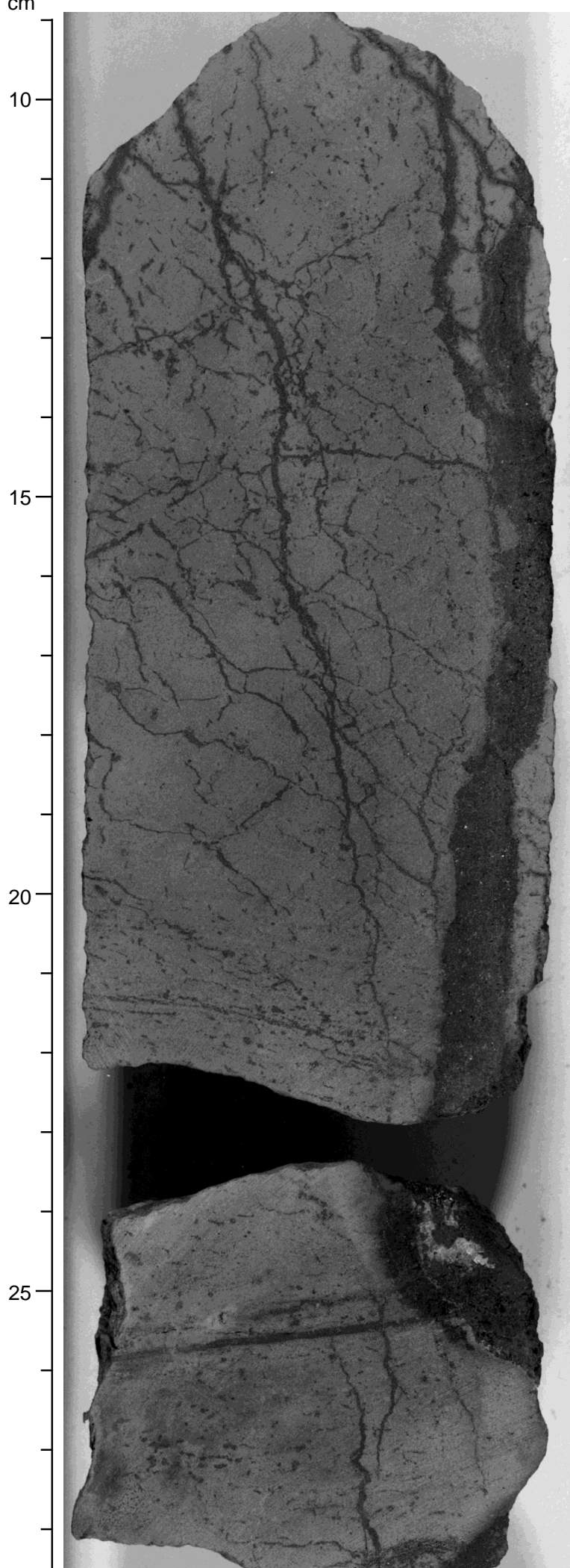

Figure 58. Subunit VIA sulfide (pyrrhotite and chalcopyrite) stockwork veins in mudstone and siltstone (interval 169-1035F-11R-2, 9-28.5 cm).

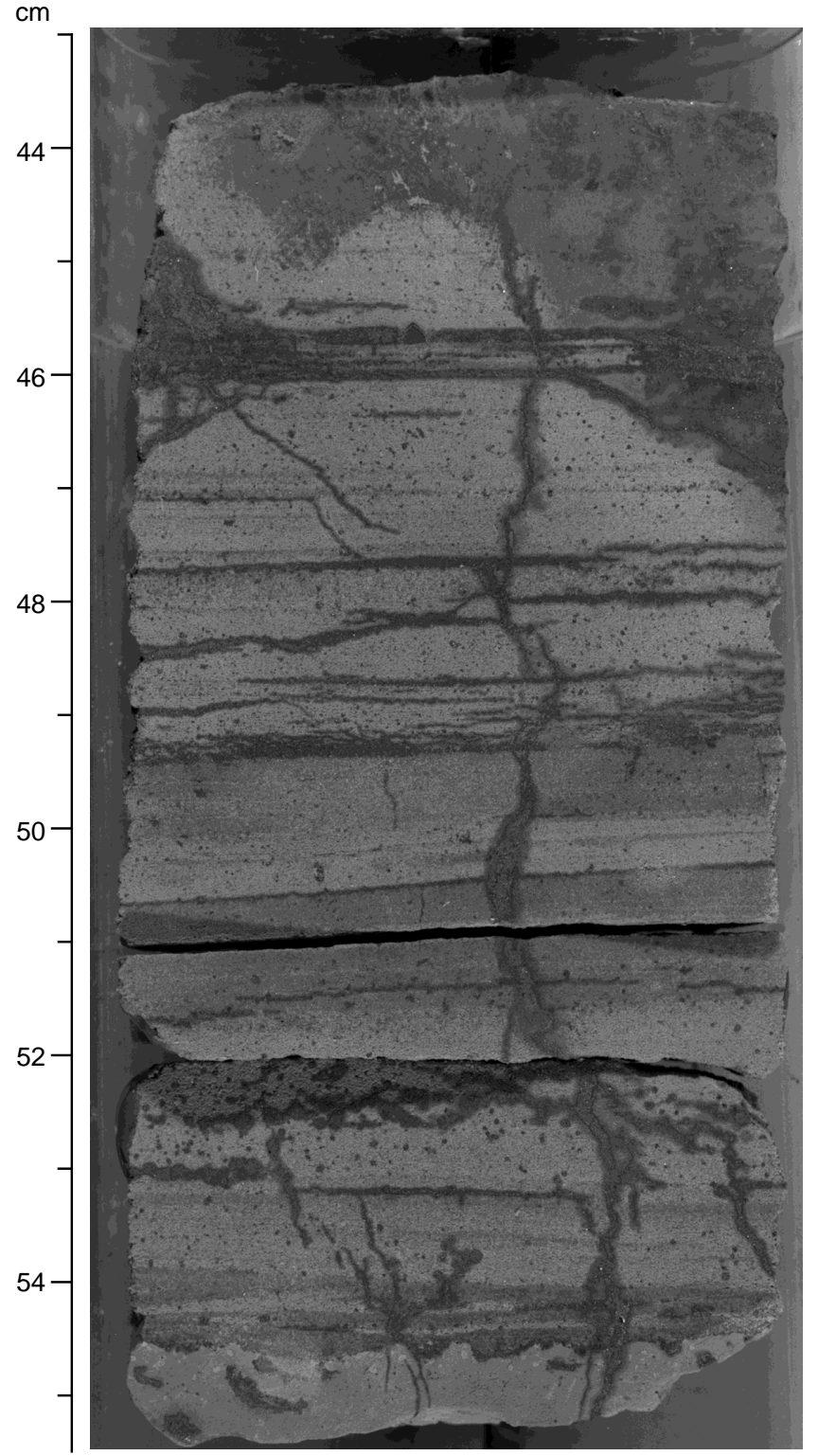

Figure 59. Subunit VIA pyrrhotite and sphalerite as bedding parallel veins and replacements, subvertical veins and disseminations and blebs in graded turbiditic sandstone (interval 169-1035F-12R-2, 43-55.5 cm).

the south beneath the ODP Mound, Subunit VIC, sulfide-banded sandstone, is extremely $\mathrm{Cu}$ rich, where it occurs in intervals 169$1035 \mathrm{H}-19 \mathrm{R}-1,49-108 \mathrm{~cm}$, and $21 \mathrm{R}-1,26-126 \mathrm{~cm}$. In addition, the interval from Sections 169-1035H-19R-1 through 21R-1 is $\mathrm{Cu}$ rich (30\%-70\%, average $60 \% \mathrm{Cu}-\mathrm{Fe}$ sulfide), and the $\mathrm{Cu}-\mathrm{Fe}$ sulfide occurs as abundant subhorizontal veins or laminae (replacements of parallel and cross-bedded strata as well as burrows) and impregnations in siltstone and silty claystone. Even weakly sulfide impregnated sedimentary rocks of Subunit VIB (Sections 169-1035H-20R-1 through 21R-1 and 22R-1 through 24R-2) are $\mathrm{Cu}$ rich in this area and are therefore included in the DCZ.

\section{Sulfide Mineralogy}

The DCZ designation is used here for $\mathrm{Cu}$-rich material displaying considerable textural heterogeneities over short intervals and highly variable sulfide contents. The diagnostic features of the DCZ, however, are its occurrence at or near the base of the feeder zone system, 


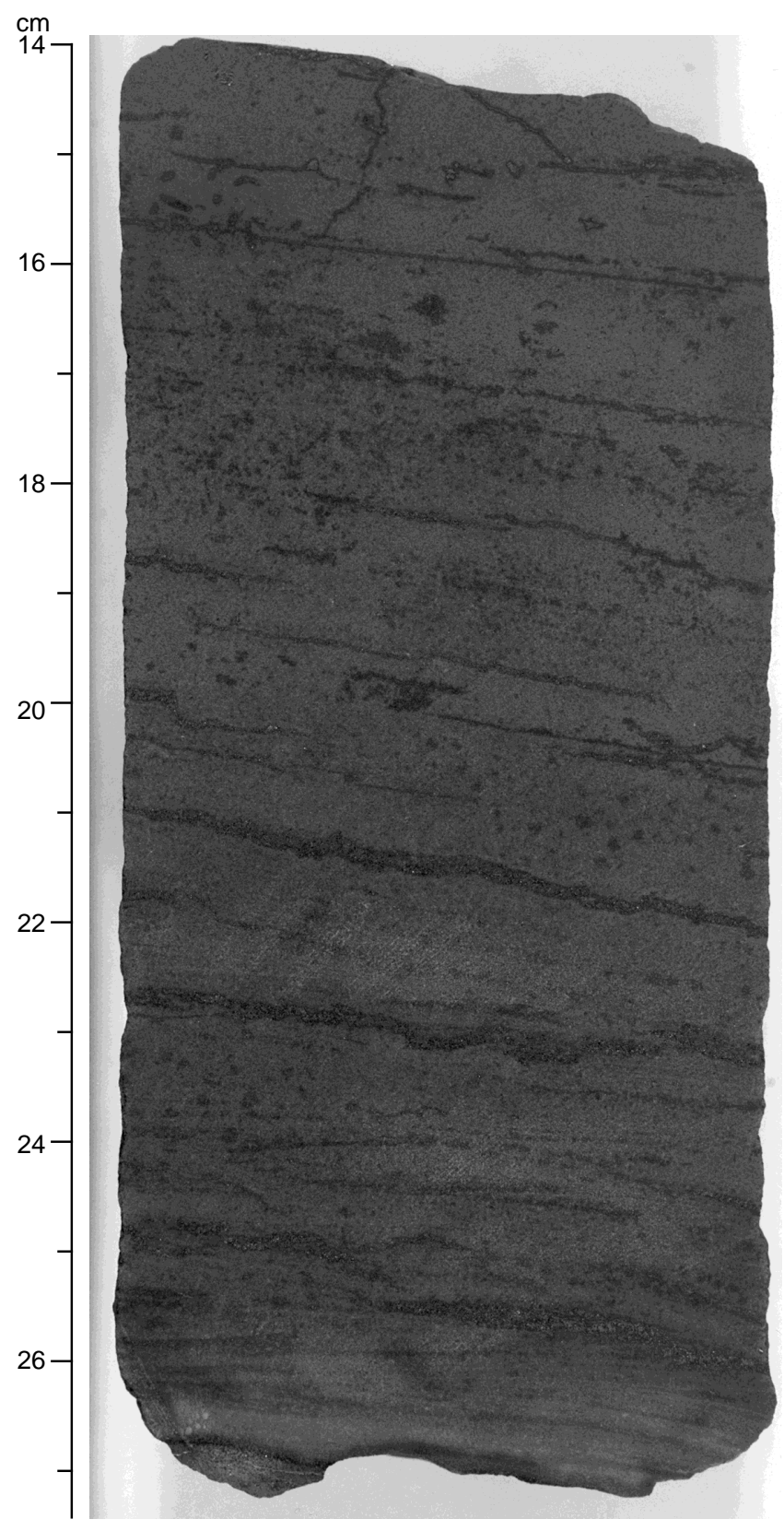

Figure 60. Subunit VIA sulfide (darker) within predominantly bedding parallel veins that the locally crosscut sediment layering (interval 169-1035F$11 \mathrm{R}-1,14-27.5 \mathrm{~cm})$.

the predominance of $\mathrm{Cu}-\mathrm{Fe}$ sulfides, and the relative absence of any other sulfide minerals. The yellow color of the $\mathrm{Cu}$-Fe sulfide mineral, which is either isocubanite or an unknown mineral from the ISS compositional field, is intermediate between that of chalcopyrite and pyrite (Fig. 70). The mineral oxidizes rapidly on cut core surfaces, leading to possible misidentification as either pyrite or pyrrhotite in hand specimens.

\section{Nonsulfide Vein Minerals and Alteration}

In the DCZ from Hole $169-856 \mathrm{H}$, most of the detrital quartz grains have been replaced with fibrous and commonly radiating white chlorite imparting a spotted appearance to the core (Fig. 71).
Sulfides can infiltrate along the radial fabric of these chlorite spots. Other non-opaque minerals include epidote, barite, apatite, sphene, brookite, anatase, muscovite, rutile, and calcite (Table 10). Rutile occurs as anhedral aggregates and euhedral needles within euhedral quartz. Muscovite forms fibrous aggregates that overgrow chlorite. In Hole $1035 \mathrm{H}$, the altered matrix is comprised of euhedral (some doubly terminated) quartz crystals and fibrous needle-shaped clinoamphibole (optical properties suggest cummingtonite) as felted aggregates and minor iron-rich chlorite.

\section{Discussion}

The DCZ, as defined by the presence of $\mathrm{Cu}-\mathrm{Fe}$ sulfide as the predominant sulfide, was only encountered in Holes $856 \mathrm{H}, 1035 \mathrm{~F}$, and $1035 \mathrm{H}$, even though drilling at Holes $1035 \mathrm{G}$ and $1035 \mathrm{D}$ penetrated through the appropriate stratigraphic levels (Fig. 6). This suggests that the DCZ forms a narrow, elongate north-south trend from the area immediately underlying the BHMS toward the area immediately underlying the ODP Mound $350 \mathrm{~m}$ to the south. However, in Holes 1035A, 1035G, and 1035D, at depths below $170 \mathrm{mbsf}$, there are zones of intense silicification with pyrrhotite and lesser pyrite (Fig. 15). These intervals are at the correlative depths to the DCZ, but they do not contain the characteristic intense copper mineralization. They may represent a distal imprint of the hydrothermal event that formed the DCZ. Further evidence supporting this interpretation comes from the interstitial water studies (see "Inorganic Geochemistry" section, this chapter) that show a dramatic decrease in $\mathrm{Cl}$ and other species, indicating hydrothermal fluid below the silicified zone in Hole 1035A.

Geological and geochemical constraints suggest that hydrothermal fluids ascended along a fault zone in the narrow north-south trend defined by the DCZ, until encountering a permeable sandstone horizon at $\sim 200$ mbsf. Near the central zone, the fluids pervasively chloritized the rock and deposited $\mathrm{Cu}-\mathrm{Fe}$ sulfide minerals. As hydrothermal fluids migrated laterally away from the central zone to the west and east in the permeable sandstone, conductive cooling resulted in intense silicification and the deposition of sulfides dominated by pyrrhotite and pyrite.

\section{SULFIDE MINERALIZATION: HYDROTHERMAL ALTERATION OF SEDIMENTS AND SEDIMENTARY ROCKS}

The distribution of hydrothermal alteration recognized in sediments and sedimentary rocks from the BHMS and ODP Mound sulfide deposits is based primarily on visual descriptions of core and supplemented by petrography, XRD, and X-ray fluorescence (XRF) of selected phases and bulk samples. Hydrothermal alteration can be subtle, and there are gradations between diagenesis, incipient hydrothermal alteration, and pervasive alteration. This is especially true for fine-grained alteration phases including clay, chlorite, and silica. Description of alteration is necessarily subjective, and some variations in alteration mapped may relate to unavoidable differences in descriptions by different core describers. This may contribute to the discontinuous nature of the observed alteration patterns (Table 11), but other factors, including the anisotropic nature of the protolith, are also important. The alteration zones are delineated by the visual detection of the following key minerals: (1) blue-green clay (smectite), (2) carbonate, (3) anhydrite, (4) chlorite, (5) epidote, and (6) silica or quartz. Each of these alteration zones contain other hydrothermal minerals such as sulfides, although the associated minerals are commonly less characteristic of a specific alteration facies. Furthermore, alteration zones may spatially overlap each other (i.e., they may overprint pre-existing alteration styles).

Hydrothermal alteration is not necessarily confined to stratigraphic units, but hydrothermal alteration facies can commonly be corre- 
Table 10. Summary of sulfide and gangue mineralogy and texture in the Sulfide Feeder Zone (Unit VI), Bent Hill area, Middle Valley.

\begin{tabular}{|c|c|c|c|c|}
\hline Description & $\begin{array}{l}\text { Lithologic } \\
\text { subunit }\end{array}$ & Sulfide mineralogy* & Alteration and gangue minerals* & Textures and structures \\
\hline \multirow[t]{3}{*}{$\begin{array}{l}\text { Sulfide-veined sediment } \\
\quad(10 \%-50 \% \text { sulfides })\end{array}$} & \multirow[t]{3}{*}{ VIA } & $\begin{array}{l}\text { Major: pyrrhotite, chalcopyrite (pyrite), } \\
\text { isocubanite (sphalerite) }\end{array}$ & $\begin{array}{l}\text { Major: clay/smectite, chlorite, quartz, } \\
\text { (epidote) (anhydrite) }\end{array}$ & $\begin{array}{l}\text { Quartz: fine-grained matrix and lining open } \\
\text { spaces/veins (comb texture) and vugs }\end{array}$ \\
\hline & & $\begin{array}{l}\text { Minor: sphalerite (pyrite) (chalcopyrite) } \\
\text { (isocubanite) }\end{array}$ & $\begin{array}{l}\text { Minor: magnetite, hematite, anhydrite, } \\
\text { (chlorite) (epidote) }\end{array}$ & Chlorite: fine-grained matrix and vein selvages \\
\hline & & Trace: marcasite (isocubanite) (galena) & $\begin{array}{l}\text { Trace: rutile, titanite, sphene, (calcite) (K- } \\
\quad \text { feldspar) (anhydrite) (magnetite) }\end{array}$ & $\begin{array}{l}\text { Clay/smectite: fine-grained matrix (sediment } \\
\text { replacement), interstitial to quartz, interstitial } \\
\text { to sulfides, colloform layer }\end{array}$ \\
\hline \multirow{4}{*}{$\begin{array}{l}\text { Sediment with sulfide veins } \\
\text { and/or impregnations ( } 2 \%- \\
10 \% \text { sulfides) }\end{array}$} & \multirow[t]{4}{*}{ VIB } & Major: pyrrhotite, chalcopyrite, pyrite & $\begin{array}{l}\text { Major: clay/smectite, Fe-chlorite, quartz } \\
\text { (epidote) }\end{array}$ & $\begin{array}{l}\text { Quartz: fine-grained matrix, interstitial to clay/ } \\
\text { smectite (and epidote) and open space }\end{array}$ \\
\hline & & $\begin{array}{l}\text { Minor: isocubanite, sphalerite, } \\
\text { (pyrrhotite) }\end{array}$ & Minor: (anhydrite) magnetite, hematite & Chlorite: fine-grained matrix and vein selvages \\
\hline & & Trace: (pyrrhotite) (pyrite) (chalcopyrite) & $\begin{array}{l}\text { Trace: rutile, sphene, calcite, K-feldspar } \\
\text { (epidote) (hematite) }\end{array}$ & Clay/smectite: fine-grained matrix \\
\hline & & & & $\begin{array}{l}\text { Epidote: fine-grained matrix } \\
\text { Magnetite: disseminations and epitaxial } \\
\text { overgrowths }\end{array}$ \\
\hline \multirow[t]{3}{*}{$\begin{array}{l}\text { Sulfide-banded/impregnated } \\
\text { sediment }(10 \%-50 \% \\
\text { sulfides })\end{array}$} & \multirow[t]{3}{*}{ VIC } & Major: isocubanite, chalcopyrite (pyrite) & Major: chlorite (quartz) & $\begin{array}{l}\text { Chalcopyrite and isocubanite: bedding-parallel } \\
\text { veinlets/impregnations, alteration completely } \\
\text { replaced original mineralogy: chalcopyrite } \\
\text { exsolution lamellae and rims in isocubanite. }\end{array}$ \\
\hline & & \multirow[t]{2}{*}{ Minor: pyrite, sphalerite } & Minor: (quartz) barite & Pyrite: neoblastic replacement of pyrrhotite \\
\hline & & & $\begin{array}{l}\text { Trace: epidote, apatite, sphene, brookite, } \\
\text { anatase, muscovite (calcite) }\end{array}$ & Chlorite: fibrous, radiating \\
\hline
\end{tabular}

Notes: $*$ relative to entire rock sample or polished thin section. Minerals placed in parentheses are present in a few samples, but are uncommon.

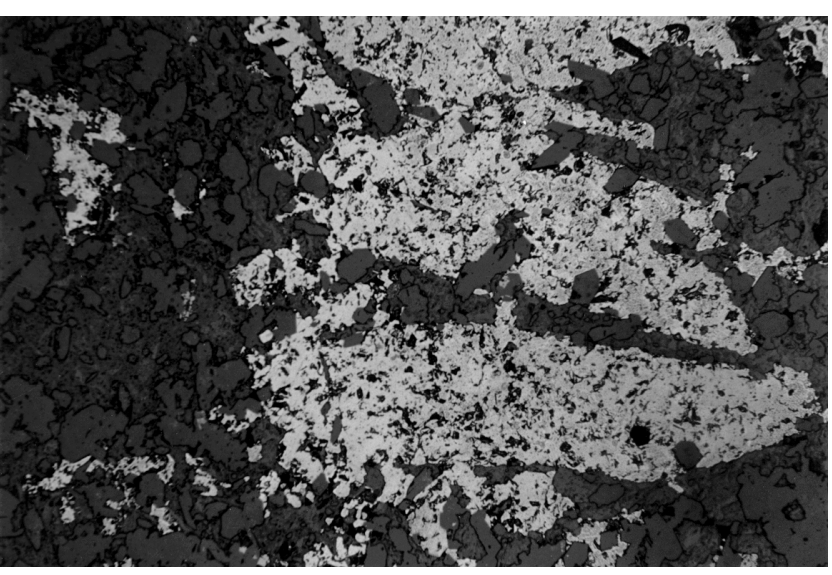

Figure 61. Subunit VIA sulfide-veined siltstone with pyrrhotite (medium gray), chalcopyrite and minor isocubanite (both light gray) pseudomorphs after earlier euhedral crystals, probably early formed pyrrhotite. Width of field $=\sim 1.0 \mathrm{~mm}$ (reflected light photomicrograph; Sample 169-856H-20R-1, $32-36 \mathrm{~cm})$

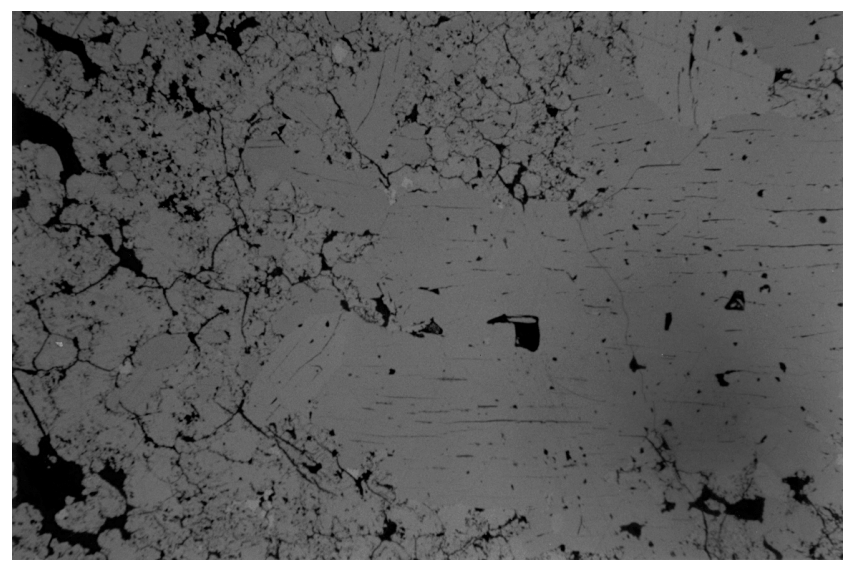

Figure 62. Subunit VIA sulfide-veined siltstone with large grains of subhedral pyrrhotite that overgrow chalcopyrite and isocubanite. Width of field $=$ $\sim 0.5 \mathrm{~mm}$ (reflected light photomicrograph; Sample 169-856H-21R-1, 54-58 $\mathrm{cm})$.

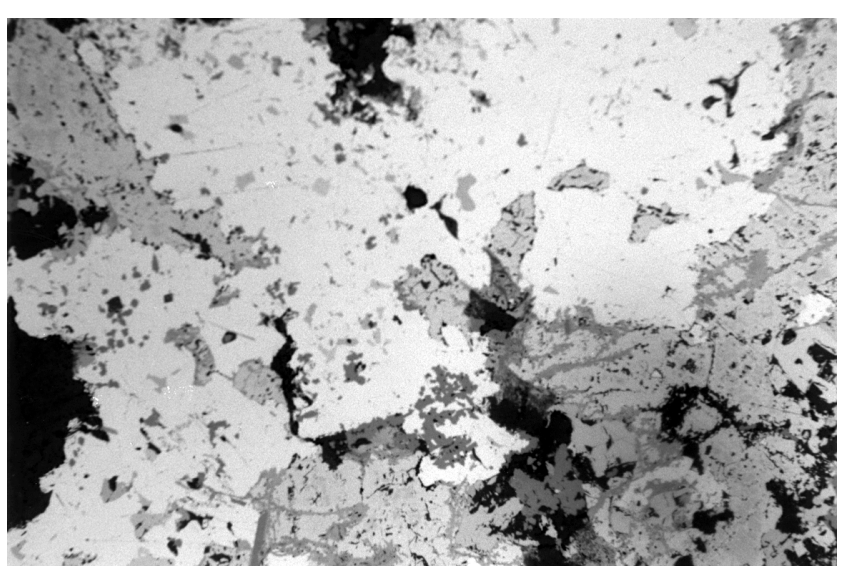

Figure 63. Subunit VIA sulfide-veined siltstone with late pyrite overgrowing a chalcopyrite-isocubanite assemblage with crosscutting hematite veins. Width of field $=\sim 0.5 \mathrm{~mm}$ (reflected light photomicrograph; Sample 169$856 \mathrm{H}-21 \mathrm{R}-1,80-84 \mathrm{~cm})$.

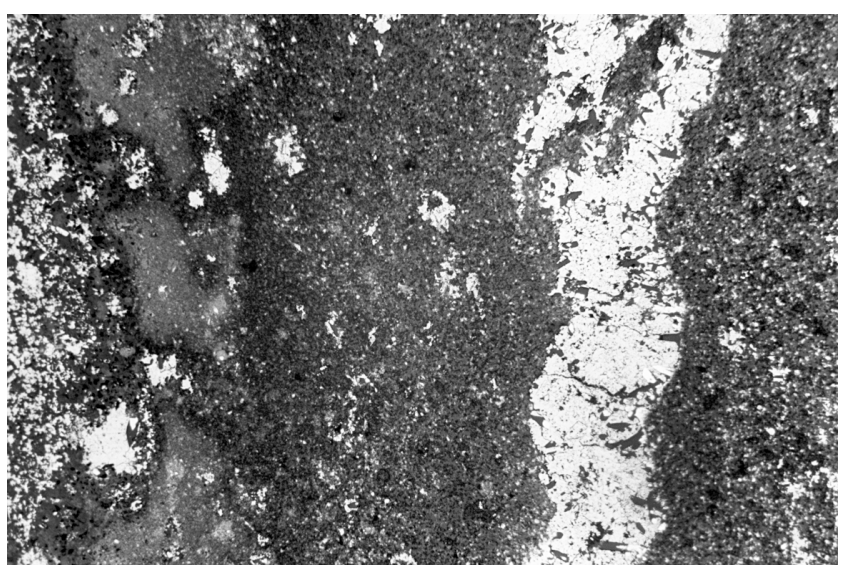

Figure 64. Subunit VIA sulfide-veined siltstone. The sulfide vein (black) is lined by euhedral quartz crystals growing into the vein, showing that fluids flowed into open fractures in the sediment. Width of field $=\sim 5 \mathrm{~mm}$ (reflected light photomicrograph; Sample 169-856H-22R-2, 57-60 cm). 


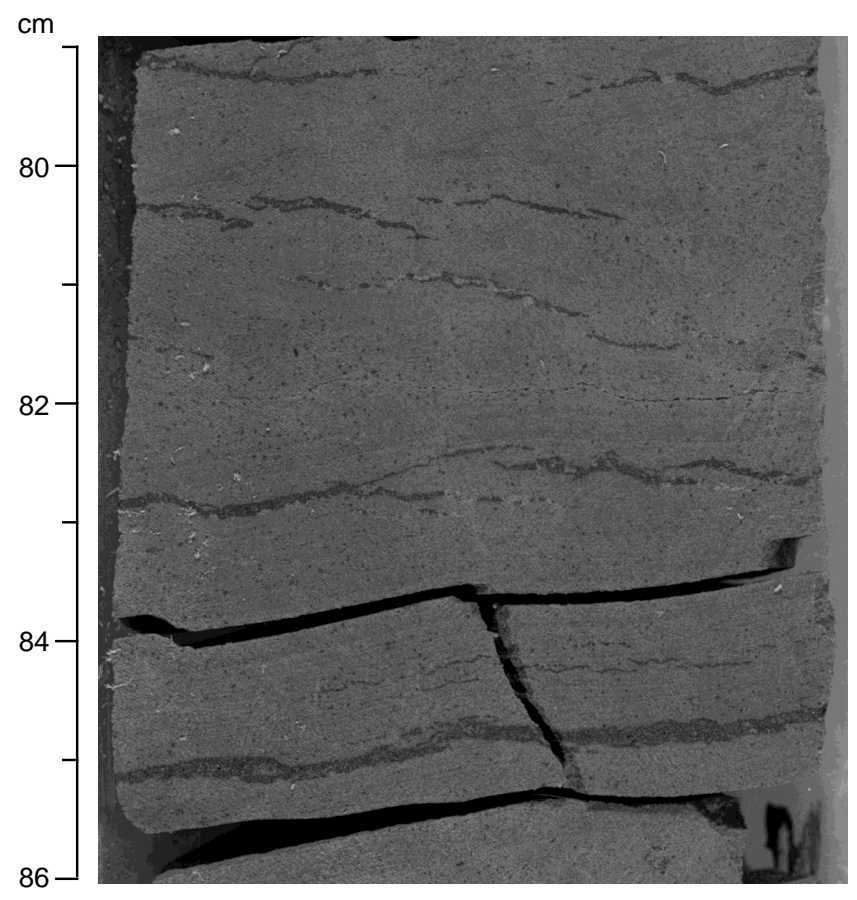

Figure 65. Subunit VIB fine-grained sandstone with enechelon replacement veins (tiger-striped texture) of chalcopyrite with minor pyrrhotite. Some veins have narrow, dark gray silicified envelopes. Pyrite-filled veins oblique to lamination suggest that mechanical anisotropy allows horizontal cracking in siltstones (interval 169-1035F-13R-1, 79-86 cm).

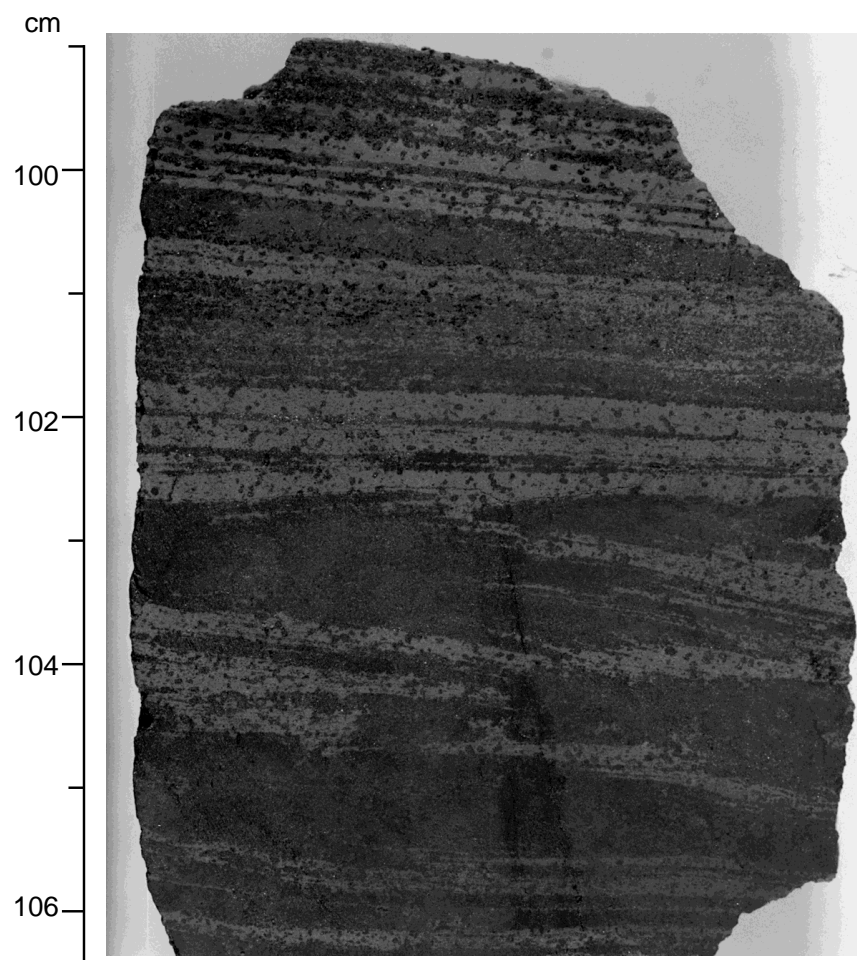

Figure 66. Subunit VIC sulfide-banded cross-laminated sandstone. Horizontal veinlets and impregnations of $\mathrm{Cu}$-rich sulfides and $\mathrm{Mg}$-rich chlorite have filled pore space and replaced sandstone. Note the absence of vertical veins (Subunit VIC; Section 169-856H-31R-1, 99-106.5 cm).

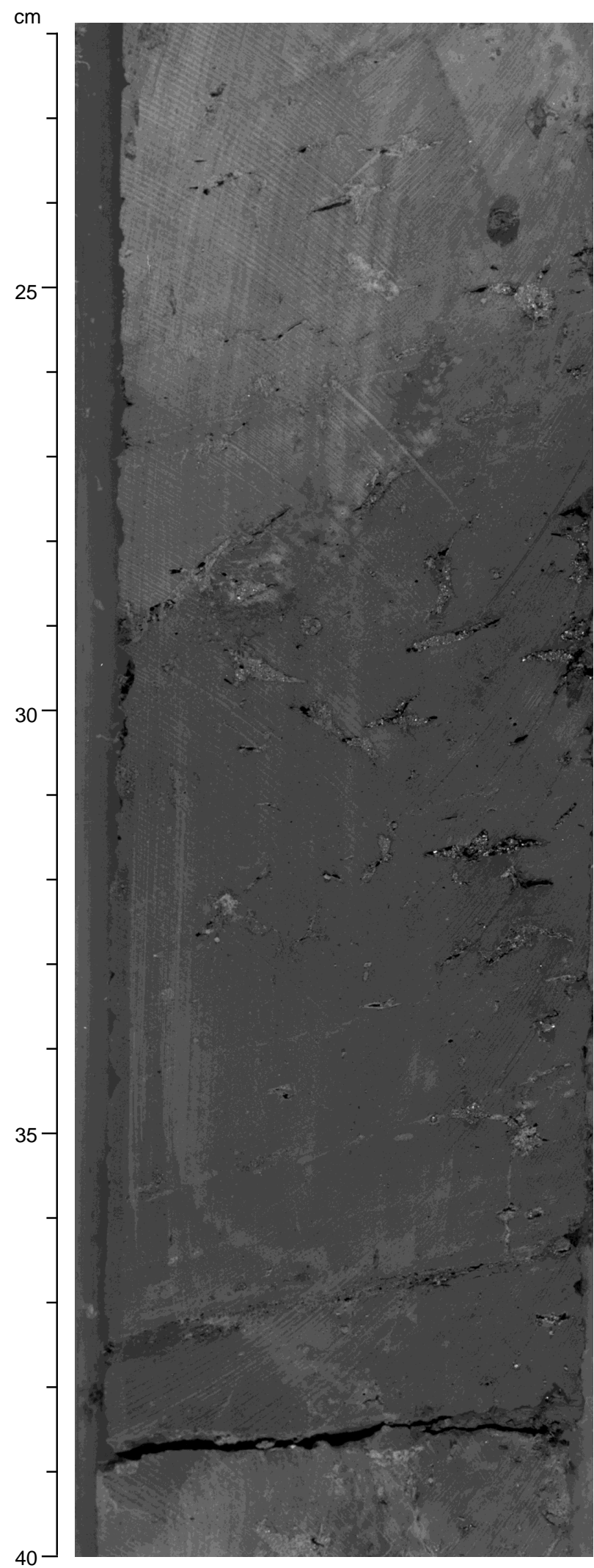

Figure 67. Subunit VIC pyrite-anhydrite replacing burrows and colorless disseminated authigenic anhydrite. Crystals and anhydrite molds in pale gray indurated silty claystone and siltstone (interval 169-1035-10R-1, 22-40 cm). 


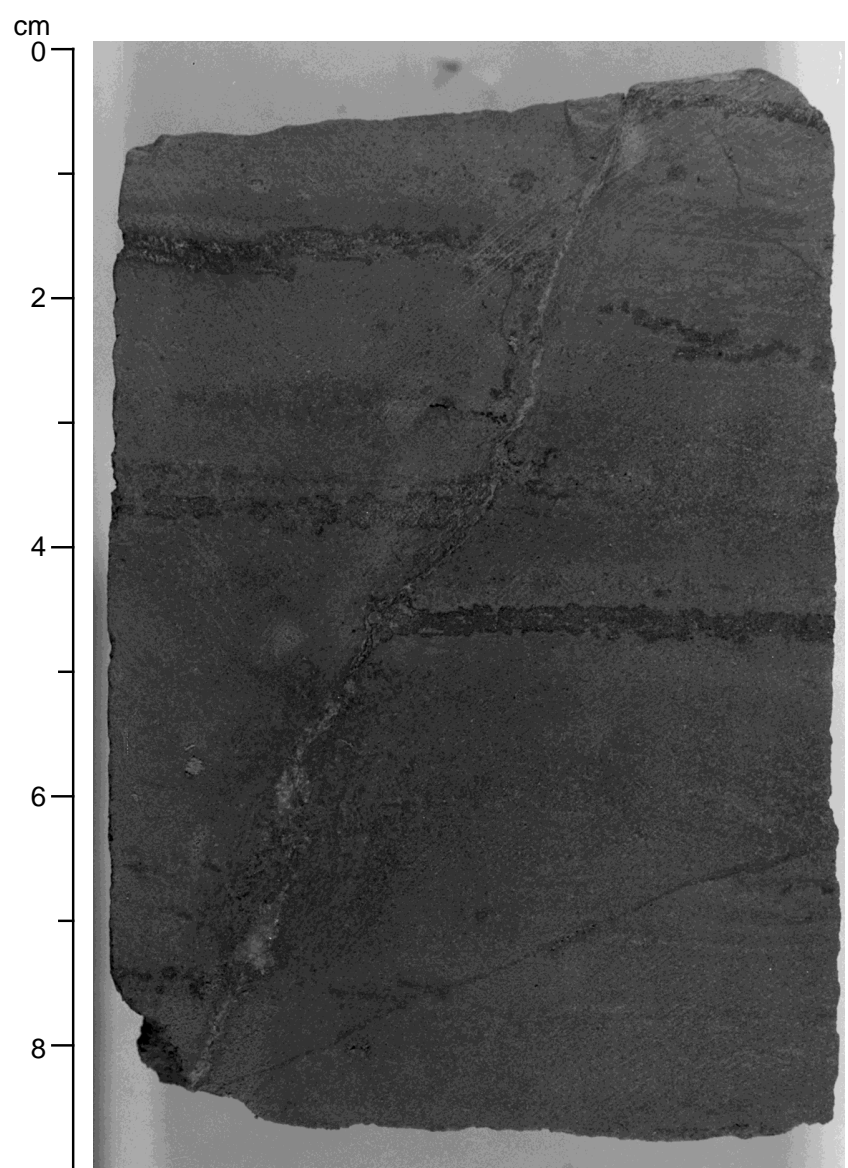

Figure 68. Subunit VIC small, reverse fault vein with anhydrite crosscutting sulfide (pyrite-pyrrhotite-sphalerite) banded (bedding parallel replacements) siltstone (interval 169-1035F-10R-2, 0-9 cm).

lated between drill holes. At Middle Valley, diachronous hydrothermal alteration facies are superimposed on hemipelagic and turbiditic sediments and sedimentary rocks (Unit II). The intensity is highly variable, generally decreasing from the center of hydrothermal fluid upflow, where the sediments can be completely overprinted by hydrothermal minerals (see "Sulfide Mineralization: Sulfide Feeder Zone" section, this chapter), to the low-temperature distal fringes of the fluid discharge conduit where the sediments are weakly altered. The downhole distribution (Table 11), intensity, and textural and mineralogical characteristics of the alteration facies are described in the following sections.

\section{Alteration Zones \\ Blue-Green Clay Alteration}

The blue-green (5G 4/1) clay alteration is associated with unconsolidated clastic sulfides (Unit III; e.g., Section 169-1035E-1H-3 through $2 \mathrm{H}-2$ ) and occurs as patches and bands in weakly to moderately indurated hemipelagic silty clay (e.g., Section 169-1035D-2H1 through $4 \mathrm{H}-1)$. In the former, the clay alteration may represent hydrothermally altered sediments that have been resedimented with clastic sulfides. The Mg-rich smectite-group minerals also display fibrous, felted, and felted botryoidal textures. Similar textures have been observed in earlier studies in the Middle Valley area (Goodfellow et al., 1993). The color is similar to blue-green smectite in anhydrite chimneys and related clastic sediments at both Sites 1035 (Bent Hill) and 1036 (Area of Active Venting; Goodfellow and Blaise, 1988; Turner et al., 1993; see "Lithostratigrapic Summary and Sedi-
169-1035F-10R-2, $9.5-24.5 \mathrm{~cm}$

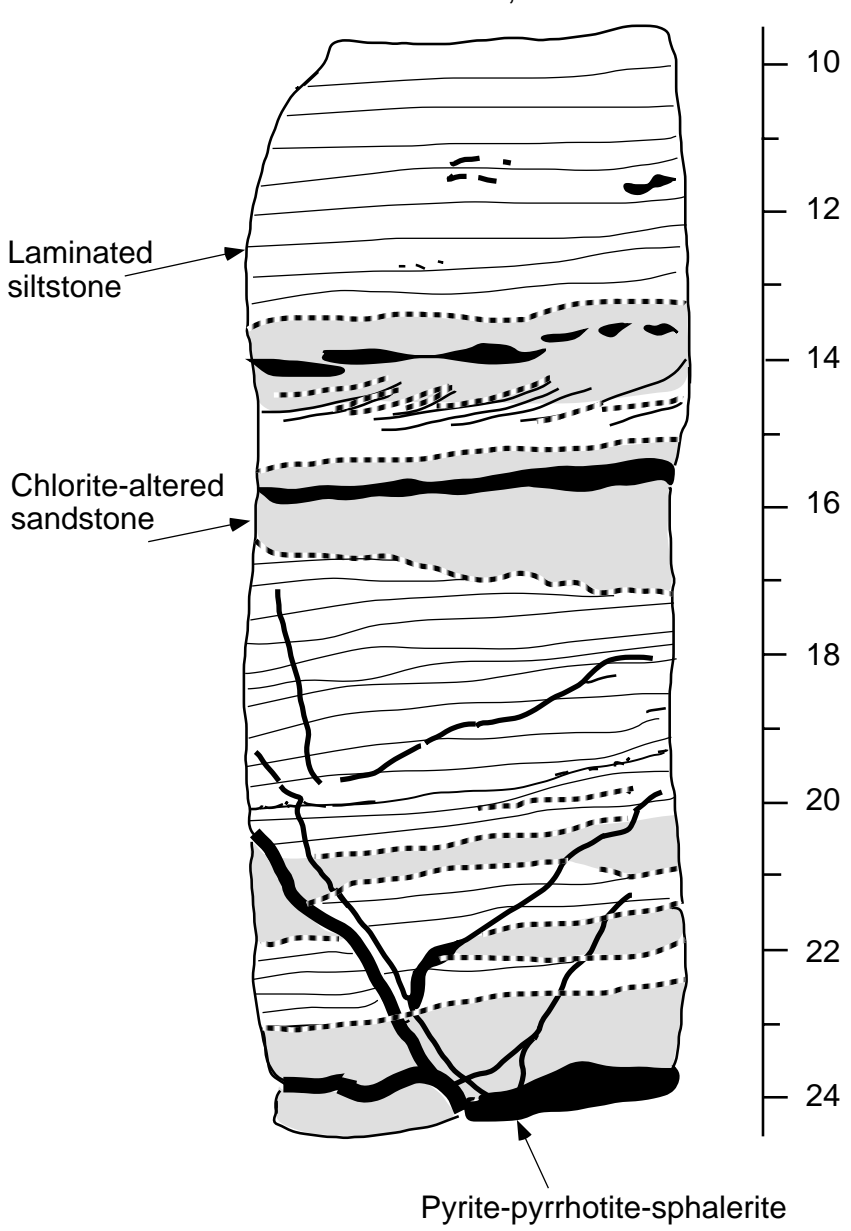

Figure 69. Subunit VIC sketch of sulfide-veined and sulfide-banded siltstone and sandstone. Chlorite alteration is associated with the sulfides, partly replacing and crosscutting the bedding. Sulfides preferentially replace the coarser sandstone beds (interval 169-1035F-10R-2, 9.5-24.5 cm).

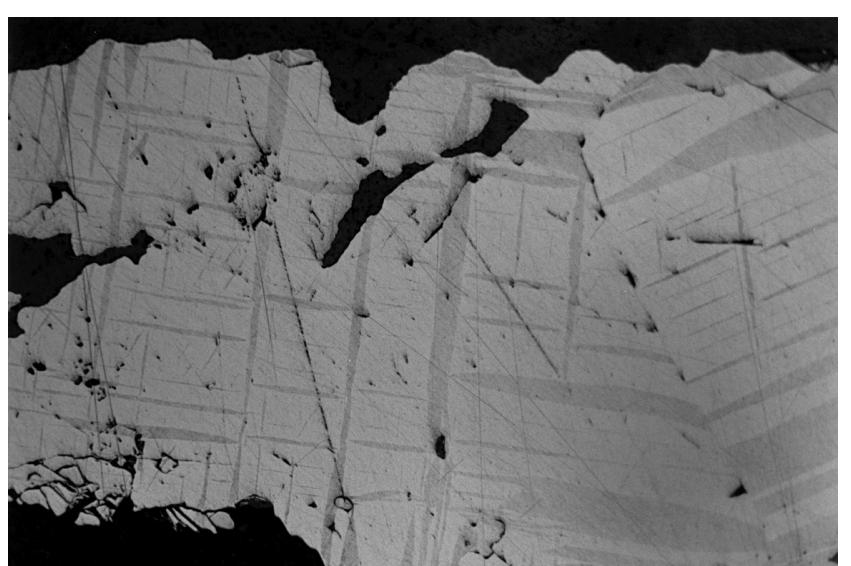

Figure 70. Subunit VIC sulfide-banded sandstone crystallographically oriented lamellar intergrowth of chalcopyrite (darker gray) within unknown isotropic sulfide (lighter gray). Width of field $=\sim 1.0 \mathrm{~mm}$ (reflected light photomicrograph; Sample 169-856H-31R-1, 48-52 cm). 


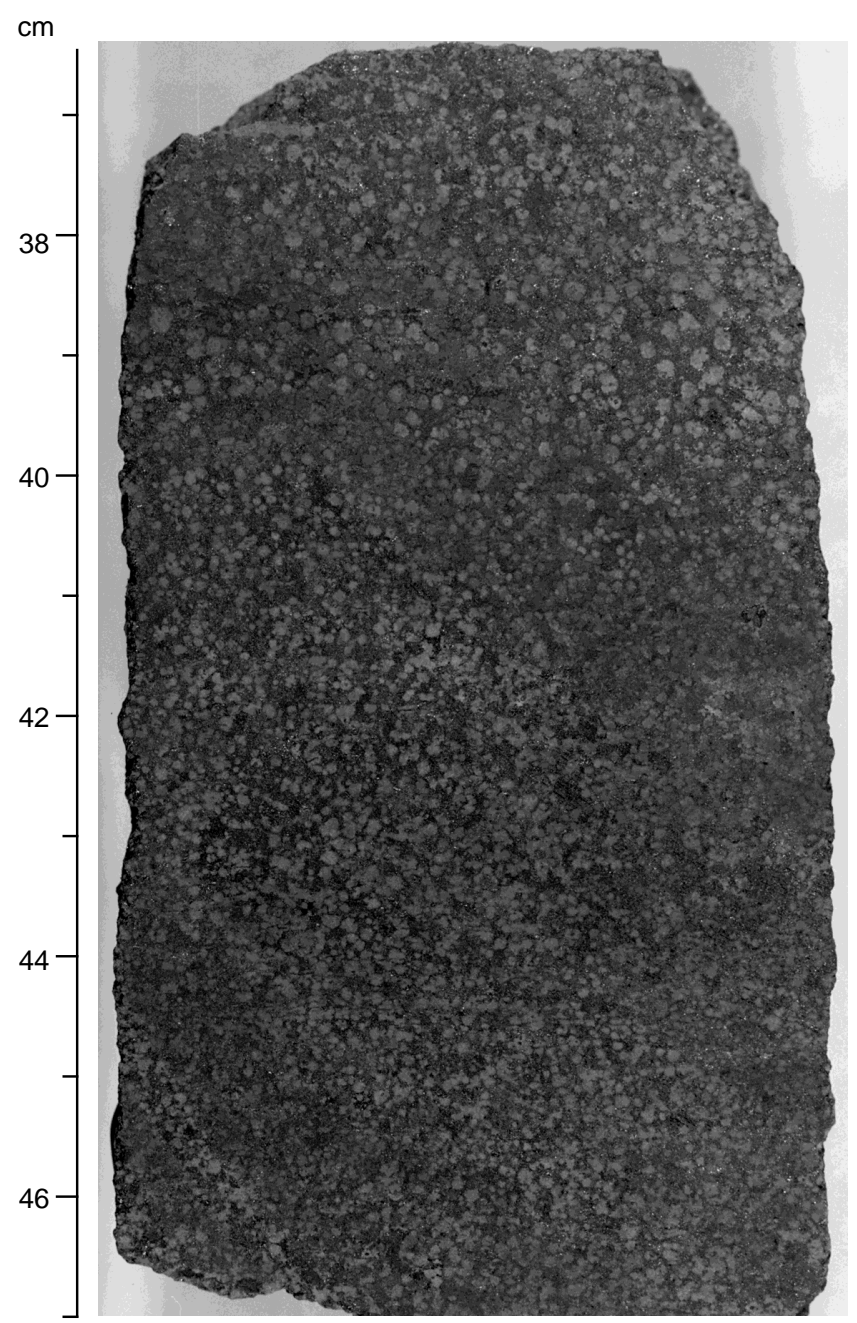

Figure 71. Subunit VIC sulfide-banded sandstone. The replacement of detrital quartz grains by fibrous chlorite imparts a spotty texture to the rock (interval $169-856 \mathrm{H}-31 \mathrm{R}-1,36.5-47 \mathrm{~cm}$ ).

mentology" section, this chapter). Previous work indicates that the blue-green color reflects the occurrence of hydrothermal Mg-smectite (Goodfellow et al., 1993). Correlative unaltered sediments in Hole 857A of Leg 139 (Davis, Mottl, Fisher, et al., 1992) that are remote from hydrothermal deposits do not display the blue-green color distinctive of this hydrothermal alteration type.

\section{Carbonate}

The distribution of hydrothermal carbonate is shown on an eastwest cross section of the BHMS in Figure 72. The carbonate is restricted to the upper sections of Holes 1035A (interval 169-1035A$3 \mathrm{H}-4,10 \mathrm{~cm}$, to $5 \mathrm{H}-3,103 \mathrm{~cm} ; 21.60-39.95 \mathrm{mbsf}$ ) and $1035 \mathrm{D}$ (interval $169-1035 \mathrm{D}-3 \mathrm{H}-3,13 \mathrm{~cm}$, to $3 \mathrm{H}-4,140 \mathrm{~cm}$; $17.73-20.50 \mathrm{mbsf}$ ). The carbonate occurs on the margins of the BHMS and above the zone of authigenic anhydrite.

Authigenic carbonate minerals, mostly calcite and dolomite, occur in several forms in the altered sediment at Site 1035: (1) concretions (intervals $169-1035 \mathrm{E}-4 \mathrm{H}-3,10$ and $85 \mathrm{~cm}$, and $4 \mathrm{H}-4,60-75 \mathrm{~cm}$, $120-145 \mathrm{~cm})$; (2) cements in worm burrows and detrital sediments; and (3) infillings of and overgrowths on foraminifers. Carbonate concretions are predominantly spheroidal or ovoid, although they com- monly display irregular shapes, particularly where the carbonate infills worm burrows. The concretions range in diameter or maximum dimension from 1 to $\sim 8 \mathrm{~cm}$. The contact between concretions and the surrounding sediment is typically sharp and irregular. Some concretions are concentrically zoned about an inner core, with an outer rim of fine-grained crystalline pyrite. Carbonate concretions also contain smectite-group minerals and disseminated pyrite as fine intergrowths with the carbonate minerals (Goodfellow et al., 1993). With increasing depth, foraminifers are more corroded and are ultimately destroyed, presumably because of dissolution by hydrothermal fluids (Davis, Mottl, Fisher, et al., 1992; see also "Biostratigraphy" section, this chapter).

\section{Anhydrite}

The spatial distribution of anhydrite is shown on a west-east cross section of BHMS (Fig. 72). At Bent Hill, anhydrite extends throughout most of Hole 1035A (Cores 169-1035A-5H through 15X-5) and the upper part of 1035D (Cores 169-1035D-2H through 9X) on the margins of the sulfide mounds, whereas it is absent from most of Hole $856 \mathrm{H}$, except between Cores $169-856 \mathrm{H}-22 \mathrm{R}$ and $47 \mathrm{R}$, where it occurs discontinuously as veins or vugs. The anhydrite in the BHMS occurs mostly in weakly altered and moderately indurated hemipelagic and turbiditic sediments on the presumed outer fringes of the hydrothermal fluid upflow zone. The mode of anhydrite deposition changes from concretions to authigenic crystals to veins as the presumed center of fluid discharge, as defined by higher sulfide contents, is approached (see "Sulfide Mineralogy: Sulfide Feeder Zone" section, this chapter).

The anhydrite content throughout Site 1035 is highly variable ranging up to $10 \mathrm{vol} \%$. Anhydrite occurs as authigenic nodules (Fig. 19) and white to clear crystals (Fig. 19) in hemipelagic sediment as massive infilling of sediments (Fig. 73) and as veins cutting indurated hemipelagic silty claystone and siltstone (Fig. 74). Anhydrite also occurs as veins that crosscut massive sulfides (Unit V; e.g., Section 169-1035D-6X-CC) and sulfide-bearing veins from the SFZ (Unit VI; e.g., interval 169-1035D-4R-2, 42-52 cm) and as infillings of vugs in altered sediment and massive sulfides. Anhydrite occurs in several forms: (1) splays and random intergrowths of needles and rectangular crystals in altered claystone (e.g., interval 169-1035D$5 \mathrm{H}-3,20-60 \mathrm{~cm}$ ); (2) radiating blades in concretions (e.g., interval $169-1035 \mathrm{D}-4 \mathrm{H}-3,20-125 \mathrm{~cm}$ ); and (3) as replacements of burrows (e.g., interval 169-1035D-4H-1, $35 \mathrm{~cm}$ ).

Higher than normal pyrite contents $(>0.2 \%$; Goodfellow and Peter, 1994) commonly occur with anhydrite in silty claystone, and the pyrite typically forms disseminated cubes that impart a speckled appearance to the pale gray altered sediment. Pyrite also fills pore space and partly replaces detrital grains in turbiditic silt and sand, giving the rock a speckled appearance (e.g., interval 169-1035D-4H-4, 0-150 $\mathrm{cm})$.

Rectangular molds after authigenic anhydrite crystals are locally common, particularly between 170 and 220 mbsf (interval 1691035H-20R-1, $0 \mathrm{~cm}$, to 25R-1, $122 \mathrm{~cm}$; Fig. 67). A complete progression is observed from authigenic anhydrite crystals to molds (e.g., interval 169-1035D-23R-1, 0-146 cm) partly filled with anhydrite, to voids of what was probably anhydrite. The voids also provide a site for precipitation of other minerals such as quartz, which occurs as a lining of singly terminated crystals.

\section{Chlorite}

Chlorite alteration imparts a green color to the sediment where the chlorite is iron rich, whereas Mg-rich chlorites impart a silvery gray color (Leybourne and Goodfellow, 1994; Zierenberg and Shanks, 1994). It is thus unlikely that Mg-rich chlorite alteration was recog- 
Table 11. Distribution of hydrothermal alteration minerals, Bent Hill.

\begin{tabular}{|c|c|c|c|c|c|c|c|}
\hline Type & Description & Hole $856 \mathrm{H}$ & Hole $1035 \mathrm{~A} / \mathrm{G}$ & Hole $1035 \mathrm{C} / \mathrm{F}$ & Hole 1035D & Hole $1035 \mathrm{E}$ & Hole $1035 \mathrm{H}$ \\
\hline Clay (smectite) & $\begin{array}{l}\text { Blue-green clay } \\
\text { (smectite) alteration of } \\
\text { weak to moderately } \\
\text { indurated hemipelagic } \\
\text { silty clay }\end{array}$ & $\begin{array}{l}\text { 20R-1, } 0 \mathrm{~cm} \text {, to } 20 \mathrm{R}-2,91 \mathrm{~cm} \\
(103.6-104.67 \mathrm{mbsf}) ; 23 \mathrm{R}- \\
1,0 \mathrm{~cm} \text {, to } 24 \mathrm{R}-2,138 \mathrm{~cm} \\
(124.10-136.58 \mathrm{mbsf})\end{array}$ & $\begin{array}{l}1035 \mathrm{~A}-1 \mathrm{H}, 0 \mathrm{~cm} \text {, to } 3 \mathrm{H}-1, \\
150 \mathrm{~cm}(0-18.50 \mathrm{mbsf}) \\
3 \mathrm{H}-3(20.0-21.50 \mathrm{mbsf}) \\
19 \mathrm{X}-\mathrm{CC}(169.47-169.85 \\
\text { mbsf })\end{array}$ & $\begin{array}{l}\text { 1035C-1X-1, } 0 \mathrm{~cm} \text {, to } 1 \mathrm{X}-\mathrm{CC}, \\
37 \mathrm{~cm}(0-1.47 \mathrm{mbsf}) \\
1035 \mathrm{~F}-17 \mathrm{R}-1,0 \mathrm{~cm} \text {, to } 18 \mathrm{R}- \\
1,31 \mathrm{~cm}(157.50-167.63 \\
\mathrm{mbsf})\end{array}$ & $\begin{array}{c}2 \mathrm{H}-1,0 \mathrm{~cm}, \text { to } 4 \mathrm{H}-1,150 \mathrm{~cm} \\
(5.10-25.60 \mathrm{mbsf}) ; 19 \mathrm{X}- \\
\mathrm{CC}, 0 \mathrm{~cm}, \text { to } 24 \mathrm{X}-\mathrm{CC}, 40 \\
\mathrm{~cm}(135.00-173.90 \mathrm{mbsf})\end{array}$ & $\begin{array}{c}1 \mathrm{H}-3,0 \mathrm{~cm}, \text { to } 2 \mathrm{H}-2,150 \\
\mathrm{~cm}(3.00-10.50 \mathrm{mbsf})\end{array}$ & $\begin{array}{l}\text { 1H-1, } 0 \mathrm{~cm} \text {, to } 1 \mathrm{H}-\mathrm{CC}, 16 \mathrm{~cm} \\
(0-2.17 \mathrm{mbsf}) ; 16 \mathrm{R}-2,0 \mathrm{~cm} \text {, to } \\
17 \mathrm{R}-1,110 \mathrm{~cm}(134.10-143.40 \\
\text { mbsf); } 17 \mathrm{R}-2,0-150 \mathrm{~cm}(143.77- \\
145.22 \mathrm{mbsf})\end{array}$ \\
\hline Carbonate & $\begin{array}{l}\text { Pale gray carbonate } \\
\text { (mostly calcite) } \\
\text { concretions and cement } \\
\text { in hemipelagic and } \\
\text { turbiditic moderately } \\
\text { indurated sediments }\end{array}$ & & $\begin{array}{l}1035 \mathrm{~A}-3 \mathrm{H}-4,10 \mathrm{~cm}, \text { to } 5 \mathrm{H}- \\
3,103 \mathrm{~cm}(21.60-39.95 \\
\text { mbsf })\end{array}$ & & $\begin{array}{l}3 \mathrm{H}-3,13 \mathrm{~cm} \text {, to } 3 \mathrm{H}-4,140 \mathrm{~cm} \\
\quad(17.73-20.50 \mathrm{mbsf})\end{array}$ & $\begin{array}{l}4 \mathrm{H}-3,10 \mathrm{~cm} \text {, to } 4 \mathrm{H}-\mathrm{CC}, 10 \\
\mathrm{~cm}(29.60-36.54 \mathrm{mbsf})\end{array}$ & \\
\hline Anhydrite & $\begin{array}{l}\text { White anhydrite } \\
\text { concretions and } \\
\text { authigenic bladed } \\
\text { crystals in hemipelagic } \\
\text { silty claystone and } \\
\text { turbiditic siltstone; } \\
\text { anhydrite molds }\end{array}$ & $\begin{array}{l}\text { 22R-2, } 0,150 \mathrm{~cm}, 24 \mathrm{R}-1, \\
0-138 \mathrm{~cm}(135.20-136.58 \\
\text { mbsf); 35R-1 (Pieces 17, } \\
\text { 18); 39R-1, 0 cm, to 42R-1, } \\
126 \mathrm{~cm}(278.00-298.56 \\
\text { mbsf); 44R-1, 0-106 cm } \\
(326.20-327.26 \mathrm{mbsf}) ; 47 \mathrm{R}- \\
1,0-150 \mathrm{~cm}(355.10- \\
356.60 \mathrm{mbsf})\end{array}$ & $\begin{array}{l}1035 \mathrm{~A}-5 \mathrm{H}-7,18 \mathrm{~cm} \text {, to } 7 \mathrm{X}- \\
\mathrm{CC}, 0.40 \mathrm{~cm}(45.10-57.07 \\
\text { mbsf }) ; 9 \mathrm{X}-6,0 \mathrm{~cm}, \text { to } 15 \mathrm{X}- \\
5,35 \mathrm{~cm}(78.10-134.55 \\
\text { mbsf })\end{array}$ & $\begin{array}{l}\text { 1035F-2R-1, } 0 \mathrm{~cm} \text {, to } 15 \mathrm{R}-1 \\
\text { (14.50-139.33 mbsf); } 18- \\
\text { R1-1 (167.10-167.63 mbsf); } \\
\text { 20R-1, } 0 \mathrm{~cm} \text {, to } 22 \mathrm{R}-1,76 \\
\mathrm{~cm}(186.40-206.75 \mathrm{mbsf})\end{array}$ & $\begin{array}{l}2 \mathrm{H}-5,80 \mathrm{~cm} \text {, to } 9 \mathrm{X}-1,83 \mathrm{~cm} \\
(11.90-61.63 \mathrm{mbsf}) ; 11 \mathrm{X}-1, \\
0 \mathrm{~cm} \text {, to } 12 \mathrm{X}-1,30 \mathrm{~cm} \\
(72.40-77.70 \mathrm{mbsf}) ; 16 \mathrm{X}- \\
\mathrm{CC}, 0-12 \mathrm{~cm}(115.80- \\
115.92 \mathrm{mbsf})\end{array}$ & $\begin{array}{r}5 \mathrm{H}-6,0 \mathrm{~cm}, \text { to } 5 \mathrm{H}-\mathrm{CC}, 60 \\
\mathrm{~cm}(42.24-46.20 \mathrm{mbsf})\end{array}$ & $\begin{array}{l}\text { 4R-1, } 32 \mathrm{~cm} \text {, to } 5 \mathrm{R}-1,10 \mathrm{~cm} \\
\quad(26.72-36.10 \mathrm{mbsf}) ; 9 \mathrm{R}-01,55 \\
\text { cm, to } 10 \mathrm{R}-1,40 \mathrm{~cm}(75.15-84.60 \\
\text { mbsf); } 14 \mathrm{R}-1,37-43 \mathrm{~cm}(123.37- \\
123.43 \mathrm{mbsf}) ; 20 \mathrm{R}-1,0-127 \mathrm{~cm} \\
\text { (171.10-172.60 mbsf; molds); } \\
23 \mathrm{R}-1,0 \mathrm{~cm}, \text { to } 25 \mathrm{R}-1,122 \mathrm{~cm} \\
\text { (199.90-220.51 mbsf; molds) }\end{array}$ \\
\hline Chloritization & $\begin{array}{l}\text { Pale to medium green } \\
\text { chloritic alteration of } \\
\text { hemipelagic silty } \\
\text { claystone and turbiditic } \\
\text { sandstone and siltstone }\end{array}$ & $\begin{array}{l}23 \mathrm{R}-2,0-95 \mathrm{~cm}(125.50- \\
126.45 \mathrm{mbsf}) ; 31 \mathrm{R}-1,0 \mathrm{~cm}, \\
\text { to } 31 \mathrm{R}-2,96 \mathrm{~cm}(201.00- \\
203.40 \mathrm{mbsf}) ; 36 \mathrm{R}-1,0 \mathrm{~cm}, \\
\text { to } 45 \mathrm{R}-1,75 \mathrm{~cm}(249.00- \\
336.55 \mathrm{mbsf}) ; 56 \mathrm{R}-1,0- \\
108 \mathrm{~cm}(434.30-435.38 \\
\text { mbsf) }\end{array}$ & $\begin{array}{l}1035 \mathrm{G}-10 \mathrm{R}-1,30 \mathrm{~cm} \text {, to } \\
11 \mathrm{R}-1,65 \mathrm{~cm}(170.10- \\
189.20 \mathrm{mbsf})\end{array}$ & $\begin{array}{l}\text { 1035F-10R-1, } 0 \mathrm{~cm}, \text { to } \\
\text { 13R-2, 150 cm (89.90- } \\
122.00 \mathrm{mbsf}) ; 18 \mathrm{R}-1,0-31 \\
\mathrm{~cm}(167.10-167.63 \mathrm{mbsf})\end{array}$ & $\begin{array}{l}\text { 18X-CC, } 0 \mathrm{~cm} \text {, to } 19 \mathrm{X}-\mathrm{CC} \\
(125.40-135.07 \mathrm{mbsf})\end{array}$ & & $\begin{array}{l}\text { 9R-1, } 115-135 \mathrm{~cm}(75.75-75.95 \\
\text { mbsf); } 11 \mathrm{R}-1,73-87 \mathrm{~cm}(94.73- \\
94.87 \mathrm{mbsf}) ; 17 \mathrm{R}-1,110 \mathrm{~cm}, \text { to } \\
17 \mathrm{R}-3,79 \mathrm{~cm}(143.40-146.01 \\
\text { mbsf); } 19 \mathrm{R}-1,49 \mathrm{~cm} \text {, to } 27 \mathrm{R}-2,86 \\
\mathrm{~cm}(161.99-240.58 \mathrm{mbsf})\end{array}$ \\
\hline Epidotization & $\begin{array}{l}\text { Light yellowish green } \\
\text { epidote alteration of } \\
\text { turbiditic sandstone and } \\
\text { siltsone, and } \\
\text { hemipelagic silty } \\
\text { claystone }\end{array}$ & $\begin{array}{l}\text { 21R-1, } 54 \mathrm{~cm} \text {, to } 23 \mathrm{R}-1,98 \mathrm{~cm} \\
(115.36-125.08 \mathrm{mbsf}) ; 43 \mathrm{R}- \\
1,70-75 \mathrm{~cm}(317.20- \\
317.25 \mathrm{mbsf}) ; 54 \mathrm{R}-1,12- \\
16 \mathrm{~cm}(422.32-422.36 \\
\mathrm{mbsf})\end{array}$ & $\begin{array}{l}\text { 1035G-10R-1, 33- } 35 \mathrm{~cm} \\
\quad(170.13-170.15 \mathrm{mbsf}) \\
12 \mathrm{R}-1,80-95 \mathrm{~cm}(190.0- \\
190.15 \mathrm{mbsf})\end{array}$ & $\begin{array}{l}\text { 1035F-13R-2, 113-116 cm } \\
\text { (120.63-120.66 mbsf); } \\
\text { 20R-1, 75-94 cm (187.15- } \\
187.34 \mathrm{mbsf})\end{array}$ & $18 \mathrm{X}-\mathrm{CC}, 0-20 \mathrm{~cm}, 24 \mathrm{X}-\mathrm{CC}$ & & $\begin{array}{l}12 \mathrm{R}-1,0-51 \mathrm{~cm}(103.70-104.54 \\
\mathrm{mbsf}) ; 16 \mathrm{R}-3,72 \mathrm{~cm}, \text { to } 17 \mathrm{R}-1 \\
126 \mathrm{~cm}(136.19-143.56 \mathrm{mbsf})\end{array}$ \\
\hline Silicification & $\begin{array}{l}\text { Medium gray spotty to } \\
\text { pervasive silicification } \\
\text { of hemipelagic and } \\
\text { turbiditic sedimentary } \\
\text { rocks; euhedral quartz } \\
\text { in vugs of anhydrite } \\
\text { molds; quartz veins }\end{array}$ & 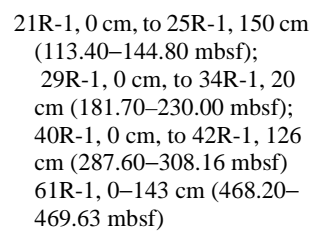 & $\begin{array}{l}\text { 1035A-19X-CC, 0-38 cm } \\
\text { (169.47-169.85 mbsf); } \\
\text { 1035G-8R-1, 0 cm, to } \\
11 \mathrm{R}-1,101 \mathrm{~cm}(150.50- \\
180.51 \mathrm{mbsf})\end{array}$ & $\begin{array}{l}1035 \mathrm{~F}-18 \mathrm{R}-1,20 \mathrm{~cm} \text {, to } \\
23 \mathrm{R}-1,34 \mathrm{~cm}(167.30- \\
215.78 \mathrm{mbsf})\end{array}$ & $\begin{array}{l}9 \mathrm{X}, 30-83 \mathrm{~cm}(61.10-61.63 \\
\text { mbsf); } 16 \mathrm{X}-\mathrm{CC}, 0 \mathrm{~cm}, \text { to } \\
17 \mathrm{X}-1,74 \mathrm{~cm}(115.80- \\
121.14 \mathrm{mbsf}) ; 23 \mathrm{X}-1,0 \mathrm{~cm}, \\
\text { to } 24 \mathrm{X}-\mathrm{CC}, 40 \mathrm{~cm}(168.50- \\
173.90 \mathrm{mbsf})\end{array}$ & & $\begin{array}{l}\text { 4R-2, 52-66 cm (28.42-28.56 mbsf); } \\
\text { 6R-2, 0-49 cm (47.06-47.55 } \\
\text { mbsf); 9R-1, 95-125 cm (75.55- } \\
75.85 \mathrm{mbsf}) ; 18 \mathrm{R}-1,10 \mathrm{~cm}, \mathrm{to} \\
27 \mathrm{R}-2,86 \mathrm{~cm}(152.00-240.62 \\
\text { mbsf) }\end{array}$ \\
\hline Talc & $\begin{array}{l}\text { Interstitial to massive and } \\
\text { semi-massive sulfides }\end{array}$ & $\begin{array}{l}29 \mathrm{R}-1,0-120 \mathrm{~cm} \\
\quad(181.70-182.90 \mathrm{mbsf})\end{array}$ & & $\begin{array}{l}\text { 1035F-16R-1, 110-130 cm } \\
(149.00-149.20 \mathrm{mbsf})\end{array}$ & & & \\
\hline Pyrite & $\begin{array}{l}\text { Pyrite concretions, blebs, } \\
\text { and disseminations in } \\
\text { hemipelagic silty clay } \\
\text { and claystone, and } \\
\text { turbiditic silt, siltsone, } \\
\text { sand and sandstone, } \\
\text { pyrite cubes giving the } \\
\text { sediment a speckled } \\
\text { appearance }\end{array}$ & & $\begin{array}{l}1035 \mathrm{~A}-4 \mathrm{H}-2,105 \mathrm{~cm} \text {, to } 8 \mathrm{X}- \\
03,92 \mathrm{~cm}(29.05-64.92 \\
\text { mbsf); } 9 \mathrm{X}-4,25 \mathrm{~cm} \text {, to } 9 \mathrm{X}- \\
6,116 \mathrm{~cm}(75.35-79.26 \\
\text { mbsf); } 12 \mathrm{X}-1,0 \mathrm{~cm}, \text { to } \\
12 \mathrm{X}-3,150 \mathrm{~cm}(99.40- \\
103.90 \mathrm{mbsf}) ; 14 \mathrm{X}-3,70 \\
\mathrm{~cm}, \text { to } 15 \mathrm{X}-6,89 \mathrm{~cm} \\
(122.30-136.59 \mathrm{mbsf}) ; \\
16 \mathrm{X}-1,0 \mathrm{~cm}, \text { to } 19 \mathrm{X}-\mathrm{CC} \\
38 \mathrm{~cm}(137.80-169.85)\end{array}$ & $\begin{array}{l}\text { 1035F-10R-1, } 0 \mathrm{~cm} \text {, to } 10 \mathrm{R}- \\
\mathrm{CC}, 20 \mathrm{~cm}(89.90-91.96 \\
\text { mbsf }) ; 22 \mathrm{R}-1,0-76 \mathrm{~cm} \\
(205.60-206.75 \mathrm{mbsf})\end{array}$ & $\begin{array}{l}3 \mathrm{H}-7,50 \mathrm{~cm} \text {, to } 5 \mathrm{H}-\mathrm{CC}, 17 \mathrm{~cm} \\
\quad(24.10-42.66 \mathrm{mbsf})\end{array}$ & $\begin{array}{l}4 \mathrm{H}-2,10-85 \mathrm{~cm}(28.10- \\
28.85 \mathrm{mbsf})\end{array}$ & \\
\hline
\end{tabular}




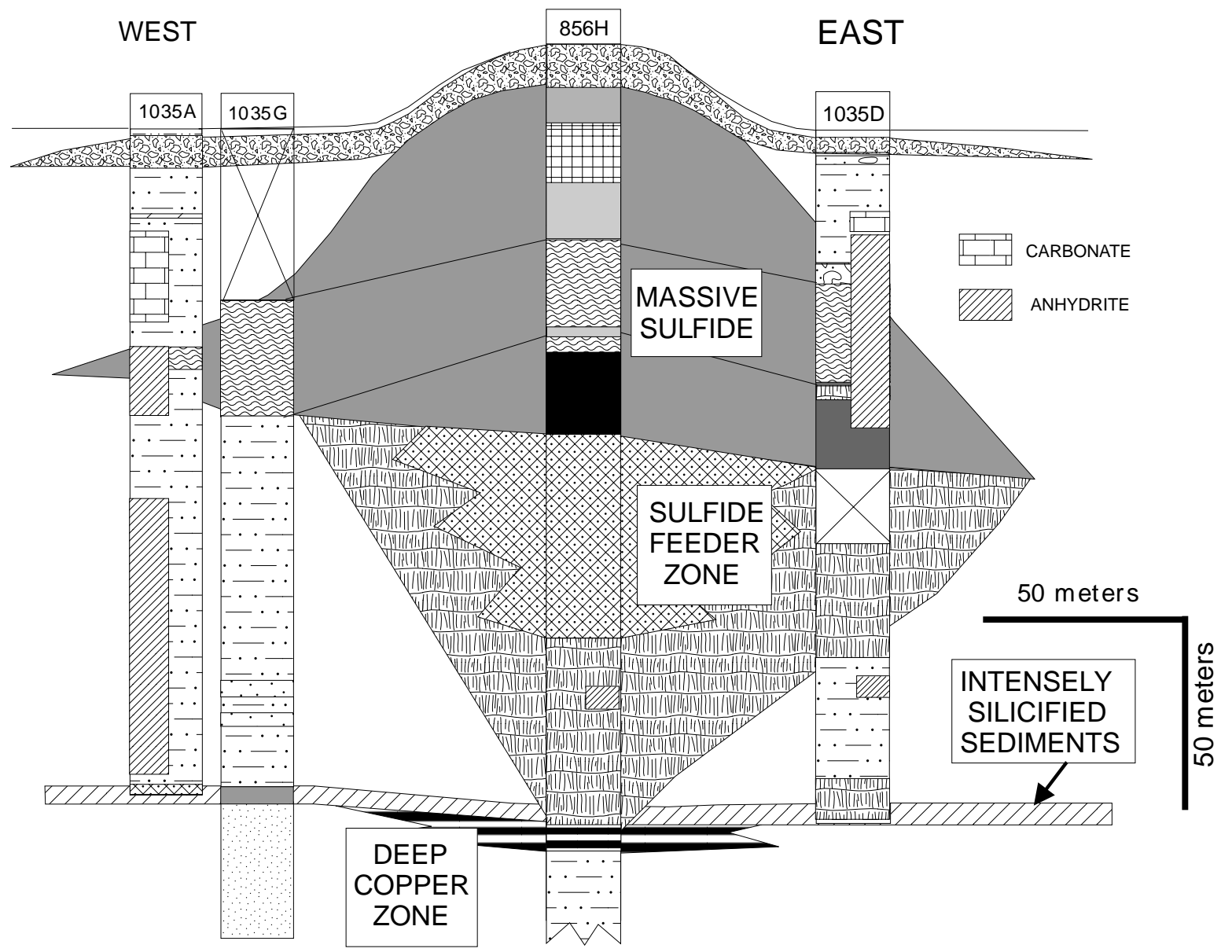

Figure 72. West-east geological cross section of the BHMS showing the distribution of carbonate concretions and anhydrite.

nized in hand specimen, except where the mineral is present in abundance. As a result, most of the chlorite alteration described here probably refers to Fe-rich chlorite.

The chlorite alteration is most common in the deeper parts of Holes $856 \mathrm{H}, 1035 \mathrm{~F}, 1035 \mathrm{G}$, and $1035 \mathrm{H}$. In Hole $856 \mathrm{H}$, the chlorite alteration extends discontinuously from Section 169-856H-23R-2 within the sulfide feeder zone (Unit VI) through Section 169-856H45R-1 (Fig. 11). In Hole 1035F, the chloritization is restricted between Sections 169-1035F-10R-1 and 13R-1 and within Section 1691035F-18R-1 (Table 11). In Hole $1035 \mathrm{H}$ intersecting the ODP Mound, chlorite alteration extends from Section 169-1035F-9R-1 near the second massive sulfide zone through the SFZ to the base of the hole (Section 27R-2; Fig. 75, Table 11).

A pale green to white chlorite alteration has been observed in sulfide-banded and impregnated sandstone in the DCZ (Core 169-856H31R; see "Sulfide Mineralization: Sulfide Feeder Zone" section, this chapter). The chlorite has almost entirely replaced a parallel- and cross-laminated sandstone (Fig. 66); the laminae are mimicked by $\mathrm{Cu}-\mathrm{Fe}$ sulfide. The chlorite also forms spheres several millimeters across, consisting of radiating fibrous Mg-rich chlorite (Fig. 76) that probably nucleated on and replaced detrital quartz grains.

Green chlorite also occurs within sulfide veins and forms selvages that are generally thin, up to $1 \mathrm{~cm}$ wide (see "Sulfide Mineralization: Sulfide Feeder Zone" section, this chapter). The chlorite alteration is most intense adjacent to sulfide veins and grades outward into hemipelagic and turbiditic sediments. Chlorite selvages are commonly wider and better developed in hemipelagic claystone compared to turbiditic siltstone and sandstone. The chlorite forms as a replacement or alteration of fine-grained clay minerals that comprise unal- tered hemipelagic sediment and less commonly pseudomorphically replaces detrital quartz.

\section{Silicification}

Some hemipelagic and turbiditic sediments and sedimentary rocks have been weakly to pervasively silicified. A zone of intense silicification generally was encountered at $\sim 170$ mbsf, just above the DCZ (see "Sulfide Mineralization: Sulfide Feeder Zone" section, this chapter). Silicified sediments also occur near the base of Holes 1035A (Section 169-1035A-19X-CC) and 1035D (Section 1691035D-24X-1). In Hole 856H, the zone of silicified sediment extends from near the top of the sulfide stringer zone at $~ 95$ mbsf (Section 169-856H-21R-1) to 310 mbsf (Section 169-856-42R-1). Silicification is present to the deepest levels drilled in Holes $1035 \mathrm{~F}(224.8 \mathrm{mb}-$ sf) and $1035 \mathrm{H} \mathrm{(247.9} \mathrm{mbsf;} \mathrm{Fig.} \mathrm{77).} \mathrm{There} \mathrm{is} \mathrm{a} \mathrm{clear} \mathrm{spatial} \mathrm{(and}$ probably genetic) association between intense silicification and the DCZ, although less strongly silicified rocks are stratigraphically and laterally more widespread.

The silica occurs in several forms: (1) pervasive and intense pale to medium gray silicification of the sediments (e.g., interval 1691035A-19X-CC, 34-38 cm); (2) incipient silicification characterized by millimeter- to centimeter-scale patches randomly distributed throughout the rock, giving it a spotted texture (Fig. 78); (3) euhedral quartz in vugs, localized within molds of minerals dissolved by hydrothermal alteration (e.g., Section 169-1035H-24R-1) and burrows; and (4) comb-textured quartz lining fractures. Intensely silicified sediment at the bottom of Hole 1035A is pale gray, fine-grained, and conchoidally fractured by drilling. 


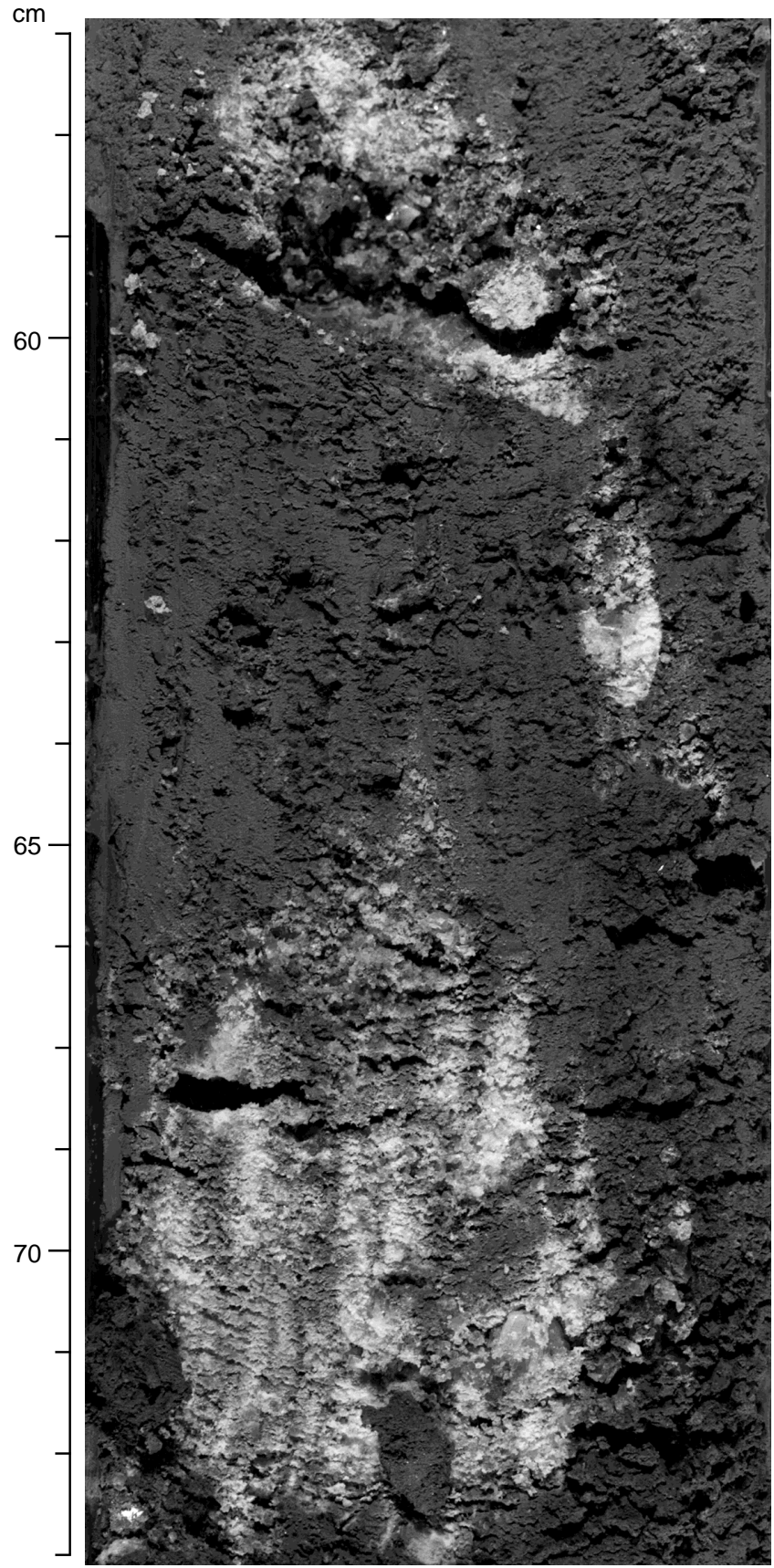

Figure 73. Semi-massive, white anhydrite filling in and replacing moderately indurated turbiditic sediments, Subunit IIC (interval 169-1035D-5H-3, 57$73 \mathrm{~cm})$.

\section{Epidote}

Epidote alteration can be pervasive, giving the rock a yellowish green color, or it can form patches within the rocks. In Hole $856 \mathrm{H}$, epidote occurs in two areas, the SFZ (intervals 169-856H-21R-1, 54$58 \mathrm{~cm}, 80-84 \mathrm{~cm} ; 22 \mathrm{R}-2,57-60 \mathrm{~cm}$; and $23 \mathrm{R}-1,94-98 \mathrm{~cm})$ and in greenish gray altered sediments in Section 169-856H-43R-1. Epidote in the SFZ in Hole $856 \mathrm{H}$ may correlate with epidote in the SFZ in Hole 1035F (interval 169-1035F-13R-2, 113-116 cm). Epidote also occurs in the SFZ in Hole 1035H (interval 169-1035H-12R-1; 16R$3,72-76 \mathrm{~cm}$; and $17 \mathrm{R}-1,48-126 \mathrm{~cm}$ ). Epidotized sediment is also present in intervals 169-1035G-12R-1 and 10R-1, 33-35 cm, and Section 169-1035D-24X-CC. In the latter case, based on thin section

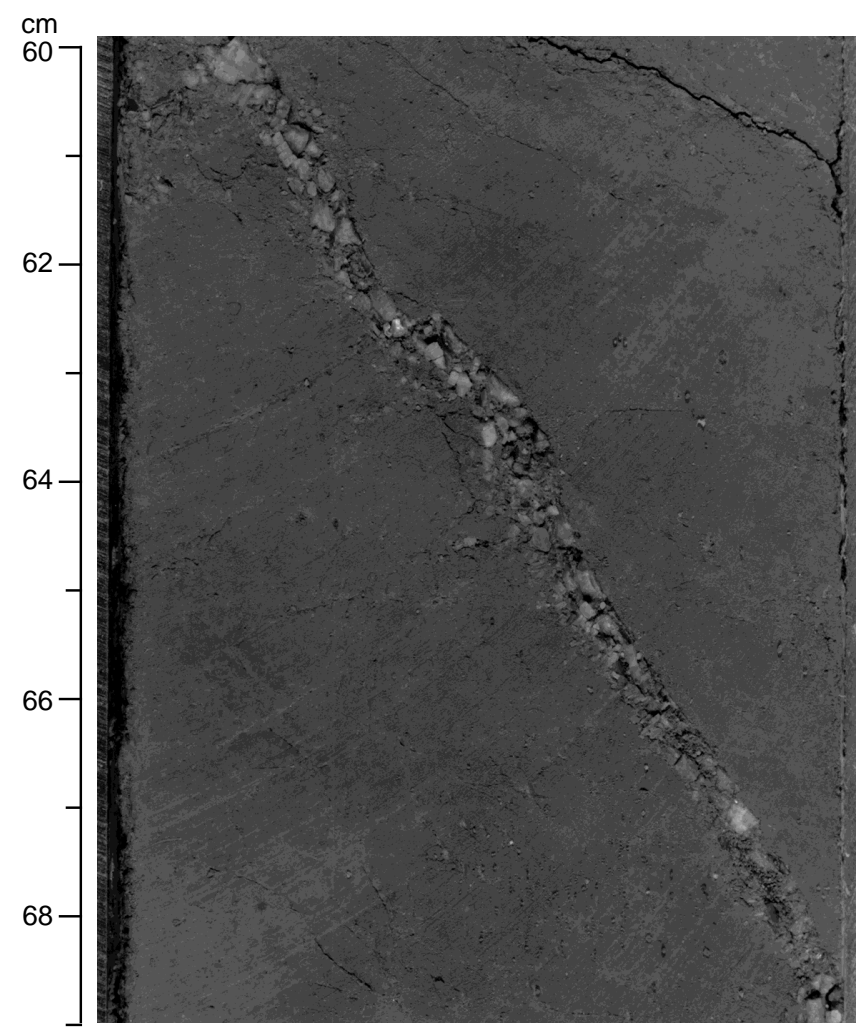

Figure 74 . White to pale gray anhydrite vein cutting indurated gray claystone and dismembered by drilling, Subunit IIC (interval 169-1035A-6H-5, 60-69 $\mathrm{cm})$.

examinations, epidote comprises $47 \%$ of the rock, forming yellowish green patches distributed throughout a hydrothermally altered mudstone containing disseminated pyrrhotite, pyrite, and anhydrite.

At a microscopic scale, the epidote occurs as disseminated euhedra in the sedimentary matrix. Examination of Sample 169-1035H$17 \mathrm{R}-1,27-31 \mathrm{~cm}$, in thin section indicates that epidote forms granular to prismatic crystals that are dispersed throughout altered and sulfide mineralized sediment, but are more concentrated in relict sedimentary layers. Sphalerite intergrown with epidote is lighter colored in transmitted light than the typical Site 1035 sphalerite, presumably because of preferential partitioning of iron into epidote. In sulfideveined sediment from Hole 1035H (thin section, Sample 169-1035H$17 \mathrm{R}-1,48-51 \mathrm{~cm}$ ), epidote forms large clots interstitial to sphalerite.

\section{Pyrite}

Pyrite does not form a well-defined alteration facies, because it is ubiquitously associated with diagenetically and hydrothermally altered rocks from Middle Valley (e.g., Leybourne and Goodfellow, 1994). For example, diagenetic pyrite commonly occurs in carbonate concretions, where it probably formed during coupled sulfate reduction-organic carbon oxidation. Pyrite is also enriched in hydrothermally altered sediments in Subunits IC and IIC, where it commonly forms euhedral crystals disseminated throughout the host sediments and sedimentary rocks.

Pyrite in altered sediments occurs as (1) homogeneously disseminated cubes, (2) concretions up to several centimeters in diameter (e.g., interval 169-1035D-5H-3, 70-75 cm), (3) impregnations that fill open spaces in turbiditic siltstone and sandstone, and (4) narrow veinlets that crosscut sedimentary rocks. Pyrite abundance is highly variable and ranges from absent to several volume percent. Because the content of diagenetic sulfides is typically $<0.2 \%$ for unaltered Middle Valley sediment (Goodfellow and Peter, 1994), sulfide con- 


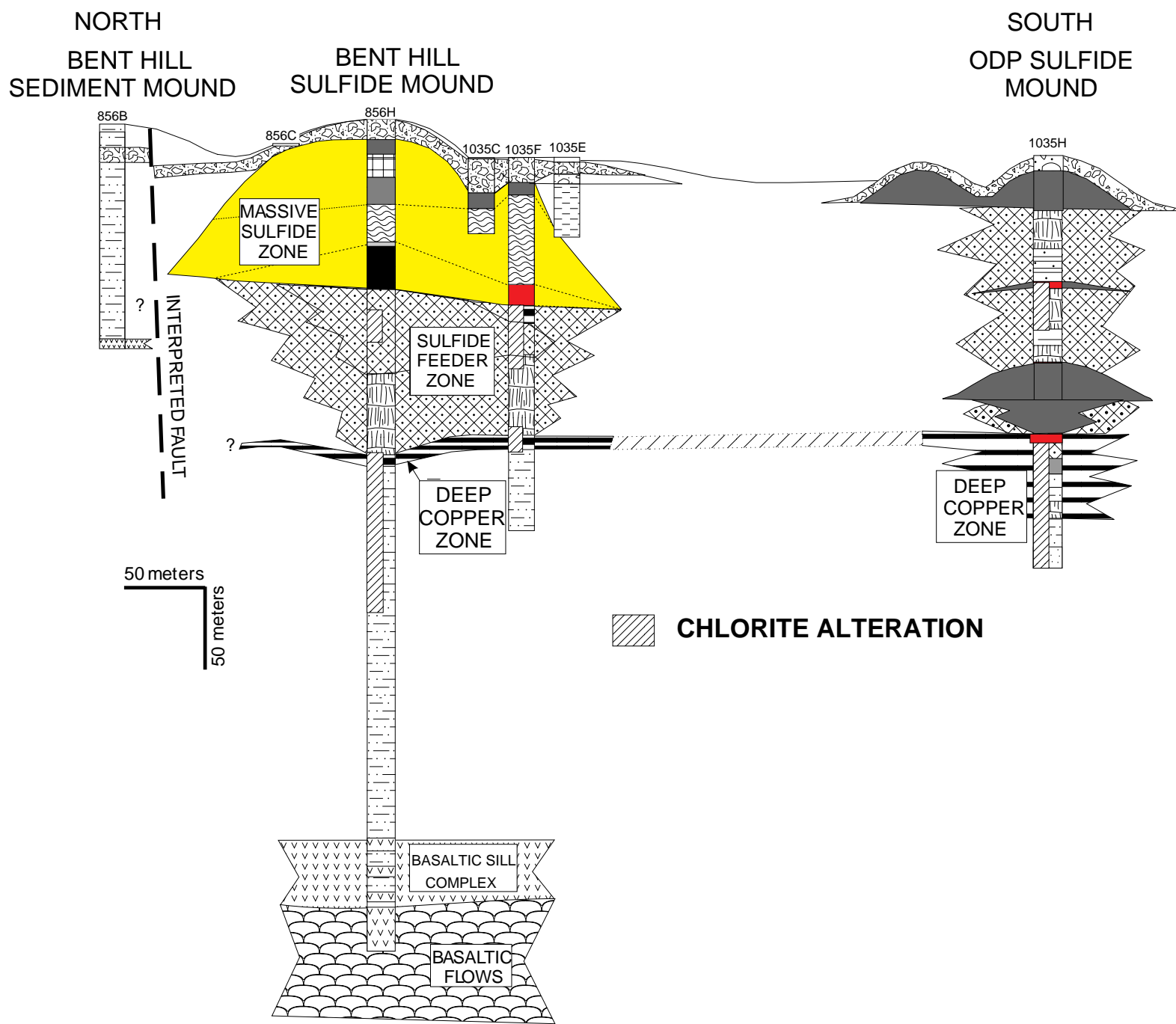

Figure 75. North-south cross section of the BHMS deposit and ODP Mound showing the distribution of chlorite based on core descriptions, X-ray diffraction, and microscopic analysis.

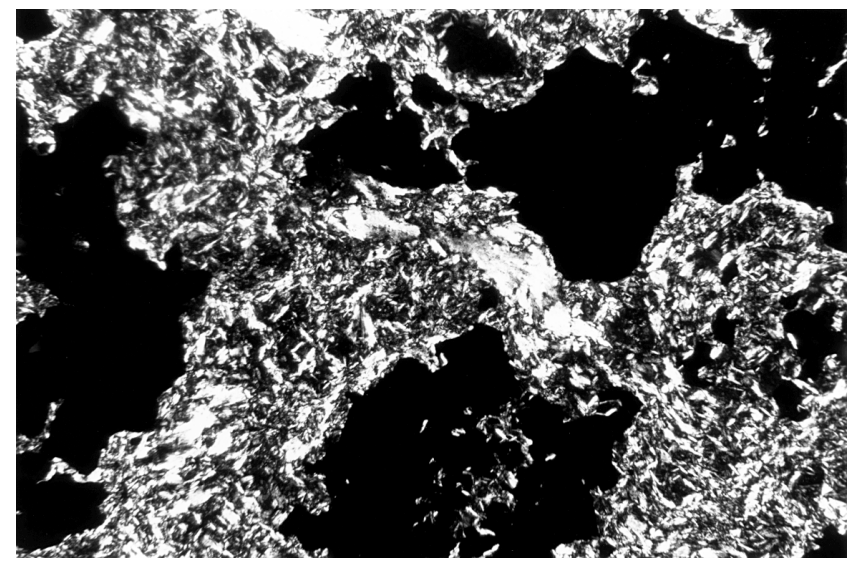

Figure 76. Photomicrograph of fibrous magnesium-rich chlorite associated with isocubanite (black), sulfide-banded zone (Subunit VIC; interval 169$856 \mathrm{H}-31 \mathrm{R}-2,1-5 \mathrm{~cm} ; 2.5 \times$; transmitted and plane polarized light). tents greater than this indicate that hydrothermal sulfides have been introduced. This interpretation is supported by sulfur isotope compositions for pyrite in hydrothermally altered sediments and sedimentary rocks recovered during Leg 139 (Zierenberg, 1994; Zierenberg et al., 1994a), that show overprinting of diagenetic pyrite by isotopically heavy hydrothermal pyrite.

\section{Discussion and Conclusions}

The type, form, and distribution of hydrothermal alteration minerals at the Bent Hill and ODP sulfide deposits have important implications for the hydrothermal system that generated the massive sulfide deposits.

1. The BHMS deposit upflow zone is texturally, mineralogically, and chemically zoned from a highly altered, fractured, and veined inner core consisting of sulfides-quartz-chlorite to moderately and weakly altered sediments consisting of anhydrite followed outward by carbonate on the margins of the hydrothermal system.

2. The textural and mineralogical zonation about the Bent Hill upflow zone is consistent with precipitation from upward-flowing and outward-flowing hydrothermal fluid that mixed with en- 
NORTH

BENT HILL BENT HILL SEDIMENT MOUND SULFIDE MOUND

\section{SOUTH}

ODP SULFIDE

MOUND

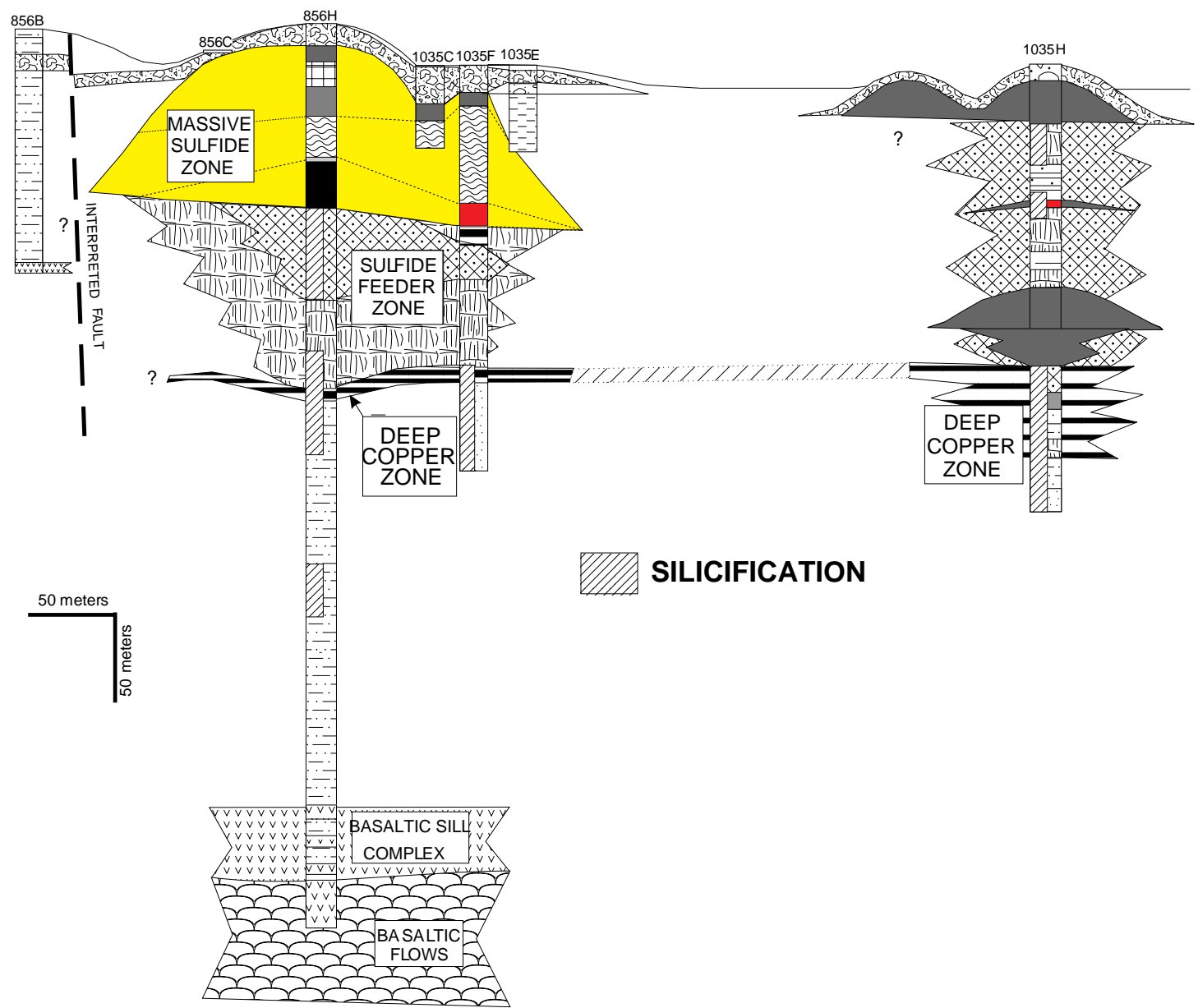

Figure 77. North-south cross section of the BHMS deposit and ODP Mound showing the distribution of silicification based on core descriptions, X-ray diffraction, and microscopic analysis.

trained and heated seawater. The inner core assemblages can be interpreted as products from reactions occurring between sediments and end-member hydrothermal fluid, whereas the surrounding alteration zones formed by the reaction of sediments with chemically evolved hydrothermal fluids and mixing with heated seawater, as indicated by the presence of anhydrite.

3. The local hydrology within zones of fluid upflow is probably complex because of the low cross-strata permeability of unaltered sediments, the highly variable permeabilities from the core to the margins of the conduit, and temporal variability in permeability caused by filling of fractures by hydrothermal minerals following hydraulic cracking (see "Structural Geology" section, this chapter). During periods of unrestricted fluid discharge in the central sulfide feeder zone, seawater was probably entrained into the discharge zone, resulting in the formation of authigenic Mg-rich silicates and anhydrite. Clogging of fluid pathways by mineral precipitation may have forced fluids laterally along permeable turbidites, producing widespread alteration that surrounds the sulfide feeder zone. Sealing of the upflow zone may have occurred episodically, and the seal may have been breached intermittently as indicated by the presence of crackseal veins (see "Sulfide Mineralization: Sulfide Feeder Zone" section, this chapter). The direction of lateral flow could have alternated from outward-flowing to inward-flowing fluids. A changing hydrologic regime may account for the overprinting of Mg-rich minerals and anhydrite (molds) by high-temperature phases such as chlorite and quartz, and the formation of lower temperature minerals in fractures (e.g., anhydrite) that crosscut higher temperature assemblages such as sulfides and silicified sediments.

4. The morphology and mineralogy of the DCZ, and its association with silicified sediments, suggest that this zone probably represents a stratabound, hydrothermal fluid-flow zone that cooled conductively as fluids migrated away from the central upflow zone.

\section{SULFIDE MINERALIZATION: SULFIDE GEOCHEMISTRY}

Thirty-one samples of massive and semi-massive sulfide (Unit V), clastic sulfide (Unit III), and feeder zone sulfide (Unit VI) were selected from the BHMS deposit and from the ODP Mound. The samples were digested aboard ship (see "Explanatory Notes," chapter, this volume) and analyzed for total $S$ by elemental analyzer (EA) and for $\mathrm{Cu}, \mathrm{Zn}, \mathrm{Pb}$, and $\mathrm{Fe}$ by atomic absorption spectrophotometry (AAS). The shipboard metal and sulfur analysis program was carried out to obtain a preliminary picture of the range and maxima of metal 


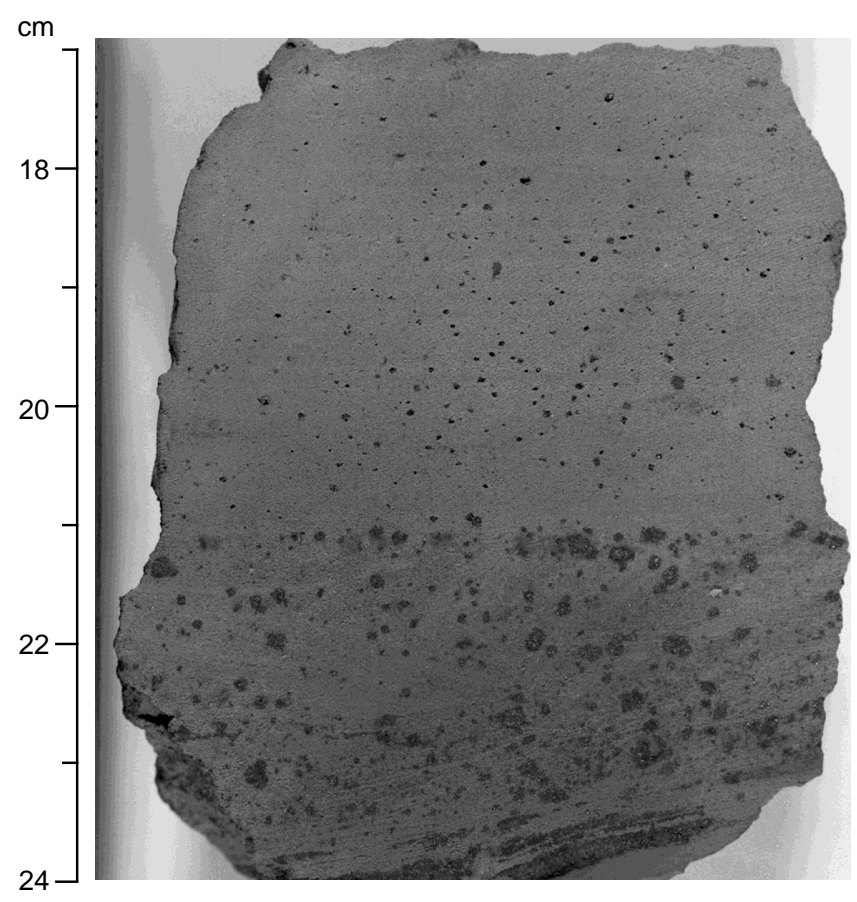

Figure 78. Siltstone with disseminated isocubanite surrounded by medium gray silicification halos (interval 169-1035H-24R-1, 17-24 cm). grades and of metal ratios for comparison to ancient, economic mineral deposits. These spot analyses cannot be used to calculate true metal grades, because they require continuous sampling of intervals. The samples chosen, however, are representative of the different styles of mineralization and confirm visual estimates of $\mathrm{Cu}$ and $\mathrm{Zn}$ abundances. These preliminary analyses thus permit discussion of metal zonation in the massive sulfides and feeder zones and allow some conclusions to be drawn with regard to fluid-flow pathways and metal depositing processes.

\section{Results}

The results of the shipboard metal and sulfur analyses for Hole $856 \mathrm{H}$ (Leg 169) and for Holes 1035A through $1035 \mathrm{H}$ are summarized in Table 12.

\section{Bent Hill Massive Sulfide Deposit}

The BHMS deposit is a relatively simple deposit with a single upper lens of massive sulfide that is at least $94.3 \mathrm{~m}$ thick (Fig. 7). This is underlain by a feeder zone that is $99.7 \mathrm{~m}$ thick. The average of 54 shipboard analyses of Bent Hill massive sulfide samples from Legs 139 and 169 (Davis, Mottl, Fisher, et al., 1992; Table 12) is $1.2 \mathrm{wt} \%$ $\mathrm{Zn}$ and $0.5 \mathrm{wt} \% \mathrm{Cu}$. High values are $6.1 \mathrm{wt} \% \mathrm{Zn}$ and $1.6 \mathrm{wt} \% \mathrm{Cu}$. In general, this deposit is dominated by pyrite and pyrrhotite, and consequently, base metal concentrations are relatively low. The average of eight analyses from the BHMS feeder zone, however, is $0.3 \mathrm{wt} \%$ $\mathrm{Zn}$ and $5.9 \mathrm{wt} \% \mathrm{Cu}$. These $\mathrm{Cu}$ concentrations, if representative, indicate that a major $\mathrm{Cu}$ resource is present underlying the relatively low grade massive sulfide subunits of the BHMS deposit. $\mathrm{Pb}$ averages

Table 12. Metal and sulfur content of mineralized samples, Bent Hill and ODP sulfide mounds.

\begin{tabular}{|c|c|c|c|c|c|c|c|c|c|}
\hline $\begin{array}{l}\text { Core, section, } \\
\text { interval }(\mathrm{cm})\end{array}$ & $\begin{array}{l}\text { Rock } \\
\text { piece }\end{array}$ & $\begin{array}{l}\text { Depth } \\
\text { (mbsf) }\end{array}$ & Subunit & Sample description & $\underset{(w t \%)}{S}$ & $\begin{array}{c}\mathrm{Fe} \\
(\mathrm{wt} \%)\end{array}$ & $\begin{array}{c}\mathrm{Zn} \\
(\mathrm{wt} \%)\end{array}$ & $\begin{array}{c}\mathrm{Cu} \\
(\mathrm{wt} \%)\end{array}$ & $\begin{array}{c}\mathrm{Pb} \\
(\mathrm{ppm})\end{array}$ \\
\hline \multicolumn{10}{|c|}{$\begin{array}{l}\text { Bent Hill Sulfide Mound: } \\
169-856 \mathrm{H}-\end{array}$} \\
\hline 19R-1, 14-15 & 3 & 93.94 & VA & Massive sulfide & 40.98 & 29.4 & 0.09 & 0.81 & 76.9 \\
\hline $19 \mathrm{R}-1,57-58$ & 9 & 94.37 & VA & Massive sulfide & 48.82 & 29.7 & 0.4 & 0.41 & 90.7 \\
\hline 19R-1, 57-58 DUP & 9 & 94.37 & VA & Massive sulfide & 48.82 & 25.5 & 0.39 & 0.64 & 83.7 \\
\hline $21 \mathrm{R}-1,53-54$ & $5 \mathrm{~A}$ & 113.93 & VIA & Sulfide-veined sediment & 38.46 & 24.8 & 0.35 & 5.2 & 60 \\
\hline $22 \mathrm{R}-1,134-135$ & $16 \mathrm{~B}$ & 118.44 & VIA & Sulfide-veined sediment & 46.03 & 27.3 & 0.13 & 3.2 & 66 \\
\hline 22R-2, 92-93 & 11 & 119.52 & VIA & Sulfide-veined sediment & 44.72 & 23.4 & 0.51 & 14.8 & 60 \\
\hline $25 \mathrm{R}-1,7-8$ & & 143.37 & VIA & Sulfide-veined sediment & 47.05 & 24.1 & 0.28 & 2.92 & 61.3 \\
\hline 25R-1, 7-8 DUP & & 143.37 & VIA & Sulfide-veined sediment & 47.05 & 27.3 & 0.28 & 3.05 & 60.8 \\
\hline 31R-1, 91-92 & 12 & 201.91 & VIC & Sulfide banded/impregnated sediment & 34.69 & 20.8 & 0.14 & 16.1 & 46.4 \\
\hline \multicolumn{10}{|l|}{$169-1035 \mathrm{~A}-$} \\
\hline $1 \mathrm{H}-5,106-107$ & & 7.06 & III & Clastic sulfide & 45.12 & 23.4 & 3.6 & 0.38 & 729 \\
\hline $2 \mathrm{H}-1,122-122$ & & 8.72 & III & Clastic sulfide & 28.06 & 25.5 & 0.93 & 0.48 & 262 \\
\hline \multicolumn{10}{|l|}{ 169-1035C- } \\
\hline $2 \mathrm{H}-1,96-97$ & & 6.06 & III & Clastic sulfide & 28.40 & 24.2 & 1.4 & 0.45 & 372 \\
\hline $5 X-1,6-19$ & & 39.36 & VD & Massive vuggy pyrite & $>55$ & 21.6 & 0.15 & 0.07 & 111 \\
\hline \multicolumn{10}{|l|}{ 169-1035D- } \\
\hline 7X-CC, 8-9 & & 48.11 & VD & Massive vuggy pyrite & $>55$ & 21.4 & 0.73 & 0.09 & 288 \\
\hline $9 X-1,25-30$ & 2B & 61.05 & VD & Massive vuggy pyrite with sphalerite & 59.84 & 17.9 & 2.7 & 0.24 & 170 \\
\hline $10 X-1,80-84$ & & 67.3 & VIA & Sulfide-veined sediment & 44.57 & 26.7 & 0.19 & 0.46 & 54.3 \\
\hline \multicolumn{10}{|l|}{$169-1035 \mathrm{E}-$} \\
\hline 2H-2, 97-99 & & 9.95 & III & Clastic sulfide & 32.66 & 21.4 & 1.4 & 0.47 & 334 \\
\hline \multicolumn{10}{|l|}{$169-1035 \mathrm{~F}-$} \\
\hline 4R-1, 36-38 & 4D & 32.46 & VD & Massive vuggy pyrite & 53.43 & 16.1 & 5.2 & 0.06 & 96.6 \\
\hline 5R-2, 134-137 & 22 & 44.47 & VD & Massive vuggy pyrite; channelway & 59.22 & 18.3 & 0.05 & 0.66 & 125 \\
\hline $7 \mathrm{R}-1,3-4$ & 1 & 61.03 & VD & Massive vuggy pyrite; channelway & 58.45 & 18.2 & 0.38 & 0.03 & 231 \\
\hline $8 \mathrm{R}-1,48-52$ & 8 & 71.08 & VB & Massive pyrite + sphalerite & 57.95 & 16.4 & 6.14 & 0.51 & 341 \\
\hline $11 \mathrm{R}-1,29-34$ & 4 & 99.99 & VIA & Sulfide-veined sediment & 36.23 & 25.4 & 0.39 & 1.48 & 73.7 \\
\hline \multicolumn{10}{|l|}{ 169-1035G- } \\
\hline 2R-1, 60-64 & 10 & 45 & VD & Massive vuggy pyrite & 57.03 & 15.6 & 0.03 & 0.03 & 187 \\
\hline \multicolumn{10}{|l|}{ ODP Mound: } \\
\hline $2 \mathrm{R}-1,32-34$ & \multicolumn{3}{|c|}{$169-1035 \mathrm{H}-$} & Massive pyrite breccia with hematite & 46.66 & 13.6 & 2.9 & 0.48 & 211 \\
\hline $9 \mathrm{R}-1,34-38$ & 8 & 74.94 & $\mathrm{VC}$ & Massive pyrrhotite + sphalerite & 28.96 & 11.2 & 46 & 0.49 & 136 \\
\hline $16 \mathrm{R}-1,44-48$ & 9 & 133.04 & $\mathrm{VC}$ & Massive sphalerite + pyrrhotite & 36.73 & 10.4 & 48 & 0.18 & 90.1 \\
\hline 16R-2, 122-126 & 18 & 135.32 & $\mathrm{VC}$ & Massive sphalerite + pyrrhotite + magnetite & 34.51 & 19.7 & 5.4 & 0.12 & 107 \\
\hline $17 \mathrm{R}-3,60-64$ & 9 & 145.82 & $\mathrm{VC}$ & Massive sphalerite + pyrrhotite & 29.34 & 8.9 & 51 & 0.16 & 174 \\
\hline $17 \mathrm{R}-3,137-140$ & 17B & 146.59 & $\mathrm{VC}$ & Coarse-grained pyrite with sphalerite & 43.10 & 21.2 & 3.2 & 0.62 & 83.2 \\
\hline 19R-1, 58-62 & 12 & 162.08 & VIC & $\mathrm{Cu}-\mathrm{Fe}$-sulfide in banded sediment & 36.36 & 27 & 0.23 & 8.01 & 71.4 \\
\hline 21R-1, 94-99 & 19 & 181.64 & VIC & $\mathrm{Cu}$-Fe-sulfide impregnating sediments & 25.21 & 20.2 & 0.19 & 16.6 & 53.8 \\
\hline
\end{tabular}

Note: DUP = duplicate 
$180 \mathrm{ppm}$ in the BHMS and is highest ( $730 \mathrm{ppm})$ in clastic sulfides (Unit III) from the upper zones.

\section{ODP Mound Sulfides}

The ODP Mound is a diverse and highly heterogeneous deposit (Fig. 14) with at least three massive sulfide zones (Unit V), each underlain by a feeder zone (Unit VI). For the eight samples analyzed, the average $\mathrm{Zn}$ content is $19.6 \mathrm{wt} \%$, and the average $\mathrm{Cu}$ content is 3.3 $\mathrm{wt} \%$, but the variances are very large. $\mathrm{Zn}$ in massive sulfide ranges up to $51 \mathrm{wt} \%$, and $\mathrm{Cu}$, which is highest in the feeder zone, ranges up to $16.6 \mathrm{wt} \%$. Pb in the ODP Mound averages $132 \mathrm{ppm}$. Considering the thickness of the massive sulfide zones- $19.1 \mathrm{~m}, 0.5 \mathrm{~m}$, and 38.6 $\mathrm{m}$ from top to bottom, respectively (Fig. 14; Table 8)-the high Zn values suggest a considerable amount of metal if these zones are laterally extensive. $\mathrm{Cu}$ is most enriched in the 49.2-m-thick feeder zone (Unit VI) below the lowermost massive sulfide (Fig. 14; Table 9). The two analyses of $\mathrm{Cu}$ from this zone (Table 12; 8.0 and $16.6 \mathrm{wt} \%$ ), plus visual core descriptions and thin section petrographic observations, suggest that the $\mathrm{Cu}$ values in this interval are likely to be similar to or above average for the samples from this deposit of $3.3 \%$.

\section{Discussion}

\section{Metal Zoning}

Composite vertical metal and sulfur profiles through the BHMS deposit, based on AAS and EA data from Holes $856 \mathrm{H}$ and 1035A through $1035 \mathrm{G}$, indicate a zoning of metals within the deposit (Fig. 79). Based on these data, $\mathrm{Cu}$ is significantly enriched in the feeder zone (Unit VI), especially in the base of the feeder zone in the sulfidebanded sediments (Subunit VIC) of the DCZ. Cu enrichment also occurs near the top of the feeder zone where veining becomes intense. Although $\mathrm{Zn}$ concentrations are generally low in the BHMS, the highest concentrations are present in the massive sulfide deposit, especially in the vuggy pyrite zone from Holes 1035D and 1035F (Subunit VD) and the upper Zone (Subunit VB). Pb is a trace element throughout, but concentrations are higher in the uppermost unit of clastic sulfides (Unit III). Pb concentrations also are higher in the vuggy pyrite zones, especially in Holes $1035 \mathrm{D}$ and $1035 \mathrm{~F}$, on the eastern and southern peripheral margins of the deposit.

In general, these zoning patterns agree with the known solubility behavior of $\mathrm{Cu}, \mathrm{Zn}$, and $\mathrm{Pb}$ in chloride solutions with respect to sulfide formation along a cooling trend (Johnson et al., 1992; Seyfried et al., 1991; Shanks and Bischoff, 1977). The BHMS metal zoning suggests that ascending fluids precipitated $\mathrm{Cu}$ first, because of conductive cooling or fluid mixing in the feeder zone, then $\mathrm{Zn}$ and finally $\mathrm{Pb}$ as cooling progressed. There is extensive textural evidence of "zone refining" within the massive mound, and the precipitation mechanisms and flow patterns are complex. The early deposition of pyrrhotite-sphalerite-chalcopyrite as chimneys is followed by the recrystallization and addition of pyrrhotite to chimney rubble to form compact, fine-grained massive sulfide. The postulated zone refining process is probably enhanced during the replacement of the early pyrrhotite by pyrite. As sulfides that formed near the mound surface are buried, continued hydrothermal circulation leads to pyritization, liberating base metals that are transported from the main feeder conduits and redeposited in other portions of the massive sulfide. The metal zonation is the result of the time and space integrated thermal gradients related to fluid flow. $\mathrm{Cu}, \mathrm{Zn}$, and $\mathrm{Pb}$ chloride complexing and sulfide solubility control metal precipitation. Even in the ODP Mound (Hole 1035H), the deep zinc-rich massive sulfide zone overlies the copper-rich feeder zone.

\section{Comparison to Sediment-Hosted, Volcanic-Associated Ancient Deposits}

$\mathrm{Cu}-\mathrm{Fe}-\mathrm{Zn}$ and $\mathrm{Cu}-\mathrm{Pb}-\mathrm{Zn}$ plots (Fig. 80) for Middle Valley sulfide deposits at Bent Hill (Holes 856 and 1035A through 1035G) and ODP Mound (Hole 1035H) clearly indicate that these are $\mathrm{Pb}$-poor,

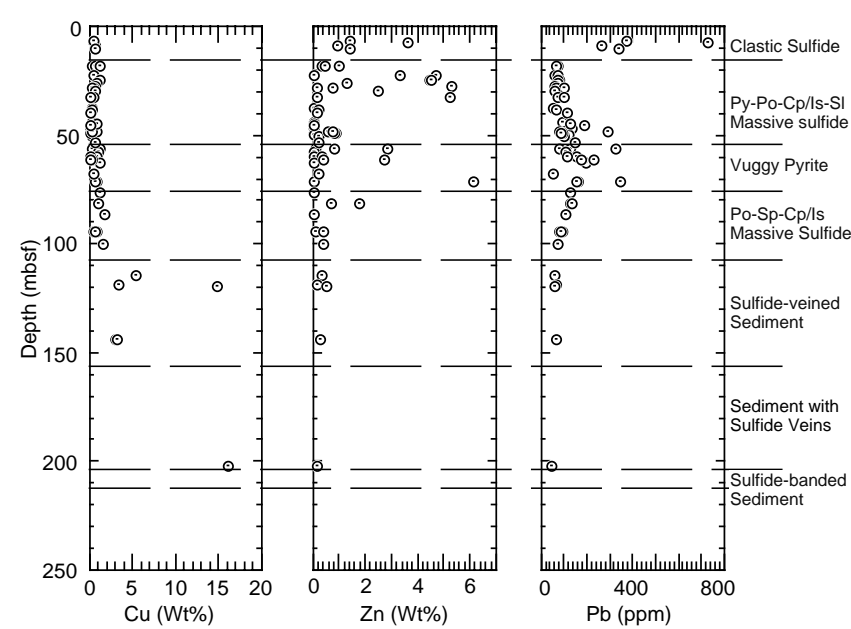

Figure 79. Vertical zoning of $\mathrm{Cu}, \mathrm{Zn}, \mathrm{Pb}$, and $\mathrm{S}$ from Hole $856 \mathrm{H}$ (including Leg 139 data) and Holes 1035A through 1035G in the Bent Hill area, Middle Valley. Data from all holes are plotted vs. depth (mbsf) without correction for seafloor topography. Data show $\mathrm{Cu}$ enrichment in the feeder zone, $\mathrm{Zn}$ enrichment in the central and upper portions of the massive sulfide, and $\mathrm{Pb}$ enrichment in the uppermost part of the massive and clastic sulfides.

Fe-rich, $\mathrm{Cu}$-Zn massive sulfide deposits with metal ratios similar to many ancient Besshi Type deposits (Slack, 1995). Despite the limited database from shipboard analyses, the metal ratio plots are likely to be representative of the BHMS and ODP Mound deposits. The relative variations of $\mathrm{Cu}-\mathrm{Fe}-\mathrm{Zn}$ show the extremely $\mathrm{Zn}$-rich nature of the massive sulfide from ODP Mound (Hole $1035 \mathrm{H})$ and the $\mathrm{Cu}$-rich nature of the feeder zones of both deposits. The $\mathrm{Cu}-\mathrm{Pb}-\mathrm{Zn}$ plot (with $\mathrm{Pb}$ $\times 10$ to expand the field) indicates that there is a range of sulfide types, from extremely $\mathrm{Zn}$ rich to extremely $\mathrm{Cu}$ rich. This is typical of Besshi Type deposits (Peter, 1992; Slack, 1995). A first approximation of the horizontal distribution of $\mathrm{Zn}$ in the BHMS can also be gained from the $\mathrm{Cu}-\mathrm{Pb}-\mathrm{Zn}$ plot; $\mathrm{Zn}$-rich samples are from the vuggy pyrite zones in Holes 1035D and 1035F, to the east and south of the BHMS, suggesting $\mathrm{Zn}$ enrichment in peripheral parts of the BHMS.

\section{Metal Sources}

Volcanic-associated massive sulfide deposits related to midocean ridge basalts (MORBs) have very low $\mathrm{Pb}$ caused by the low $\mathrm{Pb}$ contents of basalts and seawater. Deposits with significant sedimentary components in the source rocks (or muds) typically have higher $\mathrm{Pb}$ contents than volcanic settings. However, $\mathrm{Pb}$ in Middle Valley sulfides ranges up to $\sim 730 \mathrm{ppm}$, averages $180 \mathrm{ppm}$, and is low compared to deposits from unsedimented ridges (Fouquet et al., 1993). The $\mathrm{Pb}$ values also are very low compared to some other Besshi Type and modern sedimented-ridge deposits (Koski et al., 1994), suggesting that the sedimentary protolith in Middle Valley is lead poor or unreactive with respect to lead. Goodfellow and Peter (1994) report that $\mathrm{Pb}$ from unaltered Middle Valley sediments from Hole 857A is mostly below their detection limit of $20 \mathrm{ppm}$. Helium isotope studies (Stuart et al., 1994b) and lead isotope analyses (Goodfellow and Franklin, 1993) show evidence of limited sediment reaction.

\section{IGNEOUS PETROLOGY AND GEOCHEMISTRY}

Igneous and altered igneous rocks from the Bent Hill sites drilled during Leg 169 (Hole 856 H and Site 1035) are summarized on the basis of occurrence, hand specimen, and thin section descriptions, and preliminary geochemical studies. Igneous rocks were recovered from many holes drilled in Middle Valley during Leg 139, and shipboard 

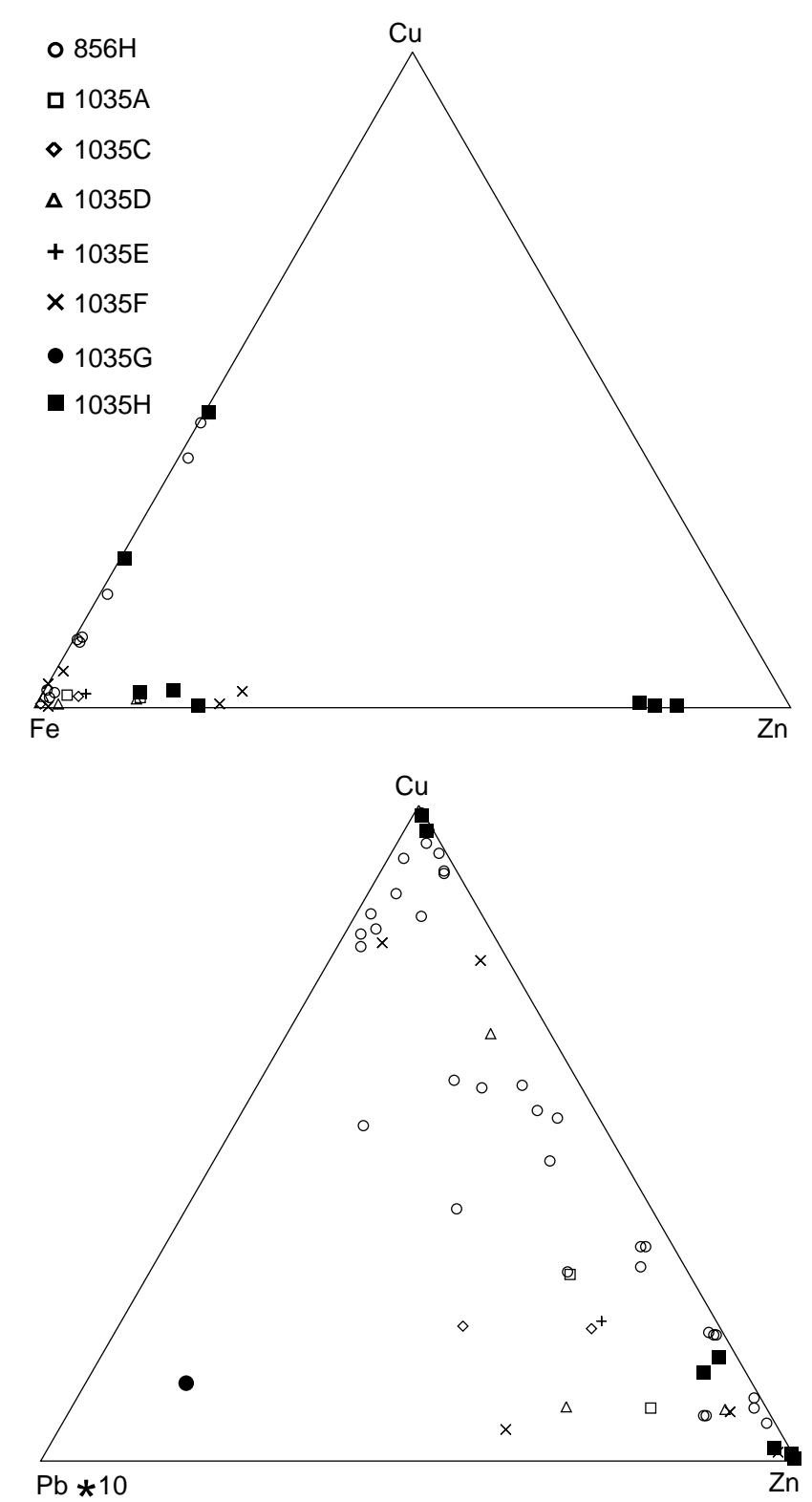

Figure 80. Triangular plots of $\mathrm{Cu}-\mathrm{Fe}-\mathrm{Zn}$ and $\mathrm{Cu}-\mathrm{Pb}-\mathrm{Zn}$ for Middle Valley sulfide deposits at Bent Hill (Holes 856H, and 1035A through 1035G) and ODP Mound (Hole 1035H). The data clearly indicate that these are Pb-poor, Fe-rich, $\mathrm{Cu}-\mathrm{Zn}$ massive sulfide deposits with metal ratios similar to many ancient Besshi Type deposits (Slack, 1995).

and shore-based studies (Davis, Mottl, Fisher, et al., 1992; Stakes and Franklin, 1994) provide the main basis for comparison with materials recovered during this leg. This chapter comprises three main parts: (1) petrography (macroscopic and microscopic); (2) whole-rock geochemistry; and (3) simple estimates of the thermal budgets of sill intrusion on the formation of massive sulfide deposits.

\section{Petrography and Occurrence of Igneous Rocks at Bent Hill}

Igneous rocks with intercalated sediment were recovered from Hole $856 \mathrm{H}$ at depths of $432-471 \mathrm{mbsf}$, where igneous basement was penetrated. Small quantities of mafic igneous material were also recovered from the Bent Hill site during Leg 139 (Davis, Mottl, Fisher, et al., 1992) in Holes 856A and 856B, including a 5- to 8-m-thick sill or dike of altered, olivine-phyric basalt with a primitive chemical composition that was intersected at 62.3 mbsf (Davis, Mottl, Fisher, et al., 1992; Stakes and Franklin, 1994). Holes 856A and 856B intersected basaltic sills at 115.7 mbsf and 121.7 mbsf respectively, but the thickness of these sills is unconstrained. No igneous rocks were recovered from Site 1035, even though a number of holes $(1035 \mathrm{~F}$, $1035 \mathrm{G}$, and $1035 \mathrm{H})$ penetrated to depths at which basaltic flows or sills may have been anticipated (total depths of 224, 208, and 247 mbsf, respectively). The absence of igneous rocks from these holes and from the upper $400 \mathrm{~m}$ of Hole $856 \mathrm{H}$ indicates that the units do not extend to the south under the BHMS deposit, and suggests that shallow-level, igneous intrusive rocks are present only beneath the recently uplifted Bent Hill.

The presence of highly altered rocks, possibly basaltic sills or hydrothermally recrystallized sedimentary rocks, was tentatively identified in some of the pieces recovered in Hole 1035H (interval 1691035H-16R-3, $17 \mathrm{~cm}$, to $169-1035 \mathrm{H}-17 \mathrm{R}-3,15 \mathrm{~cm}$; $136 \mathrm{mbsf}$ to $145 \mathrm{mbsf}$ ). Petrographic and textural observations could not provide an unambiguous confirmation of original rock type, but geochemical analyses conclusively show that the rocks had a sedimentary protolith.

\section{Igneous Rocks from Hole $856 \mathrm{H}$}

Basaltic Sill/Sediment Complex in Hole $856 H$ (Lithologic Unit VII) Interval 169-856H-55R-1, $0 \mathrm{~cm}$, to 169-856H-62R-1, $83 \mathrm{~cm}$; 432$471 \mathrm{mbsf}$

The first igneous rocks in Hole $856 \mathrm{H}$ were encountered at a depth of 432 mbsf (interval 169-856H-55R-1, $0 \mathrm{~cm}$ ). Five igneous units (Subunits VIIA-VIIE), separated by fine-grained sedimentary rocks, were recognized from the cores recovered, as well as changes in drilling penetration rates, down to a depth of 471 mbsf (interval 169$856 \mathrm{H}-62 \mathrm{R}-1,85 \mathrm{~cm}$ ). Below this depth, to the bottom of Hole $586 \mathrm{H}$ at $500 \mathrm{mbsf}$, only igneous material was recovered, indicating that the volcanic basement (Unit VIII) may have been reached. The intercalated igneous bodies are interpreted to be sills, but the possibility that these units could be flows, separated by sediment, cannot be discounted. FMS logs indicate the presence of pillow lava structures in the lowermost sill (Subunit VIIE), and some physical parameters (thermal conductivity) have affinities to rocks from the basement section of Hole $856 \mathrm{H}$ (see "Downhole Measurements" and "Physical Properties" sections, this chapter). This suggests that the lowermost "sill" may have erupted onto the seafloor as a flow. The average recovery of rock from the sill-sediment complex is low $(\sim 16 \%)$, with higher recovery for the igneous materials than for the intruded sediments. Recovery is higher within the underlying basement rocks $(\sim 26 \%)$ and is similar to other penetrations into the upper oceanic crust (e.g., Holes 504B and 896A; Alt, Kinoshita, Stokking, et al., 1993).

The occurrence and nature of igneous materials from Hole $856 \mathrm{H}$ are described and summarized in Table 13 and Figure 81. The recognition of individual sills was based on the presence of oriented pieces of basalt that were separated from other igneous materials by one or more oriented pieces of sedimentary rock. The core recovery allows for thickness variation in the sills from a minimum of $0.3 \mathrm{~m}$ (Subunit VIIB) to a maximum possible thickness of $7.2 \mathrm{~m}$ (Subunit VIIE). No regular progression of sill thickness with depth is apparent.

The sills are typically separated by thin intervals of greenish gray mudstone (Sections 169-856H-56R-1 through 169-856H-57R-1) and interbedded mudstone and siltstone (Sections 169-856H-60R-1 through 169-856H-62R-1). The presence of ilmenite along bedding planes in the sedimentary rocks near the sediment-sill contact zones records the thermal influence of the over- and underlying sills. Sill emplacement also has resulted in quartz and pyrrhotite mineralization along fractures in the uppermost mudstone. Primary sedimentary structures preserved in the sediments include parallel-laminations, cross-laminations, and graded beds with scoured basal contacts. Pink, euhedral titanite is present with drusy quartz, chlorite, and pyrrhotite on a number of subvertical fracture surfaces cutting the finely crosslaminated mudstone that separates sills VIID and VIIE (Fig. 81; Ta- 
Table 13. Summary of igneous units, Hole $856 \mathrm{H}$.

\begin{tabular}{|c|c|c|c|c|c|c|c|c|c|}
\hline Unit & Sill & & $\begin{array}{l}\text { Core, section, } \\
\text { interval }(\mathrm{cm})\end{array}$ & Piece & $\begin{array}{l}\text { Curated } \\
\text { depth } \\
(\mathrm{mbsf})\end{array}$ & $\begin{array}{l}\text { Curated } \\
\text { thickness } \\
\quad(\mathrm{m})\end{array}$ & $\begin{array}{l}\text { Expanded } \\
\text { depth } \\
(\mathrm{mbsf})\end{array}$ & $\begin{array}{l}\text { Expanded } \\
\text { thickness } \\
\text { (m) }\end{array}$ & Description \\
\hline \multirow[t]{2}{*}{ VII } & A & Top & $55 \mathrm{R}-1,0$ & 1 & 431.7 & & 431.7 & & \multirow[t]{2}{*}{$\begin{array}{l}\text { Altered, greenish gray, microcrystalline basalt to medium-grained } \\
\text { diabase. Upper and lower chilled margins. }\end{array}$} \\
\hline & & Bottom & $56 \mathrm{R}-1,35$ & 5 & 434.5 & 2.8 & 436.2 & 4.5 & \\
\hline \multirow[t]{2}{*}{ VII } & B & Top & $57 \mathrm{R}-1,50$ & 11 & 441.7 & & 447.0 & & \multirow[t]{2}{*}{$\begin{array}{l}\text { Highly altered, greenish gray, plagioclase-phyric fine-grained } \\
\text { basalt. Upper chilled margin. }\end{array}$} \\
\hline & & Bottom & $57 \mathrm{R}-1,92$ & 18 & 442.0 & 0.3 & 450.6 & 3.6 & \\
\hline VII & $\mathrm{C}$ & $\begin{array}{l}\text { Top } \\
\text { Bottom }\end{array}$ & $\begin{array}{l}58 \mathrm{R}-1,33 \\
58 \mathrm{R}-1,103\end{array}$ & $\begin{array}{r}6 \\
16\end{array}$ & $\begin{array}{l}451.3 \\
451.7\end{array}$ & 0.4 & $\begin{array}{l}454.3 \\
459.9\end{array}$ & 5.6 & Altered, greenish gray, fine to medium-grained basalt/diabase. \\
\hline VII & $\mathrm{D}$ & $\begin{array}{l}\text { Top } \\
\text { Bottom }\end{array}$ & $\begin{array}{l}59 \mathrm{R}-1,30 \\
59 \mathrm{R}-1,87\end{array}$ & $\begin{array}{r}5 \\
13\end{array}$ & $\begin{array}{l}460.9 \\
461.4\end{array}$ & 0.5 & $\begin{array}{l}461.7 \\
463.6\end{array}$ & 1.9 & Very highly altered, pinkish brown microcrystalline basalt. \\
\hline \multirow[t]{2}{*}{ VII } & $\mathrm{E}$ & Top & $59 \mathrm{R}-1,123$ & 17 & 461.7 & & 464.9 & & \multirow[t]{2}{*}{$\begin{array}{l}\text { Altered, fine- to medium-grained greenish gray, pyroxene-phyric } \\
\text { basalt/diabase. Upper and lower chilled margins. }\end{array}$} \\
\hline & & Bottom & $61 \mathrm{R}-1,90$ & 10 & 468.9 & 7.2 & 469.2 & 4.3 & \\
\hline \multirow[t]{2}{*}{ VIII } & Basement & Top & $62 \mathrm{R}-1,85$ & 15 & 471.0 & & 476.9 & & \multirow[t]{2}{*}{$\begin{array}{l}\text { Moderately to completely altered greenish gray, cryptocrystalline } \\
\text { basalt to medium-grained diabase. Common chloritized } \\
\text { quenched zones and altered volcanic glass. }\end{array}$} \\
\hline & & End of hole & $65 \mathrm{R}-2,103$ & 11 & 500.0 & 29.0 & 500.0 & 23.1 & \\
\hline
\end{tabular}

ble 13). Limited mobilization of titanium is commonly assumed under conditions of hydrothermal fluid-rock interaction. Assuming that the fluids responsible for this titanite reacted with the basaltic sills, this indicates that $\mathrm{Ti}$ has been transported for distances in excess of tens of centimeters. The sediments from the Bent Hill area have abundant titanium $\left(\mathrm{TiO}_{2} \sim 0.6-0.8 \mathrm{wt} \%\right.$; Goodfellow and Peter, 1994), and

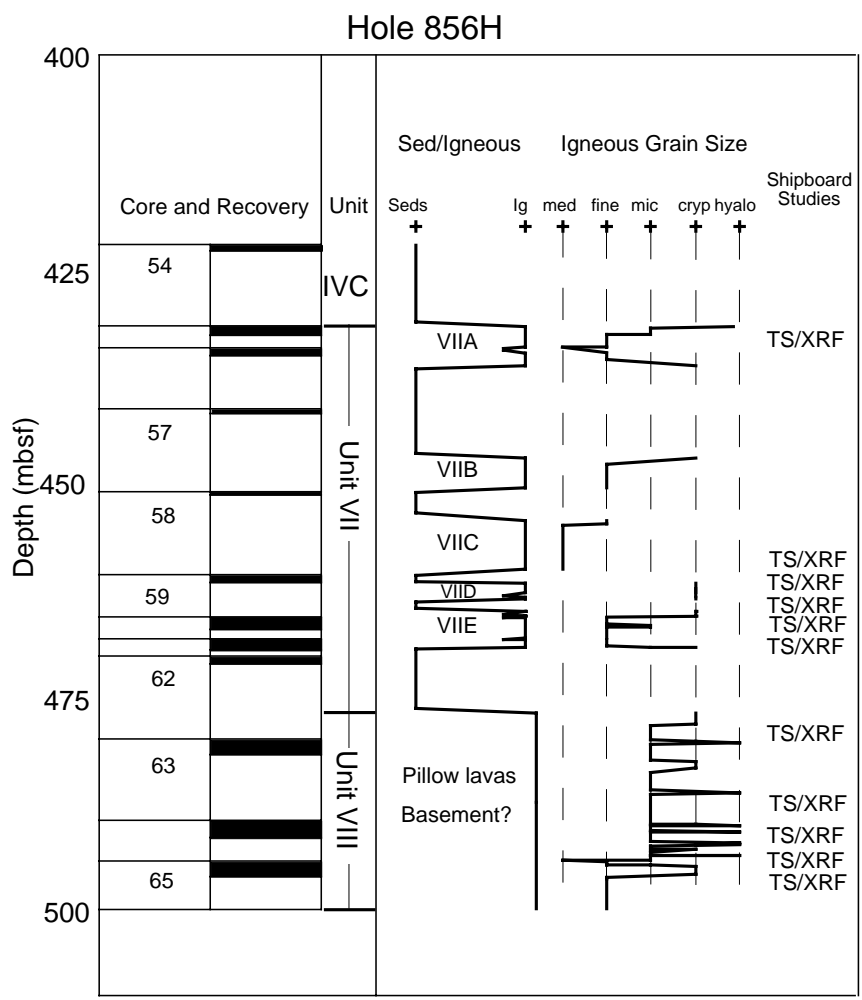

Figure 81. Stratigraphic section of the lower portion of Hole $856 \mathrm{H}$ showing the distribution and recovery of igneous and sedimentary rocks. Expanded depths are used to illustrate the intrusion of the five igneous sills into sediments (Subunits VIIA-VIIE). Grain size of the igneous rocks are plotted for each piece; finer grained basalts are present at one or both of the margins of all the sills and at the top of the subaqueously erupted pillow flows (Unit VIII). The location of samples taken for shipboard XRF analysis and thin section description are shown. titanium-bearing sedimentary phases in the intercalated sediments are recrystallized to titanite. The intensity of local Ti-mobilization in some of the basaltic sills strongly suggests that highly altered igneous rocks are the source of titanium in these fractures.

The sills are aphyric to highly clinopyroxene and/or sparsely plagioclase-phyric basalts. The rocks are cryptocrystalline, particularly in the thinner units or near the chilled margins, to medium grained (see Fig. 81). Finer grained margins are present in all five sills, and both the upper and lower chilled margin were commonly recovered. Coarser grained sill interiors appear diabasic in hand specimen and display variolitic to subophitic textures (Fig. 82).

Hydrothermal alteration of the sills is moderate to complete. The basaltic groundmass is commonly bleached by alteration or tinted green because of chloritization. Even in relatively unaltered pieces, irregular patches $(<1 \mathrm{~cm})$ of chlorite replacing groundmass are

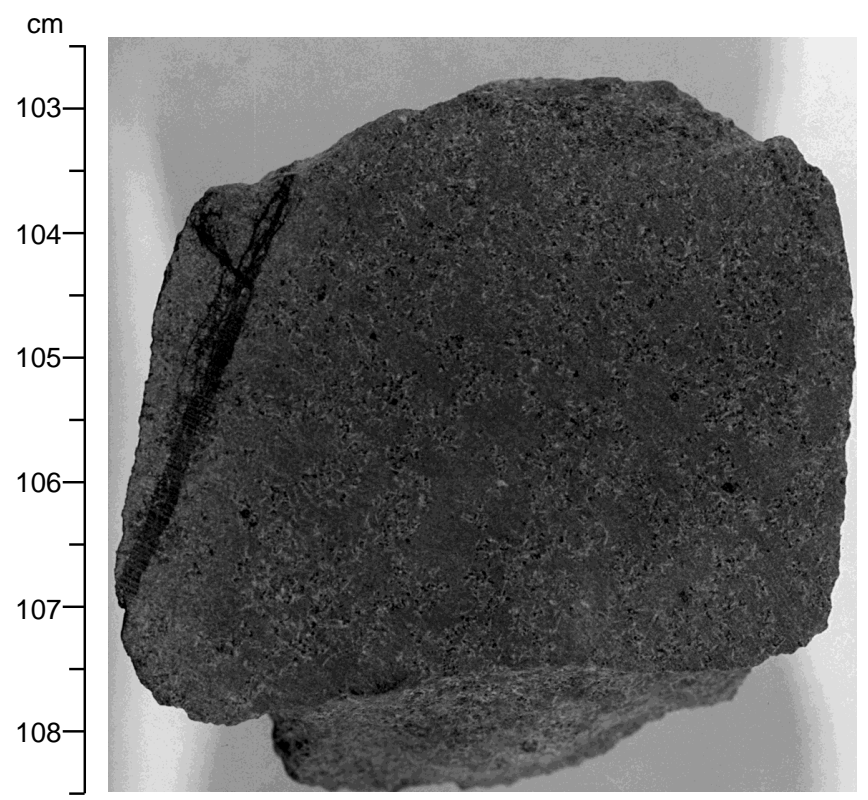

Figure 82. Interval 169-856H-55R-1, 102.5-108.5 cm, Unit VII. Purple-gray basalt with a patchy microcrystalline to fine-grained groundmass resulting in a mottled appearance. The subvertical vein is filled by chlorite >> quartz and has a $\approx 5$-mm lighter colored halo. 


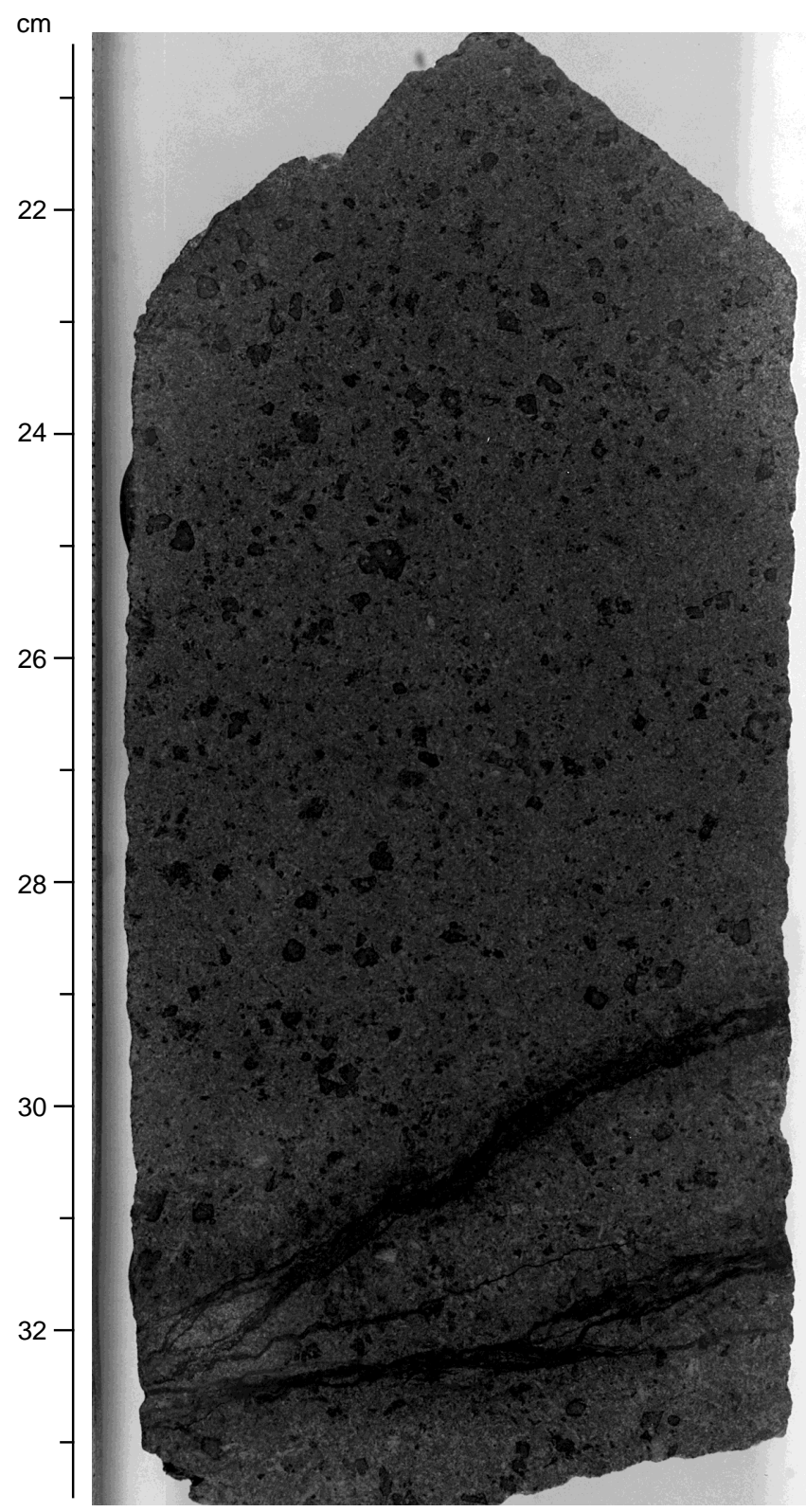

Figure 83. Interval 169-856H-61R-1, 20.5-33.5 cm, Unit VII. Fine-grained pyroxene-phyric basalt. The euhedral to subhedral clinopyroxene has been pseudomorphically replaced by chlorite. The groundmass comprises a variolitic to subophitic intergrowth of altered plagioclase and clinopyroxene. Sample cut by subhorizontal chlorite veins.

present. Sulfide minerals (chalcopyrite, pyrrhotite, and pyrite) are sparsely disseminated in the groundmass of some sills and occur in crosscutting veins.

Phenocrysts, where present, are often completely replaced. Chalcopyrite locally pseudomorphs plagioclase microlites. Clinopyroxene is pseudomorphically replaced by chlorite, commonly with fine dark rims and a more massive interior, and plagioclase is altered to pale clay minerals and/or chlorite (Fig. 83). Rounded, 0.5- to 2-mm chlorite-filled spheres, most probably filled vesicles, are present in some fine- to medium-grained basalts (e.g., interval 169-856H-60R$1,4-70 \mathrm{~cm}$ ). The presence of vesicles within these basalts suggests that the magma was volatile rich, indicating high $\mathrm{CO}_{2}$ contents (c.f.

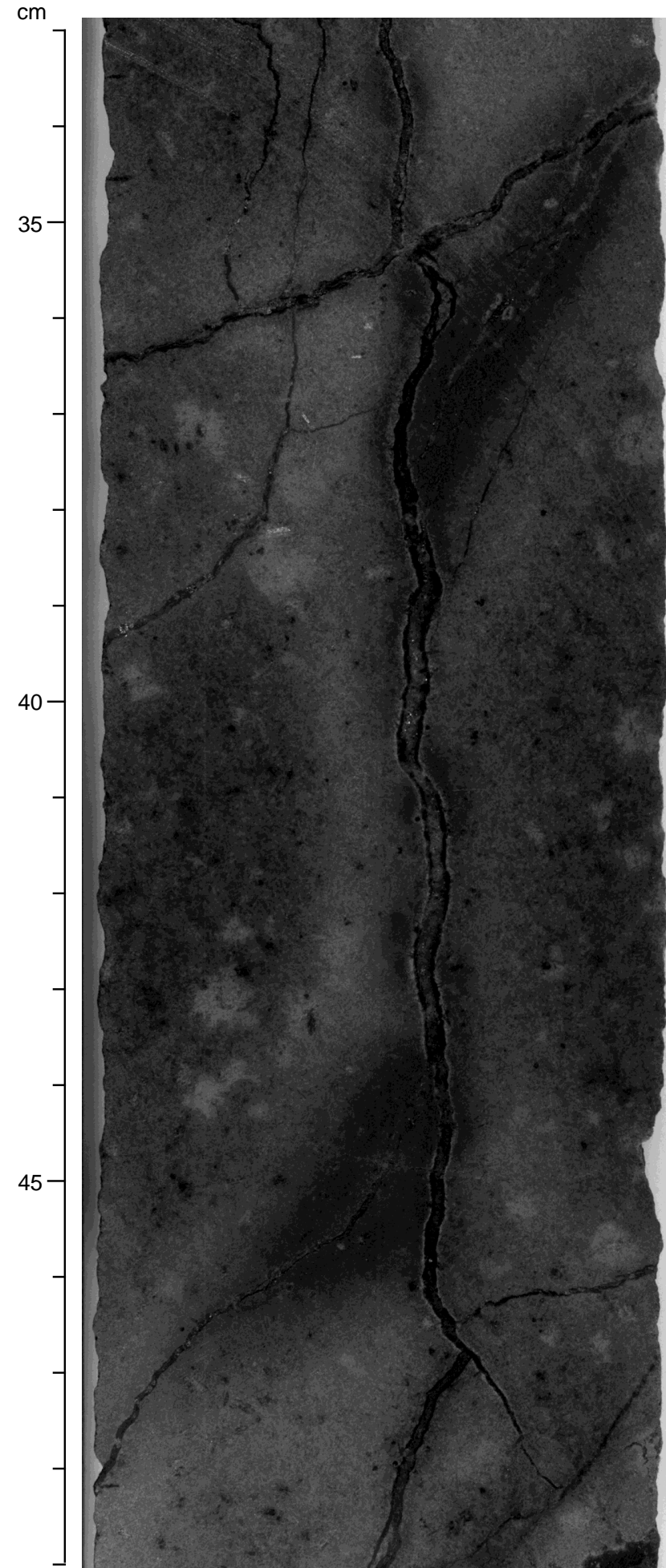

Figure 84. Interval 169-856H-65R-1, 33-49 cm, Unit VIII. Fine-grained basalt from the igneous basement of Hole $856 \mathrm{H}$. Pyroxene phenocrysts are altered to chlorite, and groundmass is replaced by irregular patches $(<1 \mathrm{~cm})$ of lighter colored chlorite. The sample is crosscut by numerous irregular quartz + chalcopyrite veins with chloritic selvages and complex, multistage chloritic alteration halos. 


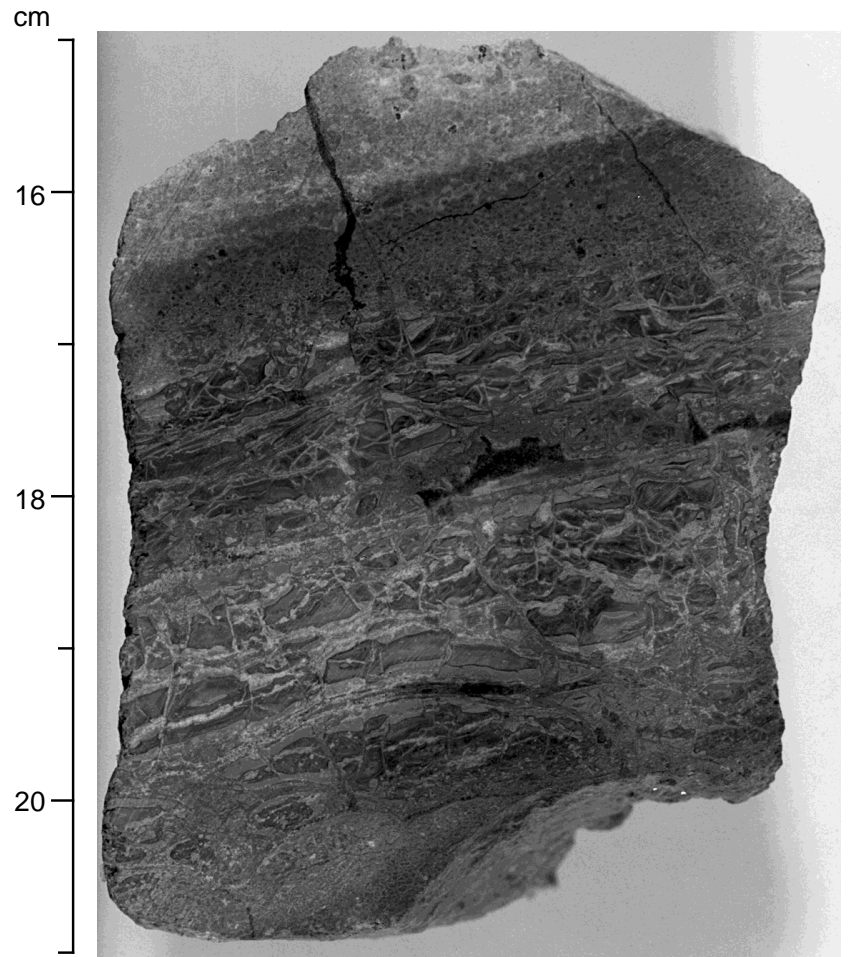

Figure 85. Interval 169-856H-63R-1, 15-21 cm, Unit VIII. Chloritized, glassy chilled margin. Altered glass fragments arranged in subhorizontal layers with conformable veins of quartz \pm sulfide. Cryptocrystalline basalt is present on either side of the glassy material.

N-MORB $\approx 0.2$ wt $\% \mathrm{H}_{2} \mathrm{O}$; Dixon et al., 1988; Michael, 1988). Chlorite-filled vesicles were also observed in the sills recovered from Site 857 during Leg 139 (Davis, Mottl, Fisher, et al., 1992).

The basalts are crosscut by numerous 0.1 - to 3 -mm chlorite \pm quartz \pm chalcopyrite \pm pyrrhotite \pm sphalerite \pm calcite \pm epidote veins. Chlorite is generally the earliest phase to have precipitated within these veins and commonly forms dark selvages along the margins of veins with siliceous interiors. Dark green chloritic alteration halos up to $2 \mathrm{~cm}$ wide are developed around many veins and at vein intersections.

\section{Pillow Basalts and Basaltic Flows from the Igneous Basement of} Hole 856H (Lithologic Unit VIII) Interval 169-856H-62R-1,85 cm, to $169-856 H-65 R-2,103 \mathrm{~cm}$; $471-500 \mathrm{mbsf}$

The deepest sedimentary rock in Hole $856 \mathrm{H}$ was recovered from a depth of $471 \mathrm{mbsf}$ (interval 169-856H-62R-1, $83 \mathrm{~cm}$ ). Below this, $\sim 29 \mathrm{~m}$ of volcanic rocks was penetrated (Table 13; Fig. 81). The rocks are moderately to highly altered, glassy to medium-grained, aphyric to sparsely pyroxene- and/or plagioclase-phyric basalts and are macroscopically similar to the igneous rocks that intrude the overlying sediments (Subunits VIIA-VIIE). Quartz + chlorite + sulfide veins with complex, multistage chloritic selvages and halos are common (Fig. 84).

Hyaloclastic material, completely altered to chlorite and disseminated sulfides and crosscut by quartz veins, was recovered in Cores 169-856H-63R and 64R (Figs. 85, 86). Chloritized, glassy chilled rims are present in both horizontal and subvertical orientations, suggesting the presence of pillow lavas (see "Downhole Measurements" section, this chapter). The presence of altered volcanic glass requires that these rocks erupted directly onto the ocean floor or intruded in the very shallow subsurface and were rapidly quenched by seawater.

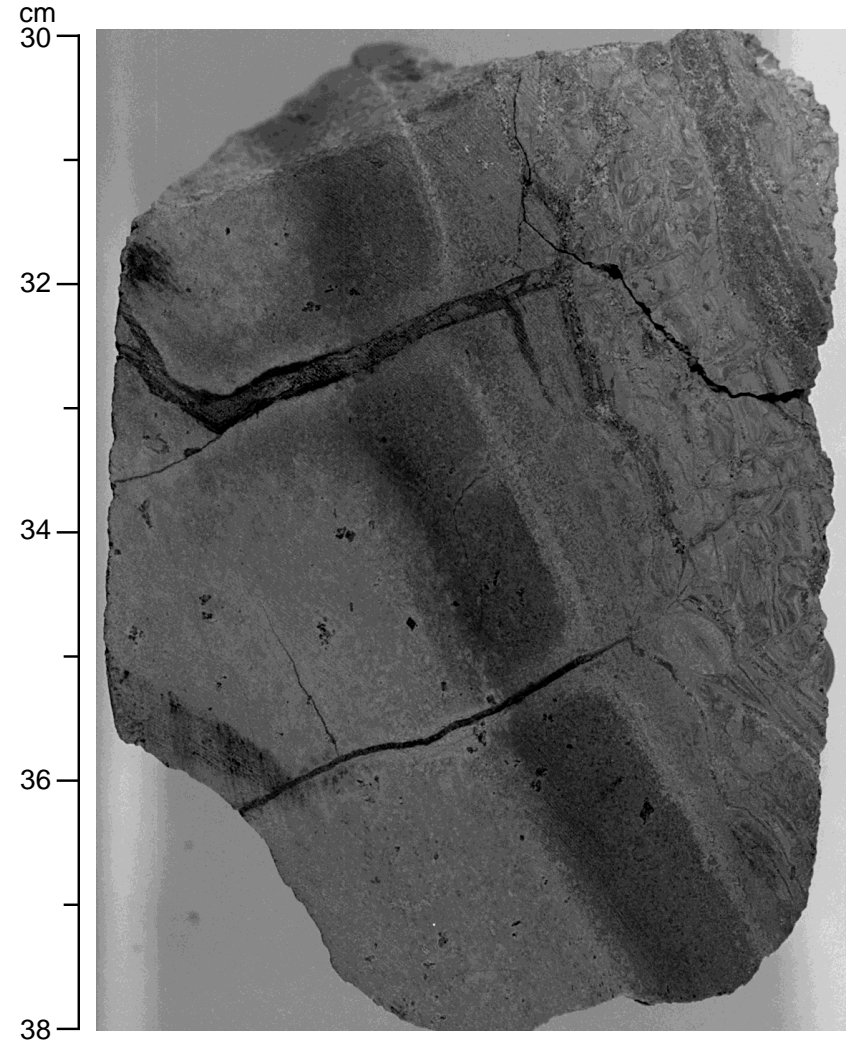

Figure 86. Interval 169-856H-64R-1, 30-38 cm, Unit VIII. Subvertically oriented chilled margin with a band of chloritized basaltic glass and a 2-cmwide chloritic halo replacing bleached microcrystalline basalt. The sample is crosscut by later stage quartz + chlorite + chalcopyrite veins. Chalcopyrite is abundant throughout the altered hyaloclastite in irregular shaped patches and as a fracture coating.

There was insufficient penetration in Hole $856 \mathrm{H}$ to establish whether these flows were erupted directly onto the basaltic oceanic crust and thus represent the uppermost basement rocks in Middle Valley, or if there are further sedimentary rocks at deeper levels.

In thin section, basalts from both the sediment-sill complex and the igneous basement are essentially indistinguishable; therefore, the petrographic highlights will be described together. Thin section descriptions of these rocks are summarized in Table 14. The igneous rocks recovered from Hole $856 \mathrm{H}$ are glassy to medium-grained, aphyric to moderately plagioclase, sparsely clinopyroxene-phyric basalts. Textures range from quenched or cryptocrystalline to subophitic/diabasic. Vesicles are generally absent or sparsely present, though some moderately vesicular rocks were recovered. Vesicles are subrounded to rounded, and completely filled by green clay minerals (Mg-smectite; commonly brown in thin section).

Fresh plagioclase phenocrysts are uncommon, though present in a number of samples. These phenocrysts are commonly zoned and occur as either laths or in acicular, "hopper-car" or open-box habits, particularly in porphyritic, quenched cryptocrystalline rocks (Fig. 87). Clinopyroxene is generally completely altered, though fresh pyroxene is rarely present in the fine to medium-grained rocks with subophitic textures. Relict traces of olivine phenocrysts are rarely present, altered to chlorite \pm clay minerals with isodiametric, serpentine-cell textures.

Alteration to secondary minerals is generally extensive to complete, though some of the fine- to medium-grained basalts are only slightly altered. Fresh plagioclase laths are commonly present in these rocks with subophitic to ophitic, unaltered clinopyroxene (Fig. 
Table 14. Summary of thin section descriptions, Hole $856 \mathrm{H}$.

\begin{tabular}{|c|c|c|c|c|c|c|c|}
\hline $\begin{array}{l}\text { Core, section } \\
\text { interval }(\mathrm{cm})\end{array}$ & $\begin{array}{c}\text { Unit/ } \\
\text { subunit }\end{array}$ & $\mathrm{XRF}$ & Rock name & Grain size & Texture & $\begin{array}{l}\text { Phenocrysts } \\
\text { (original \%) }\end{array}$ & Vesicles \\
\hline \multicolumn{8}{|l|}{$169-856 \mathrm{H}-$} \\
\hline $55 \mathrm{R}-1,22-26$ & VIIA & & Aphyric basalt & Fine & Subophitic to variolitic & None & None \\
\hline $55 \mathrm{R}-1,134-138$ & VIIA & $* * *$ & Aphyric basalt & Fine & Intersertal to subophitic & None & $2 \% \mathrm{Mg}$-smec \\
\hline $57 \mathrm{R}-1,76-80$ & VIIB & $* * *$ & Cpx-phyric basalt & Micro-crypto & Variolitic to intersertal & Cpx 5, Plg 1 & None \\
\hline $58 \mathrm{R}-1,88-95$ & VIIC & $* * *$ & Basalt & Med-fine & Intersertal to subophitic & & \\
\hline $59 \mathrm{R}-1,63-67$ & VIID & $* * *$ & Highly altered basalt & Crypto/glass & Porphyritic-variolitic & $\mathrm{Plg} 4, \mathrm{Cpx}<1$ & $1 \% \mathrm{Mg}$-smec \\
\hline $59 \mathrm{R}-1,138-143$ & VIIE & $* * *$ & Glassy, Plg-phyric basalt & Glassy to crypto & Microporphyritic-variolitic & Plg 15, Cpx 2 & $1 \% \mathrm{Mg}$-smec \\
\hline $60 \mathrm{R}-1,12-18$ & VIIE & **** & Vesicular, fine-grained basalt & Fine-micro & Intersertal & Aphyric, $\mathrm{Plg}<1, \mathrm{Cpx}<1$ & $10 \% \mathrm{Mg}$-smec, $\mathrm{Q}$ \\
\hline $60 \mathrm{R}-2,58-60$ & VIIE & $* * *$ & Diabase & Medium & Subophitic to ophitic & Plg 40, Cpx 35, Ol? 15 & \\
\hline $62 \mathrm{R}-1,120-124$ & VIIE & & Plg-cpx cryptocrystalline basalt & Crypto-glassy & Porphyritic-intersertal & Plg 3, Cpx 1 & None \\
\hline $63 \mathrm{R}-1,16-20$ & VIII & $* * *$ & Chloritized glassy pillow margin & Glassy & Hyaloclastic & $\mathrm{Plg}<1$ & $<1 \%$ \\
\hline $63 \mathrm{R}-1,127-130$ & VIII & & Crypto-aphyric basalt & Crypto-micro & Microvariolitic & $\mathrm{Cpx}<1, \mathrm{Plg}<1$ & $<1 \% \mathrm{Mg}$-smec \\
\hline $63 \mathrm{R}-2,65-70$ & VIII & $* * *$ & Sparsely Plg, Cpx basalt & Crypto-micro & Microintersertal & Plg $1, \mathrm{Cpx}<1, \mathrm{Ol} ?<1$ & \\
\hline $64 \mathrm{R}-2,9-11$ & VIII & $* * *$ & Sparsely Plg-phyric basalt & Crypto & Microporphyritic-intersertal & Plag 4, Cpx 1 & \\
\hline $65 \mathrm{R}-1,34-38$ & VIII & **** & Sparsely Plg-phyric basalt & Fine grained & Variolitic & $\mathrm{Plg} 5, \mathrm{Cpx}<1$ & $<1 \%$ \\
\hline $65 \mathrm{R}-2,10-13$ & VIII & $* * *$ & Sparsely Plg-phyric basalt & Fine grained & Subophitic, seriate & Plg 5 & \\
\hline
\end{tabular}

Notes: $\mathrm{Ch}=$ chlorite, $\mathrm{Q}=$ quartz, $\mathrm{Ab}=$ albite, $\mathrm{Ti}=$ titanite, $\mathrm{Po}=$ pyrrholite, $\mathrm{Il}=$ illmenite, $\mathrm{Ccp}=$ chalcopyrite, $\mathrm{Mg}$-smec $=$ magnesium smectite, $\mathrm{Cpx}=$ clinopyroxene, $\mathrm{Ol}=$ olivine, $\mathrm{Plg}$ $=$ plagioclase, $\mathrm{Ep}=$ epidote, $\mathrm{BnCly}=$ brown clay, act $=$ actinolite, $\mathrm{Cc}=$ calcite, and $\mathrm{Sp}=$ sphalerite. $* * *=\mathrm{XRF}$ analysis.

88). No fresh glass is preserved, and the mesostasis of all rocks is altered to a cryptocrystalline intergrowth of nearly indistinguishable quartz and chlorite with a dusting of ubiquitous titanite. Relict igneous texture is preserved in even highly altered samples by the pseudomorphic replacement of the plagioclase lath framework or radiating variolitic plagioclase fans by chlorite and quartz. Relict glassy or quenched textures are present in a number of samples, particularly from thin bodies in the sill-sediment complex. Shadows of the primary plumose or sheaf-spherical quench textures are mimicked by secondary minerals (quartz, chlorite, and titanite).

Numerous veins $(0.1-2 \mathrm{~mm})$ occur within the thin sections and are generally filled with chlorite \pm quartz \pm clay minerals. Some veins have well-developed alteration halos $(<1 \mathrm{~cm})$ in which the host rock is strongly chloritized or silicified. In rare examples, alteration is complete and centimeter-sized patches in which the primary igneous texture has been obliterated by recrystallization to equigranular quartz + chlorite are developed (e.g., Sample 169-856H-55R-1 [Piece $4,22-26 \mathrm{~cm}])$. Epidote and calcite are rarely present, generally in veins. Minor sulfide ( $« 1 \%$ pyrrhotite, chalcopyrite, pyrite, and sphalerite) is present in most samples, either in veins or halos or pseudomorphically replacing millimeter-sized plagioclase phenocrysts.

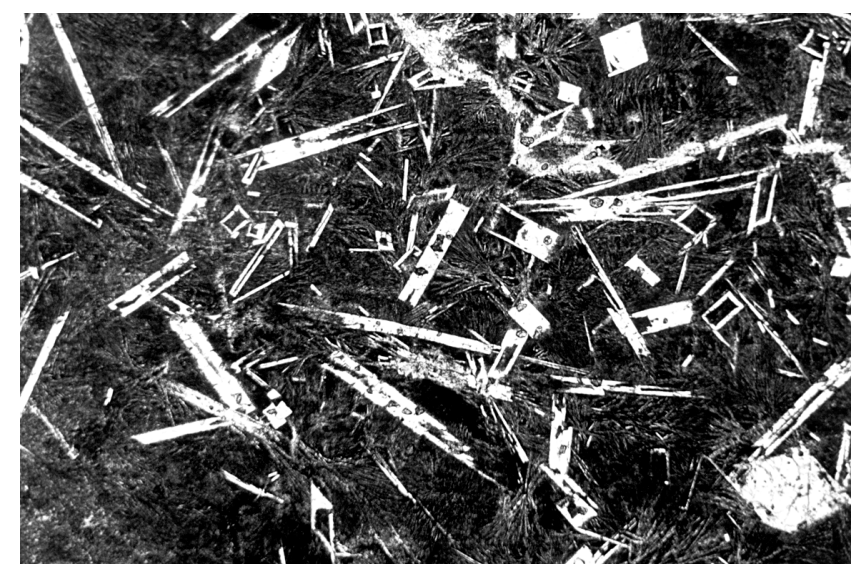

Figure 87. Photomicrograph of interval 169-856H-59R-1, 138-143 cm, showing plagioclase microphenocrysts with acicular, hopper-car, or boxy habits in a groundmass of chloritized glass. Relict plumose and sheaf-spherical quench textures are apparent (transmitted light; plane polarized light; field of view $=$ $4.6 \mathrm{~mm})$.
The mobility of titanium noted within sediments intercalated with the basaltic sills is also apparent within some basalts (e.g., Sample 169-856H-59R-1 [Piece 3A, 63-67 cm]). Coarse (up to $2 \mathrm{~mm}$ ), prismatic plagioclase phenocrysts and acicular feldspar laths within the groundmass are pseudomorphically replaced by large, euhedral grains of pinkish titanite ( \pm pyrrhotite), preserving the variolitic to porphyritic primary texture.

Hyaloclastic material with a variolitic chilled margin resembling an altered glassy pillow rind was recovered in Sample 169-856H63R-1 (Piece 4, 16-20 cm). The glass is fragmented into subhorizontal (to core), irregular zones and completely altered to chlorite. Internally, individual larger glassy shards are commonly siliceous. Altered glassy fragments are separated by subhorizontal, anastomosing $(0.5-1 \mathrm{~mm})$ veins of irregular, microgranular quartz, chlorite, epidote, and titanite (Fig. 89). Subhorizontal fractures, glass, and altered plagioclase phenocrysts are crosscut and slightly offset by narrow, $(<0.5 \mathrm{~mm})$ discontinuous, chlorite $>$ quartz-filled fractures. The upper portion of the slide shows a variolitic chilled margin of the host pillow. This region comprises coalesced, elliptical varioles flattened subparallel to the horizontal. Varioles become more common within the glassy fragments toward the top of the slide. Quenched varioles are commonly formed around plagioclase (micro-) phenocrysts (Fig. 90). These plagioclase grains are completely replaced by microgranular irregular quartz \pm chlorite \pm chalcopyrite \pm pyrite.

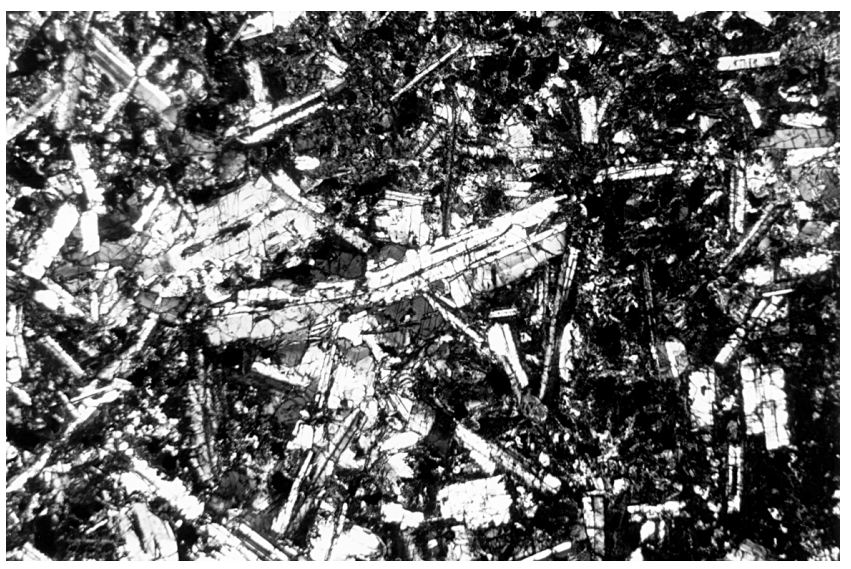

Figure 88. Photomicrograph of Sample 169-856H-60R-2, 58-60 cm. Fine grained plagioclase with subophitic clinopyroxene and altered mesostasis (transmitted light, cross-polarized light, field of view $=4.6 \mathrm{~mm}$ ). 
Table 14 (continued).

\begin{tabular}{|c|c|c|c|c|c|c|}
\hline $\begin{array}{l}\text { Core, section } \\
\text { interval }(\mathrm{cm})\end{array}$ & $\begin{array}{c}\text { Unit/ } \\
\text { subunit }\end{array}$ & XRF & Alteration & Alteration minerals & Opaques & Comments \\
\hline \multicolumn{7}{|l|}{$169-856 \mathrm{H}-$} \\
\hline $55 \mathrm{R}-1,22-26$ & VIIA & & Complete & $\mathrm{Ch}, \mathrm{Q} \pm \mathrm{Ab}, \mathrm{Ti}$ & Po, Il, Ccp & Ch vein, $\mathrm{Q}, \mathrm{Ch}, \mathrm{Ti}$ alteration patch \\
\hline $55 \mathrm{R}-1,134-138$ & VIIA & $* * *$ & Complete & $\mathrm{Q}, \mathrm{Ch}, \mathrm{Mg}$-smec, Ti & & Relict igneous texture \\
\hline $57 \mathrm{R}-1,76-80$ & VIIB & $* * *$ & Complete & $\mathrm{Ch}, \mathrm{Q} \pm \mathrm{Ab}$ & Il, Po & \\
\hline $58 \mathrm{R}-1,88-95$ & VIIC & $* * *$ & & & & \\
\hline $59 \mathrm{R}-1,63-67$ & VIID & $* * *$ & Complete & $\mathrm{Q}, \mathrm{Ch}, \mathrm{Ti}, \mathrm{Mg}$-smec, Ep & Po & Titanite after Plg phenocrysts \\
\hline $59 \mathrm{R}-1,138-143$ & VIIE & **** & Moderate & $\mathrm{Ch}, \mathrm{BnCly}$ & Ccp & Fresh Plg \\
\hline $60 \mathrm{R}-1,12-18$ & VIIE & $* * *$ & Complete & $\mathrm{Ch}, \mathrm{Q}, \mathrm{Ti}, \mathrm{Mg}$-smec & Po, Ccp & Mg-smectite, Ch, Q-veins \\
\hline $60 \mathrm{R}-2,58-60$ & VIIE & $* * *$ & Slight & $\mathrm{Q}, \mathrm{Ch}, \mathrm{Ti}$ & Po, Il & Spectacularly fresh \\
\hline $62 \mathrm{R}-1,120-124$ & VIIE & & High & $\mathrm{Ch}, \mathrm{Q}, \mathrm{Ti}, \mathrm{Mg}$-smec & & Fresh Plg phenocrysts \\
\hline $63 \mathrm{R}-1,16-20$ & VIII & **** & Complete & Ch, Q, Ep, Ti & Py, Ccp & Quenched varioles to glass \\
\hline $63 \mathrm{R}-1,127-130$ & VIII & & Complete & Q, Chl, BnCly, Ti & Po & $\mathrm{Q} \gg \mathrm{Ch}, \mathrm{Mg}$-smec vein \\
\hline $63 \mathrm{R}-2,65-70$ & VIII & **** & High & $\mathrm{Ch}, \mathrm{Q}, \mathrm{Ti}$ & & Fresh Plg \\
\hline $64 \mathrm{R}-2,9-11$ & VIII & **** & High & $\mathrm{Q}, \mathrm{Ch}, \mathrm{Mg}$-smec, Ti & Ccp & Some fresh Plg \\
\hline $65 \mathrm{R}-1,34-38$ & VIII & $* * *$ & Moderate-high & Ch(act), Q, Ti, Ep, Cc & Po, Ccp, Sp & Fresh Plg Q vein with Ch lining \\
\hline $65 \mathrm{R}-2,10-13$ & VIII & **** & Slight & $\mathrm{Ch}, \mathrm{Mg}$-smec, $\mathrm{Ti}$ & & Fresh Plg, fresh Cpx, fresh magnetite \\
\hline
\end{tabular}

\section{Whole-Rock Geochemistry of Basalt Rocks Recovered from Bent Hill, Leg 169}

A dozen samples, representative of the variation in occurrence, grain size, and texture observed in the igneous rocks recovered in Hole $856 \mathrm{H}$ during Leg 169 , were analyzed by XRF for their major oxide and trace element concentrations. Total sulfur was determined for all samples using the shipboard CNHS analyzer. Analytical results are reported in Table 15. At least one sample from each of the basaltic sills (Subunits VIIA-E) was taken as well as five samples from the basement flows. The uppermost sample of the basement that was analyzed is chloritized hyaloclastite. All samples have large loss on ignition (LOI; $\approx 1.5$ to $6.8 \mathrm{wt} \%$ ), indicating that there has been significant alteration and hydration of all igneous materials recovered in this hole. Two samples (Samples 169-856H-60R-2, 58-60 cm, and 169-856H-65R-2, 10-13 cm), from the base of sill VIIE and the deepest recovered basement respectively, have a relatively low LOI (2.74 and $1.51 \mathrm{wt} \%$, respectively), and the occurrence of primary mineral and phenocryst phases in these samples indicates that these intervals are less strongly altered and trend toward primary compositions. Both these samples are fine- to medium-grained basalts with subophitic to diabasic textures. The near holocrystalline basalts in Hole $856 \mathrm{H}$ are generally less altered than other igneous rocks that have significant mesostasis.

The downhole variations of major elements, Mg\#, LOI, and selected base metal concentrations ( $\mathrm{Zn}$ and $\mathrm{Cu}$ ) are shown in Fig. 91.

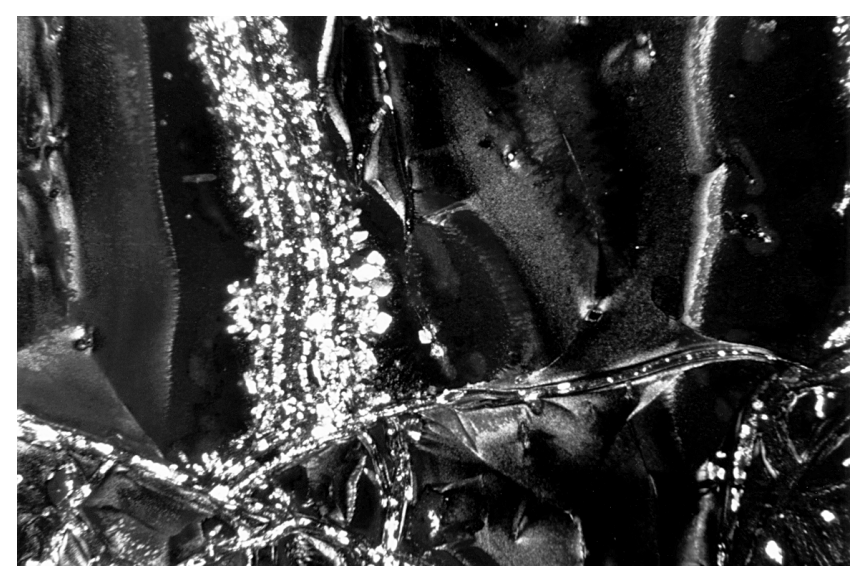

Figure 89. Photomicrograph of Sample 169-856H-63R-1, 16-20 cm. Chloritized glass fragments crosscut by veins of microgranular quartz, epidote, chlorite, and titanite (transmitted light, plane polarized light, field of view $=$ $4.6 \mathrm{~mm}$ ).
Approximate concentrations and ranges for average N-MORB are shown for comparison. There is strong variation in all chemical parameters downhole, and these variations are apparent for both rocks from the sills as well as in the underlying basement. One of the principal aims of the geochemical discussions that follow will be to elucidate which of, and to what extent, these variations are the result of primary magmatic fractionation and/or hydrothermal alteration.

Two main points are clear from Figure 91: (1) most major element concentrations are significantly different from average $\mathrm{N}$ MORB; and (2) Sample 169-856H-59R-1, 66-68 cm, recovered from sill Subunit VIID ( 0.5-1.9 m thickness), has an anomalous chemical composition and is extremely altered. $\mathrm{SiO}_{2}$ and $\mathrm{Al}_{2} \mathrm{O}_{3}$ are at or near typical concentrations for N-MORB for most analyses, although Sample 169-856H-59R-1, 66-68 cm, has low $\mathrm{SiO}_{2}$ and high $\mathrm{Al}_{2} \mathrm{O}_{3}$ contents. Regular downhole changes in $\mathrm{SiO}_{2}$ within the basement suggests that some igneous fractionation may be recorded within the volcanic pile, but these changes are inversely mimicked by LOI, indicating that hydration and alteration are the dominant processes affecting variations in whole rock chemistry. $\mathrm{TiO}_{2}, \mathrm{Fe}_{2} \mathrm{O}_{3}$, $\mathrm{MnO}, \mathrm{MgO}$, and $\mathrm{P}_{2} \mathrm{O}_{5}$ concentrations are high for all or most samples compared to average N-MORB. Titanium and iron concentrations are extreme for ocean floor basalts, with $\mathrm{TiO}_{2}$ and $\mathrm{Fe}_{2} \mathrm{O}_{3}$ contents of $>3 \mathrm{wt} \%$ and $>29 \mathrm{wt} \%$ in Sample 169-856H-59R-1, 66-68 cm. Very low concentrations of alkali $\left(\mathrm{Na}_{2} \mathrm{O}, \mathrm{K}_{2} \mathrm{O}\right.$, and $\left.\mathrm{Rb}\right)$ and alkali earth elements $(\mathrm{CaO}$ and $\mathrm{Sr})$ are present with sodium, potassium, and rubidium at or near the detection limit for XRF in many samples. The relatively unaltered basalts do have average N-MORB $\mathrm{CaO}$ contents,

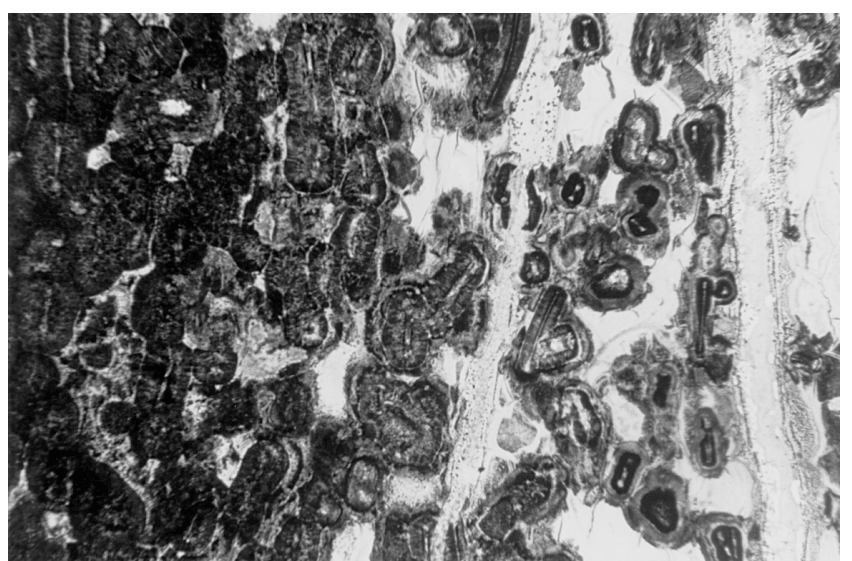

Figure 90. Photomicrograph of Sample 169-856H-63R-1, 16-20 cm. Transition from altered glass to coalesced varioles in a basaltic chilled margin (transmitted light; plane polarized light; field of view $=4.6 \mathrm{~mm}$ ). 
Table 15. Whole-rock geochemistry of basalts, Hole 856H, Bent Hill.

\begin{tabular}{|c|c|c|c|c|c|c|c|c|c|c|c|c|}
\hline Core, section: & $55 \mathrm{R}-1$ & $57 \mathrm{R}-1$ & $58 \mathrm{R}-1$ & $59 \mathrm{R}-1$ & $59 \mathrm{R}-1$ & $60 \mathrm{R}-1$ & $60 \mathrm{R}-2$ & $63 \mathrm{R}-1$ & $63 \mathrm{R}-2$ & $64 \mathrm{R}-2$ & $65 \mathrm{R}-1$ & $65 \mathrm{R}-2$ \\
\hline Interval (cm): & 134-138 & $76-80$ & $88-95$ & $66-68$ & $139-143$ & $12-18$ & $58-60$ & $16-20$ & $65-70$ & $9-11$ & $34-38$ & $10-13$ \\
\hline Piece: & 19 & 16 & 15 & 10 & 20 & $4 \mathrm{~A}$ & 6 & 4 & 12 & 1 & 4 & 1 \\
\hline Depth (mbsf): & 433.04 & 442.06 & 451.88 & 461.36 & 462.09 & 465.82 & 467.78 & 480.06 & 482.05 & 491.09 & 494.54 & 495.68 \\
\hline Location: & Sill-VIIA & Sill-VIIB & Sill-VIIC & Sill-VIID & Sill-VIIE & Sill-VIIE & Sill-VIIE & Basement & Basement & Basement & Basement & Basement \\
\hline \multicolumn{13}{|c|}{ Major elements (oxide wt $\%$ ): } \\
\hline $\mathrm{SiO}_{2}$ & 47.18 & 45.51 & 49.64 & 36.00 & 46.10 & 50.20 & 49.00 & 42.90 & 43.30 & 44.80 & 49.30 & 50.80 \\
\hline $\mathrm{TiO}_{2}$ & 2.34 & 2.88 & 2.88 & 3.16 & 2.61 & 2.35 & 1.97 & 1.76 & 2.14 & 2.37 & 1.79 & 1.91 \\
\hline $\mathrm{Al}_{2} \mathrm{O}_{3}$ & 16.06 & 15.12 & 13.46 & 18.69 & 14.69 & 13.89 & 13.73 & 16.90 & 15.59 & 17.03 & 15.07 & 14.88 \\
\hline $\mathrm{FeO}_{3}$ & 20.65 & 25.23 & 17.59 & 29.52 & 23.32 & 20.49 & 12.80 & 20.02 & 24.03 & 19.34 & 15.60 & 10.93 \\
\hline $\mathrm{MnO}$ & 0.40 & 0.28 & 0.38 & 0.18 & 0.25 & 0.26 & 0.30 & 0.35 & 0.23 & 0.32 & 0.30 & 0.21 \\
\hline $\mathrm{MgO}$ & 10.72 & 9.88 & 10.81 & 10.93 & 10.28 & 11.29 & 9.99 & 12.47 & 12.23 & 11.18 & 12.02 & 6.73 \\
\hline $\mathrm{CaO}$ & 2.87 & 1.14 & 5.11 & 1.30 & 1.92 & 2.15 & 11.66 & 5.59 & 1.97 & 3.54 & 5.54 & 12.61 \\
\hline $\mathrm{Na}_{2} \mathrm{O}$ & $<0.1$ & $<0.1$ & 0.18 & $<0.1$ & $<0.1$ & $<0.1$ & 0.68 & $<0.1$ & $<0.1$ & $<0.1$ & 0.31 & 1.26 \\
\hline $\mathrm{K}_{2} \mathrm{O}$ & 0.02 & 0.01 & 0.03 & 0.02 & 0.02 & 0.02 & 0.03 & 0.02 & 0.02 & 0.02 & 0.02 & 0.04 \\
\hline $\mathrm{P}_{2}^{2} \mathrm{O}_{5}$ & 0.19 & 0.24 & 0.25 & 0.24 & 0.21 & 0.17 & 0.15 & 0.14 & 0.17 & 0.19 & 0.13 & 0.16 \\
\hline Total & 100.42 & 100.29 & 100.33 & 100.03 & 99.40 & 100.82 & 100.31 & 100.15 & 99.68 & 98.79 & 100.08 & 99.53 \\
\hline LOI & 5.69 & 5.72 & 4.63 & 6.83 & 5.85 & 5.63 & 2.74 & 6.34 & 6.50 & 5.81 & 4.83 & 1.51 \\
\hline $\mathrm{S}$ (total) & 0.00 & 0.00 & 0.00 & 0.00 & 0.00 & 0.00 & 0.00 & 0.24 & 0.00 & 0.00 & 0.33 & 1.24 \\
\hline \multicolumn{13}{|c|}{ Trace elements (ppm): } \\
\hline $\mathrm{Nb}$ & 6 & 8 & 8 & 7 & 6 & 5 & 4 & 6 & 6 & NA & 5 & 7 \\
\hline $\mathrm{Zr}$ & 141 & 176 & 181 & 182 & 153 & 131 & 120 & 105 & 124 & NA & 104 & 125 \\
\hline $\mathrm{Y}$ & 44 & 72 & 51 & 51 & 51 & 41 & 39 & 40 & 40 & NA & 36 & 40 \\
\hline $\mathrm{Sr}$ & 29 & 4 & 48 & 3 & 8 & 8 & 62 & 95 & 7 & NA & 65 & 111 \\
\hline $\mathrm{Rb}$ & $<1$ & $<1$ & $<1$ & $<1$ & $<1$ & 2 & $<1$ & $<1$ & $<1$ & NA & $<1$ & 1 \\
\hline $\mathrm{Zn}$ & 82 & 40 & 87 & 33 & 47 & 55 & 73 & 94 & 66 & NA & 120 & 60 \\
\hline $\mathrm{Cu}$ & 9 & 12 & 64 & 19 & 17 & 24 & 53 & 2692 & 60 & NA & 479 & 147 \\
\hline $\mathrm{Ni}$ & 114 & 101 & 87 & 96 & 90 & 72 & 182 & 85 & 84 & NA & 72 & 68 \\
\hline $\mathrm{Cr}$ & 345 & 265 & 289 & 377 & 272 & 242 & 188 & 225 & 262 & NA & 232 & 201 \\
\hline $\mathrm{V}$ & 397 & 512 & 422 & 522 & 464 & 397 & 321 & 436 & 389 & NA & 336 & 343 \\
\hline $\mathrm{Ce}$ & 12 & 18 & 17 & 22 & 11 & 15 & 21 & 27 & 14 & NA & 20 & 18 \\
\hline $\mathrm{Ba}$ & $<15$ & $<15$ & $<15$ & $<15$ & $<15$ & $<15$ & $<15$ & $<15$ & $<15$ & NA & $<15$ & $<15$ \\
\hline
\end{tabular}

Notes: $\mathrm{LOI}=$ loss on ignition. $\mathrm{NA}=$ not analyzed.

although $\mathrm{Na}_{2} \mathrm{O}$ concentrations are less that half average N-MORB, despite the abundance of fresh plagioclase in these rocks. This suggests that these magmas have undergone only limited fractionation.

$\mathrm{Mg \#}$ is highly variable, although the least altered basalts plot within the average $\mathrm{N}-\mathrm{MORB}$ range. $\mathrm{MgO}$ contents are relatively constant downhole, and the large variation in $\mathrm{Fe}_{2} \mathrm{O}_{3}$ seems to be the dominant factor influencing changes in $\mathrm{Mg \#}$.

Base metal contents are generally low, although a number of extremely high $\mathrm{Cu}$ concentrations indicate the presence of secondary copper sulfides. Copper is strongly leached from the sills and the depletion in $\mathrm{Cu}$ is more complete than for $\mathrm{Zn}$.

Using LOI as a loose measure of alteration, selected major elements are plotted against LOI in Figure 92. For comparison, a compilation of geochemical data from samples recovered during Leg 139 from all the Middle Valley sites (see Davis, Mottl, Fisher, et al., 1992; Stakes and Franklin, 1994) are also plotted on this diagram. There are strong trends illustrated on this diagram, although the alteration trajectories for the Leg 169 samples are distinct from those apparent in the Leg 139 data. There are general tends of increasing $\mathrm{TiO}_{2}, \mathrm{Al}_{2} \mathrm{O}_{3}, \mathrm{Fe}_{2} \mathrm{O}_{3}$, and $\mathrm{MgO}$ with increasing LOI. $\mathrm{SiO}_{2}, \mathrm{CaO}, \mathrm{Na}_{2} \mathrm{O}$ (and $\mathrm{K}_{2} \mathrm{O}$ ), and $\mathrm{Mg \#}$ are strongly depleted with increasing LOI. The strong increases in $\mathrm{TiO}_{2}$, and in particular $\mathrm{Fe}_{2} \mathrm{O}_{3}$, are unique to the Hole $856 \mathrm{H}$ data, suggesting that more intense and different styles of hydrothermal alteration are occurring at this location than in other sites in Middle Valley.

Large variations in major element concentrations and strong trends with LOI are apparent in Figures 91 and 92, indicating that there have been significant enrichments and depletions of major elements because of hydrothermal alteration. Magmas with both $\mathrm{N}$ MORB and more enriched transitional to E-MORB chemical affinities have been documented from Middle Valley (e.g., Stakes and Franklin, 1994). The relative abundance of $\mathrm{Nb}, \mathrm{Zr}$, and $\mathrm{Y}$, trace elements that are commonly assumed to be immobile during hydrothermal alteration and are diagnostic of igneous provenance, are compared in Figure 93. Comparative data for basalts recovered during Leg 139 are shown for reference. Basalts recovered from Hole $856 \mathrm{H}$ plot as a tight cluster, firmly within the N-MORB field of this classi- fication (following Meschede, 1986). The basalts are, however, chemically quite different from the olivine-bearing basalts that were intersected as high-level sills in Holes 856A and 856B during the drilling of Bent Hill during Leg 139.

The difficulty of deciphering magmatic evolution from hydrothermal changes in altered ocean floor basalts is well illustrated in Figure

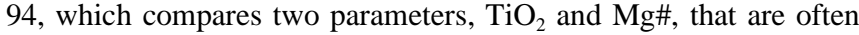
used to examine igneous fractionation. Data from Leg 139 basalts are plotted for comparison. Simple assessment of the chemical analyses from both drilling legs in Middle Valley suggest that there is a strong fractionation trend, with decreasing $\mathrm{Mg \#}$ with increasing $\mathrm{TiO}_{2}$ concentrations, and that the lavas drilled at Bent Hill during Leg 169 are significantly evolved along this trend compared to the bulk of the Middle Valley igneous data. Neither of these parameters, however, adequately accounts for hydration and dilutions/enrichments resulting from hydrothermal alteration; thus, the apparent trend of magmatic evolution may be misleading.

\section{Mass Balance Calculations on the Alteration of Sills and Basalts}

To test whether the various geochemical trends (e.g., Fig. 94) are caused by igneous fractionation or hydrothermal alteration, mass balance calculations were performed (Gresens, 1967; Grant, 1986). Calculations were done on the sills and basement basalts discussed in the next two subsections.

Sills

Sample $169-856 \mathrm{H}-60 \mathrm{R}-2,58-60 \mathrm{~cm}$, was selected as the least altered sill precursor. This is a medium-grained, subophitic to ophitic diabase with plagioclase, pyroxene, and olivine in a slightly chloritized groundmass from the base of Sill VIIE (Fig. 81). Sample 856H59R-1, 66-68 cm, from a thin sill (VIID), was selected as the most strongly altered material. This sample is a glassy to variolitic plagioclase and clinopyroxene-phyric porphyritic basalt that has been completely recrystallized to quartz, chlorite, titanite, clay, and epidote.

An isocon plot (plot of concentration of components in altered rock, $\mathrm{C}^{\mathrm{A}}$, in mass units vs. that in the unaltered rock, $\mathrm{C}^{\circ}$; Grant, 1986) 
$\mathrm{SiO}_{2}(\mathrm{wt} \%)$

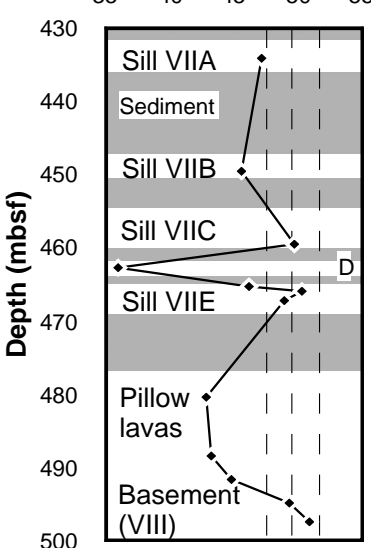

500

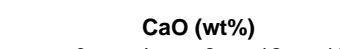

$\begin{array}{lc}\mathrm{TiO} 2 & (\mathrm{wt} \%) \\ 1 & 2\end{array}$

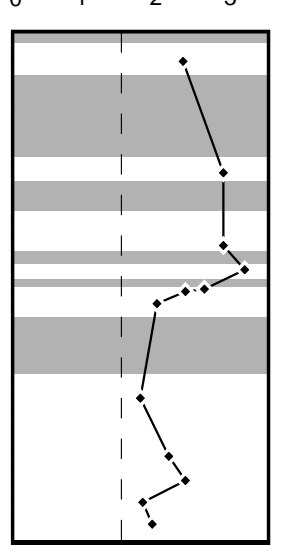

$\mathrm{Na} 2 \mathrm{O}(\mathrm{wt} \%)$

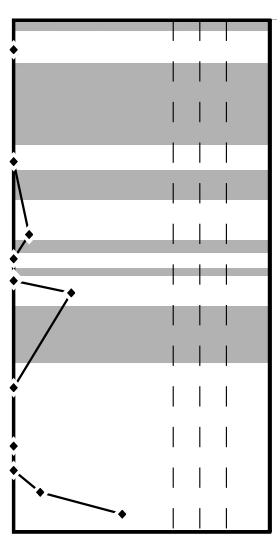

$\mathrm{Fe}_{2} \mathrm{O} 3$ tot (wt \%)

$12 \quad 14$

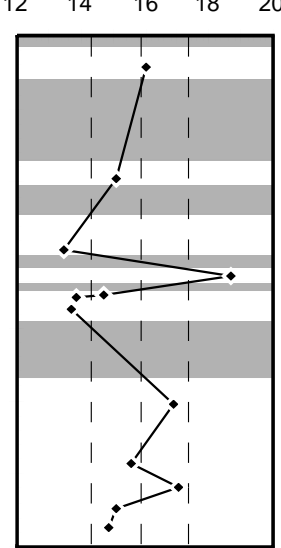

K2O (wt\%)

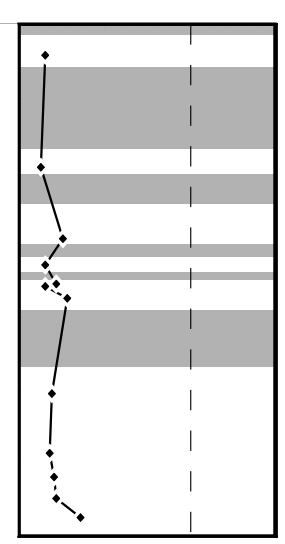

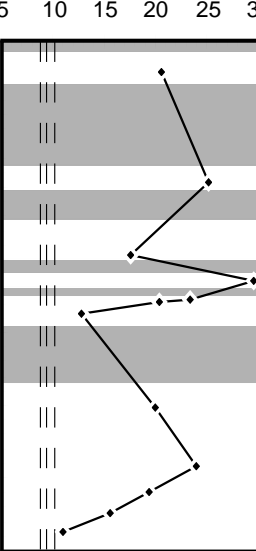

$\mathrm{P}_{2} \mathrm{O}_{5}$ (wt\%)

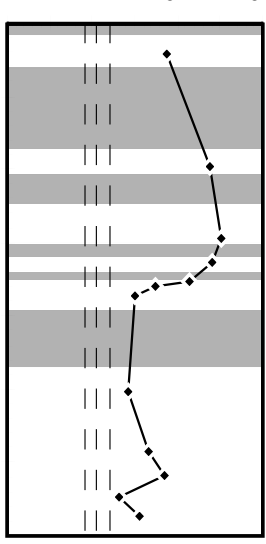

$\mathrm{MnO}$ (wt\%)

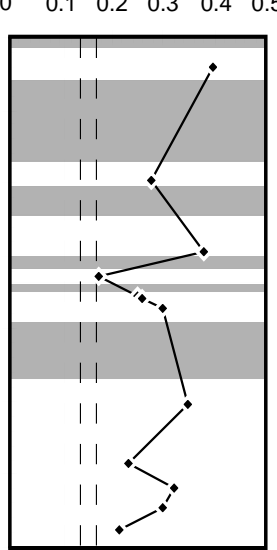

LOI (wt\%)

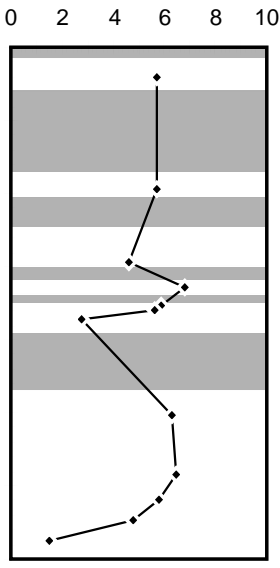

$\mathrm{MgO}(\mathrm{wt} \%)$

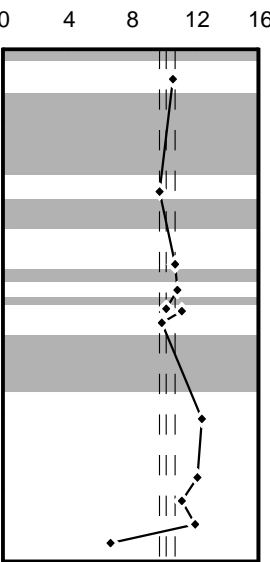

Zn (ppm)

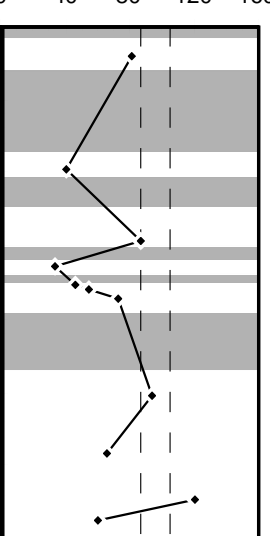

35

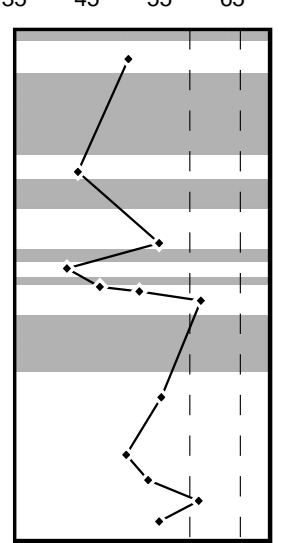

Cu (ppm)

$\begin{array}{llllll}0 & 40 & 80 & 120 & 160 & 200\end{array}$

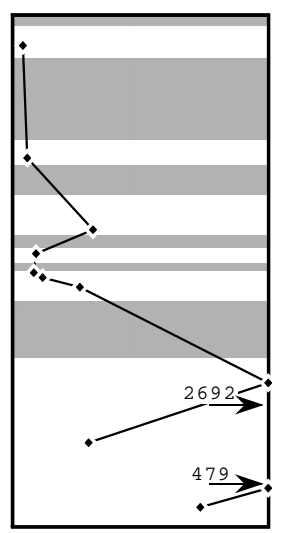

Figure 91. Diagram showing the variation of major element oxides, loss on ignition, $\mathrm{Mg} \#$ (where $\mathrm{Mg \#}=100 \times \mathrm{Mg}^{2+} /\left[\mathrm{Mg}^{2+}+\mathrm{Fe}^{2+}\right.$ (tot $]$ ), and base metals $(\mathrm{Zn}$ and $\mathrm{Cu}$ ) with depth in Hole $856 \mathrm{H}$. Gray shaded areas show the location of intercalated sediments. Dashed vertical lines show the composition of average MORB, and a range of MORB averages. The range in Mg\# follows glass analyses from Hole 896A (Fisk et al., 1996). Primary base metal contents for these basalts are estimated from the loose trend for East Pacific Rise magmas documented by Doe (1994). Note that expanded depths are used for sample and sill location. 

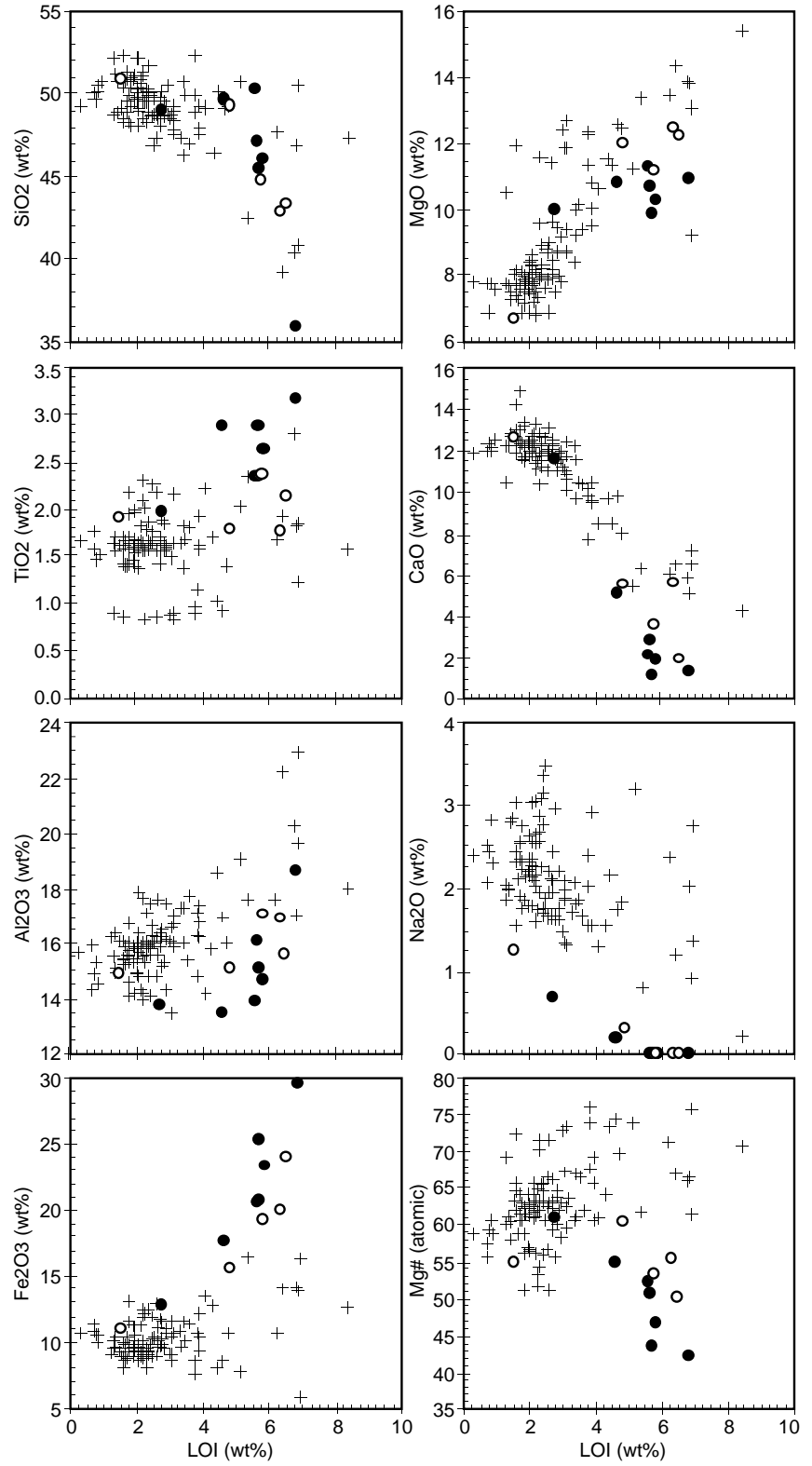

Figure 92. Diagram showing the variation of selected major element oxide concentrations, and $\mathrm{Mg \#}$ with loss on ignition. Open circles $=\mathrm{Hole} 856 \mathrm{H}$ basement basalts, solid circles $=$ Hole $856 \mathrm{H}$ sill basalts, and $\pm=$ Middle Valley basalts from all sites during Leg 139 (Davis, Mottl, Fisher, et al., 1992; Stakes and Franklin, 1994).

was constructed using the shipboard XRF analyses and density determinations for these two samples (Fig. 95). The plot shows that Nb, $\mathrm{Al}, \mathrm{Ti}, \mathrm{Zr}$, and $\mathrm{P}$ are relatively immobile. The slope of a best-fit line (isocon) through these elements that passes through the origin is the ratio of the total mass before and after alteration. The gain or loss of a mobile component thus can be measured by the displacement of its data point from the isocon. The slope of the isocon is 1.59 , which corresponds to a $\sim 37 \%$ mass loss or a $39 \%$ volume loss. It is noteworthy that the measured porosity of the altered rock ( 27\%; see "Physical Properties" section, this chapter), is generally similar to the calculated volume loss (c.f. 4\% for Sample 169-856H-60R-2, 58-60 cm).

The alteration is characterized by strong depletions ( $>25 \mathrm{wt} \%$ of precursor) of $\mathrm{O}, \mathrm{Na}, \mathrm{Sr}, \mathrm{Cu}, \mathrm{Zn}, \mathrm{Ni}$, and $\mathrm{V}$; moderately strong depletions (5-15 wt\% of precursor) of $\mathrm{Si}, \mathrm{K}, \mathrm{Ca}, \mathrm{Mn}$, and $\mathrm{Ce}$; slight deple-

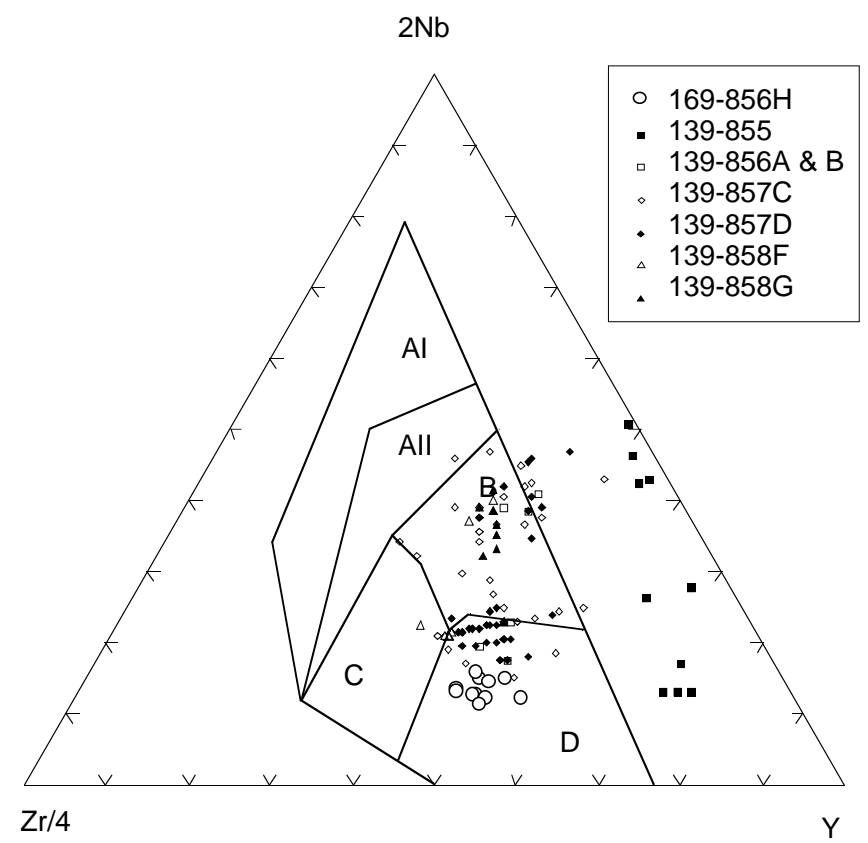

Where:

Al - within-plate alkali basalts

All - within-plate alkali basalts and within plate tholeiities B - E-type MORB

C - within-plate tholeiites and volcanic-arc basalts

D - N-type MORB and volcanic-arc basalts (after Meschede, 1986)

Figure 93. Nb-Zr-Y immobile element ternary diagram for classifying basalts (after Meschede, 1986). Leg 139 data from Davis, Mottl, Fisher, et al. (1992) and Stakes and Franklin (1994).

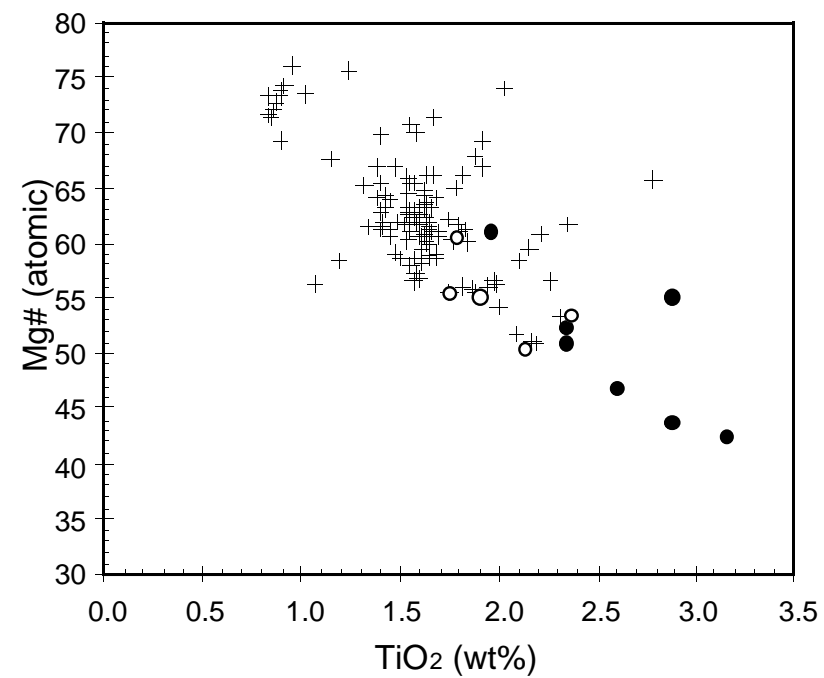

Figure 94. Plot of $\mathrm{Mg} \#$ vs. $\mathrm{TiO}_{2}$ for basalts from Middle Valley recovered during Legs 139 and 169. Open circles $=$ Hole $856 \mathrm{H}$ basement basalts, solid circles $=$ Hole $856 \mathrm{H}$ sill basalts, and $+=$ Middle Valley basalts from all sites during Leg 139 (Davis, Mottl, Fisher, et al., 1992; Stakes and Franklin, 1994). 


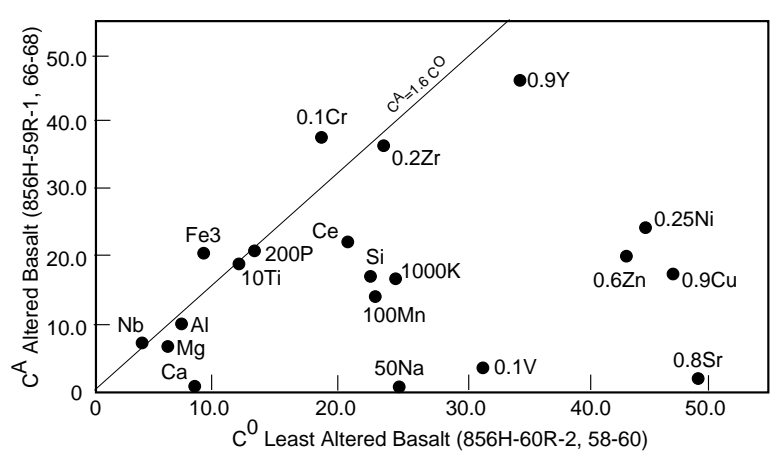

Figure 95. Isocon diagram comparing an extremely altered basalt (Sample 169-856H-59R-1, 66-68 cm) from sill Subunits VIID with a slightly altered basalt (Sample 169-856H-60R-2, 58-60 cm) from the base of sill VIIE.

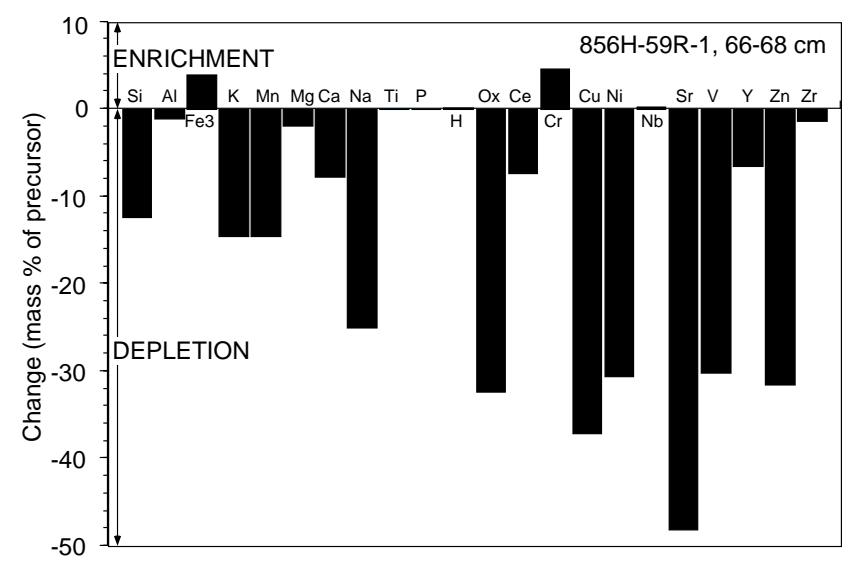

Figure 96. Enrichment/depletion diagram showing the relative changes in element concentrations between an extremely altered basalt (Sample 169856H-59R-1, 66-68 cm) from sill Subunit VIID and a slightly altered basalt (Sample 169-856H-60R-2, 58-60 cm) from the base of sill VIIE.

tions ( $<5 \mathrm{wt} \%$ ) of $\mathrm{Mg}$ and $\mathrm{Y}$; and slight enrichment (up to $\sim 6 \mathrm{wt} \%$ of precursor) of $\mathrm{Fe}$ and $\mathrm{Cr}$. The calculated absolute mobility (total gains and losses) of elements are summarized in Figure 96.

The strong alteration effects of the sills indicates that they were emplaced prior to (or during) the onset of hydrothermal activity and altered during the mineralizing process. The sulfide ore metals $(\mathrm{Zn}$ and $\mathrm{Cu}$ ) are strongly depleted in the altered basalts, and $\mathrm{Zn}$ and $\mathrm{Cu}$ leached from basalt is probably the source of these metals in the overlying massive sulfides. Indeed, $\mathrm{Pb}$ isotope analyses of massive sulfides and basalt from Bent Hill (e.g., Goodfellow and Franklin, 1993) support such an interpretation. The extreme mass loss in these rocks and the relative immobility of Ti provides strong evidence that the fractionation trends apparent in Figure 94 are principally caused by alteration and not magmatic processes.

\section{Basement Flows}

Sample 169-856H-65R-2, 10-13 cm, was selected as the most unaltered precursor. This is a relatively unaltered, sparsely plagioclasephyric basalt flow from the basement (Fig. 81). Sample 169-856H63R-1, 16-20 cm, is a highly altered, sulfidized, mineralized, and chloritized glassy margin of pillow basalt (hyaloclastite) from the basement (Fig. 81). The glass fragments are completely replaced by chlorite and are crosscut by numerous veins containing quartz, epidote, chlorite, titanite, and abundant disseminated pyrite, and $\mathrm{Cu}-\mathrm{Fe}$ sulfide of ISS composition occurs in the groundmass.

An isocon plot (Fig. 97) confirms that $\mathrm{Si}, \mathrm{Al}, \mathrm{Ti}, \mathrm{P}$, and $\mathrm{Nb}$ are immobile. The slope of the isocon is 0.85 , which corresponds to a $\sim 17 \%$ mass gain or a $12 \%$ volume increase. The alteration is characterized by a strong apparent depletion of $\mathrm{S}$, moderately strong depletions (5-

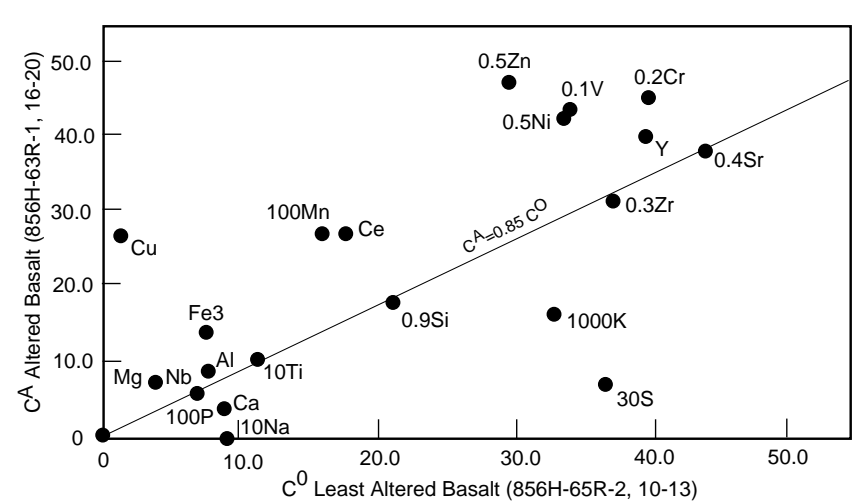

Figure 97. Isocon diagram comparing a chloritized glassy pillow margin (Sample 169-856H-63R-1, 16-20 cm) with a slightly altered basalt (Sample $169-856 \mathrm{H}-65 \mathrm{R}-2,10-13 \mathrm{~cm}$ ) from the basement in Hole $856 \mathrm{H}$.

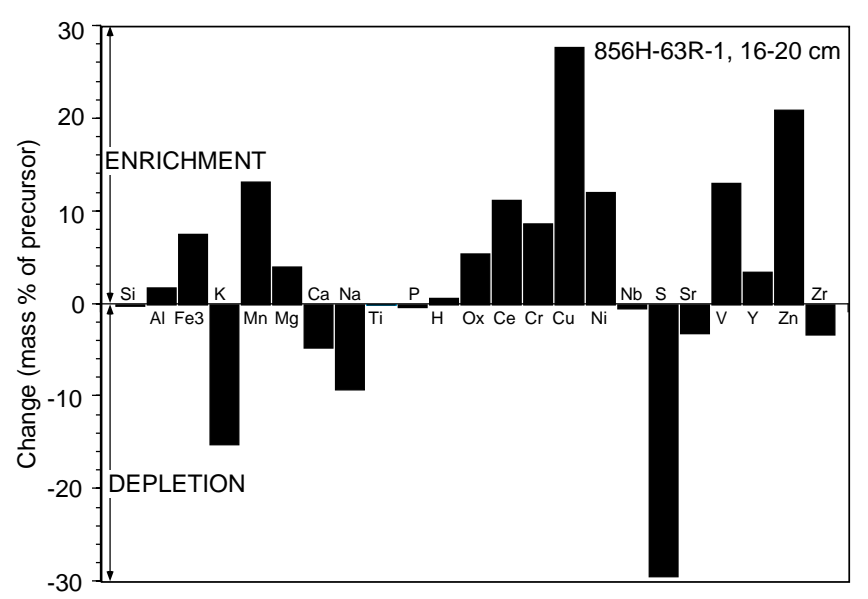

Figure 98. Enrichment/depletion diagram showing the relative changes in element concentrations between a chloritized glassy pillow margin (Sample $169-846 \mathrm{H}-63 \mathrm{R}-1,16-20 \mathrm{~cm}$ ) and slightly altered basalt (Sample $169-856 \mathrm{H}-$ $65 \mathrm{R}-2,10-13 \mathrm{~cm}$ ) from the basement in Hole $856 \mathrm{H}$.

$15 \mathrm{wt} \%$ of precursor) of $\mathrm{K}, \mathrm{Ca}$, and $\mathrm{Na}$ and slight depletions ( $<5 \mathrm{wt} \%$ ) of $\mathrm{Sr}$ and $\mathrm{Zr}$, strong enrichments $(>\sim 8 \mathrm{wt} \%$ ) of $\mathrm{Fe}, \mathrm{Mn}, \mathrm{Ce}, \mathrm{Cr}, \mathrm{Cu}$, $\mathrm{Ni}, \mathrm{V}$, and $\mathrm{Zn}$, and moderate to slight enrichments $(<8 \mathrm{wt} \%)$ of $\mathrm{Mg}$ and Y. The mass-balance calculations are summarized in Figure 98. The sulfur analyses of the unaltered precursor basalt are clearly in error, given the enrichment in $\mathrm{Cu}$ and $\mathrm{Zn}$, as well as the abundant sulfides present in the sample, and the strong depletion in $\mathrm{S}$ should be disregarded.

The strongly chloritized nature of the glassy pillow margin and the abundant sulfide mineralization indicates that it was emplaced prior to (or during) the onset of hydrothermal activity because they were altered and sulfidized during the mineralizing process. The sulfide ore metals $(\mathrm{Zn}$ and $\mathrm{Cu}$ ) are strongly enriched in the altered basalts. There is a contrast in the alteration styles of the sills and the chloritized glassy pillow margin. The former shows strong depletion in $\mathrm{Cu}, \mathrm{Mn}, \mathrm{Zn}, \mathrm{Ni}$, and $\mathrm{V}$, whereas the latter shows moderate to strong enrichment in these metals.

\section{Highly Altered Basalts and/or Hydrothermally Recrystallized} Sediments in Hole $1035 \mathrm{H}$

Interval 169-1035H-16R-3 (Piece 2, $17 \mathrm{~cm}$ ), to 169-1035H-17R-3

(Piece 2, $15 \mathrm{~cm} ; \approx 136-145 \mathrm{mbsf}$ )

The presence of highly altered igneous rocks, possibly basaltic sills, intimately intercalated with hydrothermally recrystallized sedimentary rocks, was suspected in some of the pieces recovered in interval 169$1035 \mathrm{H}-16 \mathrm{R}-3,17 \mathrm{~cm}$, to $169-1035 \mathrm{H}-17 \mathrm{R}-3,15 \mathrm{~cm}$ ( 136-145 mbsf), although an unambiguous confirmation of original protolith could not 


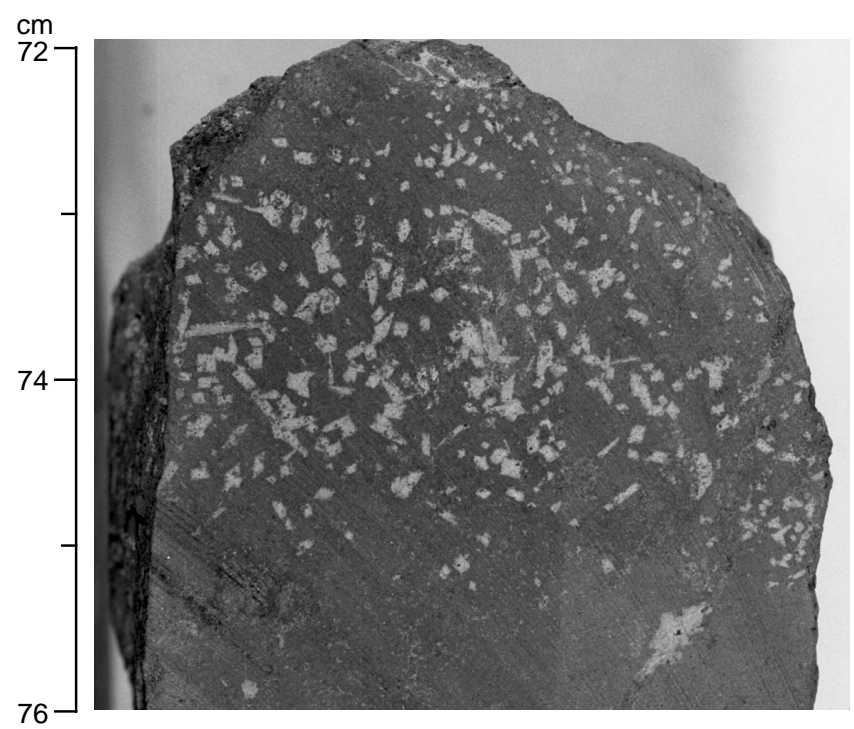

Figure 99. Sample 169-1035H-16R-3, 72-76 cm (Piece 9), showing the presence of coarse, white prismatic patches within a cryptocrystalline groundmass of a rock initially suspected to be hydrothermally altered basalt. This rock has been completely altered and recrystallized to hydrothermally phases. Thin section observation and XRD identifies the groundmass to comprise a submicroscopic mat of orthogonally interwoven amphibole (actinolite-tremolite) with abundant dispersed zoisite and luminous green pistasitic epidote. Suspected plagioclase pseudomorphs remain only as shadowy darker patches of intergrown actinolite-tremolite. Pyrrhotite and sphalerite are abundant within the groundmass.

be established by petrographic techniques. Coarse $(2-3 \mathrm{~mm})$, white prismatic patches suspected to be alteration pseudomorphs after plagioclase phenocrysts are present in interval 169-1035H-16R-3 (Piece $9,72-80 \mathrm{~cm}$ ), and this is perhaps the strongest evidence for the presence of basalt (Fig. 99). Small $(2-5 \mathrm{~cm})$ enclaves of sediment included within the suspected basalt and textures strongly resembling chilled margins were recovered in Section 169-1035H-17R-1. However, subhorizontal layering, highlighted by concentrations of bright green epidote and sphalerite, is present in some pieces (e.g., interval 1691035H-17R-1 [Piece 6, 27-37 cm]; Fig. 100). This layering represents relict sedimentary bedding within hydrothermally recrystallized mudstone, with epidote and sulfide concentrated in the slightly coarser silty layers. Abundant, luminous green epidote is present in pieces of core with both suspected sedimentary and igneous precursors. Thin section observation and XRD (Table 5) identifies the groundmass of both the suspected altered igneous and sedimentary rocks to comprise a submicroscopic mat of intergrown or orthogonally interwoven amphibole (actinolite-tremolite) with abundant dispersed zoisite and luminous green pistasitic epidote (Fig. 101). These rocks are strongly mineralized by crosscutting sulfide veins and are completely altered to hydrothermal assemblages.

To distinguish between possible sedimentary and igneous protoliths, immobile element ratios were investigated. Table 16 presents XRF analyses of a limited number of sediments and sedimentary rocks from both the Bent Hill and Dead Dog sites drilled during Leg 169. The comparison of the relative abundances of $\mathrm{Al}_{2} \mathrm{O}_{3}, \mathrm{TiO}_{2}$, and $\mathrm{Zr}$ shows a definite distinction between sedimentary and igneous rocks (Fig. 102). Analyses from Leg 169 have been complimented by the comprehensive data sets of Middle Valley sediment and basalt compositions (Goodfellow and Peter, 1994; Davis, Mottl, Fisher, et al., 1992; Stakes and Franklin, 1994). All Leg 169 basalts plot with the tight cluster of Leg 139 basaltic analyses, and the Bent Hill and Dead Dog sediments are closely associated with the dense cloud of

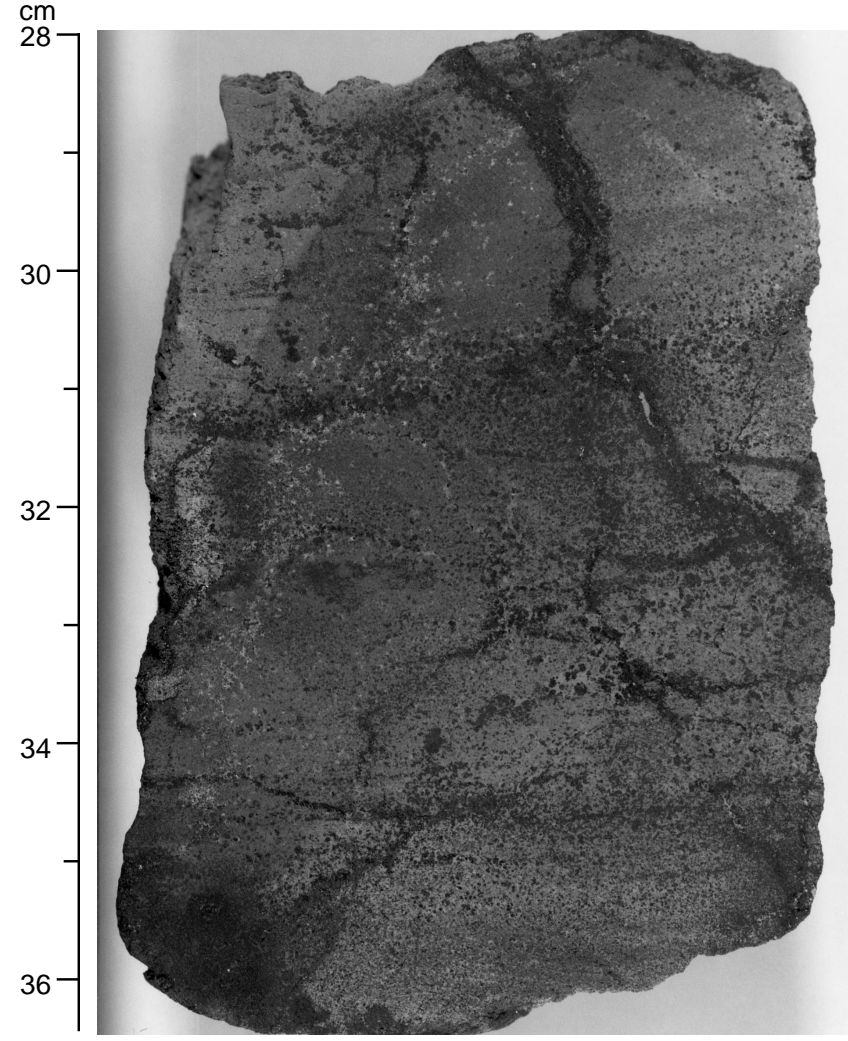

Figure 100. Sample 169-1035H-17R-1, 28-36.5 cm (Piece 6). Piece of hydrothermally recrystallized mudstone or possibly basalt. Darker areas have abundant, dispersed, luminous green epidote that is concentrated along subhorizontal bands of relict sedimentary layering. The sharp boundary in the upper left of the photograph delineates a sharp reduction in the modal proportion of epidote. Epidote is much less abundant in the lighter colored portion, although there are thin epidote-rich incursions into this zone along the relict layers. Abundant sphalerite is disseminated throughout the piece along relict layers and in crosscutting veins.

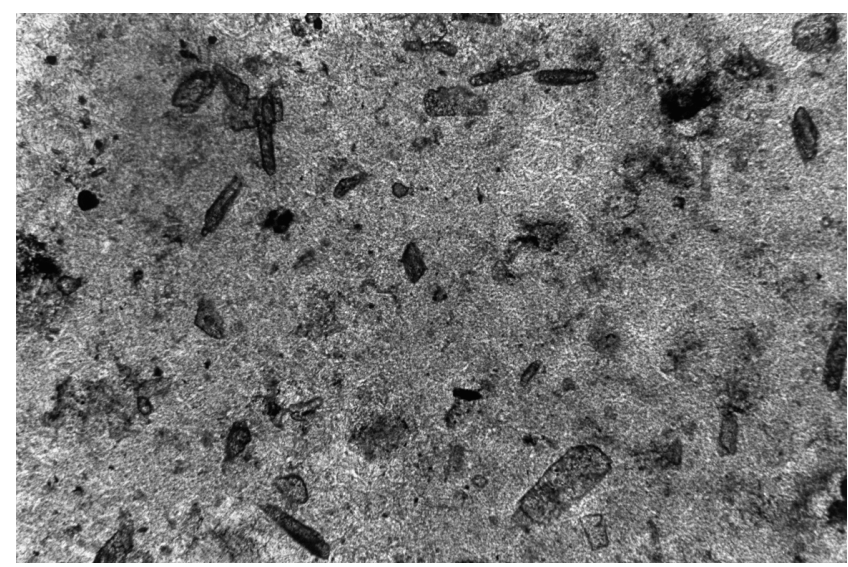

Figure 101. Photomicrograph of Sample 169-1035H-16R-3, 72-76 cm (Piece 9), showing the texture of an extremely hydrothermally recrystallized rock initially suspected to have an igneous protolith. The groundmass comprises a submicroscopic mat of intergrown or orthogonally interwoven amphibole (actinolite-tremolite) with abundant dispersed zoisite and luminous green pistasitic epidote. Geochemical studies conclusively show that the same rock had a sedimentary protolith (transmitted light, plane polarized light, field of view $\sim 1.2 \mathrm{~mm}$ ). 
Table 16. Whole-rock geochemistry of sedimentary rocks, Bent Hill $(856,1035)$ and Dead Dog $(1036)$ sites.

\begin{tabular}{|c|c|c|c|c|c|c|c|c|c|c|c|c|}
\hline Site: & $\mathrm{BH}$ & $\mathrm{BH}$ & $\mathrm{BH}$ & $\mathrm{BH}$ & $\mathrm{BH}$ & $\mathrm{BH}$ & $\mathrm{BH}$ & $\mathrm{BH}$ & $\mathrm{BH}$ & DD & DD & DD \\
\hline Hole: & $856 \mathrm{H}$ & $856 \mathrm{H}$ & $856 \mathrm{H}$ & $856 \mathrm{H}$ & $1035 \mathrm{~A}$ & $1035 \mathrm{~A}$ & $1035 \mathrm{~A}$ & $1035 \mathrm{H}$ & $1035 \mathrm{H}$ & $1036 \mathrm{~A}$ & $1036 \mathrm{~A}$ & $1036 \mathrm{C}$ \\
\hline Core, section: & 23R-1 & 35R-1 & 39R-1 & 59R-1 & $1 \mathrm{H}-4$ & $10 X-1$ & $13 X-5$ & $16 \mathrm{R}-3$ & 17R-1 & $1 \mathrm{H}-5$ & $6 \mathrm{X}-\mathrm{CC}$ & $2 \mathrm{H}-5$ \\
\hline Interval $(\mathrm{cm})$ : & $82-84$ & $88-92$ & $82-85$ & $15-17$ & $43-45$ & $78-80$ & $33-38$ & $72-76$ & $27-31$ & $18-23$ & $4-6$ & $69-71$ \\
\hline Piece: & 16 & 15 & 8 & $3 \mathrm{~A}$ & & & & $9 \mathrm{~A}$ & 6 & & & \\
\hline Depth (mbsf): & 124.92 & 240.28 & 278.7 & 460.85 & 4.93 & 80.98 & 115.33 & 136.19 & 142.57 & 6.18 & 37.54 & 13.09 \\
\hline \multicolumn{13}{|c|}{ Major elements (oxide weight $\%$ ): } \\
\hline $\mathrm{SiO}_{2}$ & NA & 66.68 & 68.70 & 69.56 & 53.13 & 58.30 & 54.30 & 51.80 & NA & 58.20 & 77.30 & 55.50 \\
\hline $\mathrm{TiO}_{2}$ & NA & 0.69 & 0.79 & 0.61 & 0.75 & 0.96 & 0.96 & 0.09 & NA & 1.04 & 0.50 & 0.85 \\
\hline $\mathrm{Al}_{2} \mathrm{O}_{3}$ & NA & 11.07 & 11.65 & 9.70 & 13.53 & 17.32 & 16.21 & 1.31 & NA & 16.16 & 8.21 & 16.22 \\
\hline $\mathrm{Fe}_{2} \mathrm{O}_{3}$ & NA & 17.11 & 13.92 & 14.69 & 17.06 & 8.23 & 7.68 & 18.16 & NA & 7.92 & 5.06 & 10.71 \\
\hline $\mathrm{MnO}$ & NA & 0.19 & 0.12 & 0.09 & 0.14 & 0.13 & 0.13 & 0.33 & NA & 0.14 & 0.12 & 0.18 \\
\hline $\mathrm{MgO}$ & NA & 4.21 & 3.07 & 5.20 & 3.62 & 7.01 & 8.76 & 13.82 & NA & 4.26 & 9.42 & 3.48 \\
\hline $\mathrm{CaO}$ & NA & 0.22 & 0.84 & 0.63 & 5.82 & 1.31 & 4.15 & 13.44 & NA & 5.56 & 0.45 & 4.37 \\
\hline $\mathrm{Na}_{2} \mathrm{O}$ & NA & $<0.1$ & $<0.1$ & $<0.1$ & 3.37 & 2.82 & 2.55 & $<0.1$ & NA & 3.01 & $<0.1$ & 2.90 \\
\hline $\mathrm{K}_{2} \mathrm{O}$ & NA & 0.02 & 0.69 & 0.02 & 1.91 & 1.73 & 1.18 & 0.03 & NA & 2.05 & 0.09 & 2.22 \\
\hline $\mathrm{P}_{2}^{2} \mathrm{O}_{5}$ & NA & 0.10 & 0.12 & 0.12 & 0.17 & 0.24 & 0.19 & $<0.01$ & NA & 0.23 & 0.03 & 0.14 \\
\hline Total & NA & 100.29 & 99.89 & 100.62 & 99.49 & 98.05 & 96.12 & 98.98 & NA & 98.57 & 101.19 & 96.57 \\
\hline L.O.I. & NA & 3.50 & 2.95 & 3.83 & 13.41 & 6.52 & 6.73 & NA & 5.75 & 6.82 & 5.37 & 6.83 \\
\hline $\mathrm{S}$ (total) & 3.81 & 0.00 & 0.16 & 0.00 & 1.35 & 0.00 & 1.76 & 2.43 & 7.87 & 0.32 & 0.13 & 4.14 \\
\hline \multicolumn{13}{|c|}{ Trace elements (ppm): } \\
\hline $\mathrm{Nb}$ & 5 & 8 & 6 & 6 & 8 & 9 & NA & 1 & 3 & 11 & 7 & 9 \\
\hline $\mathrm{Zr}$ & 55 & 102 & 181 & 83 & 99 & 120 & NA & 14 & 54 & 129 & 92 & 121 \\
\hline $\mathrm{Y}$ & 9 & 16 & 20 & 15 & 20 & 25 & NA & 1 & 4 & 23 & 12 & 21 \\
\hline $\mathrm{Sr}$ & 3 & 4 & 42 & 6 & 352 & 142 & NA & 27 & 178 & 313 & 8 & 269 \\
\hline $\mathrm{Rb}$ & 1 & 1 & 9 & $<1$ & 53 & 47 & NA & $<1$ & 1 & 55 & 4 & 89 \\
\hline $\mathrm{Zn}$ & 379 & 38 & 28 & 19 & 2,554 & 115 & NA & 4,783 & 133,000 & 121 & 106 & 125 \\
\hline $\mathrm{Cu}$ & 15,200 & 9 & 10 & 8 & 784 & 42 & NA & 118 & $511^{*}$ & 63 & 8 & 68 \\
\hline $\mathrm{Ni}$ & 10 & 32 & 21 & 30 & 47 & 62 & NA & 10 & $16^{*}$ & 78 & 28 & 56 \\
\hline $\mathrm{Cr}$ & 31 & 61 & 73 & 56 & 88 & 99 & NA & 36 & $53 *$ & 123 & 53 & 107 \\
\hline $\mathrm{V}$ & 60 & 12 & 127 & 108 & 198 & 175 & NA & 18 & $84 *$ & 173 & 76 & 211 \\
\hline $\mathrm{Ce}$ & 15 & 21 & 27 & 28 & 38 & 29 & NA & $<10$ & $12^{*}$ & 39 & 17 & 43 \\
\hline $\mathrm{Ba}$ & $<15$ & $<15$ & 335 & $<15$ & 1,552 & 304 & NA & $<15$ & $<15$ & 643 & 53 & 613 \\
\hline
\end{tabular}

Notes: $\mathrm{BH}=$ Bent Hill, DD = Dead Dog. NA = not analyzed. * = minimum values. Absorption for Zn unaccounted for.

Leg 139 sedimentary analyses. A single analysis of the sample (Sample 169-1035H-16R-3, [Piece 6, 72-76 cm]) that displayed the most basalt-like textures in both hand specimen and thin section is clearly associated with the sedimentary analyses, and hence an igneous origin is most unlikely. Note, that even intensely altered basalts from the sill-sediment complex in Hole 856H (e.g., Sample 169-856H-59R-1, $66-68 \mathrm{~cm})$ do not display evidence for the significant relative mobility of $\mathrm{Al}, \mathrm{Ti}$, or $\mathrm{Zr}$.

\section{Thermal Requirements for Forming Ore Deposits in Mid-Ocean Ridge Settings by Sill Intrusion}

The thermal requirements for the magnitude of sustained hydrothermal circulation at mid-ocean ridges are well established (e.g., Lister, 1972; Morton and Sleep, 1985; Sleep, 1991; Davis and Fisher, 1994). However, the thermal consequences of sill intrusion within a sedimentary basin and the magnitude of the related hydrothermal venting and ore deposition are not intuitively obvious. Simple calculations follow that estimate the areal extent of a 10-m-thick basaltic sill that would be required to provide the necessary heat to drive hydrothermal circulation and supply base metals to form an economic ore deposit. For all calculations, it is assumed that heat exchange and mineral precipitation are $100 \%$ efficient processes.

For a typical volcanic-associated sediment-hosted massive sulfide deposit with

$$
\begin{aligned}
& 5 \mathrm{MT} \text { sulfide (50\% pyrite, } 50 \% \text { pyrrhotite), } \\
& \text { grading } 3 \% \mathrm{Cu} \text {, and } 5 \% \mathrm{Zn},
\end{aligned}
$$

$$
\text { average } \mathrm{S}=\approx 45 \% \text { by mass }=>2.25 \times 10^{9} \mathrm{~kg} \text { sulfur. }
$$

Present-day Bent Hill hydrothermal fluids are not depositing sulfides, and the $\mathrm{Cu}-\mathrm{Fe}$ sulfide minerals in the BHMS deposit suggest that the assemblages were precipitated from $>330^{\circ} \mathrm{C}$ fluids. Calculations will be made for vent temperatures of $265^{\circ}$ and $350^{\circ} \mathrm{C}$. For Bent Hill hydrothermal fluids $\left(T=265^{\circ} \mathrm{C} ; \mathrm{H}_{2} \mathrm{~S} \sim 3 \mathrm{mmol} / \mathrm{kg}\right.$; Butterfield et al., 1994) contain
$>9.6 \times 10^{-5} \mathrm{~kg}$ sulfur per $\mathrm{kg}$ hydrothermal fluid,

and assuming complete precipitation from the hydrothermal fluid this mass of sulfur would require

$2.34 \times 10^{13} \mathrm{~kg}$ of hydrothermal fluid.

The total heat available for heating seawater caused by the crystallization of basalt and cooling from $1200^{\circ} \mathrm{C}$ to $350^{\circ} \mathrm{C}$ is $1.806 \mathrm{MJ} /$ $\mathrm{kg}$ basalt (Elderfield and Schultz, 1996). Note that over one-third of this heat comes from the latent heat of crystallization $(\sim 0.676 \mathrm{MJ} / \mathrm{kg})$. The heat required to heat seawater from $2^{\circ}$ to $350^{\circ} \mathrm{C}$ (integrated from Bischoff and Rosenbauer, 1985) is $\sim 2.252 \mathrm{MJ} / \mathrm{kg}$. Bent Hill fluids are significantly cooler $\left(\sim 265^{\circ} \mathrm{C}\right)$. Assuming a linear integrated heat capacity, heating seawater from $2^{\circ}$ to $265^{\circ} \mathrm{C}$ requires $\sim 1.7 \mathrm{MJ} / \mathrm{kg}$.

Heating $1 \mathrm{~kg}$ of seawater to the required hydrothermal temperature needs

$\sim 1.25 \mathrm{~kg}$ of basalt at $350^{\circ} \mathrm{C}$ and

$\sim 0.94 \mathrm{~kg}$ of basalt at $265^{\circ} \mathrm{C}$.

From the minimum amount of hydrothermal fluid, the mass of basalt needed to form a 5 MT sulfide deposit is

$\sim 2.9 \times 10^{13} \mathrm{~kg}$ basalt at $350^{\circ} \mathrm{C}$ and

$\sim 2.2 \times 10^{13} \mathrm{~kg}$ basalt at $265^{\circ} \mathrm{C}$.

Basalt has a density of $\sim 2.9 \times 10^{3} \mathrm{~kg} / \mathrm{m}^{3}$. The edge width of a 10 $\mathrm{m}$-thick, square basaltic sill required to form a $5 \mathrm{MT}$ ore deposit is

$\sim 32 \times 32 \mathrm{~km}^{2}$ at $350^{\circ} \mathrm{C}$ and

$\sim 28 \times 28 \mathrm{~km}^{2}$ at $265^{\circ} \mathrm{C}$.

For a 100-m-thick intrusion, this dimension is on the order of 10 $\times 10 \mathrm{~km}^{2}$. If the heat was extracted from the complete plutonic section of the ocean crust ( sheeted dikes + gabbros $=\sim 5 \mathrm{~km}$ ), this would require only a $1.4 \times 1.4 \mathrm{~km}^{2}$ area. These simple calculations clearly 


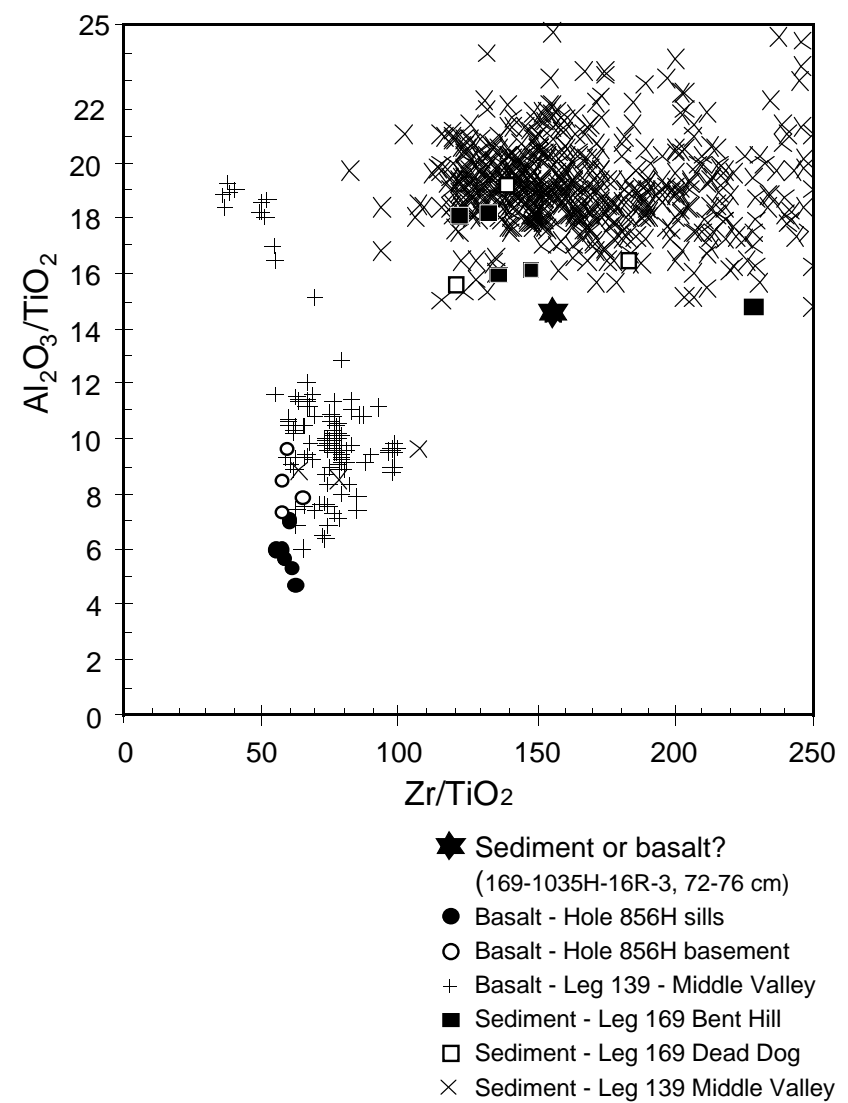

Figure 102. Diagram showing the ratio of $\mathrm{Al}_{2} \mathrm{O}_{3} / \mathrm{TiO}_{2}$ vs. $\mathrm{Zr} / \mathrm{TiO}_{2}$ for basaltic and sedimentary rocks recovered from Middle Valley during Legs 139 and 169. Two distinct clusters of analyses are defined. Sample 169-1035H-16R$3,72-76 \mathrm{~cm}$ (bold star $=$ Piece 9) plots with the cluster of sediment analyses indicating that this strongly recrystallized rock had a sedimentary precursor. Leg 139 data from Davis, Mottl, Fisher, et al. (1992), Goodfellow and Peter (1994), and Stakes and Franklin (1994).

show that sills of reasonable dimensions (1-2 km edge length) within the sedimentary sequence probably do not have the thermal mass required to form large ore deposits and that sustained hydrothermal venting requires interaction with the igneous basement. A $10 \mathrm{~m} \times 1$ $\mathrm{km}^{2}$ basaltic sill could only heat enough hydrothermal fluid to form a $\sim 6000$ T sulfide mound.

\section{Efficiency of the Leaching of Base Metals from Hydrothermally Altered Basalts}

Analyses of slightly to strongly altered basalts from the Bent Hill area shows that most igneous rocks from the sills as well as the basement are strongly depleted in base metals. Primary copper and zinc contents are estimated to be $\sim 90$ and 100 ppm, respectively (e.g., Doe, 1994). Altered rocks from Bent Hill are depleted strongly in base metals, with $\mathrm{Cu}$ and $\mathrm{Zn}$ contents commonly $\sim 15 \mathrm{ppm}$ and 45 ppm, suggesting a base metal loss of 65 and 55 ppm, respectively. To produce a $5 \mathrm{MT}$ sulfide deposit with average grades of $3 \% \mathrm{Cu}$ and $5 \%$ $\mathrm{Zn}$ would require leaching $\sim 1.6$ to $4.6 \times 10^{12} \mathrm{~kg}$ of basalt. This is $\sim 6-$ 10 times less basalt than is required to provide the thermal energy to drive the hydrothermal systems. The hydrothermal leaching of base metals from basalt, therefore, can be a relatively inefficient process compared to the extraction of heat from these rocks.

\section{STRUCTURAL GEOLOGY}

To characterize the physiochemical structure of the BHMS deposit, seven holes were drilled during Leg 169 in addition to the eight holes drilled during Leg 139. The holes are sited on a north-south and east-west transect centered on the BHMS deposit. This chapter provides (1) a brief review of the regional structural data and of the Leg 139 results, (2) a structural report of the holes drilled, and (3) a preliminary discussion on the nature of the processes involved in the formation of the structures and their implications for fluid circulation. The structural core descriptions and structural data for Site 1035 and Hole $856 \mathrm{H}$ are given in Tables 17 and 18 and in the appendixes on $\mathrm{CD}-\mathrm{ROM}$ in the back pocket of this volume.

\section{Regional Structures}

Although Middle Valley is a failed rift (Currie and Davis, 1994), it is evident from seismic studies (Rohr and Schmidt, 1994) that tectonic and volcanic processes have been active throughout the 7-kmwide zone during the late Pleistocene and possibly the Holocene. However, seismic profiles around Bent Hill show no major tectonic feature offsetting surface sediment directly associated with Bent Hill, the BHMS, or the active venting site to the south (Rohr and Schmidt, 1994). The scarp bounding the western flank of Bent Hill has been interpreted as a fault scarp (Goodfellow and Peter, 1994) that trends toward the ODP Mound.

Structural data collected during Leg 139 have been reviewed to discriminate between regional veining and veining associated with the BHMS. Holes 856A and 856B, situated north of the BHMS, crosscut more than $115 \mathrm{~m}$ of siltstone before ending in basalt intrusions. Neither hole recovered any hydrothermal veins or tectonic features within the sediment except at the basalt/sediment transition zone where pyrite-pyrrhotite-sphalerite-chalcopyrite-anhydrite fill extension fractures. Within the basalts, randomly oriented $<2-\mathrm{mm}$ wide veinlets of talc, quartz, clay minerals, and pyrite have been observed. Although the two holes are closely associated with an uplifted section of oceanic crust, no extensive vein system developed in the sediment section.

\section{Hole Review}

Visual core descriptions of the structural features and detailed structural data are provided in the appendixes (Tables 17, 18; also on CD-ROM, back pocket, this volume). Figure 103 shows the vein density, Figures 104 and 105 show the raw sulfide and nonsulfide vein width and vein dip data for each drill hole, and Figure 106 shows the vein dip vs. depth data for each drill hole.

\section{Hole $856 \mathrm{H}$}

Sedimentary bedding is within $6^{\circ}$ of horizontal. A few discrete decimeter-wide intervals with higher dips, sometimes more than $15^{\circ}$, are interpreted as synsedimentary slumping. There is a consistent sedimentary bedding $\left(\sim 190^{\circ} \mathrm{W}\right)$ observed on the FMS logs between 280 and $320 \mathrm{mbsf}$. Hole $856 \mathrm{H}$ crosses a dense network of hydrothermal veins. Evidence for major faults has not been observed in the recovered samples.

Several lithostructural units have been defined on the basis of veining and lithology: (1) massive sulfides (lithologic Unit V); (2) a sulfide feeder zone (lithologic Unit VI); (3) sediments (lithologic Units I and II); (4) mafic sills and sediments (lithologic Unit VII); and (5) basaltic flows (lithologic Unit VIII; see "Lithostratigraphic Summary and Sedimentology" section, this chapter, for details). 
Table 17. Structural measurements, Holes 1035A, 1035B, 1035C, 1035D, 1035E, 1035F, 1035G, and 1035H.

\begin{tabular}{|c|c|c|c|c|c|c|c|c|c|c|}
\hline \multirow[b]{2}{*}{$\begin{array}{l}\text { Core, } \\
\text { section }\end{array}$} & \multirow[b]{2}{*}{$\begin{array}{l}\text { Depth } \\
\text { (mbsf) }\end{array}$} & \multicolumn{2}{|c|}{ Feature } & \multicolumn{2}{|c|}{ Position } & \multicolumn{3}{|c|}{ Veins } & \multicolumn{2}{|c|}{ Apparent dips } \\
\hline & & Oriented & Identifier & $\begin{array}{l}\text { Top } \\
(\mathrm{cm})\end{array}$ & $\begin{array}{c}\text { Bottom } \\
(\mathrm{cm})\end{array}$ & Mineralogy & $\begin{array}{l}\text { Width } \\
(\mathrm{mm})\end{array}$ & $\begin{array}{l}\text { Wall } \\
\text { rock }\end{array}$ & $\begin{array}{l}\text { App dip/ } \\
\text { dir } 1\end{array}$ & $\begin{array}{l}\text { App dip/ } \\
\text { dir2 }\end{array}$ \\
\hline $169-1035 \mathrm{~A}-$ & & & & & & & & & & \\
\hline $6 \mathrm{H}-3$ & 48.89 & $\mathrm{Y}$ & V & 39 & 42 & Anh & 1 & SED & $20 / 270$ & - \\
\hline $6 \mathrm{H}-3$ & 48.92 & $\mathrm{Y}$ & V & 42 & 44 & Anh & 1 & SED & $20 / 271$ & - \\
\hline $6 \mathrm{H}-3$ & 48.97 & $\mathrm{Y}$ & V & 47 & 48 & Anh & 1 & SED & $20 / 272$ & - \\
\hline $6 \mathrm{H}-3$ & 49.00 & $\mathrm{Y}$ & V & 50 & 52 & Anh & 1 & SED & $20 / 273$ & - \\
\hline $6 \mathrm{H}-4$ & 51.30 & $\mathrm{Y}$ & V & 130 & 140 & Anh & 1 & SED & $52 / 090$ & - \\
\hline $6 \mathrm{H}-4$ & 51.40 & $\mathrm{Y}$ & V & 140 & 149 & Anh & 1 & SED & $55 / 090$ & - \\
\hline $6 \mathrm{H}-5$ & 52.10 & $\mathrm{Y}$ & V & 60 & 71 & Anh & 3 & SED & $58 / 270$ & - \\
\hline $8 \mathrm{X}-2$ & 63.74 & $\mathrm{Y}$ & V & 124 & 124 & Anh & 1 & SED & $00 / 000$ & - \\
\hline $8 X-2$ & 63.82 & $\mathrm{Y}$ & V & 132 & 132 & Anh & 1 & SED & $00 / 001$ & - \\
\hline $8 \mathrm{X}-2$ & 63.92 & $\mathrm{Y}$ & V & 142 & 142 & Anh & 1 & SED & $00 / 002$ & - \\
\hline $9 X-6$ & 78.27 & $\mathrm{Y}$ & V & 17 & 23 & Anh & 1 & SED & $40 / 090$ & - \\
\hline $13 X-1$ & 109.10 & $\mathrm{~N}$ & & 10 & 25 & Anh & 3 & SED & - & - \\
\hline $14 X-4$ & 123.70 & $\mathrm{~N}$ & V1A & 60 & 63 & Anh & 3 & SED & - & - \\
\hline $14 X-4$ & 123.70 & $\mathrm{~N}$ & V1B & 60 & 63 & Anh & 1 & SED & - & - \\
\hline
\end{tabular}

Notes: $\mathrm{Y}=$ oriented, $\mathrm{N}=$ not oriented, $\mathrm{Anh}=$ anhydrite, and $\mathrm{SED}=$ sediment.$-=$ no data.

Only part of this table is produced here. The entire table appears on the CD-ROM.

Table 17 (continued).

\begin{tabular}{|c|c|c|c|c|c|c|c|}
\hline \multirow{2}{*}{$\begin{array}{l}\text { Core, } \\
\text { section }\end{array}$} & \multirow{2}{*}{$\begin{array}{l}\text { Depth } \\
\text { (mbsf) }\end{array}$} & \multicolumn{2}{|c|}{ Planar } & \multicolumn{2}{|c|}{ Calculated } & \multirow{2}{*}{$\begin{array}{c}\text { Dip } \\
\text { direction }\end{array}$} & \multirow[b]{2}{*}{ Comments } \\
\hline & & Strike & Dip & Strike & Dip & & \\
\hline $169-1035 \mathrm{~A}-$ & & & & & & & \\
\hline $6 \mathrm{H}-3$ & 48.89 & - & - & - & - & - & Disrupted in drilling breccia \\
\hline $6 \mathrm{H}-3$ & 48.92 & - & - & - & - & - & Disrupted in drilling breccia \\
\hline $6 \mathrm{H}-3$ & 48.97 & - & - & - & - & - & Disrupted in drilling breccia \\
\hline $6 \mathrm{H}-3$ & 49.00 & - & - & - & - & - & Disrupted in drilling breccia \\
\hline $6 \mathrm{H}-4$ & 51.30 & - & - & - & - & - & Disrupted in drilling breccia \\
\hline $6 \mathrm{H}-4$ & 51.40 & - & - & - & - & - & Disrupted in drilling breccia \\
\hline $6 \mathrm{H}-5$ & 52.10 & - & - & - & - & - & \\
\hline $8 \mathrm{X}-2$ & 63.74 & - & - & - & - & - & \\
\hline $8 \mathrm{X}-2$ & 63.82 & - & - & - & - & - & \\
\hline $8 X-2$ & 63.92 & - & - & - & - & - & \\
\hline $9 \mathrm{X}-6$ & 78.27 & - & - & - & - & - & \\
\hline $13 \mathrm{X}-1$ & 109.10 & - & - & - & - & - & Near vertical in laminated silty sandstone \\
\hline $14 \mathrm{X}-4$ & 123.70 & - & - & - & - & - & Near vertical \\
\hline $14 \mathrm{X}-4$ & 123.70 & - & - & - & - & - & $\begin{array}{l}\text { Near vertical anhydrite veins occur within silty sandstone drilling biscuits, disseminated anhydrite } \\
\text { within drilling biscuits and matrix }\end{array}$ \\
\hline
\end{tabular}

Table 18. Summary of structural features observed in cores from Hole $856 \mathrm{H}$.

\begin{tabular}{|c|c|c|c|c|c|c|c|c|c|c|c|c|c|}
\hline \multirow[b]{2}{*}{ Core, section } & \multicolumn{3}{|c|}{ Feature } & \multicolumn{2}{|c|}{ Position } & \multicolumn{3}{|c|}{ Veins } & \multicolumn{2}{|c|}{ Planar } & \multicolumn{2}{|c|}{ Calculated } & \multirow[b]{2}{*}{ Comments } \\
\hline & $\begin{array}{l}\text { Depth } \\
\text { (mbsf) }\end{array}$ & Oriented & Identifier & $\begin{array}{l}\text { Top } \\
(\mathrm{cm})\end{array}$ & $\begin{array}{l}\text { Bottom } \\
(\mathrm{cm})\end{array}$ & Mineralogy & $\begin{array}{l}\text { Width } \\
(\mathrm{mm})\end{array}$ & Wall rock & Strike & Dip & Strike & Dip & \\
\hline \multicolumn{14}{|l|}{$169-856 \mathrm{H}-$} \\
\hline 18W-1, Piece 1 & & $\mathrm{~N}$ & V & 0 & 7 & $\mathrm{Cp}$ & 2 & MAS & - & - & - & - & Set of veins \\
\hline $18 \mathrm{~W}-1$, Piece 2 & & $\mathrm{~N}$ & V & 7 & 10 & $\mathrm{Cp}$ & 2 & MAS & - & - & - & - & Set of veins \\
\hline $18 \mathrm{~W}-1$, Piece 3 & & $\mathrm{~N}$ & V & 10 & 17 & $\mathrm{Cp}$ & 2 & MAS & - & - & - & - & Set of veins \\
\hline 19R-1, Piece 2 & 93.85 & $\mathrm{~N}$ & V & 5 & 9 & $\mathrm{Cp}$ & 1 & MAS & - & - & - & - & \\
\hline 19R-1, Piece 3 & 93.89 & $\mathrm{~N}$ & $\mathrm{~V}$ & 9 & 17 & $\mathrm{Cp}$ & 1 & MAS & - & - & - & - & \\
\hline 19R-1, Piece 5 & 94.05 & $\mathrm{~N}$ & V & 25 & 31 & $\mathrm{Cp}$ & 3 & MAS & - & - & - & - & Set of veins \\
\hline 20R-1, Piece 3 & 103.75 & $\mathrm{Y}$ & $4 \mathrm{~V}$ & 15 & 43 & $\mathrm{Cp}$ & 2 & MAS & 000 & 90 & 000 & 90 & Set of veins \\
\hline 20R-1, Piece 3 & 103.75 & $\mathrm{Y}$ & $4 \mathrm{~V}$ & 15 & 43 & Po & 1 & MAS & 000 & 90 & 000 & 90 & Set of veins \\
\hline 20R-1, Piece 4 & 104.06 & $\mathrm{~N}$ & V & 46 & 51 & Carb & 3 & MAS & - & - & - & - & \\
\hline 20R-1, Piece 5 & 104.15 & $\mathrm{~N}$ & V & 55 & & Carb & 1 & MAS & - & - & - & - & \\
\hline
\end{tabular}

Notes: $\mathrm{N}=$ not oriented, $\mathrm{V}=$ vein, $\mathrm{Cp}=$ chalcopyrite, $\mathrm{MAS}=$ massive sulfide, $\mathrm{Y}=$ oriented, $\mathrm{Po}=$ pyrrhotite, $\mathrm{SED}=$ sediments, Carb $=$ carbonate, and $\mathrm{CpPo}=$ chalcopyrrhotite. $-=$ no data.

Only part of this table is produced here. The entire table appears on the CD-ROM.

\section{Massive Sulfides (Lithologic Unit V)}

The first core drilled in Hole 856H during Leg 169 (Core 169856H-19R, 93.8-103.6 mbsf) recovered massive sulfide (pyrite and pyrrhotite) crosscut by a few millimeter-wide pyrite veins bordered by magnetite (Fig. 107, interval 169-856H-19R-1, 31-38 cm).

\section{Sulfide Stringer Zone (Lithologic Unit VI)}

Directly below the massive sulfide deposit (Core 169-856H-20R, 103.6-113.4 mbsf), the hydrothermal vein system is composed of millimeter-wide subvertical chalcopyrite (Cp), pyrrhotite (Po), isocu- banite (Icb), and pyrite (Py) veins that coalesce. Some of these veins occasionally "feed" small sulfide impregnation pockets (Fig. 108; interval $169-856 \mathrm{H}-20 \mathrm{R}-1,16-42 \mathrm{~cm}$ ) of a few, probably more permeable sediment layers.

This network of predominantly subvertical coalesced veins continues downhole. Coalesced $\mathrm{Cu}-\mathrm{Fe}$ sulfide veins have maximum thicknesses of several centimeters and sometimes contain relict sedimentary clasts (Fig. 109; interval 169-856H-21R-1, 54-70 cm). These composite veins typically exhibit more than 101 -mm-wide veins over a $1-\mathrm{cm}$-wide interval, are subvertical, and include relicts 

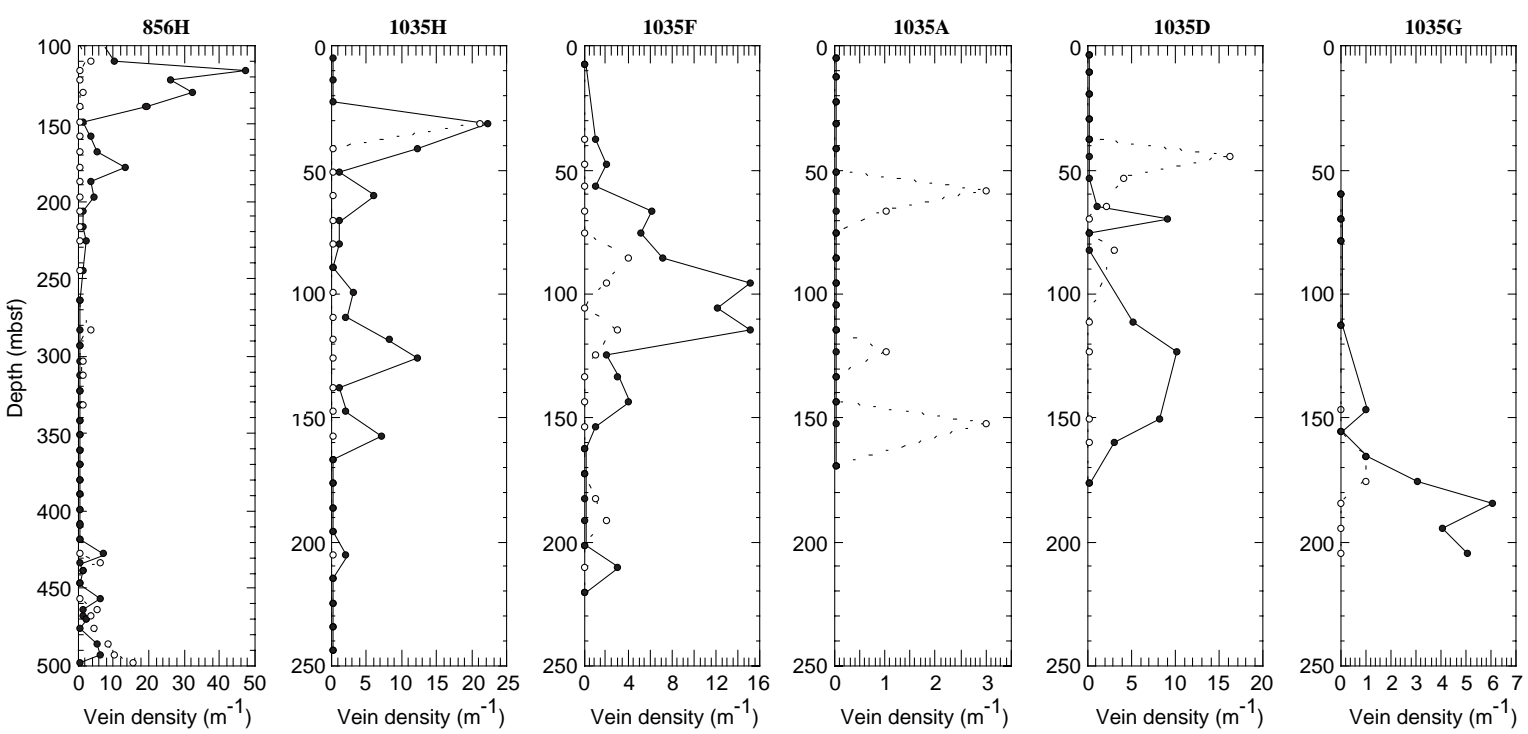

Figure 103. Vein density expressed in veins per meter $\left(\mathrm{m}^{-1}\right)$. Solid circles and lines $=$ sulfide veins, and open circles and dashed lines $=$ nonsulfide veins. Same vertical scale for all diagrams except Hole $856 \mathrm{H}$; horizontal scales are different.
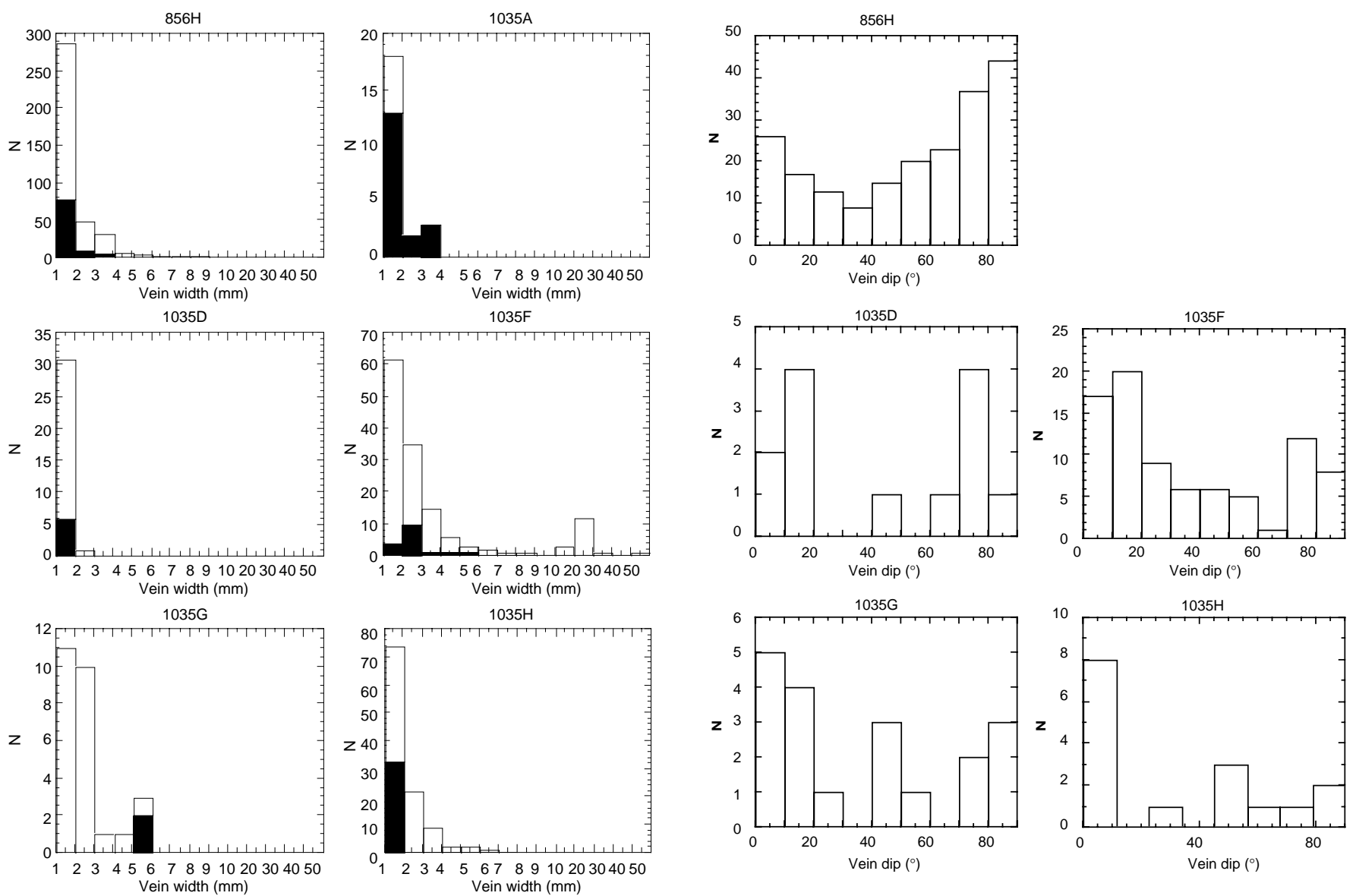

Figure 104. Vein width distribution for the different Bent Hill holes. Solid areas $=$ sulfide veins, and open areas $=$ nonsulfide veins.

Figure 105. Vein dip distribution for the different Bent Hill holes. 

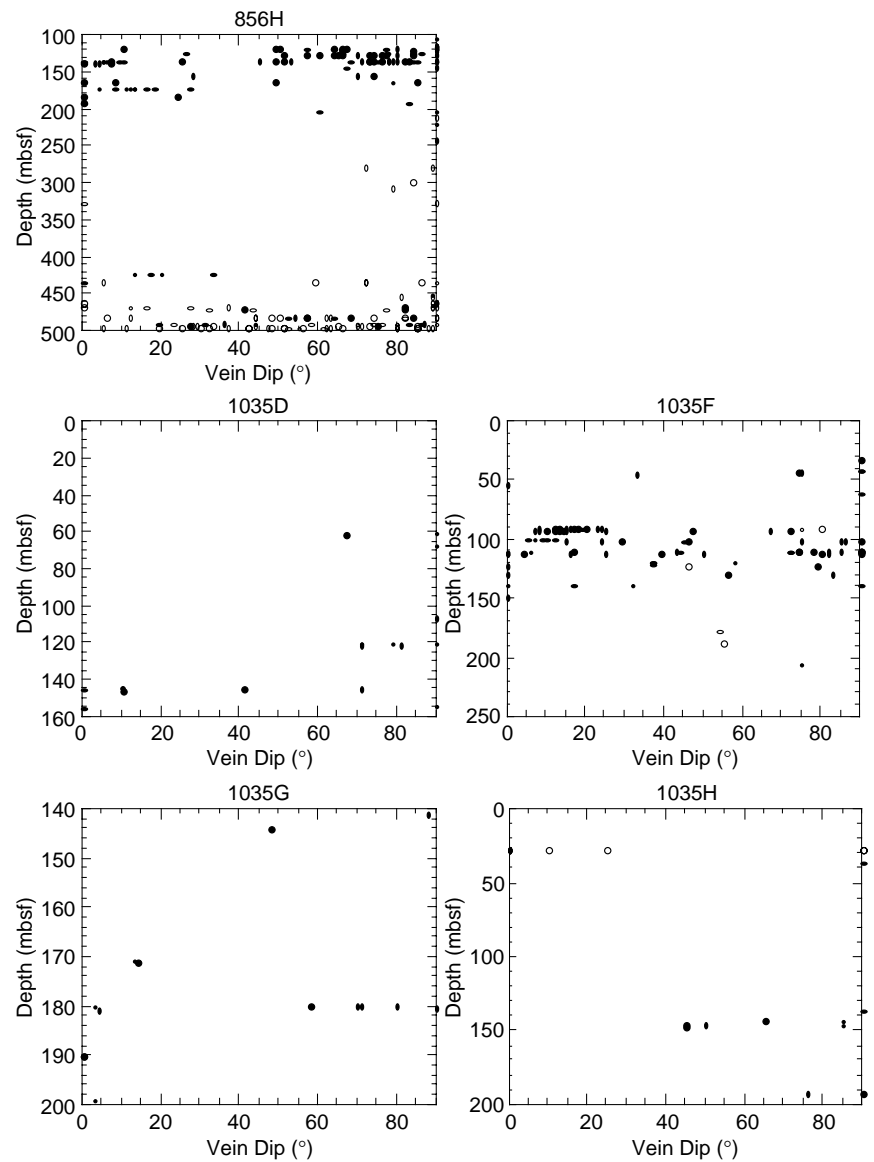

Figure 106. Vein dip vs. depth for the different Bent Hill holes. Solid circles $=$ sulfide veins, and open circles $=$ nonsulfide veins .

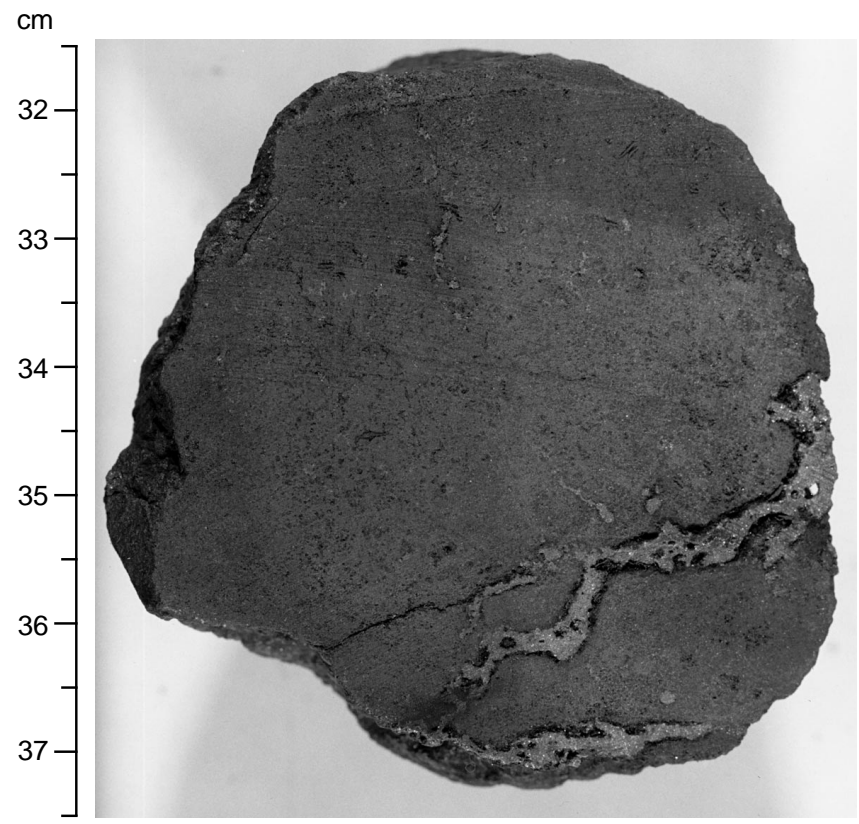

Figure 107. Massive fine-grained pyrrhotite cut by pyrite veins (interval 169856H-19R-1, 31.5-37.5 cm; Subunit IIA).

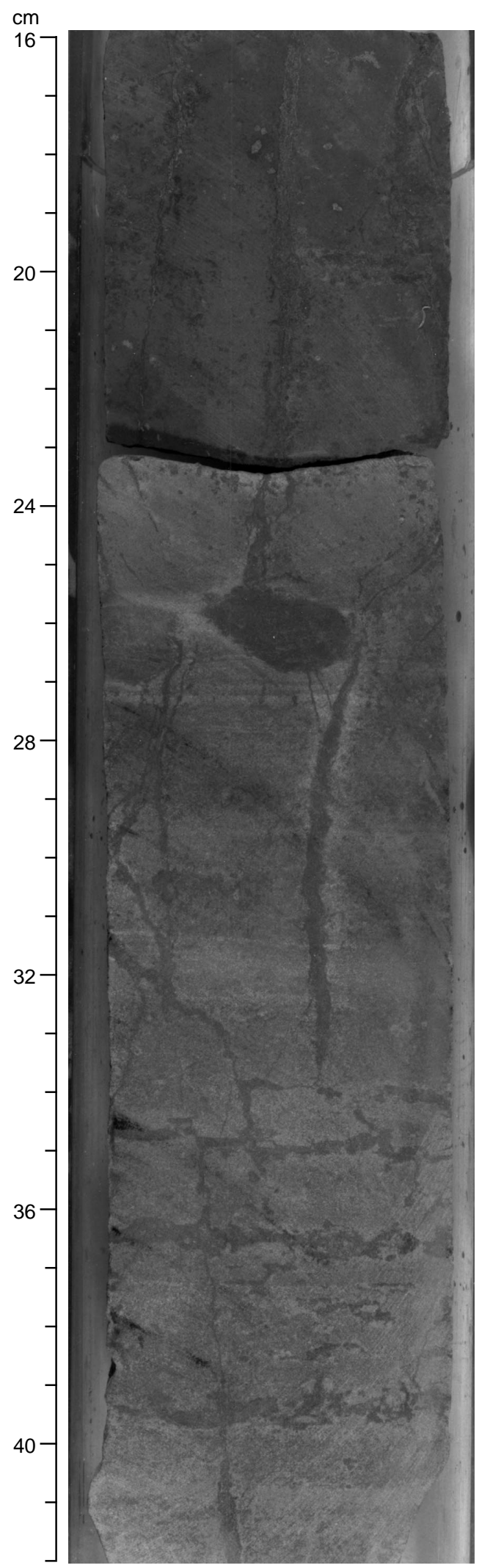

Figure 108. Subvertical set of Cp-Icb-Po-Py veinlets feeding small subhorizontal sulfide impregnation pockets and layers (interval 169-856H-20R-1, $16-42 \mathrm{~cm})$. 


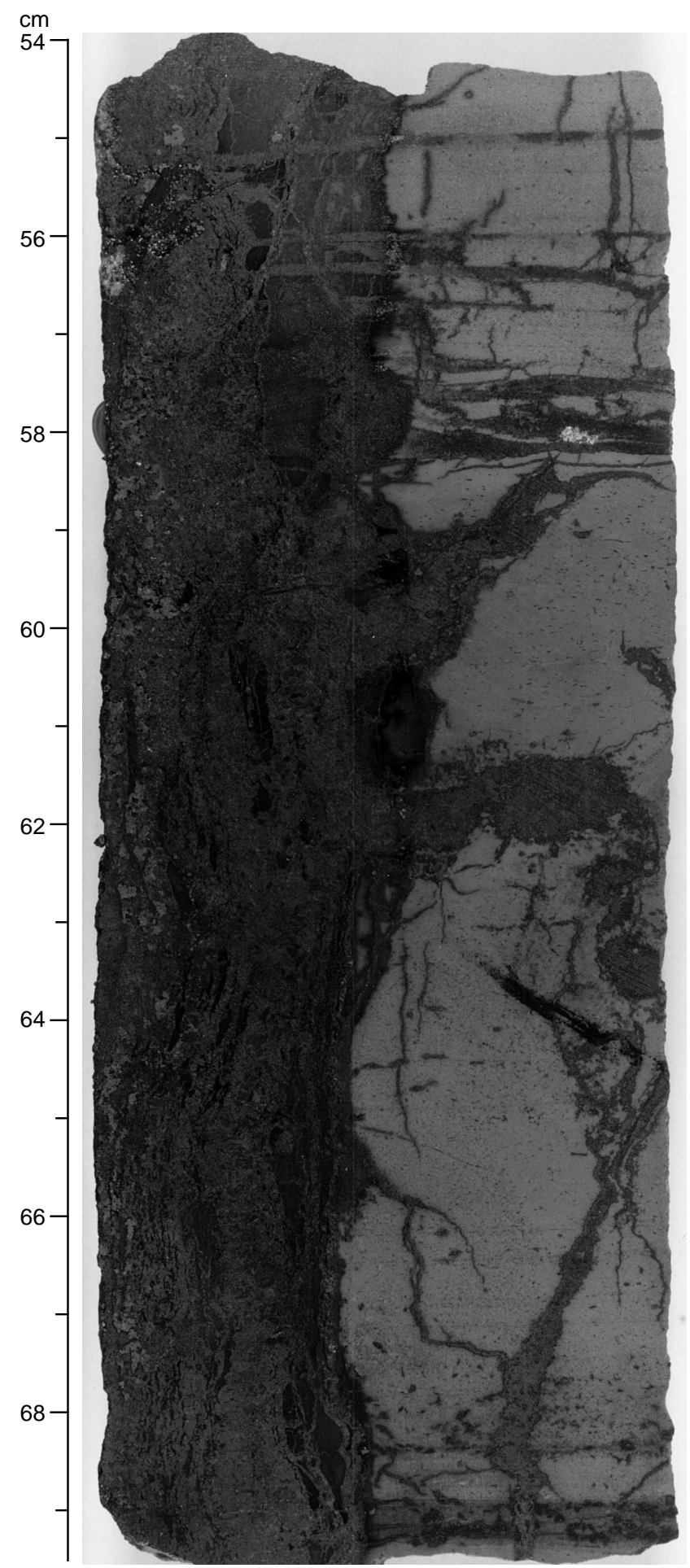

Figure 109. Composite Cp-Isb-Py-Po subvertical vein formed by the coalescence of tiny millimeter-wide veinlets and including relicts of pale gray altered sediments. A few subhorizontal layers and pockets show extensive sulfide impregnations (interval 169-856H-21R-1, 54-69.5 cm). of pale gray altered sediments. A few hydraulic breccias are present with a network of hydrothermal veins separating sediment clasts. The coalesced nature of the veins suggests that they formed by multiple increments of cracking and mineral filling, indicative of periodic fluid overpressuring.

Veins make up more than $5 \%$ of the split surface of Section 169856H-22R-1 (vein density 26/m). A few 1-cm-wide copper sulfide veins (Section 169-856H-22R-1 [Pieces 3, 4, 5, and 12]) are the result of the coalescence of 1-mm-wide veins. Section 169-856H-22R-2 shows the juxtaposition of sediments crosscut by a very dense net of sulfide veinlets and of a 1-cm-wide coalesced vein (Section 169$856 \mathrm{H}-22 \mathrm{R}-2$, Pieces 5, 7, 12, and 16; Fig. 53; interval 169-856H22R-2, 43-60 cm).

Cores $169-856 \mathrm{H}-23 \mathrm{R}$ and $24 \mathrm{R}(124.1-143.3 \mathrm{mbsf})$ show a dense net of mainly noncoalesced, subvertical anastomosing Icb-Cp-Po veins crosscutting sulfide impregnated sediments (Fig. 54, interval 169-856H-23R-1, 41-47 cm; Fig. 55, interval 169-856H-23R-1, 100-107 cm; Fig. 56, interval 169-856H-23R-2, 0-22 cm; and Fig. 57 , interval $169-856 \mathrm{H}-24 \mathrm{R}-1,50-60 \mathrm{~cm}$ ). This is in contrast to the vertical and coalesced vein set observed in the overlying cores.

Within Section 169-856H-24R-2, this dense stockwork gives way to sediments with only a few 1 -mm-wide sulfide veinlets and sulfide impregnations (interval 169-856H-24R-2, 120-126 cm). Interval 169-856H-25R-1, 8-30 cm, contains a 4-cm-wide subvertical vein filled by coarse-grained pyrrhotite. This vuggy vein is followed downcore by less-indurated sediments that are crosscut by a few millimeter-wide veins and sulfide impregnations. The veins are coppersulfide bearing and subperpendicular to the bedding plane (vein density within this interval decreases to less than $2 / \mathrm{m}$ ), whereas the impregnations are concordant with the layering and appear to follow the more permeable layers (Fig. 66; interval 169-856H-31R-1, 99-107 $\mathrm{cm})$.

Cores 169-856H-26R through 30R (152.9-201.0 mbsf) are similar in their paucity of hydrothermal veins. The veins are generally less than $1 \mathrm{~mm}$ wide, subhorizontal, and parallel to bedding. The vein density measured along the core axis is $<3 / \mathrm{m}$ in Section $169-856 \mathrm{H}-$ 26R-1, 5/m in Section 169-856H-27R-1, <13/m in Sections 169$856 \mathrm{H}-28 \mathrm{R}-1$ and $29 \mathrm{R}-1$, and $4 / \mathrm{m}$ in Section $169-856 \mathrm{H}-30 \mathrm{R}-1$. Only a few crosscutting veins are present, and these seem to be synchronous with the horizontal veins and the disseminated sulfides. Similarly, Core 169-856H-31R (201.0-210.6 mbsf), although very extensively mineralized by bedding-parallel $\mathrm{Cu}-\mathrm{Fe}$ sulfide impregnations $(>30 \%)$, is almost devoid of hydrothermal veins $(<1 / \mathrm{m})$.

\section{Interbedded Turbidites and Hemipelagic Sediments (Lithologic Unit} II)

Downhole, the number of hydrothermal veins decreases significantly, and only a few vuggy quartz veins are preserved in Section 169-856H-32R-1. From Core 169-856H-33R through 53R (220.2$422.2 \mathrm{mbsf}$ ), the density of hydrothermal veins drops to $<1 / \mathrm{m}$ of subvertical, $<1$-mm-wide anhydrite veins. One anhydrite vein shows a 5$\mathrm{mm}$ normal offset (Fig. 25, interval 169-856H-42R-1, 6-18 cm).

\section{Basaltic Sill Complex (Lithologic Unit VI)}

Abundant veining reappears in an alternating sequence of basaltic sills and sediments starting with Core 169-856H-55R (431.7-434.3 mbsf). The sediments are predominantly crosscut by a diffuse set of millimeter-wide quartz-sulfide veins (density $<5 / \mathrm{m}$ ). The basaltic sills have a much greater vein density $(>10 / \mathrm{m})$ of millimeter-wide chlorite-quartz (Fig. 110; interval 169-856H-55R-1, 42-47 cm) and vuggy quartz-pyrite veins. Trace amounts of epidote occur in the quartz-rich veins. The mineralogy and density of the veins is strongly controlled by lithology; abundant chlorite-bearing veins occur in sills, but a lower density of quartz-sulfide veins is found in the sediments. 


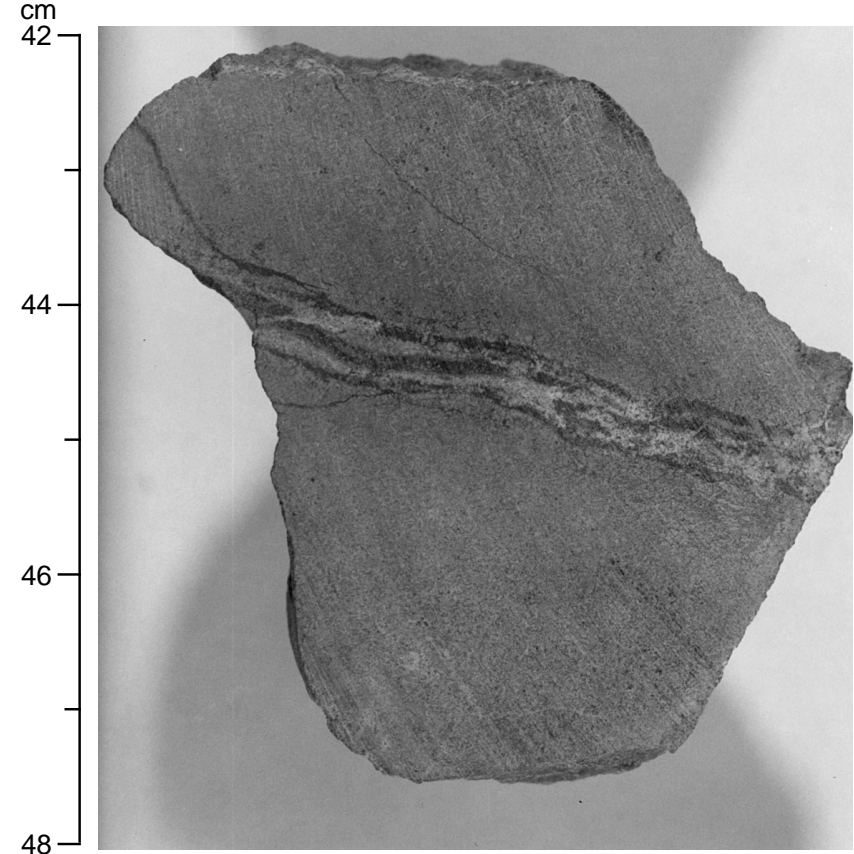

Figure 110. Tiny subparallel set of chlorite veinlets in basaltic sill (interval $169-856 \mathrm{H}-55 \mathrm{R}-1,42-48 \mathrm{~cm})$.

\section{Basaltic Flows}

With the disappearance of the sediments and the appearance of the first hyaloclastites at the top of Core $169-856 \mathrm{H}-63 \mathrm{R}(479.9-489.5$ mbsf), the density of the hydrothermal veins increases to $>10 / \mathrm{m}(>15 /$ $\mathrm{m}$ in Core 169-856H-65R, 494.2-500.0 mbsf). The veins are mainly chloritic, with trace amounts of chalcopyrite, and have chloritized margins. Compared to the overlying vein network, these veins have a sinuous and discontinuous geometry (Fig. 111; interval 169-856H$65 \mathrm{R}-1,24-52 \mathrm{~cm}$ ) that is interpreted as mineral filling of thermal contraction cracks in the basaltic pillow lava.

\section{Hole 1035A}

Hole 1035A is, with few exceptions, almost devoid of hydrothermal veins. Evidence for major faults has not been observed within the hole, and sedimentary bedding is within $5^{\circ}$ of horizontal. Hydrothermal veins are present in Cores 169-1035A-6H, 8X, 9X, 13X, and 14X and in the core catchers from Cores 169-1035A-17X and 19X. With the exception of small pyrrhotite-filled tension gashes in the core catcher from Core 169-1035A-19X (166.7-170.8 mbsf), the veins are generally 1 -mm-wide (maximum $3 \mathrm{~mm}$ ), anhydrite-filled extension veins (interval 169-1035A-6H-3, 36-55 cm; Fig. 112). A total of 17 anhydrite veins are present in the recovered cores. Only a minimum dip could be measured on most of the anhydrite-filled veins. Most veins are subvertical, although a few subhorizontal veins were recovered. The small pyrrhotite-filled tension gashes in the core catcher from Core 169-1035A-19X have a sigmoidal shape, are $1 \mathrm{~mm}$ wide, vertical, and indicate a normal displacement. The total density of hydrothermal veins is generally $<1 / \mathrm{m}$ and always $<3 / \mathrm{m}$. No stringer zone was encountered.

\section{Hole 1035D}

Most sedimentary bedding and laminations are within $5^{\circ}$ of horizontal with the exception of Core 169-1035D-20X (144.7-154.3 mbsf), which shows a consistent $10^{\circ}$ to $11^{\circ}$ dip of the lamination. This strong lamination dip could be explained as a primary feature,

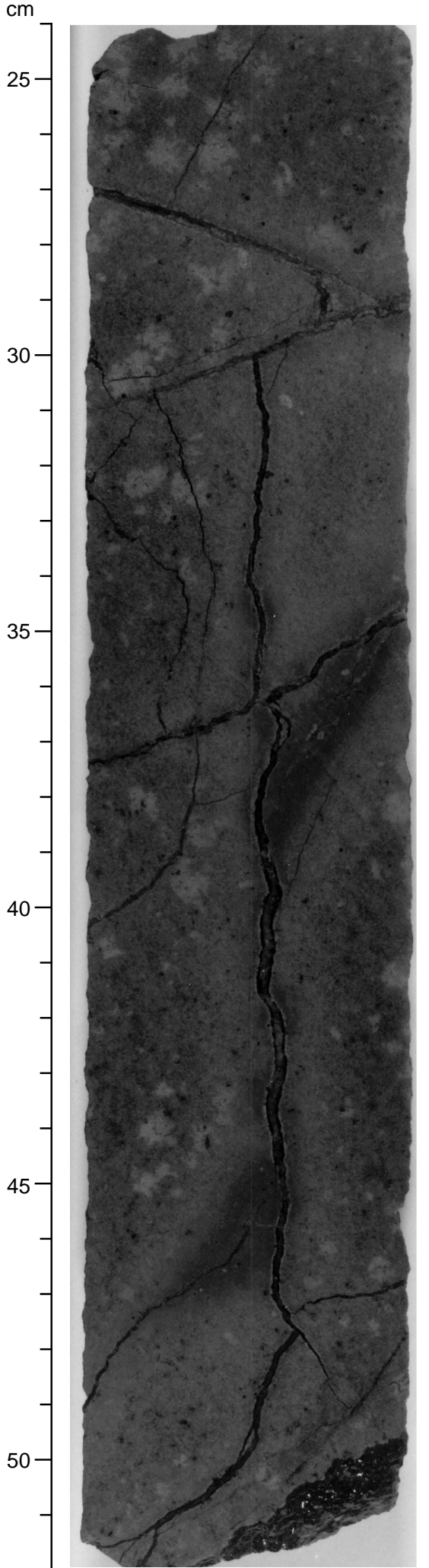

Figure 111. Interval 169-856H-65R-1, 24-52 cm, showing a fine-grained basalt from the lowermost unit of Hole $856 \mathrm{H}$. Pyroxene phenocrysts are altered to chlorite, and the groundmass is replaced by irregular patches $(<1$ $\mathrm{cm}$ ) of lighter colored chlorite. The sample is crosscut by numerous irregular quartz + chalcopyrite veins with chloritic selvages and complex, multistage chloritic alteration halos. 


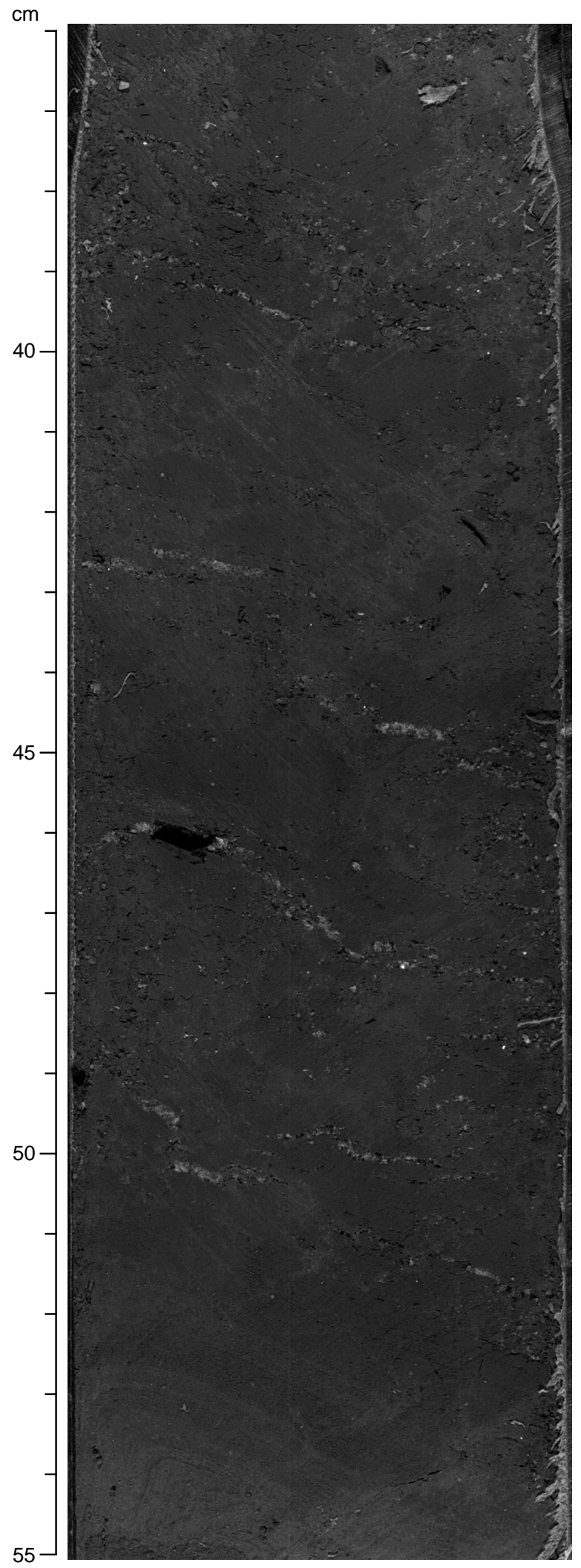

Figure 112. Mud clast breccia with up to 1-mm-wide veinlets of anhydrite (interval $169-1035 \mathrm{~A}-6 \mathrm{H}-3,36-55 \mathrm{~cm}$ ). the lamination being at a high angle to the bedding. Alternatively, it could mark a major tectonic tilting within the drilled sequence. Hole $1035 \mathrm{D}$, with few exceptions, is almost devoid of hydrothermal veins.

On the basis of lithology, vein nature, and density, three lithostructural units were distinguished: (1) sediments underlain by (2) massive sulfide and semi-massive sulfide in turn underlain by (3) slightly veined sediments.

The first lithostructural unit (Cores 169-1035D-1H through 5H, 0.0-40.6 mbsf) is interbedded hemipelagic to turbiditic sediments with clastic sulfides. No hydrothermal veins occur in this unit.

The second unit (Cores 169-1035D-6X through 9X, 40.6-66.5 mbsf) is composed of massive sulfides and semi-massive sulfides with sediment relicts. This unit is crosscut by a few anhydrite veins along with a few magnetite, chalcopyrite, and pyrite-pyrrhotite veins. The anhydrite veins are generally $1 \mathrm{~mm}$ wide or less and show no lateral continuity. The pyrite-pyrrhotite veins have a tendency to anastomose and induce sulfide impregnations of the sediment host rock (interval 169-1035D-10X-1, 70-77 cm). The sulfide and anhydrite veins tend to be subvertical and have densities $<10 / \mathrm{m}$.

The third unit (Cores 169-1035D-10X through 21X, 66.5-163.9 mbsf), is characterized by a diffuse net of pyrrhotite veins crosscutting sandstone and siltstone (Fig. 113; interval 169-1035D-20X-1, 4$21 \mathrm{~cm}$ ). This unit is devoid of anhydrite veins. The sulfide veins are millimeter wide and have a low density that can be locally higher than $10 / \mathrm{m}$. The pyrrhotite veins are characteristically subvertical extension veins or subhorizontal veins and impregnations along bedding and lamination.

\section{Hole 1035F}

Within Hole $1035 \mathrm{~F}$, most sedimentary bedding and laminations are within $5^{\circ}$ of horizontal. However, a few samples show laminations dipping at $>20^{\circ}$ over short intervals. These strong dips are primary features (cross-bedding and slumps) and do not mark a major tectonic tilting within the drilled sequence. Hole $1035 \mathrm{~F}$ crosscuts the BHMS mound and its underlying feeder zone. Direct evidence for major faults has not been observed within the core.

On the basis of lithology, vein nature, and density, three lithostructural units could be distinguished: (1) a massive sulfide deposit (Cores 169-1035F-1R through 8R, 0.0-80.2 mbsf); underlain by (2) a stockwork zone (Cores 169-1035F-9R through 13R, 80.2-128.6 mbsf); that is transitional to (3) unaltered sediment (Cores 1691035F-14R through 23R, 128.6-224.8 mbsf).

Below a few gossanized clastic sulfide samples, the top of the massive sulfide deposit is characterized by an extensive mineralogi$\mathrm{cal}$, grain-size, pore-size, and pore-abundance banding (interval 1691035F-4R-1, 18-50 cm; interval 169-1035F-5R-1, 12-27 cm, Fig. 50; interval 169-1035F-5R-1, 87-99 cm; and interval 169-1035F$7 \mathrm{R}-1,0-9 \mathrm{~cm})$. The bands are $1 \mathrm{~mm}$ to $3 \mathrm{~cm}$ wide and are mainly vertical to within $25^{\circ}$ of the core axis. Only one horizontal band was encountered in Core 169-1035F-6R-1 between 130 and $135 \mathrm{~cm}$. The bands have parallel margins, extend over more than half a meter (interval $169-1035 \mathrm{~F}-4 \mathrm{R}-1,18-50 \mathrm{~cm}$ ), and are evidently paleo fluidflow conduits. These bands extend from Core 169-1035F-4R through 7R (32.1-70.6 mbsf). The pores within the bands are up to $5 \mathrm{~mm}$ wide and $30 \mathrm{~mm}$ long, and the long axis is parallel to the band margin. Some of the pores are interconnected, they can comprise $30 \%$ of individual samples, and may maintain open fluid channels. The banding is not observed below Core 169-1035F-8R (70.6-80.2 mbsf). These nonbanded cores might represent sulfide impregnated sediment rather than veined and recrystallized sulfide mound material, as occurs in the interval above.

The underlying mineralized stockwork, from Core $169-1035 \mathrm{~F}$ 10R through 17R (89.9-167.1 mbsf), occurs within strongly indurated mudstone and siltstone. Millimeter- to 1-cm-wide lamination-parallel sulfide impregnations develop within the siltstones, whereas within the mudstones, an anastomosing subvertical system of milli- 
$\mathrm{cm}$

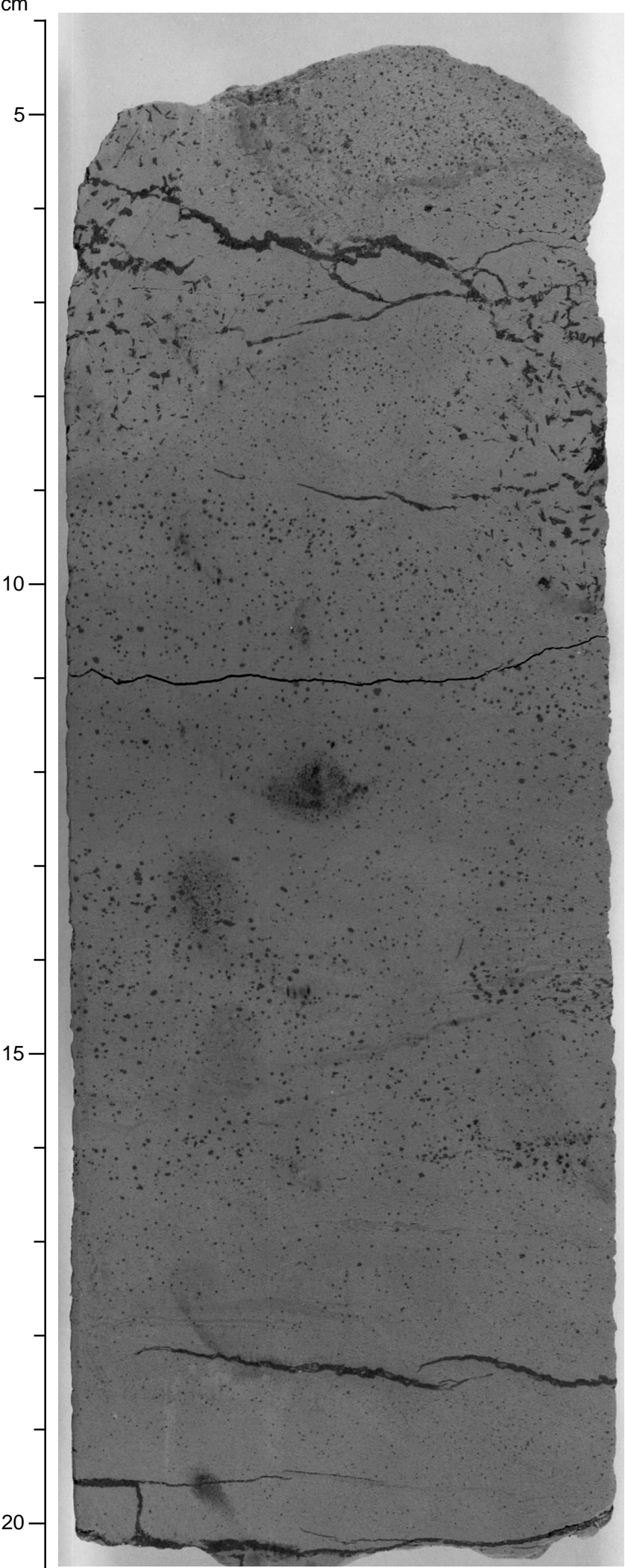

Figure 113. Subhorizontal pyrrhotite veins and dissemination parallel to siltstone bedding (interval 169-1035D-20X-1, 4-20.5 cm). meter-wide veins forms (see the transition in Core 169-1035F-13R$1,70 \mathrm{~cm}$ ). This strong lithologic control, with fracturing in the mudstone-rich layers and lamination-parallel sulfide impregnation in the siltstone layers, might be related to a primary difference in permeability between the two lithologies, where porous flow occurs in the siltstone layers and cracking occurs in the mudstone. Alternatively, the inherent differences in the vein network may be related to a different mechanical behavior of the two host rocks during cracking, with an initial subhorizontal mechanical anisotropy allowing the formation of horizontal cracks in the siltstones and not in the mudstone. Lamination-parallel, pyrite-filled wavy veins (Fig. 65, interval 1691035F-13R-1, 79-86 cm; intervals 169-1035F-10R-1, 101-102 cm, and $169-1035 \mathrm{~F}-13 \mathrm{R}-1,110-112 \mathrm{~cm}$ ) and relay fractures that are slightly oblique to the lamination suggest that both processes may be active.

The sulfide-bearing veins are mainly less than $1 \mathrm{~mm}$ wide and have a preferred lamination parallel or subvertical orientation. The veins in Hole $1035 \mathrm{~F}$ that exhibit crack-seal textures are less abundant than in Hole $856 \mathrm{H}$. The veins are all extension fractures with the minor exception of an anhydrite-filled reverse fault (1-cm offset) in interval 169-1035F-10R-2, 0-9 cm, and of an anhydrite-filled (with trace chalcopyrite), 2-cm-wide hydraulic breccia in interval 169$1035 \mathrm{~F}-14 \mathrm{R}-1,28-35 \mathrm{~cm}$, associated with a small normal fracture. Downcore, within the stockwork, the density of veins decreases from $>15 / \mathrm{m}$ in Cores $169-1035 \mathrm{~F}-10 \mathrm{R}, 11 \mathrm{R}$, and $12 \mathrm{R}$, to $<2 / \mathrm{m}$ from Cores 169-1035F-13R through 17R.

The top of Core 169-1035F-18R (167.1-176.8 mbsf) is a typical hydrothermal fault gouge. The fault gouge is $>5-\mathrm{cm}$ thick and is composed of $>50 \%$ anhydrite with chlorite and traces of sulfides. The upper and lower margins of the gouge are brecciated sulfides. No host rock has been preserved, and the recovered samples are vuggy $(10 \%$ open space). The breccia overlays a silicified sulfide-rich zone, which in turn, overlays sediments almost devoid of hydrothermal veins. From Core 169-1035F-19R through 23R (176.8-224.8 mbsf), the total vein density drops below $3 / \mathrm{m}$, with only traces of anhydrite, quartz, and pyrite veins.

\section{Hole $1035 G$}

Hole $1035 \mathrm{H}$ is located a few meters from Hole 1035A. The upper section (0-44.4 m) was drilled without coring. In the deepest part of the hole, sedimentary bedding and laminations are within $5^{\circ}$ of horizontal. However, a few limited sections or intervals within sections show laminations dipping at $>10^{\circ}$ (e.g., Sections 169-1035G-9R-2, 10R-1, and 11R-1). These dips are primary features and do not mark a major tectonic tilting of the drilled sequence.

Below a few centimeters of silty claystone, Hole $1035 \mathrm{G}$ penetrates massive sulfide (Cores 169-1035G-2R through 4R, 44.4-73.6 mbsf) overlying weakly altered sediment (Cores 169-1035G-5R through 9R, 73.6-169.8 mbsf). The massive sulfide is mainly vuggy pyrite (up to $20 \%-30 \%$ open space) and is crosscut by a few pyrite and anhydrite veins. The underlying claystones (Core 169-1035G5R, 73.6-83.3 mbsf) show two strike-slip fractures, dipping at $46^{\circ}$, with horse-tailing and subhorizontal slickensides. The constant dip of the strike-slip faults and the presence of a $2-\mathrm{mm}$-wide, small anhydrite filling (interval 169-1035G-5R-2, 70-79 cm) along one of these features suggests that these fractures are not drilling induced. The base of the massive sulfide deposit (Core 169-1035G-5R, 73.6-83.3 mbsf) is entirely devoid of hydrothermal veins. However, hydrothermal veins reappear in Core 169-1035G-7R (140.9-150.5 mbsf) with a 1-mm-wide subvertical polymetallic vein (chalcopyrite-sphaleriteanhydrite). A few chalcopyrite-bearing subvertical veins, some with a normal shear component (interval 169-1035G-7-CC, 5-35 cm), occur downhole. Section 169-1035G-10R-1 shows an impressive bedding-parallel hydraulic breccia developed in a siltstone. From base to top (interval 169-1035G-10R-1, 8-69 cm), the hydraulic breccia shows a continuous evolution in its mineralogy and texture. The base 


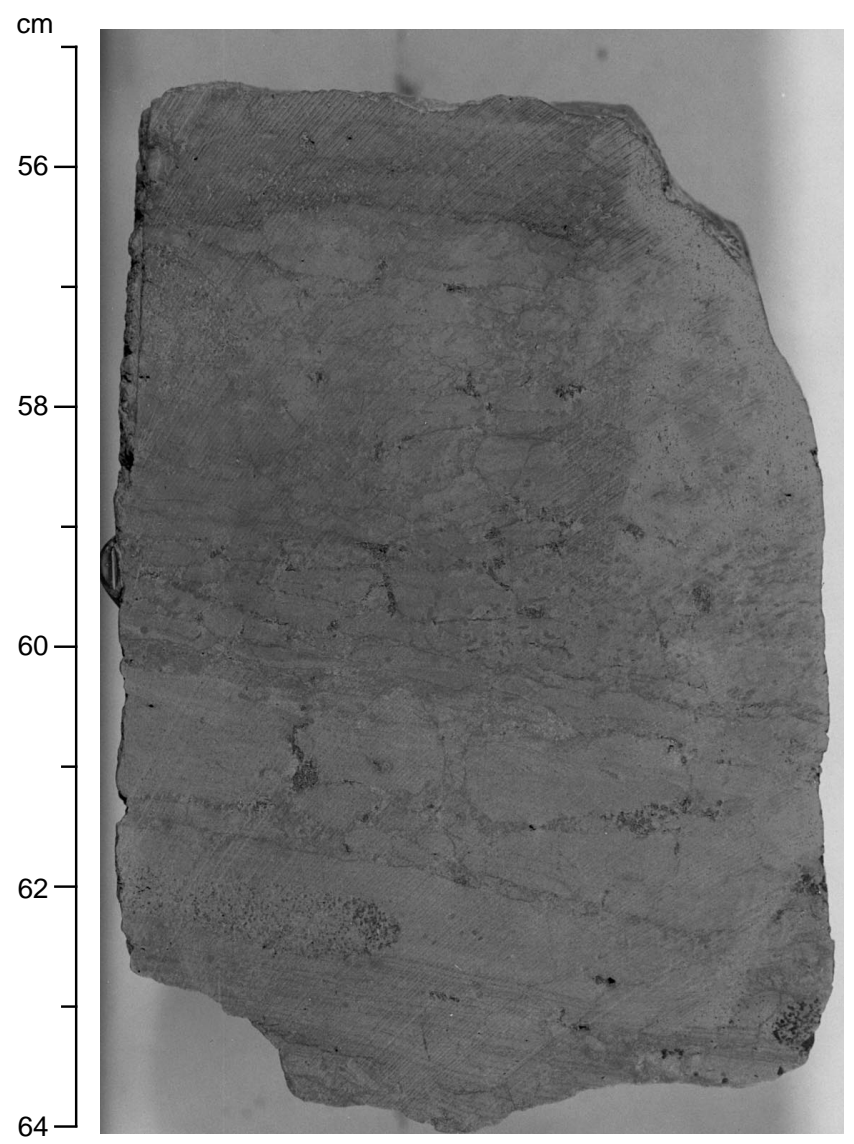

Figure 114. Bedding-parallel hydraulic breccia that preserves the original bedding planes. Minor pyrrhotite replacement occurs preferentially in the matrix (interval 169-1035G-10R-1, 55-64 cm).

of the breccia zone exhibits lamination-parallel jigsaw cracks with no movement of grains and preserves the original bedding (Figure 114; interval 169-1035G-10R-1, 54-65 cm). Minor impregnation of pyrrhotite occurs within the matrix (interval 169-1035G-10R-1, 40-65 $\mathrm{cm})$. The top of the zone is characterized by an extensive replacement of the matrix by pyrrhotite (Fig. 115; interval 169-1035G-10R-1, 20$26 \mathrm{~cm}$ ). The intermediate levels are extensively altered by talc. Below the hydraulic breccia, pyrite-dominated impregnations a few millimeters wide occur in coarser sandstone layers along with subvertical veins (vein density $<6 / \mathrm{m}$ ).

\section{Hole 1035H}

Hole $1035 \mathrm{H}$ is situated on the ODP Mound $\sim 350 \mathrm{~m}$ south of the BHMS deposit and $\sim 50 \mathrm{~m}$ south of the Lone Star active vent. The recovered cores allow subdivision of the hole into a minimum of six main lithostructural units, from top to base: (1) a massive sulfide unit (Cores 169-1035H-1R through 3R, 0.0-26.4 mbsf); (2) an underlying stockwork (Cores 169-1035H-4R through 6R, 26.4-55.2 mbsf); (3) slightly veined sediments (Cores 169-1035H-7R and 8R, 55.2-74.6 mbsf); (4) strongly veined sediments (Cores 169-1035H-9R through 13R, 74.6-123.0 mbsf); (5) massive to semi-massive sulfide (Cores 169-1035H-14R through 21R, 23.0-190.3 mbsf); and (6) slightly veined sediment (Cores 169-1035H-22R through 27R, 190.3-247.9 mbsf).

Below the upper layer of clastic massive sulfides (interval 169$1035 \mathrm{H}-2 \mathrm{R}-1,134-140 \mathrm{~cm}$ ), the hole intersected a siltstone and mudstone crosscut by a network of subvertical sulfide (Py-Po-Sph-Cp) veins and subhorizontal sulfide impregnations $(>20 / \mathrm{m}$ in Core $169-$ $1035 \mathrm{H}-4 \mathrm{R}, 26.4-36.0 \mathrm{mbsf}$ ). A dense network of very fine quartz and

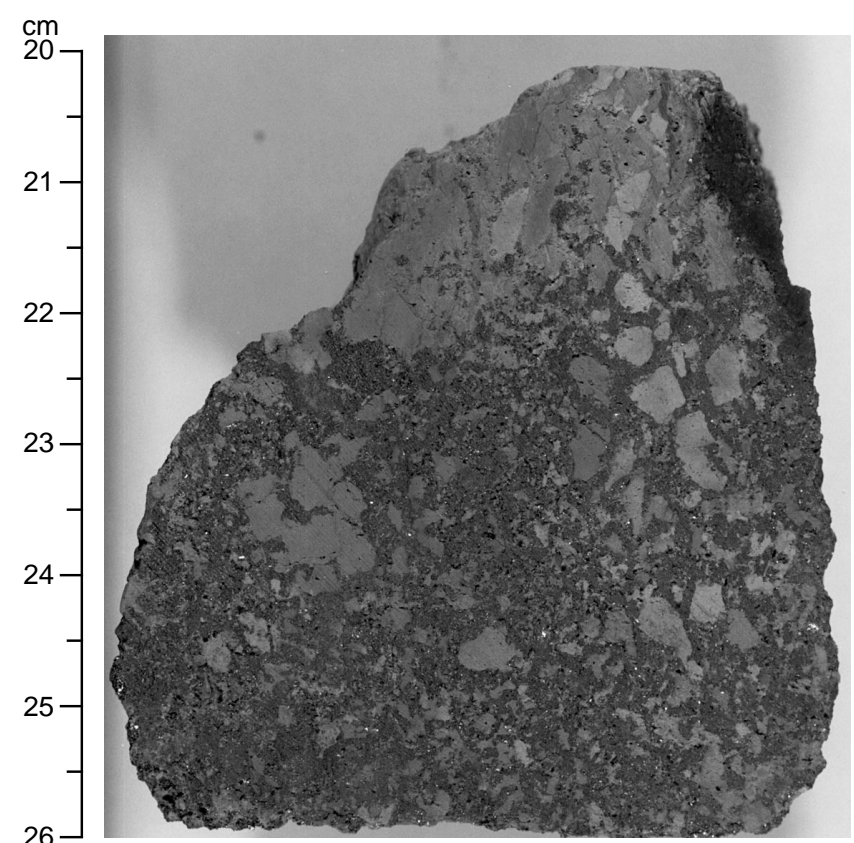

Figure 115. Hydraulic breccia with matrix completely replaced by pyrrhotite (interval 169-1035G-10R-1, 20-26 cm).

anhydrite veinlets was recovered further downcore $(>2 / \mathrm{m}$ in interval 169-1035H-4R-1, 32-49 cm). The subhorizontal sulfide impregnations are strongly discontinuous and have a wavy appearance (intervals $169-1035 \mathrm{H}-4 \mathrm{R}-1,143-150 \mathrm{~cm}$; 4R-2, 43-52 cm; and 5R-1, 16$23 \mathrm{~cm}$ ). Some of the impregnations resemble tension gashes, but they exhibit variable shear directions. A sharp decrease in the density of anhydrite and quartz veins below Core 169-1035H-4R (26.4-36.0 mbsf) is followed downcore by less abundant, mainly subvertical, 1to 5-mm-wide pyrrhotite veins.

In Section 169-1035H-9R-1, massive sulfides (Po-Sph-Cp) reappear closely associated with a hydraulic breccia (interval $169-1035 \mathrm{H}-$ 9R-1, 53-73 cm). From Sections 169-1035H-10R-1 through 13R-1, the recovered cores consist of only siltstone and sandstone crosscut by a dense pyrrhotite-vein network. The veins are subvertical, millimeter wide, have a density up to $12 / \mathrm{m}$, and are closely associated with millimeter-wide pyrrhotite impregnations. These impregnations are mainly parallel to the laminations, but evolve sometimes to slightly oblique and wavy features resembling tension gashes, similar to features seen in Section 169-1035H-4R-1 (Fig. 116; interval 1691035H-13R-1, 40-45 cm).

From Cores 169-1035H-14R through 21R (123.0-190.3 mbsf), massive sulfide (Py-Sp-Mt) and semi-massive sulfide with sediment reappear. These units alternate with strongly veined and sulfide impregnated mudstones and are overprinted by a recrystallization of the sediments to chlorite-amphibole-epidote. Hydrothermal metamorphism or metasomatism resulted in diffusion of the sulfides from the veins into the sediment (interval 169-1035H-17R-1, 27-37 cm) and in the recrystallization of the sulfides. The metamorphic recrystallization is a static overprint and shows no associated deformation or hydrothermal veins. This unit may have formed as a result of widespread sulfide impregnation (possibly unrelated to the overlying massive sulfides) into porous siltstone units interbedded with less porous mudstones. From Core 169-1035H-22R through 27R (190.3-247.9 mbsf), the drill hole intersected mainly siltstone with a very low density of quartz and chalcopyrite hydrothermal veins, $<2 / \mathrm{m}$, and minor chalcopyrite impregnations. The chalcopyrite veins are mainly subvertical and feed bedding-parallel impregnations (interval 169$1035 \mathrm{H}-22 \mathrm{R}-1,133-140 \mathrm{~cm}$ ). 


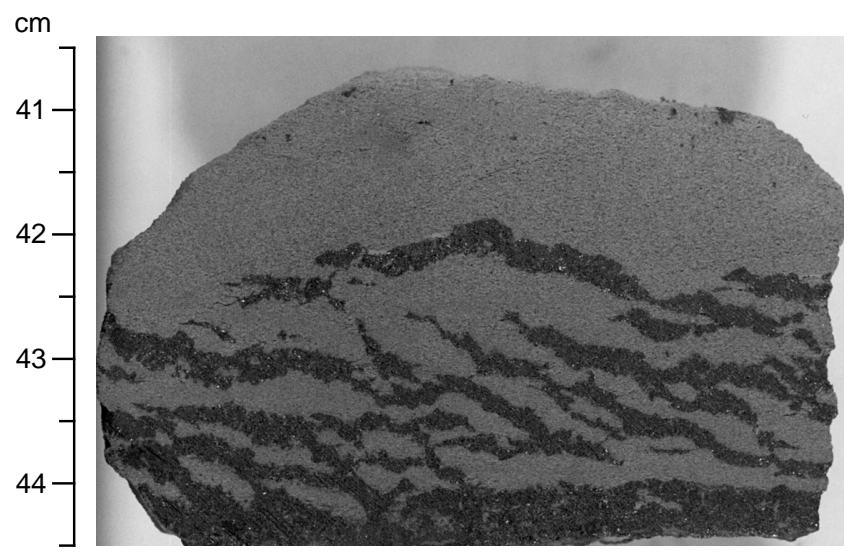

Figure 116. Sulfide impregnations slightly oblique to bedding in sandstone. Sulfide-rich fluids may have preferentially flowed along cross-beds in sandstone (interval 169-1035H-13-R-1, 40.5-44.5 cm).

\section{Conclusions}

Although all holes recovered massive sulfide, only Holes $856 \mathrm{H}$, $1035 \mathrm{~F}$, and $1035 \mathrm{H}$ crosscut major stringer zone mineralization underlying massive sulfide (Fig. 117). In Hole 1035D, there was no recovery in two cores at the bottom of the massive sulfide, so only the upper stringer zone was recovered. Away from the stringer zones, the vein densities are typically very low (Fig. 103). The transition between the BHMS deposit and the underlying stockwork is very sharp. Only in Hole 1035F has a progressive transition been observed, with an intermediate sediment subunit almost fully replaced by sulfides (Core 169-1035F-8R, 70.6-80.2 mbsf). Although several drill holes crosscut the feeder zones, the connection to igneous basement is lost in the sediment units.

With a few minor exceptions, all hydrothermal veins are extension veins. Their width is typically a few millimeters (Fig. 104), and, with the exception of the crack-seal veins in Hole $856 \mathrm{H}$, they show only one episode of extension and mineral filling. These observations, crosscutting relationships, and the occurrence of crack-seal veins in Hole $856 \mathrm{H}$ imply that the stockwork was formed by multiple increments of cracking and mineral infilling. The veins are mostly subvertical, although subhorizontal cracks are common (Figs. 105, 106) along preexisting mechanical anisotropies. The vein azimuth is unknown, however, a few observations in less disrupted cores show coherent azimuths over long intervals, suggesting that the veins may have a preferred orientation. The intensity of veining in the stringer zone implies a significant volume increase.

The genesis of the mainly subvertical extension veins, the regular periodicity shown by the crack-seal veins in Hole $856 \mathrm{H}$, and the few observed hydraulic breccias suggest a process of veining induced by hydraulic fracturing under periodic changes in pore pressure.

Beds dipping more than $30^{\circ}$ occur in Core $139-856 \mathrm{~B}-4 \mathrm{H}$ and in a few limited intervals within the cores sampled during Leg 169. These steeply dipping beds are related to slumping and do not mark in situ rotated fault blocks. Furthermore, with the notable exception of Hole $1035 \mathrm{~F}$, no fault gouge has been recovered. This, suggests that fluid flow maybe controlled by two factors: (1) the pre-existing high permeability in the turbiditic siltstone and sandstone layers; and (2) fluid-overpressure-assisted extension veining within the less permeable indurated mudstone layers or cemented coarser grained layers.

It can be speculated that coarse-grained sandstone lenses, similar to the one observed in Hole $856 \mathrm{H}$, act not only as major porous-flow conduits, but also as major hydrothermal fluid collectors. Because mudstones have a low permeability, the fluid flux and advective transport of heat through the seafloor is limited. However, the mudstones gain strength through hydrothermal alteration and thermal induration that allows the formation of contraction cracks and hydrothermal flow. The formation of the stockwork and of the initial highflow permeability in the upper hydrothermal system can be explained by an upward moving cracking front within the fine-grained sediments, associated with important lateral flow in the coarser grained sediments. This accounts for the general observation of smaller vein densities in the coarse layers that are characterized mainly by hori-

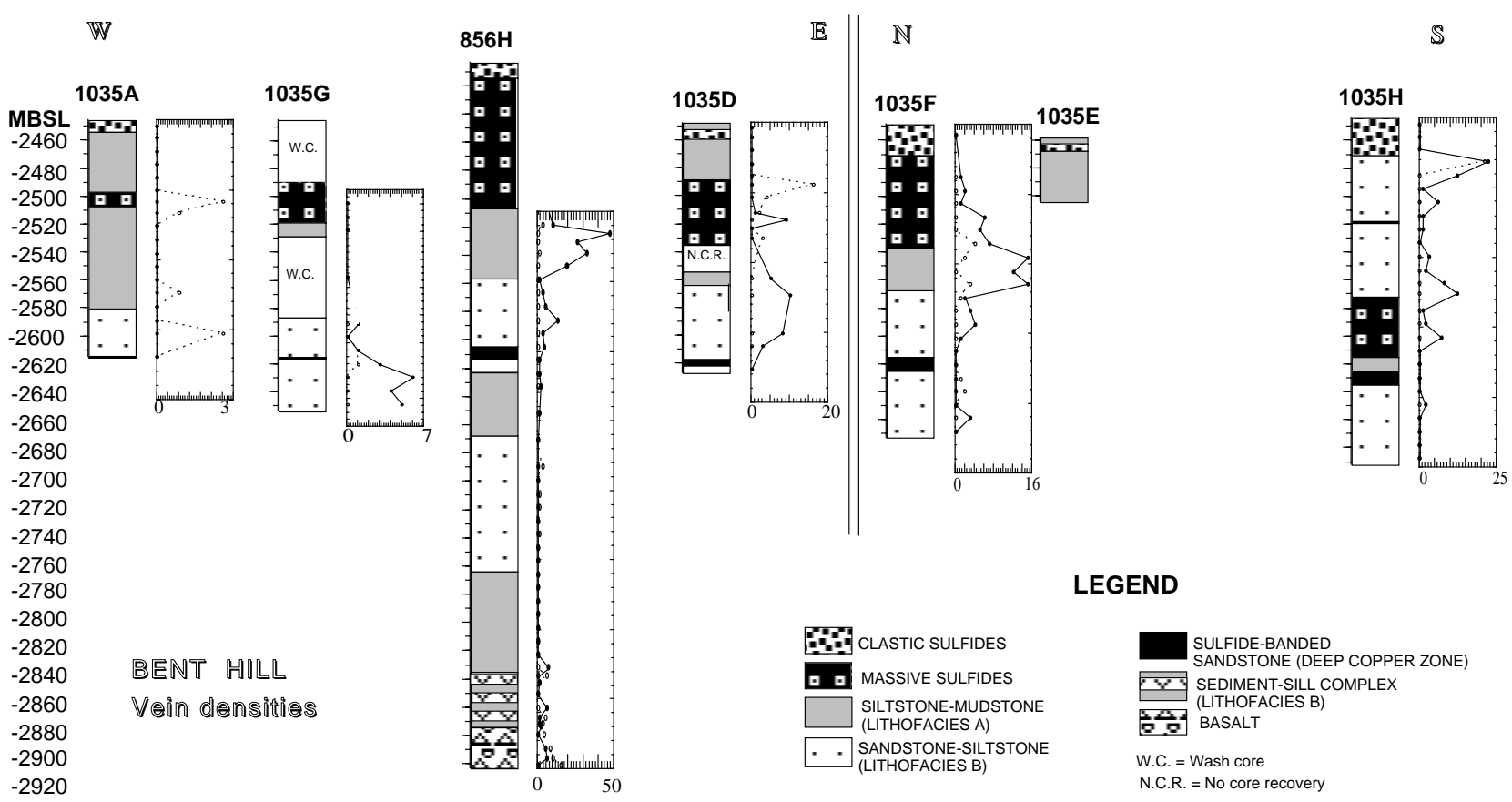

Figure 117. Vein density correlations of the Bent Hill holes (sulfide veins = solid line, and nonsulfide veins $=$ dashed line). Same horizontal and vertical scale. Within the massive sulfides, the data have only limited significance, as there is sometimes $100 \%$ veining. In cores with $<25$-cm recovery, the data were interpolated between the upper and lower cores. 
zontal porous flow, and for the high subvertical vein densities in the mudstone layers. It also accounts for the observation that sulfides are more enriched within the coarser parts of the turbidites in both lithified and non-lithified sediments. The FMS logs of Hole $856 \mathrm{H}$ show several thick conductive layers within the sediment section that could correspond to faults. Little or no physical evidence of faulting was recovered in the drill core from these intervals, but core recovery in these zones was low. At present, the data neither confirm nor preclude the presence of faulting in these intervals.

The basaltic sills interlayered within the sediment unit have caused limited increased induration, hydrothermal alteration, and fracturing of the surrounding sediments. They are highly fractured and veined, and compared to the surrounding sediments, they do not act as barriers to fluid flow. These observations indicate that the permeability structure and evolution of the Bent Hill sediment-hosted hydrothermal system is primarily controlled by the lithology and fluid-pressure induced veining.

\section{INORGANIC GEOCHEMISTRY}

Previous work on interstitial waters in the Site 856 area has been conducted on Holes 856A and 856B (Davis, Mottl, Fisher, et al., 1992). These holes are situated $350 \mathrm{~m}$ (Hole 856A) and $170 \mathrm{~m}$ (Hole $856 \mathrm{~B}$ ) north of the BHMS deposit (Fig. 7, "Introduction" chapter, this volume). Hole $856 \mathrm{~A}$ is located at the central part of Bent Hill, and Hole $856 \mathrm{~B}$ is at the southern edge of the hill closer to the BHMS deposit. Leg 139 data for calcium, magnesium, and sulfate are reproduced in Figure 118 because they provide important background information that is useful for interpreting pore fluids analyzed during Leg 169. Downhole changes in most of the constituents (as exemplified by magnesium) are minimal, but small increases in calcium and sulfate are observed. The data on the bulk sediment geochemical composition in Hole 856A (Goodfellow and Peter, 1994) indicate only minor leaching of $\mathrm{K}_{2} \mathrm{O}$ from the sediment, signifying incipient alteration. In contrast, sediment from Holes $858 \mathrm{~A}, 858 \mathrm{~B}, 858 \mathrm{D}$, and $858 \mathrm{~F}$ in the DDVF indicate extensive hydrothermal leaching of $\mathrm{K}_{2} \mathrm{O}$ (Goodfellow and Peter, 1994). The pore-fluid data from Hole 856B indicate more significant changes in calcium and sulfate. This coincides with a gradual decrease in $\mathrm{K}_{2} \mathrm{O}$ contents of the sediments (Goodfellow and Peter, 1994). The relative increases in calcium and
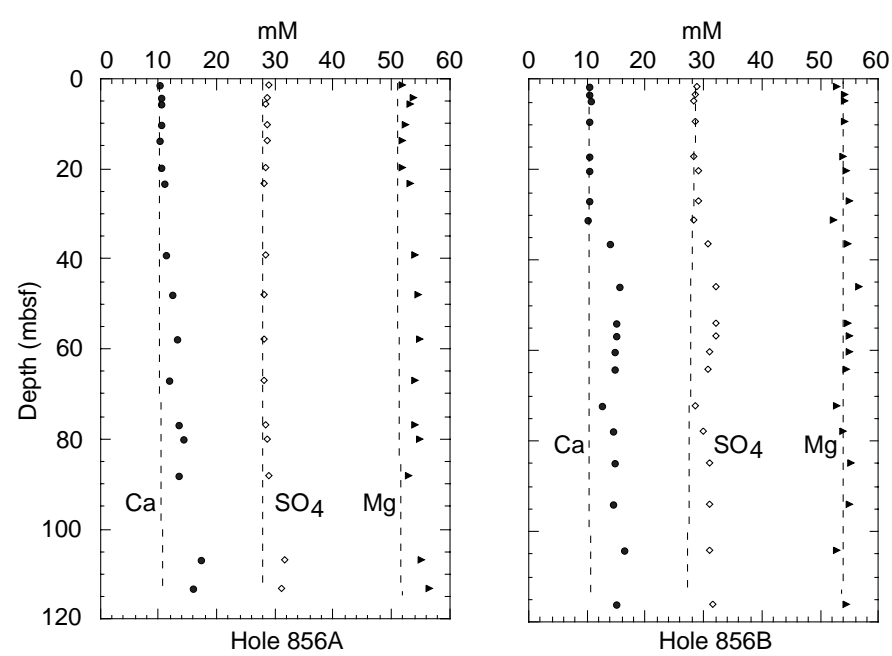

Figure 118. Pore-water profiles of $\mathrm{Ca}, \mathrm{Mg}$, and $\mathrm{SO}_{4}$ from Holes $856 \mathrm{~A}$ and 856B (Davis et al., 1992). Vertical dashed lines = seawater values. sulfate have been explained in terms of an artifact caused by the dissolution of anhydrite at lower than in situ temperatures during retrieval and squeezing of the cores (Davis, Mottl, Fisher, et al., 1992; Mottl et al., 1994). An alternate explanation is that in situ dissolution of anhydrite has occurred. Nonetheless, these observations are an important indicator of the presence of anhydrite in these sediments.

Site 1035 drill hole locations were chosen to constrain the extent of the BHMS deposit (Fig. 6). Sufficient sediment cover was present in Holes 1035A, 1035D, 1035E, and 1035G to investigate the chemistry of the pore fluids. Only one sample was obtained from sediments below the ODP Mound during the drilling of the Hole $1035 \mathrm{H}$ sulfide deposit.

The compositions of pore fluids from Holes 1035D and 1035E are considered first because relatively conservative profiles of magnesium and other components are observed. However, calcium, strontium, and sulfate concentrations clearly indicate the presence of anhydrite in these sediments. In Holes 1035A and 1035G, deeper horizons were sampled, thus allowing a more detailed investigation of processes involving potential fluxes of hydrothermal fluids at depth, similar to the observations of Davis, Mottl, Fisher, et al. (1992) in the area of the DDVF (Site 858; see also "Inorganic Geochemistry" section, "Middle Valley: Dead Dog Area" chapter, this volume).

\section{Fluid Geochemistry at Hole $856 \mathrm{H}$}

A fluid sample (Sample 169-856H-1M-1) was extracted in situ using the WSTP tool (see "Inorganic Geochemistry" section, "Explanatory Notes" chapter, this volume) from the upper part of the $\sim 20$ $\mathrm{m}$ of fill at the bottom of Hole $856 \mathrm{H}$. The base of this hole lies at 93.8 mbsf. Fluid from both the Ti sampler and the overflow chamber was collected. Results of geochemical analysis of these fluids are given in Table 19.

Within the precision of the analyses, the pore waters essentially comprise bottom seawater modified by a small sediment-derived component that has lower $\mathrm{Mg}$ and higher $\mathrm{Ca}$ and $\mathrm{Li}$ than seawater. These data, therefore, confirm that the sample was collected from the sediment fill and suggest that the temperature measurement $\left(\sim 51^{\circ} \mathrm{C}\right)$ is reliable.

\section{Results}

The data on the pore-water compositions are presented in Table 20. Data on borehole fluid compositions are presented in Table 21.

\section{Discussion}

\section{Holes $1035 D$ and $1035 E$}

In Hole 1035D, eight pore-fluid samples were obtained between 0 and 38 mbsf, and in Hole 1035E, eight samples were obtained between 0 and 50 mbsf. Holes $1035 \mathrm{D}$ and $1035 \mathrm{E}$ are located $75 \mathrm{~m}$ east and $100 \mathrm{~m}$ south of the BHMS deposit, where the mound is buried under sediments.

Most of the constituents of the pore fluids display only minor changes with depth in these two holes (Table 20). The exceptions are

Table 19. Composition of pore fluids from sediment fill, Hole $856 \mathrm{H}$.

\begin{tabular}{lcccccccc}
\hline \multicolumn{1}{c}{ Sample } & $\begin{array}{c}\mathrm{Ca} \\
(\mathrm{mM})\end{array}$ & $\begin{array}{c}\mathrm{Mg} \\
(\mathrm{mM})\end{array}$ & $\begin{array}{c}\mathrm{K} \\
(\mathrm{mM})\end{array}$ & $\begin{array}{c}\mathrm{Si} \\
(\mu \mathrm{M})\end{array}$ & $\begin{array}{c}\mathrm{Li} \\
(\mu \mathrm{M})\end{array}$ & $\begin{array}{c}\mathrm{NH}_{4} \\
(\mathrm{mM})\end{array}$ & $\begin{array}{c}\mathrm{pH} \\
\left(25^{\circ} \mathrm{C}\right)\end{array}$ & $\begin{array}{c}\text { Alkalinity } \\
(\mathrm{mM})\end{array}$ \\
\hline $\begin{array}{l}\text { Ti sampler: } \\
\begin{array}{l}\text { Overflow: } \\
\text { Local bottom } \\
\text { seawater: }\end{array}\end{array}$ & 11.9 & 52.7 & 10.4 & 163 & 55 & $<0.1$ & 7.87 & 2.96 \\
\hline
\end{tabular}

Notes: $\mathrm{Ca}$ and $\mathrm{Mg}$ are analyzed by both Dionex and titration techniques. The precision for all analyses is $\pm 1 \%$ except $\mathrm{K}( \pm 5 \%)$. 
Table 20. Chemical composition of pore fluids from Site 1035 .

\begin{tabular}{|c|c|c|c|c|c|c|c|c|c|c|c|c|c|c|c|c|}
\hline $\begin{array}{l}\text { Core, section, } \\
\text { interval }(\mathrm{cm})\end{array}$ & $\begin{array}{l}\text { Depth } \\
\text { (mbsf) }\end{array}$ & $\begin{array}{c}\mathrm{Cl} \\
(\mathrm{mM})\end{array}$ & $\underset{(\mathrm{ppt})}{\mathrm{S}}$ & $\mathrm{pH}$ & $\begin{array}{l}\text { Alkalinity } \\
(\mathrm{mM})\end{array}$ & $\begin{array}{c}\mathrm{SO}_{4} \\
(\mathrm{mM})\end{array}$ & $\begin{array}{l}\mathrm{NH}_{4} \\
(\mu \mathrm{M})\end{array}$ & $\begin{array}{c}\mathrm{Ca} \\
(\mathrm{mM})\end{array}$ & $\begin{array}{c}\mathrm{Mg} \\
(\mathrm{mM})\end{array}$ & $\begin{array}{c}\mathrm{Sr} \\
(\mu \mathrm{M})\end{array}$ & $\begin{array}{c}\mathrm{Li} \\
(\mu \mathrm{M})\end{array}$ & $\underset{(\mathrm{mM})}{\mathrm{K}}$ & $\begin{array}{c}\mathrm{Na} \\
(\mathrm{mM})\end{array}$ & $\mathrm{Na} / \mathrm{Cl}$ & $\begin{array}{c}\mathrm{B} \\
(\mu \mathrm{M})\end{array}$ & $\begin{array}{c}\mathrm{H}_{4} \mathrm{SiO}_{4} \\
(\mu \mathrm{M})\end{array}$ \\
\hline \multicolumn{17}{|l|}{ 169-1035A- } \\
\hline Seawater & 0 & 558 & 35 & 7.8 & 2.45 & 28 & 0 & 10.5 & 54.1 & 87 & 27 & 10.4 & 480 & 0.86 & 420 & 165 \\
\hline $1 \mathrm{H}-2,140-150$ & 3 & 557 & 34 & 7.53 & 3.07 & 28.1 & 30 & 10.3 & 51.7 & 86 & 28 & 11.4 & 481 & 0.86 & 523 & 502 \\
\hline $1 \mathrm{H}-4,140-150$ & 6 & 557 & 34 & 7.5 & 2.53 & 27.5 & 20 & 10.7 & 52.4 & 87 & 27 & 8.8 & 480 & 0.86 & 723 & 147 \\
\hline $2 \mathrm{H}-2,140-150$ & 10.5 & 543 & 40 & 7.8 & 3.42 & 28.2 & 60 & 11.1 & 52.9 & 89 & 25 & 10.1 & 465 & 0.86 & 653 & 38 \\
\hline $2 \mathrm{H}-5,140-150$ & 16.5 & 557 & 31 & 7.7 & 3.49 & 27.5 & 170 & 11.8 & 54.1 & 89 & 25 & 9.1 & 475 & 0.85 & 537 & 462 \\
\hline $3 \mathrm{H}-2,140-150$ & 20 & 557 & 35 & 7.57 & 4.04 & 27.9 & 260 & 11.9 & 54.5 & 91 & 27 & 7.8 & 476 & 0.85 & 462 & 381 \\
\hline $3 \mathrm{H}-4,140-150$ & 24.5 & 561 & 35 & 7.58 & 4.12 & 27.3 & 390 & 11.9 & 54.8 & 92 & 36 & 7.1 & 479 & 0.85 & 406 & 430 \\
\hline $4 \mathrm{H}-3,140-150$ & 31 & 570 & 41 & 7.4 & 2.51 & 27.4 & 610 & 14.4 & 51.9 & 110 & 34 & 5.9 & 488 & 0.86 & 397 & 344 \\
\hline $5 \mathrm{H}-3,140-150$ & 40.5 & 564 & 38 & 7.83 & 1.38 & 37.9 & 200 & 25.4 & 54.4 & 149 & 38 & 6.7 & 474 & 0.84 & 272 & 297 \\
\hline $6 \mathrm{H}-2,140-150$ & 48.5 & 564 & 41 & 7.52 & 1.31 & 40.4 & 370 & 34.3 & 44.7 & 186 & 31 & 6 & 481 & 0.85 & 246 & 304 \\
\hline $7 \mathrm{X}-1,110-115$ & 56 & 558 & 39 & 7.61 & 0.92 & 41.2 & 120 & 27.8 & 52.3 & 153 & 31 & 7.1 & 474 & 0.85 & 237 & 337 \\
\hline $8 \mathrm{X}-1,140-150$ & 62.5 & 551 & 36 & 7.84 & 1.99 & 35.2 & 130 & 30.3 & 42.2 & 170 & 31 & 7.8 & 470 & 0.85 & 151 & 291 \\
\hline $9 \mathrm{X}-3,140-150$ & 74.1 & 554 & 36 & 7.33 & 5.63 & 29 & 130 & 24.9 & 41.4 & 146 & 34 & 6.5 & 479 & 0.86 & 254 & 543 \\
\hline $10-X, 140-150$ & 84.7 & 554 & 34 & 7.47 & 7.91 & 22.6 & 190 & 24.6 & 34.6 & 152 & 37 & 6.2 & 482 & 0.87 & 280 & 675 \\
\hline $11 \mathrm{X}-\mathrm{CC}, 25-33$ & 99.3 & 567 & 37 & 7.47 & 9.19 & 18.6 & 390 & 30.7 & 24.2 & 172 & 50 & 5.6 & 498 & 0.88 & 289 & 838 \\
\hline $12 \mathrm{X}-2,140-150$ & 102.3 & 567 & 36 & 6.39 & 4.38 & 15.9 & 570 & 26.1 & 23.2 & 167 & 55 & 6 & 498 & 0.88 & 281 & 1090 \\
\hline $13 X-4,140-150$ & 115 & 570 & 37 & 6.55 & 3.38 & 24.3 & 690 & 34 & 20.5 & 194 & 63 & 6.4 & 506 & 0.89 & 397 & 1457 \\
\hline $14 \mathrm{X}-4,140-150$ & 124.6 & 580 & 36 & 6.65 & 3.41 & 24.9 & 750 & 35.8 & 18.3 & 215 & 71 & 6.9 & 517 & 0.89 & 361 & 1514 \\
\hline $15 X-5,140-150$ & 135.7 & 570 & 32 & 7.12 & 3.59 & 3.3 & 600 & 14.8 & 16.2 & 159 & 71 & 7.7 & 510 & 0.89 & 343 & 1626 \\
\hline $16 X-4,140-150$ & 143.8 & 564 & 35 & 6.94 & 2.97 & 16.3 & 650 & 22.8 & 13.6 & 196 & 76 & 9.2 & 517 & 0.92 & 334 & \\
\hline $19 \mathrm{X}-1,140-150$ & 168 & 442 & & & & 2.4 & 1440 & 46.2 & 5.9 & 173 & 288 & 14.7 & 326 & 0.74 & 1167 & 1952 \\
\hline \multicolumn{17}{|l|}{ 169-1035D- } \\
\hline $1 \mathrm{H}-2,140-150$ & 3 & 559 & 35 & 7.54 & 3.17 & 29 & 14 & 10.5 & 52.3 & 93 & 27 & 11.4 & 483 & 0.86 & 475 & 490 \\
\hline $2 \mathrm{H}-2,140-150$ & 8.1 & 560 & 35 & 7.84 & 2.72 & 27.6 & 27 & 11.9 & 52.8 & 90 & 30 & 10 & 478 & 0.85 & 404 & 281 \\
\hline $2 \mathrm{H}-4,140-150$ & 11.1 & 559 & 35 & 7.71 & 2.39 & 29.2 & 38 & 12.2 & 53.2 & 91 & 30 & 9.4 & 480 & 0.86 & 348 & 301 \\
\hline $3 \mathrm{H}-2,140-150$ & 17.6 & 561 & 38 & 7.97 & 2.67 & 29 & 94 & 14.3 & 52.5 & 102 & 36 & 7.8 & 480 & 0.86 & 255 & 319 \\
\hline $3 \mathrm{H}-4,140-150$ & 20.6 & 563 & 38 & 7.5 & 2.25 & 29.8 & 100 & 14.3 & 53.9 & 105 & 37 & 7.7 & 481 & 0.85 & 252 & 283 \\
\hline WSTP (in situ) & 24.2 & 563 & & & & & 120 & 18.7 & 50.9 & 112 & 72 & 8.7 & & & 393 & 259 \\
\hline $4 \mathrm{H}-4,140-150$ & 30.1 & 555 & 37 & 7.43 & 2 & 45.4 & 99 & 29.8 & 52.8 & 135 & 42 & 7.7 & 475 & 0.86 & 252 & 363 \\
\hline $5 \mathrm{H}-2,140-150$ & 36.6 & 545 & 36 & 7.82 & 1.17 & 38.8 & 38 & 27.8 & 54.4 & 137 & 30 & 9.3 & 450 & 0.83 & 236 & 400 \\
\hline \multicolumn{17}{|l|}{$169-1035 \mathrm{E}-$} \\
\hline $1 \mathrm{H}-2,140-150$ & 3 & 561 & 34 & 7.81 & 3.31 & 28.5 & 26 & 10.2 & 53.1 & 88 & 26 & 11.7 & 485 & 0.86 & 509 & 462 \\
\hline $1 \mathrm{H}-4,140-150$ & 6 & 563 & 34 & 7.53 & 3.17 & 28.9 & 36 & 10.5 & 53.7 & 90 & 24 & 10.6 & 479 & 0.86 & 481 & 259 \\
\hline $2 \mathrm{H}-2,140-150$ & 10.5 & 558 & 35 & 7.43 & 3.11 & 28.2 & 100 & 11.4 & 53.2 & 94 & 24 & 9.5 & 481 & 0.86 & 412 & 740 \\
\hline $2 \mathrm{H}-5,140-150$ & 15 & 562 & 35 & 7.55 & 3.82 & 28.2 & 160 & 12.9 & 53.4 & 101 & 26 & 8 & 481 & 0.85 & 318 & 280 \\
\hline $3 \mathrm{H}-2,140-150$ & 20 & 564 & 35 & 7.65 & 3.8 & 28 & 280 & 14.8 & 53.7 & 108 & 33 & 6.7 & 480 & 0.85 & 210 & 247 \\
\hline $3 \mathrm{H}-4,140-150$ & 26 & 564 & 35 & 7.28 & 2.78 & 29.5 & 330 & 15.9 & 53.7 & 110 & 37 & 6.35 & 479 & 0.85 & 272 & 305 \\
\hline $4 \mathrm{H}-3,140-150$ & 30.5 & 565 & 36 & 7.19 & 2.85 & 33.2 & 250 & 25.2 & 49.2 & 130 & 42 & 6.15 & 475 & 0.85 & 290 & 381 \\
\hline $5 \mathrm{H}-\mathrm{CC}, 17-22$ & 45 & 557 & 37 & 7.65 & 3.17 & 42.5 & 76 & 29.7 & 51.5 & 140 & 27 & 7.54 & & & 232 & \\
\hline \multicolumn{17}{|l|}{ 169-1035G- } \\
\hline $5 \mathrm{R}-1,143-150$ & 75 & 554 & 36 & 7.45 & 0.07 & 35.0 & 28 & 25.0 & 46.8 & 144 & 23 & 7.6 & 473 & 0.85 & 128 & \\
\hline $6 \mathrm{~W}-1,143-150$ & 85 & 559 & 36 & 7.28 & 3.03 & 29.0 & 20 & 21.0 & 44.3 & 130 & 28 & 7.8 & 782 & 10.86 & 229 & \\
\hline $6 \mathrm{~W}-\mathrm{CC}, 0-8$ & 85 & 562 & & & & 11 & 297 & 10 & 31 & 112 & 49 & 7 & & & 210 & \\
\hline $7 \mathrm{R}-1,140-150$ & 142 & 540 & 34 & 7.21 & 2.54 & 5.6 & 273 & 7.3 & 9.2 & 112 & 54 & 10.6 & 510 & 10.94 & 267 & \\
\hline $8 \mathrm{R}-1,132-148$ & 152 & 529 & 32 & & & 7.2 & 195 & 7.4 & 10.3 & 100 & 34 & 12.2 & 497 & 10.94 & 273 & \\
\hline 9R-1, 84-92 & 161.6 & 515 & 29.5 & & & 9.7 & & 9.9 & 9.7 & 95 & 45 & 13.0 & 484 & 10.94 & & \\
\hline \multicolumn{13}{|l|}{$169-1035 \mathrm{H}-$} & 348 & 0.79 & 1168 & \\
\hline
\end{tabular}

Table 21. Compositions of hydrothermal fluids in the Bent Hill area.

\begin{tabular}{lccrrrrrrrr}
\hline \multicolumn{1}{c}{ Sample } & $\begin{array}{c}\mathrm{Cl} \\
(\mathrm{mM})\end{array}$ & $\begin{array}{c}\mathrm{Ca} \\
(\mathrm{mM})\end{array}$ & $\begin{array}{c}\mathrm{Mg} \\
(\mathrm{mM})\end{array}$ & $\begin{array}{c}\mathrm{Sr} \\
(\mu \mathrm{M})\end{array}$ & $\begin{array}{c}\mathrm{Li} \\
(\mu \mathrm{M})\end{array}$ & $\begin{array}{c}\mathrm{K} \\
(\mathrm{mM})\end{array}$ & $\begin{array}{c}\mathrm{SO}_{4} \\
(\mathrm{mM})\end{array}$ & $\mathrm{Na} / \mathrm{Cl}$ & $\begin{array}{c}\mathrm{B} \\
(\mu \mathrm{M})\end{array}$ & $\begin{array}{r}\mathrm{NH}_{4} \\
(\mu \mathrm{M})\end{array}$ \\
\hline 1035A-19X-1, 140-150 cm & 442 & 46 & 6 & 133 & 288 & 15 & 2 & 1 & 1200 & \\
1035H-7R-1,36-43 cm & 443 & 39 & 11 & 133 & 252 & 13 & 9 & & 1168 & \\
Los Alamos tool & 523 & 18 & 48 & 122 & 39 & 10 & 33 & 1440 & 399 & 1998 \\
Seawater & 558 & 11 & 54 & 87 & 28 & 10 & 28 & 1 & 420 & 1637 \\
Bent Hill hydrothermal fluid & 421 & 41 & 0 & 166 & 379 & 14 & 0 & 1 & 1637 \\
\hline
\end{tabular}

This table also appears on the CD-ROM.

the profiles of dissolved calcium, sulfate, and strontium. Figure 119 shows the concentration depth profiles of $\mathrm{Ca}, \mathrm{Mg}$, and $\mathrm{SO}_{4}$. Compared with Holes 856A and 856B (Fig. 118), increases in dissolved sulfate and calcium, especially in Hole 1035D, are large (up to $20 \mathrm{mM}$ increase in calcium). These increases are accompanied by large increases in strontium (Table 20). Previously, Mottl et al. (1994) explained similar observations in Holes 856A and 856B in terms of a potential artifact caused by the dissolution of calcium sulfate (anhydrite). The one in situ (WSTP) pore-water sample from Hole 1035D, however, suggests that either the artifact also occurs during the in situ retrieval process, or that actual dissolution of sulfate occurs in these sediments as the result of cooler conditions than during the prevalent formation of these sulfates. Whatever the cause, the increases in calcium, sulfate, and strontium in the pore fluids (Table 20) can be understood in terms of the presence of anhydrite in these two drill holes. The extent of the anomalies is substantially larger than in Holes 856A and 856B, presumably because of increased contributions of hydrothermal interactions with seawater in these sediments. Although the correlation between calcium and sulfate may not be straightforward as a result of potential sulfate reduction processes, the relationship between calcium and strontium should be related to the distribution coefficient of strontium in anhydrite. For these reasons, a plot of $\mathrm{Ca}$ vs. $\mathrm{Sr}$ is instructive (Fig. 120). The correlation is significant and provides a molar distribution coefficient of $\mathrm{Sr}$ in anhydrite of $\sim 2.5 \times 10^{-3}(\mathrm{Sr} / \mathrm{Ca})$. This distribu- 
Figure 119. Pore-water profiles of $\mathrm{Ca}, \mathrm{Mg}$, and $\mathrm{SO}_{4}$ from Holes 1035D and 1035E. Vertical dashed lines = seawater values.

tion coefficient will be used later in an attempt to reconstruct the potential dissolved sulfate profile in Hole 1035A.

At a porosity of $70 \%$, the removal of dissolved sulfate of original pore-water sulfate $(29 \mathrm{mM})$ and calcium $(10.5 \mathrm{mM})$ as calcium sulfate will lead to an anhydrite content of only $0.1 \%$ of the sediment by weight. The reported amounts of anhydrite (see "Lithostratigraphic Summary and Sedimentology" section, this chapter) appear to exceed this amount, suggesting that circulation of seawater into the sediments must have led to the extra amounts of anhydrite observed. Substantial downdraft of seawater through the upper sediments may have occurred during the hydrothermal processes associated with the emplacement of the hydrothermal sulfide deposit, thus accounting for the excess anhydrite. This fluid then may have mixed with calciumenriched fluids of hydrothermal origin. Similar arguments must be involved in an explanation of the anhydrite observed in the massive sulfide deposits. Future measurements of the strontium isotopes both

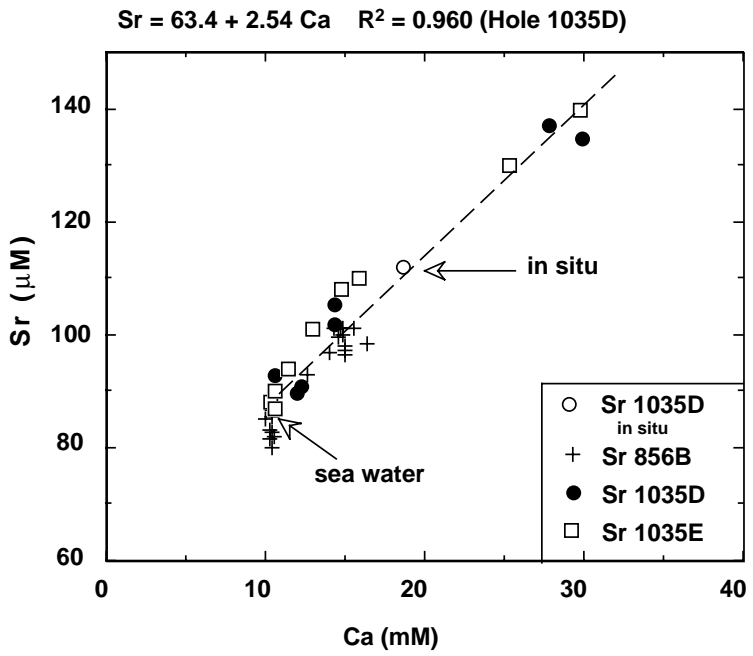

Figure 120. Strontium-calcium correlation for Holes 856A, 856B, 1035D, and 1035E. Point label in situ was collected at $24.2 \mathrm{mbsf}$ using the WSTP.
$\mathrm{mM} \quad \mathrm{mM}$

$\begin{array}{llll}30 & 40 & 50 & 60\end{array}$

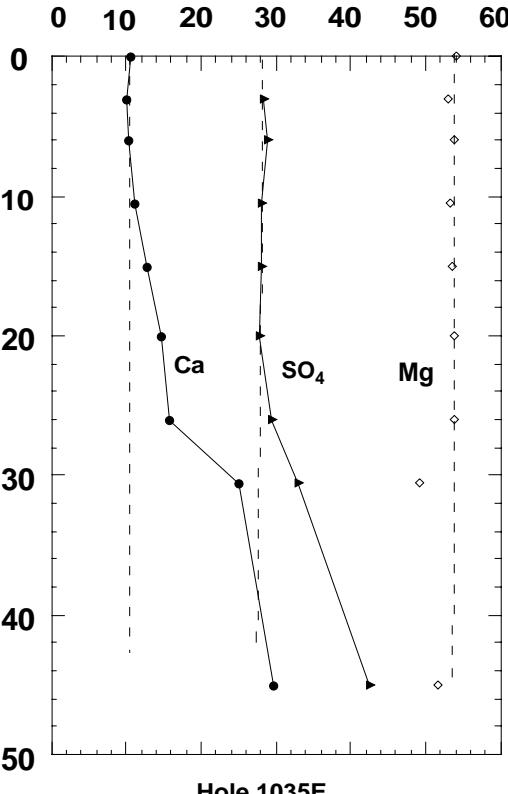

Hole 1035D

Hole 1035E

in pore-water dissolved strontium and in recovered anhydrite may help shed light on this phenomenon.

A second observation is the subsurface maximum in the distribution of dissolved chloride with depth (Fig. 121). McDuff (1985), Schrag and de Paolo (1993), and Gieskes et al. (unpubl. data, Leg 152) have noted a subsurface maximum in dissolved chloride, which is a remnant of the higher chloride contents during the last glaciation $(\sim 18 \mathrm{ka})$. This maximum is less pronounced in Holes 1035D and $1035 \mathrm{E}$, which may be attributed to the occurrence of low chloride in pore fluid in deeper horizons, thus causing different boundary conditions in the lower parts of the hole. Nonetheless, the slight maxima in dissolved chloride at $\sim 25 \mathrm{mbsf}$ can best be understood in terms of the implied glacial salinity signal.

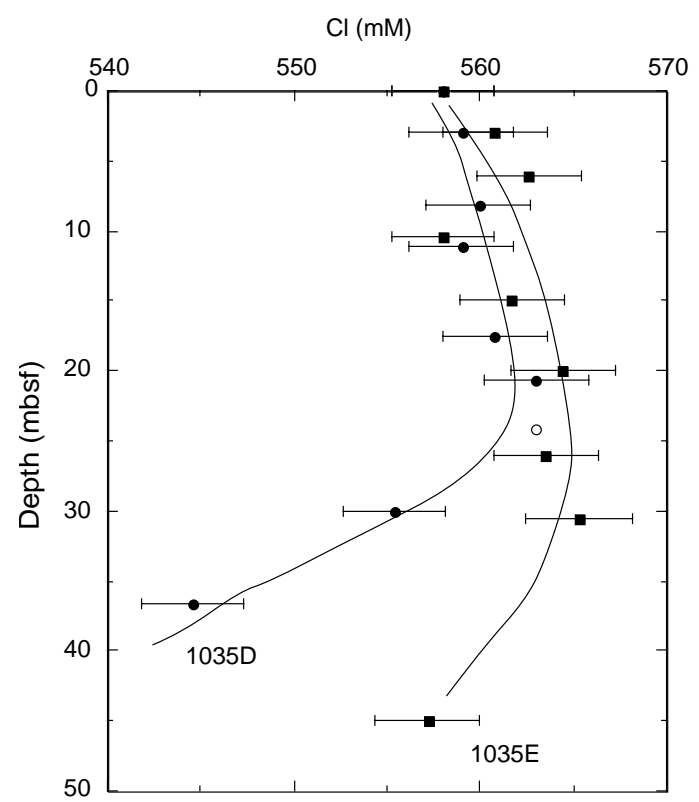

Figure 121. Upper sediment column chloride concentrations for Holes $1035 \mathrm{D}$ (circles) and 1035E (squares). 

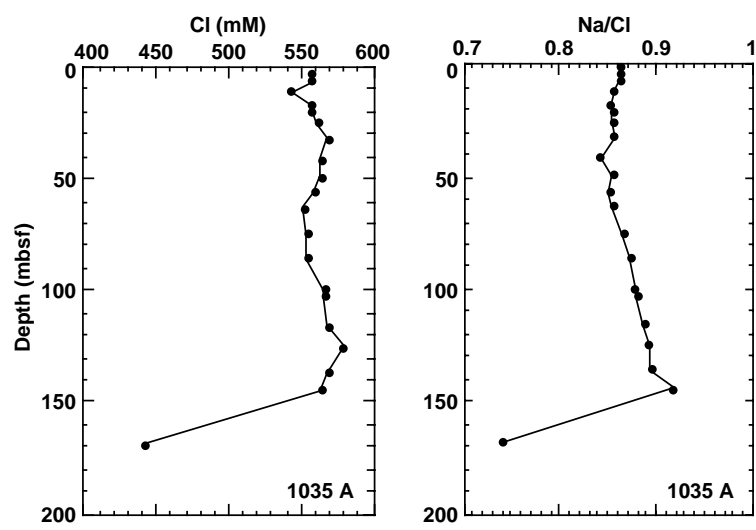

Figure 122. Chloride and $\mathrm{Na} / \mathrm{Cl}$ values of pore waters from Hole $1035 \mathrm{~A}$.

\section{Holes 1035A and 1035G}

Holes $1035 \mathrm{~A}$ and $1035 \mathrm{G}$ are located $10 \mathrm{~m}$ apart and $75 \mathrm{~m}$ west of the sulfide mound. Because of the paucity of data in Hole 1035G, these data will be discussed in relation to each other. In Hole 1035A, 20 pore-fluid samples were obtained between 3 and 168 mbsf.

\section{Hole $1035 A$}

\section{Chloride and Sodium}

The concentration depth profile of dissolved chloride, though somewhat variable, shows a gradual increase of $\sim 2 \%$ with depth (Fig. 122). A steep decrease in chloride below $\sim 150$ mbsf, however, indicates a trend toward the Bent Hill hydrothermal fluid end-member of $428 \mathrm{mM}$ (Butterfield et al., 1994). We argue that in the sparsely recovered Cores 169-1035A-17X and 18X, a barrier must occur that is "impermeable" to upward fluid flow, thus causing the virtual absence of the influence of vent fluid on the concentration profile(s) above this horizon. Lateral flow of Bent Hill hydrothermal fluid can best explain the sudden change in composition that is also reflected in other constituents (see below). The $\mathrm{Na} / \mathrm{Cl}$ value also shows a small increase with depth to a depth of $\sim 150 \mathrm{mbsf}$, again followed by a sharp change toward a value of 0.738 (Bent Hill $=0.765$ ). If anything, the values of the concentrations of the other components in the lowermost sample are more extreme than those of the Bent Hill fluids (see Table 21).

\section{Nutrient Elements}

Under this category we consider sulfate, alkalinity $\left(\mathrm{HCO}_{3}^{-}\right)$, and ammonium. The dissolved sulfate profile cannot be interpreted simply to infer the presence or absence of sulfate reduction, mainly because of the dissolution of anhydrite $\left(\mathrm{CaSO}_{4}\right)$.
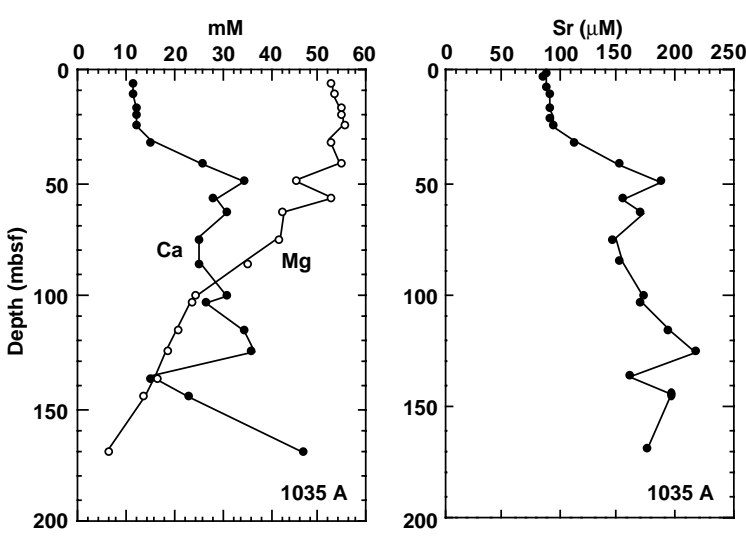

Figure 124. Alkaline earth elements $(\mathrm{Mg}, \mathrm{Ca}$, and $\mathrm{Sr})$ from the pore waters of Hole 1035A.

Dissolved sulfate (Fig. 123) shows a complicated profile, indicating a general tendency toward a decrease with depth, but associated with large variations as a result of anhydrite dissolution. Below the zone of relative impermeability, the decrease in sulfate is consistent with the increasing presence of Bent Hill vent fluids.

Alkalinity changes are variable with depth, indicating two maxima that are also reflected in extrema in the ammonium profile (Fig. 123). Changes in ammonium are relatively small, and only the lowermost sample indicates elevated concentrations. Unfortunately, no $\mathrm{NH}_{4}$ data are available on Bent Hill hydrothermal fluids for comparison.

\section{Alkaline Earth Elements}

Above $\sim 25 \mathrm{~m}$ depth, magnesium, calcium, strontium, and sulfate (Fig. 124) are relatively constant in concentration, as is dissolved sulfate. Similarly, the concentration depth profiles of magnesium in Holes 856A and 856B (as well as Holes 1035D and 1035E) are relatively constant. These observations suggest a relative absence of diagenetic reactions affecting the sediments in these upper horizons, including minimal dissolution of anhydrite which may be absent in this upper section. It appears that the upper sediments are not significantly affected by underlying hydrothermal activity. Below 25 mbsf, a decreasing trend in magnesium indicates uptake into the solid phases, presumably through the formation of magnesium-bearing phases (clays/dolomite).

The distribution of dissolved calcium and strontium is complicated by the apparent effects of anhydrite dissolution. As temperatures fall below $150^{\circ} \mathrm{C}$, in situ dissolution of $\mathrm{CaSO}_{4}$ can affect the profiles (see above section on Holes 1035D and 1035E). Below, we will use the "excess" calcium concentrations to calculate the potential concentration profiles of dissolved sulfate and strontium.
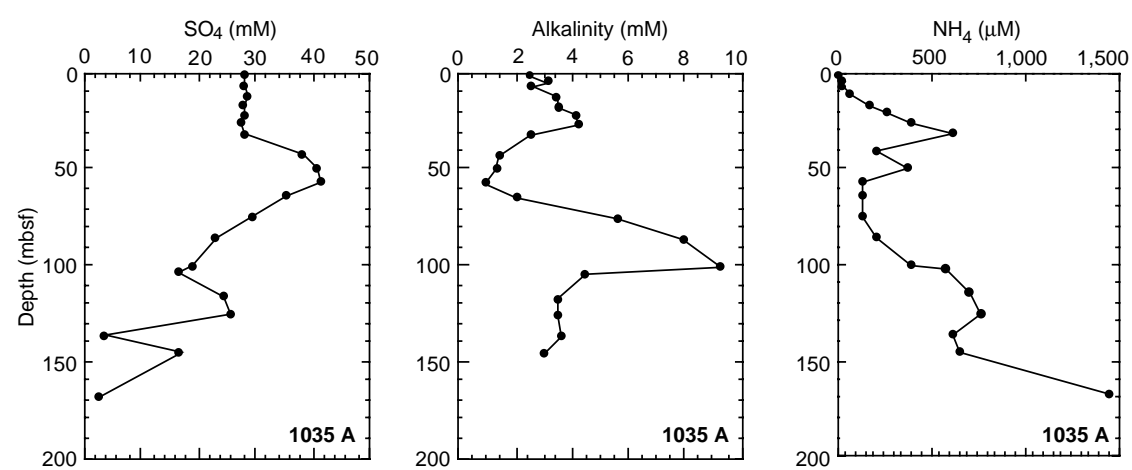

Figure 123. Nutrient element concentrations $\left(\mathrm{SO}_{4}\right.$, alkalinity, and $\mathrm{NH}_{4}$ ) from the pore waters of Hole 1035A. 
Figure 125. Alkali metal concentrations ( $\mathrm{Li}, \mathrm{K}$, and $\mathrm{Na}$ ) from the pore waters of Hole 1035A
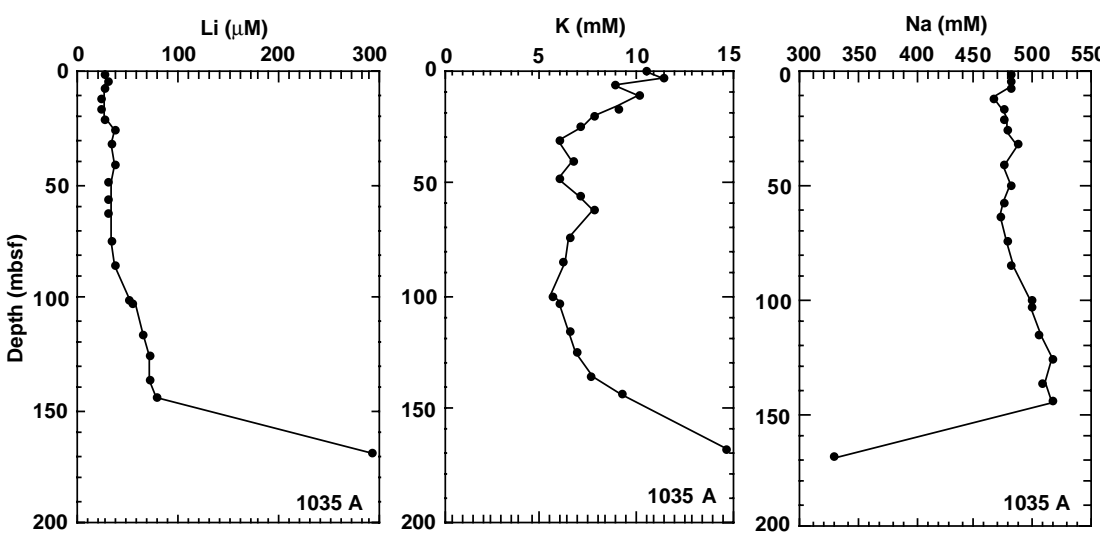

\section{Alkali Metals}

The concentration depth profile of lithium (Fig. 125) suggests only a gradual increase in lithium concentrations with depth, except for a sharp increase toward Bent Hill hydrothermal fluid compositions below the "zone of impermeability."

Potassium concentration data indicate a slight removal of potassium into the sediments in the upper sediment layers, but an increasing trend below $\sim 100$ mbsf. Sodium concentrations (calculated from a charge balance) indicate a gradual increase with depth, again followed by a sharp decrease in concentration. This is also evident from the $\mathrm{Na} / \mathrm{Cl}$ value (Fig. 122).

\section{Boron and Silica}

Dissolved boron (B) concentrations (Fig. 126) show a distinct shallow maximum in $\mathrm{B}$ followed by a gradual decrease to values almost half of the seawater concentration. This must be because of B uptake in the sediments. Only the deepest sample at $\sim 170$ mbsf shows a substantial increase, approaching the Bent Hill hydrothermal fluid end-member concentration.

Although dissolved silica (Fig. 126) shows a gradual increase below $60 \mathrm{mbsf}$, dissolved silica concentrations must be viewed with some suspicion because of the well-known artifact caused by porewater retrieval at temperatures different from those prevailing in situ (Manheim and Sayles, 1974; Fanning and Pilson, 1971; Gieskes, 1983).

\section{Hole $1035 G$}

Six samples of interstitial fluid were collected in this site, including two from a wash core, thus allowing no precise depth estimate for the latter samples.
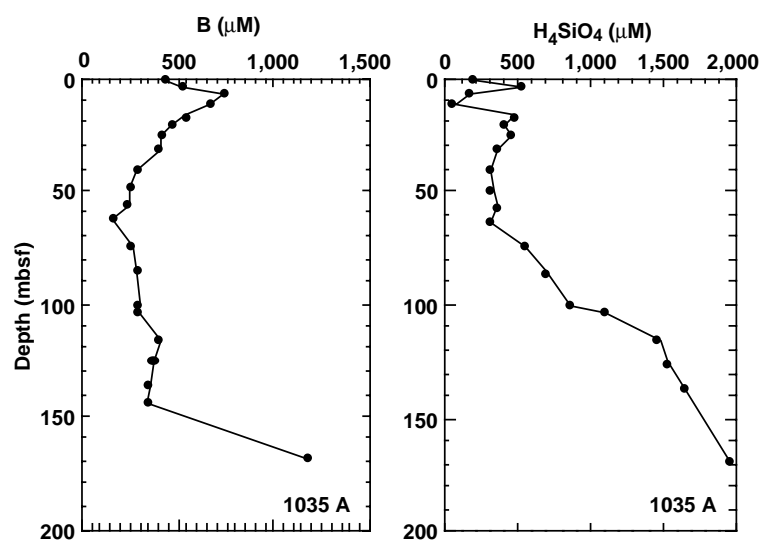

Figure 126. Boron and silica from the pore waters of Hole 1035A.
Data for Hole 1035G are combined with those of Hole 1035A (Fig. 127). In contrast to the magnesium and chloride concentrations, which are indistinguishable from the Hole 1035A trend, the data for lithium, calcium, and strontium are very different in Hole 1035G, at least in the deeper parts of the core. It appears that Hole 1035G samples below $\sim 85$ mbsf are much less affected by the redissolution of anhydrite (Table 20) than the Hole 1035A samples.

The data for sodium and the $\mathrm{Na} / \mathrm{Cl}$ values are plotted in Figure 128. In both Holes 1035A and 1035G, a gradual increase in both parameters is observed. Evidence for a Bent Hill hydrothermal fluid component in the samples of Hole $1035 \mathrm{G}$ is absent except for a small, gradual decrease in dissolved chloride.

\section{ODP Mound (Hole 1035H)}

Hole $1035 \mathrm{H}$ is $\sim 50 \mathrm{~m}$ south of the vent site $\left(264^{\circ} \mathrm{C}\right)$ from which hydrothermal fluids were obtained (Butterfield et al., 1994). One pore-fluid sample was obtained in this hole from Core 169-1035H7R. The data are presented in Table 20 and show strong similarities with the Bent Hill hydrothermal fluids (Butterfield et al., 1994). In
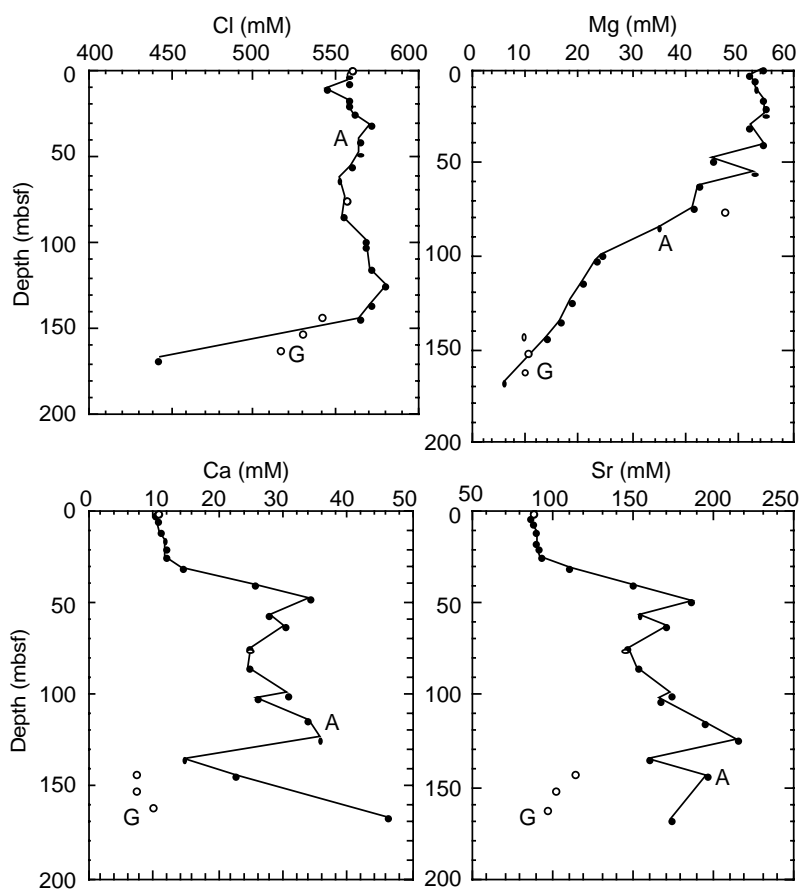

Figure 127. Element concentrations $(\mathrm{Cl}, \mathrm{Mg}, \mathrm{Ca}$, and $\mathrm{Sr})$ from the pore waters of Holes 1035A and 1035G. 

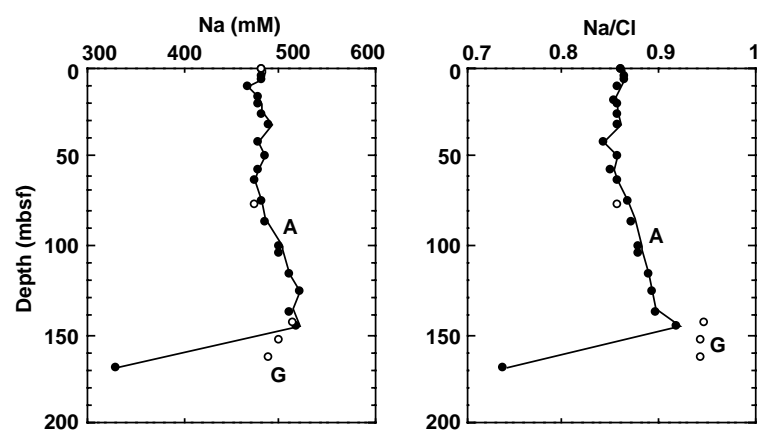

Figure 128. Sodium and $\mathrm{Na} / \mathrm{Cl}$ from the pore waters of Holes $1035 \mathrm{~A}$ and 1035G.

the following section, the data from Hole $1035 \mathrm{H}$ are compared to Bent Hill fluids and the lowermost sample of Hole 1035A.

\section{Summary Discussion}

\section{Effects of Anhydrite Dissolution}

Anomalous concentration depth profiles showing significant increases in dissolved calcium, strontium, and sulfate can best be understood in terms of the presence of anhydrite in the sediments. Calcium and strontium in the pore fluids are correlated and increase with depth, especially in Holes 1035D and 1035E, consistent with an increasing anhydrite content in the sediments downhole (see also "Lithostratigraphic Summary and Sedimentology" section, this chapter). After the sediment cools below $\sim 150^{\circ} \mathrm{C}$, anhydrite becomes soluble, and dissolution of this mineral can lead to the observed anomalies. By assuming that calcium has a relatively smooth profile with depth (dashed line in Fig. 129), one can recalculate the dissolved sulfate and strontium profiles (using mass balance for $\mathrm{Ca}$ and the distribution coefficient obtained in Holes 1035D and 1035E for Sr). The computed sulfate profile suggests near-complete removal of sulfate at $\sim 100 \mathrm{mbsf}$, coincident with a maximum in alkalinity $\left(\mathrm{HCO}_{3}^{-}\right)$. The recomputed profile of dissolved strontium also has lost much of its anomalous variability. The assumption of retrograde anhydrite dissolution thus leads to reconstructed concentration depth profiles more typical of those commonly observed.

\section{Effect of Bent Hill Hydrothermal Fluids}

We postulate that in Cores 169-1035A-17X and 18X, which had low recovery, an impermeable layer must have been present, thus inhibiting diffusive communication with the overlying sediments. The gradient of dissolved chloride (and other constituents) is steep, even though chloride has a large diffusion coefficient in aqueous media. Only dissolved potassium shows a gradually increasing trend across this boundary. The trend of the lowermost samples toward the Bent Hill vent fluid end-member composition suggests lateral advection of hydrothermal fluids through these sediments. Because no pore-water samples were obtained below the central portion of the BHMS deposit (due to very low porosities), the evidence for hydrothermal fluids is not as well established as in the Dead Dog area.

Element concentrations relative to magnesium are plotted for Bent Hill hydrothermal fluid and pore fluid from Cores 169-1035A$19 \mathrm{X}$ and $169-1035 \mathrm{H}-7 \mathrm{X}$ in Figure 130. It is not surprising that the pore-fluid sample from Hole $1035 \mathrm{H}$ is similar to the Bent Hill Hydrothermal fluid composition that was obtained from the ODP Mound (Butterfield et al., 1994). Hole $1035 \mathrm{H}$ was found to vent fluids, presumably through connection to the same aquifer that feeds the previously sampled vent. The attempt to sample this vent with the Los Alamos (LA) tool yielded only a small-size sample $\left(\sim 7 \mathrm{~cm}^{3}\right)$ that was rather heavily contaminated by seawater or drill-hole fluids. For dissolved chloride, all of the data extrapolate to the Bent Hill fluid endmember. For most of the other components this is not the case. The extrapolated values for calcium are higher, and the values for strontium, lithium, and boron are lower than those of the Bent Hill hydrothermal fluid (Butterfield et al., 1994). This may signify a change in composition, but no reasonably pristine hydrothermal fluid sample was obtained. This sampling should be carried out in the future during submersible operations in this area.

\section{ORGANIC GEOCHEMISTRY}

The shipboard organic geochemical analyses of sediment samples from Hole $856 \mathrm{H}$ and Site 1035 included total organic carbon (TOC), nitrogen, sulfur, inorganic carbon (TIC), volatile hydrocarbon and nonhydrocarbon gases, organic matter fluorescence and black carbonaceous soot estimations, and bitumen fingerprinting. Instrumentation, operating conditions, and procedures are summarized in the "Explanatory Notes" chapter (this volume).

\section{Volatile Gases}

\section{Hole $856 \mathrm{H}$}

Volatile gases (hydrocarbons, $\mathrm{CO}_{2}, \mathrm{H}_{2} \mathrm{~S}$, and $\mathrm{N}_{2}$ ) were measured on one indurated sediment sample from the sulfide stringer zone and on the headspace gas from WSTP-1. The gas was extracted from compressible pieces of sediment using the IW method (see "Explanatory Notes," chapter, this volume). The results are listed in Table 22. The methane concentration is 51 ppm in the WSTP-1 gas and 18,000 ppm (volume/volume) in the sediment gas, with minor amounts of ethane and propane. Although air leaked into the evacuated sampler, the concentration of the $\mathrm{CH}_{4}$ in the WSTP-1 gas indicates seepage of hydrothermal fluids with hydrocarbons into the hole. The $C_{1} / C_{2}$ ratio of 207 for the sediment gas indicates a composition and origin intermediate between dry gas from the high temperature cracking of organic matter and lower temperature maturation gas. Carbon dioxide was present at a concentration equivalent to methane, and $\mathrm{H}_{2} \mathrm{~S}$ was not detected (the samples had no $\mathrm{H}_{2} \mathrm{~S}$ odor).
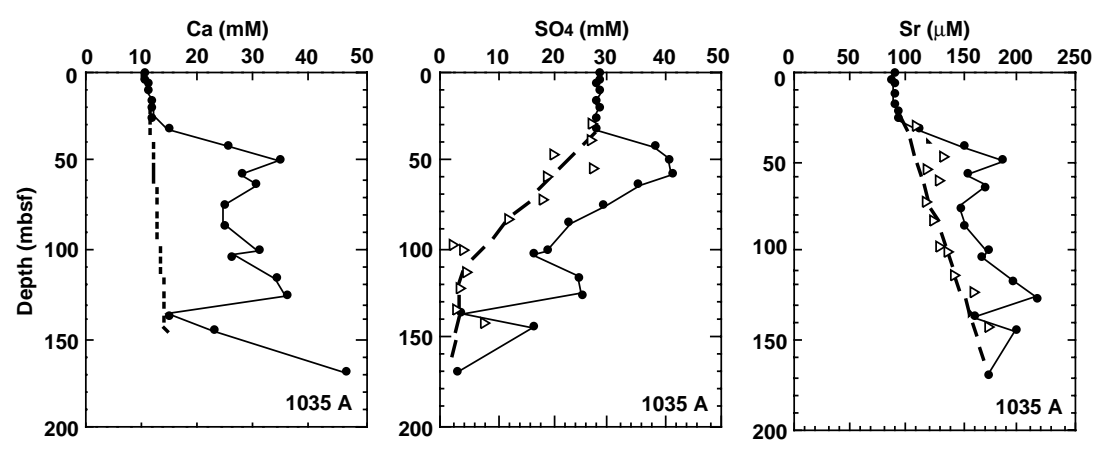

Figure 129. Reconstruction of pore-water profiles of calcium, sulfate, and strontium in Hole 1035A after correction for anhydrite dissolution. The dashed line in the $\mathrm{Ca}$ profile is the presumed distribution assuming no anhydrite dissolution. Dashed lines in $\mathrm{SO}_{4}$ and $\mathrm{Sr}=$ profiles' estimated trend through recalculated values. Solid circles in $\mathrm{SO}_{4}$ and $\mathrm{Sr}$ profiles $=$ measured values. Triangles $=$ recalculated values based on mass balance from the reconstructed Ca profiles. 

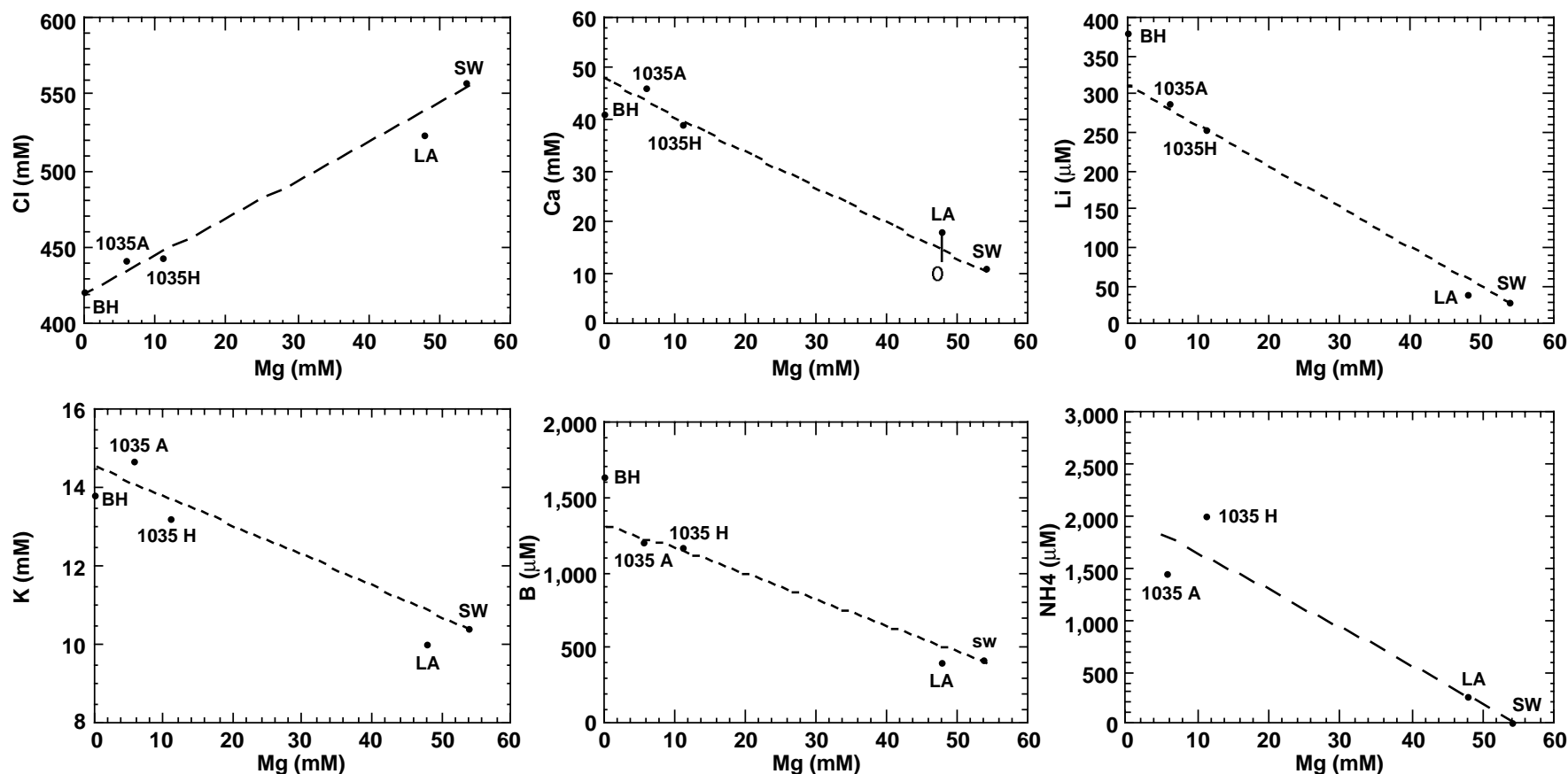

Figure 130. Magnesium-element correlations of Bent Hill hydrothermal fluids and samples from Sections 169-1035A-19X-1 and 169-1035H-7R-1. BH = Bent Hill vent fluid from Butterfield, et al. (1994), and LA = sample taken in Hole 1035H with the Los Alamos downhole sampling tool.

Table 22. Composition of gas derived from sediment and fluid headspace samples, Hole 856H and Site 1035.

\begin{tabular}{|c|c|c|c|c|c|c|c|}
\hline $\begin{array}{l}\text { Core, section, } \\
\text { interval }(\mathrm{cm})\end{array}$ & Type & $\begin{array}{l}\text { Depth } \\
\text { (mbsf) }\end{array}$ & $\begin{array}{c}\mathrm{CH}_{4} \\
(\mathrm{ppm})\end{array}$ & $\begin{array}{r}\mathrm{CO}_{2} \\
(\mathrm{ppm})\end{array}$ & $\mathrm{C}_{2}$ & $\mathrm{C}_{3}$ & $\mathrm{C}_{1} / \mathrm{C}_{2}$ \\
\hline \\
\hline 29R-2, PW gas & $\mathrm{V}$ & 191.40 & 18,000 & 17,000 & 87 & 5 & 207 \\
\hline \multicolumn{8}{|l|}{ 169-1035A- } \\
\hline $1 \mathrm{H}-5,145-150$ & HS & 7.48 & 5 & - & - & - & - \\
\hline $2 \mathrm{H}-7,145-150$ & $\mathrm{HS}$ & 17.98 & 2 & - & - & - & - \\
\hline $3 \mathrm{H}-6,145-150$ & $\mathrm{HS}$ & 25.98 & 17 & - & - & - & - \\
\hline $4 \mathrm{H}-6,145-150$ & HS & 35.48 & 14 & - & - & - & - \\
\hline $5 \mathrm{H}-6,145-150$ & $\mathrm{HS}$ & 44.98 & 8 & - & - & - & - \\
\hline $6 \mathrm{H}-\mathrm{CC}, 0-5$ & $\mathrm{HS}$ & 55.00 & 17 & - & - & - & - \\
\hline $7 X-2,0-5$ & $\mathrm{HS}$ & 56.03 & 10 & - & - & - & - \\
\hline $8 \mathrm{X}-1,135-140$ & $\mathrm{HS}$ & 62.38 & 21 & - & - & - & - \\
\hline $9 \mathrm{X}-3,135-140$ & $\mathrm{HS}$ & 74.98 & 14 & - & - & - & - \\
\hline $10 \mathrm{X}-3,135-140$ & HS & 84.58 & 13 & - & - & - & - \\
\hline $12 \mathrm{X}-2,135-140$ & $\mathrm{HS}$ & 102.28 & 26 & - & - & - & - \\
\hline $13 \mathrm{X}-3,0-5$ & $\mathrm{HS}$ & 112.03 & 20 & - & - & - & - \\
\hline $14 X-5,0-5$ & $\mathrm{HS}$ & 124.03 & 19 & - & - & - & - \\
\hline $15 X-4,0-5$ & $\mathrm{HS}$ & 132.73 & 55 & - & 1 & - & 55 \\
\hline $16 X-4,0-5$ & $\mathrm{HS}$ & 142.33 & 175 & - & 1.3 & - & 134 \\
\hline $19 \times 1,145-150$ & HS & 168.18 & 2,326 & 11,154 & 10 & - & 233 \\
\hline $19 X-2,0-5$ & $\mathrm{HS}$ & 168.23 & 9,275 & 31,130 & 100 & 10 & 93 \\
\hline \multicolumn{8}{|l|}{ 169-1035D- } \\
\hline $1 \mathrm{H}-2,135-140$ & HS & 2.88 & 3 & - & - & - & - \\
\hline $2 \mathrm{H}-5,0-5$ & $\mathrm{HS}$ & 11.13 & 4 & - & - & - & - \\
\hline $3 \mathrm{H}-5,0-5$ & $\mathrm{HS}$ & 20.63 & 5 & - & - & - & - \\
\hline $4 \mathrm{H}-5,0-5$ & $\mathrm{HS}$ & 30.13 & 5 & - & - & - & - \\
\hline $5 \mathrm{H}-6,0-5$ & $\mathrm{HS}$ & 41.13 & 7 & - & - & - & - \\
\hline \multicolumn{8}{|l|}{ 169-1035E- } \\
\hline $1 \mathrm{H}-5,0-5$ & HS & 6.03 & 4 & - & - & - & - \\
\hline $2 \mathrm{H}-5,0-5$ & $\mathrm{HS}$ & 13.53 & 4 & - & - & - & - \\
\hline $3 \mathrm{H}-5,0-5$ & HS & 23.03 & 3 & - & - & - & - \\
\hline $4 \mathrm{H}-4,0-5$ & $\mathrm{HS}$ & 31.03 & 3 & - & - & - & - \\
\hline $5 \mathrm{H}-\mathrm{CC}, 43-48$ & HS & 45.05 & 3 & - & - & - & - \\
\hline \multicolumn{8}{|l|}{ 169-1035F- } \\
\hline $12 \mathrm{R}-\mathrm{CC}, 0-6$ & $\mathrm{~V}, \mathrm{PW}$ & 119.00 & 13 & 612 & - & - & - \\
\hline \multicolumn{8}{|l|}{ 169-1035G- } \\
\hline $5 \mathrm{R}-1,143-150$ & $\mathrm{~V}, \mathrm{PW}$ & 75.10 & 124 & 1,358 & 3 & - & 41 \\
\hline $6 \mathrm{~W}-\mathrm{CC}, 0-8$ & $\mathrm{~V}, \mathrm{PW}$ & 140.80 & 102 & 3,233 & 2 & - & 51 \\
\hline
\end{tabular}

Notes: $\mathrm{V}=$ vacutainer, $\mathrm{HS}=$ headspace, and $\mathrm{PW}=$ pore water.$-=$ no data. 


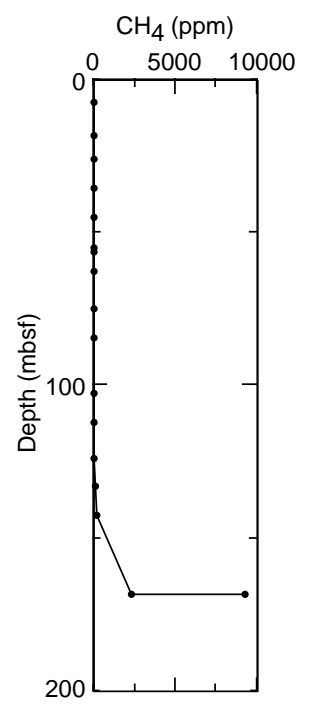

Figure 131. Methane concentration vs. depth for Hole 1035A.

\section{Site 1035}

The headspace gas analyses vs. depth for Hole 1035A showed only background levels of methane to $125 \mathrm{mbsf}$, followed by a dramatic increase to the highest value at the bottom of the hole (Fig. 131; Table 22). The gases from both the sediment headspace and from the interstitial water sample of Core 169-1035A-19X contained ethane, propane, and $\mathrm{CO}_{2}$. The $\mathrm{C}_{1} / \mathrm{C}_{2}$ ratio is $<100$ for the gas samples, which is consistent with a thermogenic origin. The upper limit for the $C_{1} / C_{2}$ ratio of thermogenic gas is generally taken as 100 (Bernard et al., 1976). This onset of $\mathrm{CH}_{4}$ increase and occurrence of $\mathrm{C}_{2}$ and higher molecular weight hydrocarbons was also reported for Hole $857 \mathrm{C}$ between 150 and 200 mbsf (Shipboard Scientific Party, 1992c, p. 342). The zone below Core 169-1035A-16X reflects a high thermal gradient based on the increasing $\mathrm{CH}_{4}$ content. The low $\mathrm{CH}_{4}$ concentrations in the shallower sections suggest that environmental conditions were not suitable for microbial methanogenesis. An enhanced $\mathrm{CH}_{4}$ and $\mathrm{CO}_{2}$ content was also observed in Hole 1035G (below $75 \mathrm{mbsf}$ ), whereas Holes $1035 \mathrm{D}$ and $1035 \mathrm{~F}$ had only background levels of $\mathrm{CH}_{4}$ and $\mathrm{CO}_{2}$ (Table 22).

\section{Fluorescence and Black Soot}

\section{Hole 856H}

The extracts from samples of sediments from Hole $856 \mathrm{H}$ were colorless; however, some samples (170-192 mbsf) contained black carbonaceous soot as revealed by black particles at the hexane/methanol-water interface. This was best observed in Sample 169-856H28R-2-CC, where the sediment was easily disaggregated in methanol, thus liberating the carbonaceous particles. Black soot was also described in the deeper intervals of Leg 139, Site 858, with a TOC value of $\sim 2 \%$. Black soot was observed from the following depths to the bottom of the holes: Hole 858A at $45 \mathrm{mbsf}$; Hole 858B at $5 \mathrm{mbsf}$; Hole $858 \mathrm{C}$ at 13 mbsf; and Hole 858D at 10 mbsf (Shipboard Scientific Party, 1992c). These particles may have adsorbed interstitial gas, as observed in Guaymas Basin, Site 477, where such samples built up gas pressure when placed into an evacuated container (Curray, Moore, et al., 1982). This may be a mechanism to retain gas in the formation when interstitial fluid levels are low (i.e., low water/rock ratio). The hexane phases of the samples above were not analyzed by gas chromatography, because hydrothermal bitumen was not detected by fluorescence nor expected based on the previous results from
Sites 856 and 857 (Shipboard Scientific Party, 1992c; Simoneit, 1994).

\section{Site 1035}

Extracts from the near-surface sediments of Hole 1035A were colorless or pale yellow and showed only slight yellow-white fluorescence. No strong fluorescence caused by the presence of a petroleum zone was observed. Black particulate matter was separated from Sections 169-1035A-6H-CC through 19X-1 (55-178 mbsf). The yellow fluorescence is interpreted as being caused by thermal maturation of bitumen to the mature stage. The black soot particulate matter is interpreted to be the residual kerogen remaining after bitumen generation, as discussed for the Dead Dog area (see "Organic Geochemistry" section, "Middle Valley: Dead Dog Area," this volume). The extracts of samples from Holes 1035C and 1035D were colorless and had a faint yellow-white fluorescence. Black particles were observed in the near surface sediments of Hole 1035C and in Section 1691035D-3H-3 (18 mbsf) to the bottom of the hole. Sample extracts for sediments from Hole 1035E were yellow in the shallow sections and colorless at depth. Black particulate matter was evident in Cores 1691035E-4H and 5H (30-37 mbsf) and in Section 169-1035G-5R-1.

\section{Bitumen Analyses}

Solvent extracts of bitumen were analyzed for sediments from Site 1035 using the hexane supernatant from the fluorescence evaluation or from subsamples of freeze-dried sediments. The extracts were concentrated to $10-100 \mu \mathrm{L}$ prior to high resolution gas chromatography (GC) analysis. Some typical GC traces are shown in Figure 132. The bitumen parameters for maturation and organic matter sources are listed in Table 23. Pristane (Pr) to $n-\mathrm{C}_{17}$ and phytane $(\mathrm{Ph})$ to $n-\mathrm{C}_{18}$ ratios are not given because of the low concentrations of these compounds in many samples, although $\mathrm{Pr} / \mathrm{Ph}$ is reported. Also, the $\mathrm{Uk}^{\mathrm{k}}{ }_{37}$ index (Shipboard Scientific Party, 1992c; Simoneit et al., 1994) could not be determined for these samples, because the $C_{37}$ alkenones also had low concentrations and coeluting compounds interfered in the gas chromatography analyses.

The $n$-alkanes $>\mathrm{C}_{26}$ have a strong predominance of odd carbon numbered homologs (carbon preference index [CPI] >1.0) and carbon number maximum $\left(\mathrm{C}_{\max }\right)$ at $\mathrm{C}_{27}, \mathrm{C}_{29}$, or $\mathrm{C}_{31}$ in the relatively unaltered shallow sediments of Holes 1035A, 1035D, and 1035E (e.g., Fig. 132A, C). This is typical for immature hydrocarbons with an origin from terrestrial higher plants (mainly the epicuticular plant waxes, Simoneit, 1977, 1978). Immature microbial lipid residues from marine autochthonous sources as reported earlier for other sediment samples from Middle Valley (Shipboard Scientific Party, 1992c) were not found. The carbon number distributions and other geochemical parameters of these bitumens can be utilized to infer the source of the organic matter and the degree of thermal alteration or maturity (Hunt, 1996; Kawka and Simoneit, 1987; Simoneit, 1985, 1990, 1994). Hydrothermal petroleums, as reported earlier for this area (Shipboard Scientific Party, 1992c; Simoneit, 1994; Simoneit et al., 1992) and found at Site 1036, are not present in these sediments. The bitumens in sediments of Holes 1035A and 1035D have undergone accelerated in situ maturation because of the high heat flow and not by contact with hydrothermal fluids. They have not migrated, but reside in situ at an essentially uniform and low concentration throughout the two holes.

The bitumen compositions with the $n$-alkane predominances $\left(\mathrm{C}_{\text {max }}\right)$ at $\mathrm{C}_{27}, \mathrm{C}_{29}$, or $\mathrm{C}_{31}$ indicate a significant terrigenous component, and the particulate organic matter (kerogen) contains many plant fragments and pollen from terrestrial sources (observed by microscopic examination of particle concentrate). As a consequence, these sediment samples have low contents of gas and volatiles compared to those formed from the more aliphatic marine organic matter in Guay- 

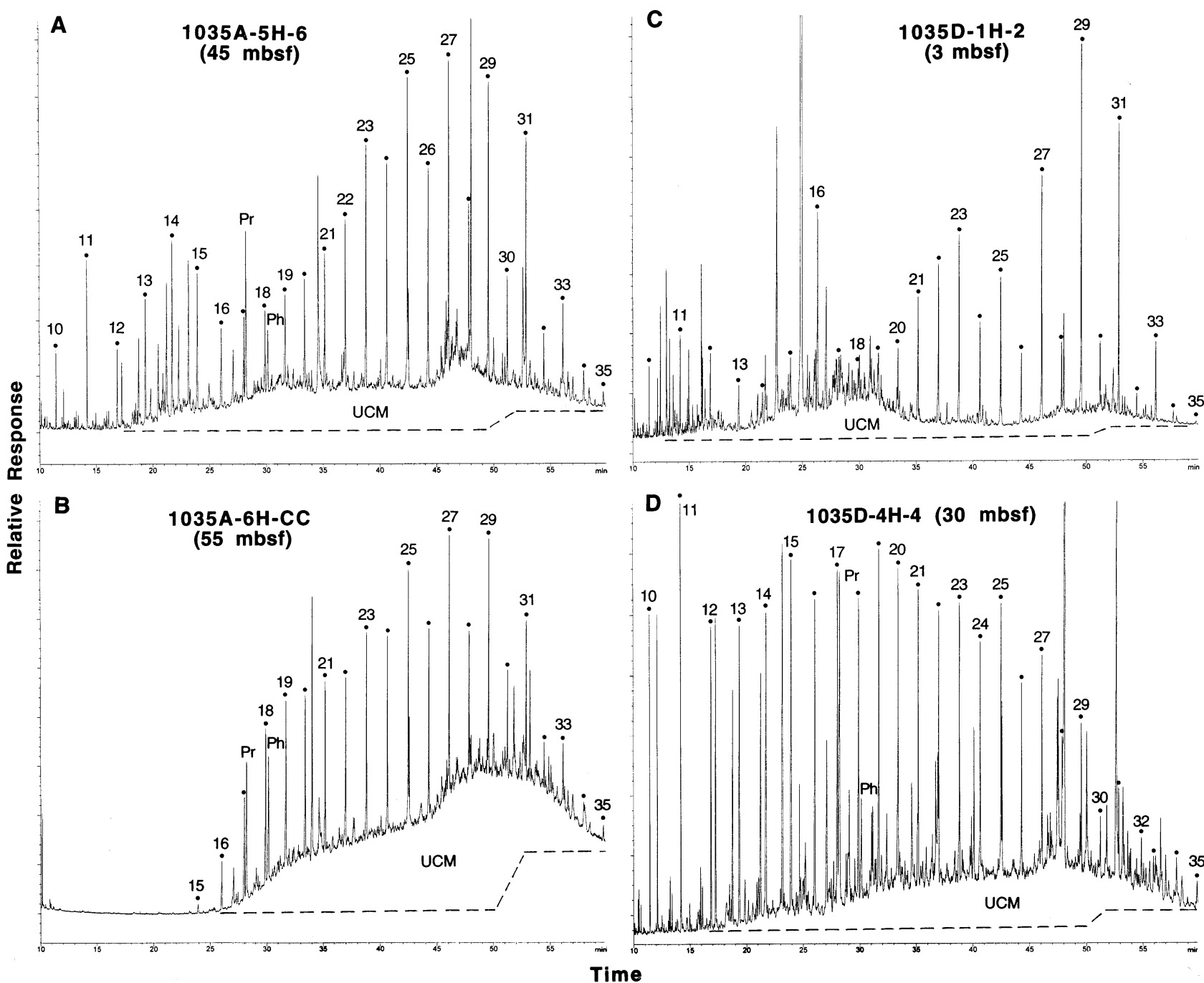

Time

Figure 132. Typical gas chromatograms for total bitumen extracts from sediments of Site 1035. A. Section 169-1035A-5H-6 (45 mbsf). B. Section 169-1035A6H-CC (55 mbsf). C. Section 169-1035D-1H-2 (3 mbsf). D. Section 169-1035D-4H-4 (30 mbsf). Plots are relative intensity vs. time, dots and numbers refer to carbon chain length of $n$-alkanes, $\mathrm{Pr}=$ pristane, $\mathrm{Ph}=$ phytane, and $\mathrm{UCM}=$ unresolved complex mixture of branched and cyclic compounds.

mas Basin, Gulf of California (Simoneit et al., 1988; Kvenvolden and Simoneit, 1990). The alkane distributions and relative amounts of the envelopes of the unresolved complex mixture (UCM) of branched and cyclic hydrocarbons are typical for petroleums (examples in Fig. 132).

Accelerated maturation is evident from the CPI (range $\mathrm{C}_{24}-\mathrm{C}_{33}$ ) values that are near one in the deeper horizons to the bottom of the holes at Site 1035 (Fig. 133). This indicates full maturity and is caused by the higher than normal thermal gradient that generates additional alkanes from the kerogen (bulk organic carbon). A CPI of $<1$ in some intervals with a strong even carbon number predominance from $n-\mathrm{C}_{16}$ to $n-\mathrm{C}_{34}$ is noted. This was reported earlier for Middle Valley (Shipboard Scientific Party, 1992c; Simoneit, 1994) and for other geographic areas (e.g., Simoneit, 1977; Grimalt and Albaiges, 1987). It seems to be a characteristic of the source organic matter. Thermal maturation of petroleums generally does not produce CPI values of $<1$, so that the low CPI for these holes must be partially source-related. The variability of the CPI values for bitumen in the shallow intervals reflects the different source inputs of marine and terrigenous organic matter.

The isoprenoid alkane $(\mathrm{Pr} / \mathrm{Ph})$ ratios show severe variation vs. depth for these cores (Table 23). This ratio is generally influenced by both source and maturation. The $\mathrm{Pr} / \mathrm{Ph}$ approaches low values at intermittent intervals in shallower horizons of these cores as well as at depth. This may be a reflection of primary organic matter sources in the shallower horizons and full maturation at depth.

\section{Elemental Analyses}

\section{Hole $856 \mathrm{H}$}

The results of the total carbon (TC), nitrogen (TN) and sulfur (TS) measurements for sediments from Hole $856 \mathrm{H}$ are given in Table 24 and Figure 134A and 134B. Total carbon and carbonate carbon are low throughout the section drilled. The organic carbon determined by difference is not reliable because of the significant experimental error at low values between the two methods. It is estimated to be $<0.01 \%$ in all samples. The nitrogen and sulfur contents are below detection levels $(0.01 \%)$, except for samples from the upper sulfide stringer zone that demonstrate high sulfur contents (Table 24; Fig. 134B).

\section{Site 1035}

The results of the elemental analyses for samples from Site 1035 are given in Table 24. For Hole 1035A, the downhole profiles of TIC 
Table 23. Various parameters for the solvent soluble organic matter in sediments from Holes 1035A, 1035D, and 1035E.

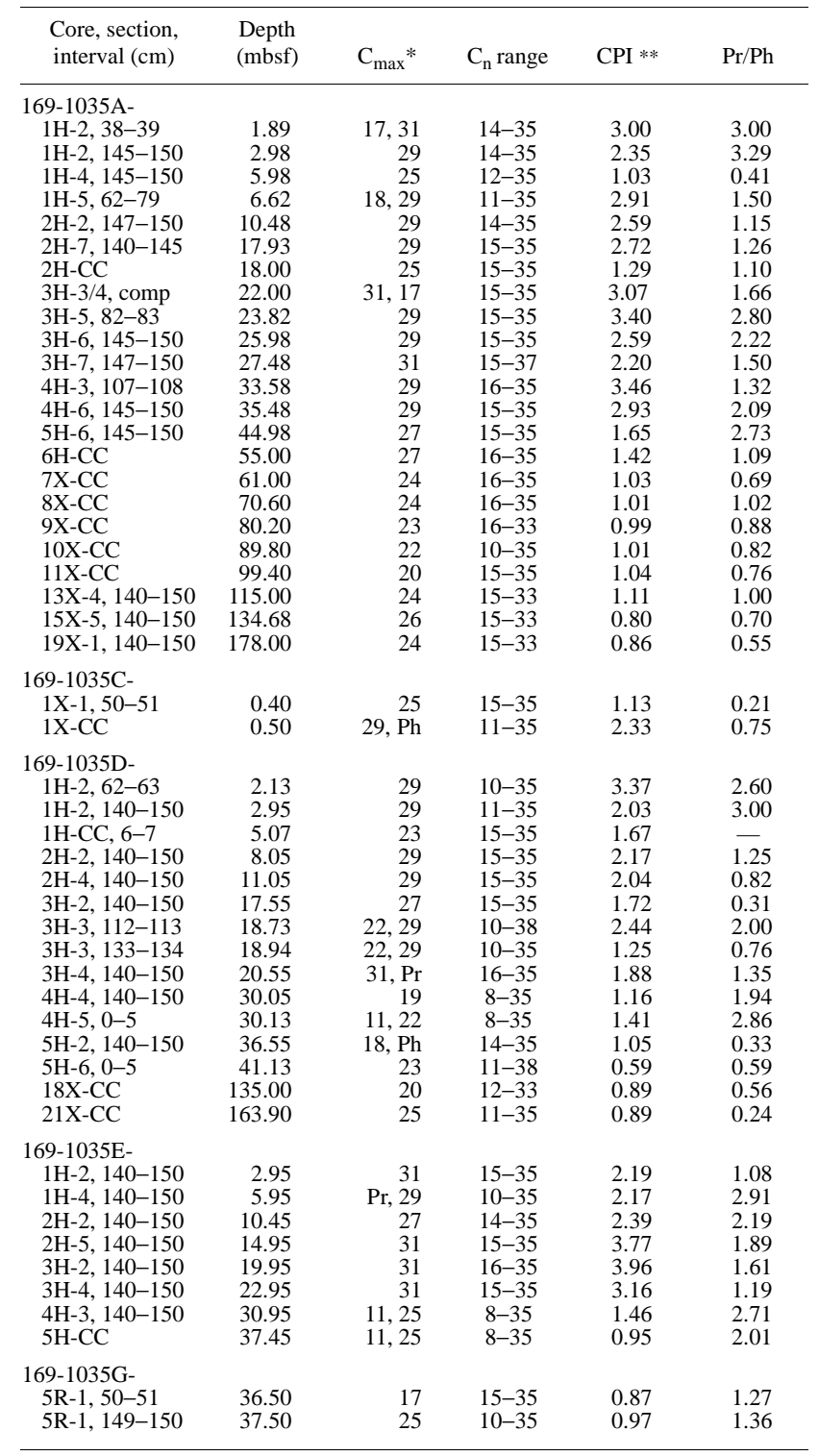

Notes: $*$ major homologs are listed in decreasing order of concentration $\left(\mathrm{C}_{\mathrm{max}}\right), * *=$ carbon preference index calculated from $n-\mathrm{C}_{24}$ to $n-\mathrm{C}_{33}, \mathrm{Pr}=$ pristane, and $\mathrm{Ph}=$ phytane. $-=$ not reported

and TOC have values that are high near the seabed (1.7\%) and generally decrease to $0.1 \%$ with depth (Fig. $135 \mathrm{~A}-\mathrm{C}$ ). There are minor carbonate horizons with $\mathrm{CaCO}_{3}$ contents of $3 \%-4.5 \%$ at $\sim 0-7,8-14$, 34 , and 83 mbsf in Hole 1035A (Table 24; Fig. 135B). The TOC content is $1.2 \%$ near the seabed and then generally $<0.5 \%$ with depth (Fig. 135C). TN mirrors the TOC, and TS has a maximum at 7-8 mbsf in the clastic sulfide zone and is enriched at 133-144 mbsf (Fig. $135 \mathrm{D}, \mathrm{E})$.

The TC, TN, and TIC profiles for sediments from Hole 1035D generally decrease at shallow depths (e.g., $0.8 \% \mathrm{TC}$ and $0.5 \% \mathrm{TN}$ ) to background values at depth (Fig. 136A-C). There is a carbonate nodule horizon in Section 169-1035D-3H-3 $\left(\sim 83 \% \mathrm{CaCO}_{3}\right)$. The organic carbon content is low throughout the hole, decreasing from $0.4 \%$ in shallow sediments to $0.02 \%$ at depth (Fig. 136D). These elemental compositions are similar to the low values reported above for Hole

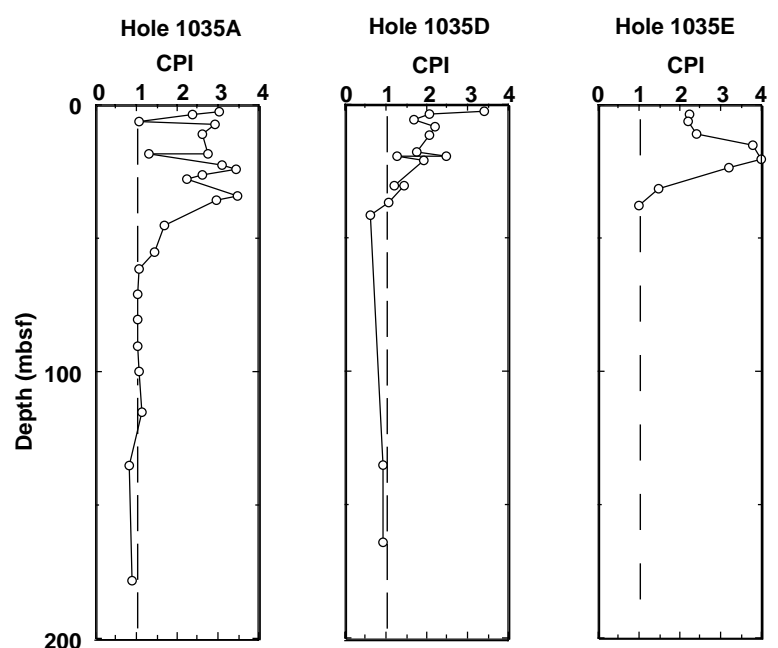

Figure 133. CPI depth profiles for sediments from Site 1035.

$856 \mathrm{H}$. There are two zones with high sulfur contents (Table 24) at $6-$ 7 mbsf (Sections 169-1035D-2H-1 through 2H-2) and at 41-67 mbsf (Sections 169-1035D-5H-6 through 10X-1). A horizon with high sulfur values is also found in Core 169-1035C-5X-1 (39 mbsf).

The TC, TN, TIC, and TOC profiles for sediments from Hole $1035 \mathrm{E}$ show no significant trends and are low throughout the core (Fig. 134C, D). A minor carbonate horizon (Sections 169-1035E-2H4 through $2 \mathrm{H}-7$ ) at $12-17 \mathrm{mbsf}$ is present just below the sulfide zone in Section 169-1035E-2H-2 (10 mbsf). The samples analyzed from Holes $1035 \mathrm{~F}$ to $1035 \mathrm{H}$ are generally sulfides (Table 24) and are discussed further in the "Lithostratigraphic Summary and Sedimentology" section, this chapter. The depth profiles of $\mathrm{C} / \mathrm{N}$ and $\mathrm{C} / \mathrm{S}$ do not show any significant trends for these holes.

\section{Conclusion}

The WSTP-1 water sample ( $73 \mathrm{mbsf}$ ) from Hole $856 \mathrm{H}$ had 51 ppm methane in the headspace, indicating that hydrocarbon gas is entering the hole. Gas removed from lithified sediment (191 mbsf), which could be compressed by the IW method, consisted of about equal amounts of methane $(18,000 \mathrm{ppm})$ and $\mathrm{CO}_{2}$, with traces of ethane and propane $\left(\mathrm{C}_{1} / \mathrm{C}_{2}=207\right)$. Soot carbon (black $\mathrm{C}$ ) occurs over the same interval (170-190 mbsf), indicating that the gas may be adsorbed to carbon in this altered section. Organic and carbonate carbon contents are low throughout Hole $856 \mathrm{H}$. Total C, N, and S and inorganic $\mathrm{C}$ levels are at the detection limit throughout, except the upper sulfide stringer zone (94-202 mbsf), which has high sulfur contents.

Significant headspace gas concentrations were only encountered at depth in Holes 1035A and 1035G, consisting mainly of $\mathrm{CH}_{4}$ and major amounts of $\mathrm{CO}_{2}$. The extractable bitumen showed accelerated maturation with depth for Holes 1035A, 1035D, and 1035E, but the low concentrations indicated in situ alteration without migration. The shallow sections of all holes had $n$-alkanes with a strong odd carbon number predominance (CPI >1.0) and $\mathrm{C}_{\max }$ at $\mathrm{C}_{27}, \mathrm{C}_{29}$, or $\mathrm{C}_{31}$, typical for terrigenous detritus. The elemental analyses of $\mathrm{C}, \mathrm{N}, \mathrm{S}$, and inorganic $\mathrm{C}$ are generally all low with high concentrations in some horizons. Carbonate is enriched in several zones of Holes 1035A, 1035C, $1035 \mathrm{D}$, and $1035 \mathrm{E}$. TOC decreases from a high of $1.2 \%$ to background values with depth in Hole 1035A and is at background levels in the other holes. The sulfur contents are high in the sulfide zones of Holes 1035A (7-9 mbsf), 1035C (39 mbsf), 1035D (6-7, >41 mbsf), $1035 \mathrm{E}$ (10, >45 mbsf), 1035F (32-100 mbsf), 1035G (45 mbsf), and $1035 \mathrm{H}(9,>75 \mathrm{mbsf})$. 
Table 24. Weight percentages of $\mathrm{C}, \mathrm{N}, \mathrm{S}$, inorganic $\mathrm{C}$, organic $\mathrm{C}$, and values of $\mathrm{C} / \mathrm{N}$ and $\mathrm{C} / \mathrm{S}$ for sediments from $\mathrm{Hole} 856 \mathrm{H}$ and Site 1035 .

\begin{tabular}{|c|c|c|c|c|c|c|c|c|}
\hline $\begin{array}{l}\text { Core, section, } \\
\text { interval }(\mathrm{cm})\end{array}$ & $\begin{array}{l}\text { Depth } \\
\text { (mbsf) }\end{array}$ & $\begin{array}{l}\mathrm{TC} \\
(\%)\end{array}$ & $\begin{array}{l}\mathrm{TN} \\
(\%)\end{array}$ & $\begin{array}{l}\text { TS } \\
(\%)\end{array}$ & $\mathrm{C} / \mathrm{N}^{*}$ & $\mathrm{C} / \mathrm{S}^{*}$ & $\begin{array}{l}\text { TIC } \\
(\%)\end{array}$ & $\begin{array}{l}\text { TOC } \\
(\%)\end{array}$ \\
\hline $169-856 \mathrm{H}-$ & & & & & & & & \\
\hline 19R-1, 14-15 & 93.95 & 0.41 & 0.00 & 40.98 & - & 0.01 & - & - \\
\hline 19R-1, 57-58 & 94.38 & 0.08 & 0.00 & 48.82 & - & 0.00 & - & - \\
\hline $21 \mathrm{R}-1,53-54$ & 113.94 & 0.14 & 0.30 & 38.46 & - & 0.00 & - & - \\
\hline $22 \mathrm{R}-1,134-135$ & 118.45 & 0.11 & 1.37 & 46.03 & - & 0.00 & - & - \\
\hline $22 \mathrm{R}-2,7-8$ & 119.53 & 0.08 & 1.13 & 44.72 & - & 0.00 & - & - \\
\hline $23 \mathrm{R}-1,1-3$ & 124.10 & 0.06 & 0.00 & 5.15 & 0.06 & 5.20 & 0.05 & 0.00 \\
\hline $24 \mathrm{R}-1,93-103$ & 134.70 & 0.06 & 0.00 & 0.20 & 0.06 & 0.25 & 0.05 & 0.00 \\
\hline $25 \mathrm{R}-1,7-8$ & 143.38 & 0.12 & 1.67 & 47.05 & - & 0.00 & - & - \\
\hline $25 \mathrm{R}-2,2-4$ & 144.80 & 0.10 & 0.00 & 0.87 & 0.10 & 0.97 & 0.07 & 0.02 \\
\hline $26 \mathrm{R}-1,85-87$ & 153.80 & 0.05 & 0.00 & 0.41 & 0.05 & 0.46 & 0.05 & 0.00 \\
\hline $27 \mathrm{R}-1,50-51$ & 163.00 & 0.03 & 0.01 & 2.35 & 0.04 & 2.38 & 0.03 & 0.00 \\
\hline $28 \mathrm{R}-1,12-13$ & 172.20 & 0.07 & 0.02 & 2.72 & 0.09 & 2.79 & 0.05 & 0.02 \\
\hline $28 \mathrm{R}-2,2-3$ & 173.60 & 0.04 & 0.02 & 5.86 & 0.06 & 5.90 & 0.03 & 0.01 \\
\hline $29 \mathrm{R}-1,38-42$ & 182.10 & 0.05 & 0.01 & 6.04 & 0.06 & 6.09 & 0.02 & 0.03 \\
\hline $31 \mathrm{R}-1,91-92$ & 201.92 & 0.31 & 1.77 & 34.70 & - & 0.01 & - & - \\
\hline $32 \mathrm{R}-1,85-95$ & 211.50 & 0.04 & 0.01 & 0.00 & 0.06 & 0.04 & 0.02 & 0.02 \\
\hline $33 \mathrm{R}-1,77-78$ & 221.00 & 0.05 & 0.00 & 0.00 & 0.05 & 0.05 & 0.07 & -0.02 \\
\hline $35 \mathrm{R}-1,68-69$ & 240.10 & 0.02 & 0.01 & 0.00 & 0.03 & 0.02 & 0.06 & -0.04 \\
\hline $37 \mathrm{R}-1,54-57$ & 259.20 & 0.05 & 0.00 & 0.14 & 0.05 & 0.19 & 0.06 & -0.01 \\
\hline $40 \mathrm{R}-1,12-14$ & 287.70 & 0.08 & 0.00 & 0.00 & 0.08 & 0.08 & 0.06 & 0.02 \\
\hline 41R-1, 89-99 & 298.20 & 0.06 & 0.00 & 0.00 & 0.06 & 0.06 & 0.05 & 0.01 \\
\hline $42 \mathrm{R}-1,70,72$ & 307.60 & 0.05 & 0.00 & 0.04 & 0.05 & 0.09 & 0.04 & 0.01 \\
\hline $43 \mathrm{R}-1,80-83$ & 317.30 & 0.08 & 0.00 & 0.00 & 0.08 & 0.08 & 0.05 & 0.03 \\
\hline $44 \mathrm{R}-1,21-24$ & 326.40 & 0.06 & 0.00 & 0.00 & 0.06 & 0.06 & 0.04 & 0.01 \\
\hline $45 \mathrm{R}-1,28-30$ & 336.10 & 0.07 & 0.00 & 0.00 & 0.07 & 0.07 & 0.05 & 0.03 \\
\hline $46 \mathrm{R}-1,73-76$ & 346.20 & 0.03 & 0.00 & 0.00 & 0.03 & 0.03 & 0.05 & -0.01 \\
\hline $47 \mathrm{R}-1,107-110$ & 356.20 & 0.05 & 0.00 & 0.00 & 0.05 & 0.05 & 0.06 & -0.01 \\
\hline $48 \mathrm{R}-1,28-30$ & 364.90 & 0.07 & 0.03 & 0.00 & 0.10 & 0.07 & 0.06 & 0.01 \\
\hline $49 \mathrm{R}-1,37-39$ & 374.60 & 0.05 & 0.00 & 0.00 & 0.05 & 0.05 & 0.06 & -0.01 \\
\hline 50R-1, 104-107 & 384.90 & 0.03 & 0.00 & 0.00 & 0.03 & 0.03 & 0.04 & -0.01 \\
\hline $51 \mathrm{R}-1,21-23$ & 393.40 & 0.05 & 0.00 & 0.00 & 0.05 & 0.05 & 0.07 & -0.02 \\
\hline $52 \mathrm{R}-1,108-110$ & 404.10 & 0.08 & 0.00 & 0.00 & 0.08 & 0.08 & 0.06 & 0.02 \\
\hline $52 \mathrm{R}-2,50-54$ & 405.00 & 0.05 & 0.00 & 0.00 & 0.05 & 0.05 & 0.04 & 0.01 \\
\hline $54 \mathrm{R}-1,46-50$ & 422.70 & 0.06 & 0.00 & 0.00 & 0.06 & 0.06 & 0.07 & -0.01 \\
\hline $56 \mathrm{R}-1,1-2$ & 434.30 & 0.06 & 0.00 & 0.00 & 0.06 & 0.06 & 0.04 & 0.02 \\
\hline $56 \mathrm{R}-1,60-62$ & 434.90 & 0.04 & 0.00 & 0.00 & 0.04 & 0.04 & 0.05 & -0.01 \\
\hline $57 \mathrm{R}-1,6-8$ & 441.40 & 0.05 & 0.00 & 0.00 & 0.05 & 0.05 & 0.06 & -0.02 \\
\hline $59 \mathrm{R}-1,60-68$ & 461.34 & 0.10 & 1.19 & 0.00 & 0.08 & - & - & - \\
\hline $61 \mathrm{R}-1,100-103$ & 469.20 & 0.04 & 0.00 & 0.00 & 0.04 & 0.04 & 0.05 & 0.00 \\
\hline $62 \mathrm{R}-1,55-59$ & 470.90 & 0.03 & 0.00 & 0.06 & 0.03 & 0.09 & 0.05 & -0.02 \\
\hline $63 \mathrm{R}-1,16-20$ & 480.08 & 0.01 & 0.00 & 0.24 & - & 0.04 & - & - \\
\hline $64 \mathrm{R}-2,9-11$ & 491.10 & 0.00 & 0.00 & 0.00 & - & - & - & - \\
\hline $65 \mathrm{R}-2,10-13$ & 495.82 & 0.00 & 0.00 & 1.24 & - & - & - & - \\
\hline 169-1035A- & & & & & & & & \\
\hline $1 \mathrm{H}-1,19-20$ & 0.20 & 1.70 & 0.16 & 0.67 & 10.87 & 2.52 & 0.51 & 1.19 \\
\hline $1 \mathrm{H}-2,38-39$ & 1.89 & 0.77 & 0.05 & 0.03 & 16.30 & 23.21 & 0.48 & 0.28 \\
\hline $1 \mathrm{H}-2,145-150$ & 3.00 & 0.95 & 0.06 & 0.98 & 15.82 & 0.97 & 0.53 & 0.42 \\
\hline $1 \mathrm{H}-5,62-63$ & 6.62 & 0.57 & 0.03 & 0.00 & 18.32 & - & 0.33 & 0.23 \\
\hline $1 \mathrm{H}-5,78-79$ & 6.78 & 0.64 & 0.07 & 17.96 & 9.78 & 0.04 & 0.07 & 0.57 \\
\hline $1 \mathrm{H}-5,106-107$ & 7.07 & 0.25 & 0.00 & 45.12 & - & 0.01 & - & - \\
\hline $2 \mathrm{H}-1,43-44$ & 7.93 & 0.73 & 0.06 & 25.27 & 12.37 & 0.03 & 0.32 & 0.41 \\
\hline $2 \mathrm{H}-1,122-122$ & 8.72 & 0.56 & 2.36 & 28.06 & - & 0.02 & - & - \\
\hline $2 \mathrm{H}-2,97-98$ & 9.98 & 0.82 & 0.06 & 0.00 & 13.38 & - & 0.49 & 0.33 \\
\hline $2 \mathrm{H}-7,140-145$ & 17.93 & 0.55 & 0.04 & 0.00 & 15.31 & - & 0.36 & 0.19 \\
\hline $3 \mathrm{H}-5,82-83$ & 23.82 & 0.65 & 0.07 & 0.44 & 9.91 & 1.50 & 0.04 & 0.62 \\
\hline $4 \mathrm{H}-3,107-108$ & 33.58 & 0.94 & 0.07 & 0.25 & 14.18 & 3.74 & 0.48 & 0.45 \\
\hline $5 \mathrm{H}-4,62-63$ & 41.13 & 0.43 & 0.09 & 0.07 & 5.04 & 6.58 & 0.12 & 0.30 \\
\hline $6 \mathrm{H}-2,94-95$ & 47.95 & 0.31 & 0.06 & 0.00 & 5.55 & - & 0.03 & 0.28 \\
\hline $6 \mathrm{H}-\mathrm{CC}, 0-5$ & 54.97 & 0.29 & 0.04 & 0.62 & 6.81 & 0.46 & 0.03 & 0.25 \\
\hline $7 \mathrm{X}-1,104-105$ & 56.05 & 0.31 & 0.04 & 0.31 & 6.98 & 1.00 & 0.06 & 0.25 \\
\hline $8 X-2,64-65$ & 63.15 & 0.27 & 0.04 & 0.14 & 6.33 & 1.85 & 0.03 & 0.23 \\
\hline $9 X-3,53-54$ & 74.14 & 0.29 & 0.06 & 0.30 & 4.47 & 0.95 & 0.05 & 0.24 \\
\hline $10 \mathrm{X}-2,103-104$ & 82.74 & 0.60 & 0.05 & 0.00 & 13.13 & - & 0.37 & 0.24 \\
\hline $10 \mathrm{X}-2,106-107$ & 82.77 & 0.65 & 0.06 & 0.00 & 11.14 & - & 0.22 & 0.42 \\
\hline $11 X-1,45-46$ & 90.36 & 0.28 & 0.03 & 0.17 & 8.90 & 1.65 & 0.11 & 0.16 \\
\hline $12 X-2,135-140$ & 102.24 & 0.34 & 0.05 & 1.41 & 6.88 & 0.24 & 0.04 & 0.29 \\
\hline $12 X-5,36-37$ & 105.77 & 0.27 & 0.04 & 0.23 & 6.95 & 1.16 & 0.06 & 0.21 \\
\hline $13 X-3,0-5$ & 112.03 & 0.36 & 0.05 & 0.31 & 6.77 & 1.16 & 0.03 & 0.32 \\
\hline $13 X-3,29-30$ & 112.30 & 0.31 & 0.05 & 0.09 & 6.66 & 3.52 & 0.05 & 0.27 \\
\hline $14 X-2,46-47$ & 120.57 & 0.11 & 0.03 & 0.14 & 3.73 & 0.82 & 0.06 & 0.05 \\
\hline $14 X-5,0-5$ & 124.63 & 0.16 & 0.03 & 0.47 & 4.70 & 0.33 & 0.03 & 0.12 \\
\hline $14 X-6,45-46$ & 126.56 & 0.26 & 0.04 & 0.30 & 7.19 & 0.86 & 0.05 & 0.21 \\
\hline $15 X-4,0-5$ & 132.73 & 0.17 & 0.04 & 2.33 & 4.55 & 0.07 & 0.03 & 0.14 \\
\hline $15 X-5,63-64$ & 134.84 & 0.09 & 0.03 & 2.13 & 3.60 & 0.04 & 0.11 & -0.02 \\
\hline $16 X-4,0-5$ & 142.33 & 0.13 & 0.02 & 1.53 & 5.78 & 0.09 & 0.03 & 0.10 \\
\hline $16 X-5,8-9$ & 143.89 & 0.16 & 0.03 & 3.08 & 5.06 & 0.05 & 0.09 & 0.07 \\
\hline $19 X-1,66-68$ & 167.37 & 0.17 & 0.04 & 0.00 & 4.58 & - & 0.03 & 0.15 \\
\hline $19 X-2,0-5$ & 168.23 & 0.08 & 0.03 & 1.09 & 2.66 & 0.07 & 0.05 & 0.02 \\
\hline $169-1035 \mathrm{C}-$ & & & & & & & & \\
\hline $1 \mathrm{X}-1,30-31$ & 0.31 & 1.13 & 0.46 & 0.88 & 2.46 & 1.28 & 0.55 & 0.58 \\
\hline $1 X-1,46-47$ & 0.47 & 0.76 & 0.53 & 1.99 & 1.43 & 0.38 & 0.41 & 0.35 \\
\hline $5 X-1,6-19$ & 39.42 & 0.10 & 0.02 & 72.53 & - & 0.00 & - & - \\
\hline 169-1035D- & & & & & & & & \\
\hline $1 \mathrm{H}-1,62-63$ & 0.63 & 0.83 & 0.34 & 0.39 & 2.44 & 2.13 & 0.46 & 0.37 \\
\hline $1 \mathrm{H}-2,62-63$ & 2.13 & 0.69 & 0.37 & 0.10 & 1.86 & 6.90 & 0.39 & 0.30 \\
\hline $1 \mathrm{H}-2,135-140$ & 2.88 & 0.59 & 0.23 & 0.58 & 2.57 & 1.02 & 0.25 & 0.35 \\
\hline $1 \mathrm{H}-3,62-63$ & 3.63 & 0.78 & 0.41 & 0.40 & 1.90 & 1.95 & 0.40 & 0.39 \\
\hline $1 \mathrm{H}-4,13-14$ & 4.64 & 0.71 & 0.47 & 1.28 & 1.51 & 0.55 & 0.31 & 0.40 \\
\hline
\end{tabular}


Table 24 (continued).

\begin{tabular}{|c|c|c|c|c|c|c|c|c|}
\hline $\begin{array}{l}\text { Core, section, } \\
\text { interval }(\mathrm{cm})\end{array}$ & $\begin{array}{l}\text { Depth } \\
\text { (mbsf) }\end{array}$ & $\begin{array}{l}\mathrm{TC} \\
(\%)\end{array}$ & $\begin{array}{l}\mathrm{TN} \\
(\%)\end{array}$ & $\begin{array}{l}\text { TS } \\
(\%)\end{array}$ & $\mathrm{C} / \mathrm{N}^{*}$ & $\mathrm{C} / \mathrm{S} *$ & $\begin{array}{l}\text { TIC } \\
(\%)\end{array}$ & $\begin{array}{c}\text { TOC } \\
(\%)\end{array}$ \\
\hline 1H-CC, 6-7 & 5.07 & 0.62 & 0.43 & 0.76 & 1.44 & 0.82 & 0.29 & 0.33 \\
\hline $2 \mathrm{H}-1,96-97$ & 6.07 & 0.43 & 0.00 & 28.40 & - & 0.02 & - & - \\
\hline $2 \mathrm{H}-2,12-13$ & 6.73 & 1.16 & 0.31 & 33.70 & 3.74 & 0.03 & 0.92 & 0.24 \\
\hline $2 \mathrm{H}-2,69-70$ & 7.30 & 0.41 & 0.33 & 0.13 & 1.24 & 3.15 & 0.07 & 0.34 \\
\hline $2 \mathrm{H}-5,0-5$ & 11.13 & 0.37 & 0.24 & 0.10 & 1.54 & 3.70 & 0.10 & 0.27 \\
\hline $2 \mathrm{H}-6,102-103$ & 13.63 & 0.44 & 0.17 & 0.23 & 2.59 & 1.91 & 0.11 & 0.33 \\
\hline $3 \mathrm{H}-3,112-113$ & 18.73 & 0.53 & 0.24 & 0.42 & 2.21 & 1.26 & 0.20 & 0.33 \\
\hline $3 \mathrm{H}-3,133-134$ & 18.94 & 10.07 & 0.14 & 0.01 & 71.93 & 1007.00 & 10.02 & 0.05 \\
\hline $3 \mathrm{H}-5,0-5$ & 20.63 & 0.51 & 0.25 & 1.57 & 2.04 & 0.32 & 0.18 & 0.32 \\
\hline $3 \mathrm{H}-7,27-28$ & 23.88 & 0.42 & 0.21 & 0.18 & 2.00 & 2.33 & 0.16 & 0.25 \\
\hline $4 \mathrm{H}-5,0-5$ & 30.13 & 0.30 & 0.23 & 0.65 & 1.30 & 0.46 & 0.03 & 0.27 \\
\hline $4 \mathrm{H}-6,110-111$ & 32.71 & 0.34 & 0.26 & 0.56 & 1.31 & 0.61 & 0.03 & 0.31 \\
\hline $5 \mathrm{H}-2,39-40$ & 35.50 & 0.25 & 0.24 & 0.18 & 1.04 & 1.39 & 0.02 & 0.23 \\
\hline $5 \mathrm{H}-6,0-5$ & 41.13 & 0.08 & 0.13 & 24.08 & 0.62 & 0.00 & 0.03 & 0.05 \\
\hline $7 \mathrm{X}-\mathrm{CC}, 1-16$ & 57.70 & 0.07 & 0.01 & 72.81 & - & 0.00 & - & - \\
\hline $9 \mathrm{X}-1,25-30$ & 61.08 & 0.03 & 0.00 & 59.84 & - & 0.02 & - & - \\
\hline $10 \mathrm{X}-1,80-84$ & 67.32 & 0.84 & 0.00 & 44.57 & - & - & - & - \\
\hline \multicolumn{9}{|l|}{ 169-1035E- } \\
\hline $1 \mathrm{H}-1,24-25$ & 0.25 & 0.81 & 0.04 & 0.20 & 20.25 & 4.05 & 0.33 & 0.48 \\
\hline $1 \mathrm{H}-2,38-39$ & 1.88 & 0.65 & 0.02 & 0.00 & 32.50 & - & 0.34 & 0.31 \\
\hline $1 \mathrm{H}-3,49-50$ & 3.50 & 0.94 & 0.05 & 0.17 & 18.80 & 5.53 & 0.35 & 0.59 \\
\hline $1 \mathrm{H}-5,0-5$ & 6.03 & 0.76 & 0.05 & 0.00 & 15.20 & - & 0.32 & 0.44 \\
\hline $2 \mathrm{H}-2,29-30$ & 9.30 & 0.39 & 0.02 & 0.00 & 19.50 & - & 0.11 & 0.28 \\
\hline $2 \mathrm{H}-2,95-96$ & 9.96 & 0.54 & 0.01 & 32.67 & - & 0.02 & - & - \\
\hline $2 \mathrm{H}-4,49-51$ & 12.50 & 1.77 & 0.06 & 0.03 & 29.50 & 59.00 & 1.04 & 0.73 \\
\hline $2 \mathrm{H}-5,0-5$ & 13.53 & 1.09 & 0.04 & 0.20 & 27.25 & 5.45 & 0.71 & 0.38 \\
\hline $2 \mathrm{H}-7,30-31$ & 16.80 & 1.52 & 0.05 & 0.00 & 30.40 & - & 1.04 & 0.48 \\
\hline $3 \mathrm{H}-2,57-62$ & 19.10 & 0.95 & 0.07 & 0.10 & 13.57 & 9.50 & 0.30 & 0.65 \\
\hline $3 \mathrm{H}-5,0-5$ & 23.03 & 1.16 & 0.03 & 0.18 & 38.67 & 6.44 & 0.90 & 0.26 \\
\hline $3 \mathrm{H}-6,38-42$ & 24.90 & 1.18 & 0.06 & 0.00 & 19.67 & - & 0.61 & 0.57 \\
\hline $4 \mathrm{H}-2,60-61$ & 28.60 & 0.82 & 0.03 & 0.00 & 27.33 & - & 0.60 & 0.22 \\
\hline $4 \mathrm{H}-4,0-5$ & 31.03 & 0.71 & 0.05 & 0.54 & 14.20 & 1.31 & 0.41 & 0.30 \\
\hline $4 \mathrm{H}-4,59-60$ & 31.60 & 0.94 & 0.05 & 0.14 & 18.80 & 6.71 & 0.46 & 0.48 \\
\hline $5 \mathrm{H}-2,10-11$ & 37.60 & 0.58 & 0.04 & 0.49 & 14.50 & 1.18 & 0.35 & 0.23 \\
\hline $5 \mathrm{H}-3,39-40$ & 39.40 & 0.56 & 0.04 & 0.15 & 14.00 & 3.73 & 0.33 & 0.23 \\
\hline $5 \mathrm{H}-\mathrm{CC}, 9-10$ & 45.40 & 0.33 & 0.05 & 0.24 & 6.60 & 1.38 & 0.06 & 0.27 \\
\hline $5 \mathrm{H}-\mathrm{CC}, 12-17$ & 45.30 & 0.45 & 0.05 & 1.62 & 9.00 & 0.28 & 0.07 & 0.38 \\
\hline \multicolumn{9}{|l|}{$169-1035 \mathrm{~F}-$} \\
\hline $4 \mathrm{R}-1,36-38$ & 32.48 & 0.10 & 0.03 & 53.43 & 3.30 & 0.00 & - & - \\
\hline $5 \mathrm{R}-2,134-137$ & 44.56 & 0.00 & 0.00 & 59.22 & - & 0.00 & - & - \\
\hline $7 \mathrm{R}-1,3-4$ & 61.04 & 0.04 & 0.00 & 58.45 & - & 0.00 & - & - \\
\hline $8 \mathrm{R}-1,48-52$ & 71.10 & 0.01 & 0.00 & 57.95 & - & 0.00 & - & - \\
\hline $11 \mathrm{R}-1,29-34$ & 100.02 & 0.01 & 0.00 & 36.23 & - & 0.00 & - & - \\
\hline \multicolumn{9}{|l|}{ 169-1035G- } \\
\hline $2 \mathrm{R}-1,60-64$ & 45.02 & 0.03 & 0.00 & 57.03 & - & 0.00 & - & - \\
\hline $5 \mathrm{R}-1,61-63$ & 74.22 & 0.32 & 0.04 & 0.54 & 8.00 & 0.60 & 0.03 & 0.29 \\
\hline $5 \mathrm{R}-1,143-150$ & 75.07 & 0.32 & 0.03 & 0.06 & 10.70 & 5.33 & 0.04 & 0.28 \\
\hline $5 \mathrm{R}-2,28-30$ & 75.40 & 0.38 & 0.04 & 0.93 & 9.50 & 0.40 & 0.04 & 0.34 \\
\hline $5 \mathrm{R}-2,77-78$ & 75.88 & 0.36 & 0.03 & 0.00 & 12.00 & - & 0.04 & 0.32 \\
\hline $6 \mathrm{~W}-1,143-150$ & 84.77 & 0.31 & 0.03 & 0.00 & 10.30 & - & 0.03 & 0.28 \\
\hline $7 \mathrm{R}-1,140-150$ & 142.35 & 0.13 & 0.02 & 0.00 & 6.50 & - & 0.07 & 0.06 \\
\hline $7 \mathrm{R}-3,9-12$ & 144.00 & 0.15 & 0.02 & 0.00 & 7.50 & - & 0.07 & 0.08 \\
\hline $8 \mathrm{R}-2,20-21$ & 151.20 & 0.10 & 0.01 & 0.00 & 10.00 & - & 0.09 & 0.01 \\
\hline \multicolumn{9}{|l|}{$169-1035 \mathrm{H}-$} \\
\hline $2 \mathrm{R}-1,32-34$ & 9.13 & 2.57 & 0.00 & 46.66 & - & 0.06 & - & - \\
\hline $5 \mathrm{R}-1,58-59$ & 36.59 & 0.14 & 0.01 & 0.00 & 14.00 & - & 0.07 & 0.07 \\
\hline $6 \mathrm{R}-2,40-41$ & 47.51 & 0.10 & 0.01 & 0.00 & 10.00 & - & 0.06 & 0.04 \\
\hline $9 \mathrm{R}-1,34-38$ & 74.96 & 0.00 & 0.00 & 28.96 & - & - & - & - \\
\hline $16 \mathrm{R}-1,44-48$ & 133.06 & 0.02 & 0.00 & 36.73 & - & 0.00 & - & - \\
\hline $16 \mathrm{R}-2,122-126$ & 135.34 & 1.84 & 0.00 & 34.51 & - & 0.05 & - & - \\
\hline $17 R-3,60-64$ & 145.92 & 0.00 & 0.00 & 29.34 & - & - & - & - \\
\hline $17 \mathrm{R}-3,137-140$ & 146.68 & 0.02 & 0.00 & 43.10 & - & 0.00 & - & - \\
\hline 19R-1, 68-62 & 162.10 & 0.01 & 0.00 & 36.36 & - & 0.00 & - & - \\
\hline $21 \mathrm{R}-1,94-99$ & 181.66 & 0.04 & 0.00 & 25.21 & - & 0.00 & - & - \\
\hline
\end{tabular}

Notes: $*$ = calculated as percentage ratios. $\mathrm{TC}=$ total carbon, $\mathrm{TN}=$ total nitrogen, $\mathrm{TS}=$ total sulfur, $\mathrm{TIC}=$ total inorganic carbon, and $\mathrm{TOC}=$ total organic carbon. $-=$ not reported.

\section{MICROBIOLOGY}

Microbiological samples were taken from the sediments at Site 1035 , in the vicinity of the hydrothermally inactive BHMS deposit, to provide a contrast with the hydrothermally active sediments at the DDVF (Site 1036). Results from drilling sediments on the flank of Bent Hill during Leg 139 (Hole 856B) showed that the sediments near the inactive mound were warm $\left(\sim 157^{\circ} \mathrm{C}\right.$ at $\left.115 \mathrm{mbsf}\right)$, but had no signature of active hydrothermal fluid flow through the sediment. No microbiological sampling has been done in this area or any other deep sediment with a history of hydrothermal activity.
Holes 1035A, 1035D, and 1035E

Section-top plugs were taken from Holes 1035A, 1035D, and $1035 \mathrm{E}$ as described previously (see "Explanatory Notes," chapter, this volume). Selected samples were inspected by epifluorescent microscopy revealing that microbial abundances in the mudline samples ranged from $10^{6}$ to $5 \times 10^{6}$ microorganisms $/ \mathrm{cm}^{3}$ of sediment. These abundances are comparatively low, even for deep ocean sediments, which normally fall in the range of $10^{7}-10^{8}$ microorganisms $/ \mathrm{cm}^{3}$ (Parkes et al., 1994). Abundances were found to decrease with depth, dropping to $5 \times 10^{5}$ organisms $/ \mathrm{cm}^{3}$ of sediment by $3 \mathrm{mbsf}$ in all three 

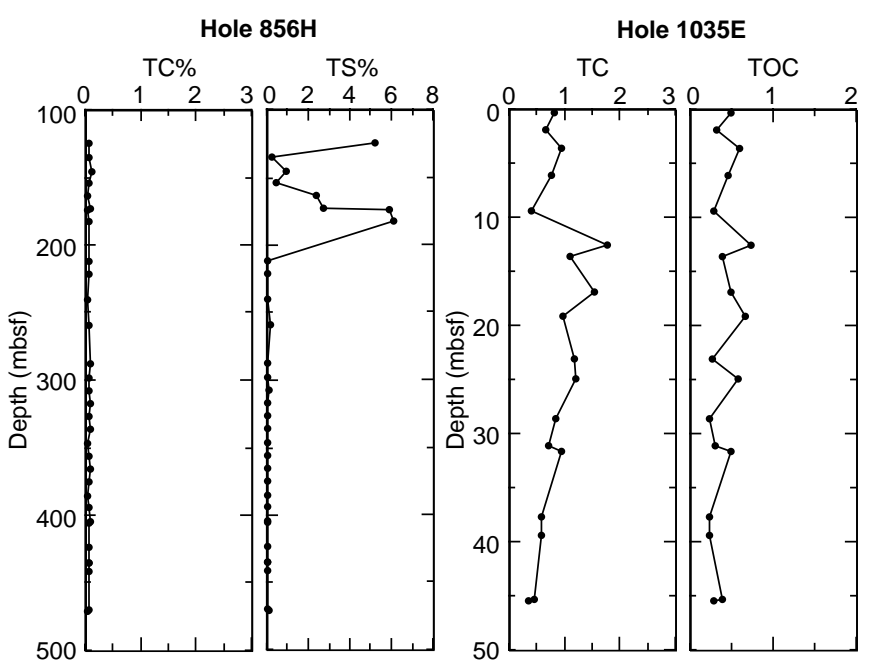

Figure 134. Percentages of total C, S, and TOC vs. depth for sediments from Holes $856 \mathrm{H}$ and $1035 \mathrm{E}$.
Figure 135. Percentages of total C, N, S, TIC, and TOC vs. depth for sediments from Hole 1035A.

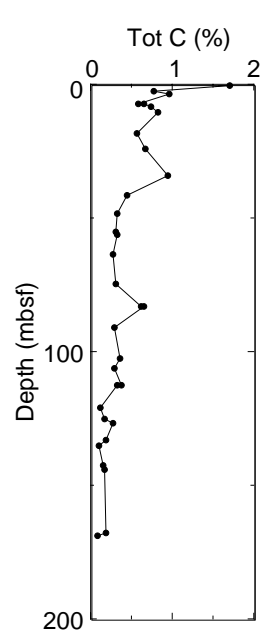

200

holes. Samples from the deepest APC cores taken at each hole (50.0, 41.75, and 43.74 mbsf for Holes 1035A, 1035D, and 1035E, respectively) had no detectable microbes, indicating abundances of $<10^{5}$ microbes $/ \mathrm{cm}^{3}$ (i.e., below the shipboard detection limit).

High-temperature culture enrichments were attempted at Holes $1035 \mathrm{D}$ and $1035 \mathrm{E}$, where the temperatures exceeded $50^{\circ} \mathrm{C}$. Four samples for culture enrichments were chosen between 25.6 and 40.25 mbsf in Hole 1035D, and two samples were chosen at 28.0 and 32.5 mbsf in Hole $1035 \mathrm{E}$ after a temperature of $55^{\circ} \mathrm{C}$ had been measured at 24.5 mbsf in Hole 1035D (see "Downhole Measurements" section, this chapter).

Sulfate is present in the pore fluids in all these holes at all depths; consequently, high-temperature sulfate reducers are likely to be members of the microbial community within these sediments. However, they were not observed in the shipboard cultures. Culturing is a poor technique for determining the presence of most components of microbial communities. The failure rate for culture work is high; even in well-studied environments, fewer than $10 \%$, or often even $1 \%$, of microorganisms have been cultured (Brock, 1987). The absence of cultured high-temperature sulfate reducers does not imply that biologically mediated, high-temperature sulfate reduction does not occur. Likewise, the negative results of the enrichment cultures for high-temperature methanogens should be viewed with caution as methanogens are notoriously difficult to grow. However, the nega-

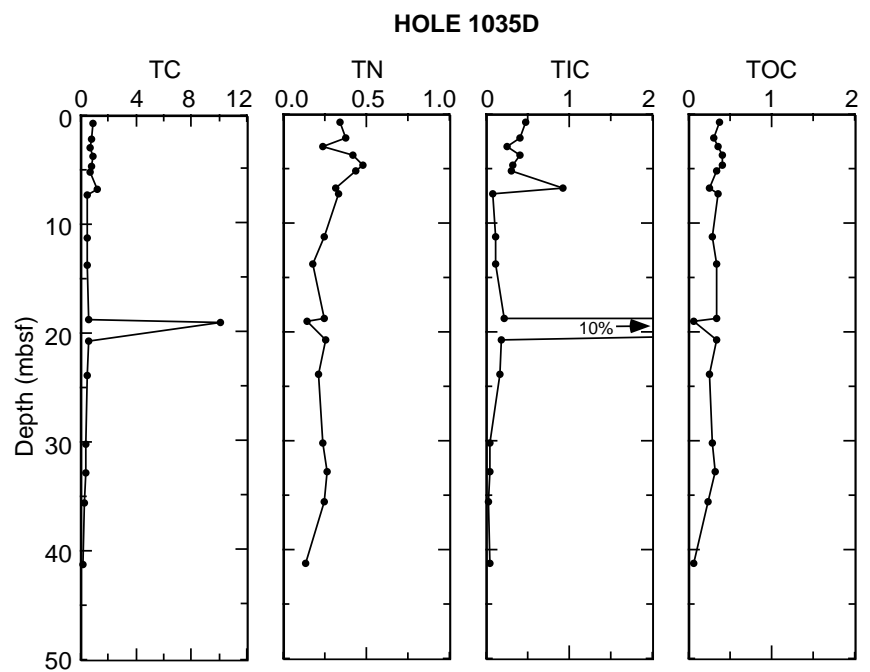

Figure 136. Percentages of total C, N, TIC, and TOC vs. depth for sediments from Hole 1035D.

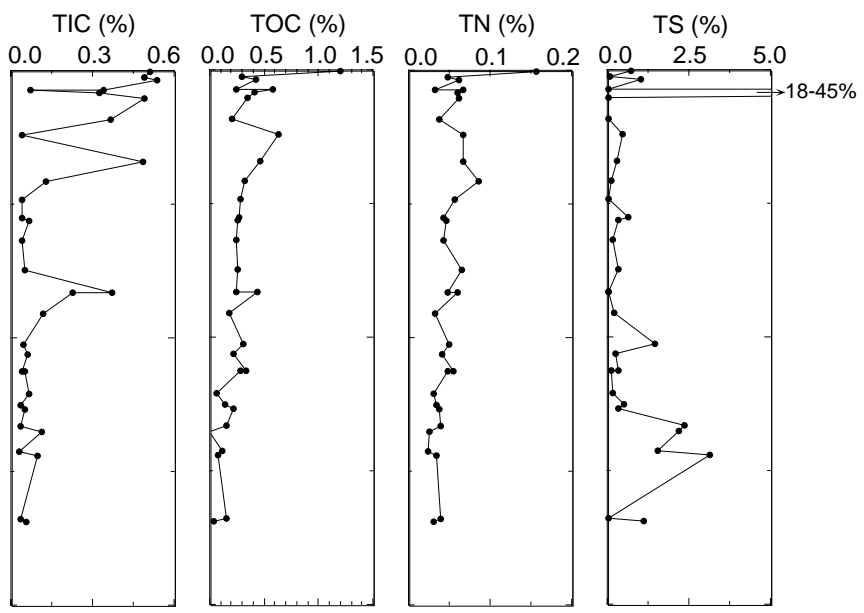

tive results of the enrichment cultures for high-temperature heterotrophic sulfur-reducers imply that this class of microorganisms probably is not present, as these organisms normally thrive in culture.

\section{Holes $1035 \mathrm{~F}$ and $1035 \mathrm{H}$}

The Ocean Drilling Program tripled the number of hot vents in the BHMS area by drilling Holes $1035 \mathrm{~F}$ and $1035 \mathrm{H}$. A camera survey of Hole $1035 \mathrm{~F}$ showed a jet of water rushing out of the borehole; white particulate material was observed in the water column to a height of at least $40 \mathrm{~m}$ above seafloor (masf). The white material appeared to have two components: flat, highly reflective, dense particles that sank rapidly and flocculent material that remained resident in the water column. White particles were also observed in the water column above Hole $1035 \mathrm{H}$. A number of creative devices were built and attached to the VIT camera frame in an attempt to collect some of these particles during a camera run. Unfortunately, none of the elusive flocculent particles was recovered, although some very large pieces of sulfide (up to $5 \mathrm{~mm}$ ), anhydrite fragments, and sedimentary rock fragments (up to $2 \mathrm{~cm}$ ), as well as the odd copepod were recovered in the makeshift nets and baskets. The size and density of the pieces could possibly be used to constrain the estimates of velocity (and flux) of fluids emanating from this new vent, but contribute nothing to the microbiology. 


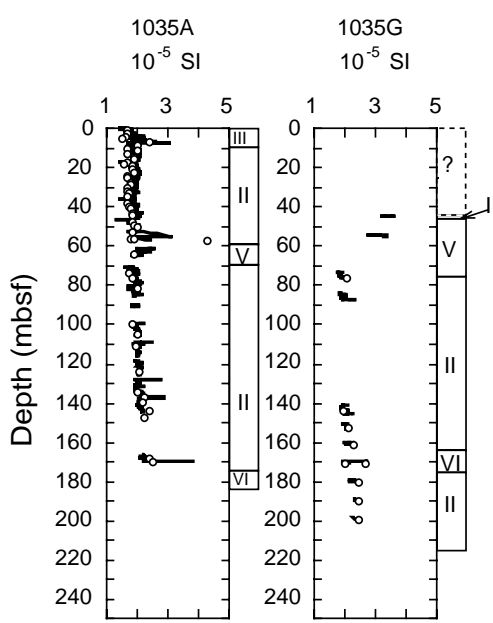

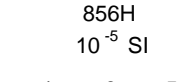
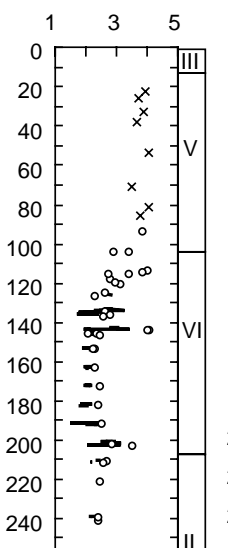

$$
260
$$

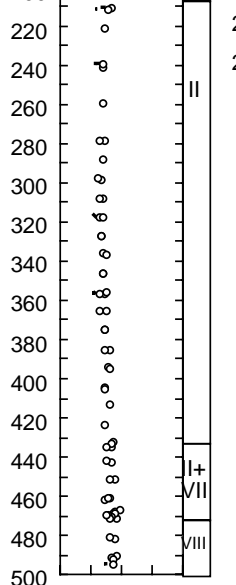

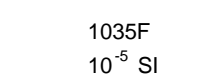

$1035 \mathrm{E}$
$10^{-5} \mathrm{SI}$

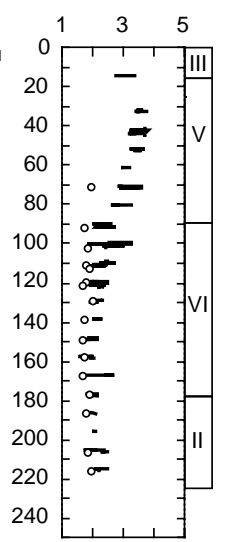

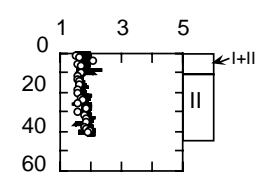

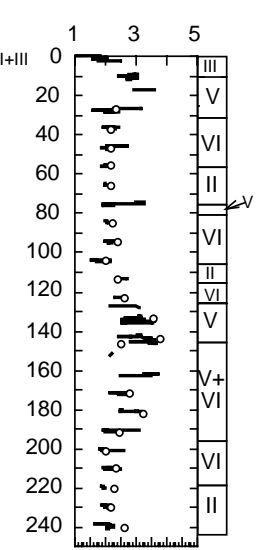

Figure 137. Gamma density (solid lines) and discrete sample wet bulk density (open circles) profiles for Bent Hill holes. Index properties measurements (x) for Hole $856 \mathrm{H}$ made during Leg 139 are also included. Holes are arranged in a west-east section (Holes $1035 \mathrm{~A}$, 1035G, 856H, and 1035D) and a north-south section (Holes 1035F, 1035E, and 1035H). Lithologic unit numbers are shown to the right of profiles for reference.

The flocculent particles are potentially of significant biological interest. Flocculent material has been observed in the water column following seafloor eruptions and the creation of new vents $\left(9^{\circ} \mathrm{N}\right.$ on the East Pacific Rise [Haymon et al., 1993]) and the CoAxial segment of the Juan de Fuca Ridge (J.F. Holden and M. Lilley, pers. comm., 1995). This material appears to be of microbial origin (Juniper et al., 1995), and may indicate a subseafloor microbial bloom stimulated by the onset of hydrothermal venting (J.F. Holden, pers. comm., 1996).

\section{Hole 856H}

A water sample was taken using the WSTP at 74 mbsf in the fill at the bottom of Hole $856 \mathrm{H}$ that had been drilled during Leg 139 through the top of the BHMS mound to a depth of $93.8 \mathrm{mbsf}$. DNA was extracted from concentrated particulates filtered from the water. High-temperature culture tubes were inoculated with this water sample, and a 5-mm rod-shaped organism grew in culture medium selective for heterotrophic sulfur-reducers when incubated at $55^{\circ} \mathrm{C}$. This result is consistent with the observation that the temperature in the hole was $51{ }^{\circ} \mathrm{C}$.

\section{PHYSICAL PROPERTIES}

The physical properties of the sediments and rocks cored at the Bent Hill sites are quite variable as a result of the variety of lithologic units recovered. Index properties samples were collected from the major lithologic units in all holes, except for some intervals of massive and clastic sulfides where recovery was limited. Incomplete re- covery and the frequently broken nature of cores from the massive sulfide units and from sediments in the deeper holes did not lend themselves to continuous automated core logging techniques. Nevertheless, most cores were run through the MST for gamma density, magnetic susceptibility, and natural gamma measurements. Selected split cores and samples were also run through the GEOTEK Multisensor Split Core Logger (MSSCL), both to obtain compressionalwave $(P$-wave) velocity measurements and to obtain more detailed information on magnetic susceptibility. In the case of Hole $856 \mathrm{H}$, most of the compressional-wave data were obtained from measurements on small rock pieces and minicore samples collected for index properties measurements. Because of the shallow depth and limited recovery in Holes 1035B and 1035C, no physical properties measurements for these two holes will be discussed.

\section{MST Records and Index Properties}

Summary plots of MST records are shown in Figures 137-139. In these figures, the holes are arranged to follow a west-east cross section (Holes 1035A through 1035D) and a north-south cross section (Holes $1035 \mathrm{~F}$ through $1035 \mathrm{H}$ ). Index properties measurements of porosity, wet bulk density, grain density, wet water content, and void ratio are listed in Table 25. Thermal conductivities measured in sediments and on split cores are listed in Table 26.

Figure 137 includes both the MST gamma density records and index properties wet bulk densities. There is generally good agreement between these two density measurements except within the massive sulfide and sulfide impregnated zones of Hole 1035F, where gamma densities are higher. This could be caused by a sampling bias toward 

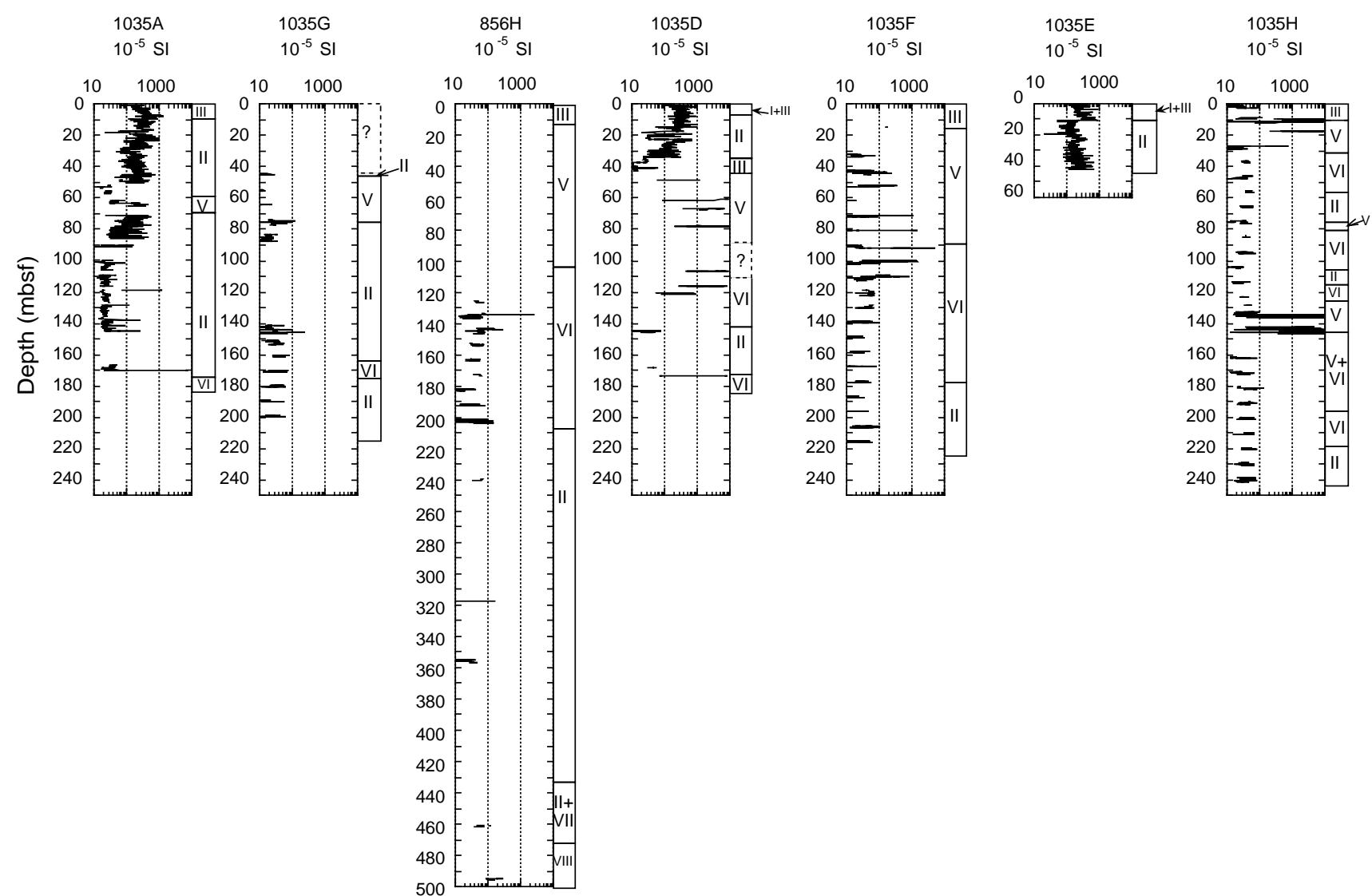

Figure 138. Magnetic susceptibility profiles for Bent Hill holes. Volume magnetic susceptibilities measured by the MST are reported in $10^{-5}$ SI units. Holes are arranged in a west-east section (Holes 1035A, 1035G, 856H, and 1035D) and a north-south section (Holes 1035F, 1035E, and 1035H). Lithologic unit numbers are shown to the right of profiles for reference.

less sulfide-rich samples for index properties measurements or could reflect higher mass attenuation coefficients in these materials. In the absence of sulfide mineralization, densities of the sediments show the expected gradual increases with increasing depth because of consolidation (e.g., the records for Holes 1035A and 1035E as well as the record for Hole $856 \mathrm{H}$ below $210 \mathrm{mbsf}$ ). Zones of massive sulfide and of sulfide-veined and impregnated sediment show up clearly on these records as higher density anomalies.

The magnetic susceptibility records (Fig. 138) displayed at the scale of an entire hole suggest significant scatter throughout the sedimentary section. More detailed examinations of these records at the scale of a few tens of meters and at the scale of single core sections will be discussed in subsequent sections. Overall, the major features that can be observed at the hole scale are several relatively narrow zones of high magnetic susceptibility associated with sulfides. A shallow zone of high magnetic susceptibility occurs in Hole $1035 \mathrm{H}$ within the upper $30 \mathrm{mbsf}$. A somewhat deeper and more vertically extensive zone can be seen in Hole $1035 \mathrm{~F}$ between 70 and $110 \mathrm{mbsf}$, within lithologic Units V and VI. This second zone likely correlates with high magnetic susceptibilities measured at similar depths in Hole 1035D during this leg and with high magnetic susceptibilities measured in the massive sulfide zone of Hole 856H during Leg 139 (Shipboard Scientific Party, 1992b). It is interesting to note that magnetic susceptibilities in Hole $1035 \mathrm{H}$ are consistently low between 40 and 120 mbsf, which correlates with lithologic Subunit VIB (sediment with veins and/or impregnations: see "Lithostratigraphic Summary and Sedimentology" section, this chapter). However, a relatively narrow, deeper zone of high magnetic susceptibility in Hole $1035 \mathrm{H}$ is found between 130 and $150 \mathrm{mbsf}$ at the top of a sulfide feeder zone in a zone of massive sulfides. The deepest zone of high magnetic sus- ceptibility occurs within the sulfide impregnated sediments recovered from the bottoms of Holes 1035A and 1035D, at $\sim 170$ mbsf. Although these mineralized sediments have been interpreted to be part of a laterally continuous DCZ, no corresponding zones of high magnetic susceptibility were found in the DCZ of Holes $1035 \mathrm{G}, 856 \mathrm{H}$, $1035 \mathrm{~F}$, or $1035 \mathrm{H}$.

Natural gamma records obtained from the MST are summarized in plots of total counts per second vs. depth on Figure 139. The main features that can be observed at this scale are a narrow moderately high zone (up to 30 counts/s) in Hole 1035D within clastic sulfides of lithologic Unit III and a more extensive high zone within massive sulfides and sulfide impregnated sediment between 130 and $170 \mathrm{mbsf}$ in Hole $1035 \mathrm{H}$, the same interval characterized by a high magnetic susceptibility.

Figure 140 shows profiles of porosity as determined from index properties measurements. In shallow sediments of Holes 1035A, $1035 \mathrm{D}$, and $1035 \mathrm{E}$, porosity generally decreases with depth from values of near $80 \%$ at the seafloor to $<60 \%$ at depths of 40 mbsf. Significantly lower porosities, of $20 \%$ or less, were measured for the lithified sediments of Hole $856 \mathrm{H}$ below $210 \mathrm{mbsf}$, reflecting both increased compaction and cementation. Subtle, but potentially significant, features are the low porosities (9\% and 14\%) and slightly higher bulk densities of two sandstone samples from Core $169-856 \mathrm{H}-$ $32 \mathrm{R}$, immediately below the DCZ. In samples taken from cores beneath this one, a gradual rise in porosity (up to $31 \%$ ) occurs with increasing depth down to 260 mbsf (Samples 169-856H-33R-1, 55-57 $\mathrm{cm}$, to $169-856 \mathrm{H}-37 \mathrm{R}-1,48-50 \mathrm{~cm})$. A similar pattern of increasing sediment porosity with depth immediately beneath the DCZ can also be seen in the data from Hole 1035G (Samples 169-1035G-11R-1, $60-62 \mathrm{~cm}$, to $169-1035 \mathrm{G}-13 \mathrm{R}-1,52-54 \mathrm{~cm})$, and possibly in the data 

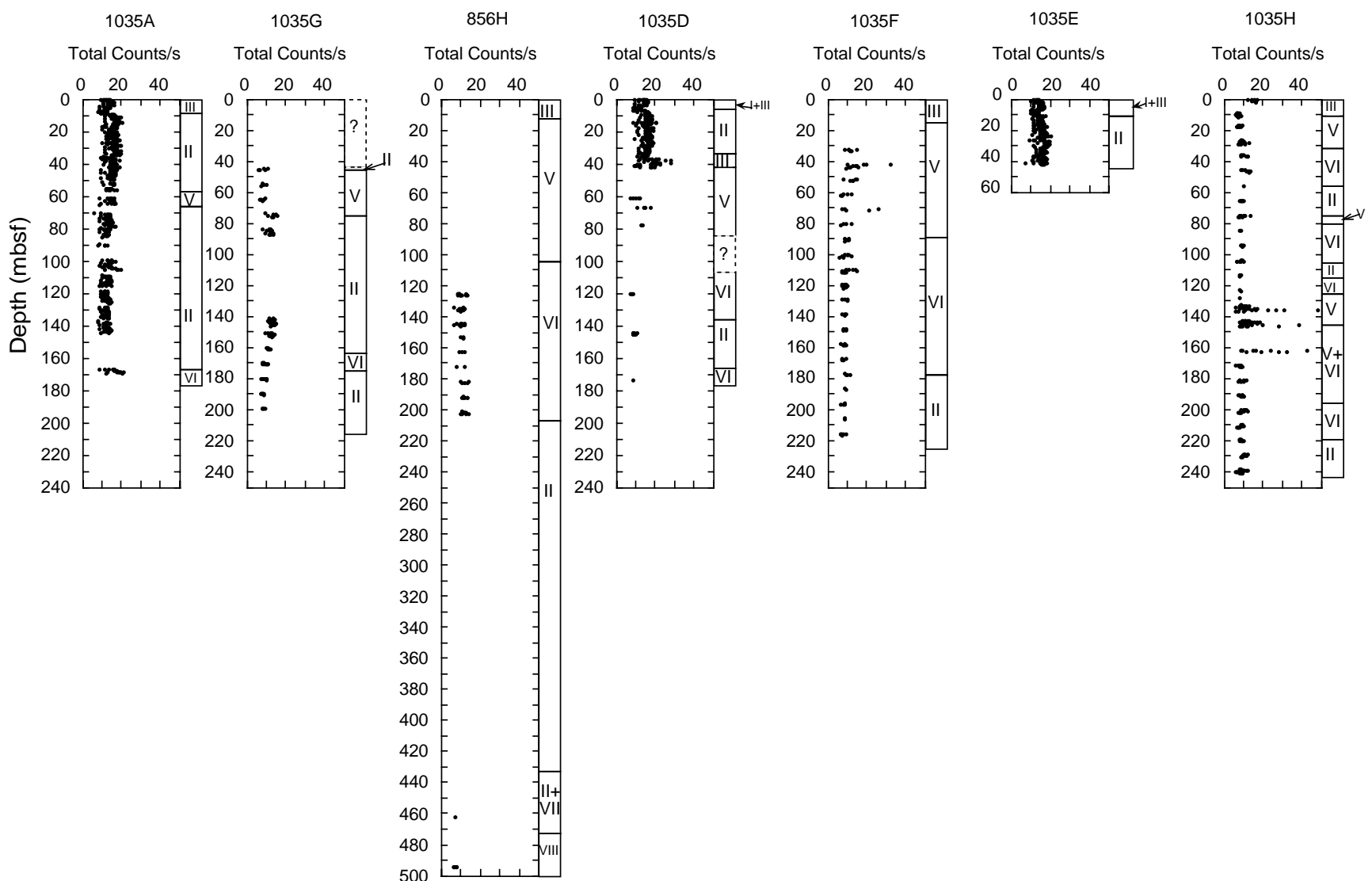

Figure 139. Natural gamma data, reported as total counts per second, for Bent Hill holes. Holes are arranged in a west-east section (Holes 1035A, 1035G, 856H, and 1035D) and a north-south section (Holes 1035F, 1035E, and 1035H). Lithologic unit numbers are shown at the right of profiles for reference.

Table 25. Index properties, Bent Hill area, Site 1035 and Hole 856H.

\begin{tabular}{|c|c|c|c|c|c|c|}
\hline $\begin{array}{l}\text { Core, section, } \\
\text { interval }(\mathrm{cm})\end{array}$ & $\begin{array}{l}\text { Depth } \\
\text { (mbsf) }\end{array}$ & $\begin{array}{c}\text { Porosity } \\
(\%)\end{array}$ & $\begin{array}{c}\text { Wet bulk } \\
\text { density } \\
\left(\mathrm{g} / \mathrm{cm}^{3}\right)\end{array}$ & $\begin{array}{c}\text { Grain } \\
\text { density } \\
\left(\mathrm{g} / \mathrm{cm}^{3}\right)\end{array}$ & $\begin{array}{l}\text { Wet water } \\
\text { content } \\
(\%)\end{array}$ & $\begin{array}{l}\text { Void } \\
\text { ratio }\end{array}$ \\
\hline \multicolumn{7}{|l|}{ 169-1035A- } \\
\hline $1 \mathrm{H}-1,57-59$ & 0.57 & 70 & 1.66 & 2.79 & 28 & 2.07 \\
\hline $1 \mathrm{H}-2,59-61$ & 2.09 & 75 & 1.65 & 3.13 & 32 & 2.66 \\
\hline $1 \mathrm{H}-3,90-92$ & 3.90 & 72 & 1.61 & 2.82 & 32 & 2.36 \\
\hline $1 \mathrm{H}-4,60-62$ & 5.10 & 80 & 1.50 & 2.85 & 37 & 3.31 \\
\hline $1 \mathrm{H}-5,98-100$ & 6.98 & 63 & 2.39 & 4.39 & 20 & 1.58 \\
\hline $2 \mathrm{H}-1,60-62$ & 8.10 & 90 & 1.99 & 3.02 & 32 & 2.57 \\
\hline $2 \mathrm{H}-2,100-102$ & 9.90 & 71 & 1.66 & 2.86 & 29 & 2.17 \\
\hline $2 \mathrm{H}-3,50-52$ & 10.90 & 51 & 1.98 & 2.84 & 18 & 0.99 \\
\hline $2 \mathrm{H}-4,90-92$ & 12.80 & 91 & 1.64 & 2.02 & 39 & 2.55 \\
\hline $2 \mathrm{H}-5,70-72$ & 14.10 & 51 & 1.86 & 2.83 & 19 & 1.08 \\
\hline $2 \mathrm{H}-6,50-52$ & 15.40 & 60 & 1.88 & 2.80 & 22 & 1.32 \\
\hline $2 \mathrm{H}-7,40-42$ & 16.80 & 64 & 1.65 & 2.82 & 26 & 1.83 \\
\hline $3 \mathrm{H}-1,80-82$ & 17.80 & 75 & 1.54 & 2.82 & 33 & 2.76 \\
\hline
\end{tabular}

Only part of this table is produced here. The entire table appears on the CD-ROM.

from Holes $1035 \mathrm{~F}$ (Samples 1035F-19R-1, 38-40 cm, to 169-1035F20R-1, 18-20 cm) and 1035H (Samples 169-1035H-25R-1, 111-113 $\mathrm{cm}$, and 169-1035H-26R-1, 83-85 cm). The lower porosities beneath the DCZ may result from original sedimentary textures and early diagenesis or from alteration associated with the sulfide mineralization. We also note that lower porosities were measured in the section above the DCZ (Core 169-856H-30R; see Table 25); however, these samples appeared to be more intensely mineralized than the samples from below the DCZ.

Grain densities and thermal conductivities for all holes are shown in Figure 141. Grain densities for sediments are relatively uniform with depth, clustering between 2.8 and $3.0 \mathrm{~g} / \mathrm{cm}^{3}$ except for samples from Hole 1035F, which have anomalously low densities of $\sim 2.6 \mathrm{~g} /$
Table 26. Thermal conductivity measurements, Bent Hill area, Site 1035 and Hole $856 \mathrm{H}$.

\begin{tabular}{|c|c|c|c|c|c|c|}
\hline Hole & Core & Type & Section & $\begin{array}{l}\text { Position } \\
\text { (cm) }\end{array}$ & $\begin{array}{l}\text { Depth } \\
\text { (mbsf) }\end{array}$ & $\begin{array}{c}\text { Thermal conductivity } \\
\mathrm{W} /[\mathrm{m} \cdot \mathrm{K}]\end{array}$ \\
\hline A & 1 & $\mathrm{H}$ & 1 & 60 & 0.60 & 0.9 \\
\hline A & 1 & $\mathrm{H}$ & 1 & 60 & 0.60 & 0.9 \\
\hline A & 1 & $\mathrm{H}$ & 2 & 60 & 2.10 & 0.9 \\
\hline A & 1 & $\mathrm{H}$ & 2 & 60 & 2.10 & 0.9 \\
\hline A & 1 & $\mathrm{H}$ & 3 & 90 & 3.90 & 0.8 \\
\hline A & 1 & $\mathrm{H}$ & 4 & 60 & 5.10 & 1.0 \\
\hline A & 1 & $\mathrm{H}$ & 4 & 60 & 5.10 & 0.9 \\
\hline A & 1 & $\mathrm{H}$ & 5 & 103 & 7.03 & 1.1 \\
\hline A & 2 & $\mathrm{H}$ & 2 & 50 & 9.40 & 0.9 \\
\hline A & 2 & $\mathrm{H}$ & 3 & 100 & 11.40 & 1.5 \\
\hline A & 2 & $\mathrm{H}$ & 4 & 90 & 12.80 & 1.0 \\
\hline A & 2 & $\mathrm{H}$ & 5 & 70 & 14.10 & 1.7 \\
\hline A & 2 & $\mathrm{H}$ & 6 & 50 & 15.40 & 1.1 \\
\hline
\end{tabular}

Only part of this table is produced here. The entire table appears on the CD-ROM.

$\mathrm{cm}^{3}$. These low values may be the result of a systematic measurement error or they may be related to the fact that the sediment in this hole is pervasively hydrothermally altered. There is no obvious difference in grain density between the sediments and the basalt near the base of Hole $856 \mathrm{H}$. Sulfide-rich samples have higher grain densities, up to nearly $5 \mathrm{~g} / \mathrm{cm}^{3}$.

Thermal conductivities of the massive sulfides and sulfide-veined sediment are generally high but extremely variable, ranging from $\sim 3$ $\mathrm{W} /(\mathrm{m} \cdot \mathrm{K})$ to $>13 \mathrm{~W} /(\mathrm{m} \cdot \mathrm{K})$. Thermal conductivities of unaltered sediments show a gradual increase with depth, from $<1 \mathrm{~W} /(\mathrm{m} \cdot \mathrm{K})$ near the seafloor to $>4 \mathrm{~W} /(\mathrm{m} \cdot \mathrm{K})$ in the deep portion of lithologic Unit II in Hole $856 \mathrm{H}$. One sample of basalt from the upper portion of the sediment-sill complex in Hole 856H (Section 169-856H-55R-1, Piece 5) 


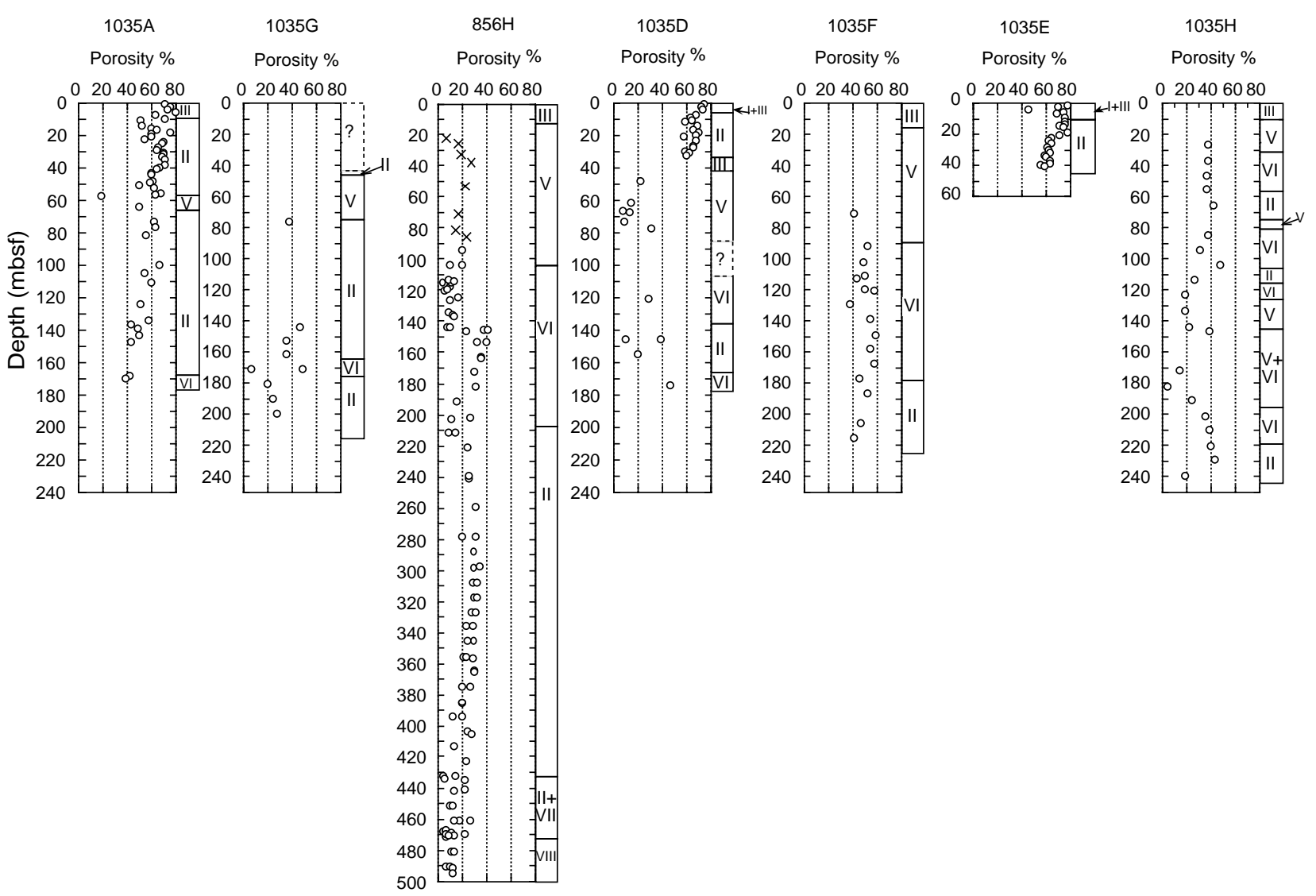

Figure 140. Index properties measurements of porosity made during Leg $169=$ open circles and in Hole $856 \mathrm{H}$ during Leg $139=\mathrm{x}$. Holes are arranged in a westeast section (Holes 1035A, 1035G, 856H, and 1035D) and a north-south section (Holes 1035F, 1035E, and 1035H). Lithologic unit numbers are shown at the right of profiles for reference.

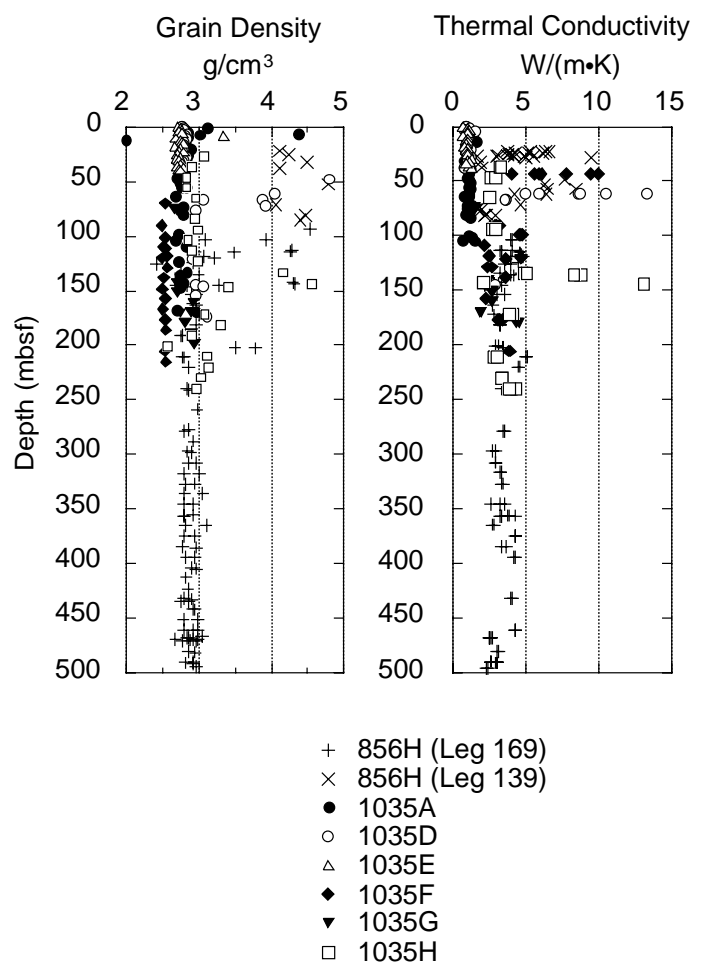

Figure 141. Grain density and thermal conductivity measurements, plotted vs. depth in mbsf, for the Bent Hill holes. had a thermal conductivity of $4 \mathrm{~W} /(\mathrm{m} \cdot \mathrm{K})$, similar to the sediments within this complex. However, two other basalt samples from the base of the sediment-sill complex (Sections 169-856H-60R-2 [Piece 6] and 61R-1 [Piece 4]) had significantly lower thermal conductivities, in the range of 2.5 to $3 \mathrm{~W} /(\mathrm{m} \cdot \mathrm{K})$, similar to those of the underlying basalt flows.

\section{Natural Gamma and Magnetic Susceptibility Correlations for Holes 1035A, 1035D, and 1035E}

Recovery was good in the upper 40 to $50 \mathrm{~m}$ of Holes 1035A, $1035 \mathrm{D}$, and $1035 \mathrm{E}$, providing an opportunity to conduct a more detailed examination of possible hole-to-hole correlations of natural gamma and magnetic susceptibility profiles. Figure 142 shows the natural gamma records for these three holes at an expanded scale relative to that of Fig. 139. A shallow zone of low natural gamma, straddling the interface between lithologic Units III and II (at depths between 4 and $11 \mathrm{mbsf}$ ), can be seen in the records from all three holes. This zone appears to be thickest in Hole 1035A and thins eastward to Hole 1035D. The upper boundary of the zone is deepest in Hole 1035E. A second zone that appears to correlate among the three holes occurs within lithologic Unit II, at depths of 25-35 mbsf, and includes a natural gamma high of $\sim 20$ counts/s. This zone appears to be deepest in Hole 1035A and shallowest in Hole 1035D. If these natural gamma signatures are related to original depositional features of the sediments rather than to later diagenetic overprints, they could provide a means to correlate portions of the stratigraphic record and to evaluate relative rates of sediment accumulation and/or compaction in these three holes. 


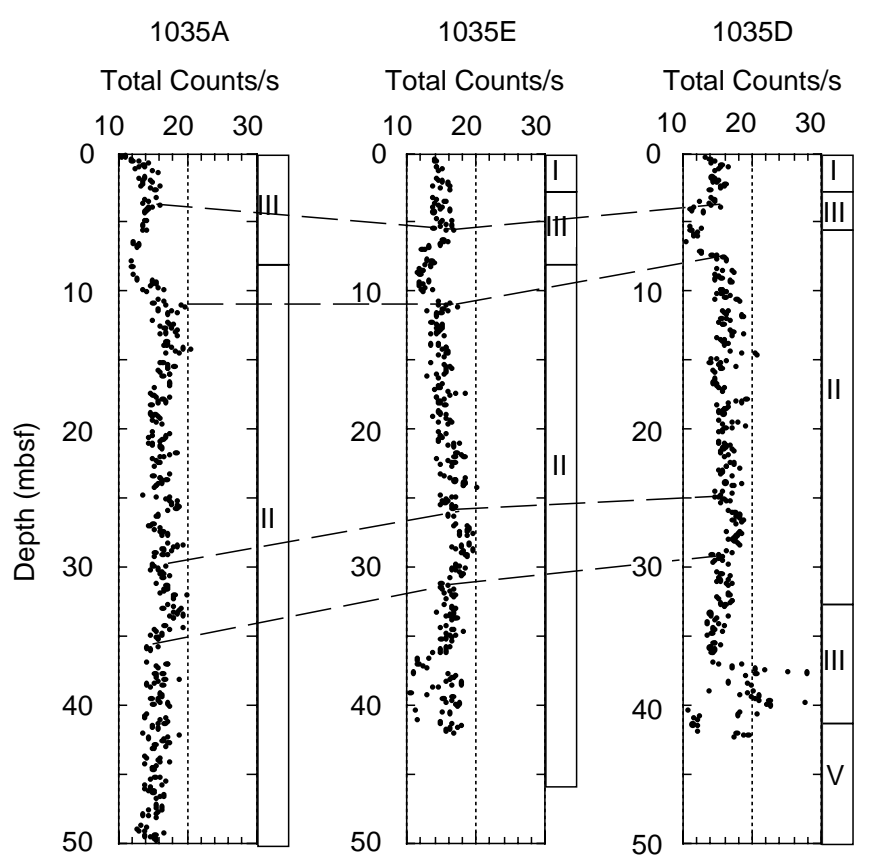

Figure 142. Natural gamma records for the upper $50 \mathrm{~m}$ of Holes 1035A, $1035 \mathrm{E}$, and 1035D. Holes are arranged from west to east. Dashed lines indicate correlations between holes based on the similarity of natural gamma profiles. Lithologic unit numbers are shown at the right of profiles for reference.
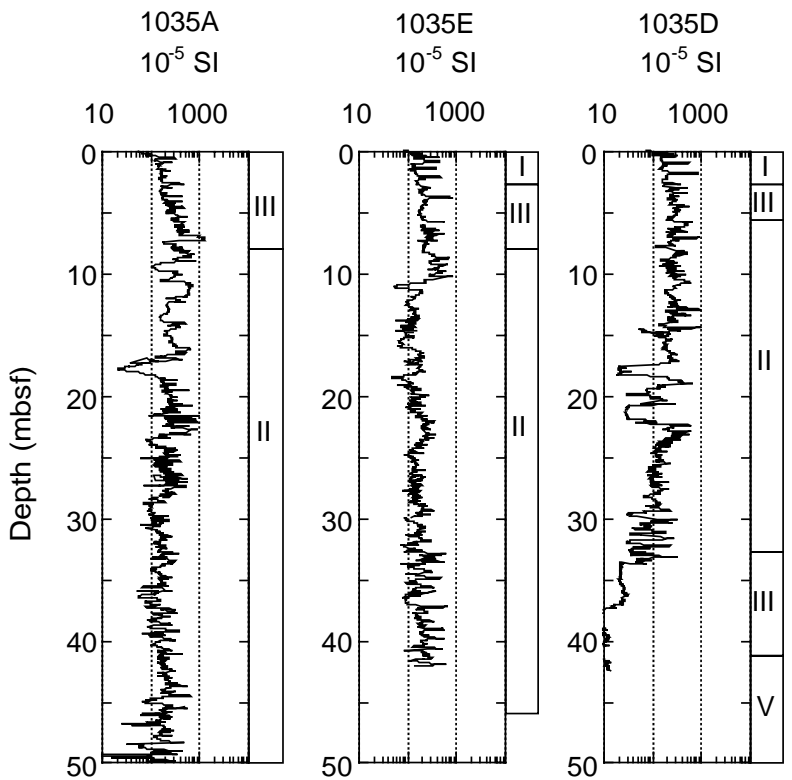

Figure 143. MST magnetic susceptibility records for the upper $50 \mathrm{~m}$ of Holes 1035A, 1035E, and 1035D. Holes are arranged from west to east. Lithologic unit numbers are shown at the right of the profiles for reference.

The magnetic susceptibility records plotted at an expanded scale (Fig. 143) also suggest a number of potential correlations, particularly between Holes 1035A and 1035E. The deeper portion of the record for $1035 \mathrm{D}$ shows very low magnetic susceptibilities in clastic and massive sulfides, probably reflecting thermal alteration effects. Using the deeper natural gamma correlation described above to align the magnetic susceptibility records, and then expanding and contracting

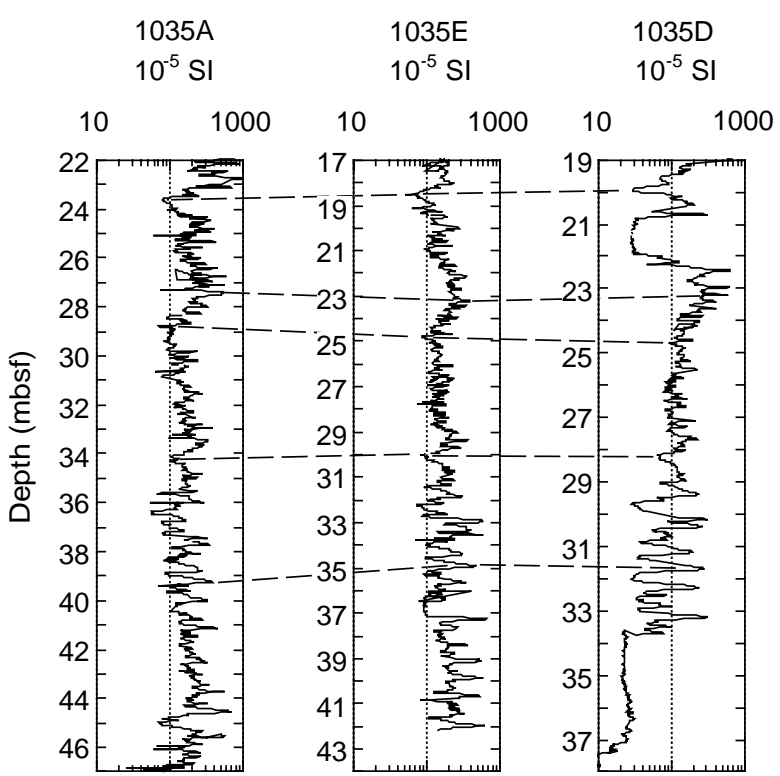

Figure 144. Expanded MST magnetic susceptibility records for Holes 1035A, 1035E, and 1035D. Holes are arranged from west to east. The depth interval includes the deeper section correlated on the basis of natural gamma profiles (see Fig. 142). Depth scales have been adjusted independently for the three holes to allow for approximately horizontal correlation lines (shown by dashes) between similar patterns on the three records.

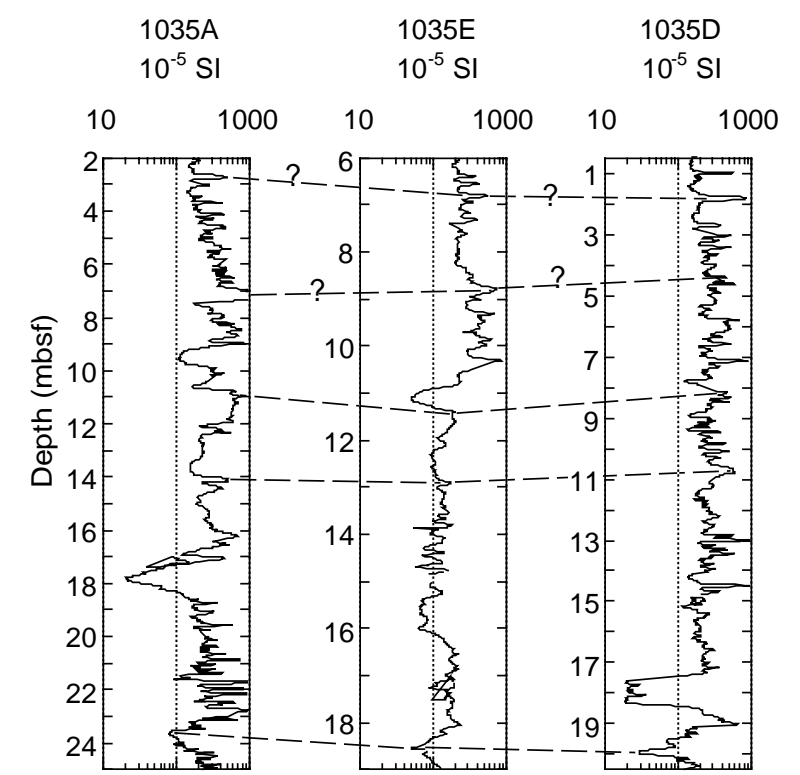

Figure 145. Expanded MST magnetic susceptibility records for Holes 1035A, 1035E, and 1035D. Holes are arranged from west to east. The depth interval includes the shallower section correlated on the basis of natural gamma profiles (see Fig. 142). Depth scales have been adjusted independently for the three holes to allow for approximately horizontal correlation lines (shown by dashes) between similar patterns on the three records.

the vertical scales of the three records, it is possible to identify numerous correlations among all three holes within the interval from $\sim 20$ to $35 \mathrm{mbsf}$, as illustrated in Figure 144. Similarities are less obvious but still present in shallower portions of the holes (see Fig. 145). The combined MST records for these holes therefore can be particularly useful tools for stratigraphic correlation. 
Figure 146. MSSCL record for Hole 1035A illustrating the more continuous nature of the $P$-wave velocity data (on recovered core) and the difference in the overall signature of the magnetic susceptibility record when using the point sensor compared with the loop sensor. Both the raw data (shaded) and maximum values (solid line) are shown for the gamma densities and $P$-wave velocities.
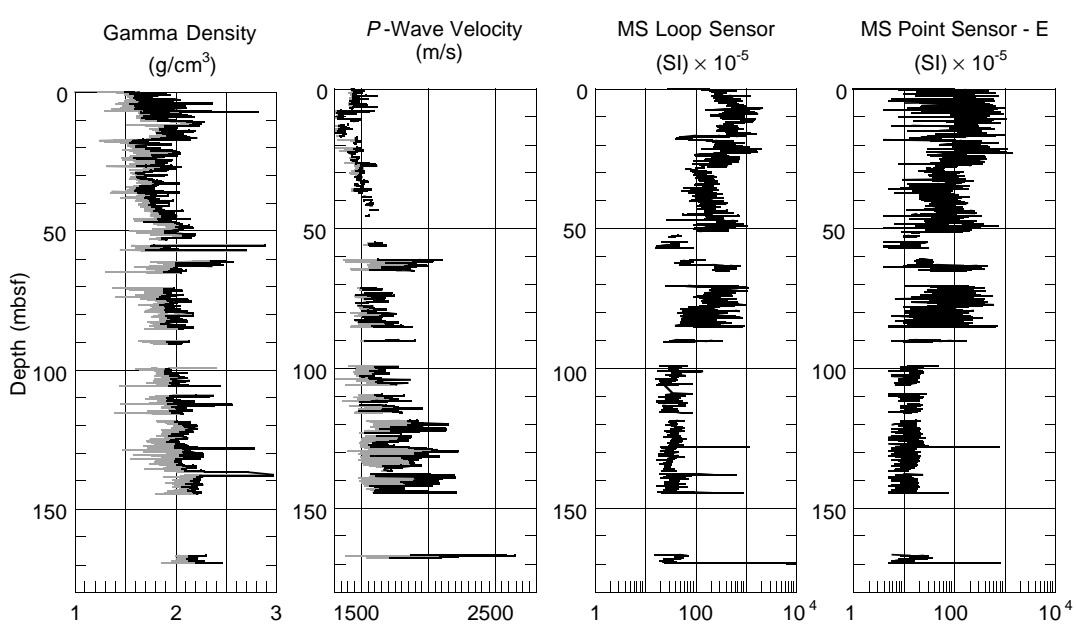

\section{MSSCL Records}

A number of cores were selected for logging using the MSSCL, depending on the quality of data obtained from the MST. An example of a data set, shown in Figure 146, illustrates the advantages of using the MSSCL to obtain velocity measurements on biscuited sediments recovered in XCB cores. The velocity data from the MST, in comparison, are not only sparse but generally inaccurately low. Poor sediment to liner contact gives very low signal amplitudes and inaccurate timing measurements in the XCB cores. The MSSCL data are more reliable. The velocity and gamma density plots (Fig. 146) show both the raw data (gray line) and a solid line following the maximum values (within 10 data points). This solid line is considered to more accurately reflect the true variability at this scale, whereas the raw data include variability primarily induced by drilling disturbance. The figure also shows the difference in the nature of the magnetic susceptibility records when using the point sensor as opposed to the loop sensor. Although the data on this scale may appear to be more noisy, they actually reflect more accurately the higher frequency nature of the magnetic susceptibility profile.

$P$-wave velocity data were also collected on small rock pieces and minicores from Holes $856 \mathrm{H}, 1035 \mathrm{~F}$, and 1035G. Some of these data were collected using the Hamilton Frame, but most were collected with the MSSCL. The data are shown in Figure 147; a high variability in values is in response to the variety of material recovered. Velocities of greater than $6 \mathrm{~km} / \mathrm{s}$ were recorded in the massive sulfides. In the sedimentary section of Hole $856 \mathrm{H}$, values increased from an average value of $3 \mathrm{~km} / \mathrm{s}$ at a depth of $300 \mathrm{mbsf}$ to $>4 \mathrm{~km} / \mathrm{s}$ at a depth of nearly $500 \mathrm{mbsf}$.

\section{DOWNHOLE MEASUREMENTS}

The initial logging plan for Hole $856 \mathrm{H}$ was to first run a temperature log, and, if the temperature permitted, to run the Triple Combo, FMS/Sonic, and geochemical combination (see "Explanatory Notes" chapter, this volume). On 29 August, after coring operations were completed and the RCB bit dropped on the seafloor, the BRGM temperature tool was deployed. The probe encountered difficulties passing several ledges in the upper section of the borehole and apparently sat on some of them for a while, which remained undetected from the surface because of the relatively light weight of the tool. As a result, the temperatures recorded are representative of the temperatures in the hole at the time of the measurement, but the depths of the measurements are inaccurate for the most part and preclude the construction of a temperature profile.

A maximum value of $160^{\circ} \mathrm{C}$ was recorded during this first run, which is the maximum operational temperature of the geochemical

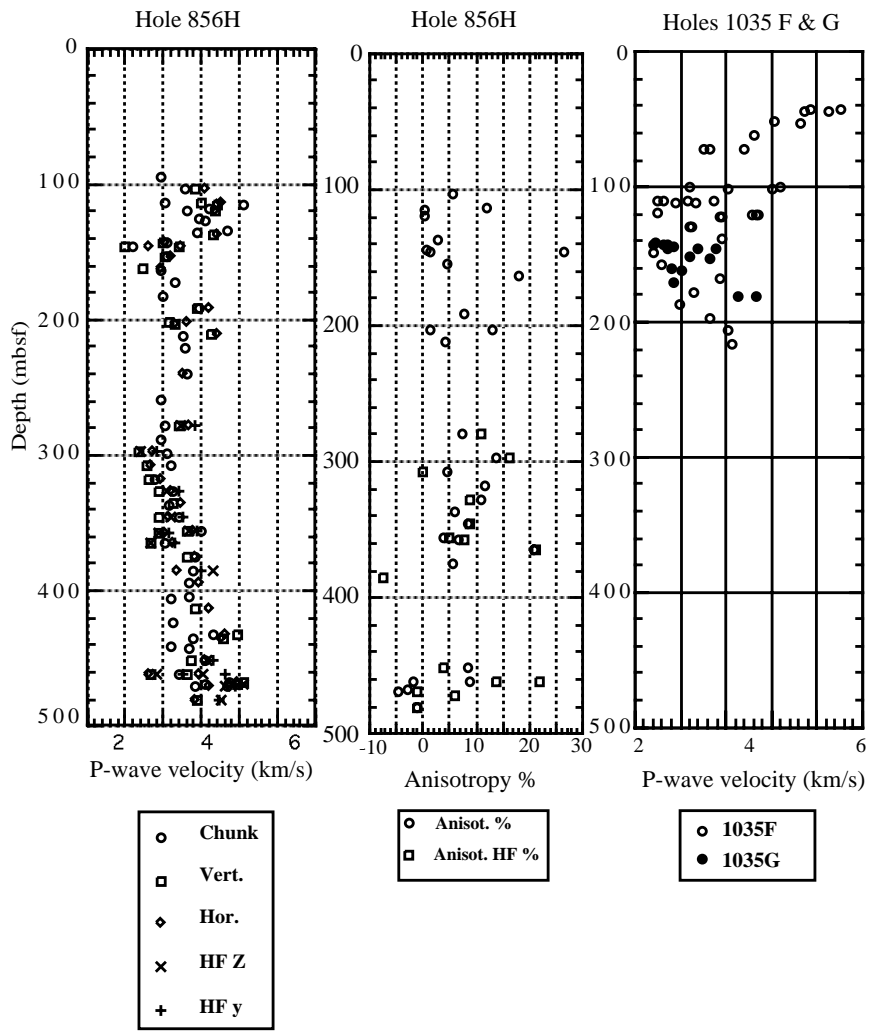

Figure 147. $P$-wave velocity (and anisotropy) data for Holes $856 \mathrm{H}, 1035 \mathrm{~F}$, and $1035 \mathrm{G}$ obtained primarily from the MSSCL, but with some discrete measurements and oriented minicore samples from the Hamilton Frame (HF). Anisotropy values were obtained from minicore samples.

tool. Such a temperature measured only a few hours after completion of drilling was also indicative of a very fast thermal recovery that would make the borehole too hot for any Schlumberger logs within a matter of hours. To allow additional logging runs, a wiper trip was made to wash the hole of possible obstructions, and drilling fluid was circulated to cool the hole. As major obstructions were detected in the upper part of the hole during these operations, the pipe was lowered to $84.5 \mathrm{mbsf}$ to prevent the logging tools from getting stuck in this section, which had been already logged during Leg 139.

The Triple Combo, composed of natural gamma ray (HNGS), resistivity (DIT), porosity (APS), and density (HLDS) probes (See "Explanatory Notes" chapter, this volume), was run without any problem from $495 \mathrm{mbsf}$ to the seafloor at $550 \mathrm{~m} / \mathrm{hr}$. This high speed 
was chosen to limit the exposure of the tool string to suspected high borehole temperatures. However, the internal temperature readings of the tools indicated that the temperature was $<100^{\circ} \mathrm{C}$, and a high resolution repeat section was recorded at $250 \mathrm{~m} / \mathrm{hr}$ from 365 to 85 mbsf. The caliper from the two passes confirmed that the hole was in a very good condition for an eventual FMS run.

The FMS/Sonic combination (composed of the FMS, the array sonic tool [SDT] and the Natural Gamma Tool, see "Explanatory Notes" chapter, this volume) was run next and was lowered without meeting any obstruction to a depth of $491 \mathrm{mbsf}$. After $\sim 60 \mathrm{~m}$ logging up the hole at $275 \mathrm{~m} / \mathrm{hr}$, the FMS readings began to deteriorate. Several unsuccessful attempts were made to improve the quality of the data while moving up the hole rapidly, as it was feared that high temperatures were the origin of the problem. The only good-quality FMS images from this run are in the deepest $60 \mathrm{~m}$ of the hole, encompassing the pillow basalts and some of the sills recovered in the cores. In the meantime, sonic velocities of good quality were recorded over the entire hole while going down, and over three different sections on the way up; 491-282 mbsf; 278-240 mbsf; and 225-109 mbsf.

A second attempt to run the FMS in the upper part of the open hole was made, owing to the importance of imaging the SFZ for the objectives of the leg and to the limited core recovery within this section. Cold seawater mixed with sepiolite was circulated for $\sim 1 \mathrm{hr}$ to recondition the hole, and the FMS alone was deployed. This run did not encounter any problem, and good quality data were recorded from 385 to $185 \mathrm{mbsf}$, and from 210 to 89 mbsf. External temperature indicators ("Temp-Plates," see "Explanatory Notes" chapter, this volume) showed that temperatures as high as $182^{\circ} \mathrm{C}$ had been reached, and it was decided not to attempt to run the geochemical string because of its sensitivity to elevated temperature.

Overall, the data recorded in this hole (Fig. 148) are of good quality and compare well to the discrete measurements made on core samples (Fig. 149), except for higher logging porosity measurements (Fig. 149B). The APS actually monitors all the hydrogen present in the formation, but in the case of clay-rich formations, it is unable to distinguish between pore water and bound water associated with clay minerals, which results in an apparent higher porosity (Schlumberger, 1989).

\section{Results}

Because of the low recovery in Hole $856 \mathrm{H}$, logging data were of primary importance for the accurate delineation of the lithologic units and structures identified from the core observations. Good hole conditions and a significant variability in the composition and physical properties between the different types of formations allowed a clear identification of very distinct logging units and subunits (Fig. 148). The main lithologic units (see "Lithostratigraphic Summary and Sedimentology" section, this chapter) are recognizable on all the curves, but narrower intervals within these units also present distinctive features that allow a refinement of the stratigraphic boundaries.

\section{Logging Unit 1 (84.5-100 mbsf)}

The position of the bottom of the pipe near the bottom of the massive sulfides precluded the acquisition of data in most of this section, but this first logging unit, extending from the bottom of the pipe (84.5 mbsf) to $\sim 100 \mathrm{mbsf}$, is characterized by the highest densities (reaching more than $4 \mathrm{~g} / \mathrm{cm}^{3}$ ) and lowest resistivities recorded in Hole $856 \mathrm{H}$. It corresponds to the massive pyrrhotite that forms the base of the sulfide mound, which was partially logged during Leg 139.

\section{Logging Unit 2 (100-210 mbsf)}

The second logging unit mostly corresponds to the SFZ, or lithologic Unit VI, described in the "Lithostratigraphic Summary and Sedimentology" section of this chapter. Over this interval, all the logs display very strong fluctuations related to the variations in the inten- sity of hydrothermal alteration and sulfide veining. Three subunits were defined. From 100 to 145 mbsf (Subunit 2A), the resistivity seems to reach extremely high values, but overall tends to decrease with depth, as do the density and the velocity, whereas porosity reaches minimum values. This subunit corresponds to lithologic Subunit VIA (sulfide-veined sediments) described between 105 and 145 mbsf, and the core observations and the FMS images show that the formation is intensely, but unevenly, veined. The high resistivity values are actually artifacts induced by the very high conductivities of the sulfides composing the veins that are out of the standard range of operation of the DIT. As the sulfides become disseminated into siltstone beds from 145 to 187 mbsf (logging Subunit 2B), the resistivity and density curves remain relatively low, with local strong extrema, and the porosity fluctuates considerably $\sim 50 \%$. This subunit corresponds to lithologic Subunit VIB (sediments with sulfide veins and impregnations) identified between 145 and $200 \mathrm{mbsf}$. The high caliper readings show that this interval is the least mechanically consistent portion of the hole and might make the porosity measurements questionable. Between 187 and 210 mbsf (Subunit 2C), resistivity, density, and sonic velocity are again influenced by a high, but unevenly distributed sulfide content and show highly variable values. The low gamma-ray readings reflect the turbiditic nature of the sediments in this interval, which corresponds to lithologic Subunit VIC described as sulfide banded sediments ("Lithostratigraphic Summary and Sedimentology" section, this volume). Over the entire logging Unit 2, the FMS images give a very good picture of the vein network and of its changes in density and general pattern with depth (Fig. 150).

\section{Logging Unit 3 (210-292 mbsf)}

Below $210 \mathrm{mbsf}$, the sediments are only moderately altered, and the logs become more stable and representative of the changes in structure and lithology through successions of interbedded mudstones, siltstones, and sandstones. The distinction between the different units and subunits relies on the standard logs, but also strongly on the FMS images. Logging Unit 3 corresponds to Lithofacies A described in the "Sedimentology" section (this chapter) and can be characterized in the FMS images by a high level of fracturing. This observation, combined with the occurrence of hydrothermal alteration in the rocks recovered over this interval (Sections $169-856 \mathrm{H}$ 33R-1 through 40R-1; "Sedimentology" section, this chapter) could indicate a fault, which would also be consistent with the particularly poor recovery (on average $7.3 \%$ ) over the entire unit. In particular, two intervals within this zone (221-239 and 250-270 mbsf) have low resistivity and very high porosity, features characteristic of fault zones or of fragmented formations. The top of these two intervals (221 and 250 mbsf; Fig. 151A) are marked by contact surfaces dipping west at $\sim 50^{\circ}$, whereas, over the rest of the unit, the FMS maps a succession of fractures clearly dipping in the same direction at angles ranging between $50^{\circ}$ and $70^{\circ}(239,240,241,244,246$, and 290.5 mbsf; see FMS images in Fig. 151). The deepest of these fractures is observed at 290.5 mbsf (Fig. 151B). Logging Unit 3 is interpreted as a fault zone consisting of two fractured intervals that might be the extension through these relatively soft sediments of actual faults deeper in the basement, and of adjacent single fractures resulting from the same stress field and acting as narrower fluid pathways. The sharp decrease in potassium above $292 \mathrm{mbsf}$, and its almost complete disappearance above $270 \mathrm{mbsf}$ (Fig. 148H), can be interpreted as the result of potassium leaching during alteration because of the circulation of hydrothermal fluids within this fault zone.

\section{Logging Unit 4 (292-432 mbsf)}

The top of this unit is marked by a sharp increase in gamma ray counts at 292 mbsf, that can be attributed to an increase in clay content and to the absence of alteration by comparison to the overlying unit. Below this depth, logging Unit 4 is characterized by a progres- 
Figure 148. Logging data recorded in Hole $856 \mathrm{H}$ during Legs 139 and 169 are (A) caliper (hole geometry), (B) resistivity, (C) porosity, (D) bulk density, (E) compressional-wave velocity $\left(\mathrm{V}_{\mathrm{p}}\right),(\mathbf{F})$ gamma ray, $(\mathbf{G})$ resistivity, (H) potassium, (I) thorium, and (J) uranium. The caliper curves are from the two orthogonal calipers of the FMS. The pipe was positioned at $84.5 \mathrm{mbsf}$ during Leg 169, and the only data recorded above this depth are the gamma ray and $\mathrm{K}, \mathrm{U}$, and Th measured through the pipe and attenuated as compared to the data from Leg 139 on the same plots. The sulfide-rich zones from the bottom of the drill pipe to $\sim 210 \mathrm{mbsf}$ have very low resistivity, but the resistivity tool responds to these conductive zones by showing very high resistivity (B). The resistivity data are useful for delineating the sulfide mineralization, but the values for the resistivity are in error. The resistivity data for the $85-210 \mathrm{mbsf}$ interval thus are not shown on the corrected logging data presented at the end of this chapter and are not included with the logging data on the CD-ROM. The original data are available from Lamont-Doherty Borehole Research Group.
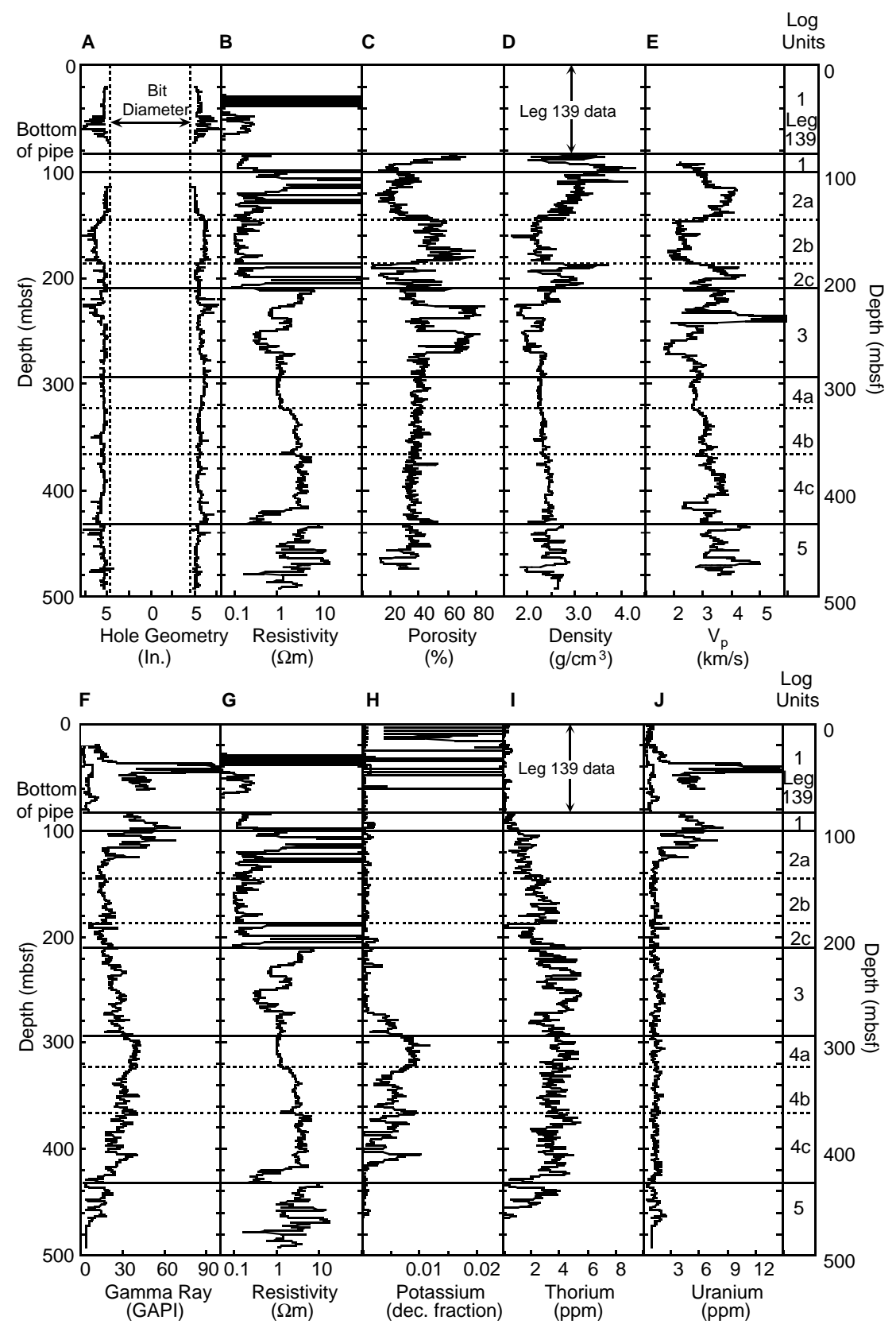

sive reduction in gamma ray counts, and by an increase in resistivity, density, and sonic velocity. The resistivity log, in particular, shows three different subunits. From 292 to 323 mbsf (Subunit 4A), all the logs display almost constant values, and the FMS images show a succession of very fine beds dipping slightly south $\left(2^{\circ}\right.$ to $10^{\circ}$; see Fig. 152). These images also indicate some fractures that dip in the opposite direction from the general pattern of the fault (at 298, 302, 304, and $311 \mathrm{mbsf}$ ) that could be interpreted as conjugate fractures resulting from the same regional stresses that generated the fault. At 323 mbsf (top of logging Subunit 4B), a discrete increase in density, resistivity, and velocity, and a decrease in gamma-ray counts indicate a higher proportion of sands. The FMS images show that the beds display similar dips and azimuth to those observed in Subunit 4A, but that the interbeds are thicker, which is also apparent in the reduction in frequency in gamma-ray variations between the two subunits. Subunits $4 \mathrm{~A}$ and $4 \mathrm{~B}$ correspond to Lithofacies $\mathrm{B}$ (siltstone and sandstone; Sections 169-856H-41R-1 through 47R-1) described in the "Sedimentology" section (this chapter), where the thickening of the sandstone interbeds with depth is also recorded. Below $365 \mathrm{mbsf}$ (top of Subunit 4C), a similar discrete increase in density, resistivity, and velocity is associated with a decrease in gamma-ray counts and likewise interpreted as an increase in sand content. This interpretation contradicts the identification of the formation within this interval as Lithofacies A ("Sedimentology" section, this chapter), but the poor recovery ( $<10 \%$ on average) could be the cause of the differences between the core and log interpretations. No FMS data were recorded over this subunit, but the reduction in the frequency of the gammaray variations suggests a thickening of the interbeds from Subunit 4B to Subunit 4C.

\section{Logging Unit 5 (432 mbsf-Bottom)}

This unit encompasses lithologic Units VII and VIII (see "Lithostratigraphic Summary and Sedimentology" section, this chapter) and is indicated by the first occurrence of igneous rocks. The distinctive log response to igneous units is a very strong increase in den- 


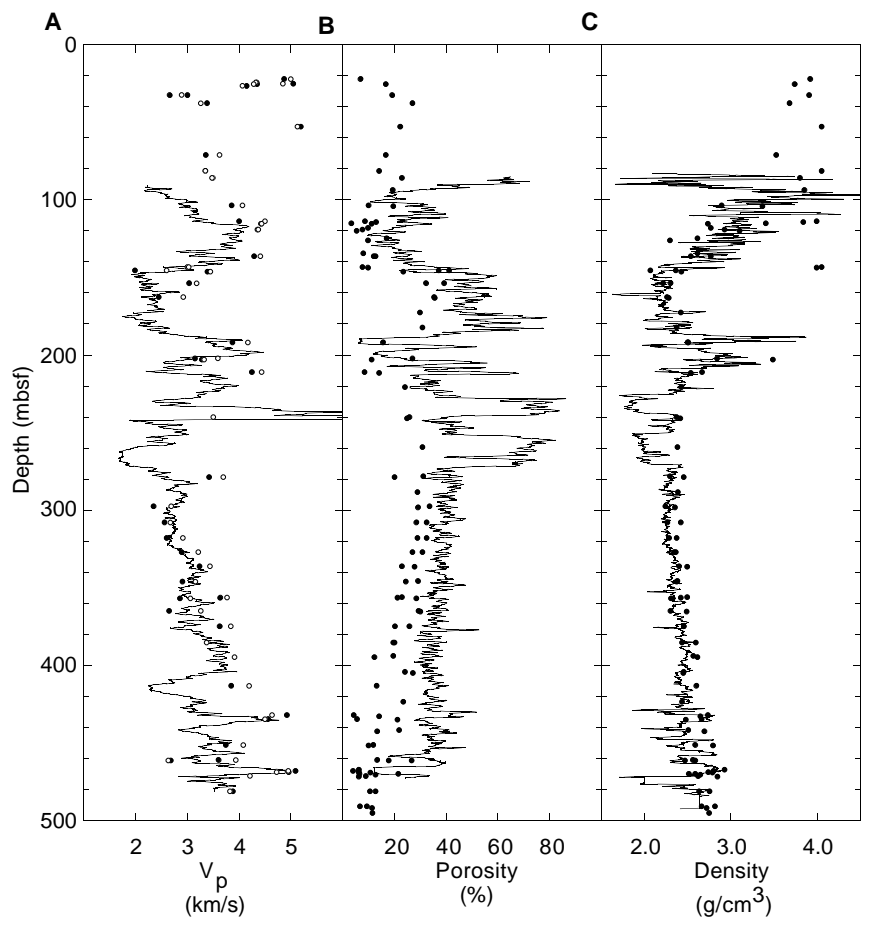

Figure 149. Comparison of the logging data with discrete measurements (circles) made on core samples from Hole $856 \mathrm{H}$. Although (A) compressionalwave velocity and (C) density show remarkable agreement, the (B) porosity is generally higher in the logs, which is partly caused by the clay content of the formation. The open and solid circles in (A) represent horizontal and vertical velocity measurements.

sity, sonic velocity, and resistivity, and proportionate drops in porosity and gamma-ray counts. The shallowest igneous intrusion could not be imaged because of the failure of the FMS shortly after the beginning of its first deployment, but the other logs show that this sill has a thickness of $\sim 4 \mathrm{~m}$. Three other igneous units produce the same characteristic changes in the different logs (Fig. 153) and can also be clearly identified on the FMS images: two narrow sills, from 447 to 449 mbsf, and from 456 to 458 mbsf, and a thicker unit from 464 to 468 mbsf. Close examination of the FMS images suggests that this unit might actually be composed of flows (Fig. 154A), but this could not be confirmed from core observation as recovery was particularly poor in the deepest section of the hole. Below this depth, the quality of the logs is poor owing to the length of the tool strings and a failure of the telemetry when the caliper arm of the Triple Combo was open. The deepest images recorded by the FMS seem to identify pillow basalts in several locations. The clearest observations, from 471 to 473 mbsf and below $485 \mathrm{mbsf}$ (Fig. 154B), corroborate the observation of highly altered hyaloclastic materials on some samples that are interpreted as old glassy pillow margins (Cores 169-856H-63R and 64R; see "Lithostratigraphic Summary and Sedimentology" section, this chapter).

\section{Temperature Measurements}

Deployments of the Adara and WSTP tools (see "Explanatory Notes" chapter, this volume) provided insights into the subsurface temperature distribution within the Bent Hill area. A total of eight discrete temperature measurements in four holes were taken with these tools at various steps of drilling at Sites 1035 and 856. Although the two tools have different geometries, the methods used for analysis and interpretation of the temperature records (Fig. 155) are similar, and the theoretical decay curves used to fit these records produced the extrapolated formation temperatures summarized in Table 27 and

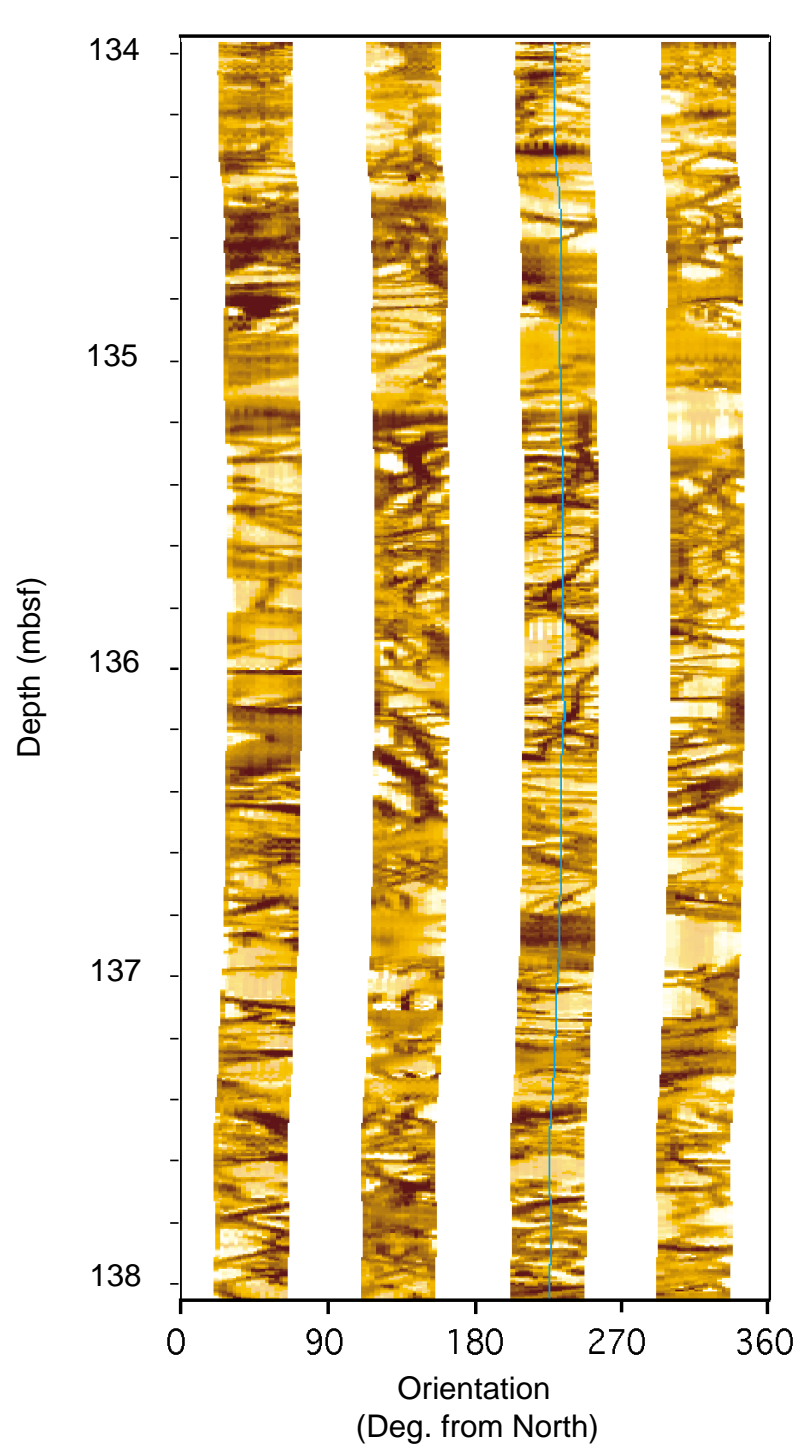

Figure 150. FMS images recorded within the SFZ or logging Unit 2. Most of the conductive features (dark) are sulfide veins characteristic of lithologic Unit VIA (see "Lithostratigraphic Summary and Sedimentology" section, this chapter). No clear preferential direction of veining is observed in these images.

Figure 156. In this figure, the same value of $2.10^{\circ} \mathrm{C}$ at the seafloor was used for the four holes, which was established by a stationary measurement of the BRGM temperature probe at the beginning of its ill-fated run. The WSTP measurement in Hole $856 \mathrm{H}$ was taken just after reentry and was actually made in the sediment fill at the bottom of this hole, which is cooler than the formation. As a result, this value probably represents a minimum temperature and underestimates the actual temperature gradient. The data recorded in Holes 1035A, $1035 \mathrm{D}$, and $1035 \mathrm{E}$ show temperature gradients ranging from 1.24 to $2.18^{\circ} \mathrm{C} / \mathrm{m}$, in agreement with the values recorded during a previous survey by Fisher et al. (unpubl. data, 1995).

To estimate the nature of the thermal regime at these sites, we also examined the relationship between the temperature and the thermal resistance of the formation. The thermal resistance can be calculated by a discrete integration over a given interval of the thermal conductivities measured on core samples (Shipboard Scientific Party, 1992a). In a purely conductive regime, a plot of temperature vs. thermal resistance would be linear, with the heat flow given by the slope of the line, and any fluctuation around this line would be indicative of the presence of 
A

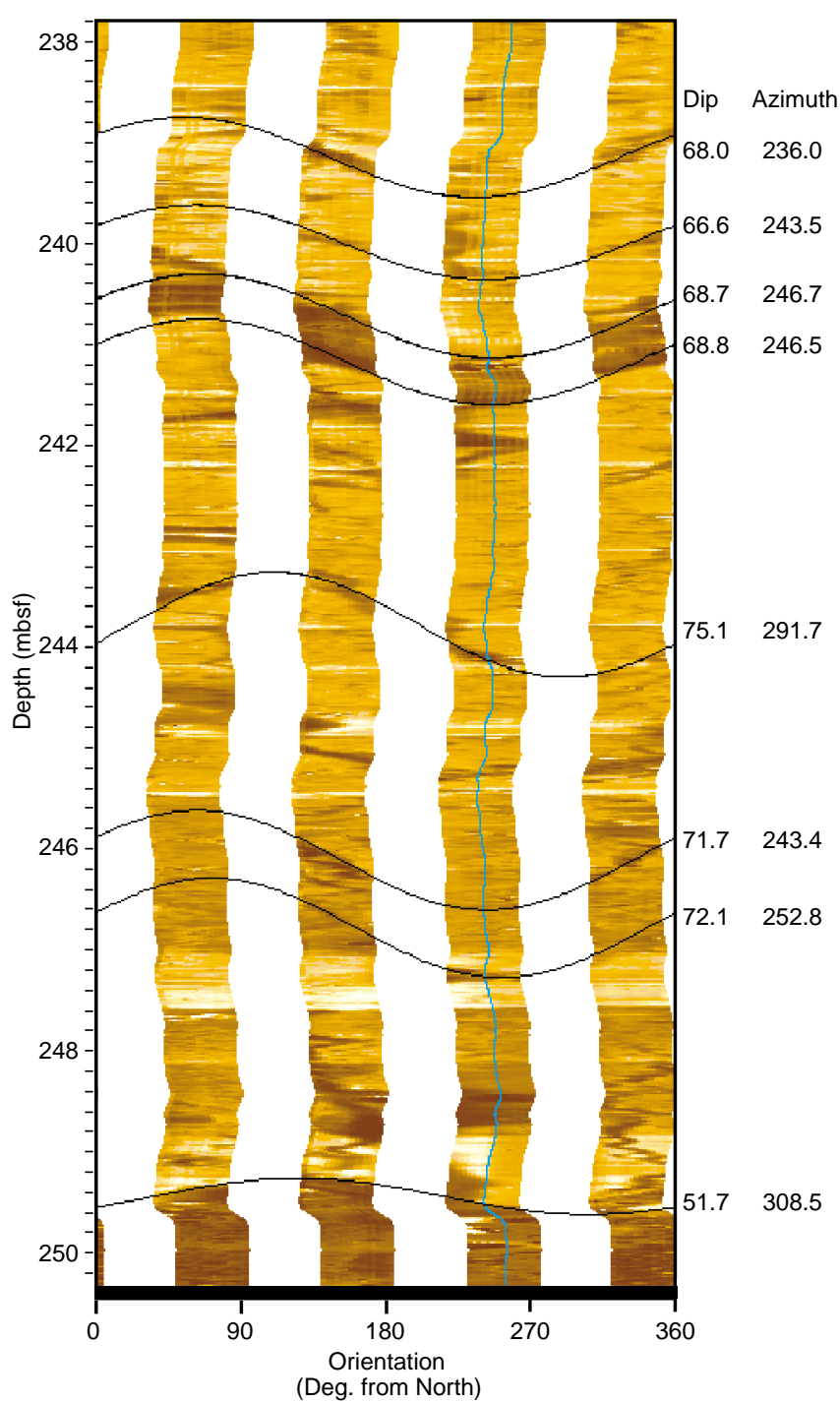

B

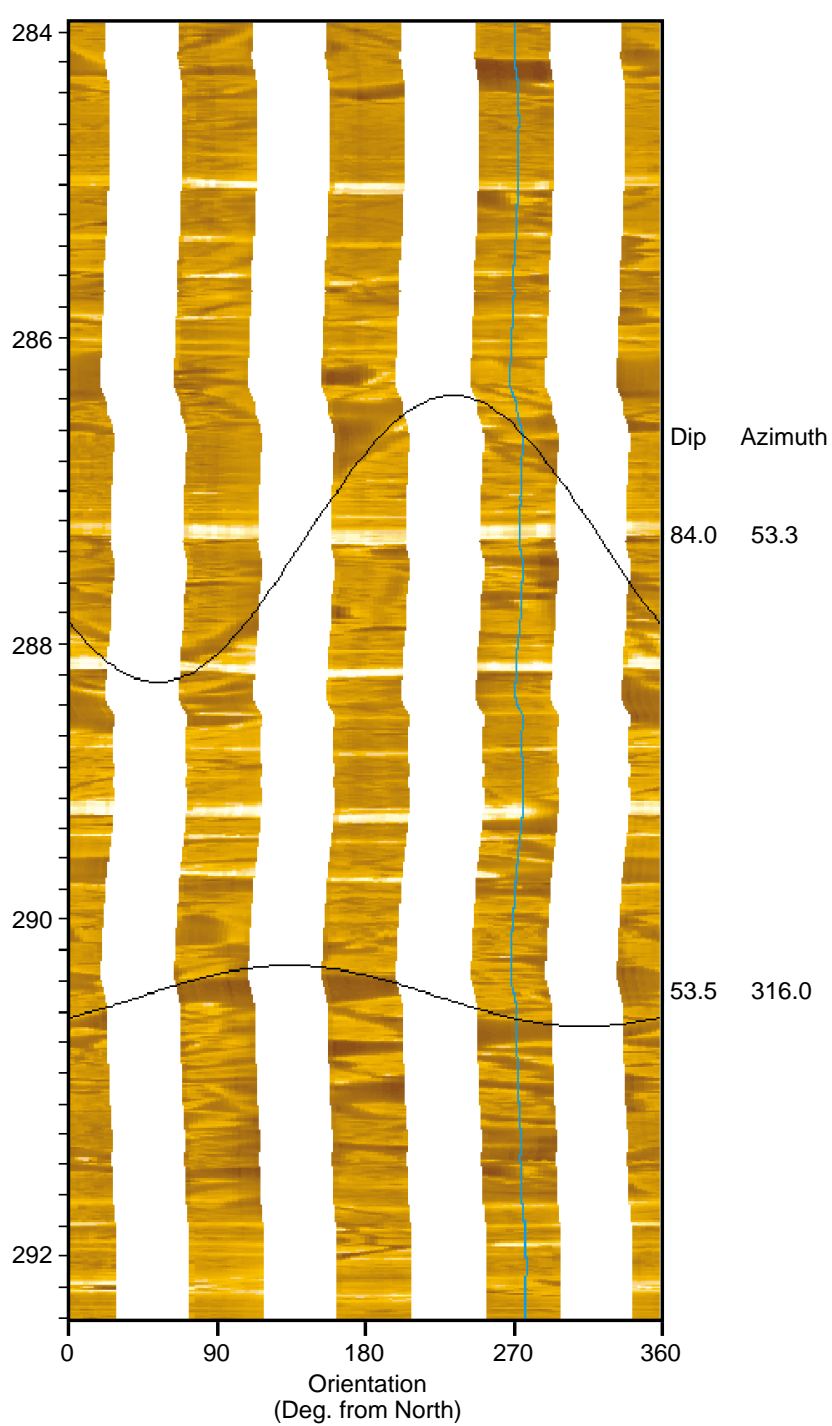

Figure 151. FMS images showing different types of fractures observed within logging Unit 3, believed to be a fault zone. A. A series of fractures dipping westsouthwest, at angles ranging from $66^{\circ}$ to $75^{\circ}$, are observed in the section between two intervals interpreted as fractured zones (see text). The bottom-most dipping feature on this figure is the upper contact of the deepest of these intervals. B. Fractures in the deepest portion of logging Unit 3 . The fracture at $290.5 \mathrm{mbsf}$, overlaying fragmented material, could be a pathway for hydrothermal circulations responsible for the decrease in potassium observed at this depth (Fig. 148). The fracture at $287 \mathrm{mbsf}$ dips opposite to most fractures observed in logging Unit 3 and is interpreted as a conjugate fracture developing under the same regional stress field.

other modes of heat transfer. Figure 156B shows such relationships at Site 1035 , and the slopes of the linear fits give the values of the conductive heat flows (Table 27). The single measurement in Hole 1035D does not allow any interpretation of the nature of the regime in this hole, but the nonlinearity of the curves for Holes 1035A and 1035E suggests that the regime is not purely conductive, even though the nature and the strength of the other modes of heat transfer in these locations still needs to be quantified.

\section{PALEOMAGNETISM}

Lithologic units used in the following paragraphs refer to those used by the Leg 169 Shipboard Scientific Party (see "Lithostrati- graphic Summary and Sedimentology" section, this chapter). The major objectives of the rock magnetic measurements (see "Explanatory Notes" chapter, this volume) performed at Hole $856 \mathrm{H}$ were to provide insight into the downhole and lateral variation of the rock magnetic properties of the BHMS deposit and the underlying hydrothermal feeder zone. Rock magnetic measurements were conducted on 36 discrete samples representing the various lithologies drilled at Hole $856 \mathrm{H}$ (see Table 28). The paleomagnetic measurements performed at Site 1035 encompassed a series of selected split cores to scan the magnetostratigraphic potential of the cores recovered (Sections $169-1035 \mathrm{~A}-1 \mathrm{H}-1$ through $16 \mathrm{X}-3$, 1035D-1H-1 through $5 \mathrm{H}-3$, and $1035 \mathrm{E}-1 \mathrm{H}-1$ through $5 \mathrm{H}-5)$. Because of the better preservation of the original sedimentary fabrics, dominantly APC-cored intervals were measured on the pass-through magnetometer (see "Explanatory Notes" chapter, this volume). XCB-cored intervals were generally 


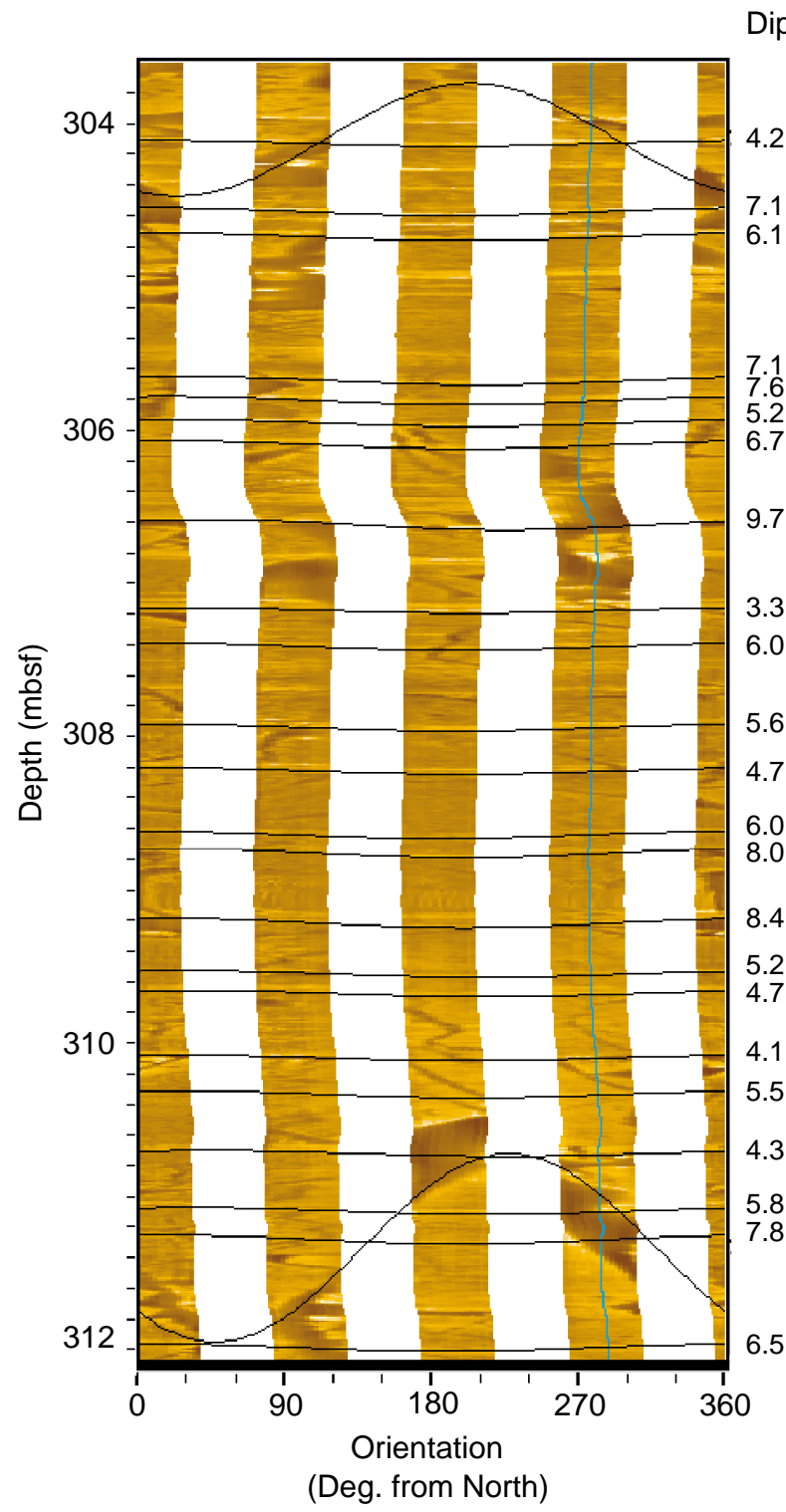

Azimuth

185.0

186.4

194.7

213.1

203.1

199.8

231.4

200.1

191.9

188.6

196.0

175.0

198.2

199.0

216.1

217.9

201.3

204.4

239.3

220.1

196.0

182.1

Figure 152. Series of turbidites as observed over logging Unit 4. The light features on this image, as well as on Figure 151, are sands dipping slightly to the south $\left(4^{\circ}\right.$ to $8^{\circ}$ in this image and $3^{\circ}$ to $10^{\circ}$ over the entire logging Unit 4). The two observed fractures are opposite to the general fault pattern of the overlying unit and might be conjugate fractures.

excluded from the measurements (except Hole 1035A), owing to the extensive drilling-induced disturbance.

\section{Hole 856H}

Magnetic susceptibility and natural remanent magnetization (NRM) and laboratory-induced isothermal remanent magnetization (IRM) intensities parallel each other in their general trends (Fig. 157). Magnetization intensities of NRM and IRM vary over 3 orders of magnitude. The downhole variations are characterized by relatively high intensity in lithologic Subunit VIA and Units VII-VIII ( 100$150 \mathrm{mbsf}$ and deeper than $430 \mathrm{mbsf}$ ) bracketing a low-intensity interval of magnetization in Subunits VIB-IIA ( 150-430 mbsf). Abrupt shifts in magnetic properties downhole can be well correlated to the respective boundaries of Units VI-VIII (Fig. 157), and correspond to changes in concentration, type, and grain-size distribution of the magnetomineralogy. Lithology independent trends of the rock magnetic parameters suggest a secondary alteration of the magnetic signal, likely as a function of hydrothermal effects on the lithology. Remanent magnetization is dominantly carried by magnetite and presumably monoclinic pyrrhotite $\left(\mathrm{Fe}_{7} \mathrm{~S}_{8}\right)$, with the exception of Subunit VIA, where hematite characterizes the rock magnetic signal. 

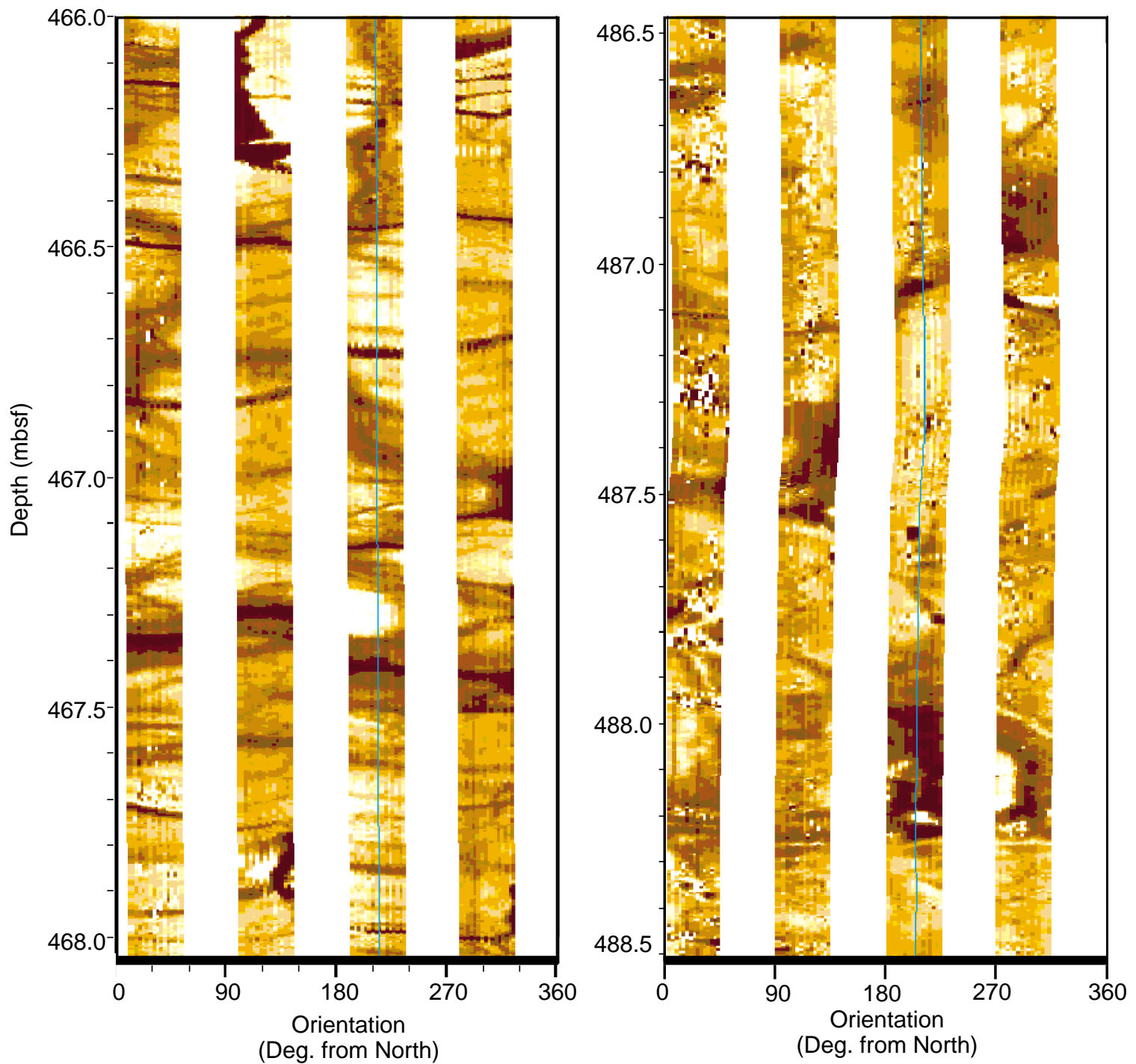

Figure 154. Extrusive pillow basalts imaged by the FMS in the deepest part of Hole $856 \mathrm{H}$.

\section{Natural Remanent Magnetization}

The NRM of samples from Cores 169-856H-20R through 22R (i.e., the uppermost four samples of the profile) was measured on the spinner magnetometer. All remaining NRM intensities were determined on the cryogenic magnetometer. Magnetization intensities are highest in Subunit VIA (reaching $6.9 \mathrm{~A} / \mathrm{m}$ ) and decrease to an average of $\sim 1 \mathrm{~mA} / \mathrm{m}$ throughout Subunits VIB-IIA (Fig. 157). The intensity after demagnetization at $15 \mathrm{mT}$ increases again by 2 orders of magnitude in the mafic sills and basaltic flows (Units VII and VIII) at the bottom of the profile. Declination and inclination values were determined from the $\mathrm{X}, \mathrm{Y}$, and $\mathrm{Z}$ intensity components after the 15 $\mathrm{mT}$ demagnetization step. Inclinations dominantly are on the order of the mean value expected for the location of Hole $856 \mathrm{H}\left(67^{\circ}\right)$. Declinations are not oriented with respect to north. Assuming a north orientation of the Earth's magnetic field at the time of NRM acquisition (Brunhes Chron), drilling perpendicular to the bedding plane, and an average time interval $>10$ k.y. being represented in a sample, the declinations given in Table 28 only reflect the relative rotation from north of the respective core section.

\section{Low-Field Susceptibility and AMS}

The degree of anisotropy (of magnetic susceptibility; AMS) $P_{j}$ is low $(<1.074)$ for the five samples measured (Samples $169-856 \mathrm{H}$ -
20R-1, $22 \mathrm{~cm} ; 21-\mathrm{R} 1,34 \mathrm{~cm} ; 21-\mathrm{R} 1,65 \mathrm{~cm} ; 22-\mathrm{R} 2,65 \mathrm{~cm}$; and $25-$ $\mathrm{R} 1,19 \mathrm{~cm}$ ) and is thus within the average range of marine sediments. The shape factor $T$ ranges from -0.485 to 0.1 . For all remaining samples only the magnetic susceptibility was determined. Susceptibilities are on the order of $1-2 \times 10^{-3}$ SI with only minor variation downhole (Fig. 157). However, unit boundaries and drastic lithological changes are still monitored by abrupt changes in susceptibility and IRM. Interestingly, the substantial and continuous decrease in remanence intensities does not affect susceptibilities (see NRM and IRM paragraphs). This suggests a qualitative change in the magnetomineralogy that was caused by a postdepositional alteration of the sediments associated with a conversion of the remanence component of the magnetic signal to paramagnetic minerals (e.g., Urbat, 1996).

\section{Isothermal Remanent Magnetization}

IRM acquisition curves were determined for most of the 36 samples from Hole $856 \mathrm{H}$ (see Table 29) and indicate that a low coercivity mineral, very likely magnetite, dominantly carries the remanent magnetization of the samples. At fields of $0.2 \mathrm{~T}$, a $95 \%-100 \%$ saturation of the IRM $\mathrm{@IT}_{1 \mathrm{~T}}$ is typically achieved. This ferrimagnetic dominance of the magnetomineralogy is confirmed by the backfield experiments, characterized by S-ratios well above 0.9 (Fig. 157; Table 28). Marked differences are encountered in Subunit VIA (Samples 169-856H- 

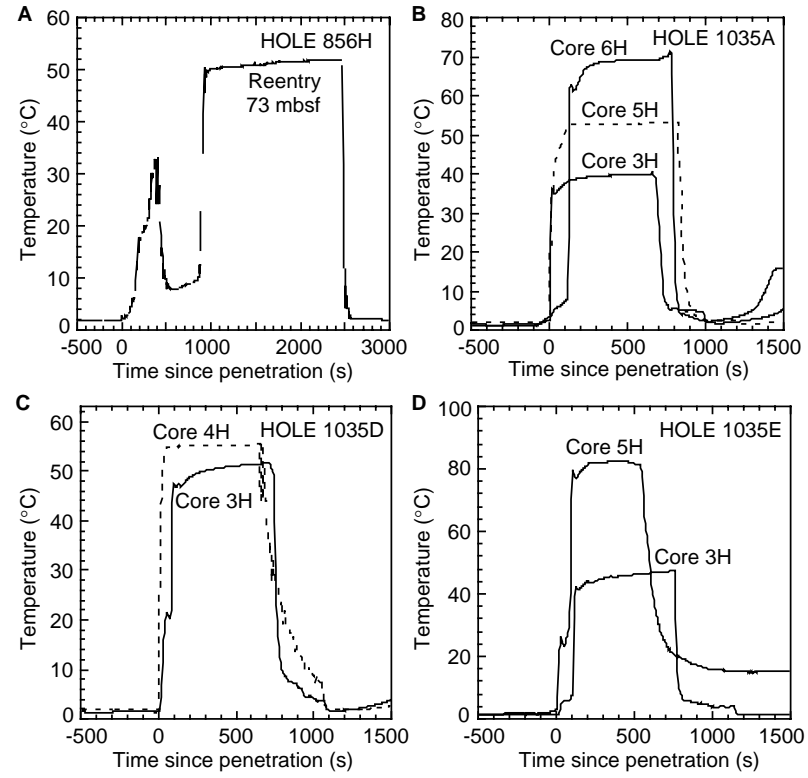

Figure 155. Temperature records of the WSTP and Adara tools in Holes (A) 856H, (B) 1035A, (C) 1035D, and (D) 1035E. A synthetic theoretical decay curve fit is applied to the portion of these curves corresponding to the time spent by the probe in the sediments to extrapolate the equilibrium temperature.

Table 27. Summary of temperature measurements taken in the Bent Hill area with the WSTP and the Adara probes.

\begin{tabular}{cccccc}
\hline Hole & Type of tool & $\begin{array}{c}\text { Depth } \\
(\mathrm{mbsf})\end{array}$ & $\begin{array}{c}\text { Temperature } \\
\left({ }^{\circ} \mathrm{C}\right)\end{array}$ & $\begin{array}{c}\text { Gradient } \\
\left({ }^{\circ} \mathrm{C} / \mathrm{m}\right)\end{array}$ & $\begin{array}{c}\text { Heat flow } \\
\left(\mathrm{W} / \mathrm{m}^{2}\right)\end{array}$ \\
\hline \multirow{2}{*}{$856 \mathrm{H}$} & WSTP & 73.0 & 51.4 & 0.70 & \\
$1035 \mathrm{~A}$ & Adara & 26.5 & 40.8 & 1.46 & 1.24 \\
& WSTP & 36.0 & 53.2 & 1.30 & \\
& Adara & 55.0 & 69.4 & 0.85 & \multirow{2}{*}{$1035 \mathrm{D}$} \\
& Adara & 24.1 & 54.9 & 2.19 & 2.33 \\
& WSTP & 24.1 & 54.4 & 2.17 & \multirow{2}{*}{$1035 \mathrm{E}$} \\
& Adara & 26.5 & 55.0 & 2.00 & 1.80 \\
& Adara & 45.5 & 83.4 & 1.49 & \\
& & & & & \\
\hline
\end{tabular}

Notes: The gradient indicated at a given depth is calculated between this depth and the nearest shallower measurement or the seafloor temperature $\left(2.1^{\circ} \mathrm{C}\right)$ if none. The heat-flow values are calculated as the slopes of the temperature vs. thermal resistance relationships (see Fig. 156).

22R-2, $65 \mathrm{~cm}$; 24R-2, $131 \mathrm{~cm}$; 25R-1, $19 \mathrm{~cm}$; and 25R-3, $16 \mathrm{~cm}$ ). These samples are controlled by a high-coercivity, remanence-carrying mineral (likely hematite) according to both the IRM-acquisition and the $\mathrm{S}$-ratio. Monoclinic pyrrhotite $\left(\mathrm{Fe}_{7} \mathrm{~S}_{8}\right.$, the only sulfide except greigite capable of carrying a remanent magnetization) very likely dominates the magnetomineralogy in Samples 169-856H-20-R-1, 22 $\mathrm{cm}$, and 21-R-1, $65 \mathrm{~cm}$ (IRM acquisition, Fig. 158). At $0.2 \mathrm{~T}$, only a $80 \%-90 \%$ saturation is achieved (cf. Körner, 1994). Comparable to the intensity after the 15-mT demagnetization step, the intensities of IRM $_{@ 1 \mathrm{~T}}$ are highest in Subunit VIA, and Units VII and VIII. (Fig. 157; Table 28). Intensities continuously decrease by 3 orders of magnitude from Subunit VIA downhole and remain low $(\sim 100 \mathrm{~mA} / \mathrm{m})$ throughout Subunits VIB-IIA.

\section{Conclusions}

Rock magnetic parameters reflect the lithologic variations in Hole $856 \mathrm{H}$ by abrupt changes in magnetomineralogy and in the concentra-
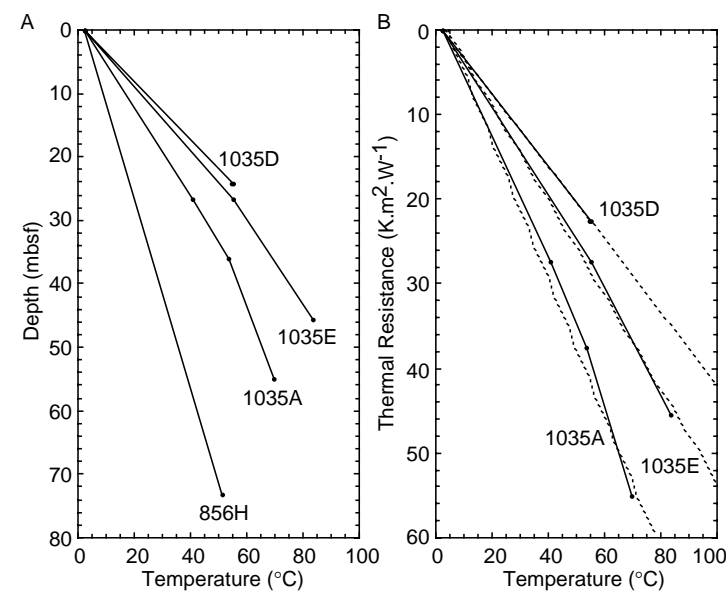

Figure 156. Summary of the WSTP and Adara temperature measurements taken at Bent Hill showing (A) temperature vs. depth and (B) thermal resistance vs. depth. The apparent low gradient in (A) for Hole $856 \mathrm{H}$ probably results from an unreliable measurement made in the sediment filling the bottom of the borehole upon reentry. In (B), a purely conductive thermal regime would be indicated by a linear relationship between temperatures and thermal resistance. The least square linear fits give an indication of the conductive heat flux, but shows that the thermal regime in these locations is not purely conductive.

tions of magnetic minerals between the different lithologic units. The transitional shift of the magnetic signal from Subunits VIA to VIB indicates a change downhole from relatively high concentrations of hematite to low concentrations of magnetite associated with an increase in paramagnetic minerals, such as pyrite or hexagonal pyrrhotite other than magnetic monoclinic pyrrhotite $\left(\mathrm{Fe}_{7} \mathrm{~S}_{8}\right)$. The latter is reflected in IRM/susceptibility decreasing downhole (Fig. 157). The increase of NRM/IRM in this interval presumably reflects a higher alignment efficiency (with respect to the Earth's magnetic field) of the remanence carrying minerals because of the qualitative and quantitative change from dominantly hematite to magnetite.

\section{Site $\mathbf{1 0 3 5}$}

The construction of a magnetostratigraphy at Site 1035 is hampered by a combination of secondary alteration of the magnetic signal and/or coring disturbances rendering pass-through measurements impractical. For the latter reason, pass-through measurements of the magnetization were restricted to the APC-cored intervals from Holes $1035 \mathrm{~A}, 1035 \mathrm{D}$, and 1035E. Downhole plots of intensity and inclination (20-mT demagnetization) parallel each other in their general trends among the respective holes (Fig. 159). Intervals of normal polarity in the magnetization are recorded in certain sections only, dominantly in lithologic Subunit IIA (Fig. 159), suggesting a magnetization during the Brunhes Chron $(\mathrm{C} 1 \mathrm{n})$. The upper part of Holes $1035 \mathrm{~A}, 1035 \mathrm{D}$, and $1035 \mathrm{E}(\sim 0-16 \mathrm{mbsf})$ is characterized by shallow positive to shallow negative inclinations, a feature of the magnetic signal that is also noted at Site 1036, in slightly greater depths (see "Paleomagnetism" section, "Middle Valley: Dead Dog Area" chapter, this volume), and also during Leg 139 at Site 856 (Shipboard Scientific Party, 1992b). In contrast to Site 1036, however, these shallow inclinations are not correlative with the higher isotherm of the hydrothermal alteration of the sediments. Moreover, the base of this interval extends through the upper meters of Subunit IIA and thus ends even above the onset of carbonate precipitation in these holes (see "Lithostratigraphic Summary and Sedimentology" section, this chapter). The most distinctive intervals of unusually shallow inclinations have been highlighted by stippled lines in Figure 159. These high- 
Table 28. Summary of rock magnetic data obtained from 36 samples, Hole $856 \mathrm{H}$.

\begin{tabular}{|c|c|c|c|c|c|c|c|c|c|c|}
\hline $\begin{array}{l}\text { Core, section, } \\
\text { interval }(\mathrm{cm})\end{array}$ & $\begin{array}{l}\text { Depth } \\
\text { (mbsf) }\end{array}$ & $\begin{array}{l}\text { Susceptibility } \\
\text { (SI) }\end{array}$ & $\begin{array}{l}\text { IRM@ IT } \\
(\mathrm{mA} / \mathrm{m})\end{array}$ & $\begin{array}{l}\text { IRM back } \\
@ 300 \mathrm{mT}\end{array}$ & IRM/sus & NRM/IRM & S-ratio & $\begin{array}{l}\text { Intensity@15 } \\
\mathrm{mT}(\mathrm{mA} / \mathrm{m})\end{array}$ & $\begin{array}{l}\text { Declination } \\
\left({ }^{\circ}\right)\end{array}$ & $\begin{array}{c}\text { Inclination } \\
\left({ }^{\circ}\right)\end{array}$ \\
\hline \multicolumn{11}{|l|}{$169-856 \mathrm{H}-$} \\
\hline 20R-1, 22-24 & 103.82 & $1.06 \mathrm{E}-02$ & $9.64 \mathrm{E}+04$ & $8.87 \mathrm{E}+04$ & $9.11 \mathrm{E}+06$ & $1.85 \mathrm{E}-02$ & 0.96 & $1.78 \mathrm{E}+03$ & 56.75 & 78.81 \\
\hline $21 \mathrm{R}-1,34-36$ & 113.74 & $6.84 \mathrm{E}-02$ & $1.69 \mathrm{E}+05$ & $1.66 \mathrm{E}+05$ & $2.47 \mathrm{E}+06$ & $4.08 \mathrm{E}-02$ & 0.99 & $6.91 \mathrm{E}+03$ & 113.84 & 69.08 \\
\hline 21R-2, 65-67 & 115.47 & $1.51 \mathrm{E}-03$ & $1.38 \mathrm{E}+04$ & $1.18 \mathrm{E}+04$ & $9.12 \mathrm{E}+06$ & $1.94 \mathrm{E}-02$ & 0.93 & $2.68 \mathrm{E}+02$ & 324.72 & 75.17 \\
\hline $22 \mathrm{R}-2,65-67$ & 119.25 & $8.59 \mathrm{E}-04$ & $2.40 \mathrm{E}+03$ & $5.39 \mathrm{E}+02$ & $2.79 \mathrm{E}+06$ & $5.77 \mathrm{E}-03$ & 0.61 & $1.39 \mathrm{E}+01$ & 56.32 & 73.81 \\
\hline $24 \mathrm{R}-2,131-133$ & 136.51 & $7.48 \mathrm{E}-04$ & $4.69 \mathrm{E}+03$ & $1.43 \mathrm{E}+03$ & $6.27 \mathrm{E}+06$ & $4.76 \mathrm{E}-04$ & 0.65 & $2.23 \mathrm{E}+00$ & 151. & 21.28 \\
\hline $25 \mathrm{R}-1,19-21$ & 143.49 & $3.16 \mathrm{E}-03$ & $2.51 \mathrm{E}+05$ & $2.25 \mathrm{E}+04$ & $7.96 \mathrm{E}+07$ & $3.58 \mathrm{E}-04$ & 0.54 & $8.99 \mathrm{E}+01$ & & \\
\hline $25 \mathrm{R}-2,62-64$ & 145.42 & $8.37 \mathrm{E}-04$ & & & & & & $3.12 \mathrm{E}+00$ & 243.98 & 44.02 \\
\hline $25 \mathrm{R}-3,16-18$ & 146.3 & $8.04 \mathrm{E}-04$ & $9.76 \mathrm{E}+02$ & $3.19 \mathrm{E}+02$ & $1.21 \mathrm{E}+06$ & $1.63 \mathrm{E}-03$ & 0.66 & 1.5 & 215 & 67.50 \\
\hline 26R-1, 91-93 & 153.81 & $6.93 \mathrm{E}-04$ & $8.05 \mathrm{E}+01$ & $7.11 \mathrm{E}+01$ & $1.16 \mathrm{E}+05$ & $1.51 \mathrm{E}-02$ & 0.94 & $1.22 \mathrm{E}+00$ & 315.42 & 75.69 \\
\hline $27 \mathrm{R}-1,21-22$ & 162.71 & $7.85 \mathrm{E}-04$ & $7.61 \mathrm{E}+01$ & $6.82 \mathrm{E}+01$ & $9.70 \mathrm{E}+04$ & $2.08 \mathrm{E}-02$ & 0.95 & $1.58 \mathrm{E}+00$ & 336.65 & 82.33 \\
\hline $30 \mathrm{R}-1,43-44$ & 191.83 & $6.15 \mathrm{E}-04$ & $2.06 \mathrm{E}+01$ & $2.15 \mathrm{E}+01$ & $3.34 \mathrm{E}+04$ & $7.58 \mathrm{E}-02$ & 1.02 & $1.56 \mathrm{E}$ & 278.88 & 81.75 \\
\hline $31 \mathrm{R}-2,74-76$ & 203.18 & $5.84 \mathrm{E}-04$ & $2.25 \mathrm{E}+01$ & $1.58 \mathrm{E}+01$ & $3.85 \mathrm{E}+04$ & $5.42 \mathrm{E}-02$ & 0.85 & $1.22 \mathrm{E}$ & 305.93 & 47.40 \\
\hline $32 \mathrm{R}-1,53-55$ & 211.13 & $1.07 \mathrm{E}-03$ & $4.93 \mathrm{E}+01$ & $4.52 \mathrm{E}+01$ & $4.60 \mathrm{E}+04$ & $5.82 \mathrm{E}-02$ & 0.96 & $2.87 \mathrm{E}+00$ & 292.24 & 48.42 \\
\hline $35 \mathrm{R}-1,42-44$ & 239.82 & $8.23 \mathrm{E}-04$ & 4. $22 \mathrm{E}+01$ & $3.86 \mathrm{E}+01$ & $5.13 \mathrm{E}+04$ & $8.31 \mathrm{E}-03$ & 0.96 & $3.51 \mathrm{E}-01$ & 348.60 & 38.84 \\
\hline
\end{tabular}

Notes: $\mathrm{IRM}=$ isothermal remanent magnetization, $\mathrm{NRM}=$ natural remanent magnetization, and $\mathrm{T}=$ tesla.

Only part of this table is produced here. The entire table appears on the CD-ROM.

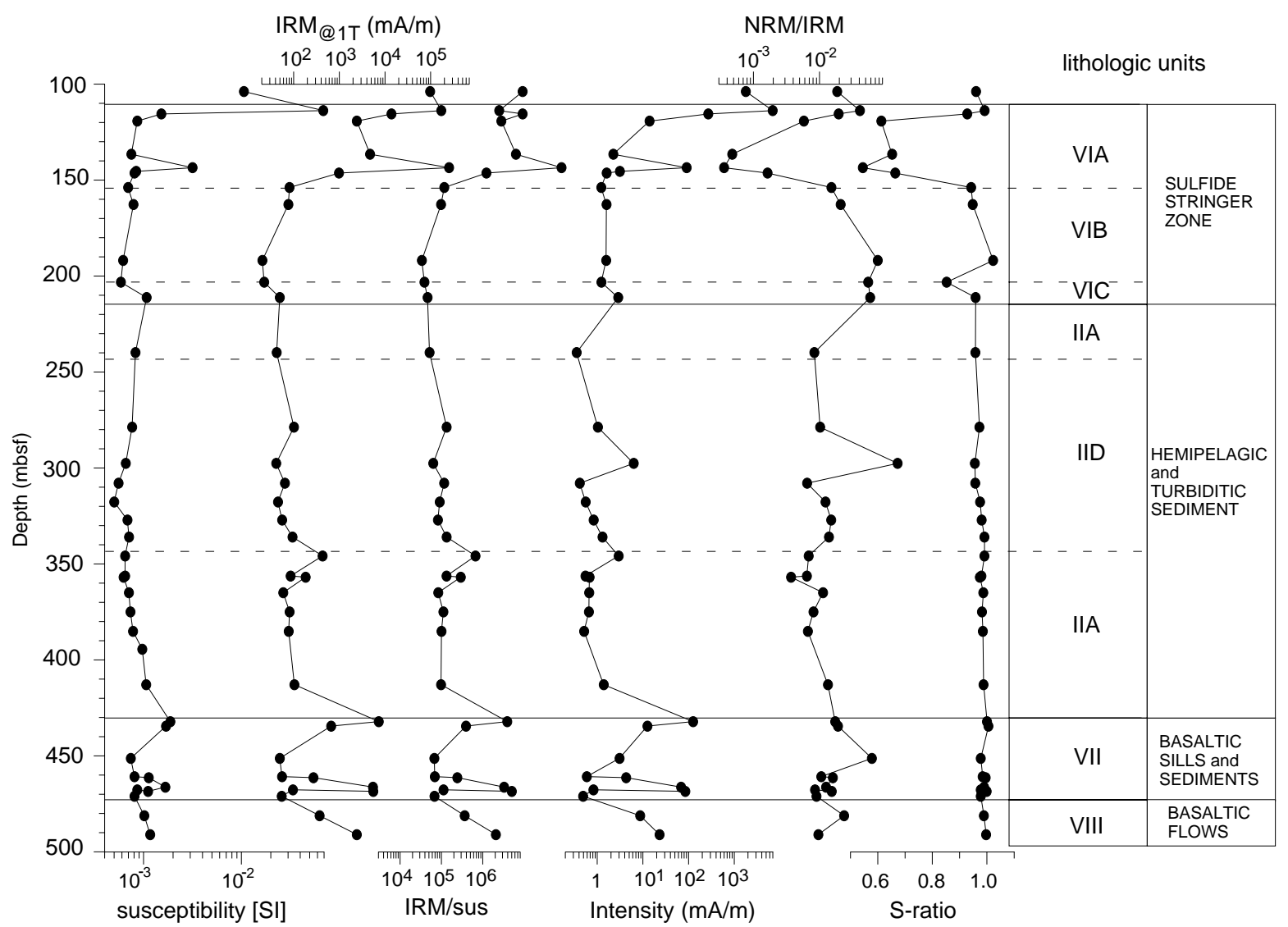

Figure 157. Susceptibility, natural and laboratory-induced magnetizations, intensity (after 15-mT demagnetization) and S-ratio vs. depth in Hole 856H. Right column indicates lithologic units (see "Lithostratigraphic Summary and Sedimentology" section, this chapter).

lighted intervals define the sections that can be magnetically correlated between Holes 1035A, 1035D, and 1035E. They also demonstrate that the upward shift of hydrothermal alteration in Hole 1035D, with respect to neighboring holes (see "Lithostratigraphic Summary and Sedimentology" section, this chapter), is mimicked by the paleomagnetic signal. The minor, but abrupt shifts in inclination below $18 \mathrm{mbsf}$ (best seen in Hole 1035A at 27 and 36 mbsf) are exactly correlative to the respective core boundaries and, hence, they are very likely related to a dip of the borehole on the order of $10^{\circ}-15^{\circ}$ in the respective interval of Subunit IIA. A short interval of negative inclinations is recorded at $40 \mathrm{mbsf}$ in sediments from Hole 1035E. It is presently unclear whether this interval could possibly be a true record of a geomagnetic event during the Brunhes Chron. This interval corresponds exactly to the base of Subunit IIB, which is characterized by an enhanced carbonate precipitation. Magnetization intensities (at 20-mT demagnetization) are weak, on the order of $10^{1}$ to $10^{2} \mathrm{~mA} / \mathrm{m}$ downhole. Trends in magnetization intensity are clearly correlative, especially in the upper $20 \mathrm{~m}$ of Holes 1035A, 1035D, and 1035E. An 
Table 29. IRM acquisition data, Hole $856 \mathrm{H}$ samples.

\begin{tabular}{crcr}
\hline $\begin{array}{c}\text { Core, section, } \\
\text { interval }(\mathrm{cm})\end{array}$ & $\begin{array}{r}\text { Field } \\
(\mathrm{mT})\end{array}$ & $\begin{array}{r}\text { Intensity } \\
(\mathrm{mA} / \mathrm{m})\end{array}$ & $\begin{array}{c}\text { Backfield } \\
0.3 \mathrm{~T}\end{array}$ \\
\hline 169-856H- & & & \\
20R-1, 22-24 & 0 & 0 & \\
& 22 & $23,952.4$ & \\
& 51 & 47,689 & 29,035 \\
& 100 & 70,739 & 61,062 \\
& 202 & 85,811 & \\
& 305 & 90,521 & 88,699 \\
& 498 & 93,919 & 95,917 \\
& 702 & 95,877 & \\
$169-856 \mathrm{H}-$ & 1,002 & 96,425 & \\
$21 \mathrm{R}-1,65-67$ & & & \\
& 0 & 0 & 0 \\
& 22 & 74,442 & 35,484 \\
& 51 & 144,513 & 102,834 \\
& 100 & 165,119 & 156,414 \\
& 202 & 169,791 & \\
& 305 & 168,119 & 166,376 \\
& 985 & 163,293 & \\
& & &
\end{tabular}

Only part of this table is produced here. The entire table appears on the CD-ROM.
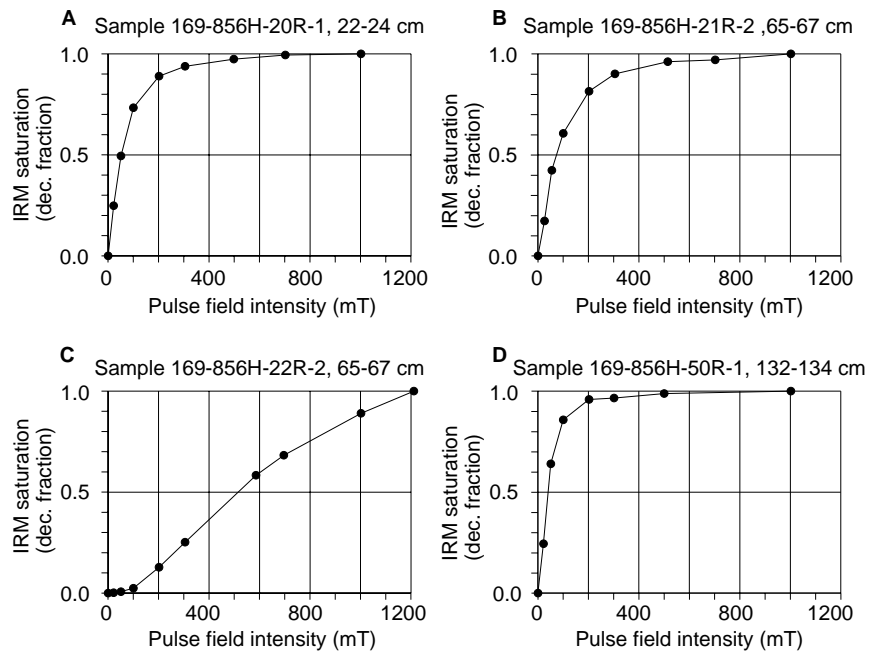

Figure 158. Selected IRM acquisition curves characterizing variations in magnetomineralogy in Hole $856 \mathrm{H}$. (A) and (B) monoclinic pyrrhotite, (C) hematite, and (D) magnetite. See further explanations in the text.
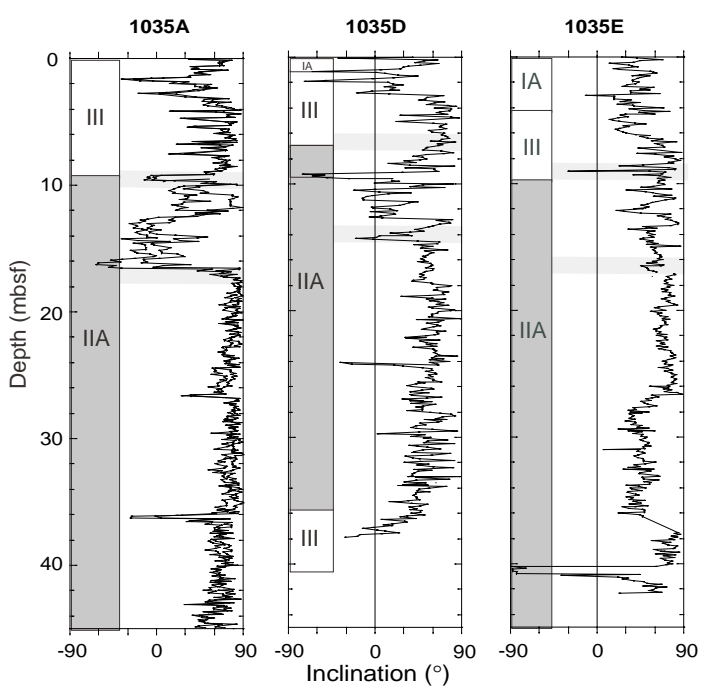

overall trend to slightly weaker magnetization intensities (especially in Hole 1035D, less distinct in Hole 1035A) suggests a secondary alteration of the magnetic signal that could be caused by the increasing hydrothermal pyritization of magnetite downhole (Shipboard Scientific Party, 1992b). Note that in cores from Hole 1035A, the intensities continue to decrease downhole (to $<10 \mathrm{~mA} / \mathrm{m}$ in Cores 169 $1035 \mathrm{~A}-10 \mathrm{H}$ through $16 \mathrm{H})$.

\section{Conclusions}

Comparable to Site 1036, the measurements of the magnetization at Site 1035 are not suitable to construct a magnetostratigraphy for the lithologies drilled. APC-cored intervals from Holes 1035A, $1035 \mathrm{D}$, and 1035E suggest a Brunhes age of the sediments extending to upper parts of lithologic Subunit IA in the respective holes. Although not related to the same process considered for Site 1036, the magnetic signal seems to reflect a strong overprint caused by the hydrothermal alteration of the sediments.

\section{REFERENCES}

Alt, J.C., Kinoshita, H., Stokking, L.B., et al., 1993. Proc. ODP, Init. Repts., 148: College Station, TX (Ocean Drilling Program).

Ames, D.E., Franklin, J.M., and Hannington, M.H., 1993. Mineralogy and geochemistry of active and inactive chimneys and massive sulfide, Middle Valley, northern Juan de Fuca Ridge: an evolving hydrothermal system. Can. Mineral., 31:997-1024.

Baker, P.A., Cross, S.L., and Burns, S.J., 1994. Geochemistry of carbonate nodules and cements and implications for hydrothermal circulation, Middle Valley, Juan de Fuca Ridge. In Mottl, M.J., Davis, E.E., Fisher, A.T., and Slack, J.F. (Eds.), Proc. ODP, Sci. Results, 139: College Station, TX (Ocean Drilling Program), 313-328.

Bandy, O.L., 1960. The geological significance of coiling ratios in the foraminifer Globigerina pachyderma (Ehrenberg). J. Paleontol., 34:671681.

Barton, P.B., Jr., and Bethke, P.M., 1987. Chalcopyrite disease in sphalerite: pathology and epidemiology. Am. Mineral., 72:451-467.

Bernard, B.B., Brooks, J.M., and Sackett, W.M., 1976. Natural gas seepage in the Gulf of Mexico. Earth Planet. Sci. Lett., 31:48-54.

Bischoff, J.L., 1969. Red Sea geothermal brine deposits: their mineralogy, chemistry, and genesis. In Degens, E.T., and Ross, D.A. (Eds.), Hot Brines and Recent Heavy Metal Deposits in the Red Sea: New York (Springer Verlag), 368-401.

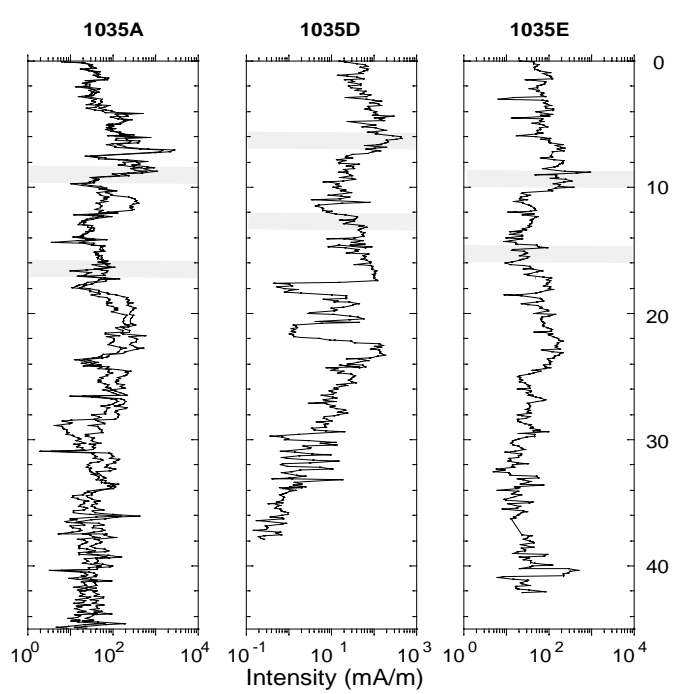

Figure 159. Downhole variation of inclination and intensity after AF demagnetization of the cores from Holes 1035A, 1035D, and 1035E at 20 mT. For Hole 1035A, the downhole variation after the 10-mT step is also shown. Columns on the left side of the inclination plots indicate lithologic units (see "Lithostratigraphic Summary and Sedimentology" section, this chapter). Thick stippled lines mark intervals of similar paleomagnetic inclinations. See text for explanation. 
Bischoff, J.L., and Rosenbauer, R.J., 1985. An empirical equation of state for hydrothermal seawater (3.2 percent NaCl). Am. J. Sci., 285:725-763.

Bradshaw, J.S., 1959. Ecology of living planktonic foraminifera in the north and equatorial Pacific Ocean. Contrib. Cushman Found. Foraminiferal Res., 10:25-64.

Brock, T.D., 1987. The study of microorganisms in situ: progress and problems. Symp. Soc. Gen. Microbiol., 41:1-17.

Brunner, C.A., 1994. Planktonic foraminiferal biostratigraphy and paleoceanography of late Quaternary turbidite sequences at Holes 856A, 857A, and 857C, Leg 139. In Mottl, M.J., Davis, E.E., Fisher, A.T., and Slack, J.F. (Eds.), Proc. ODP, Sci. Results, 139: College Station, TX (Ocean Drilling Program), 39-58.

Brunner, C.A., and Ledbetter, M.T., 1989. Late Quaternary quantitative planktonic foraminiferal biostratigraphy in turbidite sequences of the central California continental margin. Micropaleontology, 35:321-336.

Butterfield, D.A., McDuff, R.E., Franklin, J., and Wheat, C.G., 1994. Geochemistry of hydrothermal vent fluids from Middle Valley, Juan de Fuca Ridge. In Mottl, M.J., Davis, E.E., Fisher, A.T., and Slack, J.F. (Eds.), Proc. ODP, Sci. Results, 139: College Station, TX (Ocean Drilling Program), 395-410.

Curray, J.R., Moore, D.G., et al., 1982. Init. Repts. DSDP, 64 (Pts. 1 and 2): Washington (U.S. Govt. Printing Office).

Currie, R.G., and Davis, E.E., 1994. Low crustal magnetization of the Middle Valley sedimented rift inferred from sea-surface magnetic anomalies. In Mottl, M.J., Davis, E.E., Fisher, A.T., and Slack, J.F. (Eds.), Proc. ODP, Sci. Results, 139: College Station, TX (Ocean Drilling Program), $19-27$.

Davis, E.E., and Fisher, A.T., 1994. On the nature and consequences of hydrothermal circulation in the Middle Valley sedimented rift: inferences from geophysical and geochemical observations, Leg 139. In Mottl, M.J., Davis, E.E., Fisher, A.T., and Slack, J.F. (Eds.), Proc. ODP, Sci. Results, 139: College Station, TX (Ocean Drilling Program), 695-717.

Davis, E.E., Mottl, M.J., Fisher, A.T., et al., 1992. Proc. ODP, Init. Repts., 139: College Station, TX (Ocean Drilling Program).

Davis, E.E., and Villinger, H., 1992. Tectonic and thermal structure of the Middle Valley sedimented rift, northern Juan de Fuca Ridge. In Davis, E.E., Mottl, M.J., Fisher, A.T., et al., Proc. ODP, Init. Repts., 139: College Station, TX (Ocean Drilling Program), 9-41.

Dixon, J.E., Stolper, E., and Delaney, J.R., 1988. Infrared spectroscopic measurements of $\mathrm{CO}_{2}$ and $\mathrm{H}_{2} \mathrm{O}$ in Juan de Fuca Ridge basaltic glasses. Earth Planet. Sci. Lett., 90:87-104.

Doe, B.R., 1994. Zinc, copper and lead in mid-ocean ridge basalts and the source rock control on $\mathrm{Zn} / \mathrm{Pb}$ in ocean ridge hydrothermal deposits. Geochim. Cosmochim. Acta, 58:1125-2224.

Duckworth, R.C., Fallick, A.E., and Rickard, D., 1994. Mineralogy and sulfur isotopic composition of the Middle Valley massive sulfide deposit, northern Juan de Fuca Ridge. In Mottl, M.J., Davis, E.E., Fisher, A.T., and Slack, J.F. (Eds.), Proc. ODP, Sci. Results, 139: College Station, TX (Ocean Drilling Program), 373-385.

Elderfield, H., and Schultz, A., 1996. Mid-ocean ridge hydrothermal fluxes and the chemical composition of the ocean. Annu. Rev. Earth Planet. Sci., 24:191-224.

Fanning, K.A., and Pilson, M.E.Q., 1971. Interstitial silica and pH in marine sediments: some effects of sampling procedure. Science, 173:1228-1231.

Fisk, M.R., McNeill, A.W., Teagle, D.A.H., Furnes, H., and Bach, W., 1996. Data report: Major-element chemistry of Hole 896A glass. In Alt, J.C., Kinoshita, H., Stokking, L.B., and Michael, P.J. (Eds.), Proc. ODP, Sci. Results, 148: College Station, TX (Ocean Drilling Program), 483-487.

Fouquet, Y., von Stackelberg, U., Charlou, J.L., Erzinger, J., Herzig, P.M., Mühe, R., and Wiedicke, M., 1993. Metallogenesis in back-arc environments: the Lau Basin example. Econ. Geol., 88:2154-2181.

Gieskes, J.M., 1983. The chemistry of interstitial waters of deep-sea sediments: interpretation of deep-sea drilling data. In Riley, J.P., and Chester, R. (Eds.), Chemical Oceanography (Vol. 8): London (Academic), 221269.

Goodfellow, W.D., and Blaise, B., 1988. Sulfide formation and hydrothermal alteration of hemipelagic sediment in Middle Valley, northern Juan de Fuca Ridge. Can. Mineral., 26:675-696.

Goodfellow, W.D., and Franklin, J.M., 1993. Geology, mineralogy and chemistry of sediment-hosted clastic massive sulfides in shallow cores, Middle Valley, northern Juan de Fuca Ridge. Econ. Geol., 88:2033-2064.
Goodfellow, W.D., Grapes, K., Cameron, B., and Franklin, J.M., 1993. Hydrothermal alteration associated with massive sulfide deposits, Middle Valley, Northern Juan de Fuca Ridge. Can. Mineral., 31:1025-1060.

Goodfellow, W.D., and Peter, J.M., 1994. Geochemistry of hydrothermally altered sediment, Middle Valley, northern Juan de Fuca Ridge. In Mottl, M.J., Davis, E.E., Fisher, A.T., and Slack, J.F. (Eds.), Proc. ODP, Sci. Results, 139: College Station, TX (Ocean Drilling Program), 207-289.

Grant, J.A., 1986. The isocon diagram - a simple solution to Gresen's equation for metasomatic alteration. Econ. Geol., 81:1976-1982.

Gresens, R.L., 1967. Composition-volume relationships of metasomatism. Chem. Geol., 2:47-65.

Grimalt, J., and Albaiges, J., 1987. Sources and occurrence of $\mathrm{C}_{12}-\mathrm{C}_{22} n$ alkane distributions with even carbon-number preference in sedimentary environments. Geochim. Cosmochim. Acta, 51:1379-1384.

Haymon, R.M., Fornari, D.J., Von Damm, K.L., Lilley, M.D., Perfit, M.R., Edmond, J.M., Shanks, W.C., III, Lutz, R.A., Grebmeier, J.M., Carbotte, S., Wright, D., McLaughlin, E., Smith, M., Beedle, N., and Olson, E., 1993. Volcanic eruption of the mid-ocean ridge along the East Pacific Rise crest at $9^{\circ} 45-52^{\prime} \mathrm{N}$ : direct submersible observations of seafloor phenomena associated with an eruption event in April, 1991. Earth Planet. Sci. Lett., 119:85-101.

Hunt, J.M., 1996. Petroleum Geochemistry and Geology (2nd. ed): New York (W.H. Freeman and Company).

Johnson, J.W., Oelkers, E.H., and Helgeson, H.C., 1992. SUPCRT92: a software package for calculating the standard molal thermodynamic properties of minerals, gases, aqueous species, and reactions from 1 to $5000 \mathrm{Bar}$ and 0 to $1000^{\circ} \mathrm{C}$. Comput. Geosci., 18:899-947.

Jonasson, K.D., Schröder-Adams, C.J., and Patterson, R.T., 1995. Benthic foraminiferal distribution at Middle Valley, Juan de Fuca Ridge, a northeast Pacific hydrothermal venting site. Mar. Micropaleontol., 25:151167.

Juniper, S.K., Martineu, H., Sarrazin, J., and Gelinas, Y., 1995. Microbialmineral floc associated with nascent hydrothermal activity on CoAxial segment, Juan de Fuca Ridge. Geophys. Res. Lett., 22:179-182.

Karlin, R., Lyle, M., and Zahn, R., 1992. Carbonate variations in the Northeast Pacific during the late Quaternary. Paleoceanography, 7:43-61.

Kawka, O.E., and Simoneit, B.R.T., 1987. Survey of hydrothermally-generated petroleums from the Guaymas Basin spreading center. Org. Geochem., 11:311-328.

Kennett, J.P., and Venz, K., 1995. Late Quaternary climatically related planktonic foraminiferal assemblage changes: Hole 893A, Santa Barbara Basin, California. In Kennett, J.P., Baldauf, J.G., and Lyle, M. (Eds.), Proc. ODP, Sci. Results, 146 (Pt. 2): College Station, TX (Ocean Drilling Program), 281-293.

Körner, U., 1994. Rock magnetic properties of hydrothermally formed iron sulfides from Middle Valley, Juan de Fuca Ridge. In Mottl, M.J., Davis, E.E., Fisher, A.T., and Slack, J.F. (Eds.), Proc. ODP, Sci. Results, 139: College Station, TX (Ocean Drilling Program), 535-542.

Koski, R.A., Jonasson, I.R., Kadko, D.C., Smith, V.K., and Wong, F.L., 1994. Compositions, growth mechanisms, and temporal relations of hydrothermal sulfide-sulfate-silica chimneys at the northern Cleft segment, Juan de Fuca Ridge. J. Geophys. Res., 99:4813-4832.

Krasnov, S., Stepanova, T., and Stepanov, M., 1994. Chemical composition and formation of a massive sulfide deposit, Middle Valley, northern Juan de Fuca Ridge (Site 856). In Mottl, M.J., Davis, E.E., Fisher, A.T., and Slack, J.F. (Eds.), Proc. ODP, Sci. Results, 139: College Station, TX (Ocean Drilling Program), 353-372.

Kvenvolden, K.A., and Simoneit, B.R.T., 1990. Hydrothermally derived petroleum: examples from Guaymas Basin, Gulf of California and Escanaba Trough, Northeast Pacific Ocean. AAPG Bull., 74:223-237.

Lagoe, M.B., and Thompson, P.R., 1988. Chronostratigraphic significance of late Cenozoic planktonic foraminifera from the Ventura Basin, California: potential for improving tectonic and depositional interpretation. $J$. Foraminiferal Res., 18:250-266.

Leybourne, M.I., and Goodfellow, W.D., 1994. Mineralogy and mineral chemistry of hydrothermally altered sediment, Middle Valley, Juan de Fuca Ridge. In Mottl, M.J., Davis, E.E., Fisher, A.T., and Slack, J.F. (Eds.), Proc. ODP, Sci. Results, 139: College Station, TX (Ocean Drilling Program), 155-206.

Lister, C.R.B., 1972. On the thermal balance of a mid-ocean ridge. Geophys. J. R. Astron. Soc., 26:515-535. 
Lonsdale, M., and Becker, K., 1985. Hydrothermal plumes, hot springs, and conductive heat flow in the southern trough of the Guaymas Basin. Earth. Planet. Sci. Lett., 73:211-225.

Manheim, F.T., and Sayles, F.L., 1974. Composition and origin of interstitial waters of marine sediments, based on deep sea drill cores. In Goldberg, E.D. (Ed.), The Sea (Vol. 5): Marine Chemistry: The Sedimentary Cycle: New York (Wiley), 527-568.

McDuff, R.E., 1985. The chemistry of interstitial waters, Deep Sea Drilling Project Leg 86. In Heath, G.R., Burckle, L.H., et al., Init. Repts. DSDP, 86: Washington (U.S. Govt. Printing Office), 675-687.

Meschede, M., 1986. A method of discriminating between different types of mid-oceanic ridge basalts and continental tholeiites with the Nb-Zr-Y diagram. Chem. Geol., 56:207-218.

Michael, P.J., 1988. The concentration, behavior and storage of $\mathrm{H}_{2} \mathrm{O}$ in the suboceanic mantle: implications for mantle metasomatism. Geochim. Cosmochim. Acta, 52:555-566.

Miller, A.R., Densmore, C.D., Degens, E.T., Hathaway, J.C., Manheim, F.T., McFarlin, P.F., Pocklington, R., and Jokela, A., 1966. Hot brines and recent iron deposits of the Red Sea. Geochim. Cosmochim. Acta, 30:341.

Moffett, S., 1995. Recognition of Brunhes interglacial events in the subarctic Northeast Pacific Ocean [Master's thesis]. Univ. of Southern Mississippi, Hattiesburg, MS.

Morton, J.L., Holmes, M.L., and Koski, R.A., 1987. Volcanism and massive sulfide formation at a sedimented spreading center, Escanaba Trough, Gorda Ridge, northeast Pacific Ocean. Geophys. Res. Lett., 14:769-772.

Morton, J.L., and Sleep, N.H., 1985. A mid-ocean ridge thermal model: constraints on the volume of axial hydrothermal heat flux. J. Geophys. Res., 90:11345-11353

Mottl, M.J., Wheat, C.G., and Boulegue, J., 1994. Timing of ore deposition and sill intrusion at Site 856: evidence from stratigraphy, alteration, and sediment pore-water composition. In Mottl, M.J., Davis, E.E., Fisher, A.T., and Slack, J.F. (Eds.), Proc. ODP, Sci. Results, 139: College Station, TX (Ocean Drilling Program), 679-693.

Parkes, R.J., Cragg, B.A., Bale, S.J., Getliff, J.M., Goodman, K., Rochelle, P.A., Fry, J.C., Weightman, A.J., and Harvey, S.M., 1994. A deep bacterial biosphere in Pacific Ocean sediments. Nature, 371:410-413.

Peter, J.M., 1992. Comparative geochemical studies of the Upper Triassic Windy Craggy and modern Guaymas Basin deposits: a contribution to the understanding of massive sulfide formation in volcano-sedimentary environments [Ph.D. dissert.]. Univ. Toronto.

Peter, J.M., Goodfellow, W.D., and Leybourne, M.I., 1994. Fluid inclusion petrography and microthermometry of the Middle Valley hydrothermal system, northern Juan de Fuca Ridge. In Mottl, M.J., Davis, E.E., Fisher, A.T., and Slack, J.F. (Eds.), Proc. ODP, Sci. Results, 139: College Station, TX (Ocean Drilling Program), 411-428.

Quinterno, P.J., 1994. Quaternary foraminifers from Escanaba Trough, northeastern Pacific Ocean. In Morton, J.L., Zierenberg, R.A., and Reiss, C.A. (Eds.), Geologic, Hydrothermal, and Biologic Studies at Escanaba Trough, Gorda Ridge, Offshore Northern California. U.S. Geol. Surv. Bull., 2022:337-359.

Rohr, K.M.M., and Schmidt, U., 1994. Seismic structure of Middle Valley near Sites 855-858, Leg 139, Juan de Fuca Ridge. In Mottl, M.J., Davis, E.E., Fisher, A.T., and Slack, J.F. (Eds.), Proc. ODP, Sci. Results, 139: College Station, TX (Ocean Drilling Program), 3-17.

Schlumberger, 1989. Log Interpretation Principles/Applications: Houston, TX (Schlumberger Educ. Services).

Schrag, D.P., and DePaolo, D.J., 1993. Determination of $\delta^{18} \mathrm{O}$ of seawater in the deep ocean during the last glacial maximum. Paleoceanography, 8:16.

Seyfried, W.E., Jr., Ding, K., and Berndt, M.E., 1991. Phase equilibria constraints on the chemistry of hot spring fluids at mid-ocean ridges. Geochim. Cosmochim. Acta, 55:3559-3580.

Shanks, W.C., III, and Bischoff, J.L., 1977. Ore transport and deposition in the Red Sea geothermal system: a geochemical model. Geochim. Cosmochim. Acta, 41:1507-1519.

Shipboard Scientific Party, 1992a. Explanatory notes. In Davis, E.E., Mottl, M.J., Fisher, A.T., et al., Proc. ODP, Init. Repts., 139: College Station, TX (Ocean Drilling Program), 55-97.

, 1992b. Site 856. In Davis, E.E., Mottl, M.J., Fisher, A.T., et al., Proc. ODP, Init. Repts., 139: College Station, TX (Ocean Drilling Program), 161-281. 1992c. Site 858. In Davis, E.E., Mottl, M.J., Fisher, A.T., et al., Proc. ODP, Init. Repts., 139: College Station, TX (Ocean Drilling Program), 431-569.

Simoneit, B.R.T., 1977. Diterpenoid compounds and other lipids in deep-sea sediments and their geochemical significance. Geochim. Cosmochim. Acta, 41:463-476.

1978. The organic chemistry of marine sediments. In Riley, J.P., and Chester, R. (Eds.), Chemical Oceanography (2nd ed.) (Vol. 7): New York (Academic Press), 233-311.

1985. Hydrothermal petroleum: genesis, migration and deposition in Guaymas Basin, Gulf of California. Can. J. Earth Sci., 22:1919-1929.

(Ed.), 1990. Organic matter in hydrothermal systems -maturation, migration and biogeochemistry. Appl. Geochem., 5:1-248.

, 1994. Lipid/bitumen maturation by hydrothermal activity in sediments of Middle Valley, Leg 139. In Mottl, M.J., Davis, E.E., Fisher, A.T., and Slack, J.F. (Eds.), Proc. ODP, Sci. Results, 139: College Station, TX (Ocean Drilling Program), 447-465.

Simoneit, B.R.T., Goodfellow, W.D., and Franklin, J.M., 1992. Hydrothermal petroleum at the seafloor and organic matter alteration in sediments of Middle Valley, northern Juan de Fuca Ridge. Appl. Geochem., 7:257264.

Simoneit, B.R.T., Kawka, O.E., and Brault, M., 1988. Origin of gases and condensates in the Guaymas Basin hydrothermal system (Gulf of California). Chem. Geol., 71:169-182.

Simoneit, B.R.T., Prahl, F.G., Leif, R.N., and Mao, S.-Z., 1994. Alkenones in sediments of Middle Valley, Leg 139: application as thermal sensors. In Mottl, M.J., Davis, E.E., Fisher, A.T., and Slack, J.F. (Eds.), Proc. ODP, Sci. Results, 139: College Station, TX (Ocean Drilling Program), 479484.

Slack, J.F., 1995. Descriptive and grade-tonnage models for Besshi-type massive sulphide deposits. In Kirkham, R.V., Sinclair, W.D., Thorpe, R.I., and Duke, J.M. (Eds.), Mineral Deposit Modeling. Geol. Assoc. Can., Spec. Pap., 40.

Sleep, N.H., 1991. Hydrothermal circulation, anhydrite precipitation, and thermal structure at Ridge axes. J. Geophys. Res., 96:2735-2387.

Stakes, D.S., and Franklin, J.M., 1994. Petrology of igneous rocks at Middle Valley, Juan de Fuca Ridge. In Mottl, M.J., Davis, E.E., Fisher, A.T., and Slack, J.F. (Eds.), Proc. ODP, Sci. Results, 139: College Station, TX (Ocean Drilling Program), 79-102.

Stuart, F.M., Duckworth, R., Turner, G., and Schofield, P.F., 1994a. Helium and sulfur isotopes of sulfide minerals from Middle Valley, northern Juan de Fuca Ridge. In Mottl, M.J., Davis, E.E., Fisher, A.T., and Slack, J.F. (Eds.), Proc. ODP, Sci. Results, 139: College Station, TX (Ocean Drilling Program), 387-392.

Stuart, F.M., Turner, G., Duckworth, R.C., and Fallick, A.E., 1994b. Helium isotopes as tracers of trapped hydrothermal fluids in ocean-floor sulfides. Geology, 22:823-826.

Tivey, M.A., 1994. High-resolution magnetic surveys over the Middle Valley mounds, northern Juan de Fuca Ridge. In Mottl, M.J., Davis, E.E., Fisher, A.T., and Slack, J.F. (Eds.), Proc. ODP, Sci. Results, 139: College Station, TX (Ocean Drilling Program), 29-35.

Turner, R.J.W., Ames, D.E., Goodfellow, W.D., Leitch, C.H.B., Franklin, J.M., and Hoy, T., 1993. Character of hydrothermal mounds and nearby altered hemipelagic sediments in the hydrothermal areas of Middle valley, northern Juan de Fuca Ridge: shallow core data. Can. Mineral., 31:973-995.

Urbat, M., 1996. Rock magnetic properties of Pleistocene passive margin sediments: environmental change and diagenesis offshore New Jersey. In Mountain, G., Miller, K.G., Blum, P. (Eds.), Proc. ODP, Sci. Results, 150: College Station, TX (Ocean Drilling Program)

Zierenberg, R.A., 1994. Data Report: Sulfur content of sediment and sulfur isotope values of sulfide and sulfate minerals from Middle Valley. In Mottl, M.J., Davis, E.E.,Fisher, A.T., and Slack, J.F. (Eds.), Proc. ODP, Sci. Results, 139: College Station, TX (Ocean Drilling Program), 739748.

Zierenberg, R.A., Goodfellow, W.D., and Franklin, J.M., 1994a. Sulfur isotopic composition of massive sulfide from the Middle Valley sedimentcovered seafloor spreading center. In Abstracts of the Eighth International Conference on Geochronology, Cosmochronology, and Isotope geology., 370. 
Zierenberg, R.A., Morton, J.L., Koski, R.A., and Ross, S.L., 1994b. Geologic setting of massive sulfide mineralization in the Escanaba Trough. In Morton, J.L., Zierenberg, R.A., and Reiss, C.A. (Eds.), Geologic, Hydrothermal, and Biologic Studies at Escanaba Trough, Gorda Ridge, Offshore Northern California. U.S. Geol. Surv. Bull., 2022:171-197.

Zierenberg, R.A., and Shanks, W.C., III, 1994. Sediment alteration associated with massive sulfide formation in Escanaba Trough, Gorda Ridge: the importance of seawater mixing and magnesium metasomatism. In Morton, J.L., Zierenberg, R.A., and Reiss, C.A. (Eds.), Geologic, Hydrothermal, and Biologic Studies at Escanaba Trough, Gorda Ridge, Offshore Northern California. U.S. Geol. Surv. Bull., 2022:257-278.

\section{Ms 169IR-103}

NOTE: For all sites drilled, core-description forms ("barrel sheets") and core photographs can be found in Section 3, beginning on page 299. Smear-slide data and thin-section data can be found on CD-ROM. See Table of Contents for material contained on CD-ROM. 


\section{SHORE-BASED LOG PROCESSING}

Hole 856H

Bottom felt: 2434.5 mbrf (used for depth shift to seafloor)

Total penetration: $500 \mathrm{mbsf}$

Total core recovered: $49.1 \mathrm{~m}(12.1 \%)$

\section{Logging Runs}

\section{Logging string 1: DIT/APS/HLDS/HNGS}

Logging string 2: FMS/GPIT/SDT/NGT (1 downlog and upper, lower, and middle sections). Good data were collected by the FMS tool only at the beginning of the recording. Good SDT data was collected downhole and in three uphole sections.

Logging string 3: FMS/GPIT/NGT (upper and lower sections). The wireline heave compensator was initially used to counter ship heave. The wireline heave compensator was turned off during the first deployment of the FMS tool string.

\section{Bottom-Hole Assembly}

The following bottom-hole assembly depths are as they appear on the logs after differential depth shift (see "Depth shift" section) and depth shift to the seafloor. As such, there might be a discrepancy with the original depths given by the drillers on board. Possible reasons for depth discrepancies are ship heave and drill string and/or wireline stretch.

DIT/APS/HLDS/HNGS: Bottom-hole assembly at $\sim 85 \mathrm{mbsf}$

FMS/GPIT/SDT/NGT: Bottom-hole assembly at $\sim 89 \mathrm{mbsf}$ (pass 1 downlog)

FMS/GPIT/SDT/NGT: Bottom-hole assembly at $\sim 85 \mathrm{mbsf}$

FMS/GPIT/SDT/NGT: recorded in open hole (pass 1 lower section)

FMS/GPIT/SDT/NGT: recorded in open hole (pass 1 middle section)

FMS/GPIT/SDT/NGT: recorded in open hole at mbsf (pass 1 upper section)

FMS/GPIT/NGT: recorded in open hole (pass 2 lower section)

FMS/GPIT/NGT: recorded in open hole (pass 2 upper section)

\section{Processing}

Depth shift: Original logs have been interactively depth shifted with reference to NGT from DIT/APS/HLDS/HNGS run and to the seafloor $(-2434.5 \mathrm{~m})$.
Gamma-ray processing: NGT data have been processed to correct for borehole size and type of drilling fluid. HNGS data are corrected in real time during the recording.

Acoustic data processing: The array sonic tool was operated in standard depth-derived borehole compensated mode, including longspacing (8-10-10-12 ft) and short-spacing (3-5-5-7 ft) logs. Acoustic data were recorded downhole and uphole in three separate sections. The short-spacing transit times from both downhole and uphole sections have been processed to eliminate some of the noise and cycle skipping experienced during the recording. The transit times from the four sections recorded have been merged as follows:

90.5-115.5 mbsf: downlog

115.5-215.5 mbsf: uplog, upper section

215.5-288 mbsf: downlog

288-478 mbsf: uplog, lower section

\section{Quality Control}

Data recorded through the bottom-hole assembly should be used quantitatively only because of the attentuation on the incoming signal. The resistivity data in the $85-210$ mbsf interval, corresponding to a low resistivity sulfide-rich zone, are beyond the normal response range of the resistivity tool and are not included in the database. The original data are available from the Lamont-Doherty Borehole Research Group.

Hole diameter was recorded by the hydraulic caliper on the HLDS tool (LCAL) and on the FMS string (C1 and C2, upper and lower section during second pass). The hole at $856 \mathrm{H}$ is generally smooth, with most readings below 12 in. The standoff measured by the APS tool ranges from 0 to $\sim 2$ in, with most readings below 1 in.

Details of standard shore-based processing procedures are found in the "Explanatory Notes" chapter (this volume). For further information about the logs, please contact:

Cristina Broglia

Phone: $914-365-8343$

Fax: 914-365-3182

E-mail: chris@ldeo.columbia.edu 
Hole 856H: Natural Gamma Ray-Resistivity-Sonic Logging Data

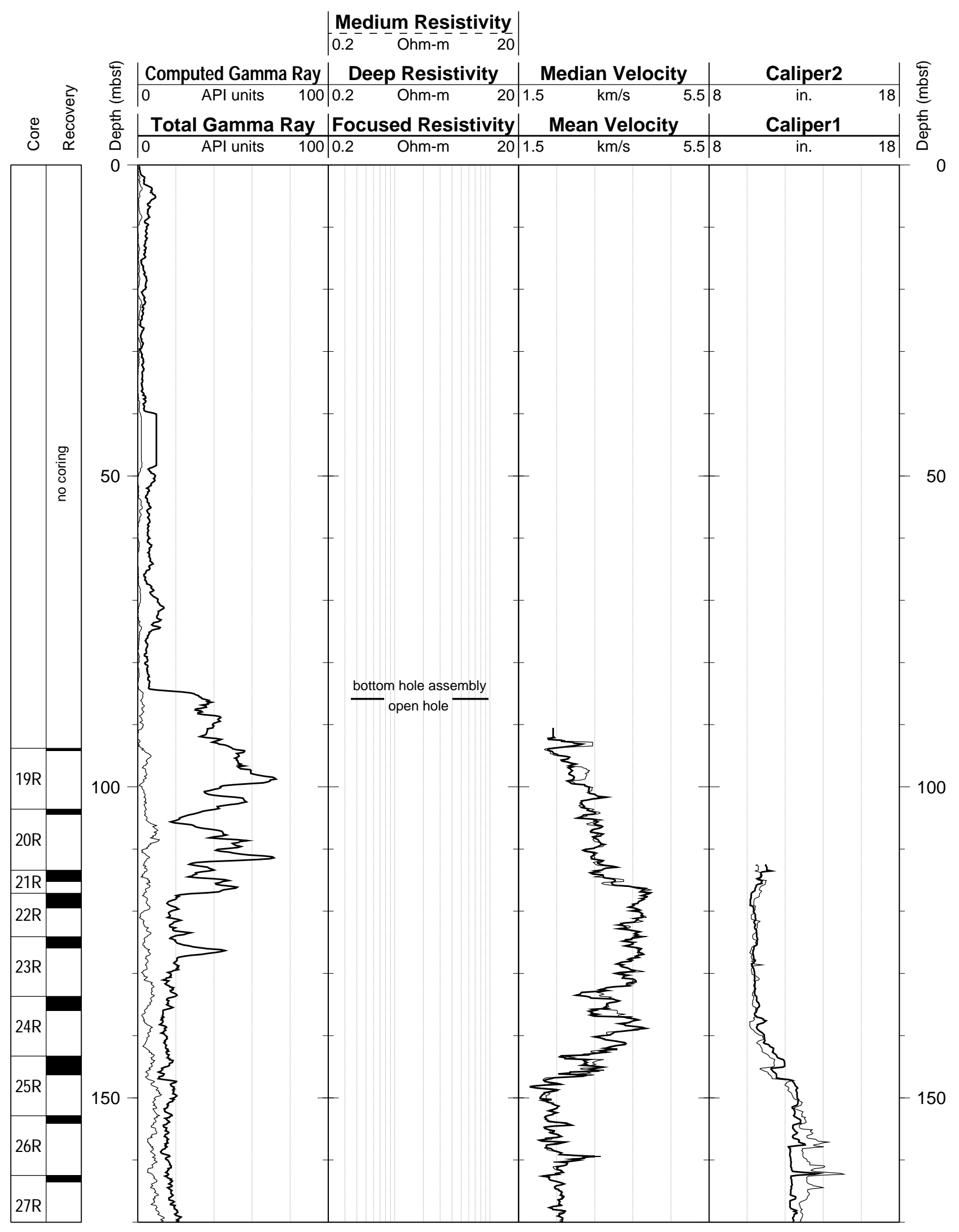


Hole 856H: Natural Gamma Ray-Resistivity-Sonic Logging Data (cont.)

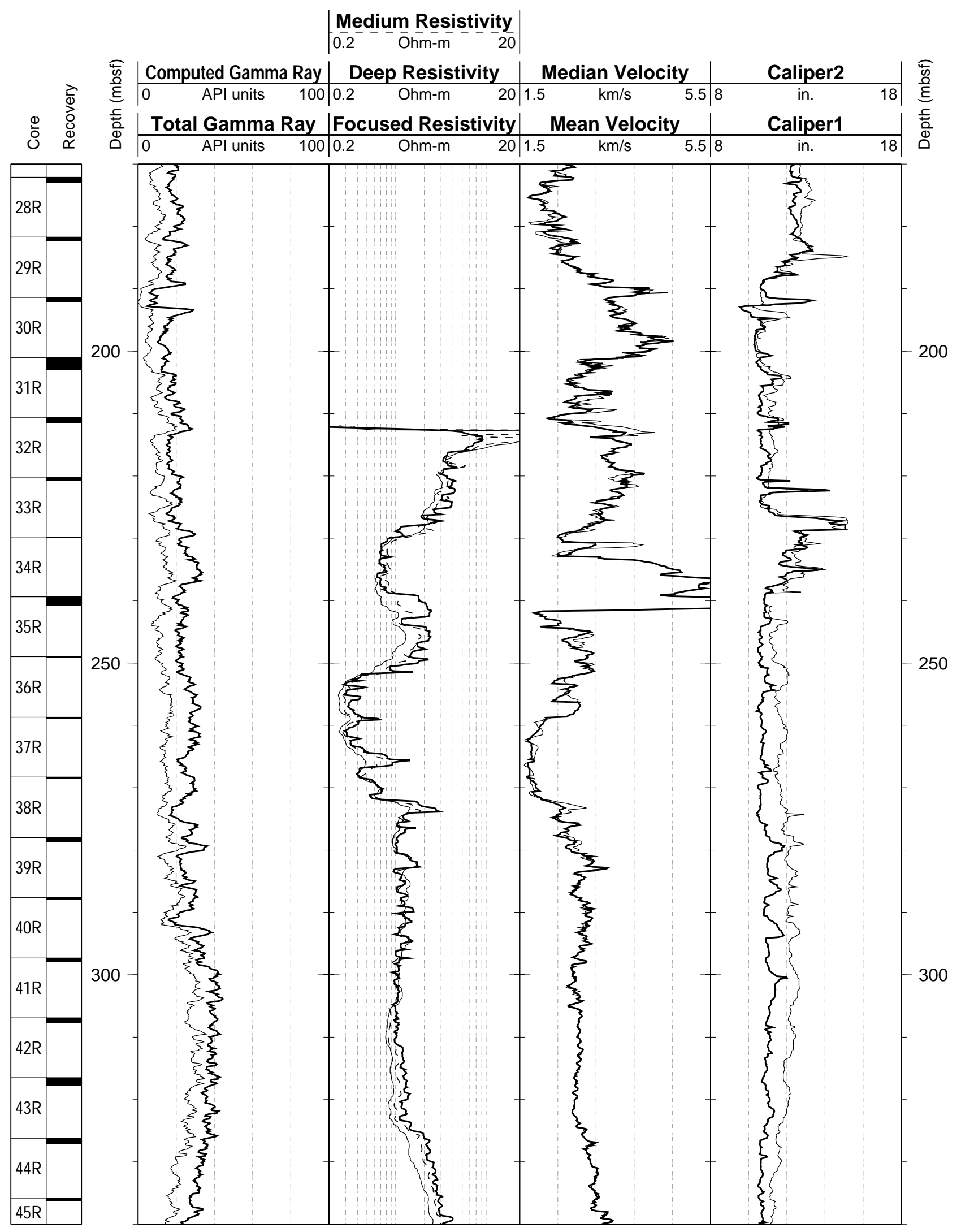


Hole 856H: Natural Gamma Ray-Resistivity-Sonic Logging Data (cont.)

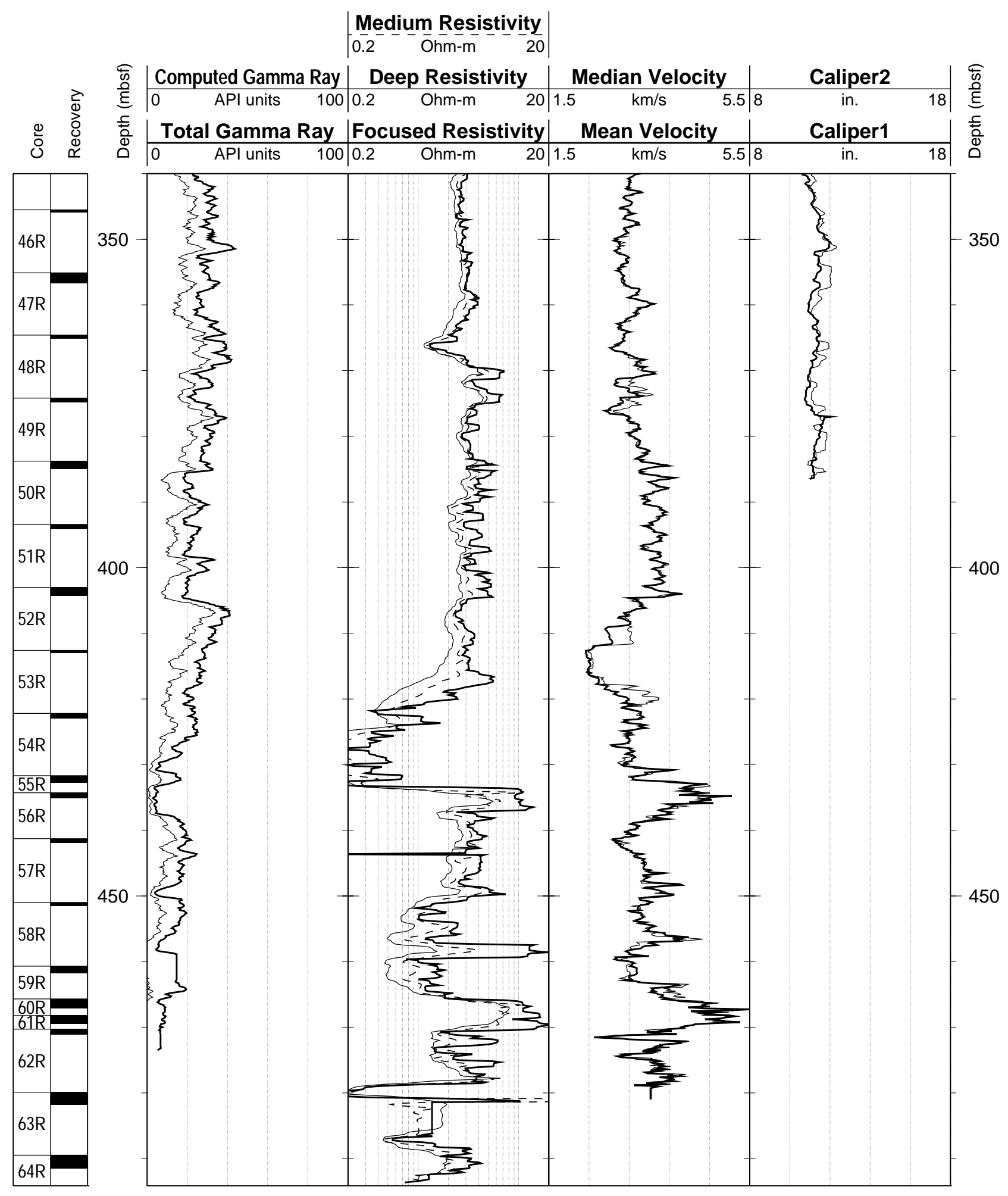




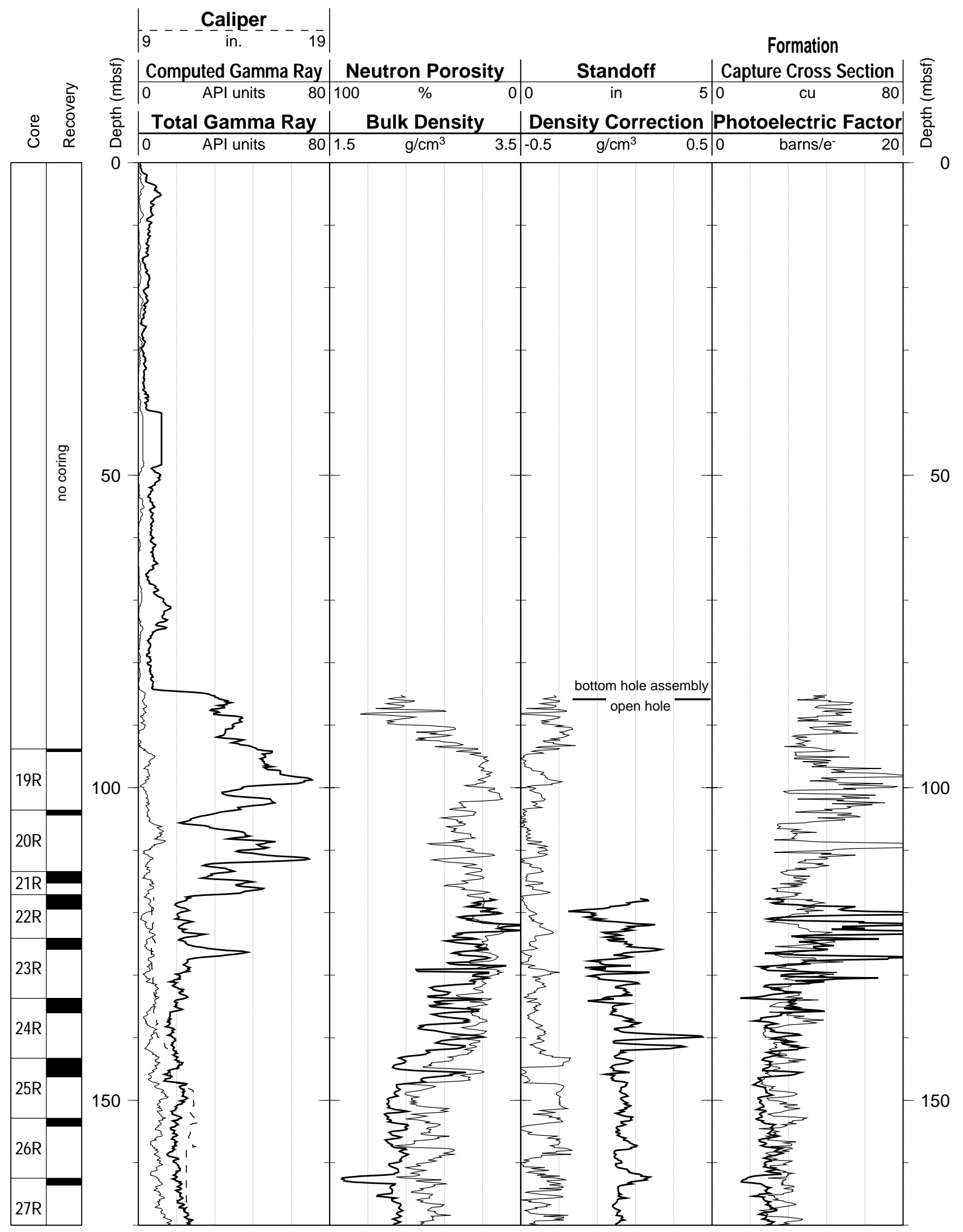


Hole 856H: Natural Gamma Ray-Density-Porosity Logging Data (cont.)

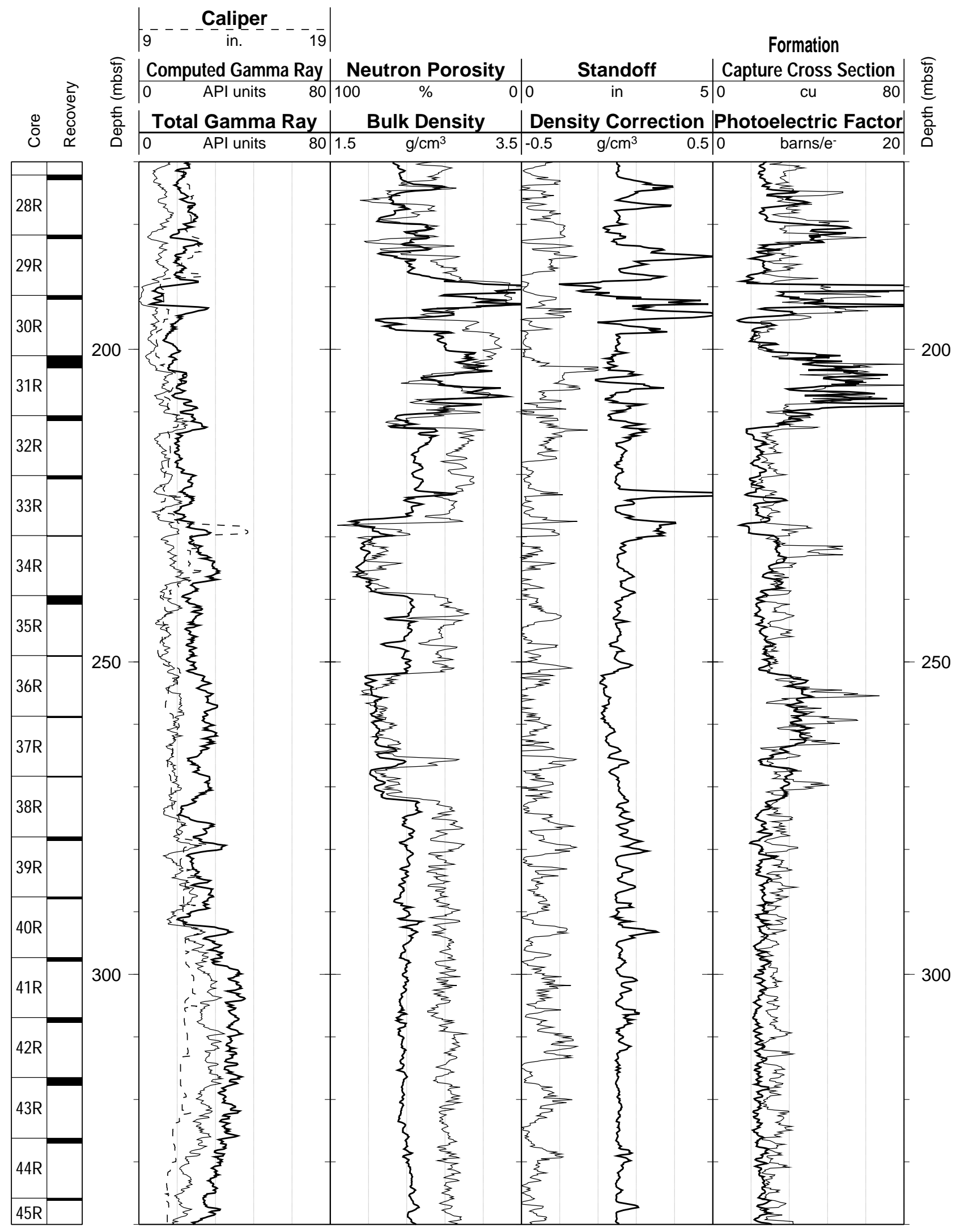


Hole 856H: Natural Gamma Ray-Density-Porosity Logging Data (cont.)

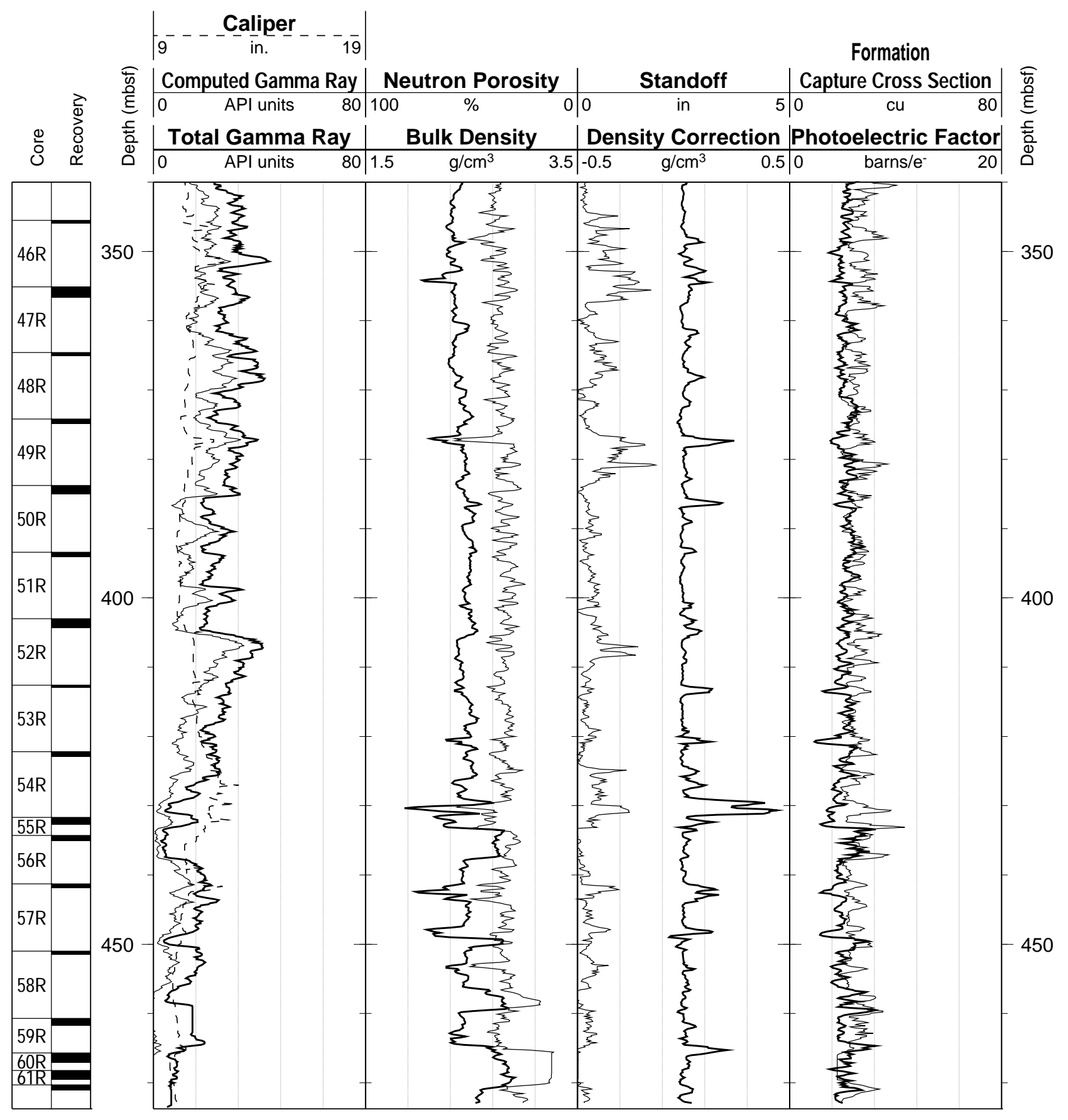


Hole 856H: Natural Gamma Ray Logging Data

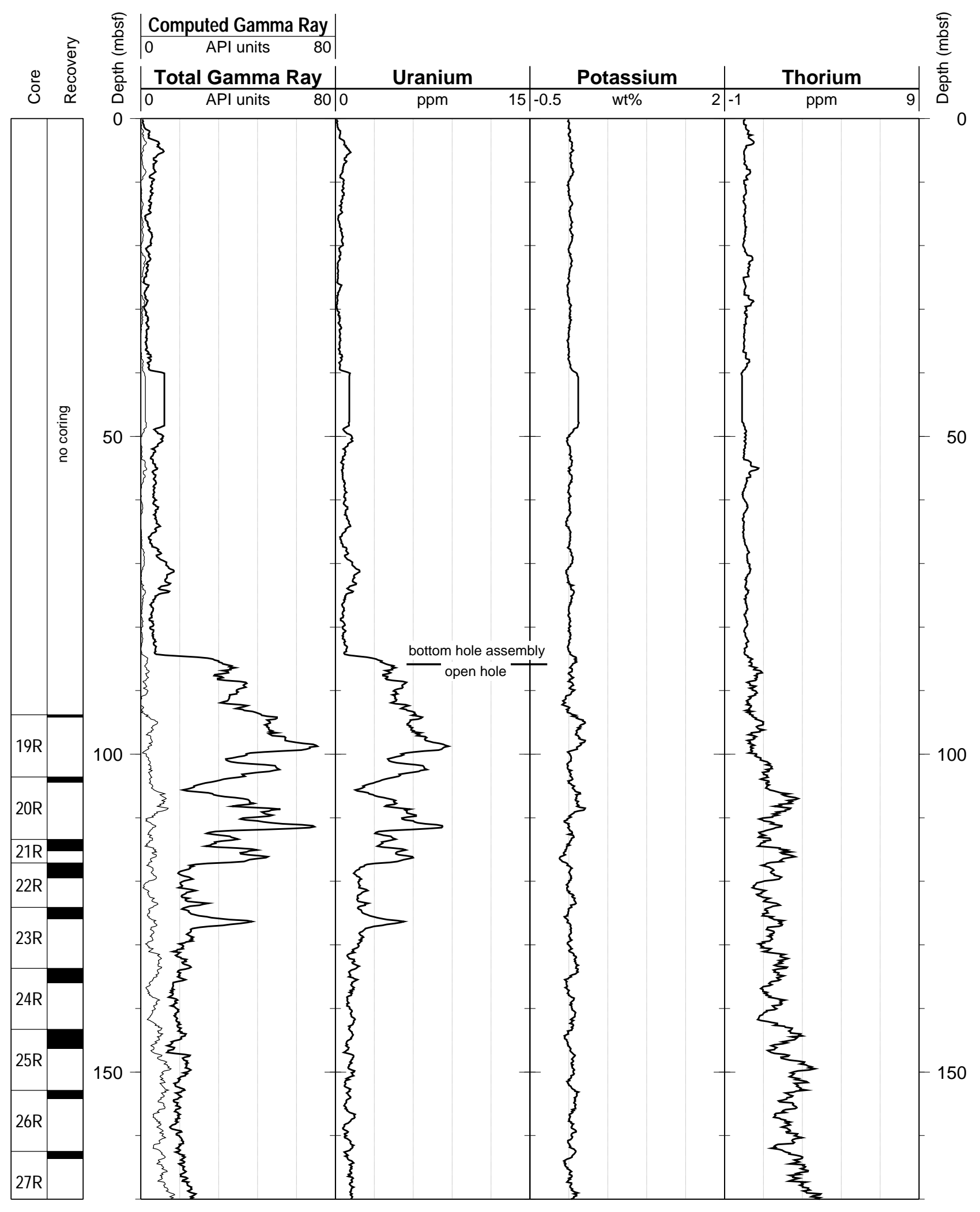


Hole 856H: Natural Gamma Ray Logging Data (cont.)

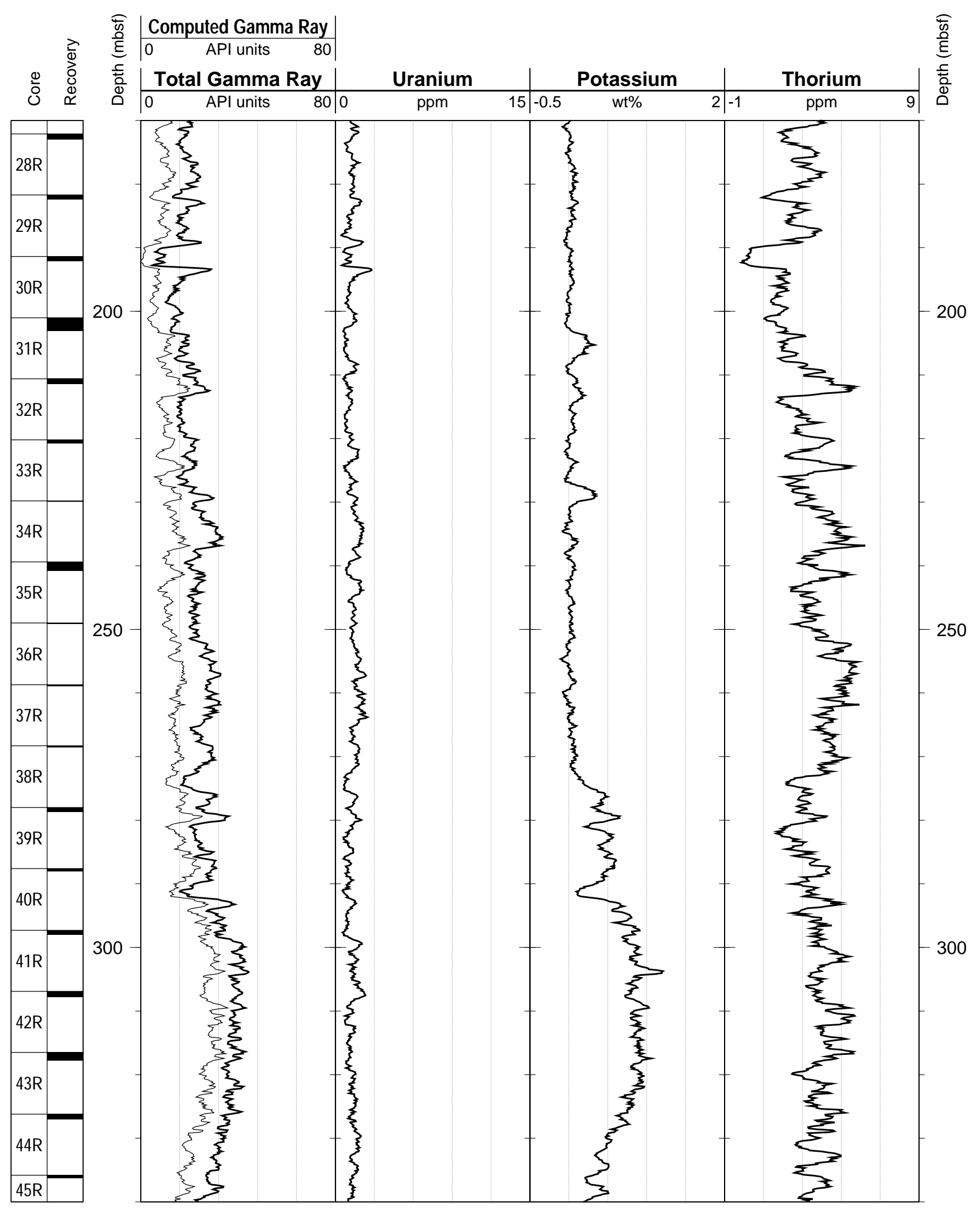


Hole 856H: Natural Gamma Ray Logging Data (cont.)

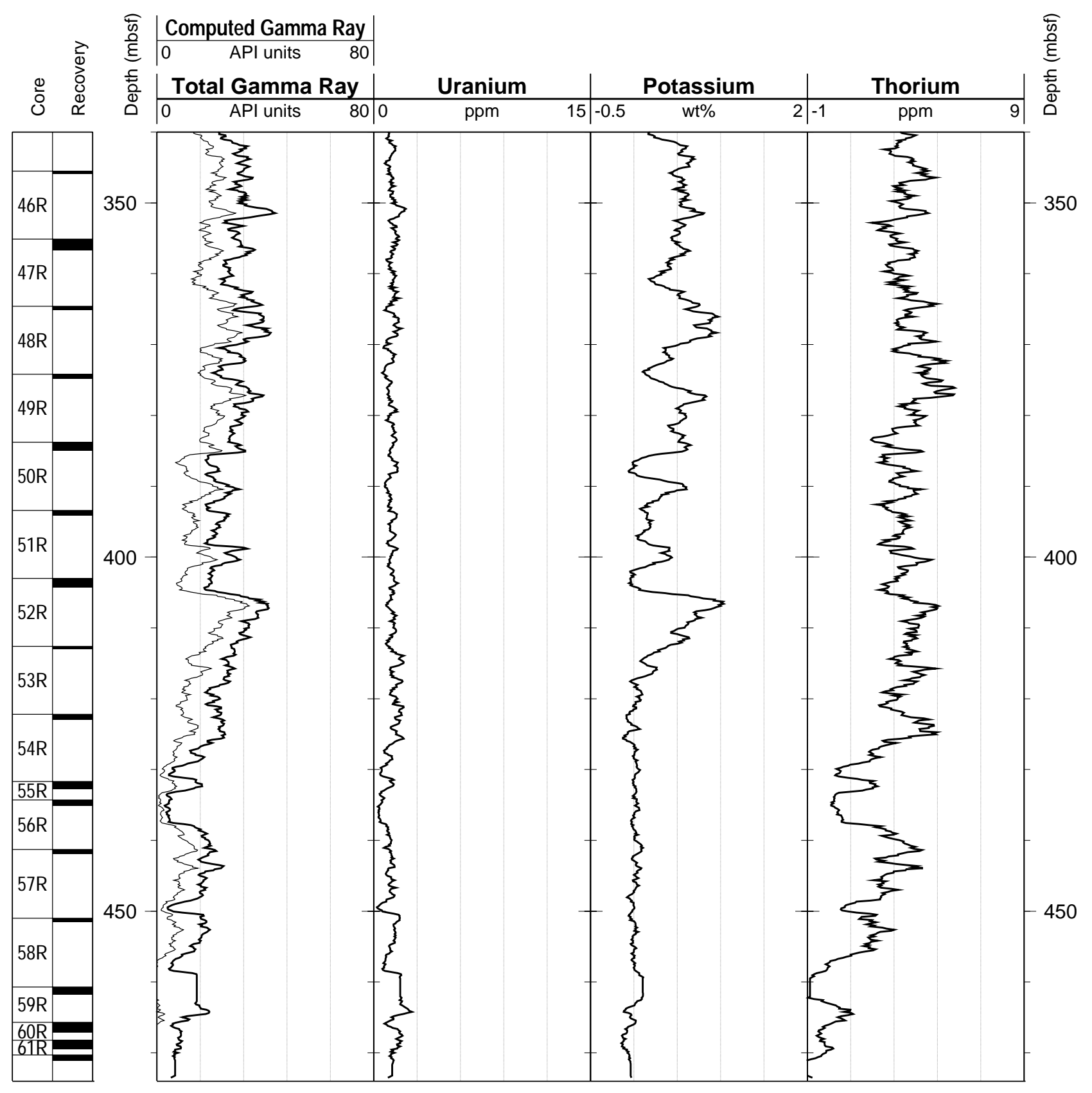

